\title{
Archeological Investigations for the Levi Jordan Plantation House Stabilization, Brazoria County, Texas
}

Jennifer K. McWilliams

Texas Historical Commission

Douglas K. Boyd

Prewitt and Associates, Inc.

Aaron Norment

AmaTerra Environmental, Inc.

Follow this and additional works at: https://scholarworks.sfasu.edu/ita

Part of the American Material Culture Commons, Archaeological Anthropology Commons, Environmental Studies Commons, Other American Studies Commons, Other Arts and Humanities Commons, Other History of Art, Architecture, and Archaeology Commons, and the United States History Commons

Tell us how this article helped you.

This Article is brought to you for free and open access by the Center for Regional Heritage Research at SFA ScholarWorks. It has been accepted for inclusion in Index of Texas Archaeology: Open Access Gray Literature from the Lone Star State by an authorized editor of SFA ScholarWorks. For more information, please contact cdsscholarworks@sfasu.edu. 


\section{Archeological Investigations for the Levi Jordan Plantation House Stabilization, Brazoria County, Texas}

\section{Creative Commons License}

\section{(c) (i) $\Theta($}

This work is licensed under a Creative Commons Attribution-NonCommercial-No Derivative Works 4.0 International License. 


\title{
ARCHEOLOGICAL INVESTIGATIONS FOR THE LEVI JORDAN PLANTATION HOUSE STABILIZATION, BRAZORIA COUNTY, TEXAS
}

\author{
by \\ Jennifer K. McWilliams \\ Douglas K. Boyd \\ and \\ Aaron Norment \\ Principal Investigators: Douglas K. Boyd and Jennifer K. McWilliams \\ REPORTS OF INVESTIGATIONS, NUMBER 166 \\ submitted to \\ Historic Sites Division \\ Texas Historical Commission \\ Austin, Texas \\ by \\ Prewitt and Associates, Inc. \\ Cultural Resources Services \\ Austin, Texas \\ PAI Nos. 210025 and 211004
}

May 2013

TEXAS ANTIQUITIES PERMIT NO. 5720 



\section{TABLE OF CONTENTS}

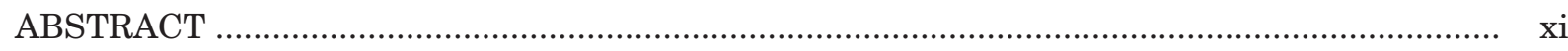

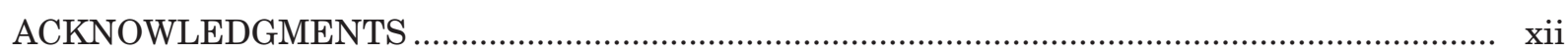

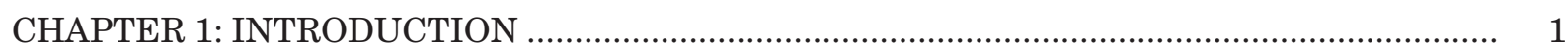

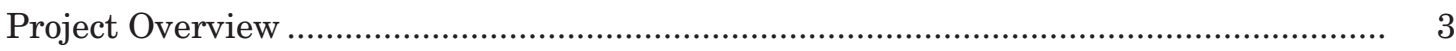

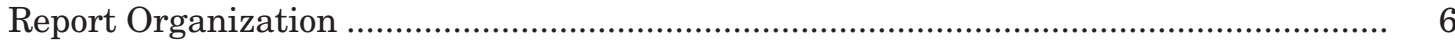

CHAPTER 2: HISTORY OF THE LEVI JORDAN PLANTATION AND PREVIOUS

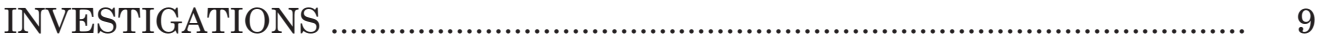

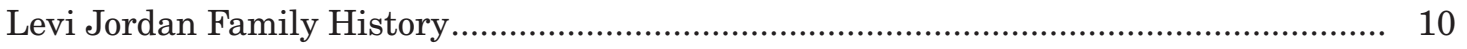

The Levi Jordan House ............................................................................................ 13

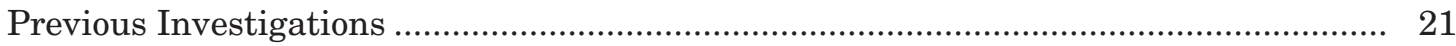

The University of Houston.......................................................................... 29

Texas Parks and Wildlife Department ........................................................... 38

Center for Archaeological Studies ................................................................... 39

CHAPTER 3: PROJECT OVERVIEW, METHODS OF INVESTIGATION, AND WORK ACCOMPLISHED ...................................................................................... 41

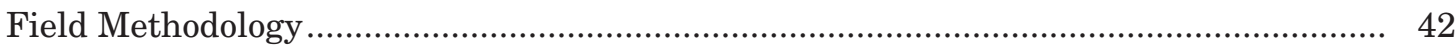

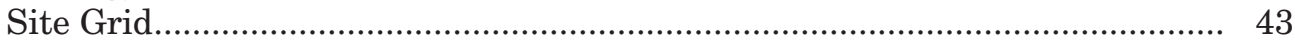

Area and Excavation Unit Designations........................................................ 43

Pier Investigations and Terminology …........................................................ 44

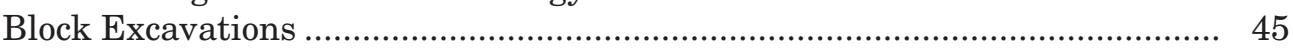

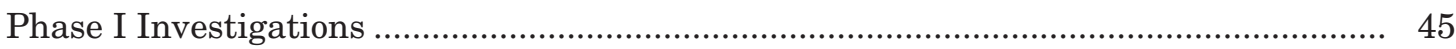

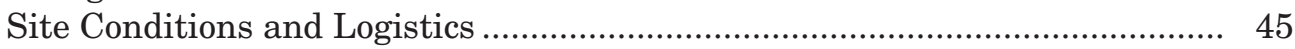

Phase I Goals and Work Accomplished ............................................................ 47

Interim Consultation and Phase II Planning......................................................... 47

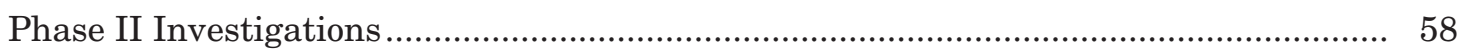

Site Conditions and Logistics .................................................................. 58

Phase II Goals and Work Accomplished........................................................... 62

Comprehensive Archeological Resources Overlay Map ................................... 65

CHAPTER 4: ARCHITECTURAL HISTORY OF THE LEVI JORDAN

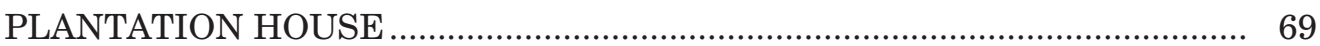

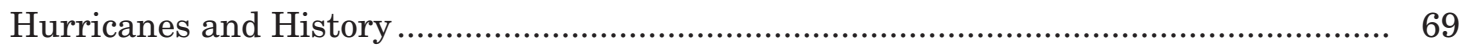

Oral and Written Histories of the Levi Jordan Plantation............................................ 69

Structural Improvements and Site Layout........................................................ 70

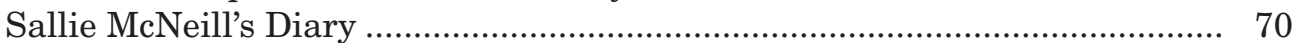

Aunt Eula's Map............................................................................................... 75

Humphries' 1937 Houston Chronicle Article ................................................... 77

Allen Andrew Platter ........................................................................... 78

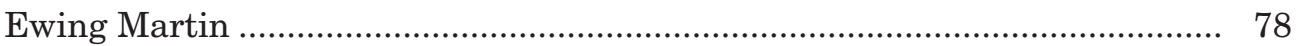

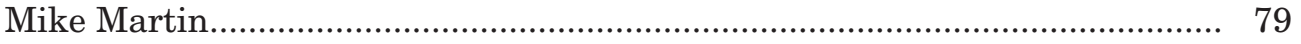

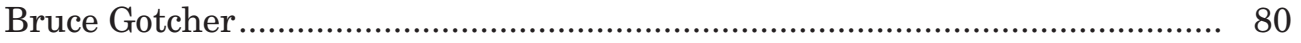


Onsite Interview with Dr. Kenneth Brown.................................................. 80

Historical Research by Martha Freeman...................................................... 81

Photographic Research ....................................................................................... 81

CHAPTER 5: REMOTE SENSING, HOUSE FOUNDATION ANALYSIS, AND WOOD IDENTIFICATION OF FOUNDATION PIERS............................................. 85

Magnetometer and Ground-Penetrating Radar Survey Results ................................... 85

House Foundation Analysis ................................................................................ 85

Wood Sample Identification ................................................................... 89

CHAPTER 6: ARCHITECTURAL FEATURES: FOUNDATION PIERS ................................. 91

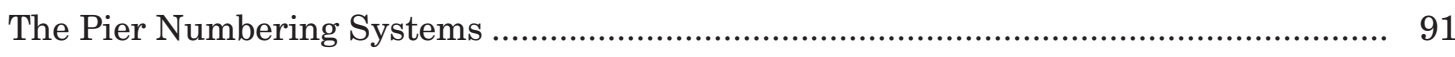

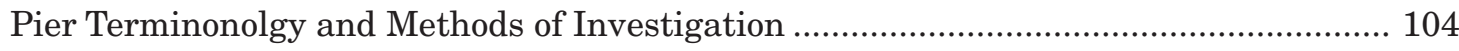

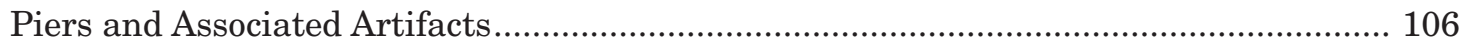

Description of the Levi Jordan Foundation Piers.............................................................. 106

Piers Associated with the Antebellum House .................................................... 108

Piers Associated with the Twentieth-Century East Wing ............................... 137

Possible Pier Features....................................................................................... 139

Interpretation of Pier Groups and Architectural Associations ......................................... 151

Variability in Pier Construction and Modification ......................................... 151

Pier Groups and Architectural Associations ................................................. 152

Historical Evidence of House Repair Episodes.................................................................... 159

Dendrochronology of Levi Jordan Pier Posts ................................................... 159

A Possible West Porch?.................................................................................. 160

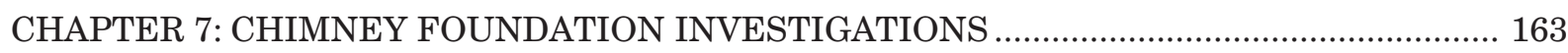

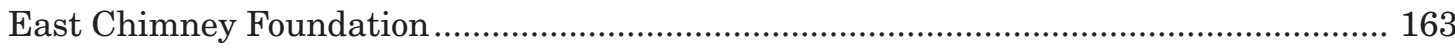

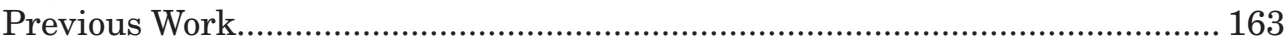

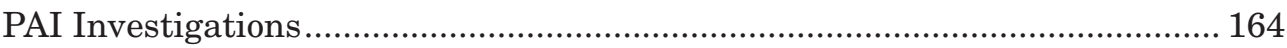

Dismantling and Examining the East Chimney Footing............................... 168

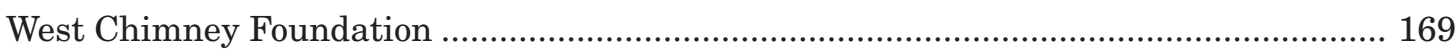

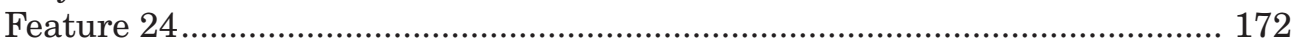

Dismantling and Examining the West Chimney Footing ............................... 172

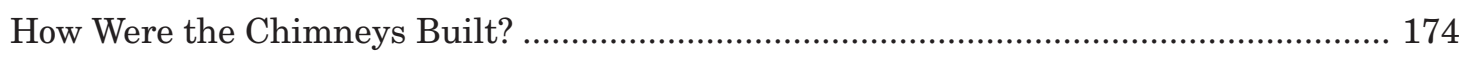

Marked Bricks Associated with the Big House Chimneys............................................ 175

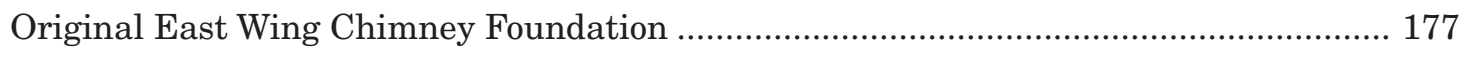

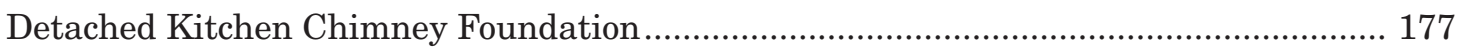

Previous Investigations................................................................................ 177

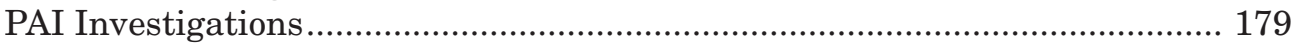

Comparison of the Levi Jordan Chimney Foundations.................................................. 182

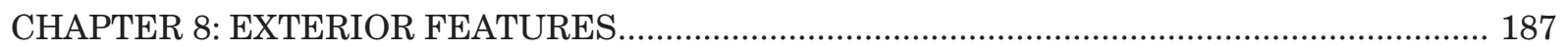

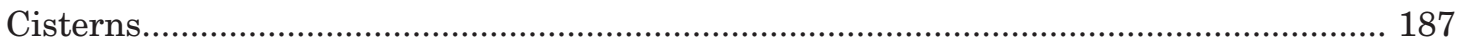

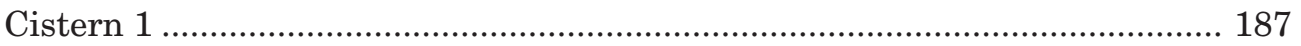




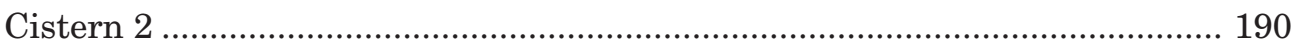

Interpretive History of the Big House Cisterns ............................................. 195

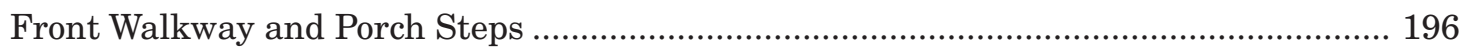

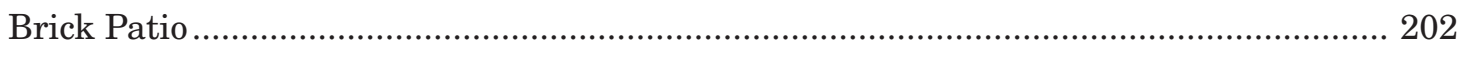

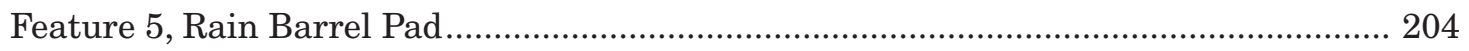

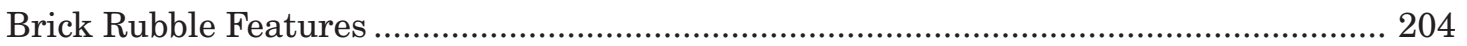

Feature 9, Eastern Brick Rubble Concentration ............................................ 204

Feature 32, Northern Brick Rubble and Artifact Scatter............................... 207

Feature 14, Small Brick Cluster.................................................................... 213

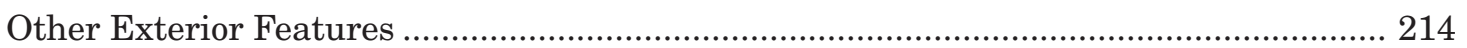

Feature 21, Buried Container..................................................................... 214

Feature 33, Seashell Concentration .......................................................... 214

CHAPTER 9: CONCLUSIONS AND RECOMMENDATIONS ................................................. 219

When Was the Levi Jordan House Built? ....................................................................... 220

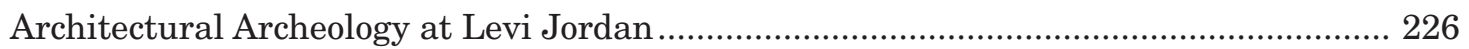

Material Culture at the Plantation House ................................................. 228

The House Foundation and Its Piers.............................................................. 228

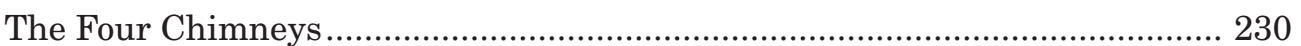

Exterior Features and Activity Areas ............................................................. 231

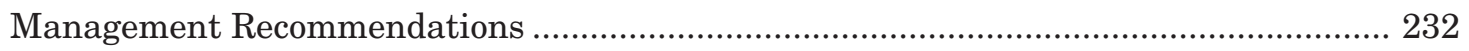

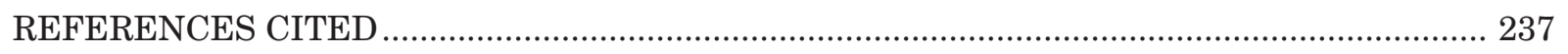

APPENDIX A: Proton Magnetometer and Ground-Penetrating Radar Surveys......................... 247

APPENDIX B: Wood Identification of Structural Piers .............................................................. 257

APPENDIX C: Preliminary Inventory of Cultural Materials Recovered .................................... 261 


\section{LIST OF FIGURES}

1.1. Location map of the Levi Jordan Plantation State Historic Site ...................................... 2

1.2. Photographs of the Levi Jordan plantation house taken in March 2006 .......................... 4

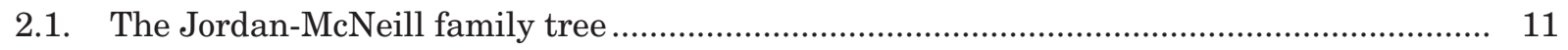

2.2. Map of previous archeological investigations at the Levi Jordan Plantation by the University of Houston from 1986 to 2002, the Texas Parks and Wildlife Department in 2003, and the Center for Archaeological Studies at Texas State University in 2005

2.3. Closeup map of previous archeological investigations in and around the Levi Jordan Plantation house by the University of Houston, the Texas Parks and Wildlife Department, and the Center for Archaeological Studies at Texas State University

2.4. Map showing the locations of University of Houston excavations in the "backyard" of the main house.

2.5. Site map of structures and features at the Levi Jordan Plantation, ca. 1990 ................... 32

2.6. Site map of structures and features at the Levi Jordan Plantation, ca. 1998 .................. 33

2.7. Closeup map showing structures and features in the main house area, ca. 1998.............. 34

2.8. Site map of structures and features at the Levi Jordan Plantation, ca. 2005 .................. 35

2.9. Site map of hypothesized buildings and features in the yard area north of the original plantation house.

3.1. First-floor plan of the Levi Jordan house showing the rooms and differentiating the original antebellum house from the later twentieth-century additions ....................... 42

3.2. Architectural diagram of pier and beam foundations .................................................... 44

3.3. Map showing the 69 house foundation piers documented for the Levi Jordan house.

3.4. Map of Prewitt and Associates, Inc., Phase I excavations at the Levi Jordan Plantation

3.5. Map of archeological features investigated during Phase I............................................ 49

3.6. Map of archeologically sensitive areas identified after PAI's Phase I archeological investigations

3.7. Photographs of the Levi Jordan house raised and supported by steel beams on wooden cribbing structures

3.8. View underneath the raised structure looking west down the row of piers along the north wall of the original plantation house.

3.9. Map of the Phase II excavations at the Levi Jordan Plantation ....................................... 63

3.10. Map of archeological features investigated during Phase II ........................................... 64

3.11. Map showing location of electrical line trench excavation ............................................... 66

3.12. Comprehensive cultural resources map of the Levi Jordan plantation compiled by the Texas Parks and Wildlife Department and Prewitt and Associates, Inc.

3.13. Closeup section of the comprehensive cultural resources map showing the structures and archeological excavations in and around the plantation house

4.1. Aunt Eula's map of the Levi Jordan plantation drawn in 1982 as part of the National Register nomination.....

4.2. Historic photographs of the Levi Jordan house showing changes to the front facade through time. 
5.1. Map of anomalies in the ground-penetrating radar survey around the Levi Jordan house

5.2. Plan map of the north-south foundation beams and selected east-west

floor joists underneath the original Levi Jordan house

6.1. Map of the Phase I foundation pier designations by Prewitt and Associates, Inc.

6.2. Map of foundation piers assigned binomial designations by the Phoenix 1 restoration contractors

6.3. Map of foundation piers beneath the original antebellum house, with binomial numbers assigned by Prewitt and Associates following the restoration contractors' numbering system

6.4. Composite drawings of the four corner pier profiles showing variations in timber remnants and brick pier pads 109

6.5. Pier 1 at the southwest corner of the main house, facing south...................................... 110

6.6. Pier 2 profile along its southern edge as exposed in Unit D7 ......................................... 111

6.7. Overhead view of the bottom layer of bricks in the Pier 2 foundation pad ....................... 113

6.8. The 1853 U.S. one-dollar gold coin, front and back sides, found in the Pier 2 brick pad.

6.9. Photographs and map of the northeast corner Pier 4 115

6.10. Photographs and profile of the "triplet" Pier 33/34/35 at the northwest corner of the antebellum house.

6.11. View west of the line of piers under the north wall of the original plantation house

6.12. Views of the bottom-course brick pads that served as footings for original piers along the north wall of the antebellum house.

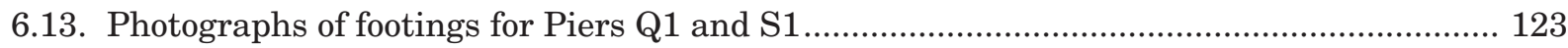

6.14. Photograph and profile of Pier 3 from the Phase I investigation ....................................... 125

6.15. Plan map and photograph of the Pier 3 footing at 12 to 16 inches below the surface 126

6.16. Profile and photograph of Pier 38 from the Phase I investigations …............................... 128

6.17. The Pier 38 brick footing at 13-16 inches below the surface 129

6.18. Feature 29, an intact brick footing for an original pier along the south wall of the antebellum house.

6.19. Overhead view of Pier H1 showing the large oak post sitting on the brick rubble zone 131

6.20. The square-cut oak block piers underneath the original house ....................................... 134

6.21. View of the interior pier posts under foundation Beam D of the original house................ 136

6.22. Map of possible pier features found around the original Levi Jordan plantation house

6.23. Views of possible pier Features 25,26 , and 27 north of the original house

6.24. Plan, profile, and photograph of Feature 20, a possible pier feature on the north side of the Levi Jordan house.....

6.25. Feature 28, a possible pier posthole and brick footing.

6.26. Possible pier Features 12 and 17

6.27. Map showing the locations of Features 13, 18, and 19 at the southwest corner of the original house 
6.28. Historic photograph that shows a possible deck or porch structure on the west side of the Levi Jordan house

6.29. Photograph and profile of Feature 13, a possible west porch pier..................................... 150

6.30. The perforated white metal disc recovered from the fill in possible pier Feature 13 151

6.31. Interpretive map of piers associated with the antebellum house ...................................... 153

6.32. Map of the original brick footings for the Group 1 piers of the Levi Jordan house............. 156

7.1. PAI crew working on the east chimney under the raised house ...................................... 164

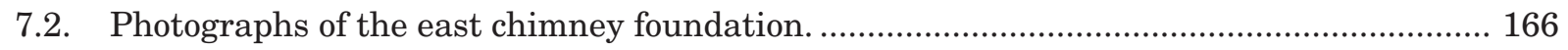

7.3. Profile drawing of the west wall of the east chimney foundation, looking east................... 167

7.4. Photographs of the west chimney spread footing at the fifth course from

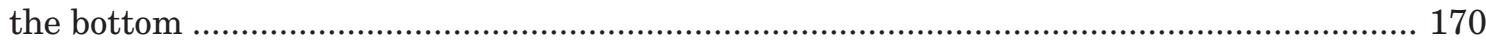

7.5. Profile drawing of the east wall of the west chimney foundation, looking west................. 171

7.6. Photographs of the Feature 24 artifacts on the south side of the west chimney

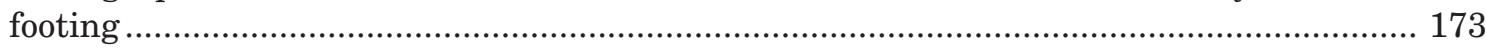

7.7. View of the compacted soil beneath the bottom course of footing bricks of the

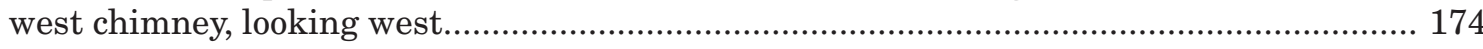

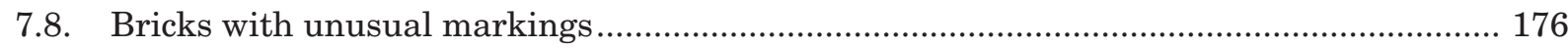

7.9. Map of the original east wing chimney foundation showing the two $3 \times 3-\mathrm{ft}$ excavation units dug by Center for Archaeological Studies archeologists in 2005 ............. 178

7.10. Photographs of the detached kitchen chimney foundation............................................... 180

7.11. Map of the detached kitchen chimney foundation ...................................................... 181

7.12. Hypothetical north-south profile reconstruction of the detached kitchen

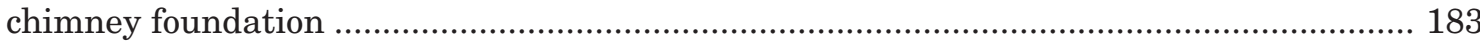

8.1. Map of investigated exterior features around the Levi Jordan house ............................... 188

8.2. Closeup map of the backyard features, including the two cisterns and the brick patio

8.3. Overview photograph of the backyard cisterns, looking southwest, before the removal of the twentieth-century additions ..................................................................... 190

8.4. Photograph and profile of Unit N1 exposing the east wall of Cistern 1 ........................... 191

8.5. Photograph and profile of Unit N2 exposing the west wall of Cistern 1............................ 192

8.6. Photograph and profile of Unit N3 exposing the south wall of Cistern 1 ........................ 193

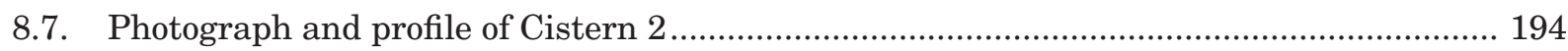

8.8. Photographs of the front walkway and front porch steps, looking north ........................... 197

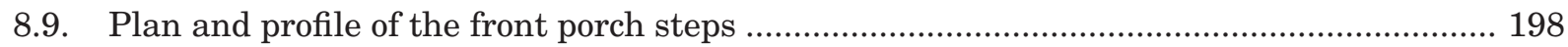

8.10. Photographs of the backyard brick patio exposed in archeological excavations ................ 203

8.11. Map of the Feature 5 brick concentration interpreted as a possible rain barrel pad.......... 205

8.12. Map of the Feature 9 brick rubble concentration on the east side of the east wing............ 208

8.13. Map of the Feature 32 brick rubble and artifact scatter .............................................. 211

8.14. Photograph of the Feature 14 brick cluster, looking north, with the southeast corner pier of the original plantation house in the background ......................................... 213

8.15. Photographs of the Feature 21 buried iron container in Unit N5 ................................... 215

8.16. Photograph of selected seashells recovered from Unit G2 ............................................. 217 
9.1. Map of the Levi Jordan house and yard as it might have looked in the

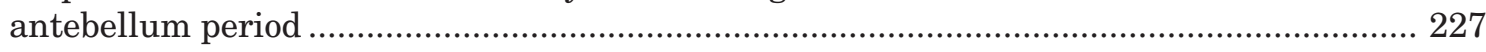

A.1. Map of remote sensing survey grids around the Levi Jordan house.................................. 250

A.2. Comparison of GPR and magnetometer survey results................................................. 251

A.3. Comparative view of GPR data depicting five horizontal slices ........................................ 252

A.4. Closeup view of GPR survey data for horizontal Slices 2 and 3 with anomaly

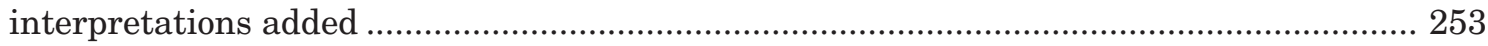

A.5. Closeup view of GPR survey data for horizontal Slices 4 and 5 with anomaly

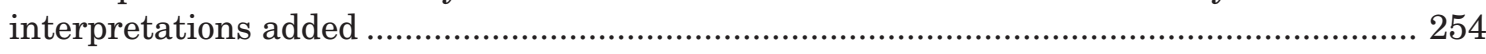




\section{LIST OF TABLES}

2.1. Chronology of hurricanes, storms, and major flooding events that impacted Matagorda, Galveston, and Brazoria Counties area between 1850 to 1961 .

2.2. Chronology of key events in the history of the Levi Jordan Plantation, with an emphasis on the construction, modifications and additions, damages, and repairs made to the big house.

2.3. Annotated list of historical and archeological reports, articles, and websites on the Levi Jordan Plantation

3.1. Features investigated by Prewitt and Associates, Inc., for the Levi Jordan Plantation House Stabilization Project in 2010 and 2011.

3.2. Features recorded at the Levi Jordan Plantation by the Center for Archaeological Studies in 2005 .

4.1. Occupant, owner, and legal history of the Levi Jordan Plantation

5.1. Summary of foundation beam and floor joist sizes and saw blade marks in the original Levi Jordan plantation house

6.1. Summary of house foundation piers associated with the original Levi Jordan plantation house and subsequent twentieth-century additions ........................................ 92

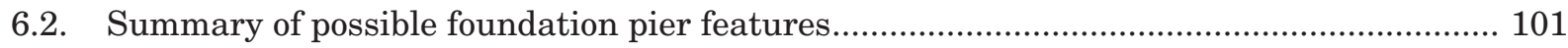

6.3. Summary of foundation piers by group and inferred age ............................................... 154

6.4. Summary of the original piers associated with the antebellum house .............................. 158

7.1. Summary of attributes and size data for four chimney foundations at the Levi Jordan Plantation

8.1. Description of bricks in the front porch steps ............................................................... 200

8.2. Summary of artifacts from the Feature 9 brick rubble concentration ............................... 209

8.3. Summary of artifacts from the Feature 32 brick rubble and artifact scatter.................... 212

B.1. Levi Jordan Phase II excavations wood samples from piers ............................................ 259

C.1. Summary of recovered cultural materials by phase for the Levi Jordan Plantation House Stabilization Project, 2010 and 2011.

C.2. Master table of artifact provenience and identification for the Prewitt and Associates, Inc., investigations at the Levi Jordan Plantation (TABLE IN ELECTRONIC FORMAT ONLY) 


\begin{abstract}
The Levi Jordan plantation house is one of the few antebellum plantation structures to have survived in Brazoria County. It is the only standing structure associated with the plantation, which began operating in 1848 and was occupied continually up through the 1990s. The original house, built in the early 1850 s using slave labor, was a $20 \mathrm{x} 60$-ft two-story wooden frame structure. It was altered many times during its long occupation, often due to hurricane damage. A portion of the Levi Jordan Plantation was acquired by the State of Texas in 2002 and managed by the Texas Parks and Wildlife Department until 2008, when the Texas Historical Commission took over its management. By then, the 160-year-old plantation house had suffered greatly and was in bad condition. The Texas Historical Commission began plans to stabilize and restore the historic house. Prewitt and Associates archeologists were contracted to conduct the archeological investigations associated with this work.

The stabilization project included the permanent removal of the twentieth-century additions, hydraulic lifting of the antebellum house, removal of the original foundation piers, and installation of a new concrete perimeter foundation. The two original brick chimneys were removed and reconstructed. The investigations, conducted in 2010 and 2011, documented the following features: 2 cisterns, 2 chimney footings and 39 foundation piers associated with the plantation house; a chimney footing associated with an east wing behind the house; a chimney foundation associated with a former detached kitchen behind the main house; a brick patio and walkway associated with the original house; two large brick rubble concentrations and a small brick cluster; and a possible rain barrel brick pad. Other features examined were 15 possible piers that may be associated with the original house, the original east wing, a possible west wing, a south porch, a west porch, and an east porch.

The archeological investigations revealed many details about the architecture of the original plantation house and subsequent additions. The evidence provides a better understanding of the building construction sequence and insights into the complex evolution of the Levi Jordan plantation house over its ca. 160-year existence. The most significant find is an 1853 gold coin found in the brick pad at the bottom of the southeast corner pier. This is almost certainly a date coin that was placed in this location by Levi Jordan or a master builder in a cornerstone foundation rite, and it provides an accurate date for the beginning of the house construction.
\end{abstract}

\title{
CURATION
}

The archeological records and collected artifacts from previous investigations, originally curated by the Texas Parks and Wildlife Department, have been transferred to the Texas Historical Commission for permanent curation. The archeological records and artifacts from the current investigations will also be submitted for permanent curation to the Texas Historical Commission repository in Austin. 


\section{ACKNOWLEDGMENTS}

This project represents the culmination of efforts by many people, including archeologists, historians, Texas Historical Commission staff, family descendants, architects, and construction contractors.

At Prewitt and Associates, archeologists Jennifer McWilliams and Doug Boyd served as coprincipal investigators. During Phase I, Ms. McWilliams was assisted by Don Badon, Mark Holderby, Tessa Noble, Matt Carter, Aaron Norment, and Rob Thrift. During Phase II, Aaron Norment, Tim Griffith, Mark Holderby, and Matt Carter assisted Ms. McWilliams in the field. The investigations at the Levi Jordan Plantation could not have been completed without the skills of these archeologists, whose effort, time, and sacrifice is greatly valued.

The Texas Historical Commission funded this project, and several people from the commission deserve special thanks and recognition. Brett Cruse, sites supervisor for the Historic Sites Division, managed the project. Bryan McAuley, the site manager for the Levi Jordan Plantation State Historic Site, was extremely knowledgeable about the site, and his assistance is especially appreciated. Onsite staff Dusty Fritts and Amanda McVay also provided invaluable help during our fieldwork. They all were supportive, friendly, and enthusiastic, supplying us with whatever we needed to get the job done.

Tiffany Osburn and Bill Pierson with the Texas Historical Commission's Archeology Division deserve thanks and recognition. Prior to our fieldwork, Osburn conducted a ground-penetrating radar survey, and Pierson completed a proton magnetometer survey. The results of these remote sensing efforts provided us with important archeological data that helped guide our work.

Architect John Volz and his staff at Volz and Associates, Inc., gave us information, advice, and support throughout the course of the project. They provided us with detailed maps and drawings that were invaluable for our work. They also conducted the Phase I wood analysis.

During the course of this archeological project, I conducted informal interviews at the Levi Jordan Plantation with five people. Dr. Ken Brown of the University of Houston graciously toured the yard space with Bryan McAuley and me. He offered his extensive knowledge of the University of Houston excavations and his understanding of the original house layout. Two Jordan family descendants, Mike Martin with his wife Ruth, and Bruce Gotcher with his wife Denise, provided valuable personal memories, family stories, and access to historic family photographs that we had not seen.

Archeologist Margaret Howard with the Texas Parks and Wildlife Department shared her experiences, interpretations, notes, and photographs from her previous investigations at the plantation. During the data analysis phase, Archeological Laboratory Supervisor Aina Dodge opened the laboratory and records to me, allowing me to review Brown's research files and artifact collection housed at Texas Parks and Wildlife. Everyone at the agency's Archeology Division was very helpful and open to sharing the Levi Jordan resources with us, despite the fact that they were still in the process of transferring the site records and information to the Texas Historical Commission.

As soon as the Phase I archeological investigations ended, it was apparent that decisions regarding the Phase II fieldwork would need to be made quickly to expedite the coordination and not delay the much-needed repairs to the Levi Jordan house. Consequently, a meeting was held on November 4, 2010, between Prewitt archeologists (McWilliams and Boyd), Volz and Associates (John Volz), and personnel from various Texas Historical Commission divisions (Donna Williams, Glenn Reed, Ellen Colfax, and Brett Cruse with Historic Sites; Stan Graves and Kim Barker with Architecture; Mark Denton and Jim Bruseth with Archeology). This meeting was an important 
step in the decision-making process with respect to evaluating the Phase I archeological data and determining the scope of the Phase II archeological work.

For the Phase II investigations, we coordinated our work schedule with Phoenix 1, a Dallasbased contractor specializing in historic preservation. Preliminary planning was coordinated with Dale Sellers, but the fieldwork scheduling and day-to-day interactions were coordinated with Jeff Maynor and Raymond McKittrick. Mr. McKittrick was always helpful, and we are grateful for his attention to detail, scheduling efforts, knowledge, and sincere interest in the preservation of the site.

At Prewitt and Associates, Sandy Hannum digitized the previously published site maps and compiled them into a comprehensive GeoPdf map that could instantly generate a wide variety of graphics for the architects and restoration specialists, site manager, and field archeologists. Laboratory supervisor Rob Thrift processed and inventoried the artifacts and prepared them for curation, and Karen Gardner managed the overall lab operations. Elaine Robbins edited the report, and Brian Wootan and Ms. Hannum drafted the figures. Their skills and dedication are greatly appreciated.

Jennifer K. McWilliams Co-Principal Investigator 



\section{INTRODUCTION}

The Levi Jordan Plantation State Historic Site is a 92.37-acre site in Brazoria County, Texas. The site lies ca. six miles southwest of Brazoria, Texas, just west of the intersection of FM 521 and CR 316 and close to the small town of Sweeny (Figure 1.1). The Texas Parks and Wildlife Department (TPWD) acquired 92.37 acres of the original plantation-including the Jordan family home-from descendants of the family in 2002 (Howard 2003b:1, 5). In 2007 the Texas Legislature transferred the historic site property to the Texas Historical Commission (THC), which took over the property in 2008 .

TPWD had not been able to secure funding for restoration work, and by the time THC took over the management of the Levi Jordan property, the original plantation house was in dire need of structural repairs. THC made the stabilization and restoration of the structure one of its top management priorities, and they initiated a contract with Volz and Associates, Inc., an architectural firm in Austin, Texas, that specializes in historic preservation. In 2009, Volz and Associates began doing measured architectural drawings along with construction drawings and plans for structural stabilization (Volz and Associates, Inc. 2012). THC then contracted to have Prewitt and Associates, Inc. (PAI) conduct Phase I archeological investigations around the exterior of the structure in July 2010, and the field investigations were completed in the fall. This was quickly followed by the Phase II archeological investigations underneath the structure, which were contracted in March 2011 and completed in September of that year. ${ }^{1}$ The PAI archeological investigations were conducted to assist THC in complying with the Texas Antiquities Code (Texas Natural Resources Code of 1977, Title 9, Chapter 191) and were authorized under Texas Antiquities Permit No. 5720.

The original Levi Jordan Plantation house, a two-story Greek Revival structure, is the only original antebellum building that is intact on the property (Figure 1.2). The wood-frame house measures 20x60 ft, with its long axis oriented east to west. A one-story addition on the back of the house dates to the early twentieth century, and may have been added soon after the great 1901 hurricane that destroyed Galveston. The original house follows the typical Greek Revival pattern, with two chimneys on opposite ends of the house that are completely enclosed within the home's exterior walls (McAlester and McAlester 1984:178-195). ${ }^{2}$ Although the precise construction date of the house is not documented in historical records, Levi Jordan acquired the property in 1848, and the house was completed by 1857 (Freeman 2004:107-113; Leezer 2006:22-26). The Texas State Historical Marker (No. 9570) at the site states: "Home built 1848-1851 by slave labor," but other evidence suggests that these dates are incorrect. Most archival evidence suggests that the house was built in the 1850s and was occupied more or less continually until TPWD acquired the property in 2002 (Leezer 2006:19, 26, Table 3-1). In this report, we present archeological evidence that

\footnotetext{
${ }^{1}$ The contractual agreements for this work are Work Authorization No. 808-10-0815-04 for the Phase I investigations and Work Authorization No. 808-10-0815-06 for the Phase II investigations.

${ }^{2}$ In contrast, on many styles of nineteenth-century houses, the chimney was built as an external feature.
} 


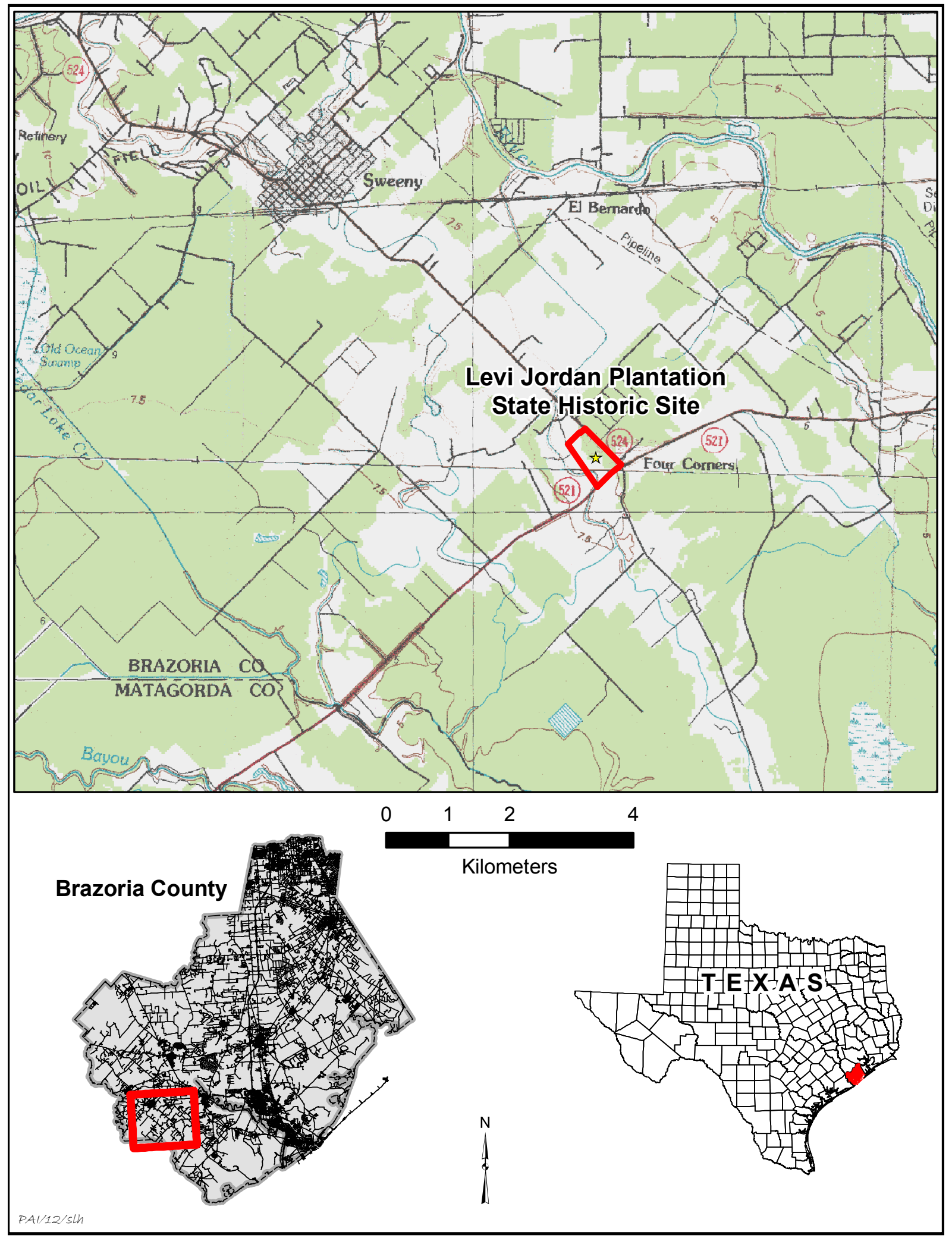

Figure 1.1. Location map of the Levi Jordan Plantation State Historic Site. 
strongly suggests that 1853 is the date when the house construction began.

The Levi Jordan house, like many nineteenth-century structures in hurricane-prone Brazoria County, has been damaged by many major hurricanes. Although periodic expansions were made to accommodate the various occupants, the major structural changes and renovations are linked to hurricanes. This has resulted in a complex history of the house over its 160-year existence. The many additions, renovations, and remodeling that occurred are mentioned in passing in various historical records, but the details of these episodes are largely undocumented. This creates a challenge in interpreting the archeological remains associated with the plantation house.

PAI's archeological investigations were specifically aimed at documenting, as accurately as possible, the construction sequence and evolution of the original plantation house through time, including such features as the cisterns, brick patio, and possible original wings on the back of the house; replacement additions in the backyard; the various incarnations of the front porch; and other porches and brick walkways around the house. An important part of the archeological work involved differentiating the piers and chimneys of the original house from those of later additions. Because the structure had to be raised off its foundation in preparation for the installation of a new concrete perimeter foundation and chimney pads, the second phase of work allowed a rare opportunity to investigate archeological deposits and architectural features beneath the structure.

Levi Jordan owned 81-98 enslaved Africans and African Americans by the early 1850s (Leezer 2006:Table 3-21). It is certain that the slaves would have molded all of the handmade bricks used in the construction of the chimneys, patio, and walkways around the main house, as well as build their own slave quarters. The white owners would have overseen the building of the original plantation house, but most of the construction would have been done using slave labor. Because some of the archeological findings in the slave quarters at Levi Jordan are interpreted as evidence of African spiritual beliefs (Brown 1994, 2003, 2004, 2005b, 2012; Brown and Brown 1998; Brown and Cooper 1990), we considered the possibility that the slave laborers might have placed spiritual offerings in specific parts of the main plantation house during its construction or while it was occupied. There is abundant evidence to suggest that enslaved peoples placed or buried conjuring or hoodoo objects in key locations in slave quarters and in plantation owner's houses, especially near fireplaces, in building corners, or under doorways and windows. (See Chapter 2 for a discussion of material culture linked to African American spiritual beliefs and rituals.) For these reasons, one of the stated goals of the PAI archeological research was to look for possible evidence of African spiritual beliefs associated with the Jordan house. $^{3}$

\section{PROJECT OVERVIEW}

Restoration of the 1850s plantation house began in earnest with the official transfer of the property to THC, which occurred in January 2008. At that time, Volz and Associates was contracted to oversee the stabilization and restoration of the structure. The firm determined that the following improvements were necessary (Volz and Associates 2011):

- Removal and reconstruction of the two remaining original chimneys

- Repair and stabilization of the framing

- Replacement of original oak timber piers with a continuous concrete foundation

- Eventual porch reconstruction

These tasks dictated the areas that were at risk of being damaged or destroyed during the stabilization and reconstruction work or from the weight of the cribbings necessary to elevate the house off its foundation. PAI investigated the following buried features in those areas:

\footnotetext{
${ }^{3}$ Useful discussions of recognizing and interpreting "Africanisms" (evidence of African-derived spiritual beliefs) in historic sites are provided by Joyner (2003), Leone and Fry (2001), and Wilkie (1997). Brown (2012) discusses at length the material evidence for "African retentions" at the Levi Jordan Plantation in his comprehensive draft report (still unpublished) on the University of Houston archeological investigations.
} 

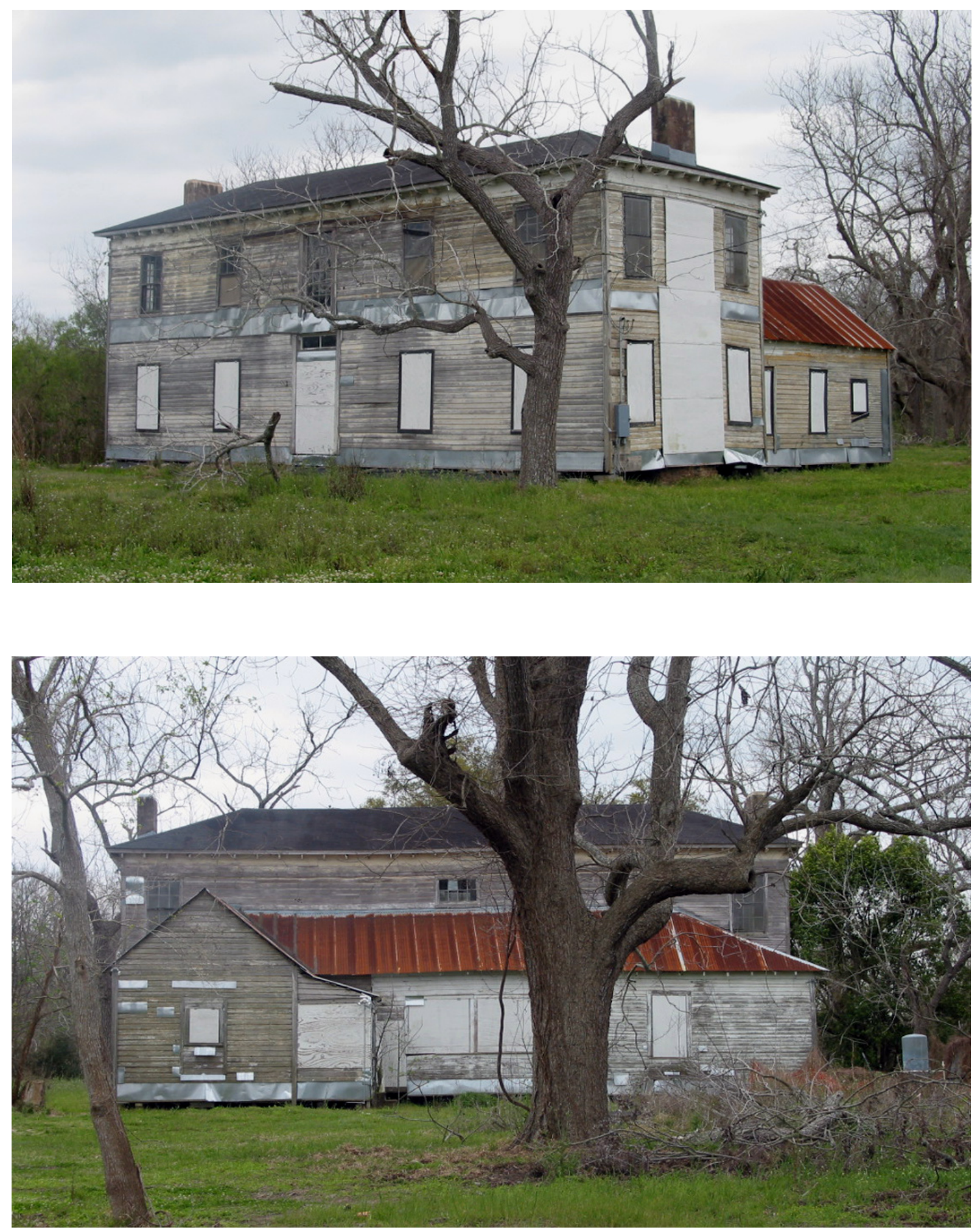

Figure 1.2. Photographs of the Levi Jordan plantation house taken in March 2006. (Top) View of the front facade, looking northwest. Note the twentieth-century east wing on the right. (Bottom) View of the back facade looking south. Note the twentieth-century additions all along the back of the original house. Photographs are from the Texas Parks and Wildlife Department collection, courtesy of the Texas Historical Commission. 
- Cistern 1, a buried underground cistern that had been razed to ground level.

- Cistern 2, an underground cistern with aboveground shoulder, neck, and mouth.

- Two chimney foundations associated with the original antebellum house, one on the east side and one on the west side.

- The remnant chimney foundation identified as the east wing chimney.

- The remnant chimney foundation identified as the detached kitchen chimney.

- 54 foundation piers classified as:

- 39 structural piers associated with the original house and its additions

- 15 possible piers associated with the house and possible porches

The piers selected for investigation were chosen for two reasons. First, some of the original house piers, including all four corner piers, were investigated because they would be destroyed by the installation of the new concrete foundation. Second, piers that had potential to reveal architectural details and the construction sequence of the plantation house were investigated. These included those associated with the east wing on the back of the house, a possible west wing that may have been attached to the back of the house, and a porch attached to the front (southwest corner) of the house.

The work presented in this report is the culmination of two phases of fieldwork conducted by PAI personnel. Archeological data collected was interwoven with data from previous excavations. Historical records compiled by previous researchers (e.g., Freeman 2004; Leezer 2006; Platter 1961) and a published antebellum diary (Raska and Hill 2009) provided a solid foundation for this work, but PAI archeologists also gathered additional historical data. Building on some of the previous oral history research (e.g., Wright 1994, 1998), McWilliams conducted interviews with descendants of the Jordan family. PAI also conducted a comprehensive review of photographs of the Levi Jordan house that show the house at different times in its history. These photographs were particularly helpful in defining changes in architectural and house-related features.

PAI's fieldwork was completed in two phases in 2010 and 2011. Phase I was conducted
September 27-October 22, 2010, and Phase II was conducted August 15-September 9, 2011. The Phase I archeological investigations concentrated on two primary tasks: (1) investigation of an underground cistern behind the house that appeared on some maps, and (2) subsurface testing of the plantation house foundation around the house exterior. Some landscape features were also investigated to supplement interpretations of improvements around the house. They focused on seeking evidence of a front porch, a patio and a brick-paved walkway on the back of the house, and other possible structures in the backyard.

In the interim between the end of the Phase I work and the beginning of the Phase II investigations, a map of sensitive areas was created to help protect buried archeological remains from damages during the house stabilization. In addition, several meetings were held between PAI, Volz and Associates, and THC to plan the Phase II investigations. As a result of these meetings, the following decisions were made:

- The Phase I and Phase II archeological investigations would be presented in a single report;

- The Phase II work would focus on features, both architectural and non-architectural;

- Because the artifacts from most contexts were of mixed ages, from the 1850 s to $1990 \mathrm{~s}$, and heavily dominated by twentieth-century materials, a standard artifact analysis was not warranted. A comprehensive inventory of recovered artifacts would be created, but it would focus on describing and interpreting materials associated with nineteenthcentury features;

- The Phase II work would include complete excavations of the chimney foundations and many structural piers associated with the original antebellum house. Additional work would focus on selected piers from the twentieth-century additions, as well as possible features in the yard area north of the antebellum house.

Before PAI began the Phase II archeological work, the restoration architects and contractors removed the twentieth-century additions, implemented procedures to protect the archeological 
remains, and raised the entire $20 \mathrm{x} 60-\mathrm{ft}$ original plantation house off of its foundation piers. To accomplish the latter, they placed long steel beams underneath the structure (three beams running north to south) and used a hydraulic system to lift the house and place the beams on heavy wooden cribbing. Once the house was raised, there was about $6 \mathrm{ft}$ of clearance under the entire structure. This enabled PAI archeologists to easily access the piers and chimney foundations under the house and allowed the restoration contractors to then remove all the perimeter piers and replace them with a continuous poured concrete foundation.

The Phase II work investigated the architectural features underneath the house. This phase focused on three tasks: (1) complete exposure of the foundations of the east and west chimneys; (2) excavation of many of the foundation piers; and (3) investigations along the north facade of the original house, which was the backyard before the addition was built. The original house piers and chimney foundations were targeted because they would be completely destroyed during the structural stabilization.

\section{REPORT ORGANIZATION}

This report is organized into nine chapters and three appendixes. Chapter 2 provides a brief history of the Levi Jordan Plantation and a summary of the previous archeological investigations. It includes two useful new documents: an updated Levi Jordan family tree and a table of hurricanes that have impacted the plantation in the last 160 years. The previous investigations at the plantation (conducted by the University of Houston, the Center for Archaeological Studies at Texas State University, and TPWD) are described to provide background information for understanding the nature of the site and the current investigations.

Chapter 3 provides a summary of THC's Levi Jordan structural stabilization project and describes the methods used and work accomplished during the Phase I and Phase II investigations. This summary highlights the sequence of events as the archeological project unfolded and explains the logic behind the way the investigations were organized.

Chapter 4 is an architectural history of the Levi Jordan plantation house and the immediately surrounding area based on written histories using primary archival documents, oral histories by knowledgeable informants, and historical photographs. The family histories-including Sallie McNeill's diary (Raska and Hill 2009) and interviews with former occupants-provide a wealth of information not available anywhere else. The information is sometimes confusing and occasionally contradictory. But when taken in context with archival records and historical photographs, multiple lines of evidence provide better support for some important interpretations of family history and the chronology of the improvements on the plantation.

Chapter 5 reports the results of three studies. The first is the proton magnetometer and ground-penetrating radar (GPR) surveys. THC archeologists conducted prior to PAI's field investigations. These studies, particularly the GPR survey, provided important evidence of buried features that was useful in the PAI investigations. The second study is an analysis by PAI of the wooden structural foundation of the original plantation house in relation to the in-ground features (piers and chimneys). Once the house was raised and the bottom of the structure could be examined, it was clear that the construction of the supporting wall beams, floor beams, and floor joists was intimately related to the locations and configuration of the foundation piers and chimney footings. The third study, by Leslie Bush, identifies the tree species represented in a selection of the original wooden piers.

The archeological features encountered by PAI are described and interpreted in Chapters 6,7 , and 8. Chapters 6 and 7 examine the architectural features that are directly associated with the original antebellum house and its twentieth-century additions, with Chapter 6 covering the foundation piers and Chapter 7 covering the chimney foundations. Chapter 8 examines the outside structures such as the two cisterns behind the house, a brick patio in the back of the house, a walkway in the front of the house (originally brick and later capped with concrete), two large brick rubble features, and a possible rain barrel pad. Some of these external features that were outside the original antebellum house were subsequently covered over by the twentieth-century additions.

Chapter 9 offers a summary of the archeological investigations and conclusions pertaining to the history of the Levi Jordan Plantation. The first section weaves all of the archeological and 
historical data into an interpretive discussion of when the plantation house was built, focusing on the new archeological evidence indicating 1853 as the construction starting date. The second section summarizes the architectural archeology and presents interpretations of what was learned from the investigations of the foundation piers, chimney footings, and exterior features. The final section is a list of management recom- mendations for future archeological investigations targeted toward specific research goals.

Appendix A presents a summary and results of the proton magnetometer and ground-penetrating radar surveys. Appendix B presents the identification of wood samples from structural piers. Appendix $\mathrm{C}$ is the provenience database for all of the cultural materials recovered during the current investigations. 



\section{HISTORY OF THE LEVI JORDAN PLANTATION AND PREVIOUS INVESTIGATIONS}

This chapter introduces the Levi Jordan family and the history of the Jordan plantation. The historical summary is not comprehensive since extensive historical overviews have been presented elsewhere. ${ }^{4}$ Rather, the brief history is necessary to set the stage for the discussions that follow. These reviews of the family and plantation histories focus on data pertaining to the layout of the plantation house and surrounding complex, who occupied the house, and structural renovations and improvements that occurred there. These historical details, while perhaps trivial in one respect, are important for understanding the archeology and architecture of the big house and adjacent facilities. The second part of this chapter discusses the previous historic and archeological investigations at the Levi Jordan Plantation.

When Levi Jordan came to Texas in 1848 , he was one of many immigrants to the fledgling state. He brought his wife Sarah, his daughter Emily and her husband James C. McNeill, ${ }^{5}$ four grandchildren, and nine slaves. Jordan was a relative latecomer to the San Bernard River area of southern Brazoria County. The region was already "a well-developed agricultural landscape having towns, businesses, and transportation and trading systems" (Freeman 2004:107). Over the next few years, Jordan oversaw the building of the plantation house, slave quarters, a sugar mill, and other improvements. He gradually amassed wealth by producing cotton and sugar, lending money, and increasing his enslaved labor force. The Jordan family prospered up to and during the Civil War, but the plantation's value and productivity declined after the war, as it did for many such enterprises in the postwar South. Many former slaves continued to live and work on the Jordan plantation after emancipation, either as wage labor or sharecroppers. But Levi Jordan's death in 1873 brought more changes and eventually led to a split between the descendant familiesthe McNeills and the Martins-that would put

\footnotetext{
${ }^{4}$ Previous investigators have compiled extensive information on the history of Levi Jordan family and plantation. The most comprehensive historical study is an unpublished report by Freeman (2004) that includes: (1) pertinent historical background data and a research methodology; (2) contextual information on the plantations and farms of the lower San Bernard River region; and (3) a detailed history of the Levi Jordan Plantation as seen within the broader framework of Brazoria County plantation history. Most subsequent studies, such as the archeological investigation report by Leezer (2006), rely heavily on the work by Freeman, and this report is no exception. Additional information is derived from oral history sources and scholarly research (e.g., Brown 2005a:47-54; Bruner 1996; McDavid 1998; Platter 1961; Wright 1994, 1998) and the published diary of Sallie McNeill, a granddaughter of Levi Jordan who lived at the Levi Jordan Plantation from 1858 to 1867 (Raska and Hill 2009; Raska 2012).

5 James McNeill's full name is commonly identified as "James Campbell McNeill," but in correspondence with Jennifer McWilliams, Levi Jordan descendant Ginny Raska states, "You list Levi's son-in-law as James Campbell, and family stories do attribute Campbell as his middle name. However, his tombstone and the record of his marriage simply give his name as James C. I do not think that I ever came across any documentary evidence to support Campbell. Of course, Campbell was his grandmother's maiden name, so that lends support to the possibility" (Ginny Raska, personal communication 2012).
} 
the plantation in further decline and cause the freedmen to leave forever. The story of Levi Jordan plantation, including the interactions between the white and black communities, is a fascinating history unto itself that has not yet been fully told (Freeman 2004:139). Much of the plantation's history played out within the walls of the Jordan family home and in the surrounding yard. Whether it was fortuitous or fate, the Jordan house is one of the few antebellum plantation structures to have survived in Brazoria County.

The following brief review of the Levi Jordan family looks at the people who occupied the Levi Jordan property and home over the past century and a half. Figure 2.1 is the JordanMcNeill family tree, presented as a visual aid. This family tree was first published by Freeman (2004:109, Figure 4) and later by Leezer (2006:23, Figure 3-16), and the one shown here is an updated version that corrects a few minor mistakes and adds some new information. This version is expanded to include the next generation of family members, some of whom have provided oral histories that offer valuable insights into its history.

In this section, the historical facts pertaining to the Levi Jordan family are taken from Freeman (2004:108-136) unless otherwise noted. A thorough review of the family history may be found in Freeman (2004) and to a lesser degree in Leezer (2006). The Levi Jordan Plantation, like many prominent historic sites, has a long history of family folklore. Such folklore is often an odd blend of fact and fiction. An important task in understanding the history of the site is to verify the folklore in the historic record whenever possible. Often it is difficult to determine what parts of a story are valid and what parts were made up, when, and by whom. Nevertheless, in examining folklore, researchers must be careful not to disregard an entire story because parts have been exaggerated, romanticized, or embellished. Freeman (2004) relates many of the popular Levi Jordan tales and "romanticized vignettes" regarding the plantation's history-many of which were publicized in a series of newspaper articles in the 1930s and repeated over the years (Freeman 2004:137-139). She dispels many of these stories as myths that have no supporting historical data, and in some cases she traces the point at which facts were altered or added.

\section{LEVI JORDAN FAMILY HISTORY}

Levi Jordan was born in Georgia in 1793. He married Sarah Stone in 1818, and their only child, Emily, was born in 1819. The family moved to Alabama, where Emily married James C. McNeill in 1838. This marriage linked the two families that would eventually become prominent figures in the history of the Levi Jordan plantation.

Together, the Jordan and McNeill families moved to adjacent plantations straddling the Louisiana-Arkansas border, where they stayed from ca. 1840 to 1848 . During this time, the McNeills lived in a "rough, log cabin" (Raska and Hill 2009:43). Five children-Sarah ("Sallie," b. 1840), Annie Royal (b. 1842), James Calvin (b. 1844), Charles Philip (b. 1846), and Mary Emily ("Missie," b. 1848)—were born to the McNeills in Louisiana. There also may have been a first son who did not survive: Some records also include Levi Jordan McNeill, who was born in 1839 in Alabama and died in Louisiana.

Though researchers do not know exactly when the extended family moved to Texas, a Brazoria County ad valorem tax account from 1848 lists Levi Jordan as a resident landowner of 2,214 acres with nine Negroes, four wagons, and other property. Also at this time, Jordan began a successful loan business in partnership with his son-in-law, James McNeill. Documents regarding these loan transactions in Brazoria County provide researchers with a view of the financial growth of the Jordan Plantation and the extended Jordan-McNeill family.

By 1850, the value of the property had increased by one third, and Jordan owned 81 Negroes (almost equally divided between male and female), 31 horses, cattle, and other livestock. The 1850 U.S. Census record lists the property as 2,371 acres and notes that Jordan had improved 350 acres and owned a significant amount of farming equipment. Cotton was his primary crop, but Indian corn, sweet potatoes, and hay were also produced, as well as butter. Sugar cane, for which Levi Jordan later became well known, was not listed in the 1850 record.

The Jordan-McNeill loan business flourished in the early days. The McNeill family grew with the births of Emily J. "Mollie" (b. 1852) and Williams Archibald (b. 1855). James McNeill died in late 1854, which ended the partnership, but the plantation continued to prosper. Jordan 


Chapter 2: History and Previous Investigations

had 111 slaves by 1857 , and this number steadily increased over the following three years, with 115 slaves in 1858, 122 slaves in 1859, and 134 slaves in 1860. Levi Jordan was No. 6 in the list of the top 10 slaveholders in Brazoria County in 1860 (Campbell 1989:Appendix 4).

Annie Royal, James and Emily McNeill's second daughter, married Robert Furniss Martin in 1865 . The Martin family name would become tightly linked to the Jordan Plantation over the next century. Robert and Annie Martin had four children between 1866 and 1873. Two of these children-Royal Furniss Martin Jr. (b. 1866) and McWillie (also called Willie or most commonly Will; b. 1868)—would later occupy the property and eventually live in the plantation's big house.

In the last quarter of the nineteenth century, the Levi Jordan Plantation was embroiled in a series of legal disputes among various descendant families, primarily the Martins and McNeills (see Freeman 2004:135-136). The courts confirmed that the Martin family owned the northern half of the plantation (1,111 acres) and a portion of the southern half (369 acres). In 1891, the Martins subdivided the northern half of the plantation among three Martin descendants. The two tracts totaling 319 acres that went to Will Martin contained the plantation house and surrounding area. He and his wife Eloise moved into the big house sometime after 1894, and the couple had six children between 1894 and 1910. Martin owned this land (now reduced to 234.5 acres) until his death in 1937 , when it went to his widow, Eloise Masterson Martin. She died in 1946 and left her estate, undivided, to her heirs. In 1978, the Martin heirs subdivided the property, and Furniss Martin Davis received the 70.5 acres surrounding the old Jordan house. When Davis died in 1981, the property went to four heirs: his son Cleveland Davis, Jr. and his daughters Eloise Davis Lostak, Dorothy Davis Cotton, and Nancy Gale Davis. These descendants sold the property to the State of Texas in 2002.

\section{THE LEVI JORDAN HOUSE}

On pre-Civil War plantations in the South, the owner's house was usually the largest and most impressive dwelling on the plantation and was sometimes referred to as the "big house" (Leone and Fry 1999; Vlach 1993). The owner's house at the Levi Jordan Plantation was no exception. The big house survives today through a series of fortuitous historical events and the protective nature of many landowners. The house has a long and complex history that is an integral component of the history of the plantation itself. The recent stabilization of the big house, completed in 2011, marks a milestone in the history of the Levi Jordan house. But it is not the first time the house has undergone major improvements.

The big house at the Levi Jordan Plantation was probably built in the $1850 \mathrm{~s}^{6}$ (see discussion below), and it has been modified, expanded, damaged by hurricanes, and repaired many times in its 160 -year history. To interpret the archeology under and around the big house, one must first understand the structural changes that have taken place. Table 2.1 is a chronology of hurricanes, storms, and major flooding events that impacted Matagorda, Galveston, and Brazoria Counties from 1850 to 1961 . All of these events could have caused damages at the Levi Jordan Plantation, and archival records and oral histories confirm that many did. Table 2.2 is a chronology of important events in the plantation's history, derived from historical records and oral histories, with an emphasis on the construction, hurricane and storm damages, and modifications, additions, and repairs to the big house and immediate area around it.

The Levi Jordan house is a two-story woodframe Greek Revival structure with two internal chimneys. The original core dwelling has flat, uninterrupted exterior walls on all four sides. It is not know if the original house had porches and wings attached to the back, but many references

\footnotetext{
${ }^{6}$ Citing Sallie McNeill's statement that the family's previous home in Louisiana was a "rough, log-cabin," Freeman (2004:111) suggests that the McNeill's first home in Brazoria County was a log home, too. This might explain why a family friend writing about the Jordan home to Sallie in 1857 stated that "The new house is almost done..." (Raska and Hill 2009:163).
} 
Table 2.1. Chronology of hurricanes, storms, and major flooding events that impacted Matagorda, Galveston, and Brazoria Counties between 1850 to 1961

\begin{tabular}{|c|c|c|c|}
\hline Year & Month and Day & Description & Citation \\
\hline 1850 & June 27 & $\begin{array}{l}\text { “A 'severe squall' came across Matagorda Bay at } \\
\text { Indianola. }\end{array}$ & Roth (2010:16) \\
\hline 1851 & June 15-26 & $\begin{array}{l}\text { A severe storm went over Matagorda Bay, causing } \\
\text { damage at Port Lavaca and Indianola. }\end{array}$ & Roth $(2010: 16)$ \\
\hline 1853 & 1853 & $\begin{array}{l}\text { The } 1853 \text { hurricane drove some residents to "seek a } \\
\text { safer place to settle" than the coast. }\end{array}$ & $\begin{array}{l}\text { Freeman }(2004: 11 \\
\text { citing Creighton } \\
[1975: 159])\end{array}$ \\
\hline 1854 & June 24-27 & $\begin{array}{l}\text { A "minor hurricane" hit the lower Texas coast but } \\
\text { caused tropical storm conditions as far north as } \\
\text { Galveston. }\end{array}$ & Roth $(2010: 17)$ \\
\hline $1854^{*}$ & September 17-19 & $\begin{array}{l}\text { A "particularly devastating" hurricane with "strong, } \\
\text { damaging winds" reported in Brazoria; Roth (2010:17) } \\
\text { notes that crops and sugar cane were ruined. Platter } \\
\text { (1961:163) notes that "The house was under } \\
\text { construction when the hurricane hit." }\end{array}$ & $\begin{array}{l}\text { Freeman 2004:12); } \\
\text { Leezer (2006:61); } \\
\text { Kleiner (2011a); } \\
\text { Platter (1961:163); } \\
\text { Roth }(2010: 17)\end{array}$ \\
\hline $1854-1856$ & - & $\begin{array}{l}\text { "Devastating floods in } 1854 \text { were followed by unusually } \\
\text { cold winter weather in } 1855-1856 \text { and extreme drought } \\
\text { in } 1856-1859 \text { that destroyed crops for several years." }\end{array}$ & Freeman (2004:12) \\
\hline 1867 & October 2-3 & $\begin{array}{l}\text { The } 1867 \text { hurricane was an "intense and destructive } \\
\text { storm that followed the same route as the famous } \\
\text { Racer's Storm of } 1837 \text {, leaving a path of destruction } \\
\text { along the entire coast (Leezer } 2006: 61) \text {. Roth }(2010: 18) \\
\text { notes that it was considred the first "million dollar } \\
\text { hurricane in Texas, most inflicted upon Galveston." }\end{array}$ & $\begin{array}{l}\text { Roth }(2010: 18) \\
\text { Freeman }(2004: 12) \\
\text { Leezer }(2006: 61)\end{array}$ \\
\hline 1869 & August 16 & $\begin{array}{l}\text { A severe storm hit the lower Texas coast but caused } \\
\text { damages as far north as Indianola. }\end{array}$ & Roth (2010:19) \\
\hline 1871 & June & $\begin{array}{l}\text { Storms damaged property all along the upper Texas } \\
\text { coast. }\end{array}$ & Freeman (2004:12) \\
\hline 1874 & July $2-4$ & $\begin{array}{l}\text { A tropical storm (or hurricane) hit Indianola and caused } \\
\text { much damage up the coast. }\end{array}$ & $\begin{array}{l}\text { Freeman }(2004: 12) \text {; } \\
\text { Roth }(2010: 20)\end{array}$ \\
\hline 1875 & September $14-17$ & $\begin{array}{l}\text { A fall hurricane that was "one of the worst in anyone's } \\
\text { memory...devastating all crops" (Freeman 2004:128). } \\
\text { Roth (2010:22) notes that "the winds were higher and } \\
\text { harder than in 1867." }\end{array}$ & $\begin{array}{l}\text { Freeman } \\
(2004: 128) ; \text { Leezer } \\
(2006: 61) ; \text { Roth } \\
(2010: 22)\end{array}$ \\
\hline 1886 & $\begin{array}{l}\text { June } 14, \\
\text { August } 19-20, \\
\text { September } 22, \\
\text { and } \\
\text { October } 12-13\end{array}$ & $\begin{array}{l}\text { A series of storms (hurricanes) hit Brazoria; Indianola } \\
\text { was destroyed and Galveston "reaped the benefits, } \\
\text { thereby becoming Indianola's successor." }\end{array}$ & $\begin{array}{l}\text { Roth }(2010: 25) \\
\text { Freeman }(2004: 12)\end{array}$ \\
\hline $1888 * *$ & $\begin{array}{l}\text { June } 17 \text { and } \\
\text { July } 5\end{array}$ & Multiple hurricanes. & $\begin{array}{l}\text { Roth }(2010: 27) ; \\
\text { Leezer }(2006: 61)\end{array}$ \\
\hline 1899 & $\begin{array}{l}\text { Late June } \\
\text { through July }\end{array}$ & $\begin{array}{l}\text { Major floods resulting from a tropical storm in which } \\
\text { "torrential rains fell over the Brazos River basin." }\end{array}$ & $\begin{array}{l}\text { Roth }(2010: 28) ; \\
\text { Kleiner }(2011 \mathrm{a})\end{array}$ \\
\hline 1900 & September 7-9 & $\begin{array}{l}\text { The Great Storm. "The building [Jordan home] was } \\
\text { relatively intact until the } 1900 \text { hurricane, which tore off } \\
\text { a kitchen-dining room annex, ruined the first floor front } \\
\text { gallery on the south, east, and north facades, and } \\
\text { damaged the roof...the roof was replaced and the } \\
\text { kitchen rebuilt"; Brazoria recieved } 10 \text { inches of rain, } \\
\text { setting a } 24 \text {-hour rainfall record for September; the first } \\
\text { capitol building in West Columbia was destroyed; } \\
\text { Leezer notes a high correlation in broken window glass. }\end{array}$ & $\begin{array}{l}\text { Roth }(2010: 30) \\
\text { Freeman }(2003: 136 \\
\text { citing The } \\
\text { Brazosport Facts } \\
\text { and information } \\
\text { from Furniss } \\
\text { Martin Davis, } \\
(1894-1891) ; \\
\text { Leezer }(2006: 61) \\
\text { Kleiner }(2011 \mathrm{a})\end{array}$ \\
\hline
\end{tabular}


Table 2.1, continued

\begin{tabular}{|c|c|c|c|}
\hline Year & Month and Day & Description & Citation \\
\hline 1902 & June 26-July 1 & $\begin{array}{l}\text { A tropical storm brought high winds and much-needed } \\
\text { rain. The corn crops were ruined, but cotton and rice } \\
\text { were saved by the rains; a tornado broke out and blew a } \\
\text { freight train from the tracks in East Bernard, north of } \\
\text { Brazoria. }\end{array}$ & Roth (2010:31) \\
\hline $1909 * *$ & July 21-22 & $\begin{array}{l}\text { Hurricane made landfall near Valasco; the cities of } \\
\text { Quintana, Columbus, and Columbia were totaled; "a } \\
\text { caboose was thrown thirty feet from the tracks in } \\
\text { Brazoria" and the train "depot was leveled by the wind"; } \\
\text { heavy rain was also seen in Brazoria "where it was } \\
\text { needed the most." }\end{array}$ & $\begin{array}{l}\text { Roth }(2010: 32-33) \\
\text { Kleiner }(2011 \mathrm{a}) \\
\end{array}$ \\
\hline 1913 & December & $\begin{array}{l}\text { "The Brazos, Bernard, and Colorado Rivers all met and } \\
\text { produced a flood in Brazoria County such as had not } \\
\text { been experienced since the terrible flood of } 1833 . " \\
\text { Freeman notes that Brown erroneously ascribed this to } \\
\text { two floods, which "deposited } 3-6 \text { inches of silt across the } \\
\text { Quarters for at least three days or longer [based on } \\
\text { descriptions of flooding in Angelton (elev } 25 \mathrm{ft} \text { asl). The } \\
\text { Levi Jordan Plantation sits at } 25-28 \mathrm{ft} \text { asl)]." }\end{array}$ & $\begin{array}{l}\text { Freeman }(2004: 13) \\
\text { Brown }(2005 b: 14- \\
\text { 15); Kleiner (2011a) }\end{array}$ \\
\hline 1915 & August 16-19 & $\begin{array}{l}\text { Hurricane hit near Galveston. Compared to the recent } \\
1900 \text { storm, it was "said to be as strong of a storm and } \\
\text { lasted for twice as long. Winds reached } 120 \mathrm{mph} \text { " (Roth } \\
\text { 2010:34-35). The storm killed } 275 \text { people, and damage } \\
\text { estimates were as high as } \$ 50 \text { million. }\end{array}$ & $\begin{array}{l}\text { Roth (2010:34-36); } \\
\text { Kleiner (2011a) }\end{array}$ \\
\hline 1929 & - & A major flood. & Kleiner (2011a) \\
\hline 1932 & August 13 & $\begin{array}{l}\text { The } 1932 \text { hurricane. "The center of the storm passed } \\
\text { slightly east of Freeport and directly over East } \\
\text { Columbia where winds were estimated at } 100 \\
\text { mph...Forty people died in Brazoria County and total } \\
\text { damage was near seven and a half million dollars." } \\
\text { Mike Martin refers to it as "like the Civil War" because } \\
\text { "everyone had a story about it. If you survived it, you } \\
\text { had a story about it." The McFarland house, just east of } \\
\text { the Jordan house, may have blown down in this storm. }\end{array}$ & $\begin{array}{l}\text { Roth }(2010: 41) \\
\text { Martin }(2010) \\
\text { Kleiner (2011a) }\end{array}$ \\
\hline 1940 & - & $\begin{array}{l}\text { A major flood. Possibly related to the hurricane that hit } \\
\text { east of Sabine Pass on August 7, 1940, and moved } \\
\text { eastward. }\end{array}$ & $\begin{array}{l}\text { Roth (2010:44); } \\
\text { Kleiner (2011a) }\end{array}$ \\
\hline $1941 * *$ & September 23 & Hurricane. & $\begin{array}{l}\text { Roth }(2010: 44-45) \\
\text { Kleiner (2011a) }\end{array}$ \\
\hline 1961 & September $11-13$ & $\begin{array}{l}\text { Hurricane Carla. By most accounts, this storm was } \\
\text { especially devastating. The storm spawned } 26 \\
\text { tornadoes, one of which destroyed } 120 \text { buildings in } \\
\text { Galveston. But Mike Martin states that Carla did a lot } \\
\text { of damage to trees but not much damage to the } \\
\text { structures at Levi Jordan. }\end{array}$ & $\begin{array}{l}\text { Roth }(2010: 50) \\
\text { Martin }(2010) \\
\text { Kleiner (2011a) }\end{array}$ \\
\hline
\end{tabular}

\footnotetext{
* The 1854 hurricane passed about 1 mile east of the Levi Jordan Plantation, according to the National Oceanic and Atmospheric Administration (2012).

**One of three hurricanes that passed within 10 miles of the Levi Jordan Plantation (National Oceanic and Atmospheric Administration 2012).
} 
Table 2.2. Chronology of key events in the history of the Levi Jordan Plantation, with an emphasis on the construction, modifications and additions, damages, and repairs made to the big house*

\begin{tabular}{|c|c|c|}
\hline Date & Description & Citation \\
\hline 1848 & $\begin{array}{l}\text { Levi Jordan purchased } 2,221 \text { acres of land in Brazoria County. Jordan } \\
\text { probably came to the new plantation in } 1848 \text { to plant a crop, then } \\
\text { returned to Louisiana and Arkansas for his family. Ad valorem tax } \\
\text { records indicate joint ownership of the property and some business } \\
\text { interests between Levi Jordan and his son-in-law, James C. McNeill. }\end{array}$ & Freeman (2004:107-108) \\
\hline 1850-1852 & $\begin{array}{l}\text { While the property valuation and number of slaves owned by Levi } \\
\text { Jordan and James C. McNeill remained steady, the two men were } \\
\text { apparently loaning large sums of money to other people in Brazoria } \\
\text { County. It appears that the profits from these loans were later used to } \\
\text { invest in capital improvements on the Jordan Plantation. }\end{array}$ & Freeman (2004:112) \\
\hline 1853-1854 & $\begin{array}{l}\text { In } 1854 \text {, the Levi Jordan plantation experienced a } 90 \text { percent increase } \\
\text { in the property tax evaluation over the } 1853 \text { evaluation, along with the } \\
\text { sudden appearance of sugar cane as a major cash crop. Freeman } \\
\text { indicates that the construction of the sugar mill accounted for much of } \\
\text { the tax value increase, but PAI investigations suggest that the } \\
\text { construction of the plantation home contributed to the value } \\
\text { increase. }\end{array}$ & $\begin{array}{l}\text { Brown (2005a:48); } \\
\text { Freeman (2004:112-113) }\end{array}$ \\
\hline 1854 & $\begin{array}{l}\text { "The 1854 Hurricane was particularly devastating" (Freeman } \\
\text { 2004:12). It was reported that "the town of Matagorda was leveled and } \\
\text { Galveston experienced flooding from the storm surge" and that } \\
\text { Brazoria "encountered strong, damaging winds" (Leezer 2006:61). It } \\
\text { was also reported for the Levi Jordan plantation that "The house was } \\
\text { under construction when the hurricane hit" (Platter 1961:163).** }\end{array}$ & $\begin{array}{l}\text { Freeman (2004:12); } \\
\text { Kleiner (2011a); Leezer } \\
(2006: 61) ; \text { Platter } \\
(1961: 163)\end{array}$ \\
\hline $1854-1856$ & $\begin{array}{l}\text { "Devastating floods in } 1854 \text { were followed by unusually cold winter } \\
\text { weather in } 1855-1856 \text { and extreme drought in } 1856-1859 \text { that } \\
\text { destroyed crops for several years." }\end{array}$ & $\begin{array}{l}\text { Freeman (2004:12) citing } \\
\text { Creighton (1975:205), } \\
\text { Platter (1961:49), and } \\
\text { Powers (1994:75) } \\
\end{array}$ \\
\hline 1857 & $\begin{array}{l}\text { In a letter to Sarah McNeill dated August } 4,1857, \text { C. T. Nuckols (a } \\
\text { family friend) told Sarah that "The new house is almost done[.] [I]t } \\
\text { looks magnificant." }\end{array}$ & Freeman $(2004: 113)$ \\
\hline ca. 1858 & $\begin{array}{l}\text { A fire on the Jordan property destroyed a slave cabin and damaged an } \\
\text { old unoccupied hospital building. }\end{array}$ & $\begin{array}{l}\text { Freeman }(2004: 116) \\
\text { citing Sallie McNeill's } \\
\text { diary (see Raska and } \\
\text { Hill 2009) } \\
\end{array}$ \\
\hline 1860 & $\begin{array}{l}\text { In February 1860, carpenters were working to roof the "new shop } \\
\text { before the door." In April that year, construction of a "carriage } \\
\text { house" was underway "opposite the dwelling" (meaning in close } \\
\text { proximity of the main house). Sallie McNeill also noted "the existence } \\
\text { of a piazza and a porch on the house, perhaps referring to a } \\
\text { configuration in which a first-floor porch across the front facade was } \\
\text { surmounted by a smaller porch on the second floor facade." }\end{array}$ & $\begin{array}{l}\text { Freeman (2004:116) } \\
\text { citing Sallie McNeill's } \\
\text { Diary (see Raska and } \\
\text { Hill 2009). }\end{array}$ \\
\hline- & $\begin{array}{l}\text { Note that Leezer (2006:Figure 3-22) reproduced an undated } \\
\text { photograph of the Levi Jordan home that shows a large front porch } \\
\text { with a smaller second-floor balcony above it. }\end{array}$ & $\begin{array}{l}\text { Leezer (2006:Figure 3- } \\
22)\end{array}$ \\
\hline 1871-1873 & $\begin{array}{l}\text { After an especially productive year (1870), Jordan leased out his land } \\
\text { to Robert Stranger, who, during the next two years, "allowed the sugar } \\
\text { cane stock to run out and fail. In sum, he ruined the sugar at the } \\
\text { plantation," and worm blight ruined much of the cotton. }\end{array}$ & Freeman $(2004: 125,128)$ \\
\hline
\end{tabular}


Table 2.2, continued

\begin{tabular}{|c|c|c|}
\hline Date & Description & Citation \\
\hline $1873-1874$ & $\begin{array}{l}\text { After Levi Jordan died (February } 3,1873 \text { ), the McNeills began } \\
\text { repairing the rundown plantation and made some improvements to } \\
\text { the main house. They hired a painter who painted much of the } \\
\text { interior and exterior of the house and repaired "an outside gate and } \\
\text { post." Fencing lumber was purchased, and a new fence was } \\
\text { constructed. It was "six miles long and consisted of two-by-three-by- } \\
\text { six-foot cypress posts ( } 528 \text { to a mile) and } 13,860 \text { pieces of fencing } \\
\text { plank." }\end{array}$ & Freeman (2004:126-127) \\
\hline 1874 & $\begin{array}{l}\text { "One of the most devastating nineteenth-century hurricanes } \\
\text { occurred in } \mathbf{1 8 7 4} \text { when a storm hit Indianola and moved up the coast } \\
\text { toward Galveston." Numerous sugar houses in Brazoria County were } \\
\text { destroyed and "loss of life was significant" (Freeman 2004:12). Note } \\
\text { that Roth (2010:20) states the July } 1874 \text { event was a tropical storm } \\
\text { that hit Indianola rather than a hurricane. }\end{array}$ & $\begin{array}{l}\text { Freeman (2004:12); } \\
\text { National Oceanic and } \\
\text { Atmospheric } \\
\text { Administration (2012); } \\
\text { Roth (2010:20) }\end{array}$ \\
\hline 1875 & $\begin{array}{l}\text { A hurricane in the fall of } \mathbf{1 8 7 5} \text { was "one of the worst in anyone's } \\
\text { memory," and it devastated all the crops along the coast (Freeman } \\
\text { 2004:128). At the mouth of the Brazos River, "Old Velasco was leveled } \\
\text { by the Storm" and the town Indianola was destroyed (Roth 2010:21). }\end{array}$ & $\begin{array}{l}\text { Freeman }(2004: 128) \\
\text { Leezer }(2006: 61) ; \text { Roth } \\
(2010: 21 ; \text { Kleiner } \\
(2011 \mathrm{a})\end{array}$ \\
\hline 1888 & $\begin{array}{l}\text { The } 1888 \text { hurricane hit Galveston, but the extent of damages at the } \\
\text { Levi Jordan Plantation are not known. Leezer ( } 2006: 61) \text { notes that a } \\
\text { peak in broken window glass dating to this time may correlate with } \\
\text { the } 1888 \text { hurricane. The National Oceanic and Atmospheric } \\
\text { Administration ( } 2012) \text { shows this as a tropical storm when it passed } \\
\text { ca. } 3 \text { miles east of the Levi Jordan Plantation. }\end{array}$ & $\begin{array}{l}\text { Leezer (2006:61); } \\
\text { Kleiner (2011a); } \\
\text { National Oceanic and } \\
\text { Atmospheric } \\
\text { Administration (2012) }\end{array}$ \\
\hline 1900 & $\begin{array}{l}\text { The September 8, } 1900 \text { hurricane that hit the Galveston region of } \\
\text { the Texas coast is the most destructive on record. Referring to the Levi } \\
\text { Jordan house, a local informant (Furniss Martin Davis) noted that } \\
\text { "The building was relatively intact until the } \mathbf{1 9 0 0} \text { hurricane, } \\
\text { which tore off a kitchen-dining room annex, ruined the first floor } \\
\text { front gallery on the south, east and north facades, and damaged the } \\
\text { roof. Subsequently, the roof was replaced and the kitchen } \\
\text { rebuilt." Leezer (2006:61) notes another significant peak in the } \\
\text { amount of broken window glass dating to the turn-of-the-century, } \\
\text { probably a result of severe damage associated with the } 1900 \\
\text { hurricane. The National Oceanic and Atmospheric Administration } \\
\text { (2012) shows this H4 Hurricane passing ca. } 30 \text { miles east of the Levi } \\
\text { Jordan Plantation, yet the destruction was incredible. }\end{array}$ & $\begin{array}{l}\text { Freeman (2003:136) } \\
\text { citing information from } \\
\text { Furniss Martin Davis } \\
(1894-1891) \text { published } \\
\text { in the Brazosport Facts } \\
\text { (July 18, 1993); Leezer } \\
(2006: 61) \text {; Kleiner } \\
(2011 a) \text {; National } \\
\text { Oceanic and } \\
\text { Atmospheric } \\
\text { Administration (2012) }\end{array}$ \\
\hline 1913 & $\begin{array}{l}\text { December } 1913 \text { flood. "The Brazos, Bernard, and Colorado Rivers all } \\
\text { met and produced a flood in Brazoria County such as had not been } \\
\text { experienced since the terrible flood of } 1833 \text {." It is clear that this flood } \\
\text { left a significant silt deposit over the region and that this } \\
\text { depositional event is represented in the Levi Jordan deposits. But } \\
\text { previous researchers have mistakenly stated that there were two } \\
\text { floods, one in } 1913 \text { and another in } 1914 \text {. Freeman (2004:13) discusses } \\
\text { these erroneous interpretations. }\end{array}$ & $\begin{array}{l}\text { Creighton }(1975: 209) \text { as } \\
\text { cited in Freeman } \\
(2004: 13) ; \text { Brown } \\
(1990: 11 ; 2005 b: 14-15) ; \\
\text { Kleiner }(2011 \mathrm{a})\end{array}$ \\
\hline
\end{tabular}


Table 2.2, continued

\begin{tabular}{|c|c|c|}
\hline Date & Description & Citation \\
\hline- & $\begin{array}{l}\text { Local informant Ewing Martin, who was born in } 1915 \text { and lived in the } \\
\text { Jordan house as a child, remembered that by "the time I had come } \\
\text { along to remember things, [the brick] was all covered up. Now } \\
\text { there were some brick walks around the place... when I was a little } \\
\text { boy (Ewing was born in 1915), it was open because I remember playing } \\
\text { on those bricks. There was a lot of brick around there." He also } \\
\text { stated that: “...there was a brick walk that came out of the front of } \\
\text { the house, of course, the concrete wasn't there...it was a brick } \\
\text { walk...It came around the side and I was thinking it went out to this } \\
\text { place where we played...It seems like there was a little fence around } \\
\text { the house area proper, but it had a back gate and Aunt Hester used to } \\
\text { wash clothes beyond outside the fence, see, in the open area back } \\
\text { there." }\end{array}$ & $\begin{array}{l}\text { Martin (1998); see } \\
\text { Appendix B }\end{array}$ \\
\hline- & $\begin{array}{l}\text { Ewing Martin also remembers: "The old cisterns were brick. Both } \\
\text { of them were up and while we lived there my Dad got some colored } \\
\text { fellows and they cleaned that cistern out - the first one - the one } \\
\text { that is all filled up now... While we lived there, Uncle Will had a well } \\
\text { dug. Before that they were relying on the cistern, see? They had these } \\
\text { gutters that channeled water into the old brick system and we left } \\
\text { there-of course, we put a cover on it so nobody could get in it..." }\end{array}$ & Martin (1998) \\
\hline $1920 \mathrm{~s}$ & $\begin{array}{l}\text { "According to several Martin descendants, major changes to the main } \\
\text { house and Quarters area occurred around 1920. At that time a portion } \\
\text { of the back of the house was removed and replaced with an L-shaped } \\
\text { 'tenant house,' and the entire house was resided. At the same } \\
\text { time, several new fence lines, and a small plantation road were built in } \\
\text { the area of the Quarters." }\end{array}$ & Brown (2005a:54) \\
\hline 1932 & $\begin{array}{l}\text { Local informant Mike Martin referred to the } \mathbf{1 9 3 2} \text { Hurricane like one } \\
\text { would refer to "the Civil War, everyone had a story about it. If you } \\
\text { survived it, you had a story about it. The McFarland house, just east of } \\
\text { the Levi Jordan house, may have blown down in this storm.”*** }\end{array}$ & $\begin{array}{l}\text { Martin (2010); Kleiner } \\
(2011 \mathrm{a}) ; \text { National } \\
\text { Oceanic and } \\
\text { Atmospheric } \\
\text { Administration }(2012)\end{array}$ \\
\hline $1936-42$ & $\begin{array}{l}\text { Mike Martin remembered that Harry Martin "spruced up the place" } \\
\text { prior to his wedding in } 1942 \text {, after which he and his wife moved in. } \\
\text { Family photos show that he removed the upper porch, repaired } \\
\text { the lower porch, and painted. Martin said it took a lot of work to } \\
\text { repair bad wood and that Harry had to work hard to "ochre" the wood } \\
\text { (a type of wood primer or sealer). He said that his father ran a } \\
\text { telephone line to the home from Brazoria in the early } 40 \text { s for use in his } \\
\text { oil business, but he believed the house already had electricity by then. } \\
\text { One ca. } 1930 \text { s photo shows an electric panel on the southeast corner of } \\
\text { the home. }\end{array}$ & Martin (2010) \\
\hline 1961 & $\begin{array}{l}\text { Mike Martin recalls that Hurricane Carla did a lot of damage to } \\
\text { trees but not much damage to the structures. }\end{array}$ & Martin (2010) \\
\hline $\begin{array}{l}\text { Prior to } \\
1961\end{array}$ & $\begin{array}{l}\text { "The frame residence, which was constructed in 1854, was made from } \\
\text { oak timbers cut from the forest and from lumber brought across the } \\
\text { Gulf and up the San Bernard by Schooner. The mansion was unlike } \\
\text { any other in the county. It was functional and simple to the point of } \\
\text { severity and almost modern in design. The main portion of the } \\
\text { building was a two storey [sic] rectangle with a low-pitched } \\
\text { hipped roof...The roof had little overhang, exposing a minimum of } \\
\text { surface for hurricane winds to batter. At each end of the building was } \\
\text { a chimney serving two fireplaces. The design of chimney was } \\
\text { unique...A front porch on the lower floor...The house had double front } \\
\text { doors. From each end of the rear of the building a one storey } \\
\text { [sic] wing extended northward." }\end{array}$ & Platter (1961:159-160) \\
\hline
\end{tabular}


Table 2.2, continued

\begin{tabular}{|c|c|c|}
\hline Date & Description & Citation \\
\hline 1961 & $\begin{array}{l}\text { A photograph shows an inscription in the front concrete porch that } \\
\text { read: "BLT BY MR-MRS L.E. BRANNON DEC 6, 1961." The } \\
\text { Brannons were renters during the } 1960 \text { s and also replaced the front } \\
\text { doors and may have made alterations to the second-story porch. }\end{array}$ & $\begin{array}{l}\text { Unpublished photograph } \\
\text { on file at the Texas } \\
\text { Parks and Wildlife } \\
\text { Department (TPWD), } \\
\text { Austin; Bryan McAuley, } \\
\text { personal communication } \\
2010\end{array}$ \\
\hline 2002 & $\begin{array}{l}\text { TPWD acquired a portion of the Levi Jordan Plantation in two } \\
\text { separate purchases ( } 70 \text { acres and } 22 \text { acres) in } 2002 \text {. The TPWD } \\
\text { immediately began planning for the restoration of the main plantation } \\
\text { house and opening the historic site to the public. }\end{array}$ & Howard (2003a:1, 5) \\
\hline 2002 & TPWD removed the front concrete porch in August 2002. & $\begin{array}{l}\text { Unpublished photograph } \\
\text { on file at TPWD, Austin; } \\
\text { Alvarado (2002) } \\
\end{array}$ \\
\hline $2007-2008$ & $\begin{array}{l}\text { The Texas legislature transferred management of the Levi Jordan } \\
\text { Plantation from TPWD to the Texas Historical Commission, which } \\
\text { began planning for the restoration of the plantation house. }\end{array}$ & McAuley (2012) \\
\hline 2012 & $\begin{array}{l}\text { The Texas Historical Commission hosted a public celebration on } \\
\text { March } 3,2012 \text {, to commemorate the completion of the stabilization of } \\
\text { the plantation house. }\end{array}$ & $\begin{array}{l}\text { McAuley (2012); McVay } \\
\text { (2012); Raska (2012) }\end{array}$ \\
\hline
\end{tabular}

*Bold lettering is used to highlight items of architectural or archeological significance.

**This hurricane passed ca. 1 mile east of the Levi Jordan Plantation (National Oceanic and Atmospheric Administration 2012).

*** This H5 Hurricane passed ca. 50 miles east of the Levi Jordan Plantation (National Oceanic and Atmospheric Administration 2012).

suggest that such additions were present fairly early in the occupation of the house. Writing in 1961, Platter (1961:160) states, "From each end of the rear of the building a one storey [sic] wing extended northward." This suggests that there were two wing additions on the back of the house, one attached to the west end and one attached to the east.

The house was regularly described as simple and lacking the architectural lavishness often seen in antebellum plantation houses. Platter (1961:160) described it as "functional and simple to the point of severity and almost modern in design." Raska and Hill (2009:11) describe the home's simplicity as a reflection of Jordan's nature as "utilitarian rather than ostentatious." The ground floor plan consists of two large rooms flanking a central hall and staircase, with the upstairs floor plan duplicating that of the ground floor.

The construction dates of the structures on the Jordan plantation, especially the big house, are a matter of disagreement among researchers. Dr. Kenneth Brown (2005a:48) states that:
Construction of the main plantation buildings was begun in 1848 and finished in 1854 with the completion of the sugar mill and, possibly, the main house. Between 1848 and 1850 a small labor force set about building a temporary brick kiln in the area of the Quarters. This kiln was likely employed to produce the estimated 650,000 to 750,000 finished bricks that were utilized in the construction of the Quarters, enslaved house servants' cabins, other outbuildings in the area of the main house, as well as fireplaces and chimneys for the main house, "Boys House" (a house constructed near the main house and occupied by Jordan's grandsons), kitchen, work house, and plantation hospital. Historic records and archeological evidence suggest that the Quarters were built first, followed by the various agricultural barns and storage facilities, then the sugarhouse, and finally the main 
house. Both the main house and sugar mill appear to have been completed by 1854 , when the first cane crop was processed. It is likely that Block I of the Quarters was the last block of cabins constructed for the enslaved labor force, and it may have been completed during 1854 , or shortly afterward.

Brown appears quite clear about the construction date of the house as being around 1853 to 1854 -an assertion supported by Platter's (1961:163) observation that the house was under construction when the 1854 hurricane struck the Texas coast. But historian Martha Freeman (2004:113, footnote 62 ) believes that a recently discovered letter, written in 1857 , has a bearing on the interpretation of when the Jordan house was built. She notes that "A date of 1854 was ascribed to the construction of the Jordan house prior to the discovery of the Nuckols letter and probably on the basis of the increase in real property valuation between 1853 and 1854." But she suggests that the 1853-1854 tax value increase was due to the construction of a sugar mill and not the house. "Indirect evidence suggests that Jordan and McNeill may have been using their funds [profits from their loan business] to invest in capital improvements on their plantation in 1853," writes Freeman (2004:112), asserting that the principal capital improvement was the sugar mill. The letter Freeman cites was written on August 4, 1857, by a family friend and neighbor, C. T. Nuckols, to Sarah McNeill. In the letter, Nuckols states that: "The new house is almost done[.] [I\}t looks magnificent. We had such a romp up stairs and often wished that you could join us" (Freeman 2004:113). ${ }^{7}$ Based on this statement, Freeman ascribes the 1857 increase in the tax value of the plantation to the construction of the house.

It is important to note that the ad valorem tax records in question will never positively identify when the sugar mill or the house were built. Historians must interpret various lines of evidence and infer what types of improvements were responsible for each particular tax value increase. What we do know is that Levi Jordan bought the land in 1848, that the big house was finished by 1857 , and that significant increases in the Jordan Plantation tax value occurred in 1854 and 1857. But it is possible that both interpretations are correct. One plausible scenario is that construction of the main house began about 1853 and that a portion of the structure was damaged in the September 1854 hurricane (Roth 2010:17). This damage may have slowed down the construction. Work on the Jordan house very well could have continued over several years. When Nuckols stated that the house "is almost done" in August 1857, perhaps this meant that the finishing touches were being added or that some major additions (perhaps wings on back of the house?) were still in progress. It certainly does not preclude the possibilities that a significant portion of the house was completed earlier or that the family was living in the house by 1855 or 1856. In this scenario, the initial construction of the house may have contributed to the tax value increase in 1854, and subsequent additions and improvements may have contributed to the 1857 tax value increase. As is discussed later in this report, an unusual archeological find provides strong circumstantial evidence that construction of the Jordan house did indeed begin in 1853 (see Chapters 6 and 9).

The Levi Jordan plantation house was occupied more or less continually by family members and various tenants from the $1850 \mathrm{~s}$ up through the 1990s (Freeman 2004:107-136; Howard 2003b:5). When Levi Jordan died in early 1873, he left behind his wife Sarah, his daughter Emily, grandsons James Calvin, Charles, and William Archibald, and his greatgrandsons, Royal Furniss and Will (McWillie), all of whom lived on the plantation lands and in the big house at various times. In the latenineteenth and into the twentieth century, the occupants of the big house included Levi Jordan's great-great-grandson, Will Martin, his wife Eloise (Masterson), and their six children. Many improvements to the house were made in the years after Levi's death, and the major hurricanes of the 1870 s and 1880 s would likely have caused damages that necessitated significant repairs (see Table 2.2). Will and Eloise Martin lived in the big house from sometime after 1894 until their deaths in 1937

\footnotetext{
${ }^{7}$ This letter was subsequently published by Raska and Hill (2009:163-164).
} 
(Will) and 1946 (Eloise). They undoubtedly made many improvements and repairs to the house during their occupation, including the major structural additions that are known to have occurred after the extensive structural damages sustained during the 1900 hurricane. During the latter half of the twentieth century, various Martin family members and renters occupied the big house, but the precise details of who lived there during this time are uncertain. The nature and extent of structural changes, repairs, and modifications to the big house are not well documented for this period, but several major hurricanes may have caused damage at the Levi Jordan Plantation between 1900 and 1932 (see Table 2.1). The 1932 hurricane was particularly severe, and it caused damage at Levi Jordan according to local resident Mike Martin (2010).

The fact that the 1850 s wooden structure survived at all is a testament to the descendants' desires to protect the historic plantation house for future generations. The State of Texas acquired a portion of the original Levi Jordan Plantation (92 acres) from the family descendants in 2002. This land contains the big house and immediately surrounding area as well as the former slave quarters, which constitute most of the significant improvements associated with the antebellum plantation except for the sugar mill. ${ }^{8}$ Howard (2003b:5) succinctly states how TPWD got involved and acquired the property:

In the year 2000, Jordan descendants, local community members, and the Levi Jordan Plantation Historical Society presented the importance of this site to the Texas Parks and Wildlife Department. Agency director Andrew Sansom convinced the state legislature of the interpretive and educational potential of the site. Funding for development was included in bond proposals approved through elections in November 2001. A grant from the Houston Endowment supported the purchase of the 70-acre tract in April 2002, and it was augmented by an adjoining 22 acre tract later that year.
As soon as Texas Parks and Wildlife Department (TPWD) took over the property, it identified the following primary goals as critical in the protection and development of the site (Howard 2003b:1):

1. Stabilization of the main house and nearby archeological excavation units.

2. Gathering of information on the age and character of the main house and surrounding archeological deposits.

3. Planning for site development and interpretation.

But TPWD failed to receive adequate funding to stabilize or restore the Levi Jordan house, much less to begin the long process of interpreting the site and opening it to the public. In 2008, the State of Texas transferred management of a number of historic sites from TPWD to THC, and the Levi Jordan plantation site was one of them. This transfer also came with sufficient funding appropriated by the Texas legislature for THC to begin the stabilization work on the Jordan house.

\section{PREVIOUS INVESTIGATIONS}

Archeological investigations at the Levi Jordan Plantation span ca. 25 years and include extensive work conducted by Dr. Kenneth Brown from the Department of Anthropology at the University of Houston, as well as investigations by TPWD and the Center for Archaeological Studies (CAS) at Texas State University under contract with TPWD (Figures 2.2 and 2.3, Table 2.3).

Excavations at the Levi Jordan Plantation began in 1986, when Dorothy Davis Cotton, a descendant of Levi Jordan and executor of the estate, endeavored to get the plantation listed on the National Register of Historic Places (Brown 2005a:3). The Texas Board of Review rejected the nomination, but Cotton learned that an archeological dig at the plantation could provide additional evidence needed to demonstrate that the property was eligible for listing on the National Register. Cotton invited Brown to visit

\footnotetext{
${ }^{8}$ The sugar mill and the Juden Cemetery, which began as the slave cemetery on the Levi Jordan Plantation, are not on the state-owned property (Bruner 1996:Figure 3).
} 


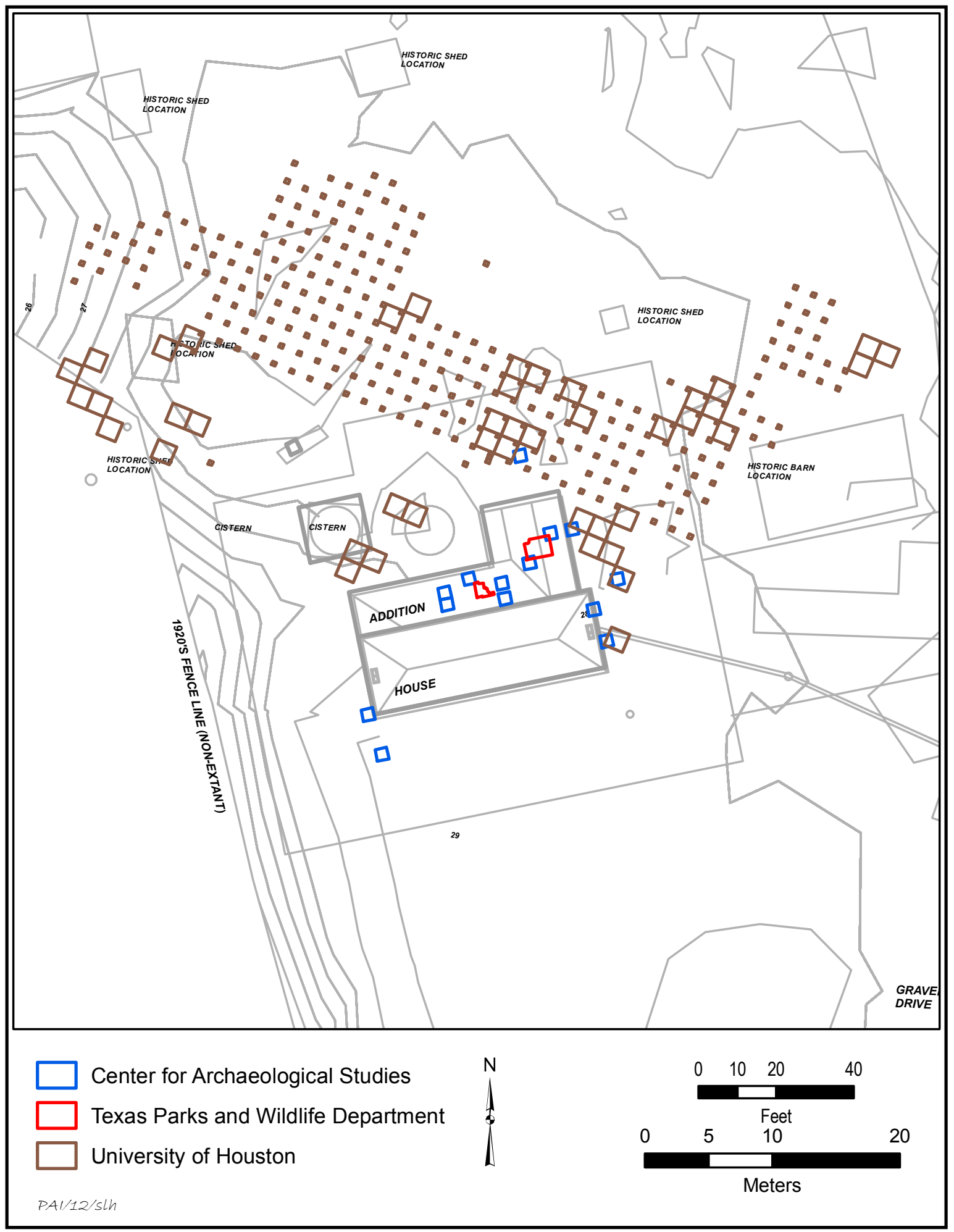

Figure 2.2. Map of previous archeological investigations at the Levi Jordan Plantation by the University of Houston from 1986 to 2002, the Texas Parks and Wildlife Department in 2003, and the Center for Archaeological Studies at Texas State University in 2005. Data are from Brown (2005a) and Leezer (2006). This map does not show the University of Houston excavations in the slave quarters area, which is located about $400 \mathrm{ft}$ north of the Jordan house. 


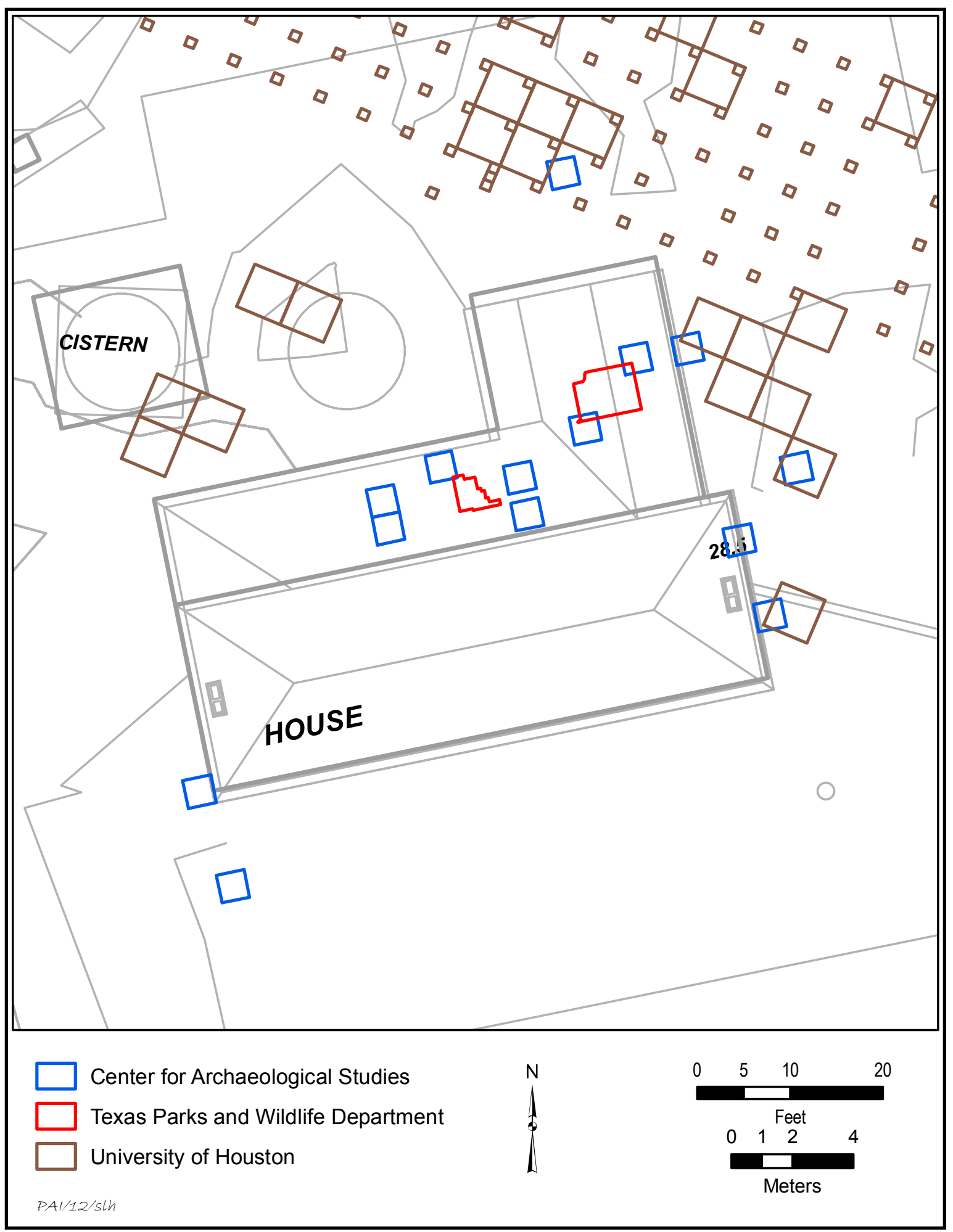

Figure 2.3. Closeup map of previous archeological investigations in and around the Levi Jordan Plantation house by the University of Houston, the Texas Parks and Wildlife Department, and the Center for Archaeological Studies at Texas State University. 


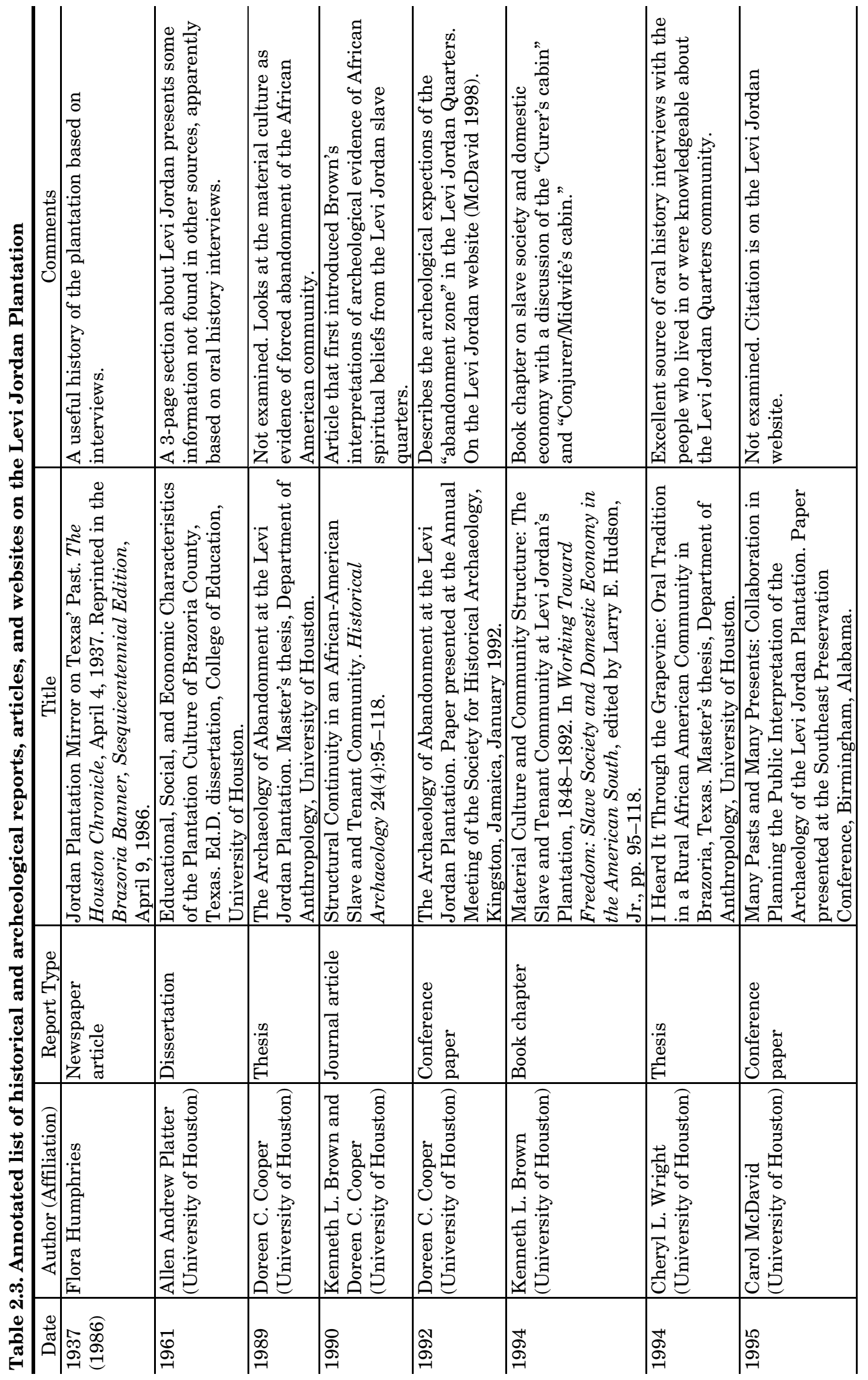


Chapter 2: History and Previous Investigations

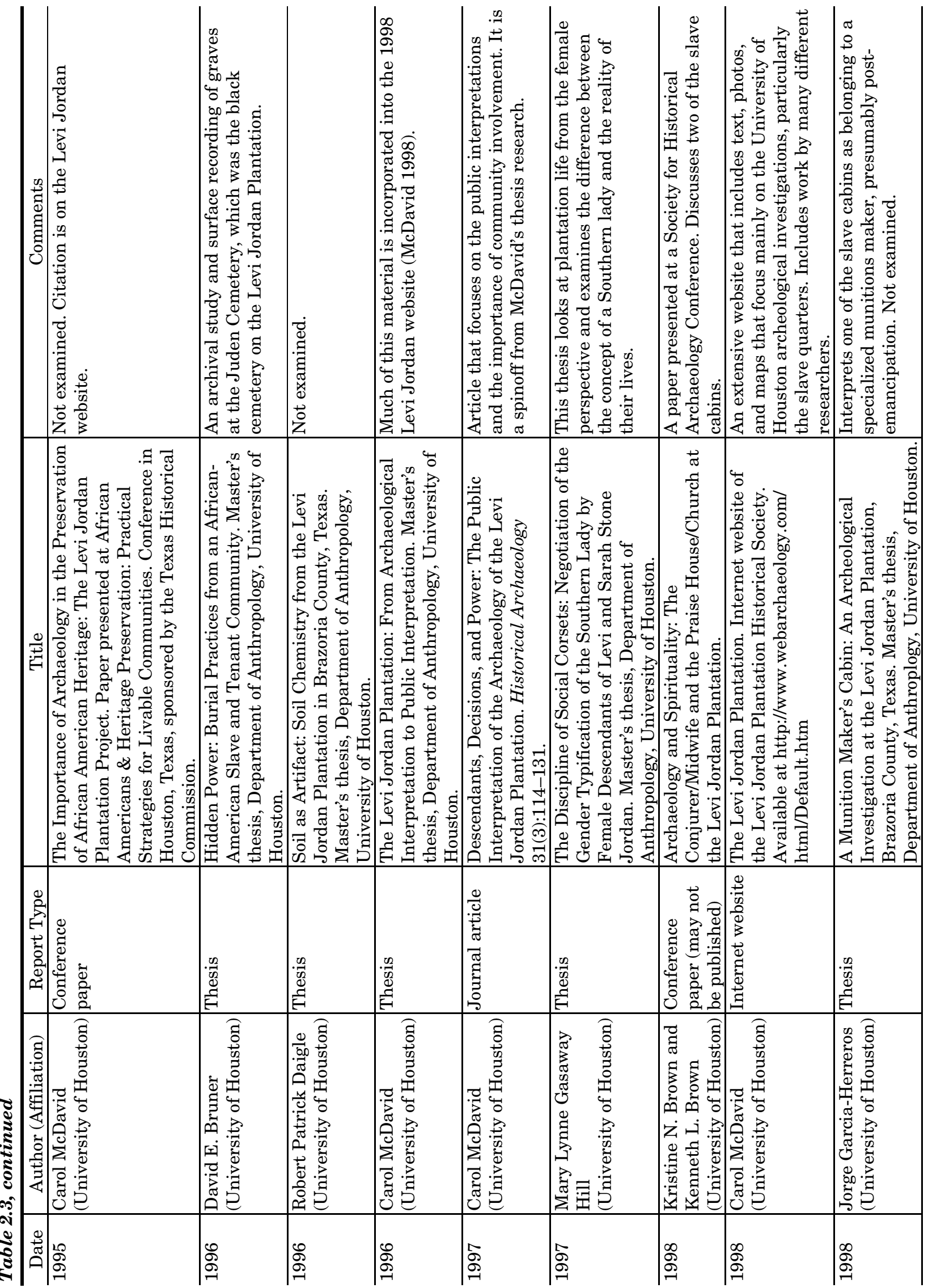


Archeological Investigations for the Levi Jordan Plantation House Stabilization

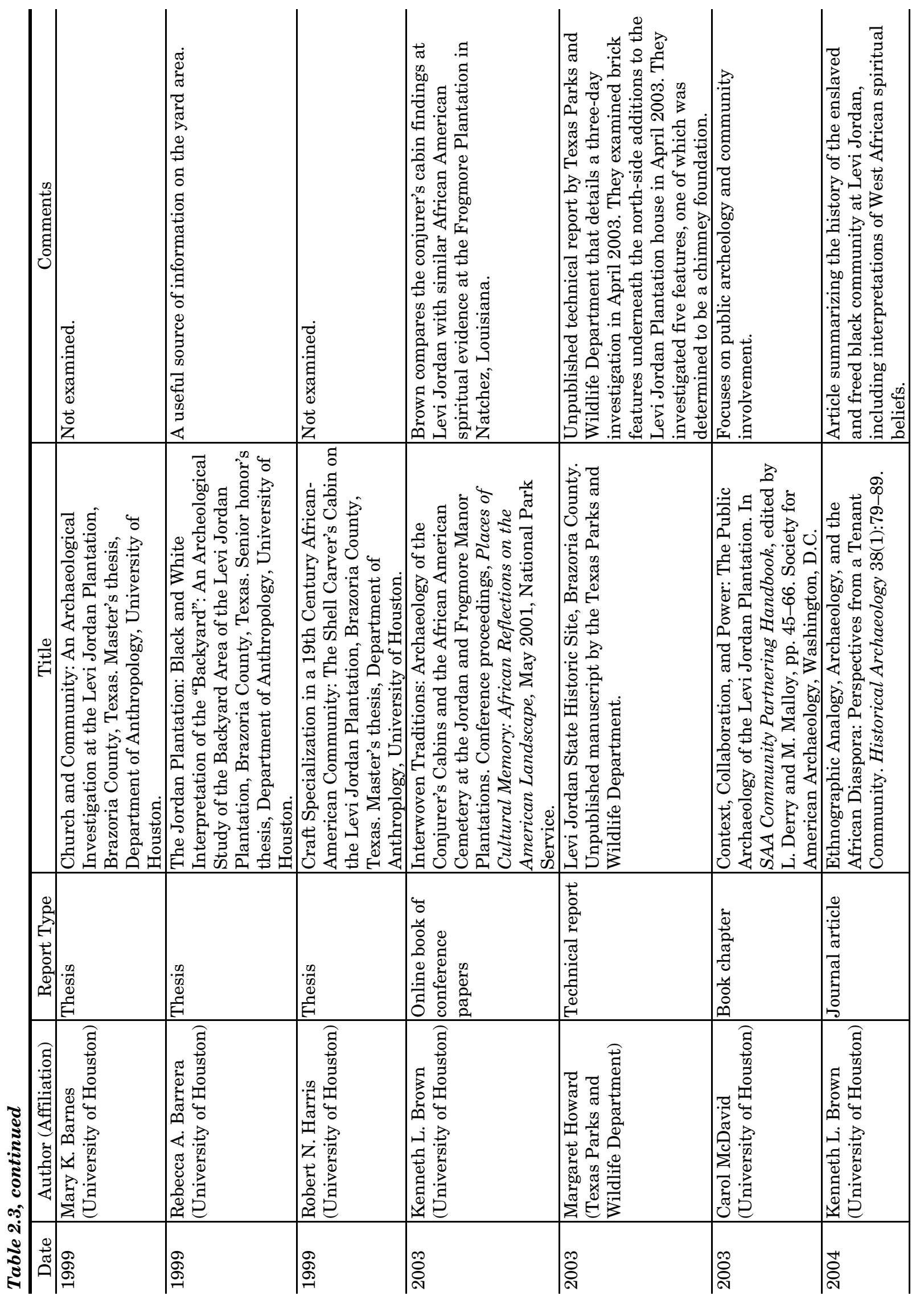


Chapter 2: History and Previous Investigations

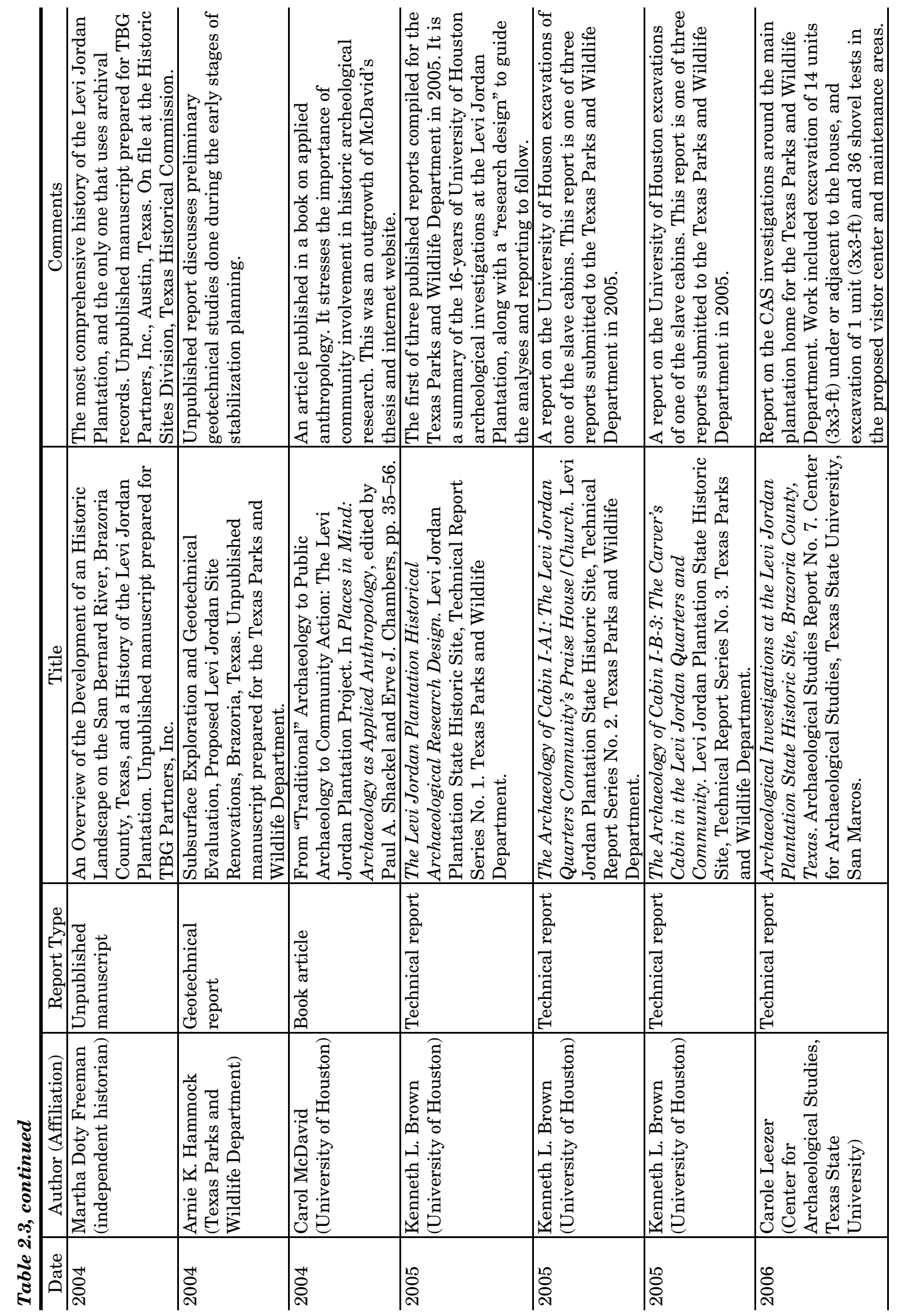


Archeological Investigations for the Levi Jordan Plantation House Stabilization

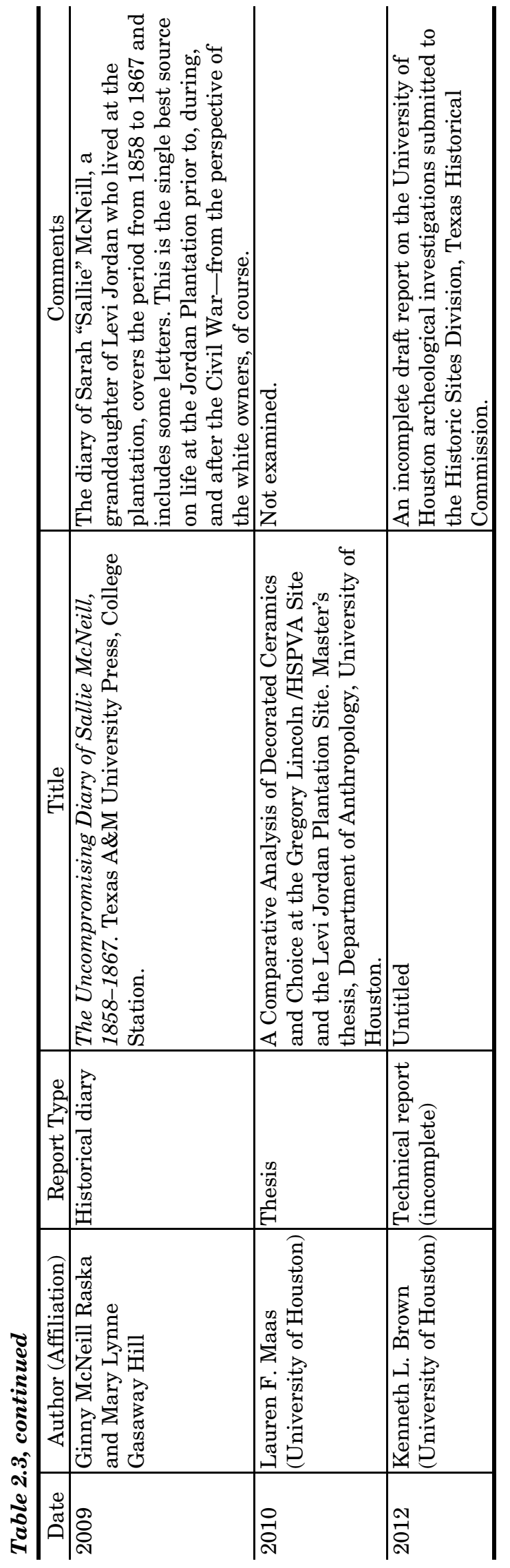


the Levi Jordan site. This visit was made with the hope of getting Brown interested in doing enough archeology to get the property listed on the National Register. The visit launched 16 years of seasonal archeological research (from 1986 through 2002) under Brown's direction (Brown 2005a:1-2). Along with substantive historical research and additional archeological studies conducted since 2002 (e.g., Freeman 2004; Leezer 2006), this intensive archeological work leaves no doubt that the Levi Jordan Plantation meets all the criteria for National Register nomination. However, no renomination has been attempted. Brown (2005a:3) has suggested that a renomination be written to get the Levi Jordan Plantation listed.

In the first two years of work by the University of Houston (1986-1987), Brown conducted extensive excavations around the house, near the cisterns, and in the east, north, and northwest portions of the backyard (Brown 2005a:26). But after testing the slave quarters located north of the big house, the team shifted the focus of their excavation efforts to this area. Although several publications have been written describing the University of Houston's archeological investigations and findings in the slave quarters (Brown 1994, 2005a, 2005b, 2005c; Brown and Brown 1998; Brown and Cooper 1990; Garcia-Herreros 1998), no archeological reports have been written on the university's work near the main plantation house and yard areas. The only exceptions are one page in Brown (2005a:26) and a student honor's thesis on the "backyard" area (Barrera 1999). Fortunately for this study, Brown accepted an invitation to visit the Prewitt and Associates (PAI) archeological investigations at the Jordan Plantation. During this visit, he shared many of his ideas and thoughts on the history of the site with PAI archeologist McWilliams and THC site manager Bryan McAuley. His input proved to be extremely valuable to our work.

Only two substantial archeological studies have been done since TPWD acquired the property in 2002. In 2002 and 2003, TPWD archeologists conducted initial archeological studies to provide some baseline archeological and architectural data pertaining to the main house to be used in planning the structural stabilization. In 2002, TPWD archeologists monitored replacement of a front gate post and assessed damages caused by the unauthorized removal of the 1961 concrete porch. The archeological team spent three days excavating at the site in 2003 and Howard (2003b) prepared a brief report that describes five features that were found underneath the northern additions. One of these was a brick fireplace foundation that was associated with the northeast wing in the back of the house. The second and more extensive investigation, conducted by CAS under contract with TPWD, collected baseline archeological data for the area around the main house. The results of these investigations are reported by Leezer (2006).

The reports by Howard (2003b) and Leezer (2006) provide the only detailed information available on archeological deposits, cultural features, and artifacts associated with the plantation house. While the University of Houston investigations provide only minimal information, the sections below describe the archeological investigations pertinent to the plantation big house in more detail.

\section{The University of Houston}

Each year between 1986 and 2002, Kenneth Brown at the University of Houston conducted excavations at the Levi Jordan site (Brown 2005a:Acknowledgments, 30). During this time, many students and volunteers worked at the plantation. The Jordan Plantation site served as a "training facility" for anthropology students at the University of Houston, as well as for "members of three local archeological societies, students from a number of elementary, middle, and high schools, and members of the local descendant community" (Brown 2005a:4). ${ }^{9}$ Under Brown's supervision, the investigations resulted in the designation of 27,000 provenience units (lot numbers assigned to individual proveniences) and collection of roughly 600,000 artifacts (Brown 2005a:30; Howard 2003b:6). Besides the work around the big house and in the slave quarters, the University of Houston

\footnotetext{
${ }^{9}$ Stan Murray, a local man who visited the site during PAI's first phase, noted that troops of Boy Scout troops also conducted archeological investigations at the Levi Jordan site, but no details have been found regarding these investigations.
} 
investigations examined a brick kiln near the slave quarters and the Juden Cemetery, which was the original slave cemetery for the Levi Jordan Plantation (Brown 2005a:28-30, 48; Bruner 1996). ${ }^{10}$ The onsite production of hand-molded bricks does have a bearing on many of the archeological features at Levi Jordan plantation because these bricks were used in the construction of many features at the site, including the slave quarters and the chimneys, cisterns, patio, and walkways at the big house.

The University of Houston began excavations in the yard area around the main house in 1986-1987, but after a family with three children rented the house, the investigations moved to the slave quarters (Brown 2005a:26). Seven years later, the excavations in the house area were resumed when a graduate student directed the systematic excavation of sampling units across the yard (Barrera 1999; Brown 2005a:30, Figure 9). Rebecca Barrera's investigations provide the only substantive information on the archeological remains in the backyard of the Jordan home. Although her work remains unpublished, Barrerra (1999) reports that:

- They dug 385 1x1-ft sampling units between the 1996 and 1998 field seasons. These sample units were placed on a 5 -ft grid across the yard area, and each was excavated in two 6-inch levels.

- The goal of excavating the sample units was to define the backyard boundaries and identify features, structures, and activity areas.

- They dug twelve 5x5-ft units to further investigate possible features indicated in the sampling units.

University of Houston archeologists excavated additional $5 \times 5$-ft units in the yard area, which, when combined with Barrera's work, include the sample units and forty-three $5 \times 5$-ft units (see Figures 2.2 and 2.3). These investigations resulted in the identification of a detached kitchen, house slave cabins/plantation store/ blacksmith shop, a well (note that a modern water pump is installed at the well location), an abandoned cistern, the "Boy's House," corn cribs, and fence lines (Brown 2005a:26).

By the time the State of Texas acquired the Levi Jordan property, the University of Houston had conducted years of investigations, but none of the work had been thoroughly reported. Howard (2003b:6) reports that in 2002, "the Texas Parks and Wildlife Department contracted with the University of Houston for reporting of these investigations, including analysis of the estimated 600,000 artifacts recovered." This produced two preliminary reports of investigations. One is a research design for the final data analysis (Brown 2005a), and it provides a good overview of the University of Houston work. The other is a report on the archeology of one of the slave cabins called the "Praise House/Church" (Brown 2005b). ${ }^{11}$ A comprehensive draft report on all of the University of Houston work at the Levi Jordan Plantation is being prepared at this time (Brown 2012).

Brown (2005a:26) presents only one page of text relating to the house and yard excavations, along with a map showing the University of Houston excavations in relation to the big house. This map is reproduced here as Figure 2.4. It is interesting that the map shows approximate locations of an inferred "House Slave Quarters" structure and the detached "Kitchen" behind the main house. But no archeological data have been published to support these structural interpretations. PAI investigations found that some of the University of Houston excavation units in the backyard barely penetrated the grassy surface and were only a few inches deep. Although the

\footnotetext{
${ }^{10}$ The University of Houston investigations also included work at the sugar mill, located on private property south of FM 521. The Juden Cemetery is also on private land.

${ }^{11}$ Brown's research design document cites many unfinished reports pertaining to the Levi Jordan archeology by the University of Houston (Brown 2005a:References). He lists himself as author of two additional "in preparation" reports in the Levi Jordan Plantation State Historic Site Technical Report Series as: Number 4, The Archaeology of Cabin II-B-1: The Curer's Cabin; and Number 5, A Summary Report of Test Excavations into the "Unnamed Cabins" within the Levi Jordan Quarters Community. He also lists two other "in preparation" reports under the titles: "and all other Personal Property that We Own or May Acquire": Archaeology of the Levi Jordan Plantation Quarters Community and Spirits and Ancestors: Archaeology of 19th Century African American Spirituality.
} 


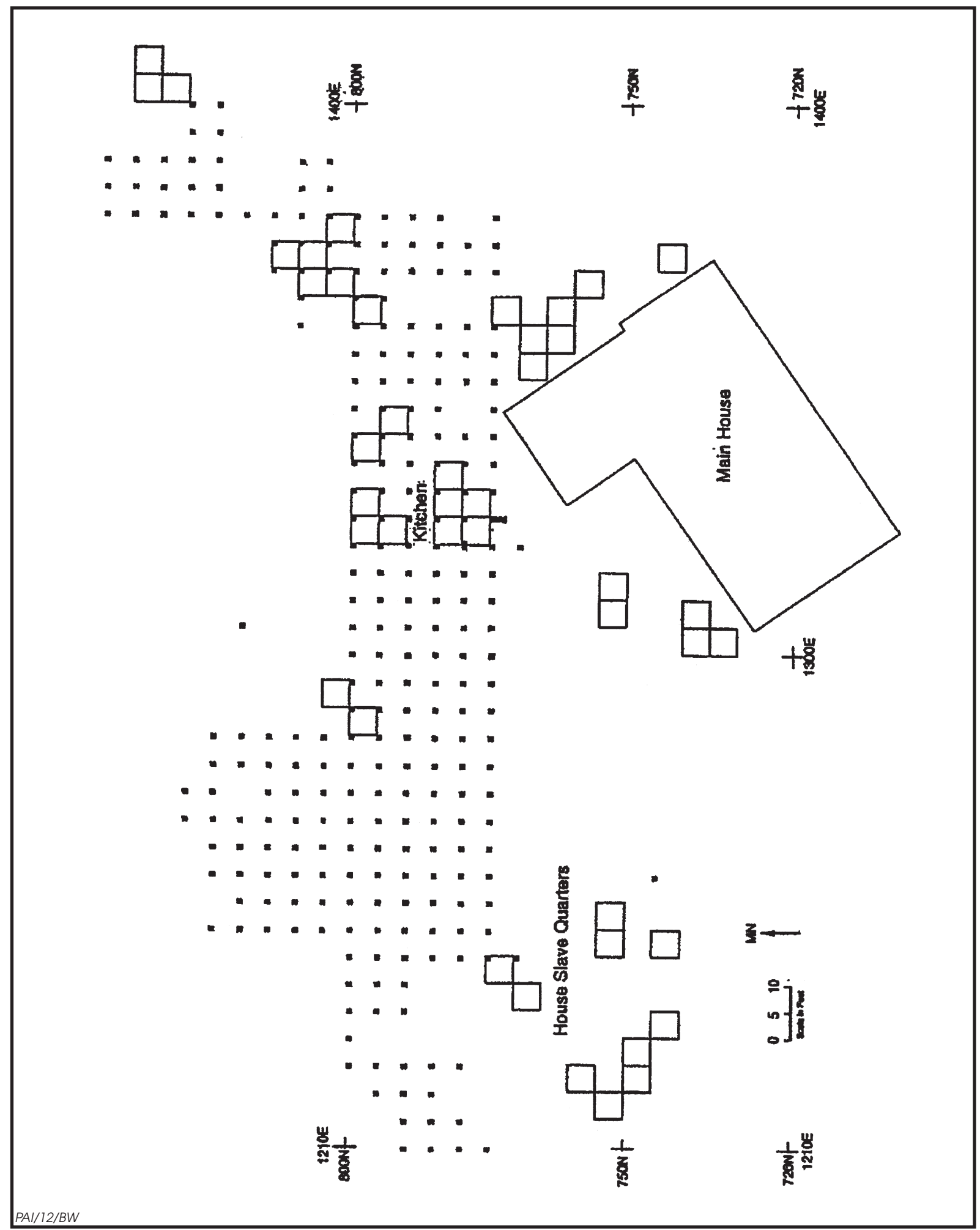

Figure 2.4. Map showing the locations of University of Houston excavations (1x1-ft and $5 \mathrm{x} 5$-ft units) in the "backyard" of the main house. Map is reproduced from Brown (2005a:Figure 9). 
results of Brown's excavations near the main house are not reported, they can be interpreted primarily through the subsequent site maps he produced and his preliminary interpretations of various structures and features.

Figures 2.5 to 2.9 are five maps illustrating the University of Houston's interpretations of the site layout through years of working at the site. Figure 2.5 is a map from Brown and Cooper (1990:Figure 1-1) showing the entire site. Figure 2.6 is a map of the entire site by Brown and McDavid (1998a) from the Levi Jordan Plantation website (McDavid 1998).

Figure 2.7 is a closeup map of the main house area by Brown and McDavid (1998b) from the Levi Jordan Plantation website (McDavid 1998). Figure 2.8 is a map of the entire site from the 2005 Levi Jordan Plantation Historical Archaeological Research Design (Brown 2005a:Figure 5). Collectively, these images show the slave/tenant quarters far to the north of the main house and consisting of four rows of parallel buildings sharing "open cisterns." ${ }^{2}$ But they also show that Brown's interpretations of structures and features in the vicinity of the big house have changed over the years. Figure 2.9 is a map of hypothesized buildings and features in the yard area north of the original plantation house as presented in a University of Houston master's thesis by Barrera (1999:Figure 2). The map is not to scale and provides only generalized locations. Collectively, these maps provide an indication of general areas where architectural features might be encountered, although they are not accurate and convey only vague spatial relationships.

The Figure 2.5 map from 1990 shows the big house with porches on the south, east, and north sides, an unlabeled cistern off the northwest corner, an unidentified structure to the east, a "Hospital/ House Slave Quarters" to the north, and a separate "Kitchen" to the northwest. Eight years later, Figure 2.6 and 2.7 still show porches on the south, east, and north sides of the big house, but Figure 2.7 shows a very different set of structures and features depicted in close proximity to the big house. The yard space has changed, the existing cistern and an abandoned ("filled") cistern are shown, and a rain barrel location

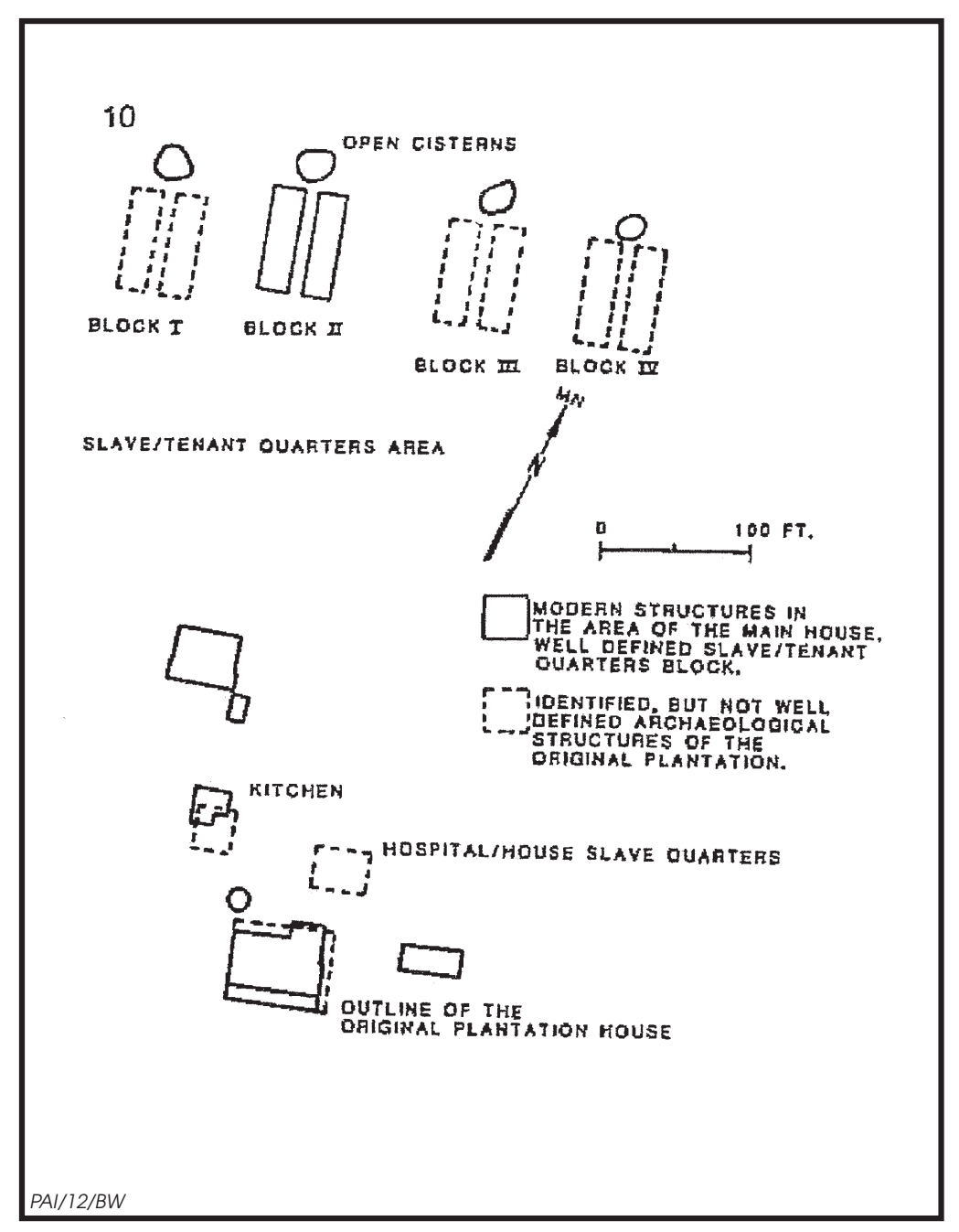

Figure 2.5. Site map of structures and features at the Levi Jordan Plantation, ca. 1990. Map is reproduced from Brown and Cooper (1990:Figure 1-1).

\footnotetext{
${ }^{12}$ It is possible these pits served two purposes. They could have been excavated to provide clay for making bricks, and then the resulting pits could have been used as open cisterns.
} 


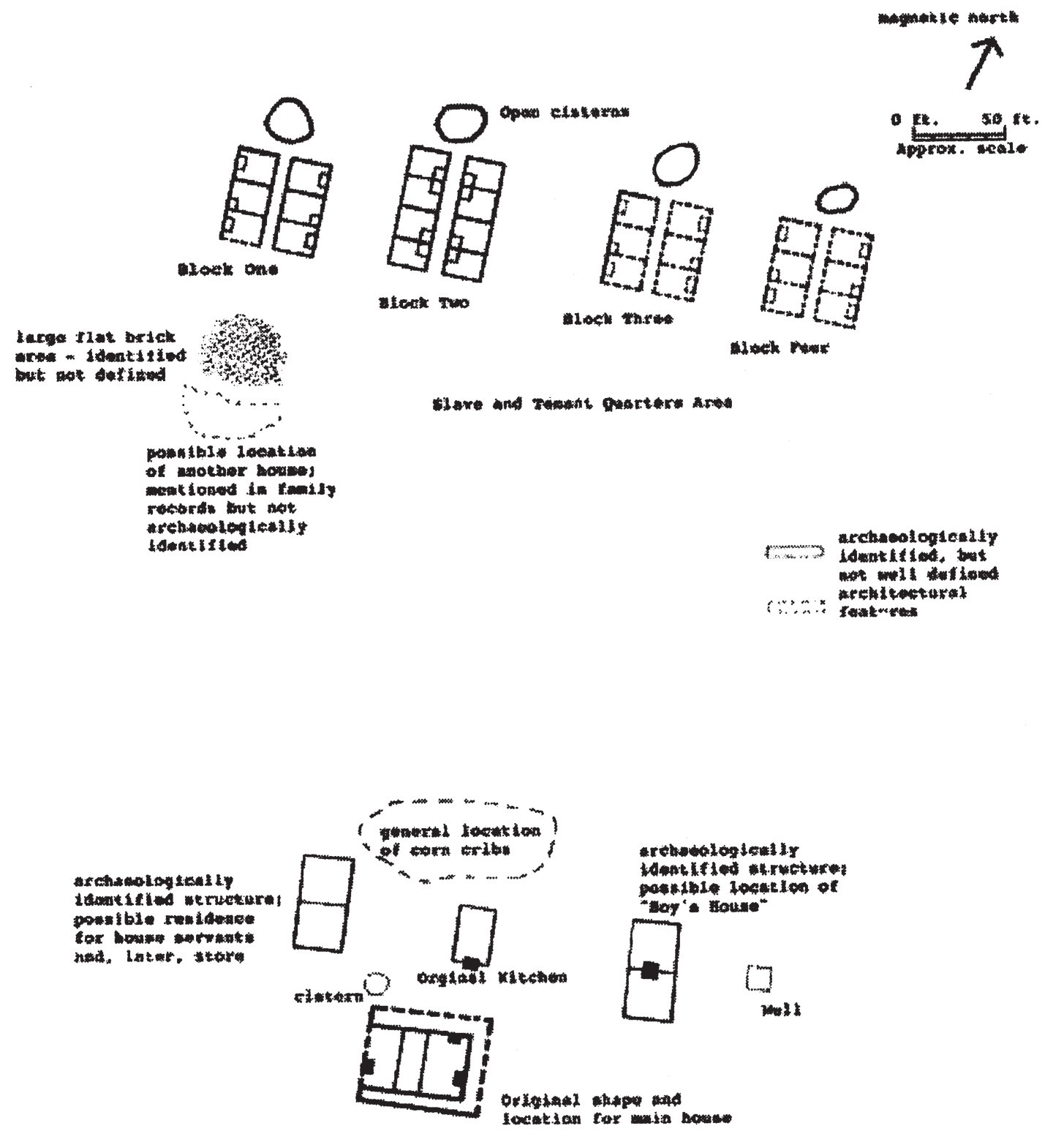

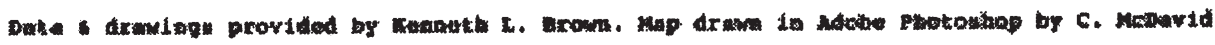

Figure 2.6. Site map of structures and features at the Levi Jordan Plantation, ca. 1998. Map is reproduced from Brown and McDavid (1998a). 


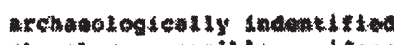
structure: powalbio coxldence for bous wrinte and, latere

* torm

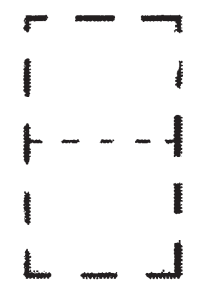

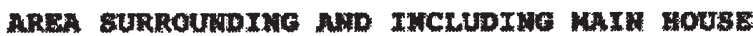

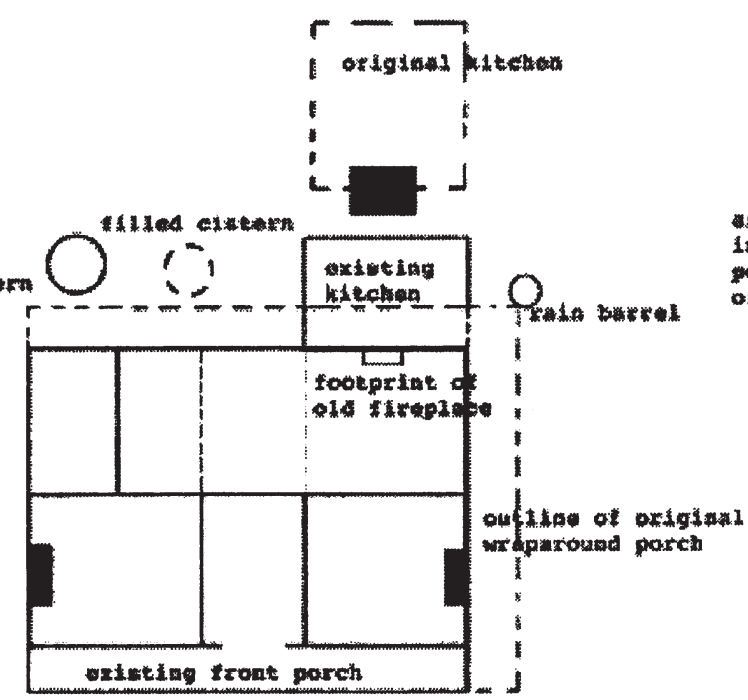

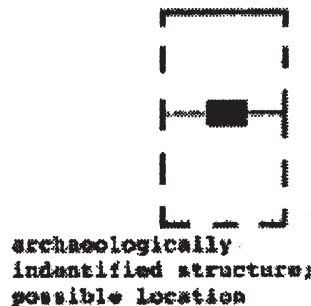

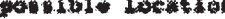
a "Doy' * Housw"

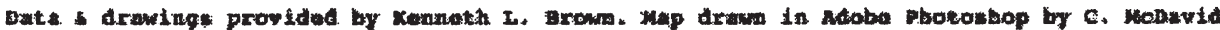

Figure 2.7. Closeup map showing structures and features in the main house area, ca. 1998. Map is reproduced from Brown and McDavid (1998b).

is depicted at the northeast corner of the big house. The three substantial structures located close behind the house are labeled (from west to east) as: "possible residence for house servants and, later a store," the "original kitchen," and "possible location of Boy's House." And then in 2005, 15 years after the first map, the Figure 2.8 map still depicts the porches on the south, east, and north side of the big house, but only three features are shown nearby: the existing cistern (not labeled), the "Kitchen," and the "House Slave Cabins." The latter is shown as a row with three contiguous rooms, much like those in the slave quarters complex farther to the north.

During the informal site tour and interview, Dr. Kenneth Brown (personal communication 2010) confirmed that he believes that the big house had a $3 / 4$ wraparound porch (on the east, south, and north sides). His basis for this conclusion is twofold. First, his work exposed dense artifact deposits in the eastern portions of excavation units placed near the east wall of the house. The artifacts recovered in this area included an 1889 quarter and ceramic sherd with a pre-1900 maker's mark. Brown believes the location of this artifact concentration, which is roughly $5 \mathrm{ft}$ beyond the east wall of the house, represents materials collected from beyond a wooden porch that ran along the east wall of the house before the turn of the century. In this scenario, debris was regularly swept off the porch to the east, resulting in relatively few artifacts being deposited under the porch. Secondly, Brown's excavations northeast of the east wing located a small brick pad. The location of this feature did not make sense relative to the location of the modern east wing. But its location relative to the hypothesized east porch led Brown to the interpretation that this brick pad was for a rain barrel to collect water off 

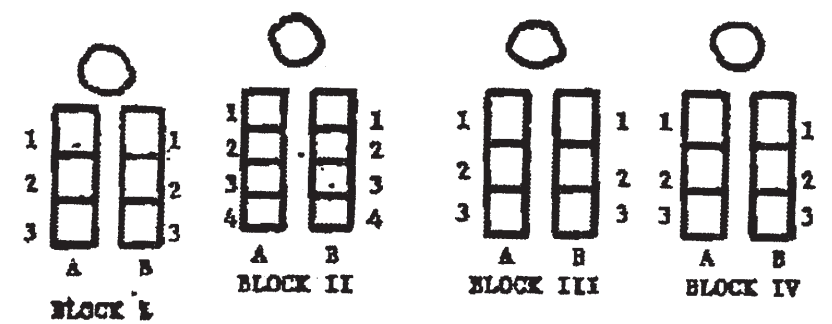

THE QUATISE
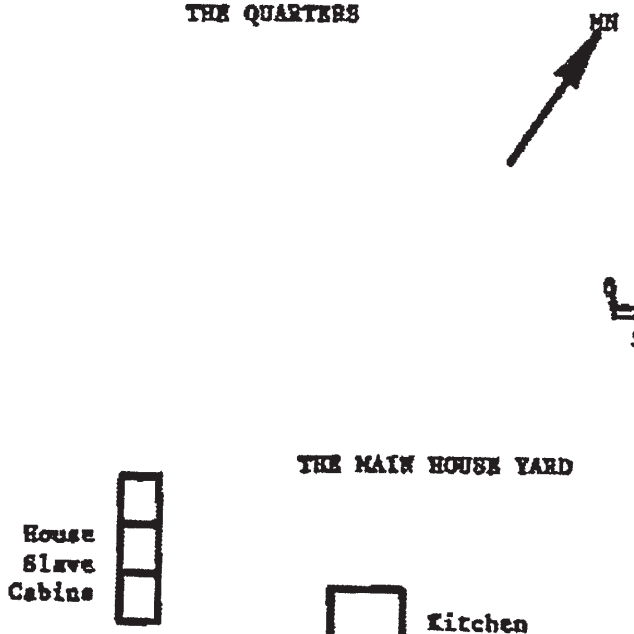

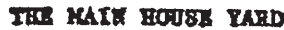

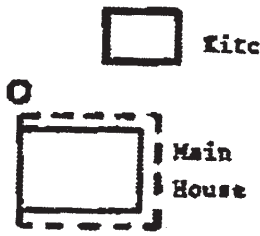

PAI/12/BW

Figure 2.8. Site map of structures and features at the Levi Jordan Plantation, ca. 2005. Map is reproduced from Brown (2005a:Figure 5).

all of the original University of Houston level record forms for excavations in this area. But it was determined that an extensive effort would be required to fully interpret all of the field records and notes, so this detailed analysis was not pursued. A more complete description of mapping issues can be found in Chapter 3.

PAI also discovered that many of the archeological excavations conducted in the $1980 \mathrm{~s}$ and 1990 s by volunteers may not be documented. While PAI was working at the site, a handmadebrick walkway found extending north of the front porch seemed to represent a new feature in an area where no previous work had been done. However, a visitor to the site ${ }^{13}$ recognized the feature and said that he had excavated a portion of it with a Boy Scout troop in the 1980s. But a review of all of the University of Houston records shows no unit plotted at this location on any site maps.

Brown's archeological interests in the area around the main house waned after ca. 1987, once he began the investigations of the slave/tenant cabins. This is the area where the majority of the University of Houston excavations occurred over the next

the roof of the house and the east porch (see Figure 2.7).

Copies of the University of Houston excavations record forms were provided to PAI archeologists by TPWD, and the forms were somewhat informative. But lacking the in-depth knowledge of how the University of Houston investigations were conducted made it difficult and time-consuming for PAI to interpret the excavation data. For example, PAI made an attempt to examine Brown's east porch theory, reviewing
15 years. In the slave quarters, Brown began to expose features that were very unusual, and he became engrossed in the literature relating to African and African American spiritual beliefs and ritual offerings. Brown found that the spiritual beliefs of enslaved peoples were often expressed in specific objects or unusual patterns of material culture but that these expressions had to be kept secret and hidden from white plantation owners and overseers. Such ritual offerings were often buried below the floors of

\footnotetext{
${ }^{13}$ THC site manager Bryan McAuley got this information from Stan Murray.
} 


\section{Linear Tree Line}

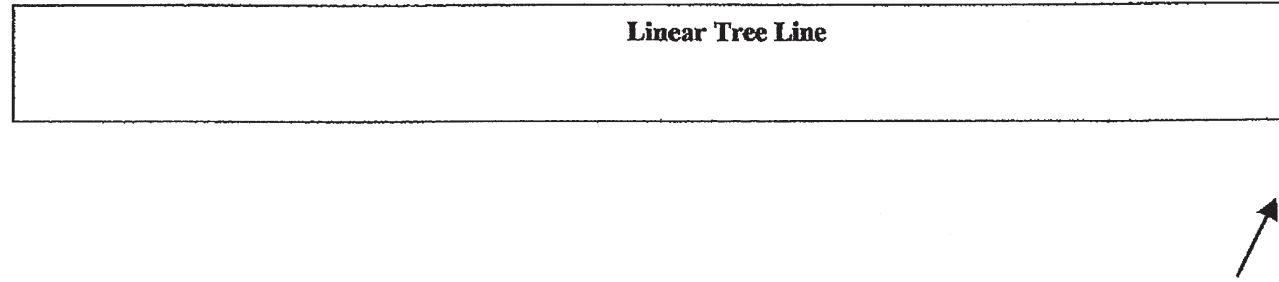

$\mathbf{N}$

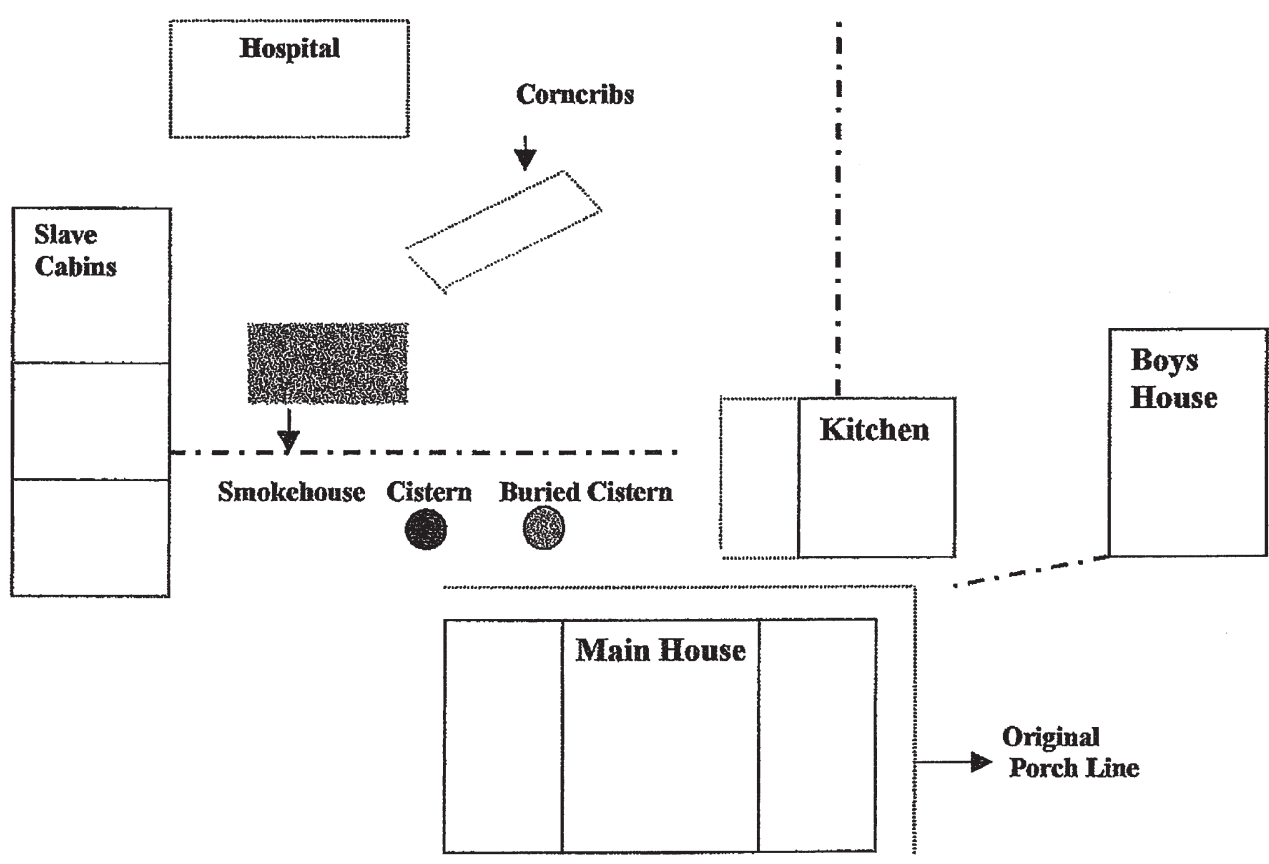

Figure 2.9. Site map of hypothesized buildings and features in the yard area north of the original plantation house. Map is reproduced from Barrera (1999:Figure 2).

their cabins or near fireplace foundations as well as in other locations on the plantation grounds (Brown 2005a; Brown and Cooper 1990).

Brown exerted significant effort to research ritual deposits within the Quarters at the Levi Jordan Plantation. ${ }^{14}$ A detailed explanation of his work is not necessary for our purposes, but an overview of his findings is important for un-

\footnotetext{
${ }^{14}$ Brown also worked at the Frogmore Manor site in Louisiana and found African American ritual deposits there (Brown 2003).
} 
derstanding the PAI investigation strategy in and around the main house. Therefore, a brief review of Brown's slave quarters interpretations is warranted.

\section{African American Rituals at the Levi Jordan Plantation Quarters}

The University of Houston investigations discovered artifacts placed in locations that were too unusual to be ignored, and Brown believes the placement of certain objects was intentional. Furthermore, Brown (2005a:32) "systematically attempted to avoid the use of a functional [artifact] classification system" because he felt such classification schemes impose the researcher's culture onto the artifacts and the data. He felt that precise archeological contexts of specific items were extremely important in interpreting how material culture really functioned within a household.

In several articles and reports, Brown and others (Brown 1994, 2003, 2004, 2005a, 2005b; Brown and Brown 1998; Brown and Cooper 1990; McDavid 1996, 1998) have presented circumstantial evidence for objects and groups of objects found in the Levi Jordan slave cabins representing ritual placement connected to spiritual beliefs of African origin. These cabins were occupied from the late 1840s through 1865 by enslaved African Americans and from 1865 to the 1890 s by free blacks working on the plantation. Brown (2012) lists many features in four cabins as representing some form of African American spiritual beliefs (e.g., charms, curing, and conjuring), and he suggests that the relative placement of many of the features has ritual meaning. These include the following:

\section{Cabin I-A-1, The Praise House (Church)} and School

- Plaster sculpture

- Symbols carved and molded onto shell and glass buttons

- Knife burial in center of cabin

- Charm (coin/crystal/artifact) deposit

- Coins, metal artifacts, and brick altar deposit

- Cross burial (necklace with jeweled cross)

- Ash, burned metal, and burned shell deposit
- Two upturned cut iron vessel bases/ash deposits

- Ash and artifact deposit near reconstructed hearth

- Spoon, chicken egg shells, brown glass bead, and chain links

\section{Cabin I-A-2, The Elder's Cabin}

- A handmade brick with a raised cosmogram symbol (oval with cross)

- Artifact feature (fly whisk, necklace, chicken spur)

\section{Cabin II-B-1, The Curer's (Midwife) Cabin}

- Curer's kit found beneath a large kettle in the southeast corner of cabin (the curer's kit consisted of two or three cast-iron kettle bases, cubes of white chalk, two bird skulls, an animal's paw, two sealed cartridge cases, perforated and unmodified cockleshells, a porcelain doll, mirror fragments, an iron ring, a concave perforated metal disc, small water-worn pebbles, two chipped stone scrapers, several patent medicine bottles, and pieces of a thermometer and numerous nails, spikes, and knife blades)

- Coin deposit. Seven silver coins (4 quarters, 2 dimes, and 1 perforated half-dime; all dated 1853 and 1858) wrapped in cloth and buried in a small pit

- The Amula deposit (various objects surrounding two cast iron kettles, both nested and wrapped in heavy chain inside a pit)

- Three ash/burned shell/burned nail deposits

- Chicken burials (pit with articulated bones of three chickens)

\section{Cabin II-B-2, The Munitions Maker's/ Hunter's Cabin}

- Button workshop (many hand-made buttons contain possible ritual symbols)

Brown equates most of these finds with spiritual beliefs of West African origin, and he is not alone in his interpretations of material culture linked to African spiritual beliefs among enslaved peoples. The literature of African American archeology in the southern United States demonstrates that archeologists need to look closely at the contextual relationships between 
certain objects to derive meaningful interpretations. There are many archeological examples of material culture used by African Americans in religious, spiritual, or ritual contexts, and these behaviors are well-documented in oral histories and archival records. Some examples include concentrations of sewing items and shiny objects associated with conjure bags; symbols engraved or painted onto objects or placement of particular objects into symbolic patterns (representing cosmograms or minkisi [spirits]); coins worn in a shoe; coins (typically dimes) with drilled holes worn as necklaces and ankle bracelets; exotic natural stones (e.g., crystals), polished rocks, and projectile points and other Native American artifacts (e.g., Arnett et al. 2000; Brown 2005a, 2005b; Brown and Cooper 1990; Davidson 2004; Edwards-Ingram 2001; Lindsey 2000; Russell 1997; Singleton 1995, 1999; Wilkie 1997; Yakubik and Mendez 1995). One African American oral history recalls the use of "chimney charms" that bring good luck or "keep things from entering the house" (Arnett et al. 2000:79). In addition, there are documented cases in which slaves intentionally placed diviner's bundles or conjure bags in selected places around the houses of white masters to persuade spirits into helping or harming others. In seventeenthand eighteenth-century Virginia, for example, Leone and Fry (1999:383-384) observed that "there was a hidden set of everyday cultural practices going on in and beneath the master's house in places that can be termed sacred spaces, practices with their origins very clearly in Africa." In another article, Leone and Fry (2001:147) note that African Americans most commonly placed ritual items and caches "under chimney bases and hearths, under a room's northeast corner, and around doorways: under their sills, over the door, and by doorposts." In addition to specific artifacts, spiritual behaviors may be represented by modification to mundane artifacts, such as crosses or cosmograms carved onto objects-like bricks, spoons, and pottery-that may have West African origins (e.g., Fennell 2007; Leone and Fry 1999, 2001). The most comprehensive ethnographic documentation of nineteenth-century folk magic spiritual beliefs is the five-volume HoodooConjuration-Witchcraft-Rootwork by Hyatt (1900-1978). The extensive and more easily accessible study of southern Negro folk beliefs by Puckett (1926) and the "Slave Narratives" of the 1930s (Library of Congress 2001) are also excellent compilations of primary sources. Brown's interpretations of selected items and groups of items in the Levi Jordan slave quarters as being related to spiritual beliefs of African origin had a direct bearing on how PAI approached the archeology of the Levi Jordan big house. The owner and his master builder would certainly have directed construction of the house, but slaves would have provided most of the labor. The enslaved workers would have had ample opportunity to place ritual objects in specific places during the construction if they believed that conjuring items could alter the behavior of the owners or otherwise provide some form of protection. Consequently, PAI archeologists felt it was important to fully excavate and examine many architectural features, such as foundation piers and chimney foundations, with an eye for possible ritual offerings. As it turns out, the only definitive case of a ritual offering that we found was not related to the enslaved or free black population but to the white plantation owner or builder (see Pier 2, southeast corner, in Chapter 6). One perforated metal disk found in a pre-1905 possible pier hole may reflect African American beliefs, but this interpretation is tentative (see Chapter 6).

\section{Texas Parks and Wildlife Department}

TPWD archeologists conducted work at the Levi Jordan Plantation twice in July 2002, soon after the agency purchased the site. During the first investigation, conducted from July 8 to 12, Alvarado (2002) monitored the backfilling of some old University of Houston excavation units and the removal of the 1961 concrete porch from the front of the house. At that time, the 1961 concrete porch was being removed because it caused drainage problems, and water running under the house was causing wood rot to the house. As workers removed the concrete porch, it became apparent that the west half of the structure's south wall was supported by a concrete beam that was attached to and part of the porch. Because the concrete beam then served as part of the house foundation, removing it was impossible without putting in additional supports. Consequently, the concrete beam was left in place while the concrete porch was broken apart and removed. As of July 12, 
2002, Alvarado (2002) reported that the concrete porch in front of the house was completely removed, but that:

The main concrete beam that ran around the perimeter [south wall] is all that is now left of the porch. The removal of this beam may be the biggest threat to intact deposits and to the archeology in and around the porch area. The footing is thought to be buried at a minimum one foot below ground surface. It is not clear whether or not the beam was poured over a bed of sand, like the porch, or if it is laying on the original ground surface.

Sometime after this, TPWD personnel conducted an unauthorized removal of about 90 percent of the concrete beam without archeological monitoring. TPWD archeologists Howard and Strutt returned to the site on July 24, 2002, to "assess the extent of damage caused to archeological deposits by unauthorized removal of the front porch perimeter beam" (Howard 2002:n.p.). They discovered that although the 1961 construction of the concrete perimeter beam had damaged some archeological deposits, its removal in 2002 had not. The archeologists conducted excavations in five areas along the perimeter beam to search for evidence of original house piers or piers associated with previous porches. At that time, pier locations were identified by exposed holes where tenons had once attached to the house beam. They determined that the entire area beneath the $10 \times 60$-ft porch had been previously excavated ca. 6 inches deep in preparation to lay the porch slab, but that the perimeter beam trench was 7 to 10 inches deep in most places. Howard (2002:n.p.) stated that "The extensive excavation in this area could have destroyed all archeological evidence of piers for earlier porches." But she also recommended that "exploratory excavations will be merited in the future to ascertain whether any archeological evidence of the older porches has survived."

While at the site in July 2002, TPWD personnel found two brick features that were exposed through the floorboards of the house. ${ }^{15}$
One was thought to be a chimney foundation under the east wing addition of the house, and the second was a brick feature under the central porch of the back addition of the house. They returned to the site in April 2003 to investigate these two brick features (see Figure 2.2), and these investigations are reported in the field journal and a short report by Howard (2003a, 2003b). The first brick feature was confirmed to be a chimney footing from a fireplace inside an earlier east wing. The function of the second feature remains unknown, but it was described as a prepared platform made up of different sizes of bricks embedded in a layer of mortar. The feature was tentatively thought to be a foundation for a wooden porch (Howard 2003b:14).

During the 2002 investigations, TPWD archeologists observed a thin layer of white powder that covered large areas of ground surface under the central portion of the back addition (Margaret Howard, personal communication 2011). PAI also encountered the white powder, in some places reaching a thickness of $1 / 2$ inch and forming a hard, plaster-like surface. After conversations with Howard and THC site manager Bryan McAuley, PAI archeologists determined that the white powder is some sort of pesticide that was blown under the house.

\section{Center for Archaeological Studies}

In 2005, TPWD contracted with Texas State University's Center for Archaeological Studies to excavate portions of the Levi Jordan Plantation. Under the supervision of Carol Leezer, CAS personnel excavated 13 units adjacent to and underneath the house. They recorded eight features, including one unit in an exterior feature now interpreted as a chimney foundation for a detached kitchen just north of the house (see Figure 2.2). CAS also excavated 36 shovel tests and one unit in a 15-acre area slated for a visitor's center (Leezer 2006:40). This portion of the property northeast of the house is not particularly pertinent to the PAI archeological investigations described in this report.

\footnotetext{
${ }^{15}$ Access to the ground surface under the house was made possible by the removal of the floorboards in two rooms (the den and the east wing), which was done by TPWD personnel in 2002.
} 
The CAS excavations underneath and around the main house were intended to aid in the understanding of the house's building sequence and original layout (Leezer 2006:35). To this end, units were placed on the exterior of the structure against the east chimney and the west end of the front porch. Excavations underneath the house were placed under the east wing to investigate the chimney footing, and under the rear gallery. One additional unit was placed in a previously investigated brick feature north of the east wing, interpreted as the detached kitchen chimney foundation.
The CAS investigations recovered 10,045 artifacts relating to architectural, vessel, munitions, and personal functions (Leezer 2006:55). Leezer followed classification criteria established by Brown, classifying first by material type (e.g., ceramics, glass, metal, rubber, brick, lithics) and then by artifact identification or function (e.g., munitions, coins, buttons). She then selected diagnostic artifacts for further analysis and description (Leezer 2006:55-75, Appendix B). These artifacts were found to support the previously expected plantation occupation dates, from the 1840 s through the $1980 \mathrm{~s}$. 


\section{PROJECT OVERVIEW, METHODS OF INVESTIGATION, AND WORK ACCOMPLISHED}

This report presents findings from two phases of archeological fieldwork. Phase I was conducted in September and October 2010, and Phase II was conducted in August and September of 2011. The nature of the fieldwork varied significantly between these phases, with the archeological investigation strategy linked to the areas being examined, the future impacts to the archeological resources in those areas, archeological research and preservation goals, and time constraints. For each phase, the archeological team was allotted four weeks in the field. During the interim between Phase I and Phase II, PAI archeologists had several meetings and communications with staff from the Texas Historical Commission's (THC) Archeology and Historic Sites Divisions to discuss the Phase I findings, plan the Phase II findings, and modify the terms of the antiquities permit.

Some notes on terminology are warranted here with respect to the layout of the Levi Jordan Plantation. Figure 3.1 depicts the house as it appeared during the Phase I investigations, with the various names used for the different rooms and sections of the house. As used in this report, the terms "original house" or "antebellum house" denote the $20 \mathrm{x} 60$-ft wood-frame plantation house that was constructed in the 1850 s (excluding any nineteenth- or twentieth-century additions). The terms "plantation house" and "big house" are used interchangeably to refer to the original structure with all of its subsequent additions. There is also evidence that one or more additions were built very early in the house's history, possibly within a few years after it was built. The evidence indicates that there was an "east wing" on the north side of the house in the nineteenth century; this is called the "original east wing" to differentiate it from the twentieth-century east wing. There are also historical hints that there might have been a nineteenth-century "west wing," perhaps one that was a mirror image of the east wing. Although it existence cannot be substantiated at this time, some discussions will refer to the possible "original west wing."

Historical evidence indicates that the original east wing may have been destroyed by the 1900 hurricane and that the additions to the back of the house (north side) were built sometime in the early twentieth century. When referring to this, the term "ell" denotes the entire addition that ran the full length of the house attached on the north side, including the north-projecting "east wing" (also called the "rear wing" by Leezer [2006:Figure 4-1]). The ell, which is also called the "twentieth-century addition" or the "twentieth-century ell," is the part of the house that was removed in 2011 as part of the stabilization of the original house. Some architectural evidence suggests that the ell was not a single addition but that various sections were added at different times (John Volz, personal communication 2012).

As documented in the oral history and published reports, the names of the rooms in the Levi Jordan house changed though time. This is related mainly to changing owners and occupants and the functional changes that occurred within the house through time. But it is important to know the various names that were used (see Figure 3.1) because archeologists and historians have used all of these names at one time or another.

Historical evidence does not reveal if the entire ell was added in a single construction event or if it happened in phases (e.g., the east wing was added first, and the other rooms to the 


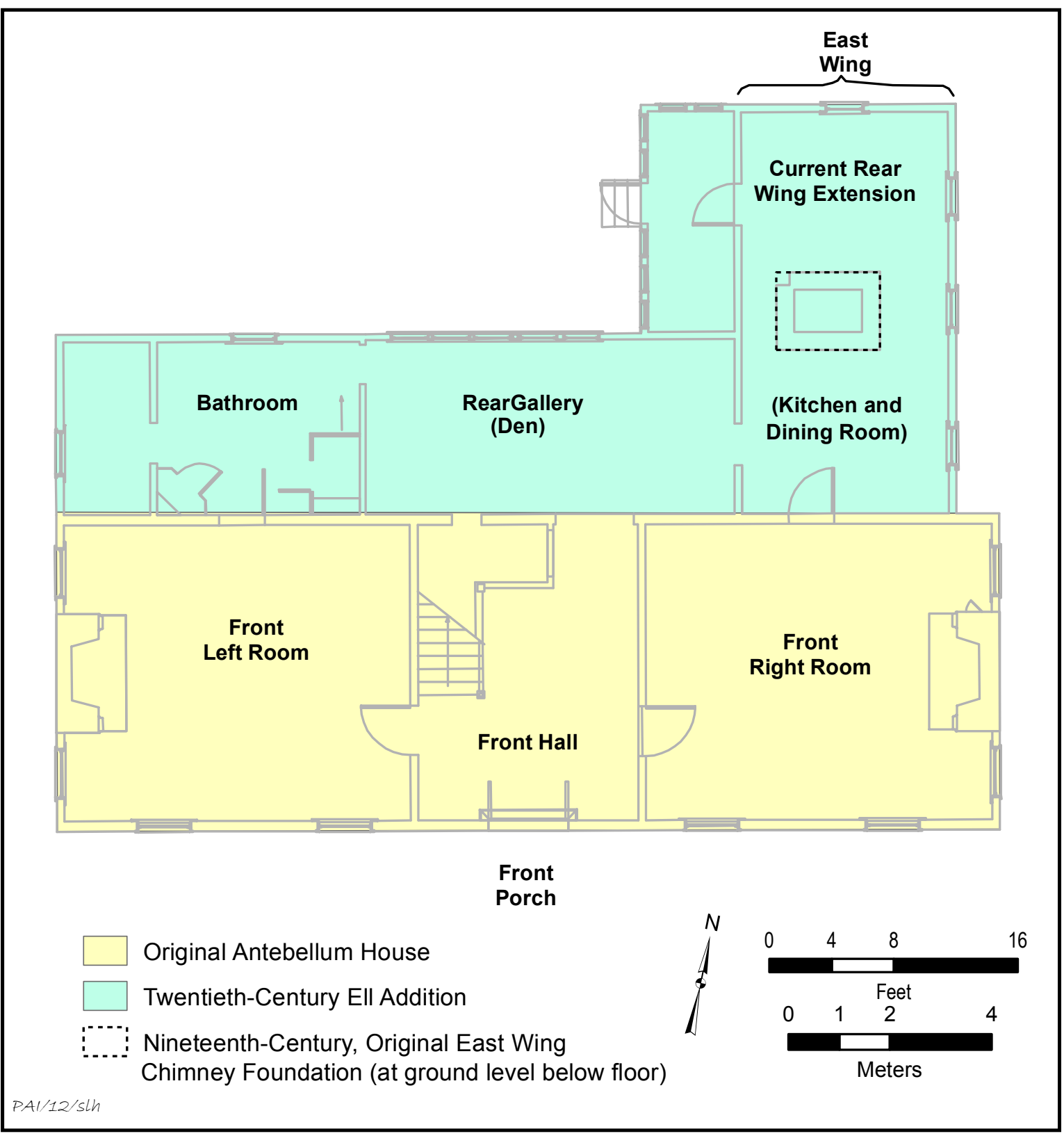

Figure 3.1. First-floor plan of the Levi Jordan house showing the rooms and differentiating the original antebellum house from the later twentieth-century additions. The primary room names are from Leezer (2006:Figure 4-1). Secondary room names (in parentheses) are from Howard (2003b:Figures 1 and 2) based on written and oral recollections by former occupants.

west were added, and then the east wing porch). There could have been earlier twentieth-century additions, but there is no historical evidence of this. The ell is the only major twentieth-century addition that is historically documented, and all its rooms were intact until it was removed.

\section{FIELD METHODOLOGY}

All of the archeological investigations at the Levi Jordan Plantation for this house stabilization project were feature-oriented. This focus was appropriate given the nature of the impacts 
associated with the house stabilization and the fact that the artifacts that would be recovered around the house would be temporally mixed assemblages with minimal interpretive value. The work conducted reflects the feature-oriented research goals. Collectively, the Phase I and Phase II archeological investigations resulted in the documentation of 69 house piers (see Chapter 6), 4 chimney foundations (see Chapter 7), and 10 exterior features (see Chapter 8).

There were some differences in how the archeological investigations were conducted that are specific to the Phase I or Phase II investigation that are discussed later in this chapter. But the standard field methods that were employed during one or both phases of work are described below.

\section{Site Grid}

Dr. Kenneth Brown established an excavation grid aligned to magnetic north, and all University of Houston excavations in both the "Main House Backyard" and the "Quarters" were placed on this grid (2005a:Figures 8 and 9). TPWD archeologist Howard (2003b:14) recommended that all future archeological work follow the University of Houston grid system. But Brown did not take into account the entire size of the site when establishing his arbitrary N1000/E1000 datum point, and some mistakes were made with unit designations. Howard spent a significant amount of time correcting these mistakes, and in the process created a "decoder map" to facilitate her research (Margaret Howard, personal communication 2011) ${ }^{16}$ But in the next TPWD-sponsored excavation, Center for Archaeological Studies (CAS) archeologists did not follow the University of Houston grid aligned to magnetic north. All of the 2005 CAS excavations were aligned with the orientation of the main house, and this orientation became their "grid north" (Leezer 2006:Figure 4-1). It is quite reasonable to orient excavations associated with historic buildings with the structural axes rather than strictly adhering to magnetic north. Because architecture was the focus of the Prewitt and Associates, Inc. (PAI) excavations in the stabilization project, we also aligned our excavation units with the walls of the main house, and used the same grid north as CAS (which is 11.5 degrees west of magnetic north). PAI also followed the CAS protocol of using standard English measurements for the excavation units and for recording depth below surface, feature dimensions, etc. As noted by Leezer (2006:35), "This practice greatly facilitates correlating data with historical documents, as this was the system used [by] builders and occupants of the plantation."

Because the PAI investigations were oriented toward investigating features, the unit size and configuration varied greatly. Some units were standard sizes (e.g., many $3 \times 3-\mathrm{ft}$ units were dug in Phase I) but the excavations to examine features were different shapes and sizes. The locations of all excavation units and features were plotted on large-format scaled architectural drawings of the house or sections of the house. This enabled the field archeologists to quickly and accurately plot archeological data relative to the house location using tape measures, even after the ell was removed and the house was elevated.

\section{Area and Excavation Unit Designations}

As discussed in Chapter 1, the portion of the Levi Jordan Plantation site owned by the State of Texas and managed by THC is 92.37 acres. It incorporates the locations of many structures and outbuildings from both the original antebellum and post-Civil War periods. PAI's work focused on the main plantation house (the only extant historic structure) and immediate yard space around it; no work was done elsewhere on the THC property.

PAI designated all exterior excavation areas following the CAS zone designation system described by Leezer (2006:35-40). Each excavation area was assigned a letter, and units within that excavation area were assigned a number in the sequence they were excavated. For example, CAS designated the front porch Area $\mathrm{D}$, and the two units excavated there were designated Units D1 and D2. PAI excavations in this same area were designated Units D3-D12. CAS designated the area north of the east wing Area G, and their

\footnotetext{
${ }^{16}$ A copy of the "decoder map" created by Howard was graciously made available to PAI by the Texas Parks and Wildlife Department.
} 
investigation of the detached kitchen chimney foundation was CAS's Unit G1. PAI excavations in this area include Units G2-G4.

PAI did deviate from the CAS zone designations in some minor ways and conducted excavations in some areas that were not previously investigated by CAS. Leezer (2006:Figure 4-1) designated the area along the east side of the original house Zone $\mathrm{C}$ and the area east of the rear wing (east wing) Zone E. But PAI chose to designate all excavation units on the east, west, and north sides of the house with letters that correspond with the cardinal compass directions. PAI designated the units on the east side of the house Units E3-E9, on the west side Units W1-W7, and on the north side Units N1-N6.

During Phase II, the smaller excavations targeting specific features were not assigned unit names or numbers. They are simply referred to by the feature or pier numbers.

\section{Pier Investigations and Terminology}

Piers were an important focus of the archeological work in both phases of the investigations. The goal was to gather information on pier construction techniques and materials to help define the original antebellum piers, later piers, and pier repairs or modifications through time. The investigation of piers associated with the original house was deemed especially critical because all of the perimeter piers and some of the interior piers would ultimately be destroyed when the new concrete foundation was put in place.

Architecturally, the original house and all its additions are pier and beam construction. Figure 3.2 illustrates a pier and beam foundation. The variability of piers and pier footings documented for the Levi Jordan house is notable. Above the ground, most of the piers were wood posts that were cut sections of trees (i.e., logs or timbers), milled lumber (e.g., square blocks and round posts or utility pole sections), or railroad ties. Concrete blocks and other modern materials were commonly used as replacement piers. Below the ground, some pier posts sat on brick footings consisting of one- to three-course square or rectangular pads of handmade bricks, while modern repairs were placed on poured concrete, concrete blocks, milled lumber boards, or bricks (or brick rubble) inside a posthole.
Most archeological investigations of plantation houses in Texas involve sites where the structures disappeared long ago, but the Levi Jordan investigations provided an opportunity to examine the direct link between the foundation piers and the house architecture. In this manner, the house helps interpret the piers, and the piers help interpret the house. Levi Jordan piers that were archeologically investigated can be linked to the original antebellum house, the twentieth-century ell, the original east wing, the possible original west wing, and various other exterior features such as porches. For the piers around the perimeter of the original house, each location is linked to a specific place on the aboveground house foundation. For the piers underneath the house, their locations could be linked to the specific foundation beams and floor joists. As discussed in Chapter 5, a detailed examination of the cut lumber beams and floor joists documented the distinctive arc-shaped marks made by large circular saw blades and the straight cuts made by sash saws. Knowledge of mid-nineteenth-century sawmills and technology helps interpret the marks and date parts of the Levi Jordan house foundation, and the Levi Jordan evidence in turn adds to our knowledge of mid-nineteenth-century sawmills.

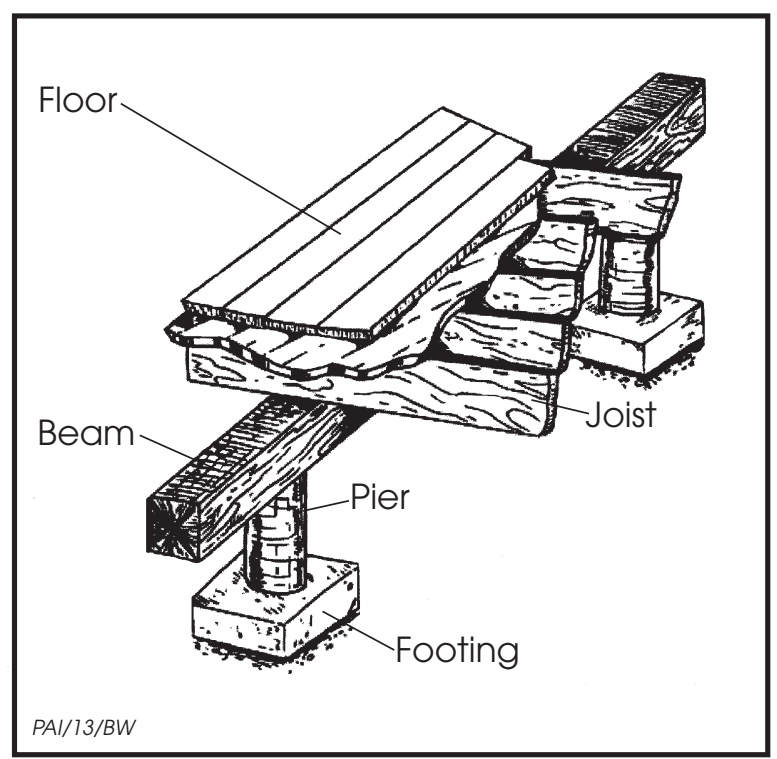

Figure 3.2. Architectural diagram of pier and beam foundations. 
During field investigations, three different systems were used to identify the piers. The numbering of the piers is described in more detail in Chapter 6, but the three systems are mentioned here. In Phase I, PAI numbered all of the visible piers around the perimeter of the whole house complex sequentially, from Pier 1 to Pier 38. After Phase I, the Phoenix 1 crew removed all of the structural components associated with the twentieth-century additions, which exposed all the foundation piers underneath it as well as all the piers along the north wall of the original house. Phoenix 1 mapped the piers and assigned each one a letter and number designation that identified the rows of piers and the piers within each row. Nineteen piers were designated in this manner during the Phase II investigations. Since the Phoenix 1 crew did not assign any numbers to the piers underneath the elevated antebellum house, PAI followed their binomial (row and pier) system, with a minor modification, to assign numbers to thirteen additional piers.

Sixty-nine piers ${ }^{17}$ were documented during both phases of work (Figure 3.3). Some level of archeological investigation was conducted on many of these, and 39 piers are described in Chapter 6. The archeological investigations of piers generally involved a hand-dug unit on one side to expose a profile. During Phase I, access to the exterior side of the pier relative to the structure was the only option. For most of the piers associated with the original house, the entire pier feature was excavated in Phase II to locate any underground components and to document the original brick or modified footings when present. The unit sizes varied, with the excavation area generally being square or rectangular and just large enough to expose each pier feature.

\section{Block Excavations}

In addition to the small excavation units and pier investigations, PAI conducted some large block excavations during both phases. These are designated by location or architectural name. In Phase I, a large block was excavated to expose the detached kitchen chimney foundation. Units N3 and N5 started as small excavations but turned into large blocks. Unit N3 was expanded to follow a large brick patio area, and N5 was expanded to search for evidence of a possible original west wing.

Other large block excavations were done on the four chimney foundation features. The detached kitchen chimney block was excavated in Phase I, while Phase II blocks investigated the east and west chimneys of the original house and the original east wing chimney.

In Phase II, two large excavation blocks were placed on the north side of the original house to investigate the deposits under the "den" of the twentieth-century ell. These blocks had to be placed between the square cribbing structures, and they were designated as the northeast and northwest blocks. ${ }^{18}$ Both of these blocks were then extended with block excavations called the northeast extension and the northwest extension. As with all of the other PAI excavations, the focus was on identifying features rather than recovering artifacts.

\section{PHASE I INVESTIGATIONS}

The Phase I work involved four weeks of field investigations. The work focused on investigating the perimeter piers of the Levi Jordan house and exterior features around the house.

\section{Site Conditions and Logistics}

When the Phase I investigations began, the main house consisted of the original $20 \times 60-\mathrm{ft}$ structure with the twentieth-century ell attached on the back of the house (north side). The large concrete front porch that was poured by a tenant in 1961 had been removed by TPWD in 2002, leaving the front porch area open. But the 2 -ft-wide and 31-ft-long section of concrete foundation beam (originally attached to the front porch) was present under the west half of the south wall (see Pier 37 in Figure 3.3).

\footnotetext{
${ }_{17}$ This number includes one brick footing that was assigned a feature number (Feature 29) rather than a pier number because it had no aboveground component.

${ }^{18}$ At the beginning of the Phase II investigations, these block areas were covered with a ca. 6-inch protective layer of sand and plywood sheets. When PAI requested to work in these areas, the plywood and sand were removed.
} 


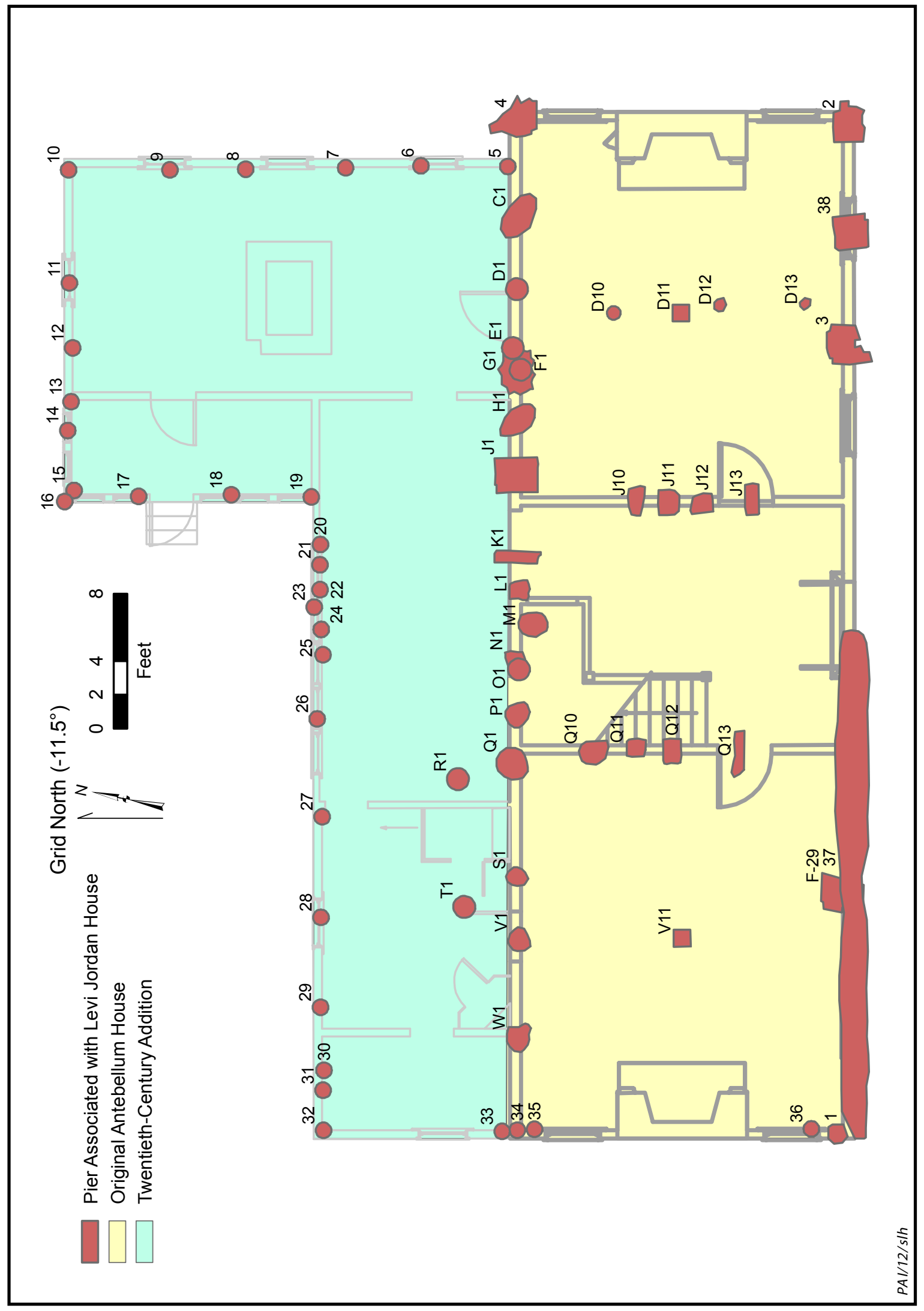

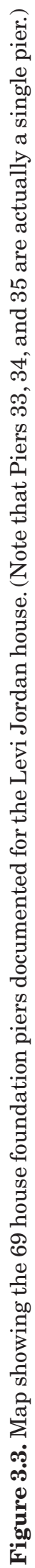


Placement of the test units during Phase I was dictated by the need to investigate certain external features around the house and architectural features associated with the house. The excavations were placed to investigate the original cistern, the backyard behind the ell, some external features that were identified in the GPR survey (see Chapter 5 and Appendix A), and the exterior side of some of the architectural features around the house. The latter included excavations focusing on the two chimney foundations and the foundation piers.

Throughout Phase I, archeologists had easy access to the inside of the house and to the detailed architectural drawings. This allowed for precise placement of archeological test units relative to the house layout as well as the targeting of specific architectural features. For example, it was easy to go inside the house and look at the room layout and locations of doors and windows as they might relate to outdoor features and activities, and then place excavation units on the ground just outside specific rooms or underneath a specific door or window. It was also helpful to see the plumbing inside the house and where it went into the ground to predict the locations of buried water and wastewater lines. Access to the inside of the house also allowed the archeologists to examine the architectural differences between the original house and subsequent additions to infer the building sequence.

\section{Phase I Goals and Work Accomplished}

The Phase I investigations went smoothly and little time was lost to weather, despite being conducted during the hurricane season. The stated goals were to gather architectural information about the construction of the antebellum house and the twentieth-century addition and to search for other features and activity areas around the house that might be impacted by the house stabilization project. Features targeted for investigation were the buried cisterns in the backyard, selected pier features around the perimeter of the house, the exterior side of the west chimney, the possible detached kitchen chimney, and the front steps. Additional work focused on the front porch and other areas where possible porches might have been, and excavations in the backyard to identify unknown features there.
The Phase I work included excavation of 37 units, primarily consisting of $3 \times 3$-ft units (Figure 3.4). In total, an area of $701 \mathrm{ft}^{2}$ was exposed, and $488 \mathrm{ft}^{3}$ of fill was removed by hand excavations. PAI archeologists also mapped the locations and documented details for 38 piers around the perimeter of the house. Intensive feature investigations included documentation of two cisterns behind the house, 15 house foundation piers, 6 probable porch piers, the front steps and walkway (concrete over bricks), a large brick patio, a brick rain barrel pad, a large brick concentration, a small brick cluster, and a seashell concentration (Figure 3.5; Table 3.1). Features previously documented by CAS are summarized in Table 3.2.

Three chimney foundations were investigated. Two units were dug on the exterior of the west chimney of the original house. PAI reexcavated the CAS Unit G1 adjacent to the detached kitchen chimney foundation (Leezer 2006:Figures 4.1 and 5.17, 52-53, 86) and then expanded it into a shallow block over the whole footing and deep trench along its east side. PAI also examined the original east wing chimney that had been previously exposed by TPWD archeologists underneath the east wing of the ell addition (Howard 2003a, 2003b).

In addition to excavations described above, the Unit N3 excavation was expanded with shallow shovel scraping to expose a large portion of a brick-paved patio on the north side of the house. The Unit N5 excavation was expanded to search for evidence of a possible original west wing, focusing on the area just north of the ell addition. This location was selected because it was surmised that an original west wing might be symmetrical with respect to (i.e., a mirror image of) the original east wing. If the hypothesized west wing had a fireplace like the one in the east wing, its foundation should have been located in this area, but no such evidence was found.

\section{INTERIM CONSULTATION AND PHASE II PLANNING}

In the interval between Phases I and II, many decisions were made regarding the archeological investigations in Phase II. On November 4, 2010, PAI archeologists met with THC and Volz and Associates, Inc., representatives to discuss upcoming house stabilization work 


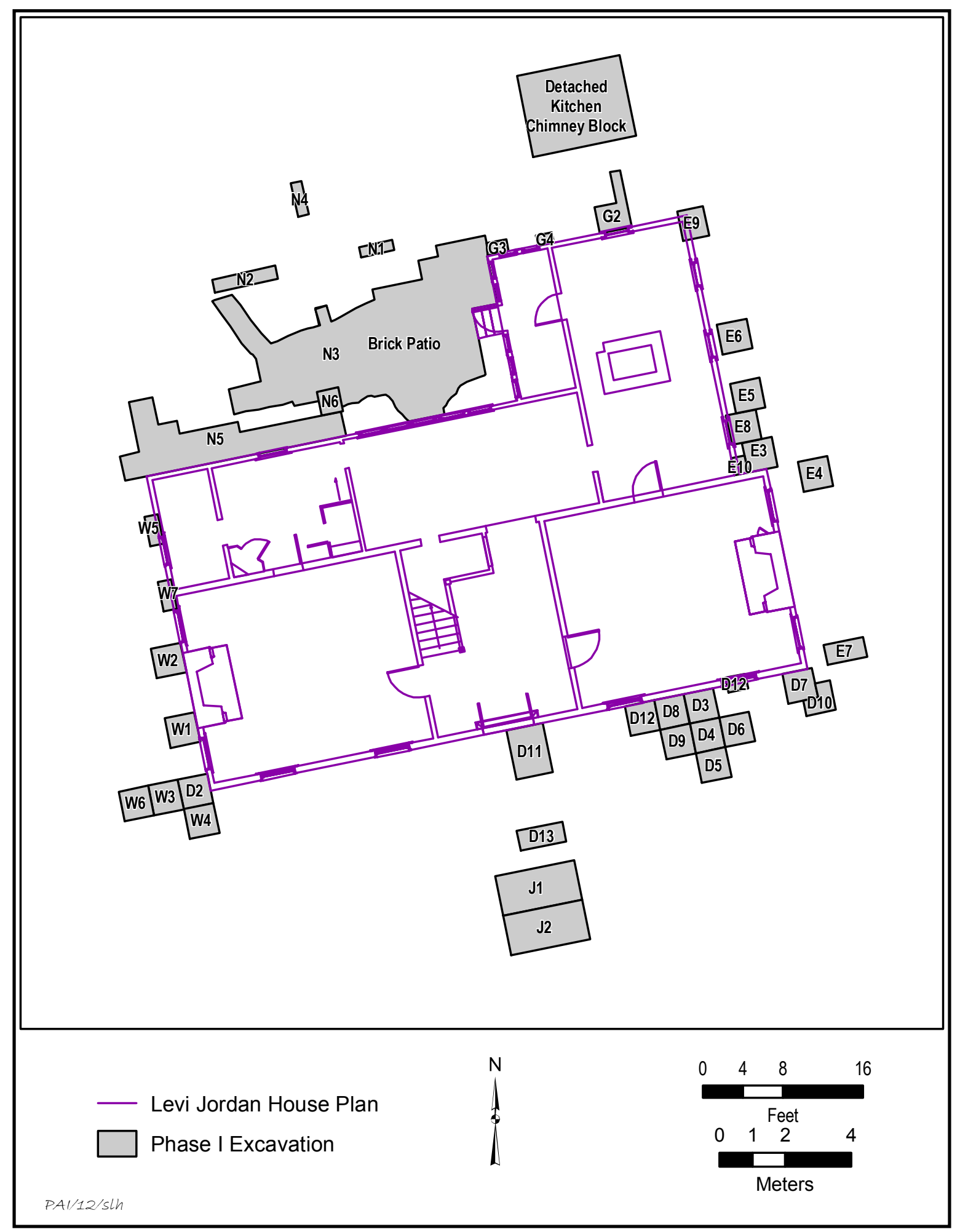

Figure 3.4. Map of Prewitt and Associates, Inc., Phase I excavations at the Levi Jordan Plantation. 


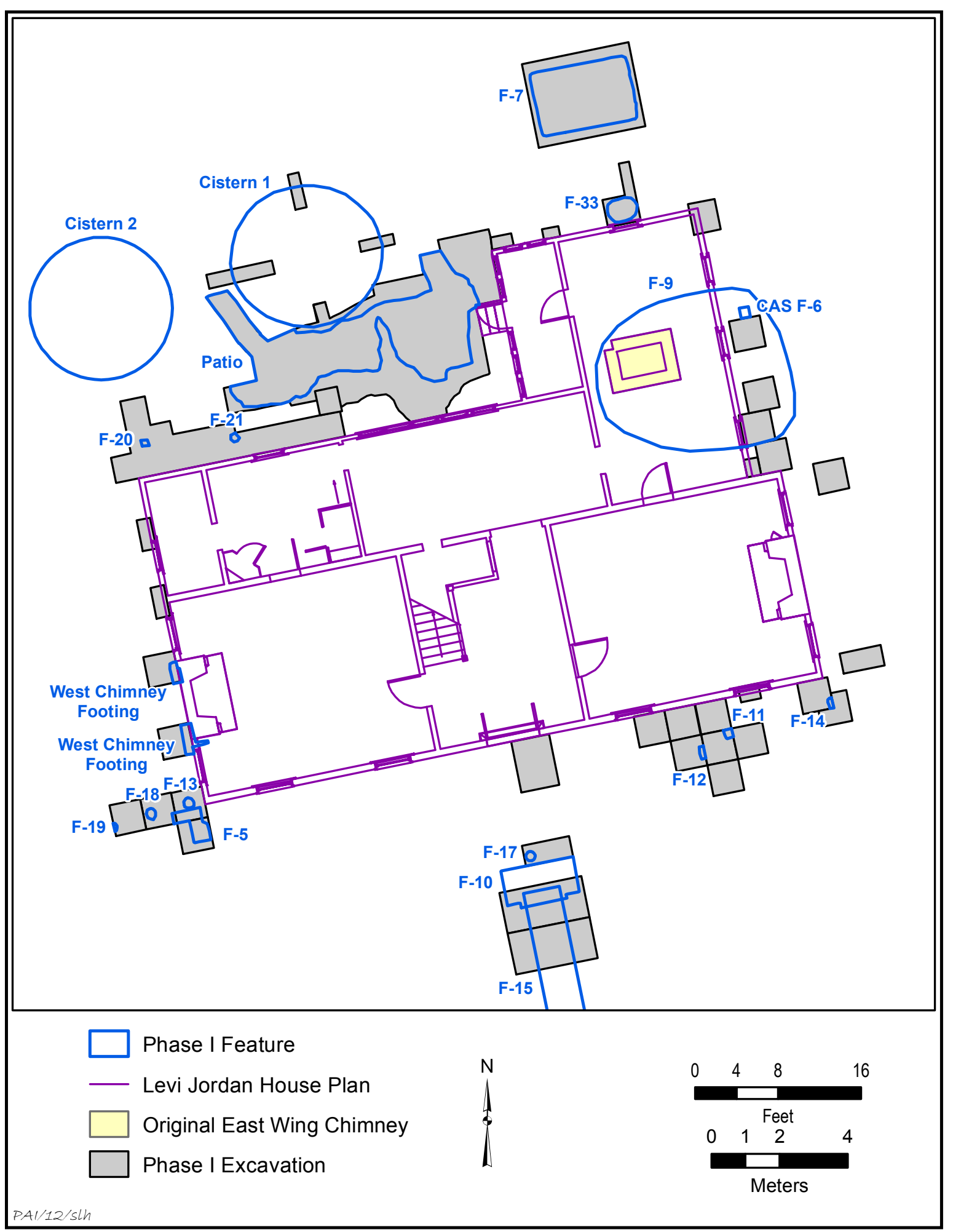

Figure 3.5. Map of archeological features investigated during Phase I. 


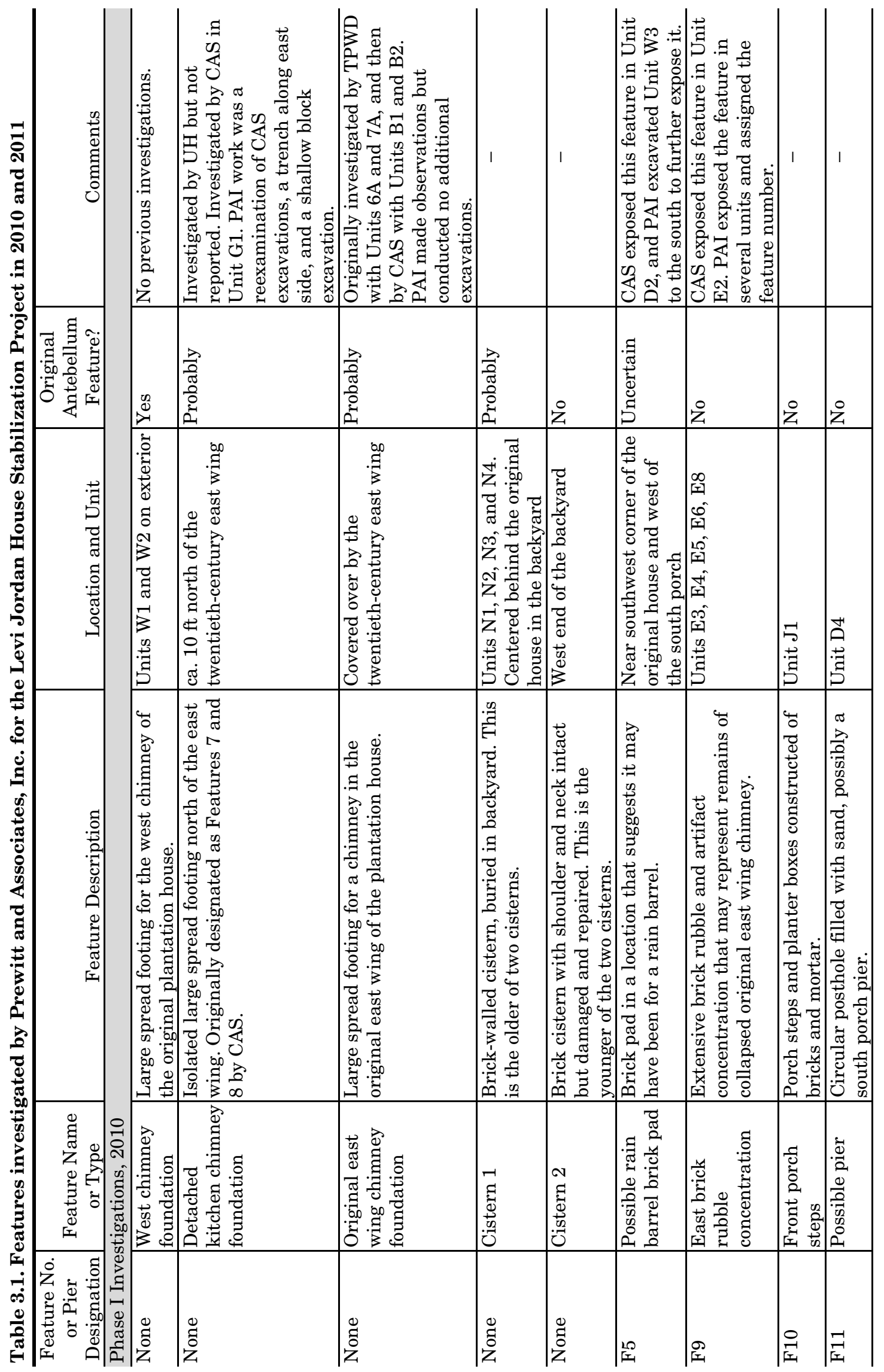


Chapter 3: Project Overview and Work Accomplished

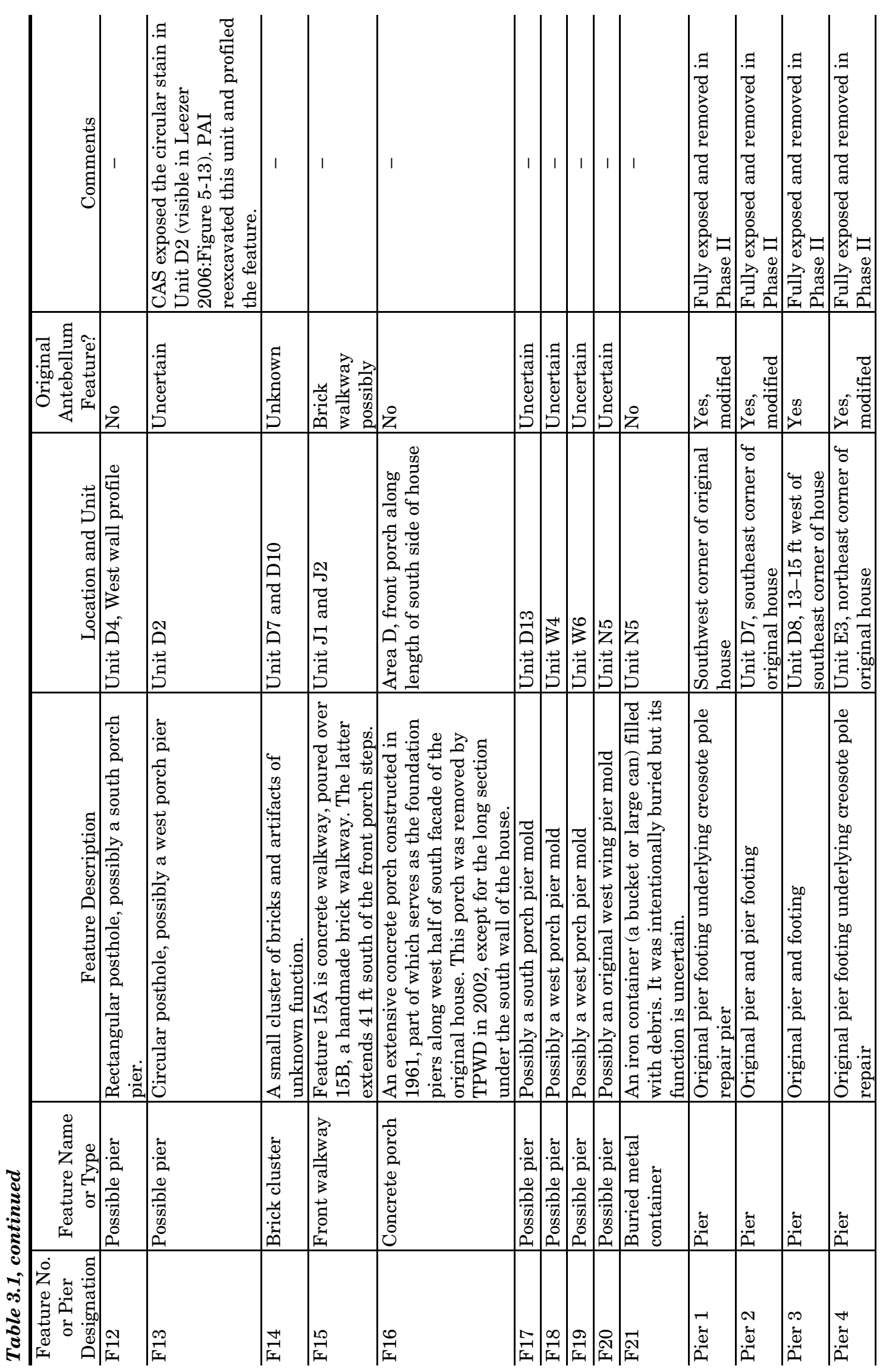




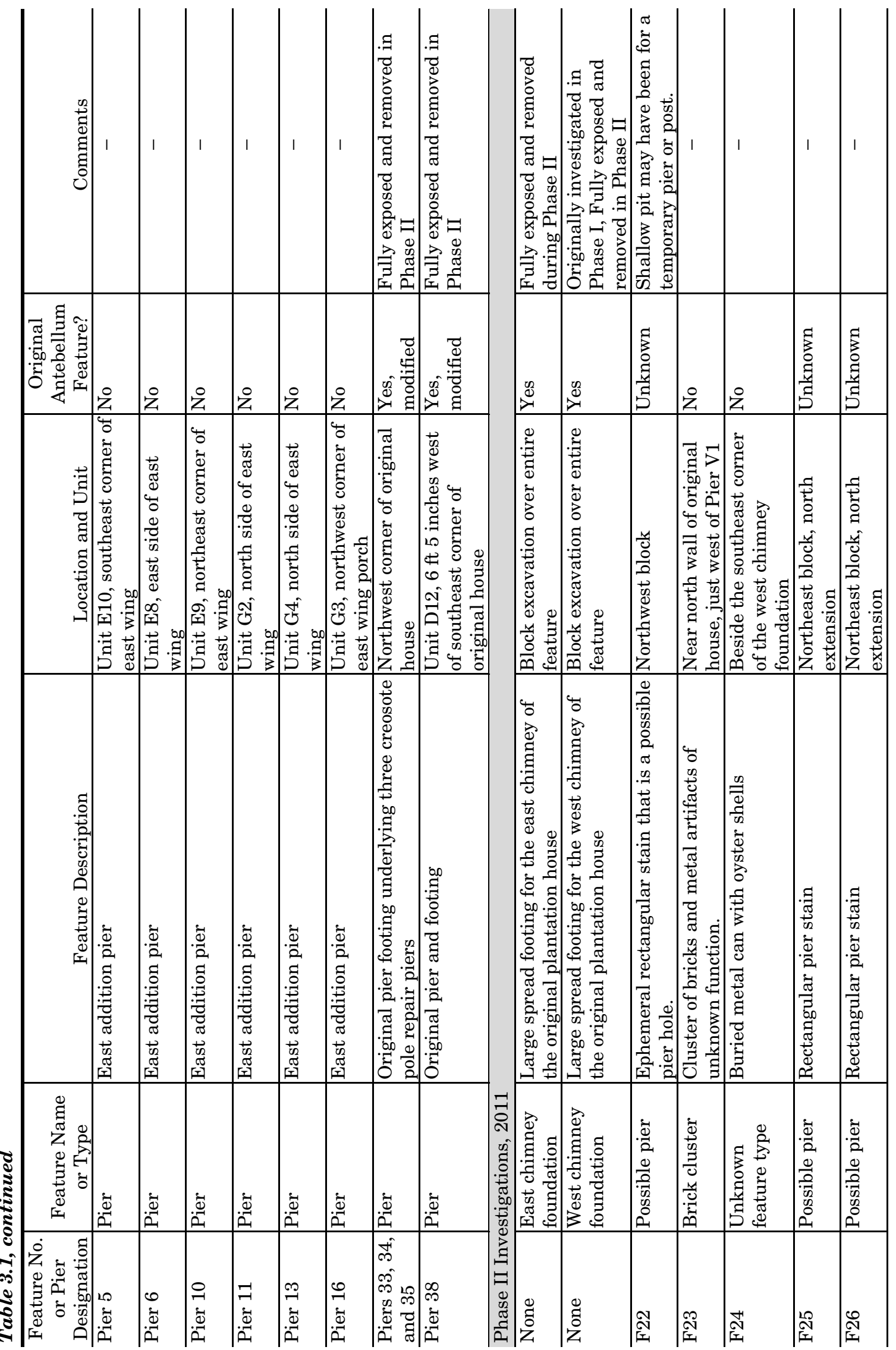


Chapter 3: Project Overview and Work Accomplished

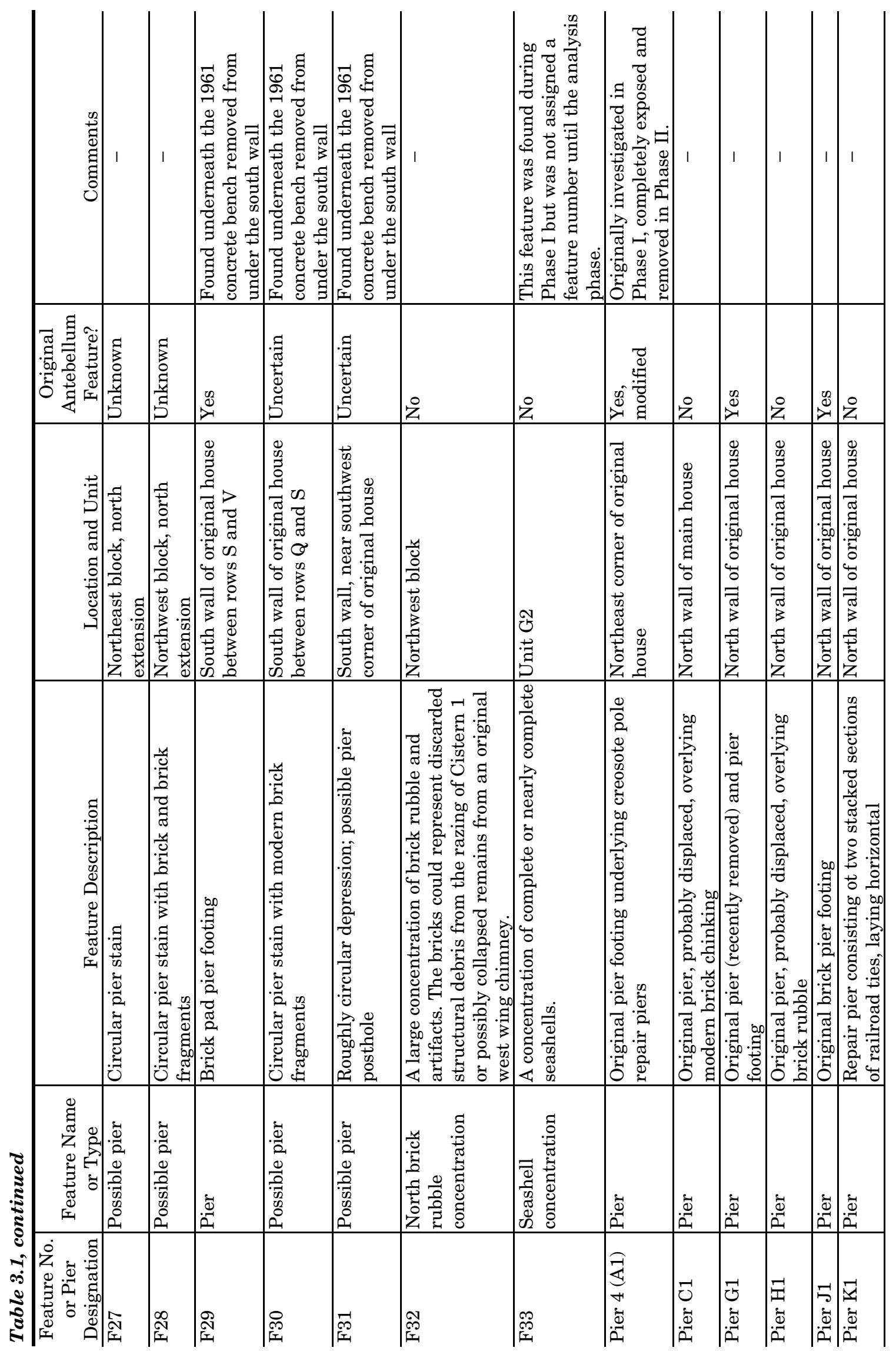




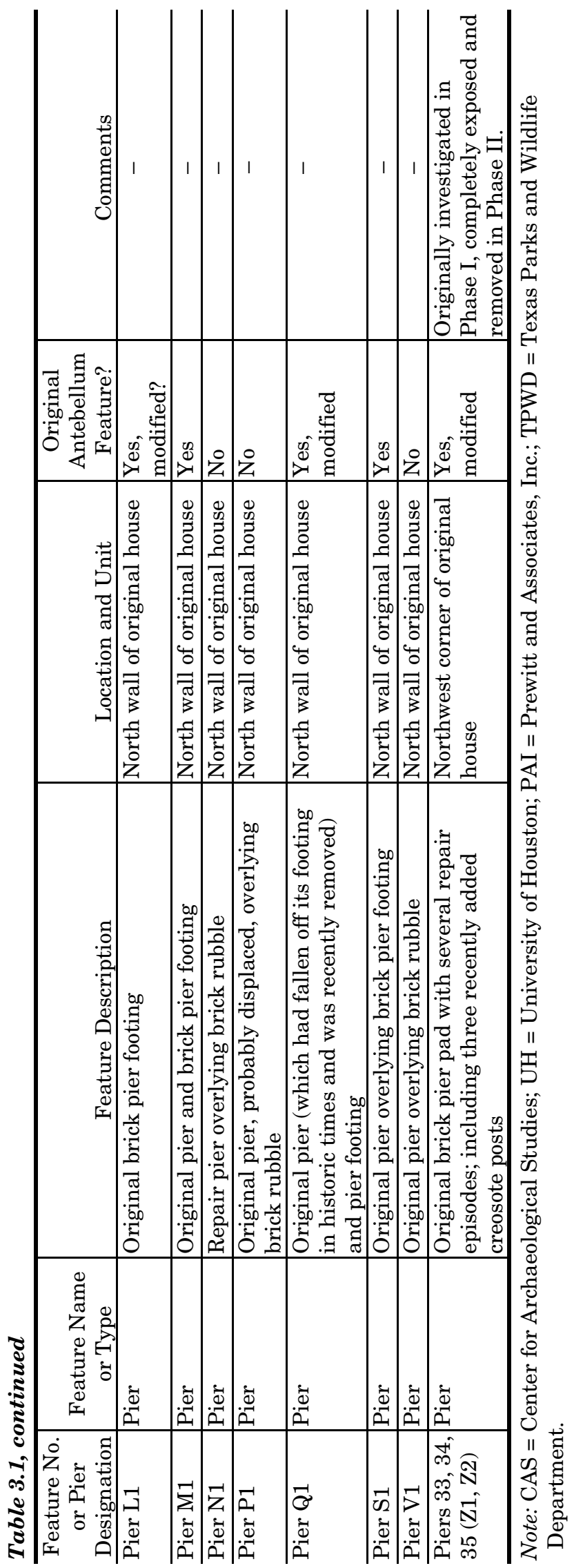


Chapter 3: Project Overview and Work Accomplished

Table 3.2. Features recorded at the Levi Jordan Plantation by the Center for Archaeological Studies in 2005

\begin{tabular}{|c|c|c|c|c|c|}
\hline $\begin{array}{l}\text { Feature } \\
\text { No. }\end{array}$ & Description & $\begin{array}{l}\text { Depth } \\
\text { Below } \\
\text { Surface } \\
\text { (inches) }\end{array}$ & Location & $\begin{array}{l}\text { Page No. } \\
\text { in Leezer } \\
(2006)\end{array}$ & PAI Investigations and Comments \\
\hline F1 & $\begin{array}{l}\text { Soil stain suggesting } \\
\text { brick walkway }\end{array}$ & - & $\begin{array}{l}\text { Rear Gallery, } \\
\text { Units A1 and A2 }\end{array}$ & 44,78 & None \\
\hline F2 & $\begin{array}{l}\text { Construction trench for } \\
\text { the east wing fireplace }\end{array}$ & 4 & $\begin{array}{l}\text { East Wing, Unit } \\
\text { B1 }\end{array}$ & $46-47,80$ & None \\
\hline F3 & $\begin{array}{l}\text { Construction trench for } \\
\text { the east chimney }\end{array}$ & $4-12$ & $\begin{array}{l}\text { East Chimney, } \\
\text { Unit C1 }\end{array}$ & 48,82 & $\begin{array}{l}\text { Entire east chimney foundation } \\
\text { was reinvestigated by PAI }\end{array}$ \\
\hline $\mathrm{F} 4$ & $\begin{array}{l}\text { Construction trench for } \\
\text { the east chimney }\end{array}$ & $8-12$ & $\begin{array}{l}\text { East Chimney, } \\
\text { Unit C2 }\end{array}$ & $49-50,82$ & $\begin{array}{l}\text { Entire east chimney foundation } \\
\text { was reinvestigated by PAI }\end{array}$ \\
\hline F5* & Brick walkway & $4-8$ & $\begin{array}{l}\text { Southwest corner } \\
\text { of home, Unit D2 }\end{array}$ & $50,83-84$ & $\begin{array}{l}\text { Reinvestigated by PAI and } \\
\text { determined to be a possible brick } \\
\text { rain barrel pad }\end{array}$ \\
\hline $\mathrm{F} 6^{*}$ & $\begin{array}{l}\text { Well-defined } 12 \times 10- \\
\text { inch soil stain }\end{array}$ & $16-24$ & $\begin{array}{l}\text { East side of East } \\
\text { Wing, Unit E2 }\end{array}$ & $51,84-85$ & $\begin{array}{l}\text { PAI excavated an adjacent unit, } \\
\text { and this feature is now } \\
\text { interpreted as a possible pier that } \\
\text { may have been associated with an } \\
\text { old porch on the east side of the } \\
\text { east wing }\end{array}$ \\
\hline F7* & $\begin{array}{l}\text { Handmade brick wall } \\
\text { and step-out foundation }\end{array}$ & - & $\begin{array}{l}\text { North of East } \\
\text { Wing, Unit G1 }\end{array}$ & $52-53,86$ & $\begin{array}{l}\text { Reinvestigated by PAI and } \\
\text { confirmed as a chimney } \\
\text { foundation, probably associated } \\
\text { with a detached kitchen }\end{array}$ \\
\hline F8* & $\begin{array}{l}\text { Brick rubble fill (see } \\
\text { Feature 7) }\end{array}$ & 24 & $\begin{array}{l}\text { North of East } \\
\text { Wing, Unit G1 }\end{array}$ & $52-53,86$ & $\begin{array}{l}\text { Reinvestigated by PAI and } \\
\text { confirmed as a chimney } \\
\text { foundation, probably associated } \\
\text { with a detached kitchen }\end{array}$ \\
\hline
\end{tabular}

*Feature also investigated by Prewitt and Associates, Inc. (PAI).

and the Phase II archeological studies. For this meeting, PAI prepared a map showing the sensitive archeological areas that would need to be considered during the stabilization work (Figure 3.6). Based on what was learned in Phase I, this map defined four types of sensitive archeological areas in and around the Levi Jordan plantation house that needed to be considered:

1. Areas to be totally avoided. These were areas with known archeological features that needed to be protected. Some of them were intrusive features (such as the cistern) that would have pockets of subsurface instability. These areas were fenced or marked so that they could be avoided by vehicles, construction equipment, and heavy cribbing.
2. Areas to be covered with protective materials. These areas were known archeological features that needed to be protected from construction equipment, vehicles, foot traffic, and other impacts. These areas were fenced or covered with plywood for protection.

3. Areas where plumbing pipes were present. Only two areas with plumbing pipes were identified during Phase I archeological investigations. To avoid impacting buried archeological deposits, all pipes and utility lines were cut and left in place rather than being ripped from the ground.

4. Areas recently excavated. All the areas excavated around the structure by PAI in Phase I were marked or covered to avoid 
further impacts. Although they had been backfilled, the fill had not settled completely.

The attendees agreed with these recommendations and the need to protect the buried archeological remains. This map was then provided to all of the architects, engineers, and contractors who would be involved in the Levi Jordan house stabilization.

A second planning meeting was held on January 19, 2011, and attended by PAI and personnel from THC's Historic Sites and Archeology Divisions. PAI summarized the Phase I findings, and the subsequent discussion focused on planning for the Phase II archeology. Two primary research goals were identified:

1. To salvage important architectural information that would aid in reconstructing the sequence of structural changes and improvements to the house.

2. To recover artifacts from pre-Civil War contexts that will contribute to an understanding of African Americans and Euro Americans in the antebellum period.

PAI archeologists continued the discussions with THC over the next few months, and both parties agreed that the scope of work for Antiquities Permit No. 5720 should be amended to include the Phase II work. It was agreed that all of the Phase I and Phase II work should be integrated into a single archeological report. In addition, both parties agreed that the recovered artifacts would generally represent accumulations of materials from mixed contexts dating from the 1850s through the 1990s and that the interpretability of such assemblages was limited.

The initial estimate of expected Phase I artifact recovery was based on the artifact densities encountered by CAS (Leezer 2006). However, PAI's actual artifact recovery from Phase I far exceeded that estimate. Thousands of artifacts were recovered, dominated by window glass fragments and unidentifiable corroded iron. With few exceptions, the artifacts were recovered from mixed deposits. Almost all excavated contexts contained materials that could date to any of the plantation occupation periods, from the 1850 s to the 1990 s.

Based on these limitations, PAI and THC agreed that the following analysis and reporting procedures would be appropriate for dealing with the artifact assemblages and cultural features:

- Scale back the focus on artifact description and analysis and concentrate the work effort on more comprehensive analysis and interpretation of the cultural features.

- Create an inventory of all the cultural materials by lot number and provenience, but simply weigh the redundant and nondiagnostic artifacts (e.g., square nails, wire nails, window fragments, and unidentifiable corroded iron objects) in groups rather than count them individually.

- Examine all of the artifacts to sort out any that are possibly functionally and temporally diagnostic of the nineteenth century. Inventory these specimens separately and attempt to identify their ages and functions.

- Closely examine all artifacts from selected feature contexts that could represent nineteenth-century deposits and identify them as accurately as possible. A separate inventory would be created for these artifacts, and they would be individually labeled and bagged by lots.

In the Phase I investigations, PAI archeologists did examine nineteenth-century features and documented a few contexts where featureassociated artifacts were found in contexts believed to date to the original house construction (e.g., artifacts found in builder's trench fill associated with original house piers). Relative to the artifacts from temporally mixed deposits, the cultural materials from selected nineteenthcentury feature contexts are certainly more valuable for interpreting activities associated with the original plantation. Consequently, PAI and THC agreed that the Phase II investigations should focus on investigating probable nineteenth-century features, especially architectural features that would help define the house construction techniques and the evolution of the structural additions through time. It was also agreed that the excavations could be extended as much as 4 or $5 \mathrm{ft}$ beyond the northern edge of the original house to define features and activity areas in the original yard or patio, but that features much farther away would need to be investigated at another time. 


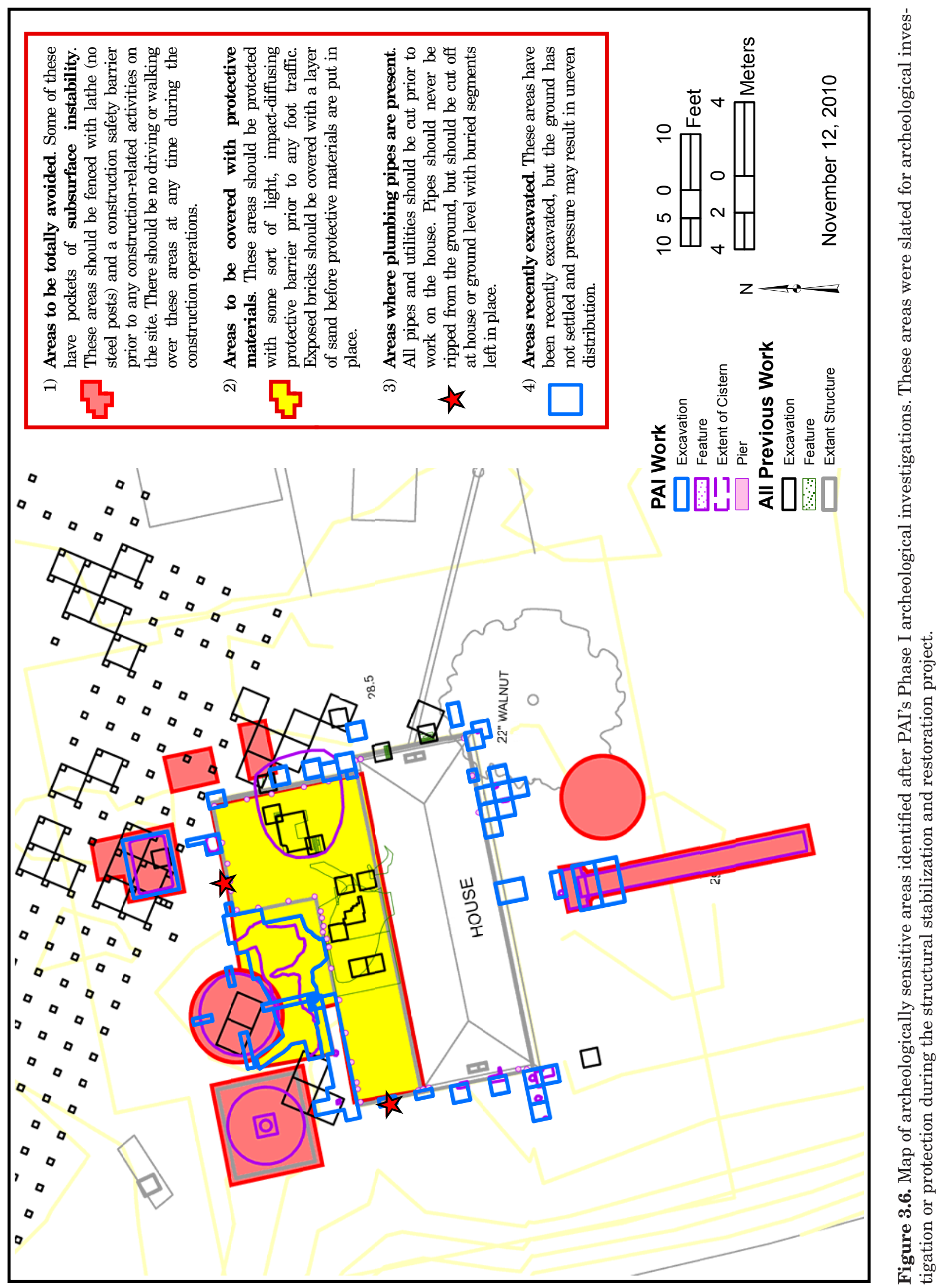


As a result of these negotiations, PAI requested a modification to Permit No. 5720 on March 14, 2011. The revised scope of work specified these three things: (1) It expanded on the Phase I investigations to include Phase II archeological studies underneath the Levi Jordan plantation house. (2) It specified that all of the Phase I and Phase II investigations were to be reported together in a single report of investigations. (3) It specified a streamlined descriptive inventory (with limited analysis) of the large amount of cultural materials recovered during the Phase I investigations. THC concurred with the permit modifications and approved the revised scope of work on March 31, 2011.

Because the structural history on the north side of the house is poorly known, the Phase II investigations were planned to increase the chances of finding archeological evidence of possible nineteenth-century wings, patios, porches, etc. This evidence was considered critical to defining the architecture of the original Levi Jordan house, as well as the sequence and age of the subsequent additions, repairs, and modifications. The construction of the new 3 -ft-wide concrete perimeter foundation would destroy everything under the walls of the original house, including the critical back yard areas below doors and windows on the north facade. Because of this, some excavation was proposed at each of these locations.

Excavations to target the areas below the doors and windows of the original house were proposed for two reasons. First, the excavations could yield material culture related to African American spiritual beliefs because conjuring items were often placed under doors and windows. Second, recovered broken window glass along the north facade could provide chronological evidence relating to damages from hurricanes and subsequent repairs to the most controversial side of the structure, the north facade. If sufficient window glass were recovered, PAI could compare the glass thicknesses with the data compiled by Leezer (2006:60-62, Appendix A) in a window glass study that correlated broken glass of different thicknesses with specific hurricane events. As it turned out, however, PAI excavations on the north side of the original house were minimal due to the placement of three large cribbing structures, and window glass recovery was limited.

Considerable time was spent planning the Phase II archeological investigations, but everyone acknowledged that we could not anticipate what types of features and artifacts might be encountered. It also was impossible to precisely determine the placement of excavation units in advance or to define the horizontal extent or excavation depth that would be needed. Another important factor that hindered the Phase II planning was that the number and placement of cribbing structures for supporting the elevated house was not known.

\section{PHASE II INVESTIGATIONS}

The Phase II fieldwork began almost 10 months after the Phase I work ended, and it lasted for four weeks. These archeological investigations focused on the areas underneath the antebellum house and the twentieth-century ell.

\section{Site Conditions and Logistics}

Site conditions were significantly different when PAI returned for Phase II work (Figure 3.7). The entire ell addition had been removed, and the original house was raised about $6 \mathrm{ft}$ above the ground and completely wrapped in Tyvek, a water-resistant protective barrier. The house rested on seven steel I-beams running east-west, and these sat on two longer steel I-beams that ran north-south a few feet beyond and parallel to the north and south house walls. The long I-beams rested on three cribbing structures, each of which consisted of railroad ties stacked in square or rectangular alternating layers like Lincoln Logs with the ends jutting out. The front walkway was topped with scaffolding to keep vehicles and people from crossing it, and a large sand pile covered one of the archeologically sensitive areas southeast of the front door where an unidentified subsurface feature was found during the ground-penetrating radar survey.

On the north side of the house, the look of the backyard had changed considerably. Not only was the entire twentieth-century ell gone, but all of the piers that had supported it were removed. The renovation contractors had placed a thick layer of sand topped by plywood over the entire area where the addition had been. This was done to protect the sensitive archeological deposits during the stabilization work. The result was an odd view of the original house wrapped in plastic and the ground tiled with plywood topped with awkward support structures but without 

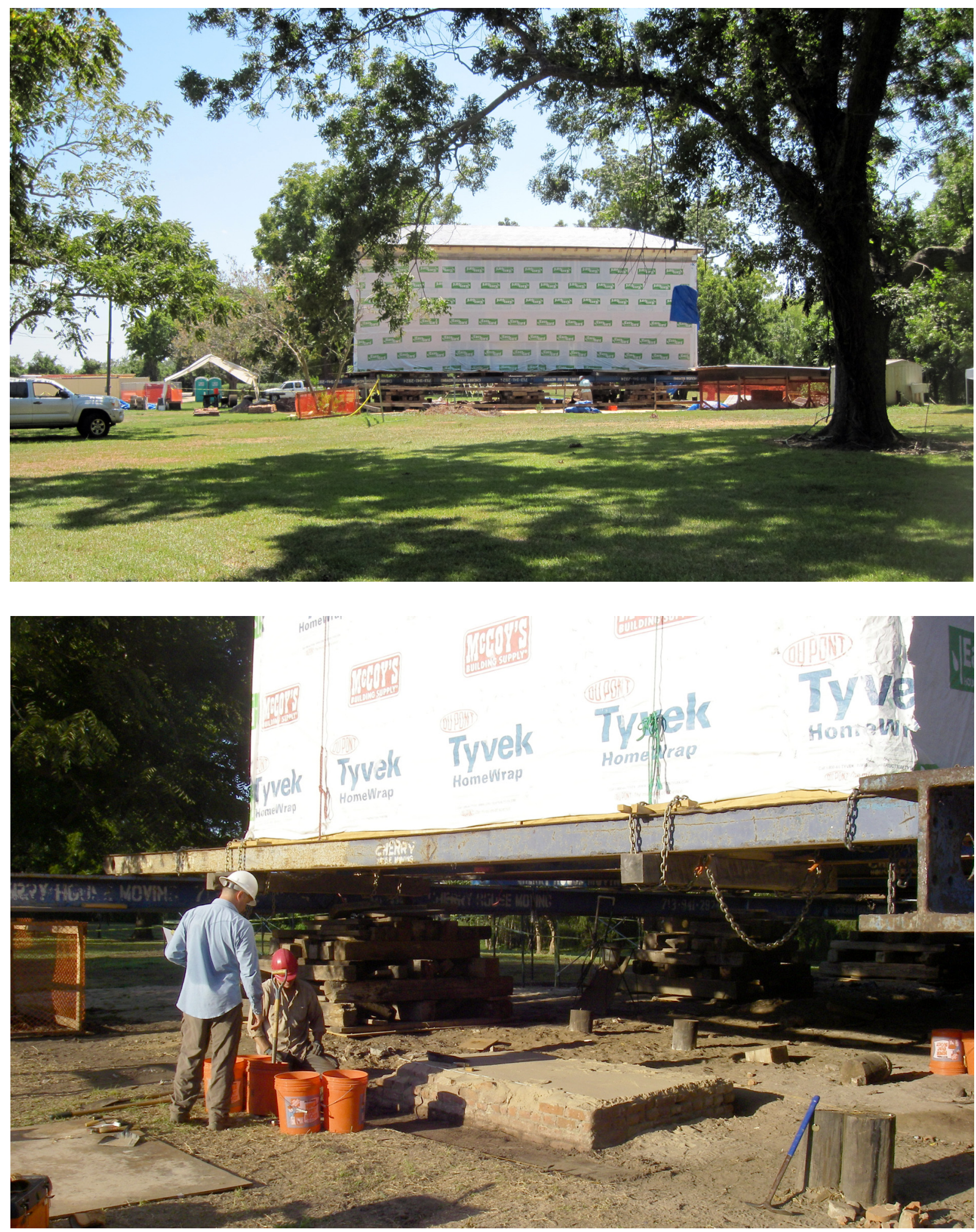

Figure 3.7. Photographs of the Levi Jordan house raised and supported by steel beams on wooden cribbing structures. (Top) View of the back of the house, looking south. The twentieth-century additions have been removed and the original structure is wrapped in Tyvek plastic sheeting for protection. (Bottom) View of the east side of the house, looking southeast. The wooden piers at left are at the northeast corner of the house (Piers 4A and $4 \mathrm{~B})$, and the excavation of the east chimney foundation is in progress. 
the chaotic architectural trappings that had accumulate over decades of repairs, rebuilding, and modifications.

Much of the PAI Phase II archeological work took place underneath the elevated house (Figure 3.8). For archeologists, it was a somewhat unusual working environment. The natural surface under the house sloped downward to the west, toward the slough, but the ground was far from smooth. Minor rainwater tributaries had formed, and the surface was undulating in many areas due to animal burrowing and other disturbances. The archeological excavations added to the chaos of the ground surface, with feature and linear excavations dotted and crisscrossed throughout the cramped area under the house. Overhead, the large I-beams (12 inches thick), the foundation beams, the floor joists, and the house floor created an inverse stairstepped ceiling. Large chains and ropes were hung sporadically from the I-beams to secure a massive tarp system that covered the roof of the structure. Because the lower steel I-beams were about $5 \mathrm{ft}$ above the ground, the PAI archeological team quickly learned to appreciate their hard hats.

With the house wrapped in Tyvek plastic sheeting, all the doors, windows, and interior wall locations were obscured. It was beneficial that most of the Phase II archeologists had also worked there during Phase I, but the area had changed so dramatically that it was still disorienting. It was difficult to know exactly where things were in relation to the house, which was especially problematic for the placement of excavations and in judging pier locations. It became difficult to line up a unit with a door or a window, or to reconstruct where the pier rows under the twentieth-century ell had been.

The solution to these problems was relatively simple. PAI archeologists added a measuring tape and string line following the north wall of the house. Using the architectural drawings, the tape was used to measure the exact distances to the doors and windows along the north wall, and these locations were then plotted on the string line using a black permanent marker. The tape and string lines were left in place for the duration of the Phase II work, and they provided a much-needed on-the-ground link to the original house floor plan.

Another significant change from Phase I was the presence of architectural contractors onsite. The Phoenix $1 \mathrm{crew}$, comprised of three to ten workers on any given day, worked alongside PAI personnel during three out of the four weeks of the Phase II work. Therefore, it was necessary to coordinate the archeological excavations with the exterior restoration work. For safety reasons, PAI archeologists could work north of the original house only when the Phoenix 1 crew was not working on the exterior walls directly above them. On some occasions, PAI had to move people to work underneath the house when Phoenix 1 needed to work on the exterior north wall.

Despite the logistical challenges, the Phoenix 1 personnel were very helpful. They assisted with the removal of the chimney bricks down to the top foundation layer and with the removal of remaining portions of the 1961 concrete beam under the south wall to expose an area where several piers could be investigated.

The locations of the cribbing stacks that supported the elevated house also presented some logistical challenges. The number, locations, and sizes of cribbing structures were unknown to PAI archeologist until a few days before the Phase II fieldwork began. The decisions regarding cribbing were left to the house movers, and they selected their final size and locations just before the house was lifted. Just days before elevating the structure, the number of I-beams used to lift the house was increased based on an engineer's recommendation, and this altered the house mover's plans for lifting the structure. Longer I-beams were eliminated in favor of shorter ones, and the cribbing locations had to be moved closer to the house. Because of these final decisions late in the game, even the Phoenix 1 restoration contractors could barely get close enough to the house to do their foundation work.

The final cribbing decisions did have an impact on the Phase II archeological plans that were so well thought out in the interim period. Much of the excavation strategy developed by PAI and THC in the weeks prior was based on engineering assumptions that the cribbing would be located well away from the elevated house. Ultimately, because the cribbing structures were so large (i.e., $6 \times 8 \mathrm{ft}$ to $8 \times 8 \mathrm{ft}$ ), and because the archeological excavations had to be at least $2 \mathrm{ft}$ from their edges for safety reasons, their final placement effectively removed large areas north of the house from all archeological consideration. 


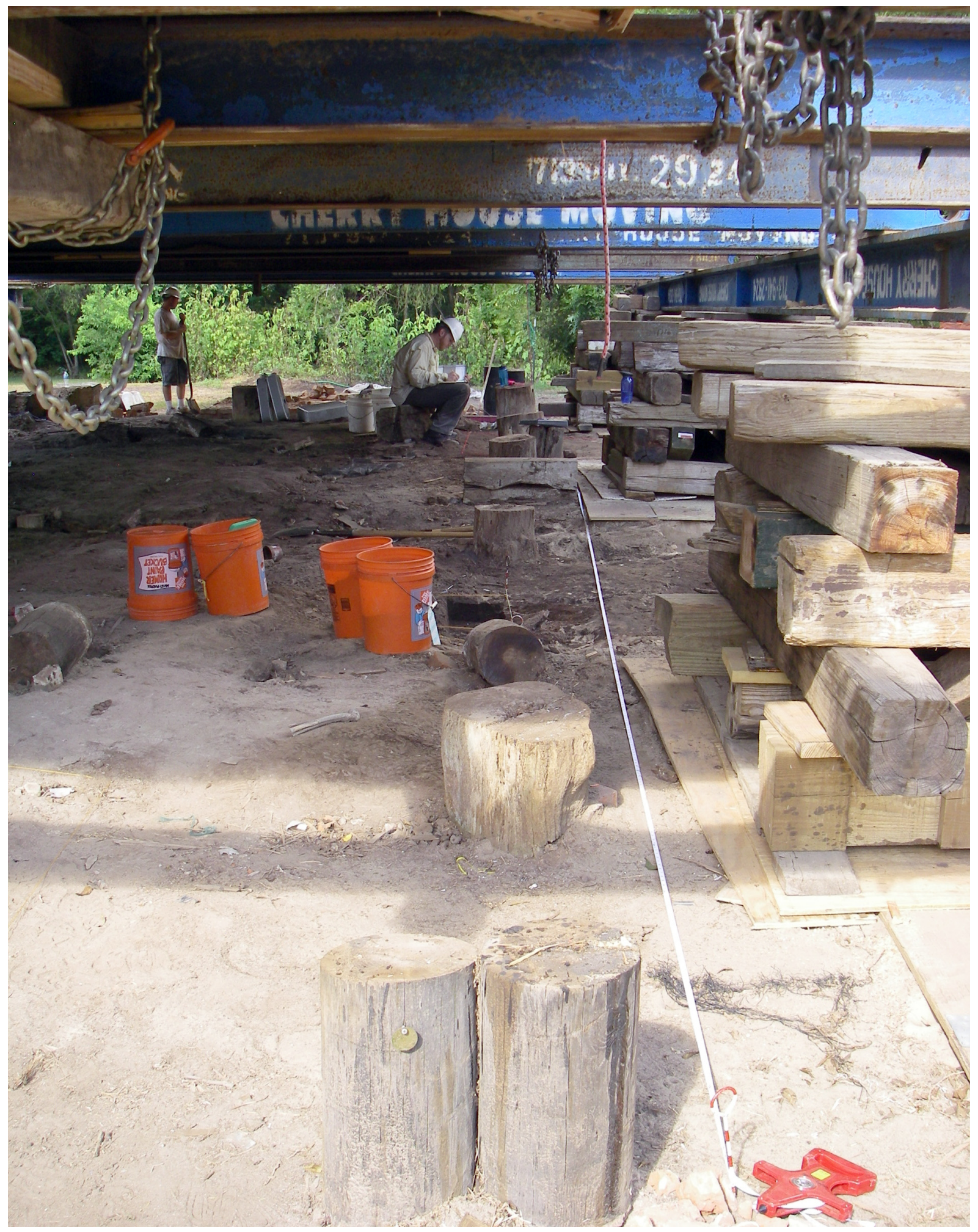

Figure 3.8. View underneath the raised structure looking west down the row of piers along the north wall of the original plantation house. Note the wooden cribbing and steel I-beams supporting the structure. 


\section{Phase II Goals and Work Accomplished}

The four specific goals of the Phase II field investigations were (1) to recover architectural information associated with the construction and maintenance of the plantation house, concentrating on the foundation and chimney features that would be destroyed in the stabilization process; (2) to investigate the interface between the structure's footprint and the adjacent areas where porches, walkways, yards, and other features may have been located; (3) to investigate the doorway areas to search for evidence that would support the theory that there were one or two "wings" attached to the back (north) side of the original house; and (4) to search for artifacts and features that may provide evidence of African American (or Euro American) spiritual beliefs. To meet these goals, the excavations focused on the foundation piers along the perimeter of and underneath the house and on four large blocks excavated to expose the east and west chimneys and two locations north of the original house (Figure 3.9). The Phase II investigations documented 11 features underneath the house (Figure 3.10).

Goal No. 4 was considered important given the substantial archeological evidence for African American rituals found in the Levi Jordan "Quarters"19 (see Chapter 2). In the PAI investigations, two archeological finds are mentioned as possible examples. The first is a small circular metal disk with a hole drilled through it that was recovered in the post hole of a probable porch pier off the west side of the house (Feature 13) during the Phase I investigations. ${ }^{20}$ Drilled coins and disks are frequently tied to African American spiritual beliefs in many contexts (Fennell 2007:44), and very similar drilled disks were found in the slave quarters at Levi Jordan (Dr. Kenneth Brown, personal communication 2011), as were drilled coins (Brown 2005b:Figure 85; 2012:129-130). However, it is worth noting that these small disks could have functioned as buttons or perhaps even as some type of washer.
This artifact is discussed further in Chapter 6 (see Feature 13). In addition, several bricks with possible ritual markings were found, some of which may have come from the east or west chimneys of the main house. These artifacts are discussed in Chapter 7.

\section{Foundation Pier Investigations}

A significant part of the Phase II investigations were aimed at exposing foundation pier features, and the goal was to sample features in three contexts: (1) around the perimeter of the original house; (2) underneath the footprint of the original house; and (3) immediately north of the original house and underneath the twentieth-century additions (see Figure 3.9). The Phase II goal of sampling piers in all three contexts was accomplished.

As in Phase I, the piers investigated in Phase II were treated as individual features, with the feature numbers keyed to the PAI designations for the perimeter piers and the Phoenix 1 designations for piers under the main house. In several cases, a pier that was partially excavated in Phase I was investigated again in Phase II for the purpose of removing the entire pier feature. Whenever possible, each excavated pier was completely disassembled, and its brick pad was removed entirely to determine if any objects were intentionally placed inside the pier holes or among or underneath the footing bricks.

\section{East and West Chimney Investigations}

Prior to PAI's Phase II work, Phoenix 1 personnel dismantled the east and west chimneys down to the lower few courses of exposed brick. This varied in elevation, but 3 to 5 courses of brick above ground were left intact. For both chimneys, the Phase II work included reexcavating previously excavated units and then expanding the excavations all the way around

\footnotetext{
${ }^{19}$ The "Quarters" is the term used by Brown in several publications to refer to the brick cabins that housed the enslaved and later free African American community.

${ }^{20}$ Other drilled disks were found, but only this one was found in a context indicating that it probably dates to the nineteenth century.
} 


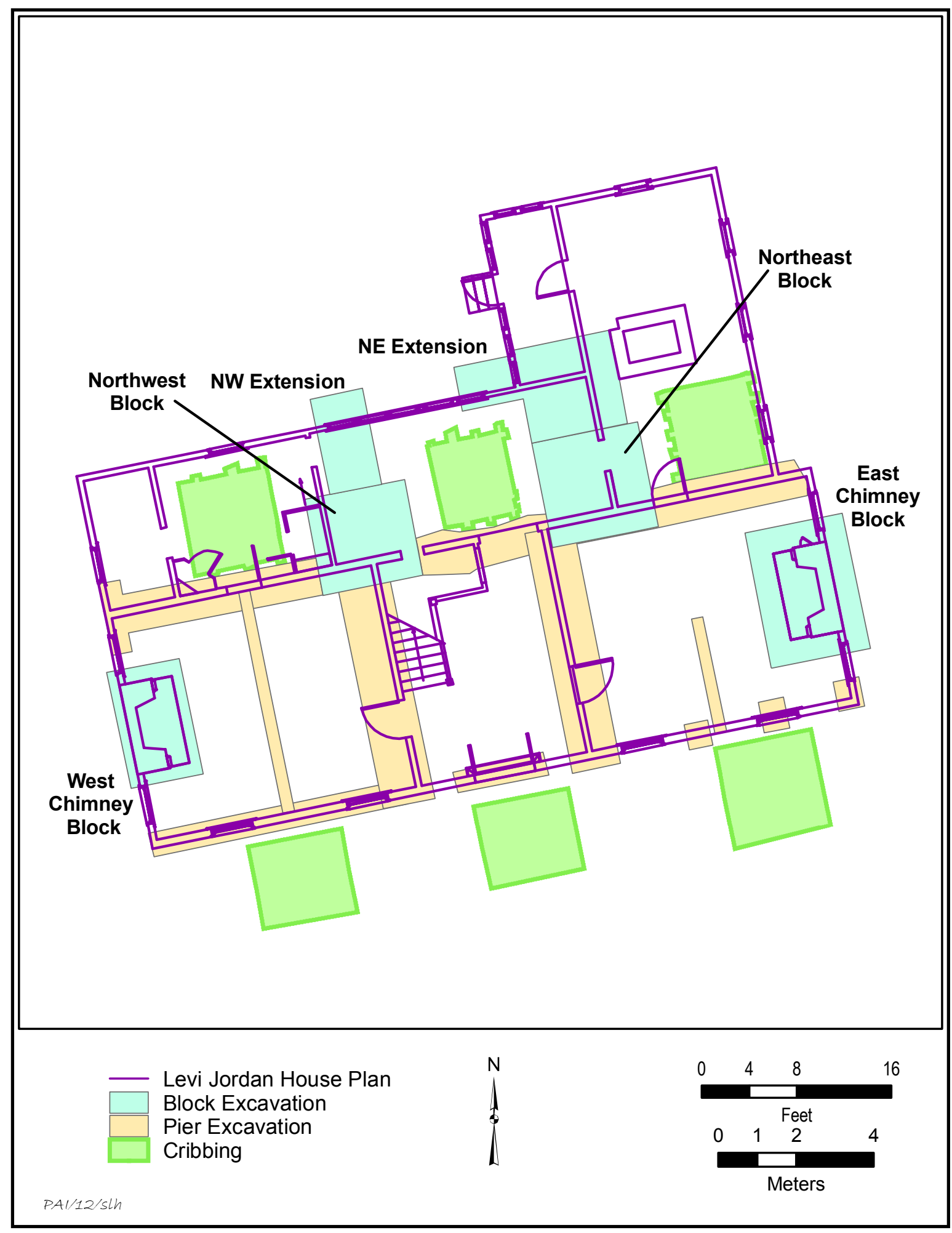

Figure 3.9. Map of the Phase II excavations at the Levi Jordan Plantation. 


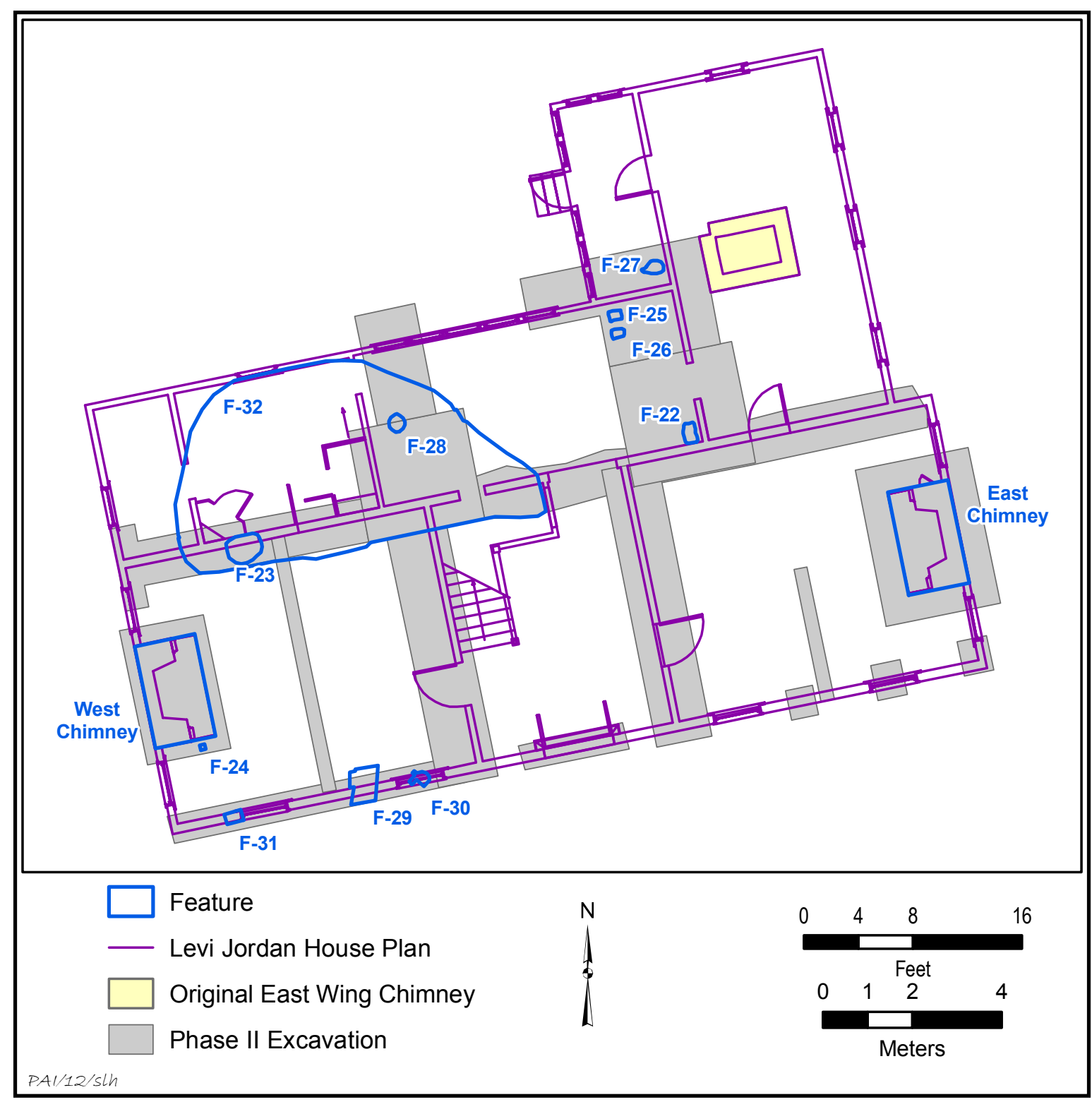

Figure 3.10. Map of archeological features investigated during Phase II.

each foundation. CAS had previously excavated two $3 \times 3$-ft units on the east side (exterior) of the east chimney (see Figure 4.1 in Leezer 2006), and PAI archeologists had excavated two 3x3$\mathrm{ft}$ units on the west side (exterior) of the west chimney during the Phase I investigations. The Phase II goal was to completely expose both chimney foundations and thoroughly document the architectural and construction details. The chimney foundations were mapped and photographed as excavation progressed, and the edges of the original builder's trenches were documented. Once the stair-stepped foundation footings were exposed below the bottom course of bricks, PAI archeologists disassembled and documented each brick layer until the features were completely removed. Finally, the bottom was troweled and shovel-skimmed to reach sterile soil and remove all of the original fill inside the builder's trench. 


\section{Monitoring of Electrical Line Trenching}

Phase II work also included monitoring of an electrical line trench (Figure 3.11). The trench ran from an existing electrical pole behind (east of) THC's temporary onsite office building, across the driveway, and under the Levi Jordan house, ending along the east wall of the house's staircase. The trench was ca. $95 \mathrm{ft}$ long and 30 inches deep, and it was excavated by Phoenix 1 personnel using a Ditch Witch. The trench excavation was monitored by a PAI archeologist.

The central portion of the trench exposed a ca. 1-3-inch-thick lens of oyster shell associated with the driveway. Several isolated metal artifacts were observed, but no cultural features other than the driveway were recorded. The driveway is a twentieth-century feature, and all the recovered artifacts appeared to be of twentieth-century age. Consequently, no additional archeological investigations were warranted.

\section{Comprehensive Archeological Resources Overlay Map}

In 2004, TPWD produced a "Cultural Resources Map” of the Levi Jordan Plantation that included many different data layers (Texas Parks and Wildlife Department 2004:32, Figure 13). Background layers include a modern aerial photograph and site topography with selected topographic features added (e.g., the slough). Other layers consisted of versions of maps of existing structures and the locations of "confirmed" and "tentative" structures found or inferred by Brown. The tentative structure locations appear to be based primarily on Aunt Eula's map (discussed in Chapter 4) and recollections of other people who lived on the plantation in the first half of the twentieth century.

When PAI began its work around the plantation house, it became necessary to build on this effort and add more data layers to this map. PAI scanned and rectified a number of other data sets and created a comprehensive site map in ArcGIS, which was then converted to GeoPDF format for use in the field and office. The data layers added to PAI's comprehensive map include data from the ground-penetrating radar and magnetometer surveys and the locations of all previous excavations. ${ }^{21}$ The resulting maps provide overview (Figure 3.12) and closeup (Figure 3.13) views of the known and suspected structures and archeological excavations at the Levi Jordan plantation.

\footnotetext{
${ }^{21}$ This included all of the University of Houston excavations units dug from 1986 to 2002, with data derived from a number of sources; the Texas Parks and Wildlife Department excavation and features derived from Howard (2003a, 2003b); and the Center for Archaeological Studies excavation units derived from Leezer (2006:Figure 4.1).
} 
Archeological Investigations for the Levi Jordan Plantation House Stabilization

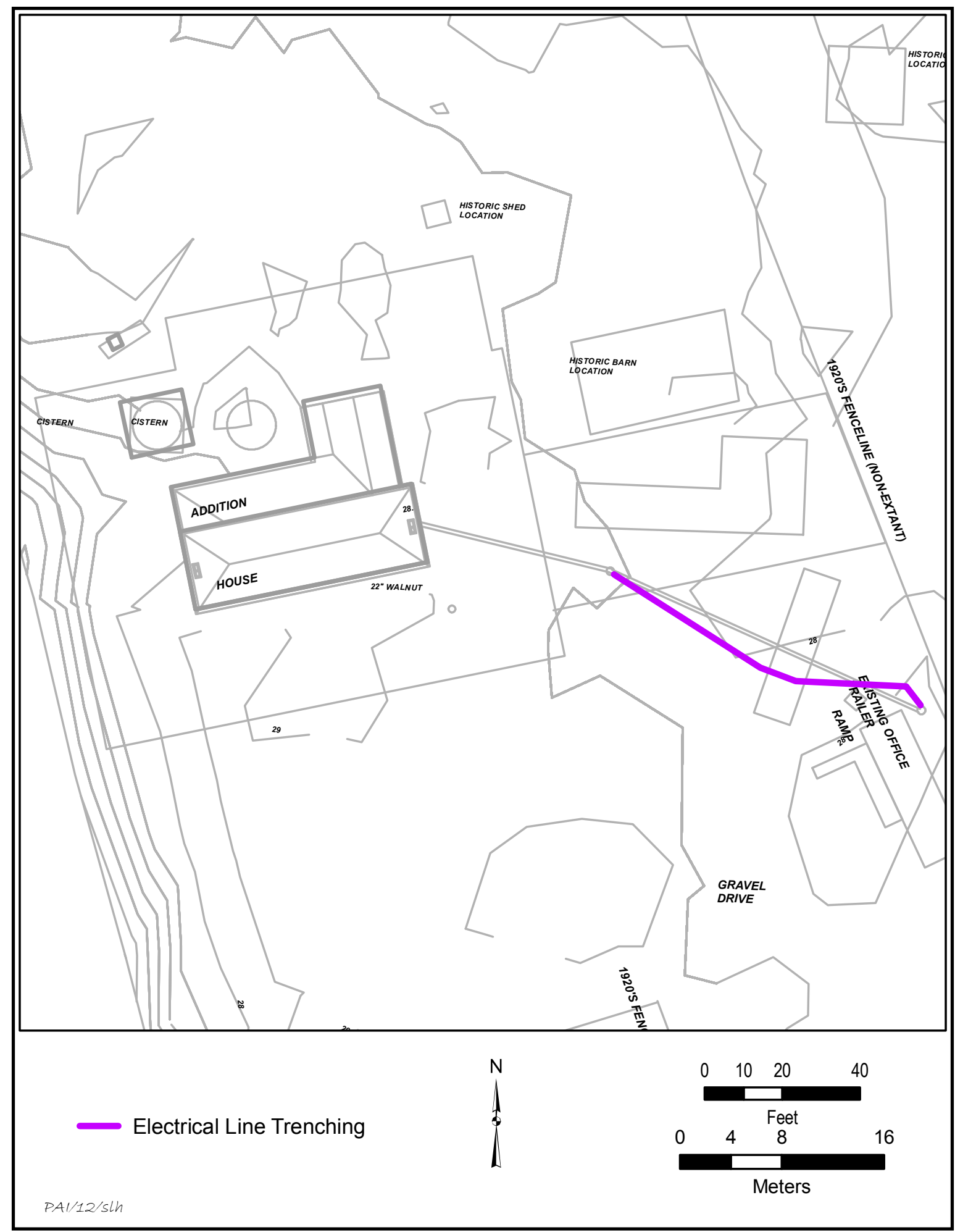

Figure 3.11. Map showing location of electrical line trench excavation. 


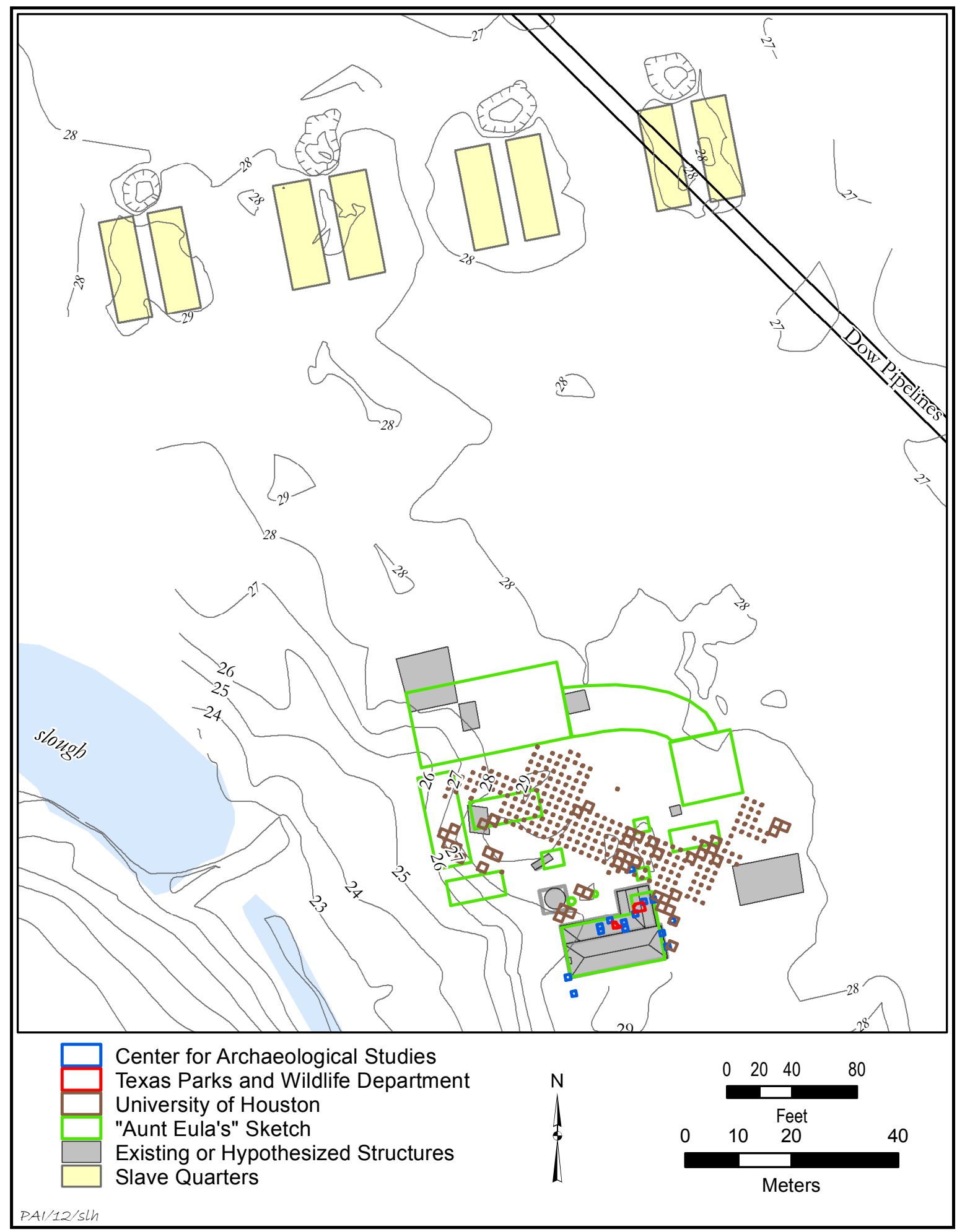

Figure 3.12. Comprehensive cultural resources map of the Levi Jordan plantation compiled by the Texas Parks and Wildlife Department and Prewitt and Associates, Inc.. Archeological features are not shown but are in the ArcGIS data layers. Note that Aunt Eula's sketch map is not to scale but is shown to indicate possible structures in the vicinity of the plantation house. 


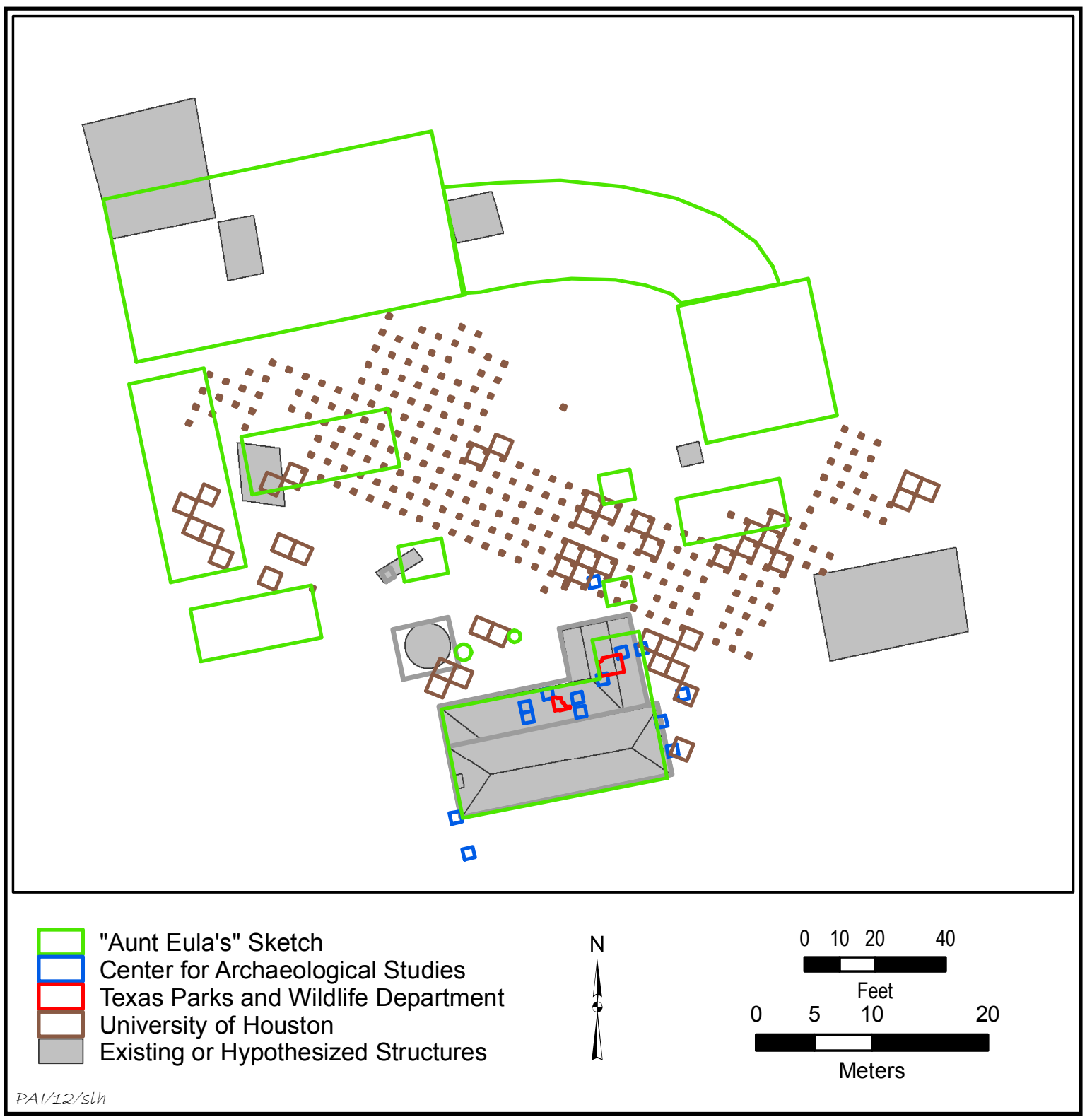

Figure 3.13. Closeup section of the comprehensive cultural resources map showing the structures and archeological excavations in and around the plantation house. Archeological features are not shown but are in the ArcGIS data layers. Note that Aunt Eula's sketch map is not to scale but is shown to indicate possible structures in the vicinity of the plantation house. 


\section{ARCHITECTURAL HISTORY OF THE LEVI JORDAN PLANTATION HOUSE}

This chapter presents an architectural history of the Levi Jordan house. This history is based on an examination of three types of historical evidence: oral history interviews with former residents, key published historical references based on oral history and archival research, and historical photographs of the plantation house and property. This evidence provides a unique perspective on the evolution of the plantation house, offering snapshots in time that document what the house was like at specific points, including when hurricanes caused major damage and when significant repairs and renovations occurred. When combined, the oral testimonies, archival records, and images aid in mapping out the historic landscape of the Levi Jordan plantation. The primary goals of this study were to define a chronology of structural changes to the plantation house and to gather information relevant to interpreting the archeological features.

\section{HURRICANES AND HISTORY}

Before delving into the house description and repair episodes documented in oral histories, archival records, and photographs, the impact of hurricanes on the Gulf Coast must be considered. The Levi Jordan Plantation is in a hurricane-prone region, and it has been impacted by many hurricanes over time, some of which caused significant damage (see Table 2.1). Although many instances of storm damage undoubtedly were not recorded or handed down in family histories, the most significant hurricane events left an indelible mark on the plantation's occupants. Many former residents provided oral or written recollections of hurricanes and the damage they inflicted over the years (see Table
2.2). Hurricanes and history go hand in hand on the Texas Gulf Coast, and the history of Levi Jordan Plantation is no exception.

It is notable that destructive hurricanes are mentioned in the early $1850 \mathrm{~s}$, just a few years after Jordan bought the property. Therefore, the house location was probably selected with an eye for avoiding flood-prone areas. The house builders also would have certainly had knowledge of the soils and weather conditions when determining where and how to build the house. In addition, big weather events would have had a serious impact on the construction schedule, and it is likely that the 1854 hurricane caused serious delays in the building of the Levi Jordan house, a fact noted by Platter (1961:163)(see Table 2.2; this hurricane passed 1 mile east of the Levi Jordan Plantation [National Oceanic and Atmospheric Administration 2012]). As discussed below, hurricanes that had a significant impact on the Jordan Plantation occurred in 1874, 1875, 1900, and 1961. The 1900 hurricane was particularly devastating over a huge portion of the Texas Gulf Coast, causing major structural damages to the plantation house.

\section{ORAL AND WRITTEN HISTORIES OF THE LEVI JORDAN PLANTATION}

This section introduces the plantation through the eyes of Levi Jordan's descendants. Unfortunately, it is temporally biased, since there are no oral histories or diaries from the earliest period. This journey begins in 1858 with observations and descriptions from the diary of Jordan's granddaughter, Sarah "Sallie" McNeill (Raska and Hill 2009). The plantation 
era comes alive as she describes her world before, during, and immediately after the Civil War. A generation later, a second descendant, Katherine Eulalie Martin Prell, provided important data to Dr. Kenneth Brown in the form of a hand-drawn map of the Levi Jordan plantation. The "Aunt Eula" map (Brown 2005a:Figure 2) provides an important snapshot of structures and features on the property in the early twentieth century. Next, Carol McDavid's interview with Ewing Martin (1998) presents his memories of the plantation lands as a child in the 1920s. Informal interviews with descendants by PAI archeologist McWilliams provide more recent recollections. Mike Martin (2010, 2011, and 2012) remembered the plantation property and house in the early 1940s, and Bruce Gotcher (2010) shared his memories of the land in the $1950 \mathrm{~s}$ to $1970 \mathrm{~s}$. The stories documented in these oral histories are augmented by historical facts gathered by historian Martha Freeman (2004) and by personal observations of another Levi Jordan descendant, Ginny Raska, in her recently published book on Sallie McNeill's diary (Raska and Hill 2009). ${ }^{22}$

In the discussions that follow, firsthand written accounts and oral history recollections of the various Levi Jordan descendants and former site occupants provide the most meaningful observations regarding plantation life and changes on the property. The JordanMcNeill-Martin family tree (see Figure 2.1) shows the relationships of interviewees whose words and thoughts appear below. Table 4.1 provides a chronological listing of the known occupants of the Levi Jordan plantation house over the past 160 years.

It is worth noting that many other oral history interviews, in addition to Ewing Martin's, were completed in conjunction with the University of Houston archeological and historical investigations at Levi Jordan. Unfortunately, most of these are not yet published and were not available to PAI researchers.

\section{Structural Improvements and Site Layout}

The oral history evidence provides some details about what structures were on the Levi Jordan Plantation at different times, and their relative locations and conditions. In addition to the main house, the Levi Jordan plantation had a brick sugar mill, brick cabins for the enslaved laborers, and many barns, sheds, and outbuildings. Some of these structures may have occupied parcels of land that were split off as the plantation was divided-the sugar mill, for example, is located on private lands and is not part of the Texas Historical Commission (THC) historic site property. However, several structures were close to the main house, including a detached kitchen, cabins for the house slaves/ servants, a house immediately east of the main house referred to as the McFarland house, and another structure called "the Boy's House" (referring to the two older Martin boys). Finally, a house that was referred to as "the house at the head of the field" ${ }^{23}$ was located at the far northwest corner of the plantation.

\section{Sallie McNeill's Diary}

The handwritten diary of Levi Jordan's granddaughter, Sarah "Sallie" McNeill, was published in 2009 by a Jordan descendant, Ginny McNeill Raska, and University of Houston graduate student Mary Lynne Gasaway Hill. The Uncompromising Diary of Sallie McNeill, 1858-1867 (Raska and Hill 2009), with its introduction, historical contextual notes, and epilogue by the editors, is perhaps the most valuable historical document pertaining to the Levi Jordan Plantation. Sallie was born in 1840 and was about 8 years old when the Jordan-McNeill family moved to Texas and established the plantation. Her diary begins in 1858 , when she 18 years old and away at school, but she returned to the plantation in February of 1859. Sallie made

\footnotetext{
${ }^{22}$ Descendants of Levi Jordan who shared their knowledge of the plantation through diary, map, or oral history are highlighted in the Levi Jordan family tree (Figure 2.1).

${ }^{23}$ In an interview with Carol McDavid, Ewing Martin (1998) explained that "After [his sister] Gloria was born we moved to a house that they called 'the house at the head of the field.' That was [at] the far northwest corner of the plantation...it was next to a huge wooded area. It has never been cleared there as far as I know. And there was a house there, and that creek that runs by the place there, it headed up in that direction..."
} 
Table 4.1. Owner, occupant, and legal history of the Levi Jordan Plantation*

\begin{tabular}{|c|c|c|}
\hline $\begin{array}{c}\text { Years of } \\
\text { Occupation }\end{array}$ & $\begin{array}{l}\text { Events Relating to Owners and Occupants } \\
\text { of the Jordan Plantation and House }\end{array}$ & References \\
\hline $1824-1848$ & $\begin{array}{l}\text { The land that would eventually become the Levi Jordan plantation is } \\
\text { owned by Samuel May Williams, but it is unoccupied. }\end{array}$ & Freeman (2004:107) \\
\hline 1848-1853 & $\begin{array}{l}\text { Levi Jordan purchased the plantation property in } 1848 \text { and moved there } \\
\text { with } 9 \text { slaves. The family during these years was Levi and Sarah (Stone) } \\
\text { Jordan, James and Emily (Jordan) McNeill, and five McNeill children. } \\
\text { By } 1850 \text {, they probably all lived on the plantation, but the Jordan house } \\
\text { was not yet built. }\end{array}$ & $\begin{array}{l}\text { Brown }(2012: 24) ; \\
\text { Freeman }(2004: 108- \\
\text { 110); Platter } \\
(1961: 163) ; \text { this report }\end{array}$ \\
\hline 1853 & $\begin{array}{l}\text { Historical and archeological evidence suggests that construction of the } \\
\text { Jordan house began sometime in } 1853 \text {. }\end{array}$ & This report \\
\hline \multirow[t]{2}{*}{$1854-1855$} & $\begin{array}{l}\text { The Jordan house was under construction when it was damaged by the } \\
\text { September } 1854 \text { hurricane. Although the house was not considered } \\
\text { "finished" until 1857, it was probably being occupied by } 1855 \text {. The family } \\
\text { living in the Jordan house was Levi and Sarah Jordan, James and Emily } \\
\text { McNeill, and five or more McNeill children. }\end{array}$ & $\begin{array}{l}\text { Platter (1961:163); } \\
\text { Raska and Hill } \\
(2009: 163) ; \text { this report }\end{array}$ \\
\hline & $\begin{array}{l}\text { James McNeill, Levi Jordan's son-in-law and partner, died in October } \\
1854 .\end{array}$ & Freeman (2004:113) \\
\hline \multirow[t]{5}{*}{ ca. $1855-1873$} & $\begin{array}{l}\text { The Jordan family continued living in the Jordan house. In 1860, the } \\
\text { family consisted of } 10 \text { people: Levi and Sarah Jordan, widowed daughter } \\
\text { Emily McNeill, and seven McNeill children. }\end{array}$ & Freeman (2004:117) \\
\hline & $\begin{array}{l}\text { Jordan's oldest grandchild, Sarah Sallie McNeill, lived in the Jordan } \\
\text { house and began writing in her diary at age } 18 \text { in } 1858 . \text { She continued } \\
\text { writing in the diary until September } 1867 \text {, and she died one month later. }\end{array}$ & $\begin{array}{l}\text { Freeman }(2004: 115- \\
117) ; \text { Raska and Hill } \\
(2009)\end{array}$ \\
\hline & $\begin{array}{l}\text { The two youngest of Levi Jordan's grandchildren, Mary and Emily } \\
\text { McNeill, died in December 1861. Two of Jordan's grandsons, James } \\
\text { Calvin and Charles Phillip McNeill, joined the Texas Cavalry to fight for } \\
\text { the Confederacy. }\end{array}$ & Freeman $(2004: 120)$ \\
\hline & $\begin{array}{l}\text { In 1870, the family living on the plantation was: Levi (age 77) and Sarah } \\
\text { (age 78); daughter Emily McNeill (age 50); three grandsons, James } \\
\text { Calvin McNeill (age 25), Charles Phillip McNeill (age 23), and William } \\
\text { McNeill (age 16); and great-grandson McWillie Martin (age 2). Four } \\
\text { unrelated people were also listed as part of the Jordan household and } \\
\text { lived in the Jordan house or elsewhere on the property (farm manager } \\
\text { Robert Stanger, farm laborer John McCullough, family friend Kate } \\
\text { Jackson, and physician Stephen Rae). }\end{array}$ & Freeman (2004:125) \\
\hline & \begin{tabular}{|l|} 
In 1871 Levi Jordan leased the plantation to Robert Stanger, who \\
mismanaged the property over the next two years.
\end{tabular} & Freeman (2004:125) \\
\hline 1873 & Levi Jordan died in February 1873, at age 79. & $\begin{array}{l}\text { Freeman }(2004: 125) \\
\text { Raska and Hill } \\
(2009: 155)\end{array}$ \\
\hline \multirow[t]{2}{*}{$1873-1874$} & $\begin{array}{l}\text { The youngest grandson, William Archibald McNeill, inherited the entire } \\
\text { Jordan plantation because the two older grandsons, James Calvin and } \\
\text { Charles Phillip McNeill, had already been given property by Levi Jordan. } \\
\text { The two older brothers were made executors of the estate and would } \\
\text { manage the plantation until William came of age. But Levi Jordan's will } \\
\text { stated that his wife Sarah would share in the proceeds of the plantation } \\
\text { and that she would "have management and control of the house and yard } \\
\text { during her lifetime." }\end{array}$ & Freeman (2004:126) \\
\hline & $\begin{array}{l}\text { Sarah Jordan, Emily McNeill, and William A. McNeill continued to live } \\
\text { on the plantation, while brothers James Calvin and Charles Phillip } \\
\text { McNeill attempted to restore the plantation. William went to the } \\
\text { Virginia Military Institute. By the end of } 1874 \text {, the McNeill brothers had } \\
\text { made major improvements to the plantation and the Jordan house. }\end{array}$ & $\begin{array}{l}\text { Freeman }(2004: 125, \\
127)\end{array}$ \\
\hline
\end{tabular}


Table 4.1, continued

\begin{tabular}{|c|c|c|}
\hline $\begin{array}{c}\text { Years of } \\
\text { Occupation }\end{array}$ & $\begin{array}{c}\text { Events Relating to Owners and Occupants } \\
\text { of the Jordan Plantation and House }\end{array}$ & References \\
\hline 1876 & $\begin{array}{l}\text { William A. McNeill returned to the Jordan plantation from the Virginia } \\
\text { Military Institute and attained his majority. His brothers, James Calvin } \\
\text { and Charles, turned the operation of the plantation to William and his } \\
\text { grandmother, Sarah Jordan (age 84). }\end{array}$ & Freeman (2004:129) \\
\hline 1877 & $\begin{array}{l}\text { Sarah Jordan (age 84) sold her one-half interest in the Jordan plantation } \\
\text { to her grandson, William A. McNeill. Sarah and William both continued } \\
\text { to live in the Jordan house along with Emily McNeill (age 57) and one or } \\
\text { more great-grandsons. }\end{array}$ & Freeman (2004:129) \\
\hline 1878 & $\begin{array}{l}\text { An indenture document between William A. McNeill and } 17 \text { freedmen } \\
\text { and women living on the Jordan plantation was signed in January } 1878 . \\
\text { The document "suggests that theft had become a significant problem at } \\
\text { the plantation." }\end{array}$ & $\begin{array}{l}\text { Freeman (2004:129- } \\
130)\end{array}$ \\
\hline 1879 & $\begin{array}{l}\text { William A. McNeill accidentally shot himself and died three weeks later } \\
\text { in June } 1879 \text {. The family decided to divide the Jordan plantation } \\
\text { property. "A friendly suit to partition the property was filed in } 1879 \text {, and } \\
\text { the court divided the property..." One half went to William's mother, } \\
\text { Emily Jordan, and this } 1,107 \text {-acre parcel included the Jordan house. The } \\
\text { other half was split three ways, with one lot going to each of William's } \\
\text { brothers (James Calvin and Charles), and the third lot going to William's } \\
\text { four nephews. These four Martin brothers were all minors to Royah } \\
\text { Furniss, McWillie, Charles Ernest, and Cavlin Earle. }\end{array}$ & $\begin{array}{l}\text { Freeman }(2004: 130) \\
\text { Raska and Hill } \\
(2009: 157)\end{array}$ \\
\hline \multirow[t]{2}{*}{ 1880-1882 } & $\begin{array}{l}\text { At the division of the land, Emily McNeill (age 61) moved out of the } \\
\text { house and rented it to Hal Chinn. It is not clear if he lived in the Jordan } \\
\text { house alone of if others lived with him. }\end{array}$ & Freeman (2004:132) \\
\hline & $\begin{array}{l}\text { The four young Martin brothers and their grandmother, Emily McNeill, } \\
\text { could not run the plantation, so its operation was turned over to three } \\
\text { unrelated men: Hal Chinn, Robert Stanger, and H. W. Zimmerman. } \\
\text { Chinn, and perhaps others, continued to live in the Jordan house, but } \\
\text { Stanger probably lived elsewhere on the property. Parts of the plantation } \\
\text { lands were rented to freedmen and women. }\end{array}$ & Freeman (2004:132) \\
\hline 1882 & $\begin{array}{l}\text { The matriarch of the family, Sarah Jordan, died in December } 1882 \text { at age } \\
89 .\end{array}$ & $\begin{array}{l}\text { Freeman }(2004: 133) \\
\text { Raska and Hill } \\
(2009: 18-19,157)\end{array}$ \\
\hline 1884-1885 & $\begin{array}{l}\text { In June } 1884 \text {, Emily McNeill deeded the 1,111-acre Jordan plantation, } \\
\text { including the Jordan house, to four of her grandchildren (Royal Furniss } \\
\text { Martin, b. 1866; McWillie Martin, b. 1868; Charles Martin, b. 1871; and } \\
\text { Calvin Martin, b. 1873). These Martin brothers were minors at the time } \\
\text { they acquired the property. Emily died less than a year later, in March } \\
\text { 1885, at age } 66 \text {. The Jordan house was probably occupied by Hal Chinn } \\
\text { and possibly others at this time. }\end{array}$ & $\begin{array}{l}\text { Freeman }(2004: 133) \\
\text { Raska and Hill } \\
(2009: 18-19,157)\end{array}$ \\
\hline 1886 & $\begin{array}{l}\text { Brothers Royal Furniss and McWillie (Will) Martin got into serious legal } \\
\text { troubles (assault and murder charges) while attending different schools. } \\
\text { The Martin brothers were minors, and their uncle, James Calvin } \\
\text { McNeill, had been the legal guardian. But he resigned in 1886, and the } \\
\text { boys' father, Robert F. Martin, was appointed guardian. }\end{array}$ & $\begin{array}{l}\text { Freeman (2004:133- } \\
\text { 134); Raska and Hill } \\
(2009: 157)\end{array}$ \\
\hline ca. $1887-1891$ & $\begin{array}{l}\text { The Martin brothers, McNeills, and H. Masterson (the Martins' lawyer) } \\
\text { become involved in a series of legal battles over a three-year period. "As } \\
\text { the [Martin] boys come of age disagreements led to the filing of numerous } \\
\text { lawsuits that divided the plantation and fractured family harmony." In } \\
\text { one lawsuit in 1888, Royal Furniss Martin (age 22) filed to have his } \\
\text { uncles, James Calvin and Charles Phillip McNeill, removed as managers } \\
\text { of the planation. It is unclear who was actually living on the plantation } \\
\text { and in the Jordan house at this time. }\end{array}$ & $\begin{array}{l}\text { Freeman }(2004: 136) \\
\text { Leezer }(2006: 31-33) ; \\
\text { Raska and Hill } \\
(2009: 157)\end{array}$ \\
\hline
\end{tabular}


Table 4.1, continued

\begin{tabular}{|c|c|c|}
\hline $\begin{array}{c}\text { Years of } \\
\text { Occupation }\end{array}$ & $\begin{array}{c}\text { Events Relating to Owners and Occupants } \\
\text { of the Jordan Plantation and House }\end{array}$ & References \\
\hline $1891-1894$ & $\begin{array}{l}\text { When the lawsuits were resolved in } 1891 \text {, they all "confirmed the } \\
\text { Martins' ownership of the north half of the Jordan Plantation and } 369 \\
\text { acres in the south half for a total of } 1,480 \text { acres." }\end{array}$ & Freeman (2004:134) \\
\hline \multirow[t]{2}{*}{ ca. $1894-1934$} & $\begin{array}{l}\text { McWillie (Will) Martin and his wife, Eloise (Masterson), lived in Brazoia } \\
\text { in 1894, but they moved into the Jordan house sometime after that. } \\
\text { Between } 1894 \text { and } 1910 \text {, they had six children. }\end{array}$ & $\begin{array}{l}\text { Freeman }(2004: 134- \\
136)\end{array}$ \\
\hline & $\begin{array}{l}\text { The Will and Eloise Martin family was living in the Jordan house when } \\
\text { it sustained serious damages from the } 1900 \text { hurricane. This family } \\
\text { probably lived in the Jordan house up through the early 1930s. }\end{array}$ & Freeman (2004:136) \\
\hline \multirow[t]{3}{*}{$1934-1946$} & $\begin{array}{l}\text { Harris (Harry) Martin (the fifth child of Will and Eloise Martin) married } \\
\text { Marguerite Polk in 1934. They moved into the Jordan house soon after. } \\
\text { Their son Mike was born in 1942, and Marguerite died in } 1946 \text { giving } \\
\text { birth to their second son. Helen Martin Carradine (Harry's sister), and } \\
\text { her husband, John Carradine, moved into the Jordan house in the 1940s } \\
\text { to help care for the two young boys. }\end{array}$ & $\begin{array}{l}\text { Ewing Martin (1998); } \\
\text { Mike Martin (2010) }\end{array}$ \\
\hline & $\begin{array}{l}\text { In December 1937, Will Martin died in } 1937 \text { at the age of } 69 \text {, and his } \\
\text { estate went to his wife Eloise (age } 66 \text { ). The estate was } 234.5 \text { acres and } \\
\text { included the Jordan house. }\end{array}$ & Freeman $(2004: 136)$ \\
\hline & $\begin{array}{l}\text { In July 1946, Eloise (Masterson) Martin died at age 75, leaving her } \\
\text { estated (including the Jordan house) to six heirs: Furniss Eloise Martin } \\
\text { Davis, Joseph Archibald Martin, Katherine Eulalie Prell, Gertrude } \\
\text { Nadine Gotcher, Harris Masterson Martin, and Helen Martin Carradine. }\end{array}$ & Freeman $(2004: 136)$ \\
\hline ca. $1946-1957$ & $\begin{array}{l}\text { Archibald (Archie) Martin was the last Jordan descendant to live in the } \\
\text { Jordan house, and he lived there sometime in the } 1950 \mathrm{~s} \text {. Archie, who was } \\
\text { a great-great-great-grandson of Levi Jordan, died in } 1957 .\end{array}$ & $\begin{array}{l}\text { Gotcher (2010); } \\
\text { Martin }(2010,2012)\end{array}$ \\
\hline $1957-1970 \mathrm{~s}$ & $\begin{array}{l}\text { The Jordan house was occupied by various tenants, including Mr. and } \\
\text { Mrs. Les E. Brannon in the early 1960s. An inscription in the concrete } \\
\text { porch indicates that Brannon constructed a new front porch in December } \\
\text { 1961. How long the Brannon's lived in the house is not known. }\end{array}$ & $\begin{array}{l}\text { Gotcher (2010); Bryan } \\
\text { McAuley (personal } \\
\text { communication 2010) }\end{array}$ \\
\hline \multirow[t]{2}{*}{$1970 s-1981$} & $\begin{array}{l}\text { A renter named June Birmingham lived in the Jordan house during the } \\
1970 \text { s and } 1980 \text { s, although the precise dates of occupation are unknown. } \\
\text { Her two boys lived with her and eventually some of her grandchildren } \\
\text { lived there also. }\end{array}$ & $\begin{array}{l}\text { Gotcher (2010); Bryan } \\
\text { McAuley (personal } \\
\text { communication 2010) }\end{array}$ \\
\hline & $\begin{array}{l}\text { In August 1978, the heirs who inherited the Jordan plantation in } 1946 \\
\text { partitioned the land. The 70.5-acre tract that contained the Jordan house } \\
\text { went to Furniss Martin Davis. }\end{array}$ & Freeman $(2004: 136)$ \\
\hline 1981 & $\begin{array}{l}\text { Furniss Martin Davis died in } 1981 \text {, leaving the } 70.5 \text { acres of the Jordan } \\
\text { plantation and the Jordan house to her four children: Cleveland Davis, } \\
\text { Jr., Eloise Davis Lostack, Dorothy Davis Cotton, and Nancy Gale Davis. }\end{array}$ & Freeman $(2004: 136)$ \\
\hline \multirow[t]{2}{*}{$1986-2002$} & $\begin{array}{l}\text { The Jordan descendants who owned the plantation house and } \\
\text { surrounding area allowed the University of Houston to begin } \\
\text { archeological investigations on the property, and this work continued } \\
\text { through } 2002 \text { under the direction of Dr. Kenneth L. Brown. The last } \\
\text { permanent occupantion of the house was in } 1988 \text {. }\end{array}$ & $\begin{array}{l}\text { Brown }(2005 a) \\
\text { TGB Partners } \\
(2003: 3)\end{array}$ \\
\hline & The Levi Jordan Plantation Historical Society was created in 1993. & $\begin{array}{l}\text { McDavid (1998); TGB } \\
\text { Partners (2003:3) } \\
\end{array}$ \\
\hline 2002-present & $\begin{array}{l}\text { The State of Texas acquired a portion of the original Levi Jordan } \\
\text { Plantation, including the Jordan house, in } 2002 \text { ( } 70 \text { acres) and } 2003 \text { ( } 22 \\
\text { acres). The Texas Parks and Wildlife Department managed the property } \\
\text { until } 2008 \text {, when the management authority was transferred to the } \\
\text { Texas Historical Commission. Since } 2002 \text {, no one has lived in the Jordan } \\
\text { house, but maintenance and renovation activities have occurred there. }\end{array}$ & $\begin{array}{l}\text { TGB Partners } \\
(2003: 3) ; \\
\text { Texas Parks and } \\
\text { Wildlife Department } \\
(2004: 1,4)\end{array}$ \\
\hline
\end{tabular}

*This is an expanded version of a table by Leezer (2006:Table 3-1). The data are derived primarily from the historical overviews by Freeman (2004) and Raska and Hill (2009), along with several oral history interviews. All pertinent sources are noted in the References column. 
entries in her diary from then until September 28,1867 , exactly one month before she died of unknown causes (Raska and Hill 2009:155). The diary is filled with observations, descriptions, and opinions about plantation life from a young woman who had just returned home from Baylor College in Independence, Texas. While her life on the plantation was filled with the boredom of "the usual monotonous routine!" (Raska and Hill 2009:103), her periodic entries provide the earliest descriptions of the plantation and its occupants before, during, and after the Civil War. Many of the details in the diary are extremely valuable for understanding and interpreting archeological remains found at the Levi Jordan plantation.

Unfortunately, the diary begins after the house was built, so it does not provide construction dates or details. Raska and Hill state that the house was built while Sallie was away, attending college. A letter dated August 1857 to Sallie from a family friend, Charlotte Nuckols, states, "The new house is almost done and looks magnificent" (Raska and Hill 2009:11, 163). Many researchers have combed the pages of the diary for clues that may piece together what we see on the property today with what Sallie saw in the late nineteenth century. The diary is also significant for its social and political implications, providing many glimpses of daily life and thoughts on her surroundings. But it is the details about the house and the yard around it that are of interest here.

\section{The Piazza, Veranda, and Gallery}

Sallie uses three words that evoke a deeper understanding of the house's architecture: piazza, veranda, and gallery (Raska and Hill 2009):

- In March 1860, Sallie and her family were "gathered in the piazza" while they talked, read, and ate walnuts. From this place, she could see "the gate" and ran in to hide in the parlor (p. 71).

- After the death of her youngest sister in June 1861, the family would sit on the "veranda" at sunset (p. 107).

- Out of boredom she would "walk the gallery in the evening perhaps, -go down to my meals," (p. 129) implying the gallery is upstairs.

- In April 1867, Sallie states that her grandfather, Levi Jordan, "swept the Hall and Piazza" (p. 139), as if the two are attached and or at least in close proximity.

The use of the term "piazza" may have been common at the time and perhaps had a more specific meaning than it does today. By today's definition, a piazza generally refers to a porch, patio, enclosed patio, or veranda. Raska and Hill (2009:11) suggest that the gallery and piazza were common words for a porch. Freeman (2004:116, citing Raska n.d.) notes that Sallie mentioned both a piazza and a porch on the house, and that these terms may both refer to "a configuration in which a first-floor porch across the front facade was surmounted by a smaller porch on the second floor facade."

Sallie does provide more details (Raska and Hill 2009:107), adding that they watched the sunset from the piazza. This suggests that this feature was on the west or north side of the house, all locations from which one can see the sunset. ${ }^{24}$ She also noted that she could see "the gate" from the piazza. That could have meant the front gate of the property or a front gate closer to the house, but in either case it suggests that her piazza vantage point was in the front of the house (south side), on the west side, or perhaps on the east or west ends of the north side of the house. Regardless, Sallie had a straight line of sight from somewhere on the piazza to this gate, and she ran into the parlor to hide when a new visitor came, perhaps indicating the parlor was near the piazza. Unfortunately, Sallie's statements do not reveal exactly what or where the piazza was.

\section{Miscellaneous Archeological Clues}

Additional clues of archeological interest are found in Sallie's diary. Sallie describes

\footnotetext{
${ }^{24}$ McWilliams observed the setting sun several times at the Jordan home. It could not be seen from the front (south) of the house, but was clear from the north and west sides.
} 
the "excitement" caused by a fire that broke out February 17, 1859. The fire began in Jacob's house (probably a slave) and caught the "unoccupied Hospital" and threatened the "Clairborn's Cabin \& the [corn] cribs" (Raska and Hill 2009:42). The evidence of this fire should be preserved archeologically, and it could help archeologists identify Jacob's house and the hospital structure.

Sallie also mentions a few changes to the house's yard space (Raska and Hill 2009). In February 1860, she noted that carpenters were "roofing the new shop" (p. 58) and later that year workmen were building "a carriage-house opposite the dwelling" (p. 70). Freeman (2004:116) brings attention to this second entry, noting Sallie's objection to the construction on the grounds of aesthetics: "I objected to the situation, but of course convenience must decide the question here" (p. 70).

\section{Weather-Related Entries}

Sallie was clearly aware of the needs of the farming community as far as weather was concerned. Rain is a common topic in her entries, and she often mentions the farmers' need for rain (Raska and Hill 2009:45, 62, 96, 118, 141). There has been much speculation about what the family did when hurricanes came through. Unfortunately, the diary does not provide this information. No major hurricane hit Brazoria during the span of Sallie's diary (1858-1867). A powerful hurricane hit the entire Texas coast October 2-3, 1867 (see Table 2.1), just four days after Sallie's last diary entry.

\section{Landscape and Vegetation}

By the 1850s, most of Brazoria County was carved up into plantations (Few 2006:6-7; Platter 1961), and many were known for having elegant homes and lavish landscapes with ornamental gardens (Few and Dial 2002). The China Grove Plantation, for example, was so named for the chinaberry trees imported for shade, with figs and oranges grown in the orchards (Kelley 2010:27; Kleiner 2011b).

In her diary (Raska and Hill 2009) Sallie notes the various plants, both native and ornamental, on the Levi Jordan property. She mentions grapes ("Have been to the Sugarhouse twice to gather green grapes for pies!") and magnolias ("Johny climbed for magnolia flowers") (p. 103). In a May 25, 1866, entry, she paid homage to Nature by stating: "A bright morning - all Nature rejoices." Continued in her Thoreau-esque style, she mentions pecans and mimosa trees and notes that from the window she can see "green tasseled corn" and the "darker hued foliage of the wood beyond" (p. 133). From another vantage she could see the "sluggish waters of the slough, by its willow-fringed margin meandering through the plantation" as well as a cane field and dense cotton weed (p. 133).

\section{Aunt Eula's Map}

Just as Sallie McNeill's letters and diaries provide a glimpse of the plantation from 1858 to 1867, "Aunt Eula's Map" offers an important snapshot of the plantation layout in the early twentieth century. The map was obtained in the 1980s as part of the University of Houston's historical and archeological research on the Levi Jordan plantation.

Katherine Eulalie "Eula" Martin Prell (1895-1987) was the third child of Will Martin and Eloise Masterson. Will Martin obtained ownership of the home and a portion of the plantation in 1891, and he moved into the plantation house sometime after 1894 (Freeman 2004:134136), a year before Eula was born. It was Eula's niece, Dorothy Davis Cotton, the executor of the Jordan-McNeill estate, who handled the sale the Levi Jordan plantation to TPWD in 2002. Eula drew the plantation sketch map in 1982 as part of the original National Register nomination package. The original hand-drawn map was subsequently published by Brown (2005a:Figure 2 ), with the added handwritten caption: "configuration of Jordan plantation based on 'Aunt Eula's' recollections and site evidence, April 1982." For the CAS archeological study, Leezer (2006:Figure 3-10) published a modified version of this map in which typed words replace the handwritten labels. Both versions of Aunt Eula's map are depicted in Figure 4.1.

Aunt Eula lived in the Levi Jordan house as a child, and the map is her recollection of the structures and features around the main house just after the turn of the century. The map shows the plantation house with two chimneys and the twentieth-century ell, but no porches are depicted. Other buildings to the north include the locations of the two brick cisterns, a "wood cis- 


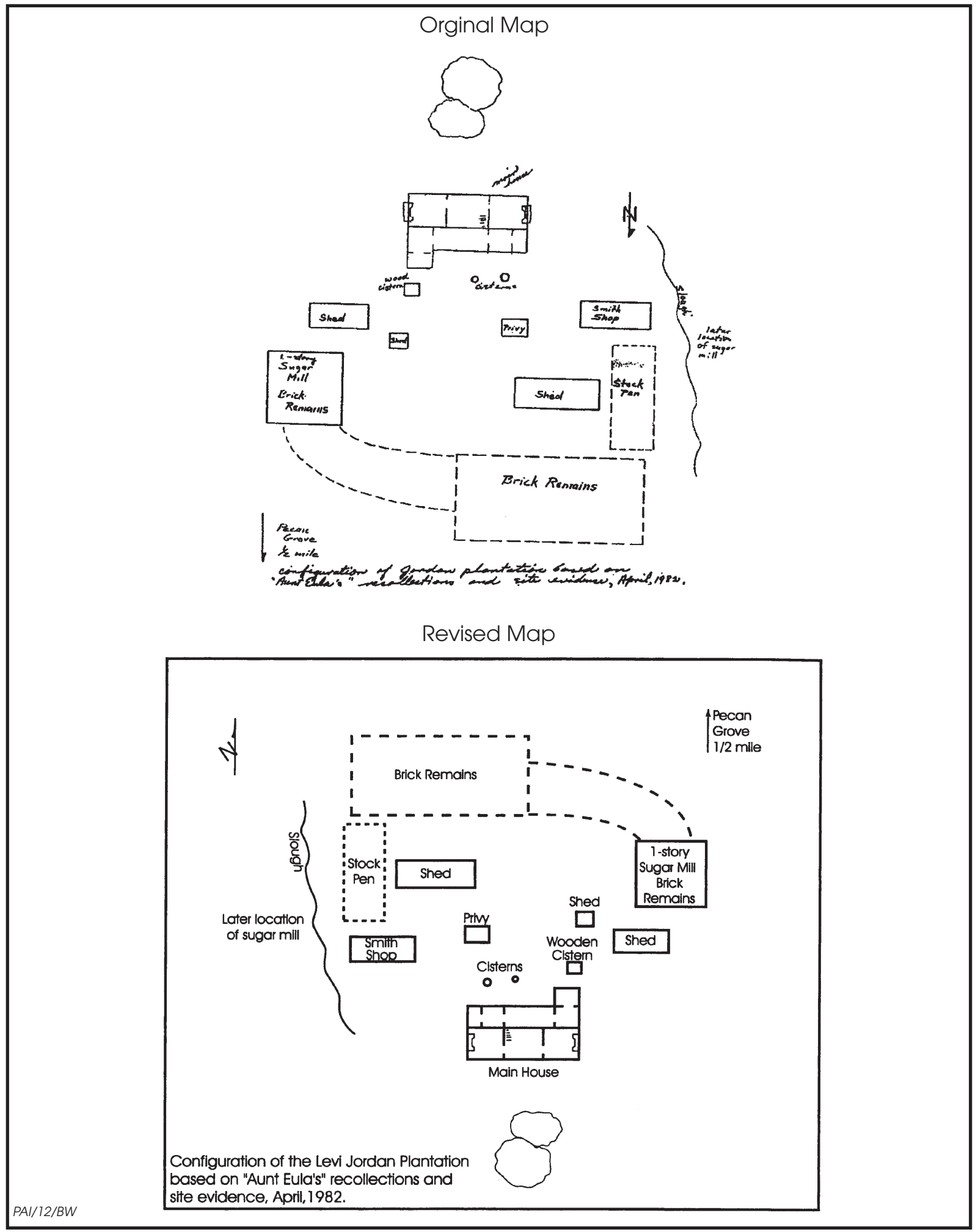

Figure 4.1. Aunt Eula's map of the Levi Jordan plantation drawn in 1982 as part of the National Register nomination. The original hand-drawn version is from Brown (2005a:Figure 2), and it is shown upside down so that north is to the top. The drafted version is from Leezer (2006:Figure 3-10). Maps are not to scale. 
tern," a one-story brick sugar mill, three sheds, a privy, a smith shop, and a large expanse of brick remains farthest to the north. It also depicts the slough to the west, and an arrow indicates that a pecan grove was " $1 / 2$ mile" away. In the front (to the south of the house), Eula depicts two large oak trees, both of which remain standing today. What is most notable is that Dr. Kenneth Brown (personal communication 2010) believed the area of the "Brick Remains" probably represents the quarters of the slaves and later the free black community. This is a reasonable assumption because Aunt Eula's map was not drawn to any scale and the Quarters is the northernmost prominent feature area. The African American community was disbanded and its occupants left the property about 1887, before Eula was born. She only remembered the area because of the bricks (Brown 2005a:5-6).

Many aspects of Aunt Eula's map are clearly correct. The slough runs along the west side of the house. Photographs from the 1980s show several sheds, varying in size, as well as a nearby privy. ${ }^{25}$ Even though the shed and privy locations cannot be determined from the photographs, the approximate locations of these features are depicted on the map. Though only one cistern was visible above ground in the $1980 \mathrm{~s}$, recent descendants knew about the earlier cistern located just east of the extant cistern, and Eula shows both in her sketch map. Eula's "wood cistern" is a small square located just north of the east wing. She definitely misidentified this feature, which was exposed by the University of Houston, then by CAS (see Features 7 and 8 in Leezer [2006:Figures 5-17 to 5-19), and most recently by PAI (see Chapter 7). It is a chimney footing that was probably associated with a detached kitchen behind the main house.

\section{Humphries' 1937 Houston Chronicle Article}

An excellent written description of the plantation can be found in a 1937 Houston Chronicle article titled "Jordan Plantation Mirror on Texas' Past" (Humphries 1937:12-13). The original article, provided to PAI by descendant Bruce
Gotcher, was republished in 1986 with some editorial notations (Humphries 1986). Humphries attributes the stories presented in her article to Mr. and Mrs. Will Martin; Will Martin died in December 1937. Humphries is relating their oral histories, and her writing style is extremely romanticized, so all the stories must be taken with a grain of salt. But some of the information appears to be valuable and should not be discounted. The buildings and structures were not the focus of the article, but Humphries (1937) specifically mentions the following:

- “...underground cisterns lift their heads where no roofs remain to fill them" (p. 12). This statement probably refers to the two cisterns behind the house, and it suggests that the original Cistern 1 was still standing in 1937. The phrase "no roofs remain to fill them" could refer to the cisterns being abandoned and roofs that no longer had gutter systems. Or it could refer to other isolated cisterns on the property where no structures existed.

- “...old fashioned flowers line a worn brick wall to the long front gallery" (p. 12). This could refer to the brick "walk" leading to the house that was exposed in archeological investigations, but no brick "wall" was exposed.

- "The first house was built of logs with chimneys of homemade bricks" (p. 12). Researchers have commonly assumed that the first house on the Jordan Plantation was a log structure (Freeman 2004:111), but the location of this original house has not been identified.

- "The kitchen, a brick building apart from the mansion..." (p. 12). A chimney foundation to this structure has been identified, but the excavations have not been extensive enough to determine if it was inside a larger brick structure. The ground-penetrating radar survey indicated a square-shaped anomaly in this area that could be the perimeter brick wall footing of the detached kitchen.

\footnotetext{
${ }^{25}$ A 2004 photograph by Randolph Terzis of Lake Jackson, Texas, also shows this outhouse. It is available, along with earlier photos taken by Allen Platter in 1960, on the Brazoria County Historical Museum website (http://www.bchm.org).
} 
- A "smoke house, dairy, and loom house" were present on the property (p. 12). None of these structures have been identified at the site.

\section{Allen Andrew Platter}

The next written description of the Levi Jordan Plantation is from Allen Platter's 1961 dissertation. This study has only a short, fourpage description of the Levi Jordan plantation, and he uses several primary sources. But Platter occasionally presents some misinformation, and he fails to cite his sources or informants when stating specific facts. Platter (1961:160) writes:

- The frame residence, which was constructed in 1854, was made from oak timbers cut from the forest and from large lumber brought across the Gulf and up the San Bernard [River] by schooner. ${ }^{26}$ The mansion was unlike any other in the country. It was functional and simple to the point of severity and almost modern in design. The main portion of the building was a two storey [sic] rectangle with a low-pitched hip roof. The roof had little overhang, exposing a minimum surface for hurricane winds to batter. At each end of the building was a chimney serving two fireplaces. The design for the chimney was unique. The outside of each chimney was flush with the wall of the house so that the end wall was a plane without interruption except for windows. A front porch on the lower floor provided a large shady sitting area facing the breeze from the south. The house had double front doors. From each end of the rear of the building a one storey [sic] wing extended northward.
But many of Platter's observations regarding the plantation house are important. Platter (1961:160) also notes that the Jordan Plantation had many outbuildings such as a smokehouse, cotton gin, stables, and brick slave quarters, and that the sugar house was "reputed to contain the largest sugar making machinery manufactured" with two trains of six kettles. ${ }^{27}$ Platter's (1961:163) statement that "The house was under construction when the hurricane hit" in 1854 is particularly significant, but he does not cite his source for this. Much of Platter's information came from an interview with an L. J. McNeill (1916-1983; see Figure 2.1) at the Mims Plantation in August 1960 (Platter 1961:159, footnote 1), and this could be the source for this statement.

\section{Ewing Martin}

Ewing Martin, one of five of Calvin Earl Martin's children, was interviewed in 1998 by his daughter, Sarah Martin, and historical archeologist Carol McDavid (Martin 1998). Ewing Martin lived on the Levi Jordan property from age one until he was five years old, in 1920. He lived in two houses on the property, one of which, the McFarland house, sat just east of the Levi Jordan home. He provides details of playing in the yard and the surrounding property that are valuable contributions to the overall understanding of the site's history. Some of his important recollections with regard to the plantation are:

- The McFarland House was still standing in 1917 when Ewing's sister, Gloria, was born "in the house that was known as the McFarland House. It was directly east of

\footnotetext{
${ }^{26}$ Historian Martha Freeman questions this statement. After chasing some erroneous information to its source in two Houston Chronicle articles from 1936 and 1937, Freeman (2004:138) notes that statements like this have been repeated in many theses, dissertations, and articles without further research into the original documents. The author of the 1937 article gave an 1850 construction date for the "mansion" and "stated that lumber for the walls and floors was brought to the site by Jordan's own ship on repeated voyages from Pensacola, Florida" (Freeman 2004:138). This statement was latter embellished to include the use of barges on the San Bernard River (Freeman 2004:139). Furthermore, Freeman (2004:139) notes that a 1993 article (The Brazosport Facts, July 18, 1993) implies the existence of some correspondence showing that Jordan ordered the "lumber, door knobs, window glass, and other items" from Florida for "a house that was built between 1848 and 1851 ." Consequently, it appears that Platter's statement about the lumber being "brought across the Gulf and up the San Bernard by schooner" may be incorrect.
}

${ }^{27}$ See Freeman (2004:18 and footnote 8) for a historiography of this final sugar cane machinery comment. 
the plantation house...there was all kinds of pecan trees there."

- There "was a house north of [the McFarland House] that they called 'the house at the head of the field.' That was the far northwest corner of the plantation...it was next to a huge wooded area. It has never been cleared there as far as I know. And there was a house there, and that creek that runs by the place there [not to be confused with the slough], it headed up in that direction...it might have run parallel to the quarters..."

- The clay for the bricks may have been quarried in the creek mentioned above. Ewing noted "an old pit, and I assume it's where [the slaves] dug the clay to make the brick. I told Ken [Brown] about it, but I'm not sure if he dug back there."

- By ca. 1920, the brick (possibly the Quarters) was "all covered up. Now, there were some brick walks around the place...when I was a little boy...it was open because I remember playing on those bricks. There was a lot of brick around there.

- Both cisterns were still standing in ca. 1915-1920. Ewing notes that "the old cisterns were brick. Both of them were up and while we lived there my dad [Calvin Earl Martin] got some colored fellows and they cleaned that cistern out-the first one-the one that is all filled up now."

- "Uncle Will [Martin] had a well dug. Before that they were relying on the cistern, see? They had these gutters that channeled water into the old brick system and [when] we left there [in ca. 1920] —of course, we put a cover on it so nobody could get in it..."

- "There was a brick walk that came out the front of the house. Of course, the concrete wasn't there...it was a brick walk...It came around the side and I was thinking it went on out to this place where we played...It seems like there was a little fence around the house area proper, but it had a back gate and Aunt Hester used to wash clothes beyond outside the fence, see, in the open area back there."

Brown (2005a:54) notes that: "According to the Martin descendants, major changes to the main house and Quarters area occurred around 1920. At that time a portion of the back of the house was replaced with an L-shaped 'tenant house,' and the entire house was [resided]." This interpretation may be based on the recollections of Ewing Martin, or it could be based on statements made by other Martin descendants.

\section{Mike Martin}

Mike Martin was informally interviewed by McWilliams in 2010, 2011, and 2012. Martin is the son of Harris "Harry" Masterson Martin and the grandson of McWillie "Will" Martin. In the 1930s, Mike's father, Harry Martin, repaired the Levi Jordan house in preparation for moving into after his wedding to Marguerite Polk in 1934. Mike Martin was born in the house in 1942. Harry's wife Marguerite died during the birth of their second son in 1946. At this time, Harry's youngest sister, Helen Martin Carradine, and her husband John came to the Jordan Plantation to care for Mike and the baby. It is not known how long they stayed there, but Helen and John shot many photographs of the family during this time. A photograph of "Aunt Hester," a freed Levi Jordan slave, is attributed to Mr. Carradine.

The details below are from these interviews (Martin 2010):

- Mike recalls his father, Harry, describing the effort he had to put into preserving the wood siding on the Jordan house. Harry used "ochre" (reddish paint) as a primer or sealant before painting.

- Harry ran a gasoline business and had an office in Brazoria as well as at the home. To operate the home office, Harry needed a phone line, and he laid a 7-mile-long line himself from Brazoria. The house already had electricity and indoor plumbing.

- When playing as a child, Mike regularly buried his father's tools in the yard around the house. Three of these burials may have been found during PAI excavations. Two wrenches were found on two corners of the external kitchen fireplace, and a coffee can of nails, screws, and trash was found on the north side of the ell (see Feature 21 in Chapter 8). 
- Mike believes the McFarland house blew down in a storm in 1932. That was a serious event and "everyone had a story about the 1932 storm."

- In the 1930s-'40s, Mike's uncle, Archie, moved a house onto the land ca. $200 \mathrm{ft}$ east of the Jordan house.

- A couple named York and Ola Mack lived on the west side of the pasture, in a house that is no longer standing.

- Mike remembers hearing that the family washed clothes in a large metal kettle over a fire and said that this tradition continued into the $1940 \mathrm{~s}$.

- Mike remembers Hurricane Carla (1961) but says it caused little destruction on their property other than tree damage.

\section{Bruce Gotcher}

Bruce Gotcher (b. 1952), grandson of Gertrude Nadine Martin Gotcher, came to the site and walked the grounds with his wife, Denise, site manager Bryan McAuley, and Jennifer McWilliams during the Phase I archeological investigations. In this informal interview, Mr. Gotcher provided family stories from his childhood and personal recollections of the Levi Jordan house (Gotcher 2010). Family stories that he heard growing up include:

- There is a deep hole in the center of the slough where the clay for the bricks was quarried.

- The whole backyard was solid brick, stretching from the house to a large walnut tree ca. $100 \mathrm{ft}$ north of the back of the house.

- The driveway to the house originally went west of the house, and there were two garages on the west side.

Gotcher's personal recollections of the house include the following:

- Archibald Martin lived in the Jordan house until the late 1950s. He raised turkeys in pens at the far north end of the backyard.

- A man named Brannon rented the Jordan house in the late $1960 \mathrm{~s}$. He replaced the front door, laid the concrete front porch, and built a white wood fence.

- June Birmingham rented the Jordan house beginning in the early 1970 s. She also excavated the old cistern, and Bruce has two of the artifacts she recovered, a bear trap and a cannonball, which are discussed and pictured in a 1937 Houston Chronicle article (Humphries 1937).

- Two elderly African American men lived in a one-story, two-room house north-northeast of the Jordan house between two large walnut trees.

- Bruce and his uncle, Harry Martin, built a smokehouse in the late $1960 \mathrm{~s}$. It was located on a slight rise north of the east wing of the Jordan house. Bruce pointed to a backdirt pile left by CAS, noting that the smokehouse they built was nearby (the location of this dirt pile is shown in Figure 5.1).

- Bruce repaired the later cistern (see Cistern 2 in Chapter 8) in 1970. He inscribed his name and the date in the cement of the cistern because he knew that Will had inscribed his name in the cement sidewalk in front of the house.

\section{Onsite Interview with Dr. Kenneth Brown}

Dr. Kenneth Brown walked the Levi Jordan grounds with Jennifer McWilliams and THC site manager Bryan McAuley during the Phase I investigations (Brown 2010). Brown made the following points:

- Jordan's large two-story wood frame house differentiated him from the slaves, who were housed in small brick quarters. Brick structures are easier to rebuild, whereas wood structures would be more work to build and were more apt to burn.

- Brown originally thought the bricks were not manufactured onsite but at a brick factory in the area. However, a heavily burned area at the far end of Block 1 in the Quarters was identified, and Brown now believes this is the location of the original brick kiln. 
- The hearths in the Quarters are not continuous brick but rather have a rubblefilled space in the center. ${ }^{28}$

- Many 1x1-ft excavations were placed on a grid in the backyard, but there was no evidence of a ca. 100-ft-long patio.

- He agrees with Platter (1961) that the Jordan house had two wings on the north side of the house: one on the east and one on the west.

- Excavations at the location of the detached kitchen exposed pier supports indicative of a frame structure with an exit to the west (based on walkway exposed). ${ }^{29}$

- There was a porch along the east side of the house, delineated by a line of cultural material, including an 1880 quarter and ceramic sherd with a maker's mark. Also, a rain barrel pad beyond the current east wing wall indicates the width of the porch.

- The 1900 storm tore off the back of the house; the backyard was full of paper, and the roof was gone.

- The east wing of the house was added in the 1920 s or 1930 s, according to Ewing Martin. Furthermore, the entire ell (removed in 2011) was built with lumber from a tenant cabin that was moved from the pecan orchard. ${ }^{30}$

- Jud McNeill quarried the brick from the Quarters and house slave quarters and used it for road base.

\section{Historical Research by Martha Freeman}

As mentioned in Chapter 2, historian Martha Freeman (2004) compiled the most comprehensive history of the Levi Jordan Plantation. Her research is based on many primary historical records, including oral histories, diaries, family papers, and a variety of public documents (e.g., census data, court records, deed records). Her work is mentioned here because she reveals information about the plantation house that is not found in any other published source.

Citing court records, Freeman (2004:127) provides details of improvements to the house in 1873 or early 1874, soon after Levi Jordan's death. At that time, the house was scraped and repainted bright colors (red, yellow ochre, burnt umber, chrome green, and chrome yellow), and an ornamental star was painted in the hall entry. Six miles of fence was constructed around the yard, garden, and orchard (Freeman 2004:129). Several major hurricanes damaged the house, including an 1875 hurricane immediately following the recent repairs. Up to that point, the house was "relatively intact" (Freeman 2004:136). The 1900 hurricane caused serious damage. Winds "tore off the kitchen-dining room annex, ruined the first floor front gallery on the south, east, and north facades, and damaged the roof. Subsequently, the roof was replaced and the kitchen rebuilt" (Freeman 2004:136).

\section{PHOTOGRAPHIC RESEARCH}

A detailed analysis of historic photographs of the Levi Jordan house was undertaken during the Phase I and Phase II archeological investigations. The analysis focused on examining images that would help interpret the archeological remains and features that were found, but it also helped establish the history of improvements to the Levi Jordan house through time.

TPWD collected photographs of the Levi Jordan house, family, and plantation, many of

\footnotetext{
${ }^{28}$ This point is important relative to the various styles of fireplace/hearth construction and is discussed further in Chapter 7.

${ }^{29}$ The "piers" that Brown reported exposing do not correspond with the GPR map (Figure 5.1) and Appendix A, which seems to depict a rectangular footing. This distinct outline denotes a strong radar reading, such as a brick wall footing.

${ }^{30}$ Ewing Martin's (1998) interview states that the McFarland house was surrounded by pecans. While there were surely several pecan "orchards," Brown's statement suggests that the ell, which was added to the Levi Jordan house in the twentieth century, might have been built from the remnants of the old McFarland house. However, Mike Martin's interview states that the McFarland house blew down in 1932.
} 
which were provided by descendants. Digital copies were made available to PAI personnel. Additional historic photographs of interest were available online in the digital collection of the Brazoria County Historical Museum in Angleton. Bruce Gotcher and his wife Denise shared their family albums with PAI and helped identify people and dates on many historic images. Collectively, these historic photos provided reliable visual information that was often otherwise unattainable. Many photos showed the house's front facade over the years, providing important clues to remodeling episodes and changes in the front porch architecture through time. Unfortunately, there are no known pictures showing the house's back facade (north side).

Figure 4.2 is a selection of four historic photographs that illustrate the changing front facade of the Levi Jordan house through time. Figure $4.2 \mathrm{a}$ is one of the earliest known photographs of the front of the house, and it shows the upper and lower covered porches in approximately the same configuration described by Sallie McNeill in the late 1860s (Raska and Hill 2009:11-12, Figure 1). Information on the Levi Jordan Plantation website reports that a date of 1904 is written on the back of this photograph, and notes that the house still looked like this in the 1930s (Dorothy Cotton 1998).

Figure $4.2 \mathrm{~b}$ shows the house in the $1940 \mathrm{~s}$, after it had been renovated. This view shows that the upper porch was removed and the lower porch roof was altered. This would have been how the house looked when Mike Martin lived there. This picture may have been taken after the death of Marguerite (Polk) Martin in 1944.

Figure $4.2 \mathrm{c}$ shows the house in the late $1950 \mathrm{~s}$ or early 1960s. This picture shows the house with essentially the same porch cover as in the 1940s. Based on information provided by Gotcher (2010), this photo may have been taken after the last family member, Archibald Martin, lived in the house. Archibald died in 1957, and the house fell into disrepair. L. E. Brannon rented the home in the early 1960s and made some repairs.

Figure $4.2 \mathrm{~d}$ shows the Levi Jordan house after the removal of the large lower front porch cover and the addition of a small upper porch or balcony. This photo was probably taken while L. E. Brannon rented the house in the 1960s. This is essentially how the house appeared when the property was acquired by TPWD in 2002 (as seen in other photos in the TPWD collection). We know that Brannon added the concrete porch at ground level in 1961 because the following information was inscribed into the wet concrete:

\author{
BLT By \\ MR-MRS \\ L. E. BRANNON \\ Dec 6, 1961
}

As the discussion above makes clear, precise dates of old family photographs are not always known, and dating the Levi Jordan photographs is sometimes problematic. While some photographs had handwritten dates that could be corroborated by other evidence, other handwritten dates were found to be incorrect. Approximate ages could be assigned to some undated photos because they pictured people with known death dates, thereby providing a terminus ante quem ("limit before which") date. Similarly, approximate dates could be assigned to some photographs by estimating the ages of people shown in the photos.

A second method of dating historic photographs also proved to be helpful in some cases. Historic photographs often retain their original printed borders, and many original prints from the Gotcher family had a distinctive, stylized Egyptian scroll or wave, with a small "FOX CO" label in the top-right and bottom-left corners. Fox Photo originated in San Antonio, Texas, and grew into one of the largest mail-order photo printing business in the world by 1920 (Sprague 1920:155-156). Stamped on the back of these photographs is "Guaranteed For Life / [the date] / This is a Genuine Border Fox Tone Picture / Fox Co San Antonio Texas / Copyrighted 1927 by Carl D. Newton." Thus, an original Fox Photo print from this era will have a date printed on the back. The 1927 copyright for this particular style of border provides a terminus post quem ("limit after which") date for any photos with this border. This information, combined with knowing the ages or death dates for people in the pictures, often helped to narrow down the probable date when a photograph was taken. Of course, many photos in family collections are copies made from the original, and the copies lack these backstamps.

A second problem encountered with family photo collections is that many images are scanned and reproduced, and their original borders are often cropped out. For example, the 

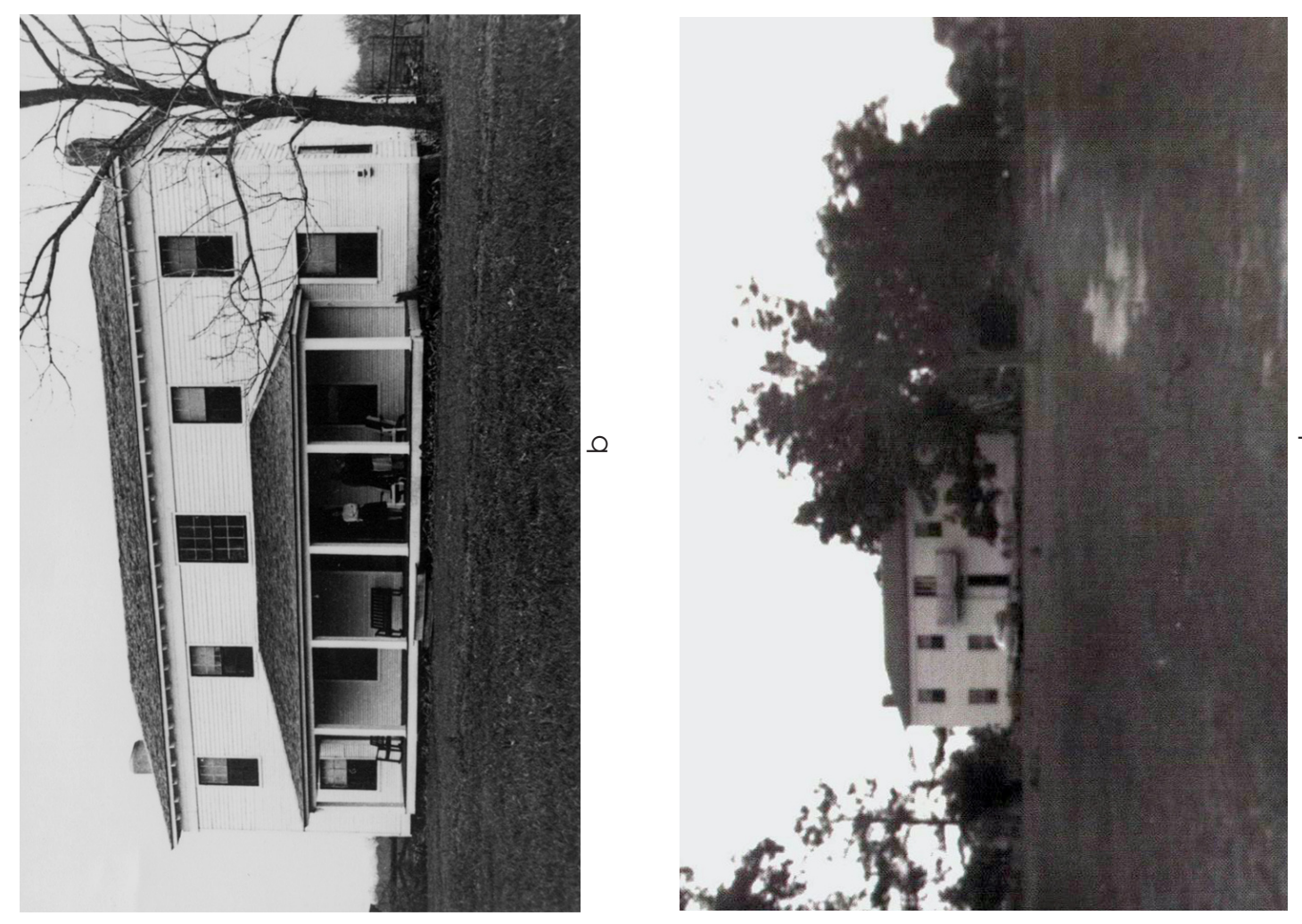

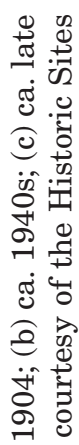

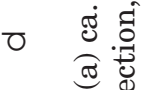

苛

क्ष

站

용

苟

爱

串

両

की

$\infty_{0}$

สี कृ

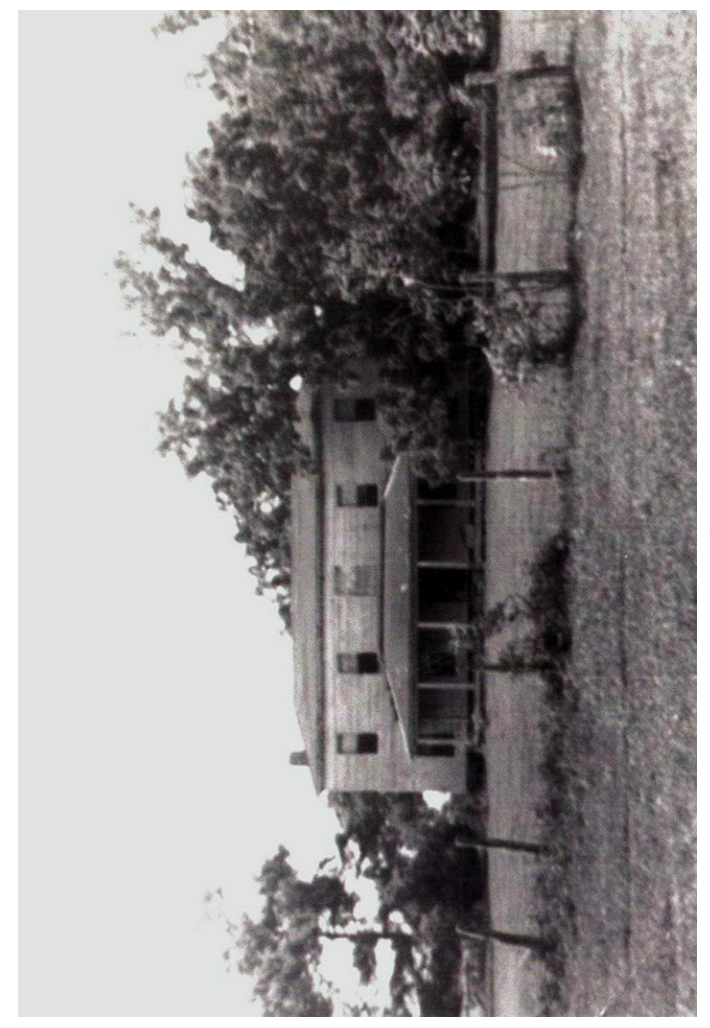

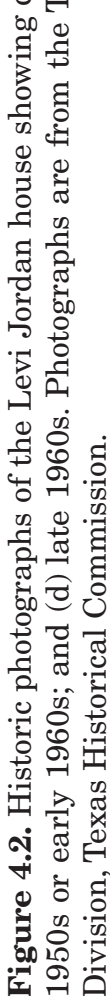

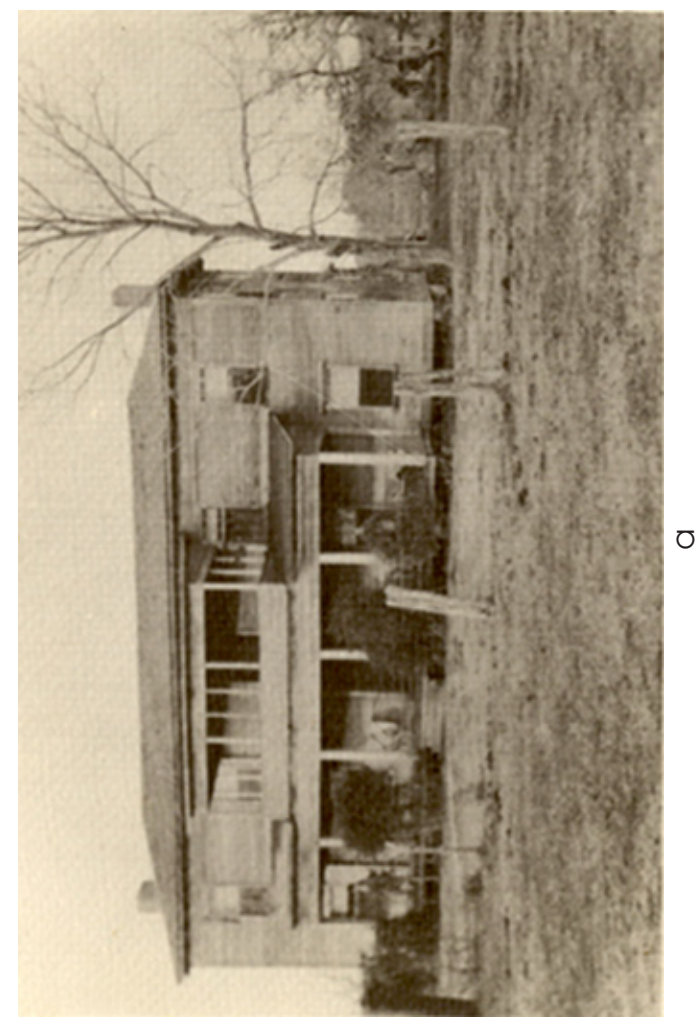


original TPWD photograph collection contains several photos that are identical to those in the Gotcher family collection, but the scanned images lack the distinctive defining borders, and no scans were made of the photo backs that had printed dates.

Photographs can also be analyzed in conjunction with family stories to determine a more reliable date for the images, which in turn can provide better evidence for interpreting historical events and archeological evidence. A case in point is a series of three photographs in the Gotcher family collection (with duplicates in the TPWD collection) that depicts people skinning a bear on the west side of the plantation house. These images correspond with the oral history recollections of bear-killing events. Ewing Martin (1998:n.p.) remembered the Christmas when Will Martin shot a black bear:

Ewing: This is 1917 now...sometime between the time she was born [sister, born in September] and Christmas we moved to that house and that's when I start to remember things. This is around two years of age. Uncle Will killed a bear that winter.

Carol: Is that the bear that Bruce has the pictures of?

[Bruce Gotcher, another Martin descendant, has some pictures of a bear that was killed...]
Ewing: Probably so. Well, anyhow he [may] have killed another one later, but he killed one that year. It was the winter of 1917-somewhere around that time. I don't know whether it was before or after Christmas but there came a snow. Of course, not a real heavy snow.

Although Ewing's statements about the 1917 event are correct, the three photographs in the Gotcher family collection are probably not from this 1917 event. Gotcher (2010) believes the two young girls in one of the pictures are his grandmother and her sister. Based on their estimated ages relative to their birth years, Gotcher believes the photograph was taken around 1900-1905. The dating of this photograph, which is illustrated in Chapter 6, was important because it is the only historic photo that shows a porch on the west side of the Levi Jordan plantation house. Because the photo shows a turn-of-the-century porch, it provides a plausible interpretation for three postmolds found west of the southwest corner of the house (see Features 13, 18, and 19 in Chapter 6).

Several of the historic photographs that were examined provide evidence useful for interpreting the archeological features found during PAI's archeological investigations. They are discussed along with specific features in Chapters 6, 7, and 8 . 


\section{REMOTE SENSING, HOUSE FOUNDATION ANALYSIS, AND WOOD IDENTIFICATION OF FOUNDATION PIERS}

This chapter summarizes the results of three types of investigations conducted for the Levi Jordan Plantation House Stabilization Project: (1) two remote sensing surveys conducted by the Texas Historical Commission (THC); (2) an examination of the foundation of the original house; and (3) the identification of wood samples from the foundation piers.

\section{MAGNETOMETER AND GROUND-PENETRATING RADAR SURVEY RESULTS}

Before Prewitt and Associates (PAI) began the field investigations, THC archeologists Tiffany Osburn and Bill Pierson conducted two remote sensing surveys over a large area around the Levi Jordan house: a proton magnetometer survey and a ground-penetrating radar (GPR) survey. The magnetometer detected many cultural anomalies, some of which correspond well with the GPR anomalies. But the magnetometer data are dominated by confusing patterns that most likely relate to buried metal artifacts. The GPR data, on the other hand, revealed many anomalies that are clearly linked to specific subsurface features. Figure 5.1 is a summary map of the GPR anomalies identified. The complete results of the magnetometer and GPR surveys are presented in Appendix A. The "possible feature" on the east side of the house corresponds with the brick rubble feature inferred to be the collapsed chimney fall (see Feature 9 in Chapter 8).

\section{HOUSE FOUNDATION ANALYSIS}

Once the structure was lifted and the steel beams were placed 5-6 ft above ground on the cribbing, the underside of the original
Levi Jordan plantation house revealed many strange and complicated secrets. Numerous disturbances were observed under the big house, and there was evidence of occasional floods and water movement as well as animal nesting. After a thorough examination, it was clear that the original frame house had been constructed with large wooden log piers that were essentially cut tree trunk sections with the bark removed. These piers were all located around the perimeter of the antebellum house, providing the only support for the structure in its earliest days. The north-south floor beams under the central portion of the house (i.e., under the interior north-south walls) appear to have later suffered from wood fatigue. Each of these beams had large horizontal cracks running lengthwise down the middle of the beam. It is uncertain when this occurred, but a series of four large square wooden piers (logs cut using a circular saw) were added in a single row running east to west down the middle of the structure, with each square pier placed underneath the center of a north-south beam. Excavations revealed that all of the original log piers had been placed on prepared brick pads that served as pier footings, but none of the wooden block piers were resting on footings (see Chapter 6 for detailed descriptions of the house piers).

After the ground surface and wooden piers underneath the original house were examined, a careful study of the foundation beams and floor joists was made to identify some of the construction and architectural details. Figure 5.2 is a plan map showing the placement of beams and joists comprising the floor of the house.

The structural framework of the house starts with two 60 -ft-long foundation beams, each running east to west under the north and 


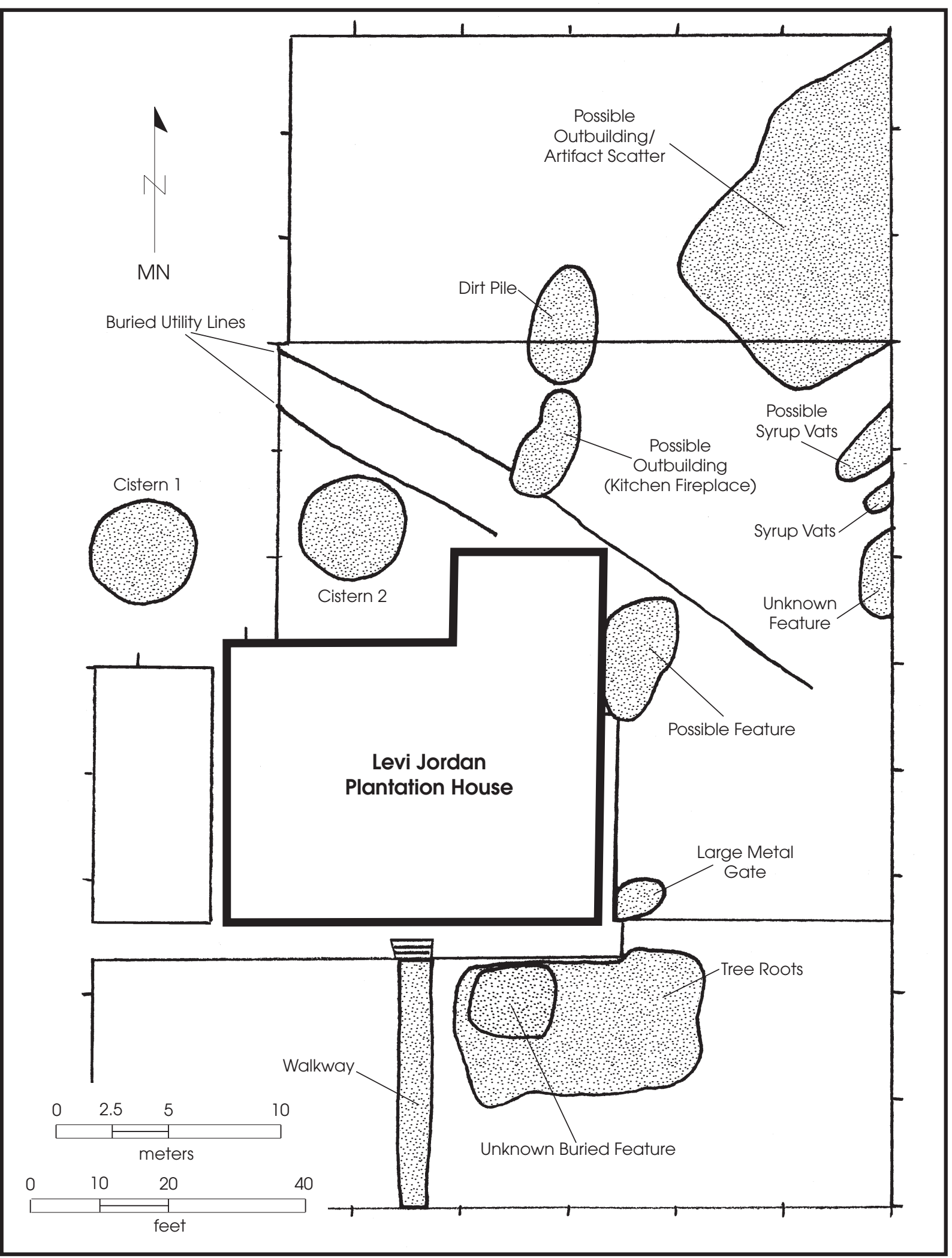

Figure 5.1. Map of anomalies in the ground-penetrating radar survey around the Levi Jordan house. This map shows anomalies seen in five horizontal slices. 


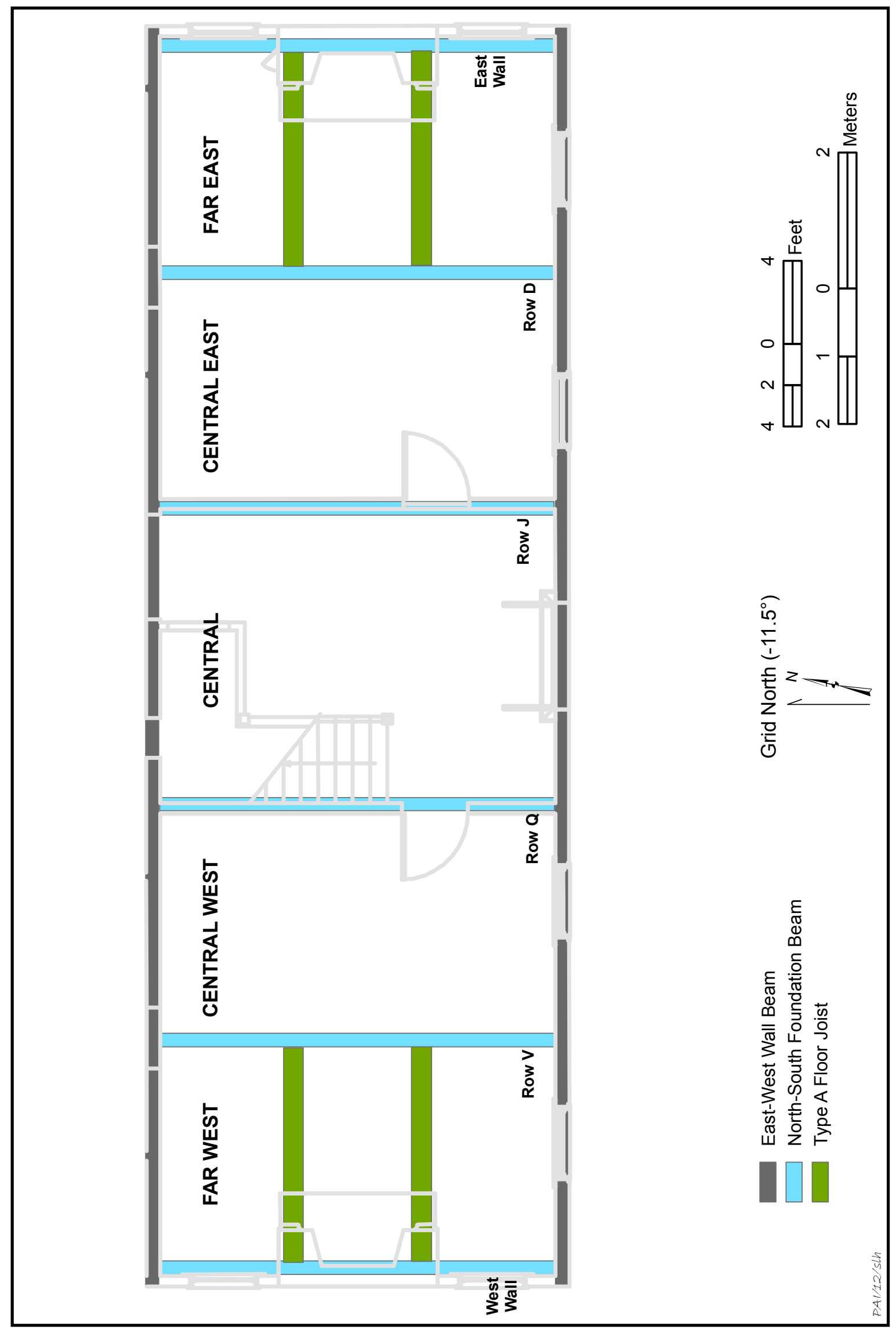

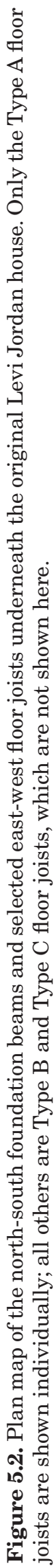


south walls, respectively. The other six main foundation beams are each $20 \mathrm{ft}$ long, and they run north to south and tie into the long beams to comprise the foundation. Two are exterior beams, one under the west wall and the other under the east wall. The other four are interior beams. Two of these beams (Rows P/Q and J) are underneath the interior walls that divide the house into the central stairway room with the large east and west rooms on either side. The last two interior beams (Rows V and D) are roughly centered underneath the west and east rooms. All six of these north-south structural beams has circular saw cut marks. Rubbings (graphite on paper) were made to copy the saw marks on each beam, and the rubbings were then compared with a concentric ring graph. All six piers were cut with a circular saw blade that was ca. 48 inches in diameter (24-inch radius).

These six north-south beams all have roughly the same dimensions, about 10 inches high and 8 inches wide. The west beam was completely rotted away and was immediately replaced with modern lumber by restoration contractors during the stabilization process. Foundation and floor joist sizes and saw blade marks are summarized in Table 5.1. Beam $D$ was cut by a circular saw running in only one direction. Beam $J$ was cut by a circular saw running in two (opposite) directions. Beam P/Q also was cut by a circular saw in two directions. Beam $\mathrm{V}$ was cut by a circular saw in two directions. Like the west wall beam, the east beam had almost rotted away. What did remain was immediately treated with antifungal chemicals, filled with epoxy, and coated in a protective resin. A precise measurement of the east beam was not possible.
All six of the foundation beams run perpendicular and are attached to the two main east-towest wall beams using mortise and tenon joints. The entire floor frame appears to be constructed using only mortise and tenon joints.

The areas between all the foundation beams are spanned by floor joists, and the wooden house floor is attached to these joists (see Table 5.1). The floor joists are of three different types described as joists Type A, B, or C. All joists run east to west and are attached to the main northsouth beams via mortise and tenon joints.

There are four Type A joists, with two in the far east and two in the far west sections of the frame. These are the largest floor joists, measuring 4 inches wide and from 8.5 to 9.0 inches tall. The Type A joists span a distance of about $11 \mathrm{ft}$. Each Type A joist has circular saw marks that match the marks on the large floor beams; they were cut with a ca. 48-inch-diameter saw. The Type A joists are found at $6 \mathrm{ft}$ and $13 \mathrm{ft}$ south of the north wall, and their placement is not random. These larger joists were placed in these locations so they would tie into the chimney foundations and become the floor support for the north and south brick walls of the east and west chimneys. It is clear that the builders chose these larger floor joists because they knew they would have to support much of the weight of the brick chimney walls.

All of the joists in the central section under the main hall are Type B joists, each spanning $13 \mathrm{ft} 4$ inches. They range from 2.75 to 3.0 inches wide and 7.75 to 8.0 inches tall. Each of these joists has straight, parallel cut marks that denote lumber cut in a sash mill.

The floor joists in the central east and

Table 5.1. Summary of foundation beam and floor joist sizes and saw blade marks in the original Levi Jordan plantation house*

\begin{tabular}{l|c|c|c|c|l}
\hline \multicolumn{1}{c|}{ Description } & Number & $\begin{array}{c}\text { Width } \\
\text { (inches) }\end{array}$ & $\begin{array}{c}\text { Height } \\
\text { (inches) }\end{array}$ & $\begin{array}{c}\text { Span Length } \\
\text { (feet) }\end{array}$ & \multicolumn{1}{|c}{ Saw Blade Type, Size } \\
\hline Foundation Beam D & 1 & 8.0 & 10.0 & 20 & Round, 48-inch diameter \\
\hline Foundation Beam J & 1 & 8.25 & 10.0 & 20 & Round, 48-inch diameter \\
\hline Foundation Beam Q & 1 & 8.5 & 10.5 & 20 & Round, 48-inch diameter \\
\hline Foundation Beam V & 1 & 8.25 & 9.75 & 20 & Round, 48-inch diameter \\
\hline Floor Joist Type A & 4 & 4.0 & $8.5-9.0$ & 11 & Round, 48-inch diameter \\
\hline Floor Joist Type B & Not counted & $2.75-3.0$ & $7.75-8.0$ & 13.33 & Straight, parallel \\
\hline Floor Joist Type C & Not counted & $2.0-2.25$ & $7.75-8.38$ & 11 & Straight, parallel \\
\hline
\end{tabular}

*No data are available for the east and west wall beams because the wood had rotted and been replaced or stabilized before they could be examined. 
central west sections of the floor frame, as well as the floor joists in the far east and far west sections (except of the aforementioned Type A joists), are Type $\mathrm{C}$ joists. These are the thinnest joists, measuring 2.0 to 2.25 inches wide and varying from 7.75 to 8.38 inches tall. They span a distance of about $11 \mathrm{ft}$. All Type $\mathrm{C}$ joists have the same straight, parallel cut marks as the Type B joists, meaning they were cut in a sash mill.

The types of wood and cut marks on the beams and joists are important because of what they reveal about Brazoria County in the early years of Texas's statehood. Assuming that the Jordan house was constructed in the late 1840 s or early $1850 \mathrm{~s}$, it is interesting that the house foundation is constructed of local oak wood and that a sash mill and circular saw mill were used to cut the lumber. According to Maxwell and Baker (1983:17), steam-powered sawmills first appeared in East Texas in the 1830s. A circular sawmill was operating in Harrisburg on Buffalo Bayou by the end of 1830 , and a small sash mill was on the Sabine River near present-day Orange by 1836 . By the 1840 s, sawmills were common, and the demand for cut lumber was high. Sash mills were the most common type early on, but they began to be phased out in favor of circular sawmills in the years before the Civil War. By 1860, there were 200 sawmills operating in Texas, employing about 1,200 workers. Large amounts of cut lumber were shipped from major mills along the coast, while smaller inland mills produced lumber for local use (Maxwell and Baker 1983:17-19). Freeman (2004:67) also notes that several of the plantation owners in Brazoria County had sawmills.

It is possible that Levi Jordan purchased lumber from a big mill on the coast and had it shipped in to build his home. But it is more likely that he bought lumber from a local mill or even brought in a portable sawmill to cut his own lumber. At least one man operated a commercial sawmill in Brazoria County in the 1830s (Handbook of Texas Online 2012). Several types of circular sawmills were patented in the 1840 s (e.g., Cushwa 1841; Phillips 1849), and the July 1841 patent by George Page was for a portable circular sawmill that housed blades up to $4 \mathrm{ft}$ in diameter (Page 1841). The "Page Portable Sawmill" was quite popular, and it was described in The Cultivator (Anonymous 1842:46) and in The Ohio Cultivator (Anonymous 1850:118). It could be operated using horse power or steam power. Although there were probably many types of sawmills that used the same size blade, it is notable that the popular Page Portable Sawmill matches the 48-inch-diameter saw marks on the Levi Jordan lumber. When Jordan needed to obtain cut lumber to build his home, the deciding factor was probably the cost of transportation. Was it cheaper to buy or rent a portable sawmill than it was to buy cut lumber and have it shipped from a coastal port up the river and then by wagon to the plantation?

Additional rubbings were taken of two of the square-cut block piers (Piers D11 and V11) that are centered under the north-south floor beams. Both of these exhibit circular saw marks with an estimated radius of 24 inches (saw blade diameter of 48 inches). Thus, these piers could have been cut by the same circular saw that cut the original floor beams and Type A floor joists. But it is not certain that this is the case, and the nature of the pier construction suggests these were probably added later (see Chapter 6).

\section{Wood Sample Identification}

Before PAI began the Phase I investigations, John Volz took three wood samples from the Levi Jordan foundation, all identified as "live oak group." The first sample was from a pier on the north wall of the house, the second was from the north wall beam, and the third was from the east wall beam just south of the east chimney.

During the Phase II work, PAI took more wood samples from structural piers, and 11 samples were submitted to Leslie Bush of Macrobotanical Analysis in Austin for identification. All 11 samples were identified as Quercus virginiana (live oak) (see Appendix B). The samples are summarized in Table B.1. They include eight log piers from the southeast corner of the house (Pier 2) and along the north wall (Piers C1, H1, $\mathrm{M} 1, \mathrm{~N} 1, \mathrm{P} 1, \mathrm{~S} 1$, and V1). These are essentially cut sections of tree trunks with the bark removed. The other three samples are square-cut interior piers that were underneath the north-south floor joists (Piers D11, J11, and V11). Although the perimeter log piers are considered original and the square-cut interior piers appear to have been added a later date, it is likely that all of the piers are from live oak trees that were cut on the plantation property, most likely in close proximity to the Levi Jordan house. 



\section{ARCHITECTURAL FEATURES: FOUNDATION PIERS}

The Levi Jordan plantation house is a twostory wooden frame structure supported by a pier and beam foundation. During the stabilization project, 69 individual piers associated with the house were investigated, including those of the twentieth-century ell addition. Of these, 30 piers were investigated more intensively through excavation, and 39 are described individually in this chapter. Table 6.1 summarizes the attributes of the documented piers. In this chapter, a distinction is made between piers and pier features. The piers were observable above ground, generally because they had some section of the wooden pier posts still in place or near their original locations. One pier feature (Feature 29) was not evident on the surface but was found in excavations.

In addition to the definite structural piers, 15 subsurface soil stains or intrusive pits that appear to be postholes or subsurface remnants of foundation piers were found. They all lack any surface evidence and were discovered in excavations. These features, summarized in Table 6.2, are probably associated with older architectural structures or ancillary features such as porches that are no longer present. These possible foundation pier features are described at the end of this chapter.

\section{THE PIER NUMBERING SYSTEMS}

None of the pier excavations were assigned unit numbers since the feature was the focus of these investigations. Each pier was given a unique designation keyed to the site maps and related architectural features, but two different pier numbering systems were employed.

During the Phase I work, Prewitt and Associates, Inc. (PAI) archeologists investigated many of the piers around the perimeter of the house, digging on the exterior side of each pier to expose a profile. At this time, the perimeter piers around the original house and the ell addition were designated Piers 1 to 38 (Figure 6.1).

In the yearlong interval between the Phase I and Phase II archeological work, project architects (Volz and Associates, Inc.) and restoration contractors (Phoenix 1) had worked on the house stabilization. When the twentieth-century northern ell addition (including the east wing, south porch, and west wing; see Figure 3.1) was removed, the piers under it and under the north wall of the antebellum house were exposed. Phoenix 1 workers marked all of these piers with brass tags stamped with an identifying letter and number. A binomial designation including a letter and a number was assigned to each pier (Figure 6.2). Pier rows were assigned letters $\mathrm{A}$ through $\mathrm{Z}$ from east to west. The system was not rigorous, however, and closely spaced piers that were not in the same row were sometimes assigned to the same row (e.g., Piers Z1 and Z2 at the northwest corner of the original house), and some letters were skipped entirely. Within each row, piers were numbered sequentially from south to north. In some rows there was only one pier (e.g., Pier W1), while others had as many as seven piers (Piers D1 to D7). For the Phase II investigations, PAI personnel decided to continue the Phoenix 1 numbering because the contractors 
Archeological Investigations for the Levi Jordan Plantation House Stabilization

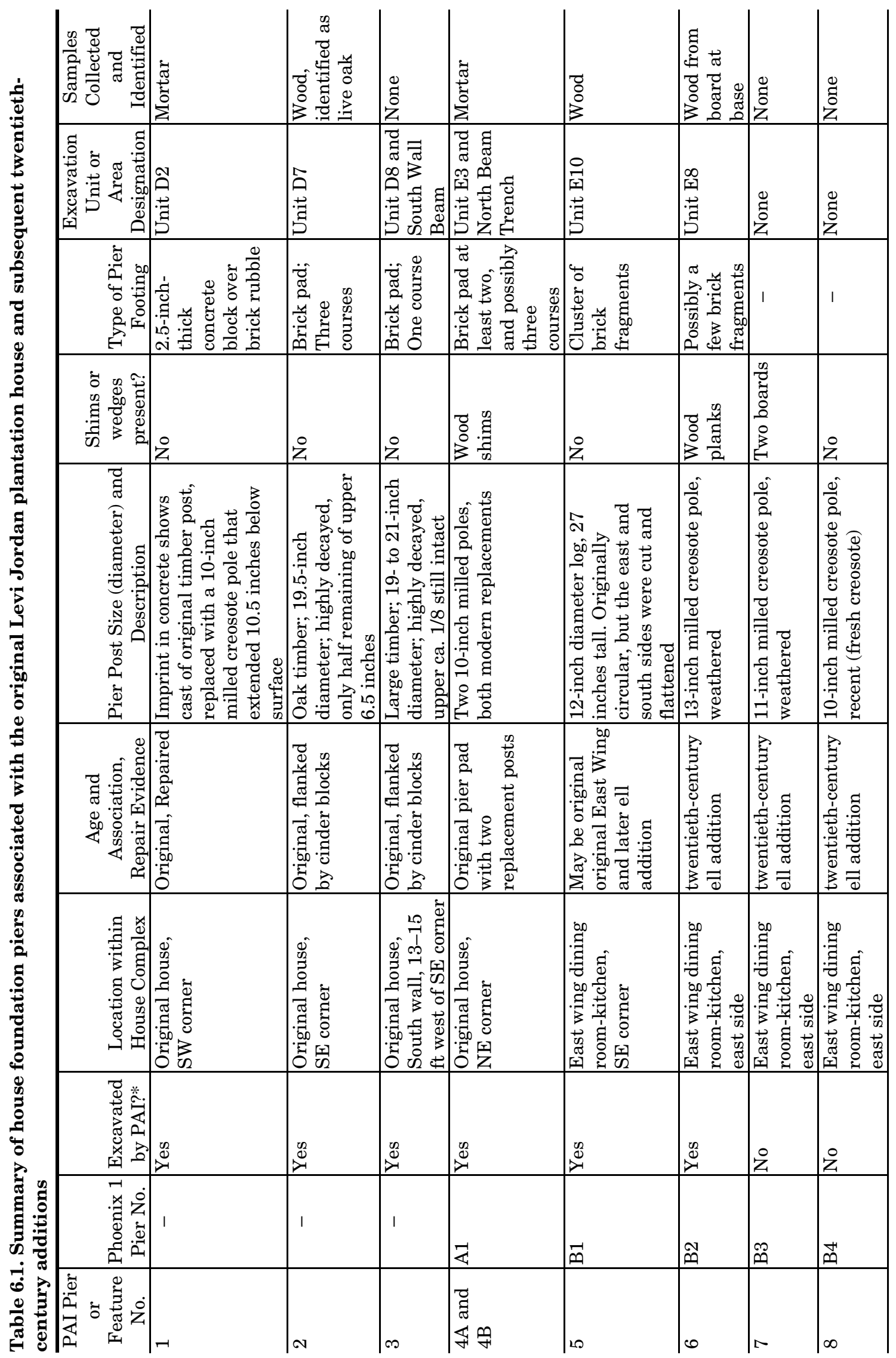


Chapter 6: Foundation Piers

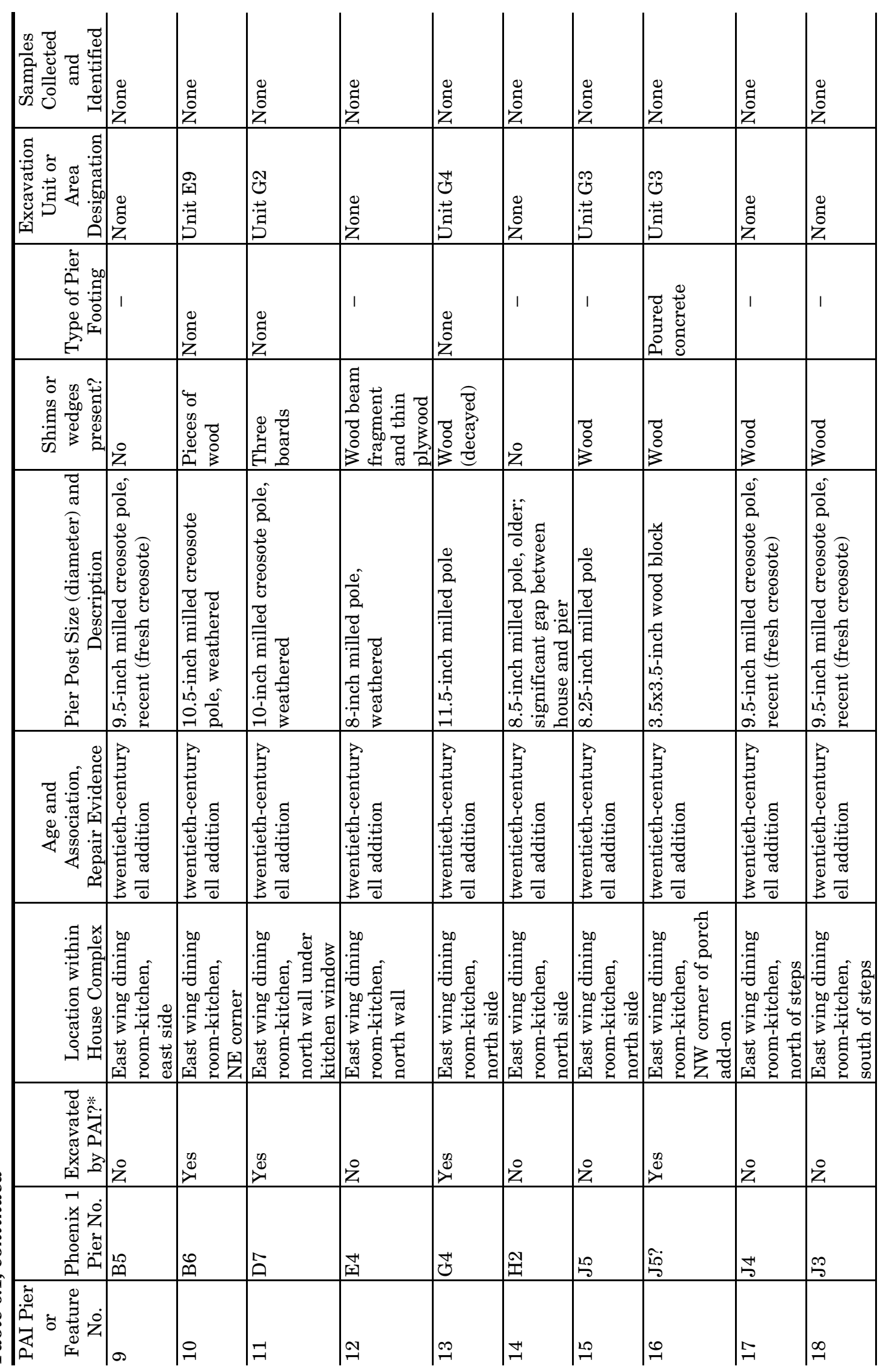


Archeological Investigations for the Levi Jordan Plantation House Stabilization

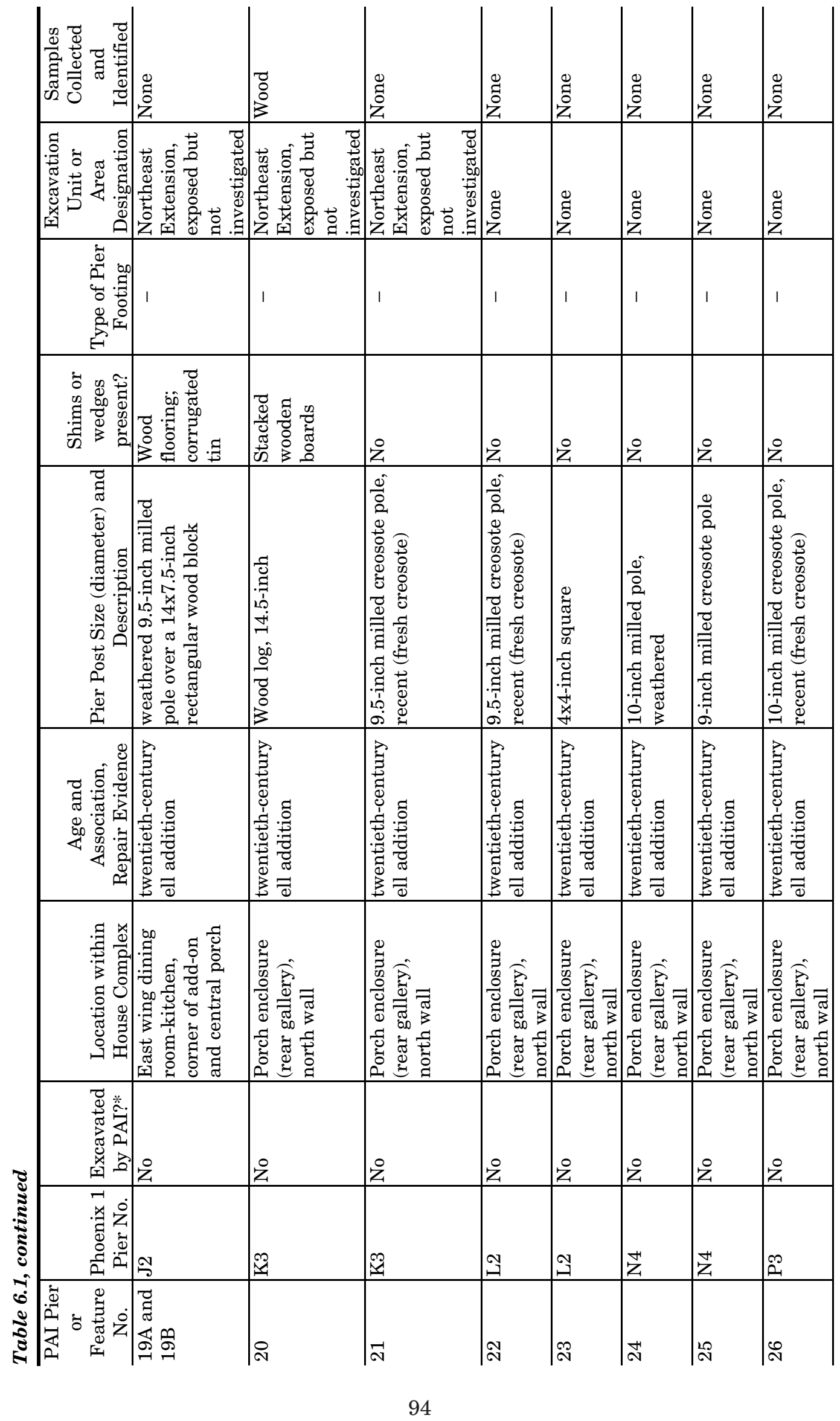


Chapter 6: Foundation Piers

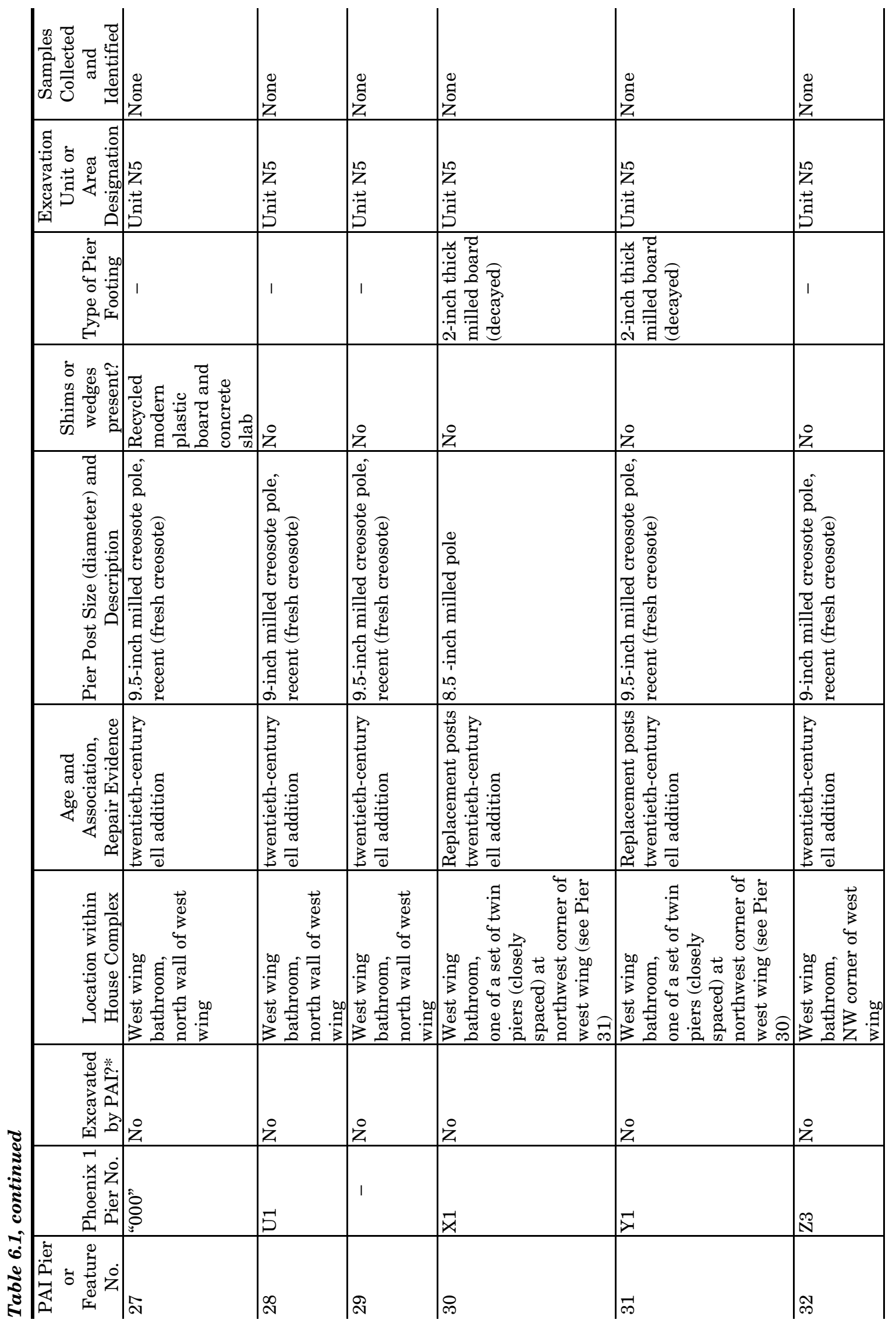


Archeological Investigations for the Levi Jordan Plantation House Stabilization

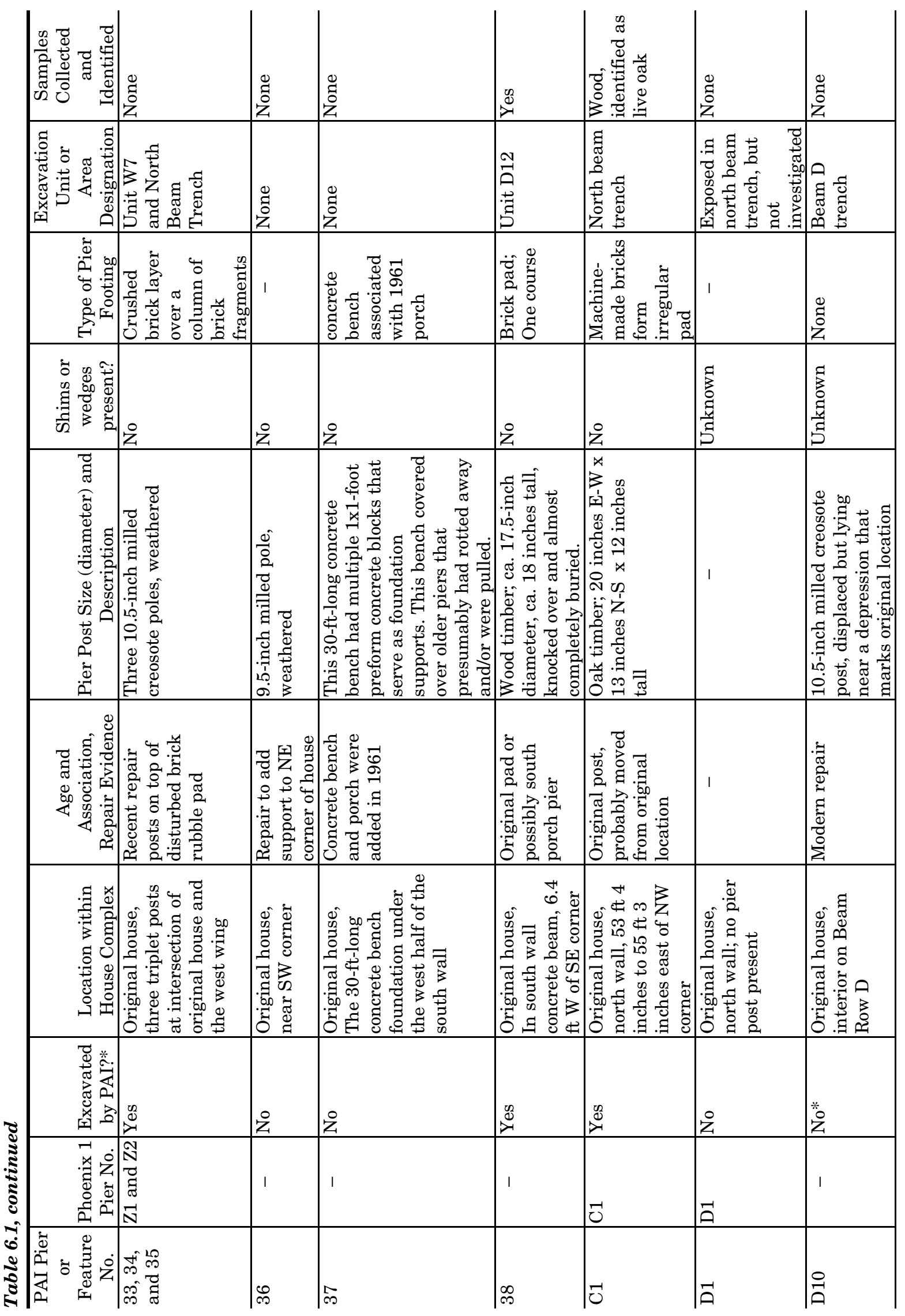


Chapter 6: Foundation Piers

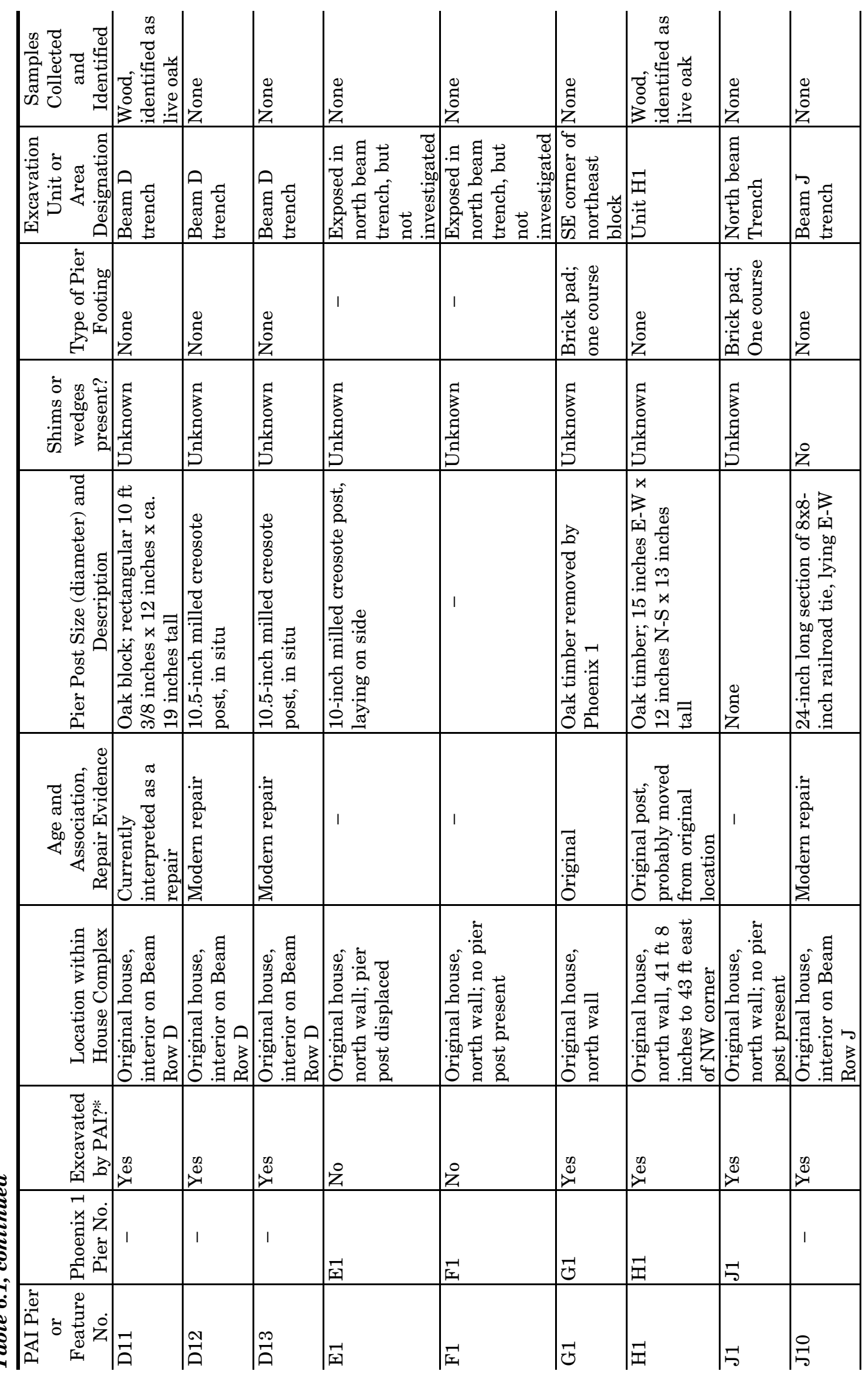


Archeological Investigations for the Levi Jordan Plantation House Stabilization

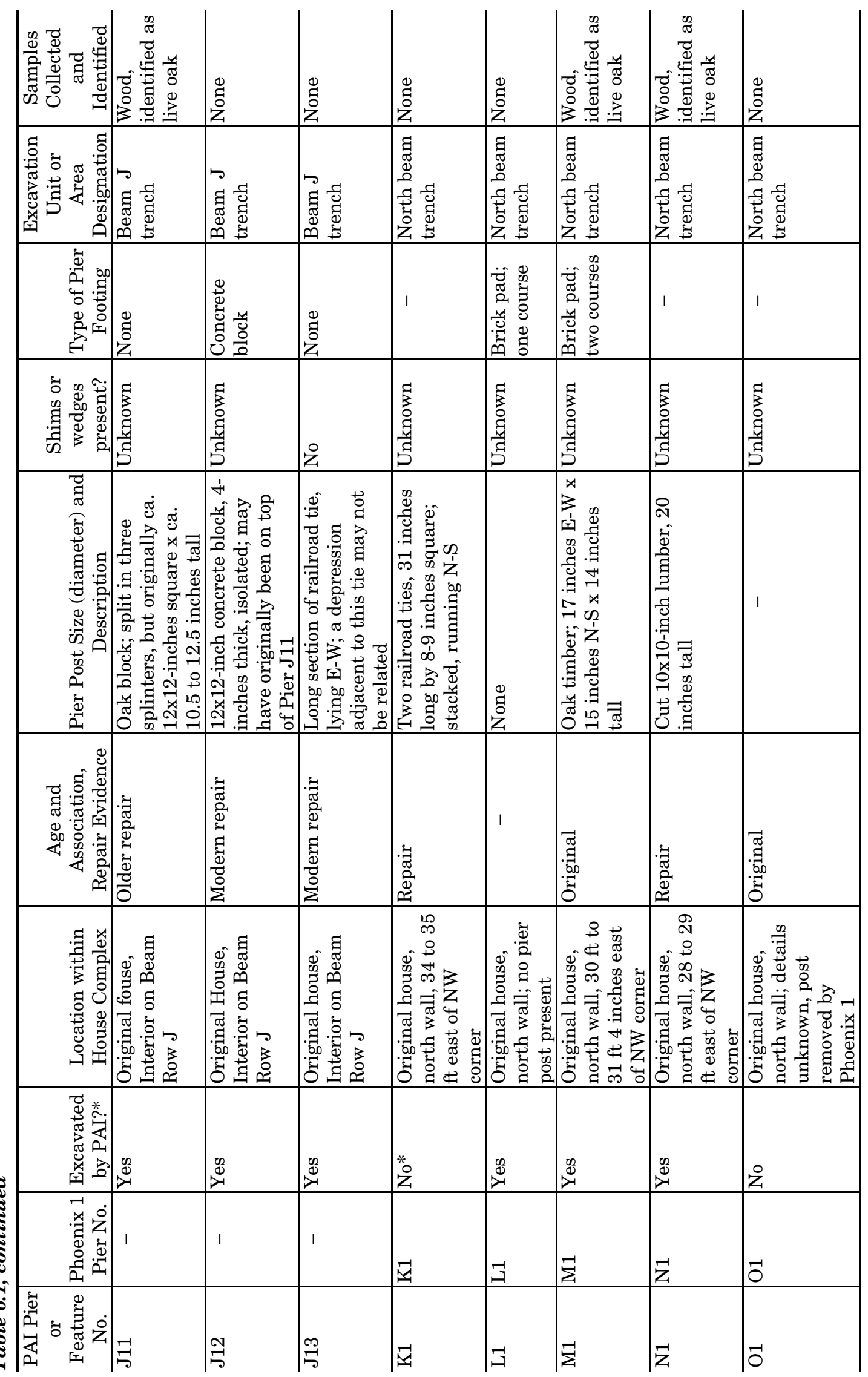


Chapter 6: Foundation Piers

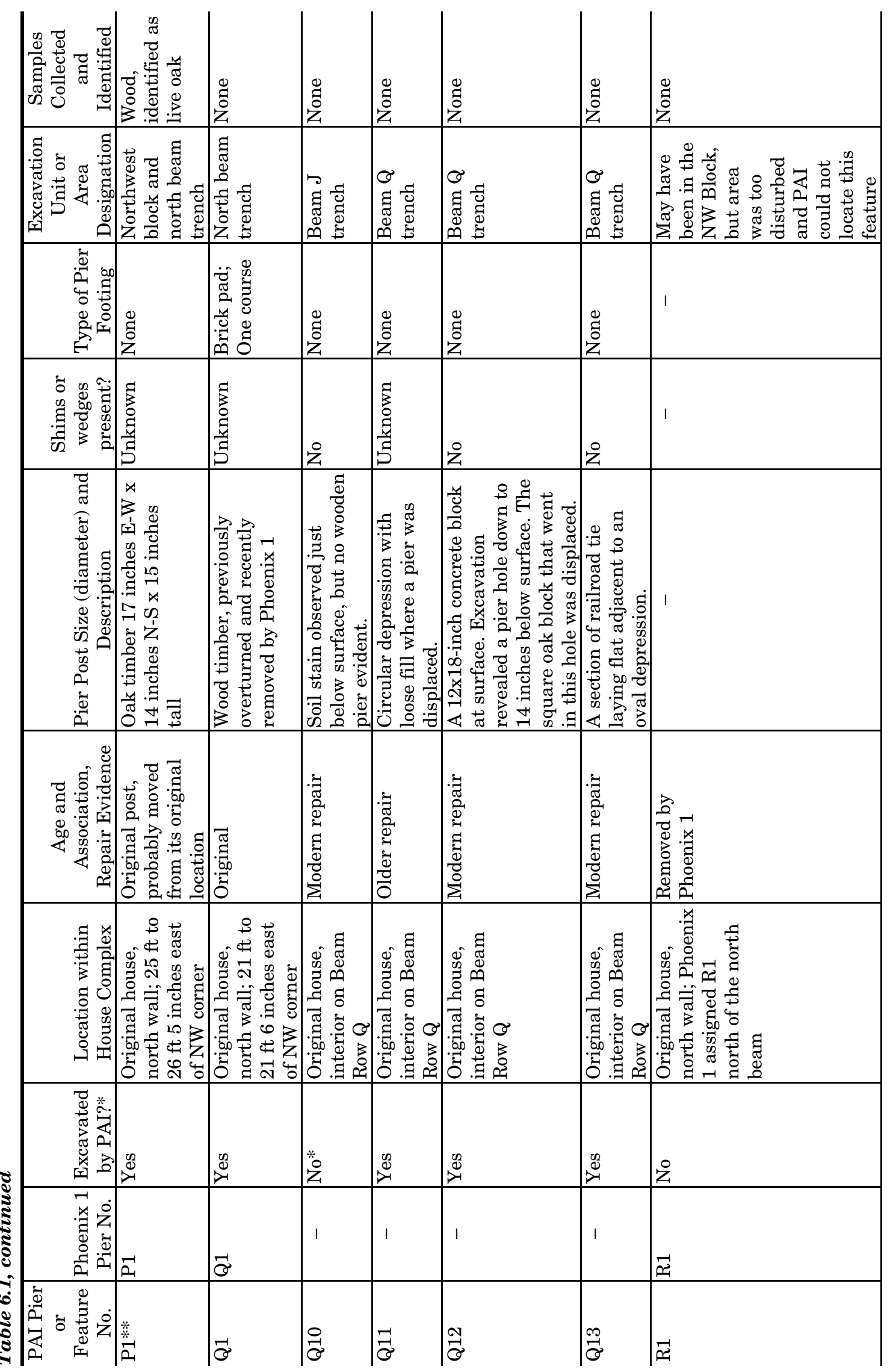


Archeological Investigations for the Levi Jordan Plantation House Stabilization

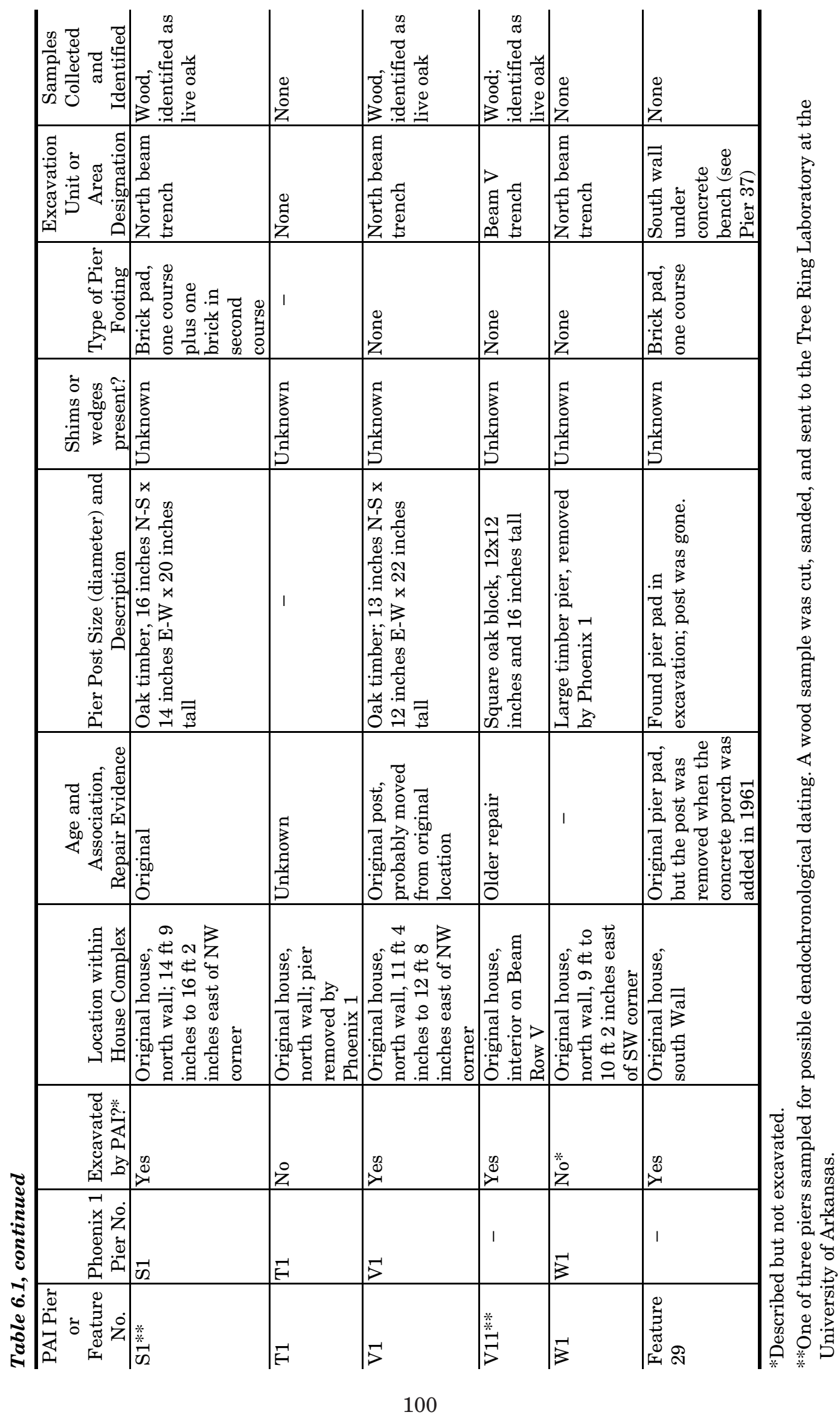




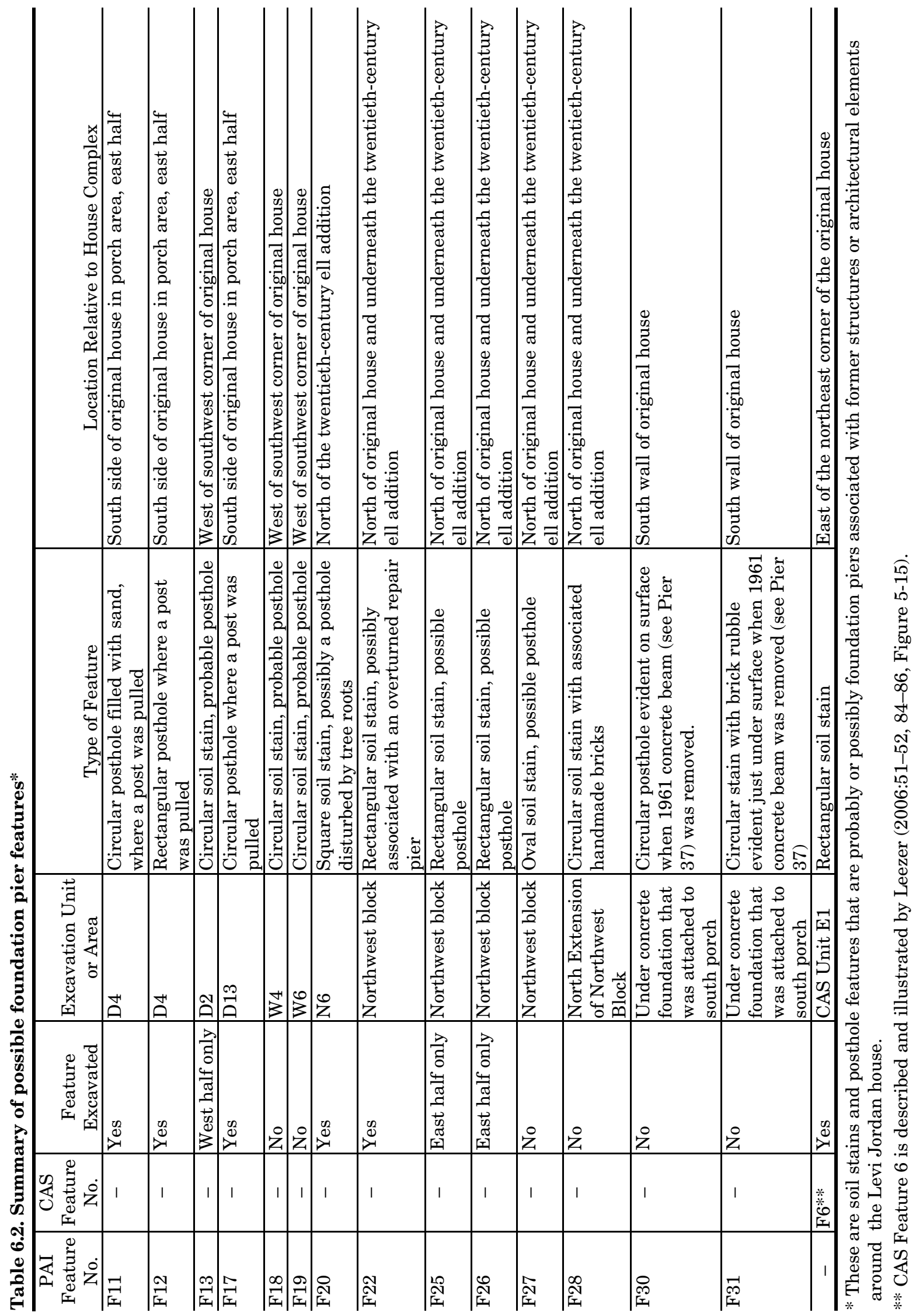




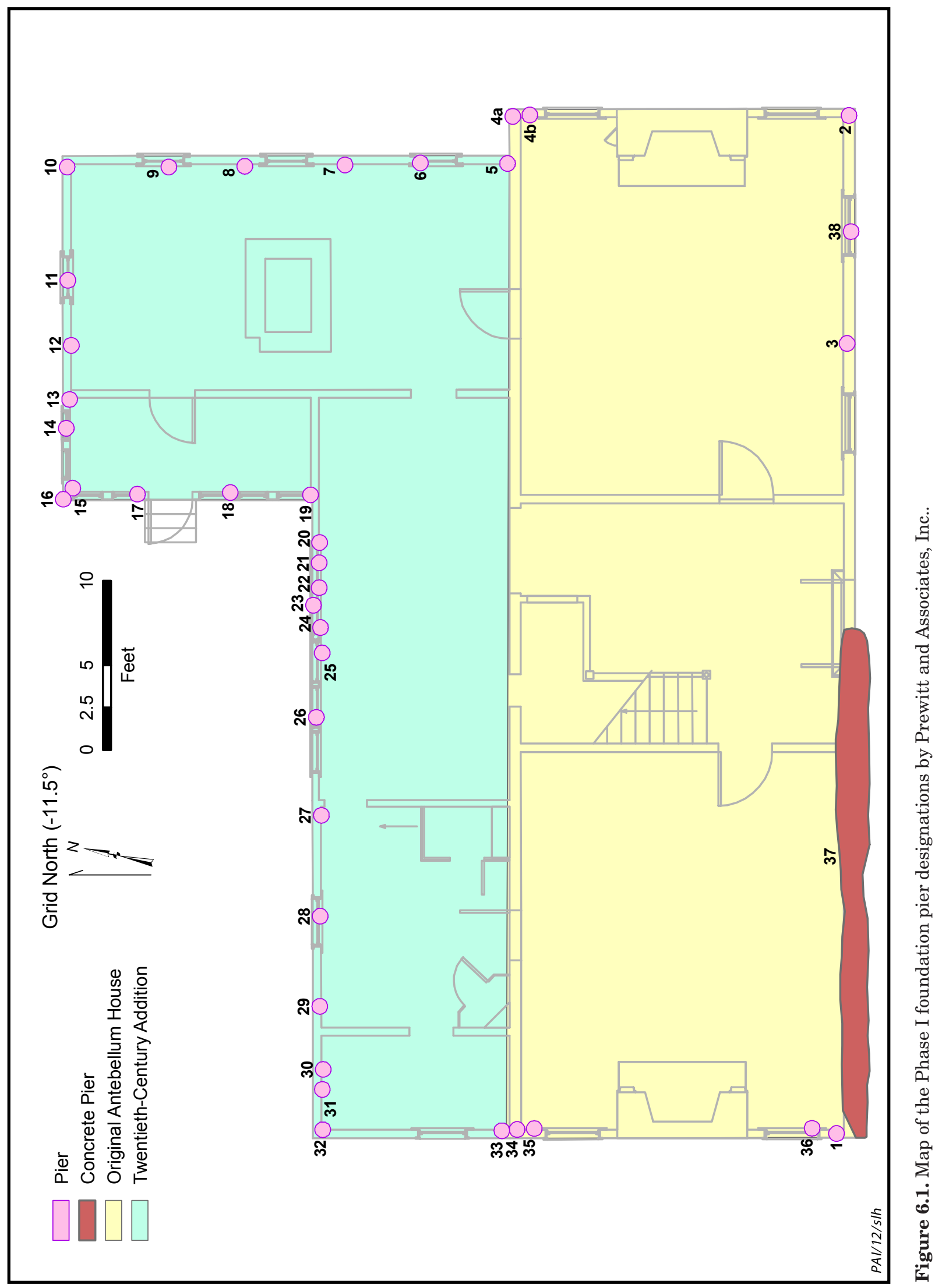




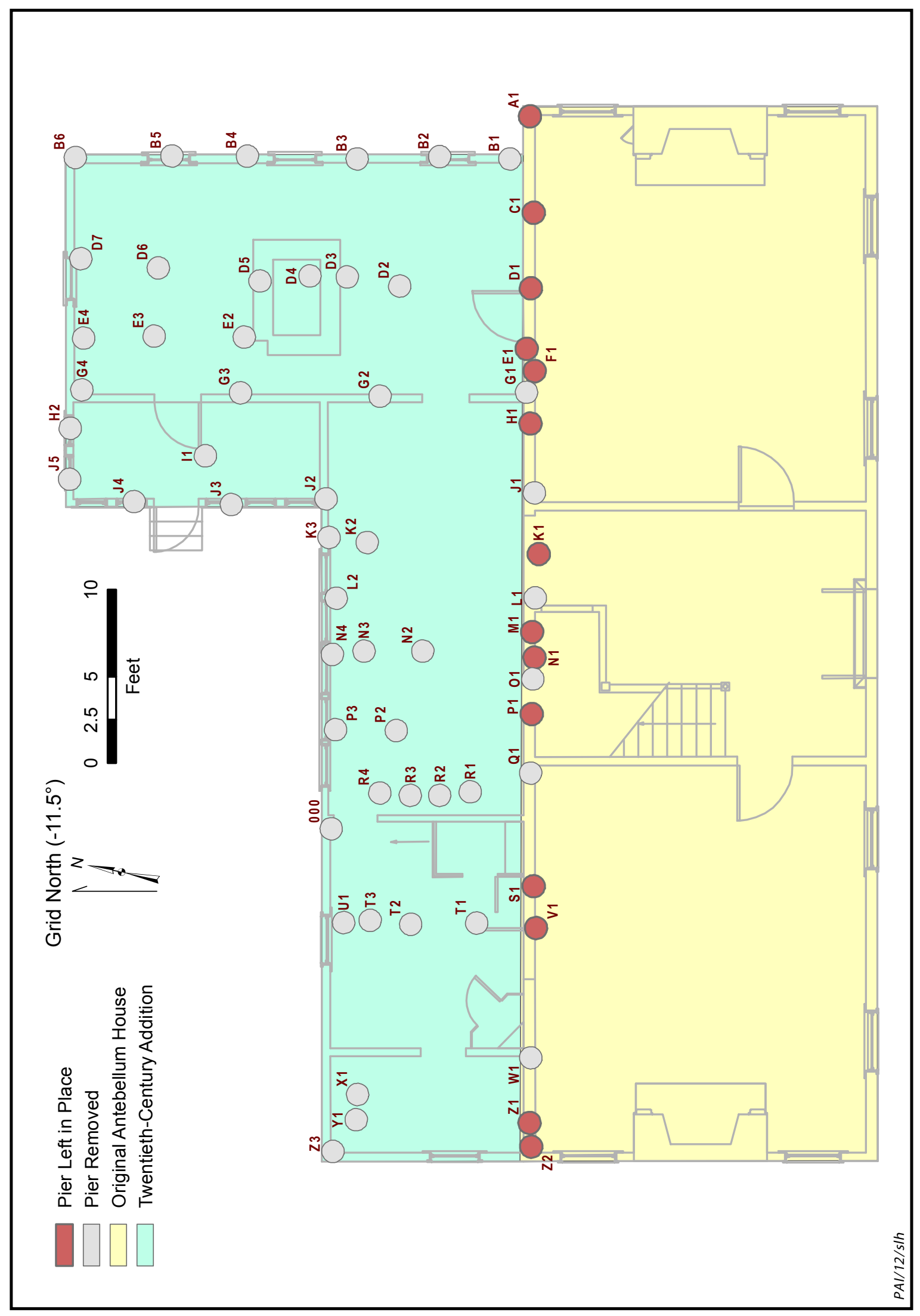

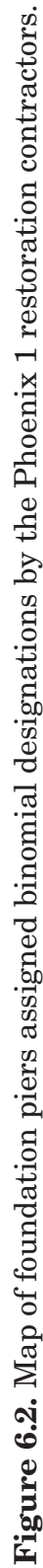


had already recorded data and collected piers using this system. ${ }^{31}$

When the house was lifted and placed on cribbing structures, the Phoenix 1 contractors did not number any of the piers underneath the house (except for those along the north wall). PAI decided that these interior piers would be designated with binomial numbers, with the letter corresponding with the rows in the Phoenix 1 system. To avoid confusion, all of these new pier numbers began with the number " 10 ," and the numbers increased to the south (Figure 6.3). The piers under the house were aligned north with one of the four major north-south beams designated from east to west, Beams D, J, Q, and V.

The investigation of the floor beams and areas below the beams, including shallow trenching with some deeper excavations, helped define the relative ages of foundation piers underneath the house. This evidence became crucial to understanding the foundation repair episodes.

\section{PIER TERMINONOLGY AND METHODS OF INVESTIGATION}

Generally, each foundation pier consisted of a foundation pad set into an excavated pit, with a wooden post placed on the pad, as illustrated in Figure 3.2. The pad and a portion of the wooden post were below ground, and a portion of the post extended above ground. As used in this chapter, the term "pier" refers to the entire feature, and "pier post" refers to the wooden portion. The terms "telephone pole" or "utility pole" refer to sections of creosote-soaked, round milled logs used as pier posts. The "pier pad" or "footing" (used synonymously) refer to the subsurface foundation structure on which a pier post was placed (see Figure 3.2). The footings varied widely from platforms of brick to concentrations of rubble. And many pier posts were placed directly into the clayey sediments without any footing.

For piers without footings, or with small footings that corresponded to the size of the post, there might or might not be evidence of a posthole that was excavated for inserting the post. For piers that had larger footings set into the ground, each one would have had an original "construction pit" or "builder's trench." The edges of these construction pits were sometimes evident and sometimes not. Construction pits were especially difficult to identify in shallowly buried footings.

The investigations were aimed at documenting the attributes of each pier feature so that a comparative analysis would allow a better understanding of the building techniques of the original Levi Jordan house, the additions through time, and ancillary features such as porches. It was hoped that the archeological evidence would reveal some chronological details of the construction and renovation sequence, and this goal was met in large part. The evidence is especially significant with regard to differentiating the antebellum construction associated with the original house from that of all the subsequent additions.

The intact, aboveground components of the piers were documented whenever possible, but many pier posts were removed prior to Phase II and before they could be examined. In these cases, excavations were made adjacent to selected piers to look for evidence of the original construction pit and to create a profile to show the relationship of the various components. Some piers were only partially excavated to expose them in plan view or to obtain a feature profile. Some of the more important piers associated with the original house were half-excavated and profiled during Phase I, and then were completely excavated and removed during Phase II to thoroughly document the construction details and look for associated artifacts that might aid in relative dating of the features. During all pier excavations, special attention was paid to looking for sediment changes that would denote the edges of original builder's pits. When observed, sediment from builder's pits were screened separately to look for diagnostic artifacts.

"Possible piers" are those that had no aboveground evidence and were discovered

\footnotetext{
${ }^{31}$ Unfortunately, most of the wooden piers from the original house were removed by the Phoenix 1 contractors before PAI archeologists had an opportunity to examine them in situ. But PAI investigators did make additional observations about all aboveground portions of the wooden pier posts that were left in place and at the locations of the removed wooden posts (see Table 6.1). All of the removed piers were kept onsite at the plantation.
} 


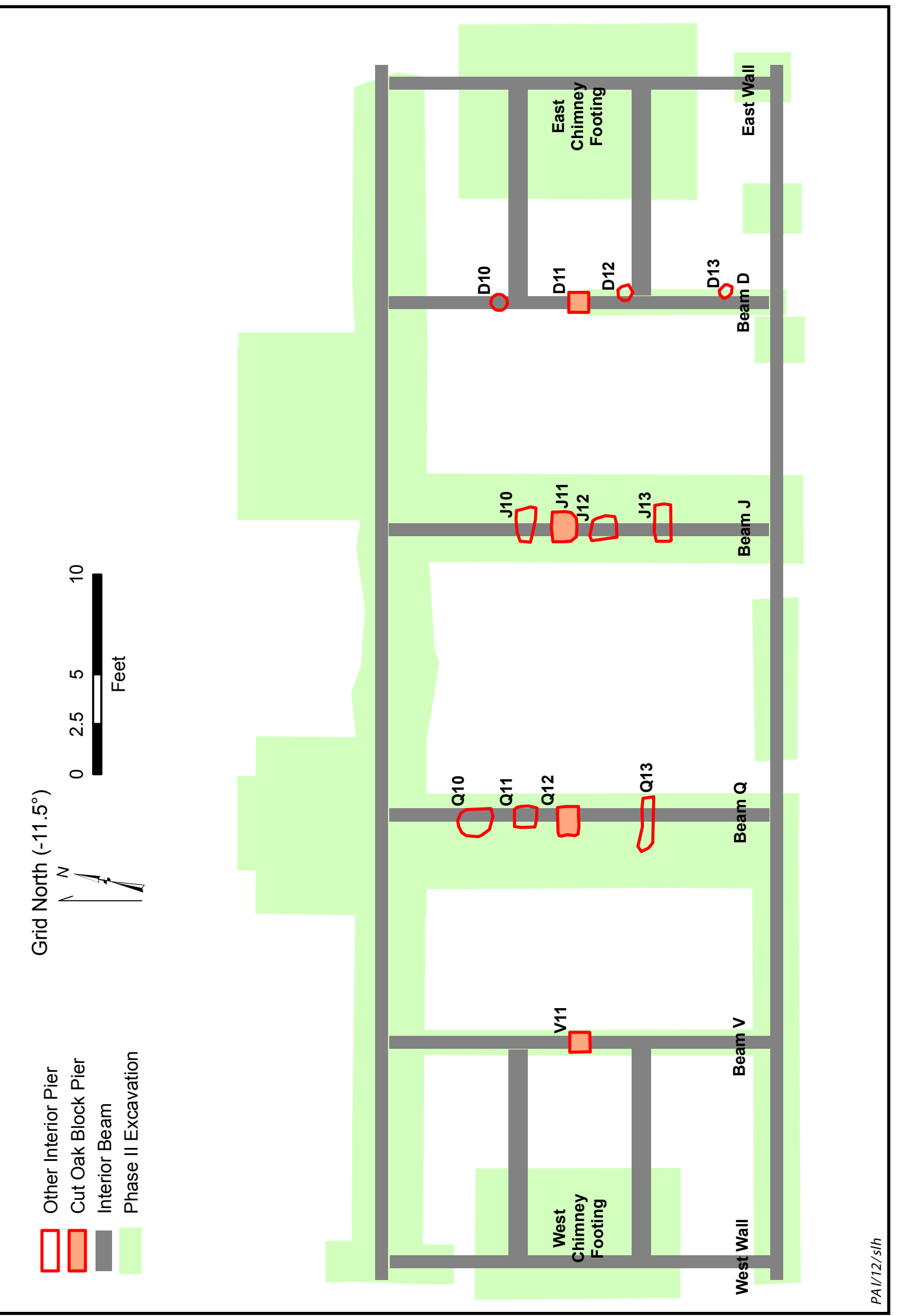

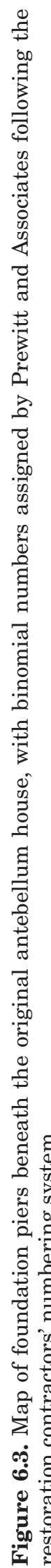


entirely subsurface. These features are presumed to represent locations where the posts had been removed long ago, and they were designated using feature numbers rather than pier numbers. When first encountered, some were irregular brick clusters or uniform brick footings, while others were simple soil stains. These features were generally bisected and profiled. In some cases, their interpretation as foundation piers is probably sound, but in other cases it is tentative. The strength of the interpretation often depends on having excavated a large enough area to see a pattern of features with similar attributes.

Elevation control for pier excavations was relative to the ground surface, so profile drawings are the best way to see the relationships of the piers to the house floor foundation and other architectural features such as corners, doors, and windows. Vertical provenience for pier excavations was assigned by natural or cultural sediment layers rather than arbitrary levels. When possible, the sediment around each pier was excavated in cultural or natural stratigraphic layers, with the observations and any collected artifacts keyed to the stratigraphy. Once the excavations reached the brick pier pads, the sediments and bricks were excavated by level corresponding to brick courses, and observations and any associated artifacts were keyed to these courses.

\section{PIERS AND ASSOCIATED ARTIFACTS}

Artifacts were often found in the pier excavations, and it is important to understand their archeological contexts and associations. The best context is an artifact found at or near the bottom of an original antebellum pier, especially between the post and the brick pad, in the brick pad, or in the fill inside the original builder's pit. Such contexts were encountered, but they were rare. More commonly, the excavators found artifacts in disturbed deposits or scattered across the ground surface in contexts where they were probably associated with later pier repair episodes. In most of the pier excavations, it was difficult or impossible to estimate the age of the deposits.

The use of "associated" artifacts to date original pier construction or repair episodes is tricky business. In most cases, the spatial association of artifacts and piers was generally not very informative, with some notable exceptions. A gold coin found in an undisturbed context beneath the original antebellum Pier 2 and the coin's 1853 year of manufacture is known. This, obviously, is an ideal situation. More commonly, however, artifacts of various ages became mixed in the upper deposits around piers through bioturbation and human activities. In time, more and more artifacts accumulated around the house, and periodic pier repairs increased the potential to introduce artifacts into the sediments next to the piers. When the underground portion of a pier post deteriorated and the pier became unstable, it would have been a quick and temporary fix to dig down beside the post and shove wood blocks or other materials along the sides and under the post. In an area scattered with debris, it was easy for artifacts to fall into these repair holes. If a pier was repaired once or multiple times, the deposits around the pier post and footing might contain artifacts spanning a century or more. In addition, the archeological material culture of the late nineteenth and early twentieth centuries is dominated by fragmentary and nondiagnostic items that are difficult to date precisely. For example, fragments of ceramics and container glass were ubiquitous in some pier excavations, but they rarely provide precise chronological evidence.

Preservation conditions posed another challenge in using material culture for dating features. Because this area of coastal Texas gets so much rainfall, and clay sediments are constantly subjected to wetting and drying, the environment is not conducive to preservation of buried metal artifacts, especially iron. Iron items were found in many of the excavations, but they were usually so highly oxidized (i.e., rusted) that they were no longer recognizable, and any diagnostic markings were no longer visible.

\section{DESCRIPTION OF THE LEVI JORDAN FOUNDATION PIERS}

This section describes the foundation piers and possible pier features that were investigated to some degree, most being partially or wholly excavated. Table 6.1 summarizes the 69 piers for which observations or investigations were made. The 39 piers and 15 possible pier features 
described individually ${ }^{32}$ are grouped by archi-

tectural association and inferred age as follows:

PIERS ASSOCIATED WITH THE

ANTEBELLUM HOUSE

Original Corner Piers

Pier 1 at the southwest corner

Pier 2 at the southeast corner

Pier 4 at the northeast corner (A1)

Pier 33/34/35 at the northwest corner (Z1 and Z2)

Original North Wall Piers

Pier G1

Pier J1

Pier L1

Pier M1

Pier Q1

Pier S1

Original South Wall Piers

Pier 3

Pier 38

Feature 29

Other Piers on the Shared North Wall

Pier C1

Pier H1

Pier K1

Pier N1

Pier P1

Pier V1

Pier W1

Interior Piers Centered under the House

Pier D11

Pier J11

Pier Q12

Pier V11

Other Interior Piers

Pier D10

Pier D12

Pier D13

Pier J10
Pier J12

Pier J13

Pier Q10

Pier Q11

Pier Q13

PIERS ASSOCIATED WITH THE

TWENTIETH-CENTURY EAST WING

Pier 5 (B1)

Pier 6 (B2)

Pier 10 (B6)

Pier 11 (D7)

Pier 13 (G4)

Pier 16 (J5?)

POSSIBLE PIER FEATURES

North of Original House

Feature 22

Feature 25

Feature 26

Feature 27

Possible Original West Wing

Feature 20

Feature 28

South Wall of Original House

Feature 30

Feature 31

Possible South Porch Piers

Feature 11

Feature 12

Feature 17

Possible East Porch Pier

CAS Feature 6

Possible West Porch Piers

Feature 13

Feature 18

Feature 19

\footnotetext{
32 Thirty-one other numbered piers are not formally described in this chapter: Piers 7-9, 12, 14, 15, 17-32, 36, 37 (concrete beam), D1, E1, F1, N1, O1, R1 and T1. Some are discussed in the context of their relationships with other piers, but PAI data on these piers is minimal. Most of them are associated with the twentieth-century ell addition and therefore have no bearing on interpretations of the nineteenth-century house.
} 


\section{Piers Associated with the Antebellum House}

\section{Original Corner Piers}

Four corner piers from the original antebellum plantation house were archeologically investigated (see Figure 6.1). These include the four corner piers: Pier 1 (southwest corner), Pier 2 (southeast corner), Pier 4 (northeast corner), and Pier 33/34/35 (northwest corner). All four of these piers were excavated are described below (Figure 6.4).

\section{PIER 1, SOUTHWEST CORNER}

Pier 1 was first exposed by Center for Archaeological Studies (CAS) archeologists in Unit D2, but because "the feature was not within the unit, it was not labeled or identified as a feature" (Leezer 2006:50). Brick was exposed at 16 inches below ground level at the southwest corner (Leezer 2006:50 and Figure 5-13).

At the time of the PAI investigations, Pier 1 abutted a concrete porch remnant on its north and east sides. The porch was laid in 1961 by a renter (L. E. Brannon), and it affected investigations along the entire front facade (south side) of the house. Even after most of the concrete porch was removed, a long section of concrete under the south wall of the main house was left in place because it served as the foundation (designated Pier 37; see Figure 6.1). This concrete foundation beam covered many previous features, including several foundation piers on the south wall of the original house. These features were not accessible for investigation until late in Phase II when the massive concrete beam was finally removed.

During Phase I, PAI removed the backfill from CAS Unit D2 to expose and record the pier. The east wall of the unit provided a partial profile of the west side of the pier, but the pier was not fully bisected at this time due to concerns that additional excavations might destabilize the structural integrity of this corner pier. The Phase I work revealed that this pier had obviously been repaired in the twentieth century. ${ }^{33}$ It consisted of a 10-inch utility pole atop a 12-inch-square preform concrete block exposed 10 inches below the surface. The pad was 2 inches thick and extended several inches westward into Unit D2. Small handmade brick fragments (2-3 inches long) were exposed below the slab and also extended several inches into the unit. No construction trench was visible in the profile or in the bottom of the Unit D2. No bricks or other portions of this pier were removed during the Phase I work.

Phase II work on Pier 1 began after the house was lifted but before the concrete foundation beam was removed. The creosote-soaked wooden pier post was removed at that time. This exposed a clear imprint in the concrete beam to the north and east of where the original wooden pier had been. The shape and texture of the imprint revealed the post had been a large, generally circular timber about 18 inches in diameter (Figure 6.5). The impression matched the undulating surfaces of the other original pier logs, thus providing unmistakable evidence that the original Pier 1 post was a live oak log section that was still in place when the concrete porch was built in 1961 . This original log post was removed sometime later and replaced with a modern utility pole section.

Phase II excavation exposed the north side of Pier 1. Two modern cement bricks found just north of the pier post were clearly related to the post-repair episode. The larger cement brick was imprinted with "201 / Security / A.A O o V," while the smaller brick fragment was inscribed with " $21 / 2$ X 4 ." When these modern bricks were removed, several large pieces of window glass were found.

At ca. 9 inches below the surface, a tightly packed cluster of brick rubble was encountered, measuring 13 inches (east-west) by 8 inches (north-south). ${ }^{34}$ It was next to a $12 \times 12$-inch concrete block on which the modern post sat. The brick rubble extended to 13 inches below the surface, for a total thickness of 4 inches. The

\footnotetext{
${ }^{33}$ A second creosote post, Pier 36, was located about 15 inches north of Pier 1 . This pier was removed during Phase II. No overlying pad was found, and it appears to have been added about the same time as the Pier 1 post.

${ }^{34}$ As the term is used here, "brick rubble" refers to a concentration of bricks and brick fragments lacking any cohesive patterning and without any flat-lying bricks or fragments.
} 


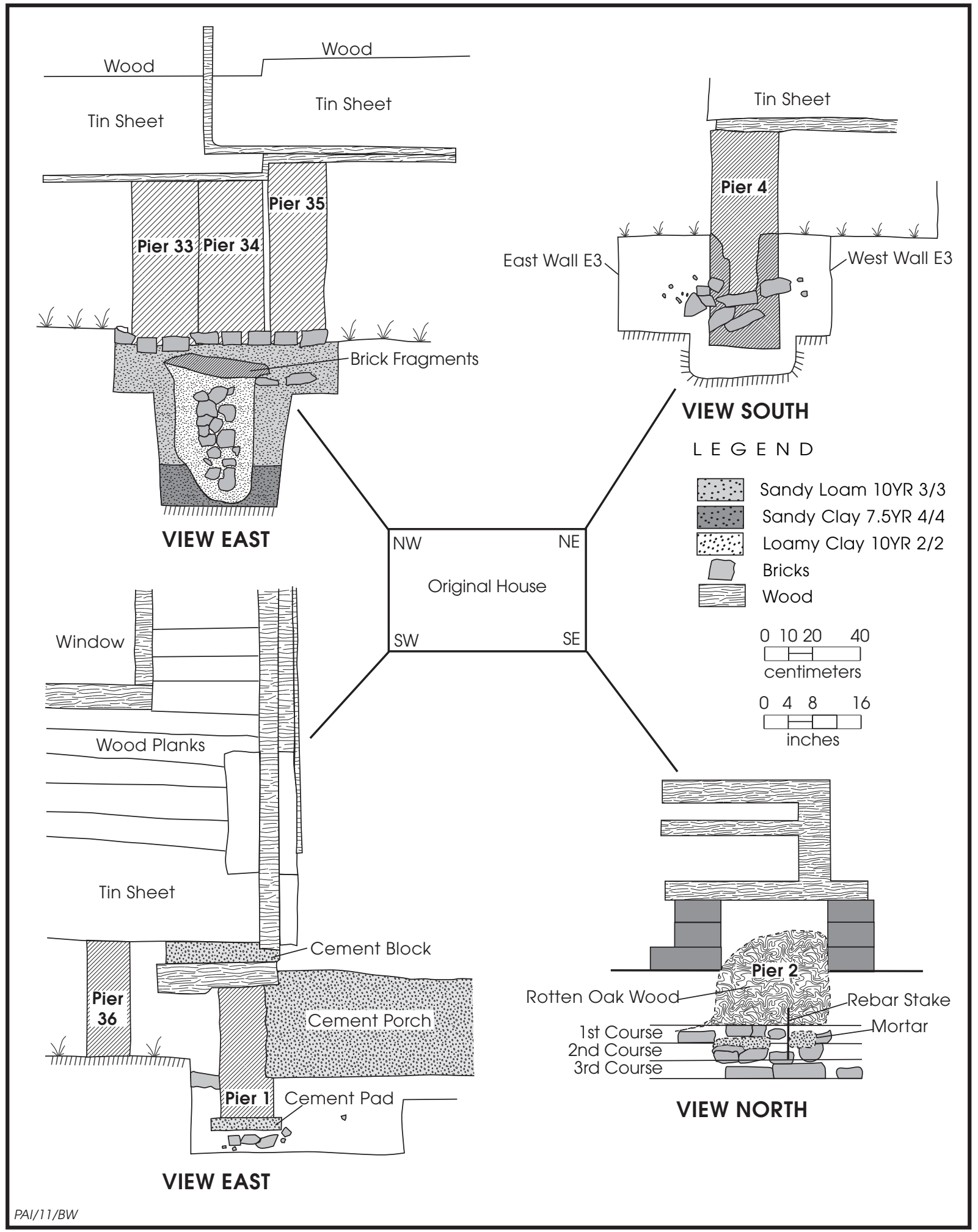

Figure 6.4. Composite drawings of the four corner pier profiles showing variations in timber remnants and brick pier pads. 


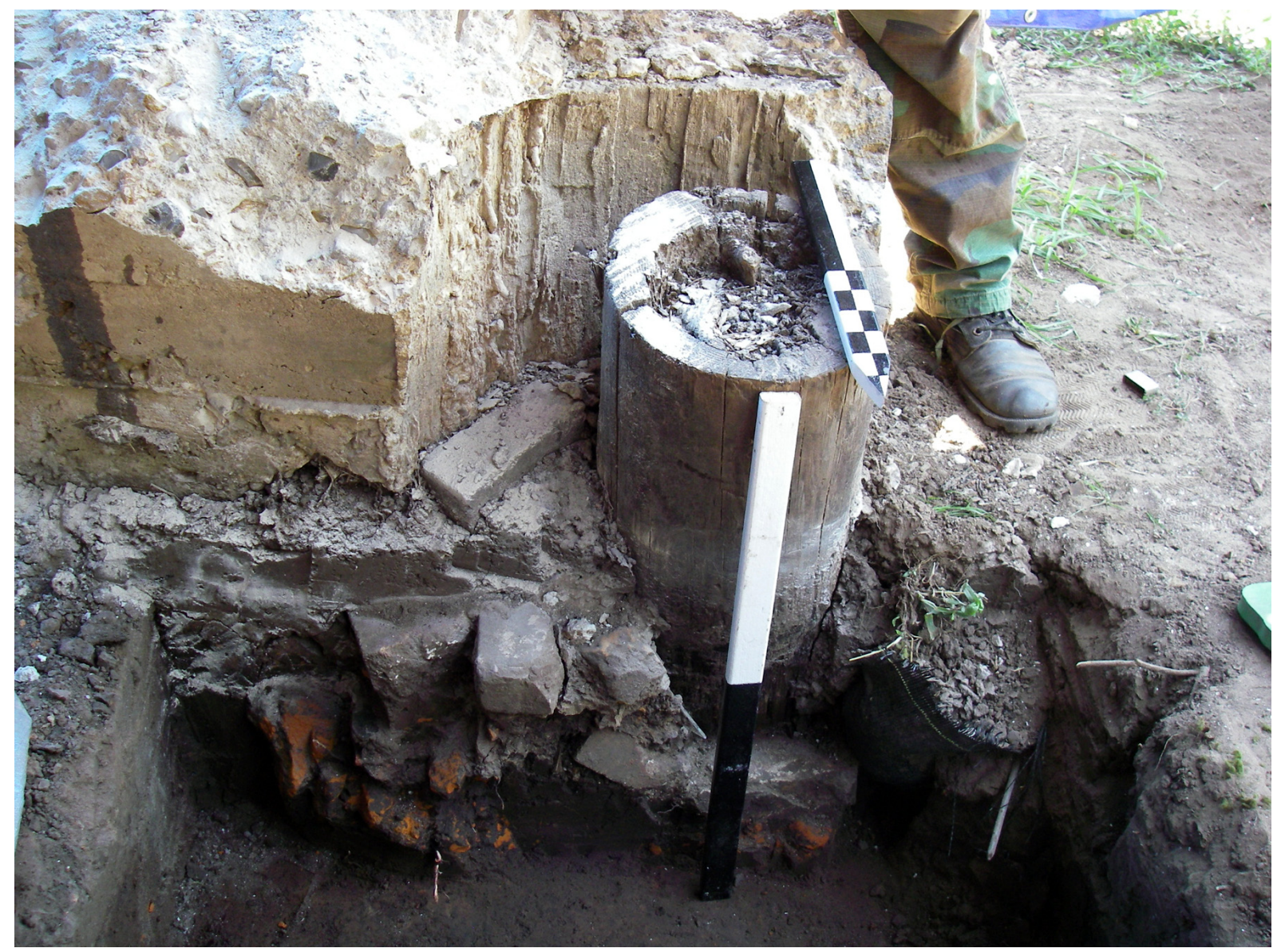

Figure 6.5. Pier 1 at the southwest corner of the main house, facing south. The imprint of the original timber pier is visible in the concrete foundation remnant behind the replacement pier post. The vertical scale is in 1-ft increments, and the north arrow is $1 \mathrm{ft}$ long.

rubble appears to be the remnant of a singlecourse brick footing, but much of it was removed when the square concrete block was added as a replacement footing. The concrete block was broken down the middle and had been pushed deeper by the weight of the house.

After removing the brick rubble and concrete block, a triangular cluster of brick rubble was exposed ca. 2 inches below the northwest corner of the pad. Below this brick deposit, at 15 inches below the surface, a densely packed homogenous dark clay loam was exposed, followed by sandy mottles and more brick fragments, forming an amorphous oval-shaped dark soil stain, which became well-defined at 17 inches below the surface. This disturbance, which measured 17 inches (east-west) by 15 inches (north-south), probably represents the original builder's trench and the filled-in hole where the original pier post had been.

This intrusive stain was profiled and continued to 24 inches below the surface, but brick rubble only penetrated the upper two inches, giving way to brown, silty clay loam with sandy horizontal striations, possibly representing remnants of mortar that had been placed in the bottom of the original builder's trench. In places this deposit graded into loose matrix that appeared to be bioturbation resulting from either rodent or root activity, possibly encouraged by the old rotting wood of the original timber post.

Pier 1 experienced at least two and possibly three or more repair episodes. The underlying brick fragments were remnants of an original brick footing, which was partially removed and disturbed when the utility pole was installed 
after 1961. The bricks were either pulverized by the weight of the structure and/or damaged at the time of the pier's replacement. Although the evidence was removed, it seems likely that the original footing was a multicourse brick pad.

Artifacts collected from the Pier 1 builder's trench at 11-17 inches below the surface include one clear bottle glass fragment, one undecorated whiteware sherd, and $20.5 \mathrm{~g}$ of bulk nails. These artifacts are not temporally diagnostic and do not aid in dating the original construction of Pier 1.

\section{PIER 2, SOUTHEAST CORNER}

Pier 2 was located at the southeast corner of the original house and the timber post was visible, albeit not upright, on the ground sur- face. The profile was first exposed in Phase I in Unit D7 (see Figure 6.1). The north wall of Unit D7 exposed the south edge of Pier 2 in profile (Figure 6.6). This revealed that the original pier consisted of a 19.5-inch-diameter wood timber on top of a $2 \mathrm{x} 2 \mathrm{-ft}$ square pad composed of three courses of handmade bricks. Many of the bricks were fractured by compression from the weight of the house, resulting in a spreading effect on the brick pad. A vertical iron rod on the south side of the pier was an abandoned lightning rod ground stake. No original construction trench was visible in the north profile or in the bottom of the unit, although the rotted wood and dark sediment below the oak timber remnant clearly defined the postmold and posthole.

The original Pier 2 was no longer functional when it was first investigated, and the Phase I

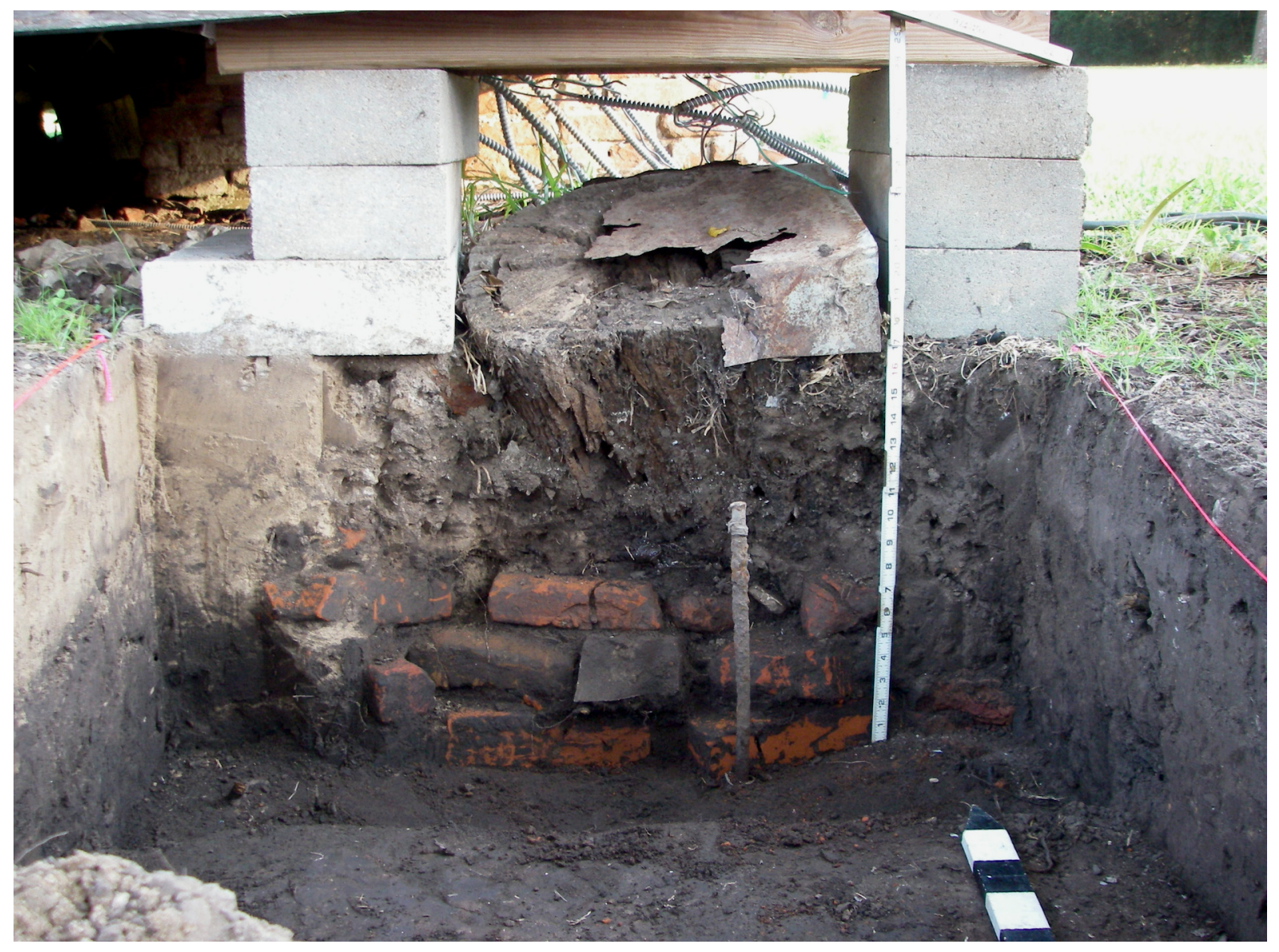

Figure 6.6. Pier 2 profile along its southern edge as exposed in Unit D7. View is to the north showing the original brick pad and rotting oak pier post, with concrete blocks added on either side. The vertical metal object is a lightning rod ground stake. The north arrow is marked in 5-cm increments. 
profile illustrates the problems that were encountered with the rotting timber. The large timber had decayed below ground, leaving only a slightly darker soil stain, and the remaining portion had sunk or been pushed deeply into the ground. The remaining intact portion of timber was angled downward to the south and was in poor condition. It had fractured in a radiating pattern from its center, leaving numerous large wedge-shaped chunks. To support the southeast corner of the house, three stacked concrete blocks flanked each side of the old pier, and a wooden board had been placed on top of the blocks. The concrete blocks and board represent a modern repair episode and may have been installed when the 1961 concrete porch was demolished. But the gap between the original pier post and the house frame suggests that other objects (e.g., wood or concrete blocks) must have been added at various times as the original post decayed and sank into the ground.

The stability of the southeast corner pier had been a concern for the TPWD and the Texas Historical Commission (THC) (Bryan McAuley, personal communication 2010). When the 1961 concrete porch was added, the builders dug an east-west trench and laid down a 1-ft-thick layer of sand as a base for the concrete. Since then, rainwater had drained off the house, percolated easily through the sand layer, and flowed underneath the house. The west and south sides of the pier became unstable on the south side close to the porch, where the original sediments were replaced by sand (note the light-colored sand underneath the concrete blocks on the left in Figure 6.6). The wooden timber decayed faster on the western and southern edges, where the sediments were saturated more frequently. Unit D7 was backfilled soon after its excavation due to concerns for the stability of the structure.

During the Phase II investigations, a block was excavated around the feature, exposing the entire pier. Three additional vertical metal stakes were exposed, and clamps at the top indicated that they were ground stakes for lightning rods. The brick pad was then excavated, one brick layer at a time, and the construction details of this intact original pier pad were documented with photographs and maps. A sample of the original wooden pier was collected and identified as live oak (see Appendix B).

The upper sediments around the feature were obviously disturbed and were not screened.
As the excavation proceeded, the fill from the middle and lower parts of the feature was screened. No definite indication of the original builder's trench was found, and most of the artifacts recovered from the feature (whiteware sherds, window glass fragments, bottle glass fragments, a cartridge case, four wire nails, two square nails, a bone fragment, and an unidentifiable iron object) are from unknown and probably disturbed contexts. When the brick layers were taken apart and documented, however, an interesting find was made between the second and third (bottom) courses of bricks in the pier footing. An 1853 gold coin was recovered from on top of the third course of bricks, sealed in a context that clearly indicates it was placed there at the time the pier pad was constructed (Figures 6.7 and 6.8).

The face of the 1853 U.S. one-dollar coin has an image of Lady Liberty surrounded by a ring of 13 stars. On the back is printed " $1 /$ DOLLAR / 1853" encircled by a wreath and "UNITED STATES OF AMERICA" printed in an arch around the top. This Liberty Head coin is $1.00 \mathrm{~mm}$ thick and $13.13 \mathrm{~mm}$ (1/2 inch) in diameter. The coin is slightly worn and has fine scratches on its faces but would probably be considered in "fine" condition in collector's terms. It was probably in circulation for only a short time, and the scratches could have resulted from the coin being sandwiched between the bricks while the house settled and shifted over many years rather than from circulation.

The coin lacks a mint mark, indicating that it was minted in Philadelphia. After 1854 the size of these coins was increased and the front design was changed to an Indian Head. Over 4 million of the 1853 coins were minted. The coin weighs 25.8 grains, and the percentage of gold or "fineness" is .900 , or 90 percent gold with 10 percent alloy (Yeoman 1961:138, 231, 244).

The context in which this coin was found indicates that it was placed on top of the bottom layer of bricks in the pier footing before the next layer of bricks was laid down. This pier was in a prominent location in the house - the front right corner when facing the house. It is likely that this object was placed as a date coin in a ritual or ceremonial context by the owner or builder when the house construction began. This coin probably dates the beginning of the house construction to 1853 (see Chapter 9). 


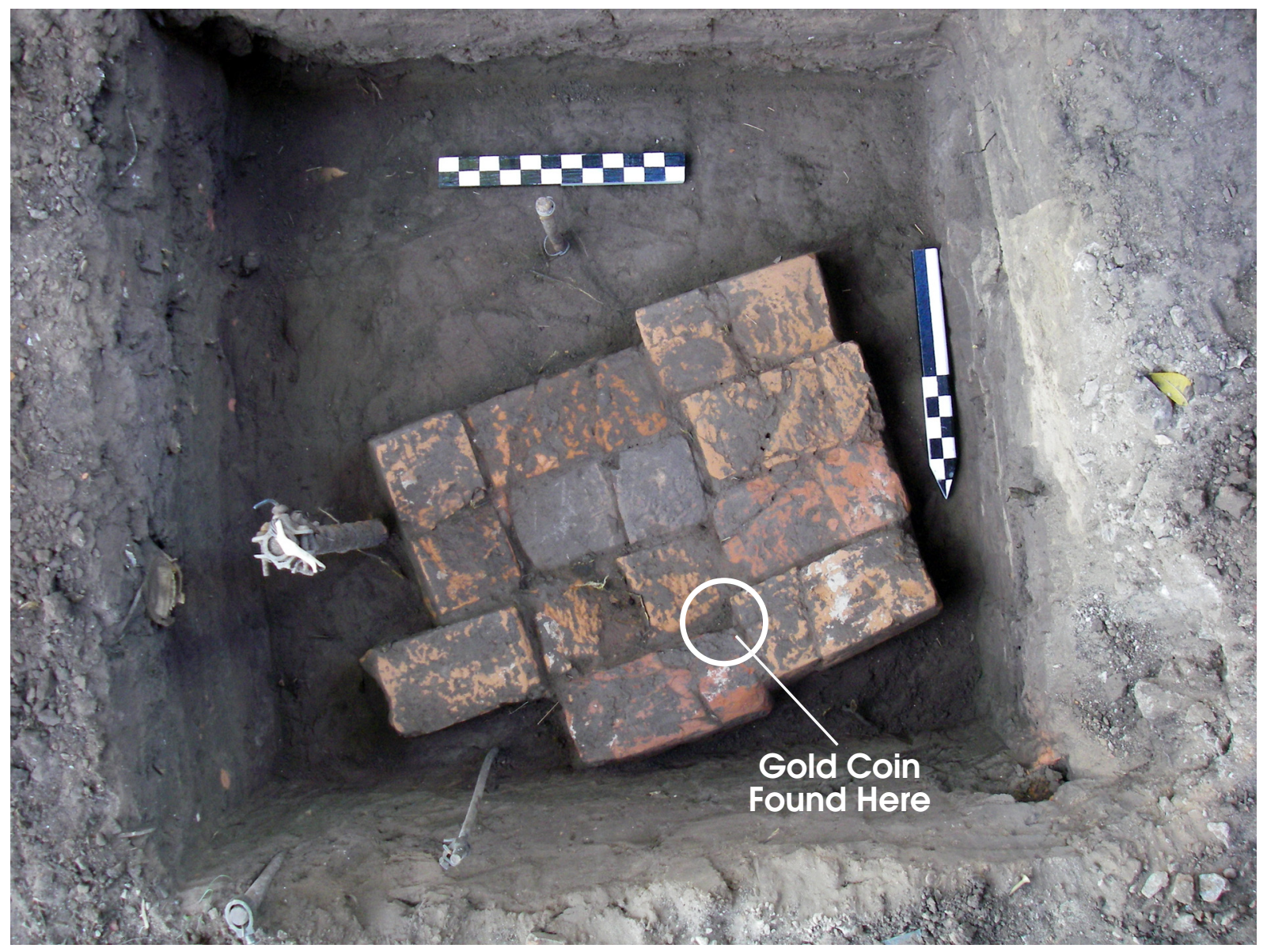

Figure 6.7. Overhead view of the bottom layer of bricks in the Pier 2 foundation pad. The circle shows the location where the 1853 gold dollar coin was found. View is to the south, and the north arrow and scale are each $1 \mathrm{ft}$ long.

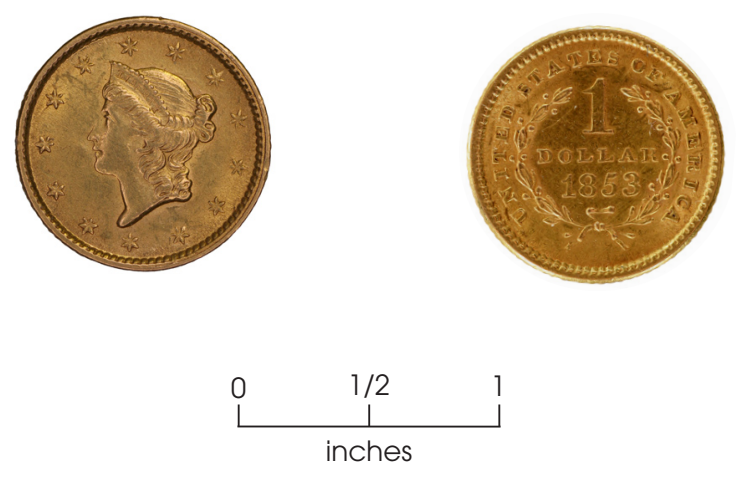

Figure 6.8. The 1853 U.S. one-dollar gold coin, front and back sides, found in the Pier 2 brick pad.

\section{PIER 4, NORTHEAST CORNER}

The pier at the northeast corner of the original house was designated as Pier 4 (later as A1 by Phoenix 1), and its profile was first exposed in Unit E3 during Phase I. This pier had a double set of milled posts, each 10 inches in diameter and set vertically in the ground. The posts were numbered $4 \mathrm{~A}$ and $4 \mathrm{~B}$, and it was obvious that these were replacement posts added in the twentieth century.

The Phase I work involved excavation of the north side of the feature to expose a profile of the northern side of the northernmost of the two posts $(4 \mathrm{~A})$. This revealed that the post was more than $3 \mathrm{ft}$ long and extended 18 inches above ground, with its bottom being about 18 inches below ground. This replacement post went 
through a layer of dense brick rubble, and it was apparent that this was the original brick pier pad that had been crushed in place. It appears that the pier pad was already crushed when the original post (presumably an oak timber section) was removed and replaced with the milled pole. This milled utility pole also extended 5 inches below the brick cluster, indicating that some of the bricks were removed when this pole was set into the ground.

The northeast corner pier was exposed again during Phase II work. The excavations began with a partial profile, exposing the east half of the feature and revealing that the second milled post was virtually identical in size and configuration to the first. Both went relatively deep and through a portion of the brick rubble layer. The two posts were removed, exposing the brick rubble layer. The feature was cleaned and photographed several times as the excavation proceeded. No evidence of an original builder's trench was observed.

At the bottom of the pier feature, a remnant of the intact brick footing was encountered (Figure 6.9). It had a distinct circular depression in its northeast side, probably where bricks were crushed from the weight of the original timber pier. The bottom layer appeared to be a remnant of the original pier pad. When the feature was completely removed, the bricks and fragments composing the pad weighed $24 \mathrm{lbs}$. It appears that the original brick pad was about 18x24 inches in size.

The crushed nature of the brick layers made it difficult to discern how many brick courses were in the original footing. The bottom course of bricks below the crushed brick rubble was fairly intact, except for its northeast corner, which had been partially crushed as well. The original brick pad appears to have been two courses thick, or possibly three, and it measured about $3 \mathrm{ft}$ northsouth by $2 \mathrm{ft}$ east-west. Artifacts recovered from the Pier 4 excavations include two undecorated whiteware sherds, one embossed whiteware sherd, nine bottle glass fragments, window glass, and many nails. None of these are particularly diagnostic, and their association with the pier is dubious because the pier pad was extensively modified when the pier posts were replaced.

\section{PIER 33/34/35, NORTHWEST CORNER}

The northwest corner of the original house was supported by three contiguous pier posts, each being a utility pole segment 10 1/2 inches in diameter. This triple-pole configuration served as the single pier on the northwest corner of the original house, and it also supported the southwest corner of the west end of the ell addition. The three pier posts were designated as Piers 33 to 35, aligned north to south. Pier 33 sat under the west addition, Pier 34 sat under the juncture between the west addition and the original house, and Pier 35 sat under the original house.

During Phase I, Unit W7 was excavated to expose the west side of the "triplets" (Figure 6.10). Investigations exposed the bases of three adjacent modern repair piers that extended $3 \mathrm{ft}$ above the surface. ${ }^{35}$ The excavation revealed that these pole sections sat on top of a single brick layer that was on top of a 3-ft-deep concentration of handmade brick rubble that may have served as the original pier footing. Most of the unit excavation was terminated at 11 inches below the surface, but a deeper probe was dug to investigate the older pier footing. This smaller excavation reached 34 inches below the surface.

The triplet piers sat on a single-course brick pad that barely extended beyond the edges of the pole bases. This pad was composed of handmade bricks that were neatly aligned north-south (with only the ends of the bricks visible when looking eastward). Though they were handmade, these bricks exhibited very little cracking or fragmentation characteristic of the older pier footings. Because this brick layer was also found at or near surface, it clearly represents a modern repair episode with the pad laid down when the triplet piers were added.

Beneath the brick course was 4-5 inches of dark brown clay loam mixed with small (1- to

\footnotetext{
${ }^{35}$ Piers 33/34/35 are much taller (relative to the ground surface) than all the other piers in the original house. They are on the downslope corner of the house, closest to the slough that runs northeast to southwest just west of the home. Thus the piers at the northwest corner of the home should be the tallest, and this may have been accentuated through time by erosion of soil from the western end of the house.
} 


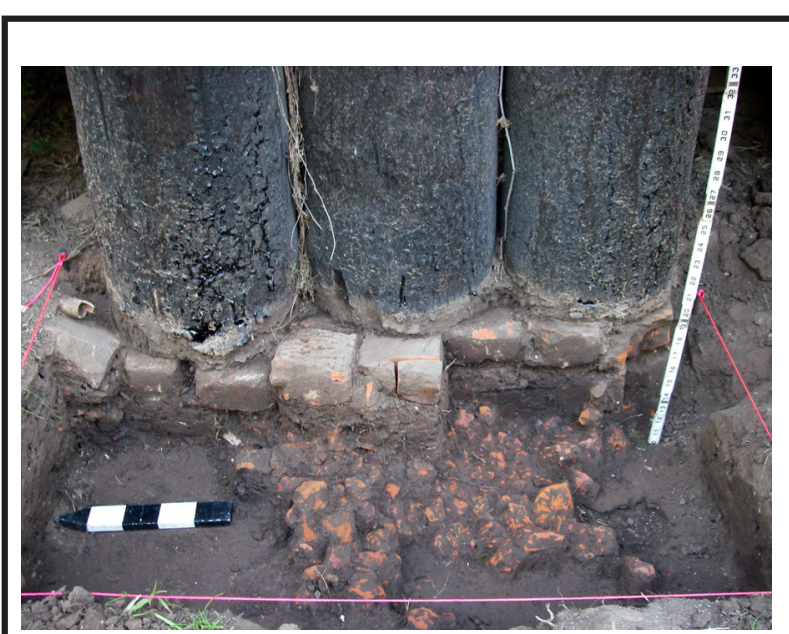

a

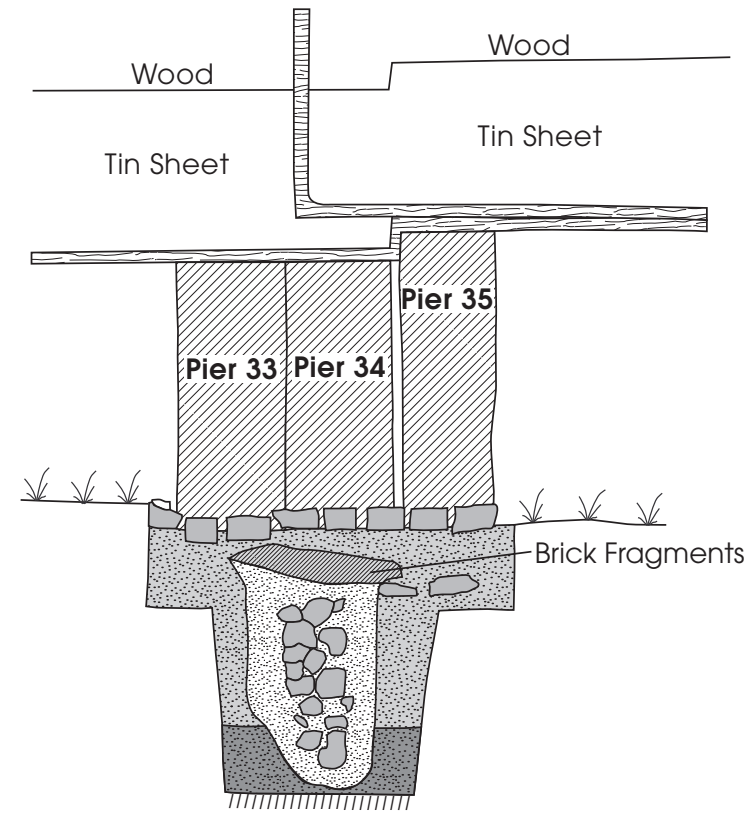

LE E N D

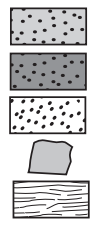

Sandy Loam 10 YR $3 / 3$

Sandy Clay 7.5 YR 4/4

Loamy Clay 10 YR 2/2

Bricks

Wood

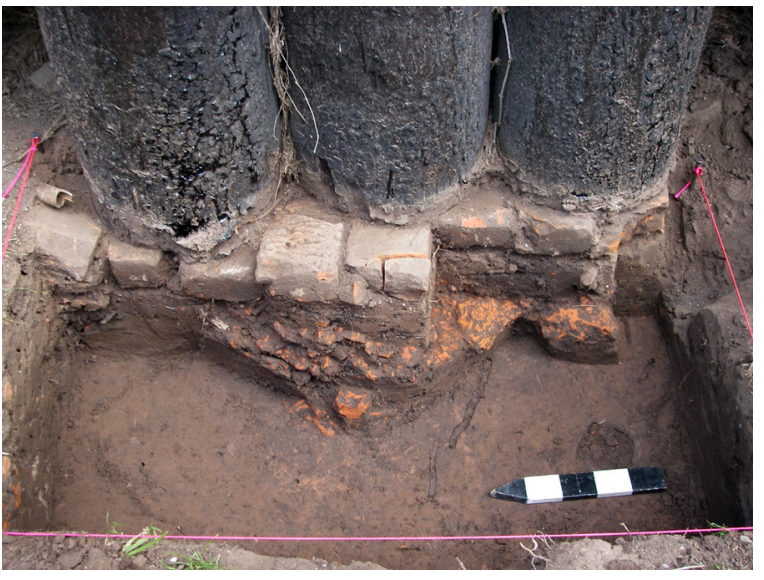

b

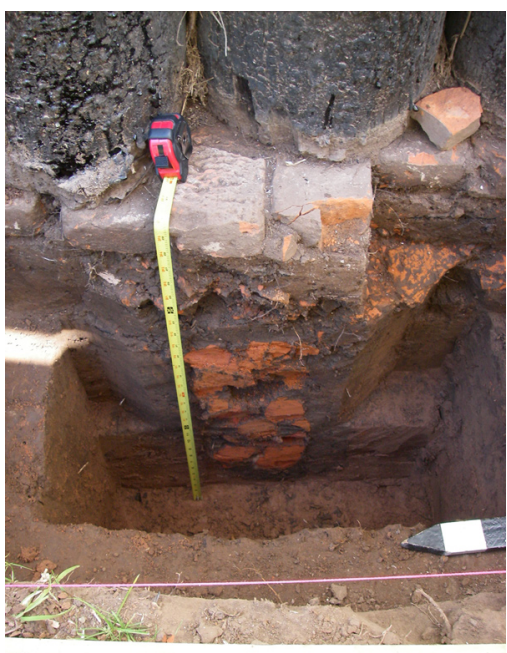

C

Figure 6.9. Photographs and map of the northeast corner Pier 4. Map shows the pier footing. (a) View south of one of the two milled posts extending 18 inches above ground and 18 inches below ground. Vertical scale is one yard. (b) Overhead view of the intact portion of the brick pad. North arrow is $1 \mathrm{ft}$ long. 


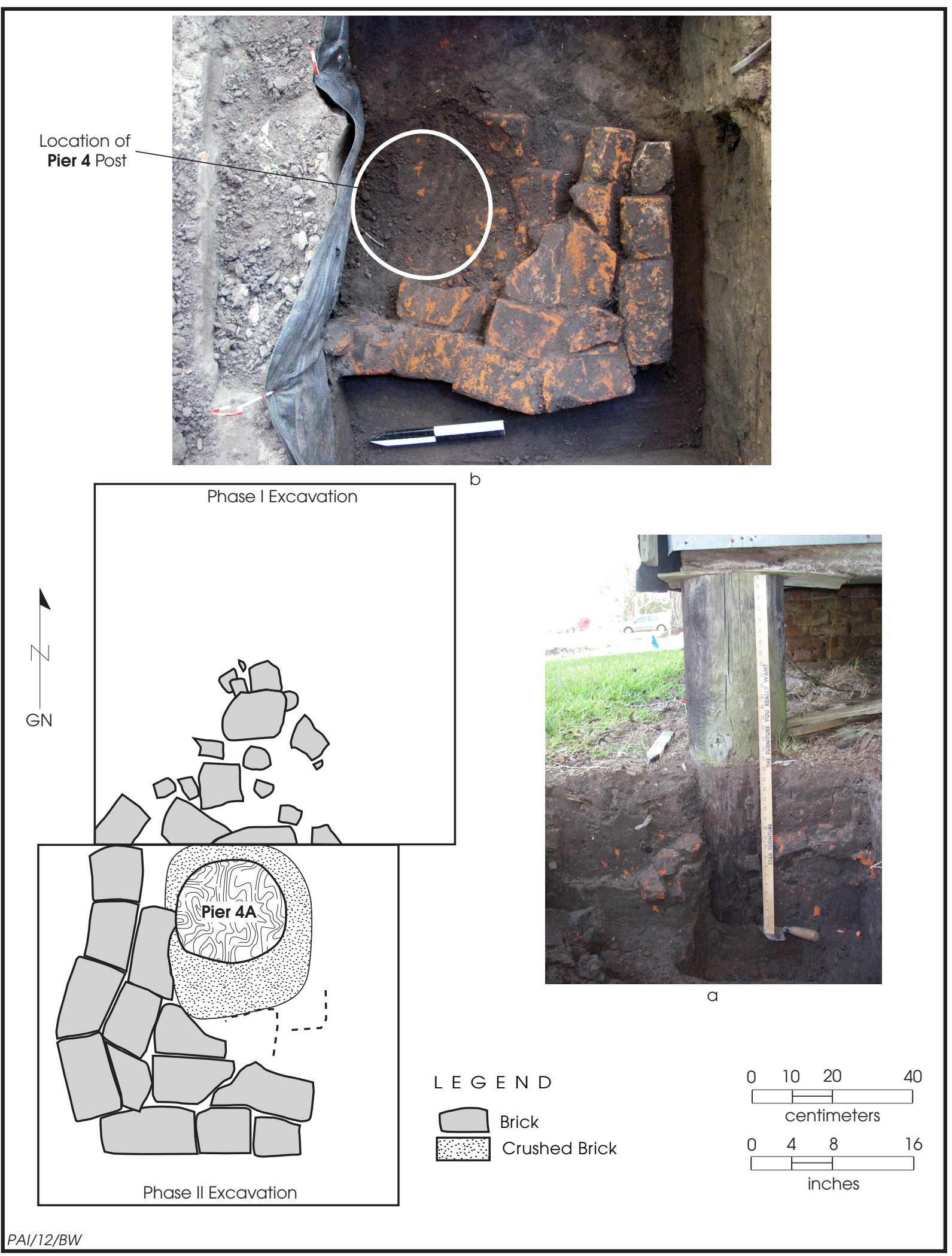

Figure 6.10. Photographs and profile of the "triplet" Pier 33/34/35 at the northwest corner of the antebellum house. All photos are looking east, and the north arrow is $25 \mathrm{~cm}$ long (ca. 10 inches). (a) Photo showing the three piers overlying a layer of modern brick and older brick rubble; (b) photo showing the three piers with most of the brick rubble removed to expose the original builder's trench; (c) photo showing the deep column of brick rubble underneath Piers 33 and 34. 
2 -inch pieces) handmade brick fragments. This rubble zone was primarily under Pier 34 , but it also extended northward underneath Pier 33. Two larger brick fragments found under Pier 35 may represent an intact remnant of the original pier pad. When the brick rubble was removed, a well-defined builder's trench was exposed in the excavation west of the piers (see Figure 6.10b). The stain was first observed at 8 inches below the surface ( 4 inches below the brick pad) and continued to 33 inches below the surface. In profile the stain had straight edges but it tapered slightly toward the bottom. Centered within the pit stain, and directly below Pier 34, was a column of brick fragments that was 7 inches wide (north-south) and consisted of five to six layers of brick fragments (see Figure 6.10c). The brick fragments were somewhat disorganized but formed a fairly tight column. All of the evidence indicated that the brick column surrounded by the discolored sediment (see Figure 6.10 profile) was the brick pad and builder's trench for the original northwest corner pier, but it had been bisected at an odd angle.

Phase II work began with the reexcavation of Unit W7 (which was backfilled at the end of Phase I) and the excavation of a 16-inchwide trench along the south side of Pier 34 (Piers 33 and 35 had already been removed). Pier 34 was removed, and the upper brick pad was cleaned and photographed. The modern footing consisted of eight bricks arranged in two rows of bricks, with all of them aligned east-west. This brick pad was removed, and all sediment below this point was screened. A 2- to 3-inch layer of mottled soil was exposed below the footing. Underlying this zone was a tightly packed, oval-shaped cluster of brick fragments measuring 23 inches east-west by 21 inches north-south. This layer, which was only 3 inches thick, may represent a brick pad or debris layer of intermediate age, certainly earlier than the upper one.

Below this crushed brick pad, a dark brown clay loam was exposed that continued to 7 inches below the surface. At this depth, a 12x15-inch concentration of bricks was observed; its long axis was oriented north-south, and the uppermost bricks were heavily fragmented. The brick concentration is outlined by a well-defined band of an unidentified white powdery substance, with the clear edges of the original construction trench another 2 inches farther out.
The excavation continued, and the dense brick rubble layer (that was observed in the Phase I profile) was found 4 inches below this second brick cluster, at a depth of 20 inches below the surface. At this point, it measured only $5 \times 6$ inches. Additional excavation revealed that this brick rubble layer extended to 27 inches below the surface. The bricks were removed and the matrix was screened, but no artifacts were recovered. A distinct construction trench was observed around this brick column that extended 3 inches to the north and 4-5 inches to the south and east. At the bottom of the brick cluster, the construction trench had narrowed to a 3 -inch square. The brick fragments in this lower concentration were small, ranging from 1 to 4 inches, but they were very tightly packed. After removing all the brick fragments, the construction trench was excavated and its fill was screened, but no artifacts were recovered.

Taking all of the evidence into account, it appears that this pier feature probably experienced at least one major repair episode (perhaps two). Given the location of this pier at the northwest corner of the antebellum house, it is almost certain that it originally had a square brick pad and a cut oak tree post. It appears that the pier post was removed and a hole was dug through the original pier pad, destroying most of it, with the possible exception of a few bricks left in place at 10 to 12 inches below the surface. This hole was then filled with tightly packed brick rubble and a few bricks laid in gross layers, but not in any formal pattern. This brick-filled hole was intended to serve as the new pier pad. It is possible that the upper brick pad at the surface level and the triplet posts represent this same repair episode. This brick pad is constructed of handmade bricks that could have been from the original brick pad. An alternative hypothesis is that the lower brick-filled hole is a foundation of an earlier repair episode, while the upper brick pad and triplet posts represent a much later repair.

Many artifacts were recovered from the pier hole fill below the triplet Pier 33/34/35. Collected materials include undecorated whiteware sherds, porcelain sherds, window glass fragments, bottle glass fragments, square nails, wire nails, unidentifiable nails, a bone fragment, and a 1984 penny. These artifacts are obviously of mixed ages and represent materials introduced into the pier hole during the repair episode(s). 
Unfortunately, it is impossible to date these repair episodes with any confidence.

Investigation of the triplet pier afforded a look into the deeper soils around the Levi Jordan house. The excavations exposed dark brown (10YR 3/3) loamy sand, and the amount of clay increased with depth. At 23 inches below the surface, the soil color became lighter (brown, 7.5 YR 4/4), and the sediment transitioned to a sandy clay. This lighter brown sediment, with a faint red or pink tint, provided a sharp contrast to the darker upper soils. Any intrusive features that went deep enough to encounter this lower zone would be easy to see if they were backfilled with the mottled sediment created by mixing these different soils. However, the majority of the piers and other features that were investigated were not originally dug deep enough to reach this depth, with the only exception being Feature 13 (a possible west porch pier, described below). This evidence helps explain why original builder's trenches were not observed for most of the investigated piers and possible pier features. Most of these intrusive features were simply too shallow to encounter the lighter soil zone. An intrusive pit that was restricted to the upper dark brown loamy sand and backfilled with the same sediment would be essentially invisible.

\section{Original North Wall Piers}

Archeological investigations along the north wall of the original house were conducted only during Phase II, since this wall was inaccessible until the ell addition was removed. Six piers investigated along this north wall are considered to be the original house piers, while seven others (described later) represent piers added with the ell addition. The original Levi Jordan house piers described in this section have, or once had, an oak timber post and a brick footing or pad (Figure 6.11). When PAI began the Phase II work, the Phoenix 1 workers had identified 20 pier posts and had removed six of them (see Figure 6.2). Subsequent archeological investigations revealed that six of the piers are likely to have been original piers associated with the antebellum house: Piers G1, J1, L1, M1, Q1, and S1. All of these piers proved to have brick pier pads or remnants of brick pads (Figure 6.12). Interpretation of piers along the north wall were complicated by a large brick rubble feature (Feature 32 in Chapter 8; see Figure
3.10). This brick rubble contained artifacts and spread beyond the north wall and under the house. It extended around the original piers as well as under repair piers.

\section{PIER G1}

Pier G1 consisted of a large wood timber (presumably oak) and a single-course brick footing (see Figures 6.4 and 6.12a). Phoenix 1 removed the timber prior to PAI investigations, exposing two parallel arcs of decayed wood. Within the decayed wood, pale orange to pink mottled (7.5 YR 4/6) splotches represented scattered fragments of bricks. The circular stain of decayed wood was dark brown (10YR 2/1.5), but it was lightly darker than the surrounding natural clay (dark brown, 10 YR 2/2). A faint and narrow builder's trench extended 3 inches to the east and west sides of the brick base and 1-2 inches on the south side, as evidenced by a slightly lighter sediment with brick-mottling. The loose matrix of rotted wood, sediment, and brick fragments was screened, yielding two clear bottle glass fragments, eight bone fragments, and one gray Prosser button, and $46.5 \mathrm{~g}$ of bulk nails.

The feature was cross-sectioned along an east-west axis, and its southern half was excavated first to expose a portion of the brick footing at 4-5 inches below the ground surface and under the rotted wood stain. The excavation was then expanded to expose the entire pier footing in plan view. The pad measured approximately 30 inches (east-west) by 28 inches (north-south).

As shown in Figure 6.12a, the intact footing was made up of 17 bricks, with two isolated brick fragments on the north side. The southern two rows are fairly tight and well aligned, with the bricks laid header. The northern two rows have bricks laid stretcher. The builder's trench extends a few inches to the north, and two isolated brick fragments were in this area but offset to the brick pad. The builder's trench was homogenous and showed no evidence of disturbance. It is interesting that the pier footing is not a neat rectangular pad. The offset brick rows suggest that the footing pad might have been originally constructed with only the two southern rows of bricks (perhaps 10 of the 12 bricks), and that the other bricks $(\mathrm{n}=7)$ may have been added to the footing or moved laterally 


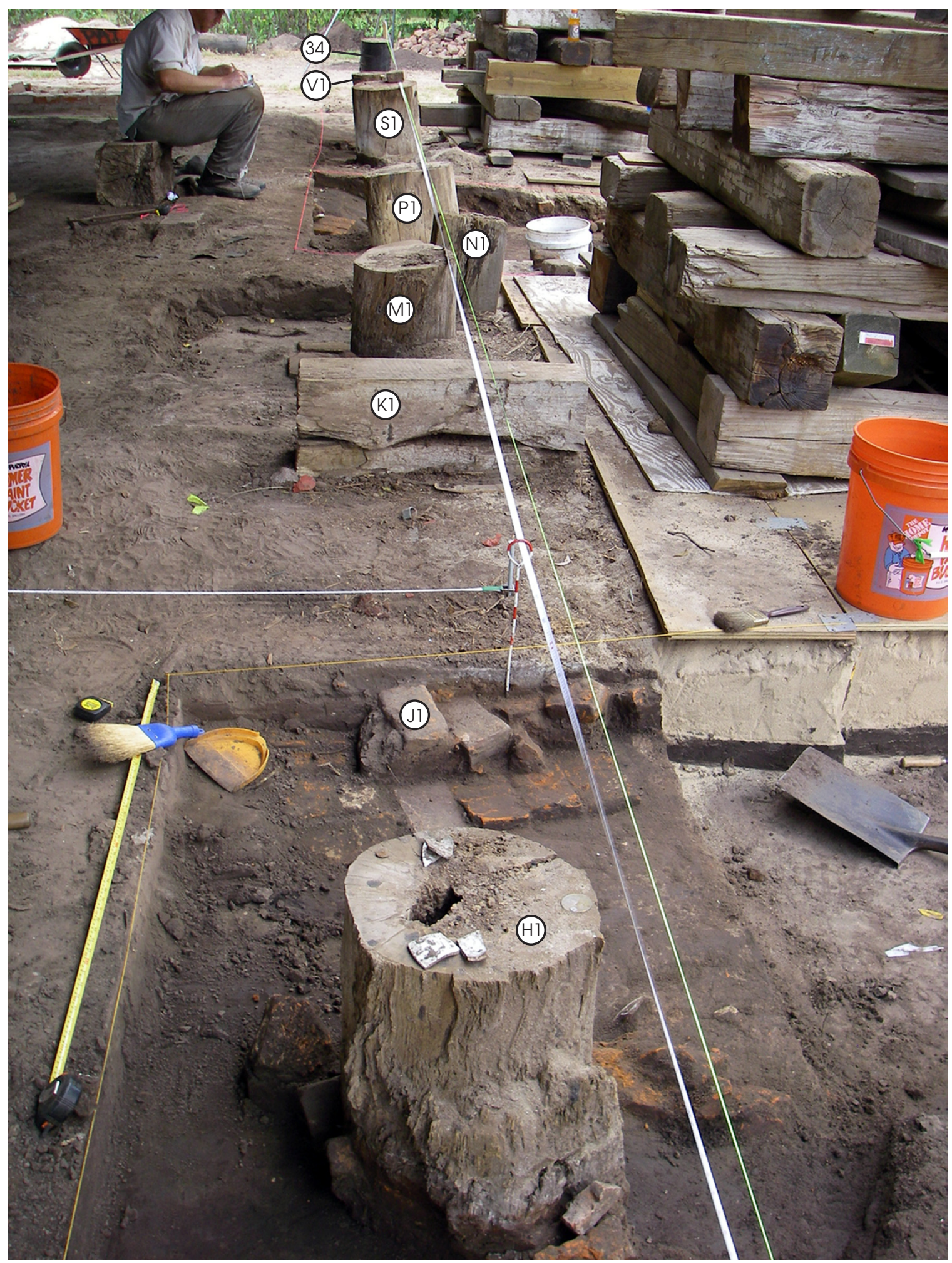

Figure 6.11. View west of the line of piers under the north wall of the original plantation house. The cribbing structures supporting the raised house are on the right. The tape and string line run down the wall line at the level of the pier tops. 


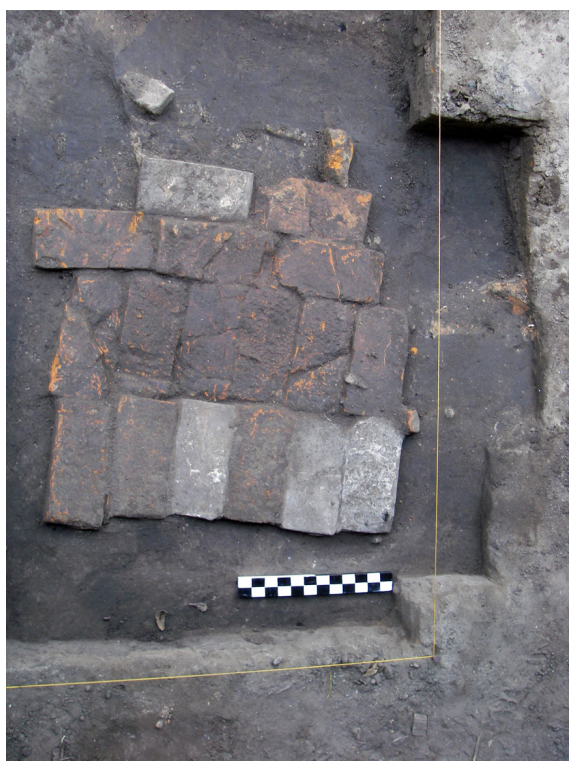

a

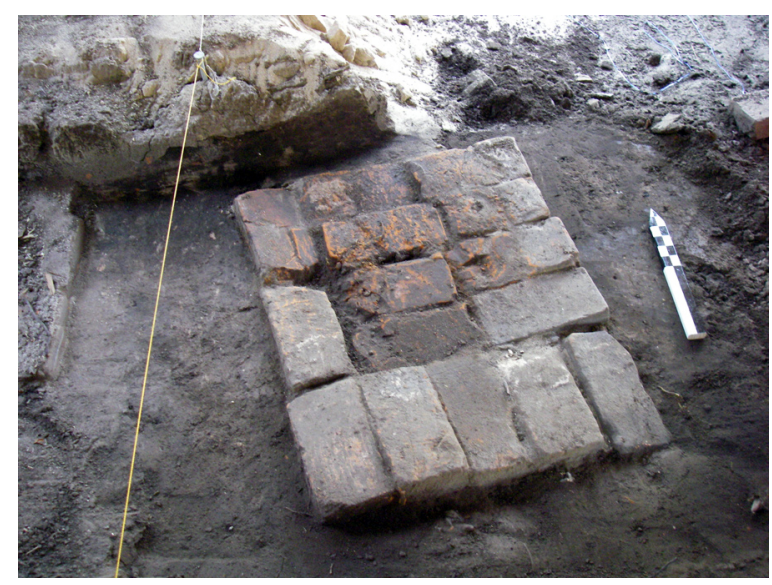

b

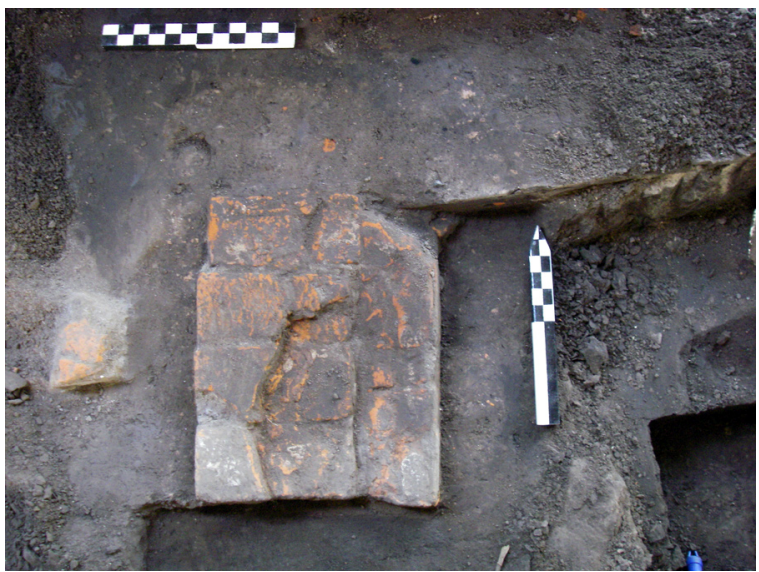

C

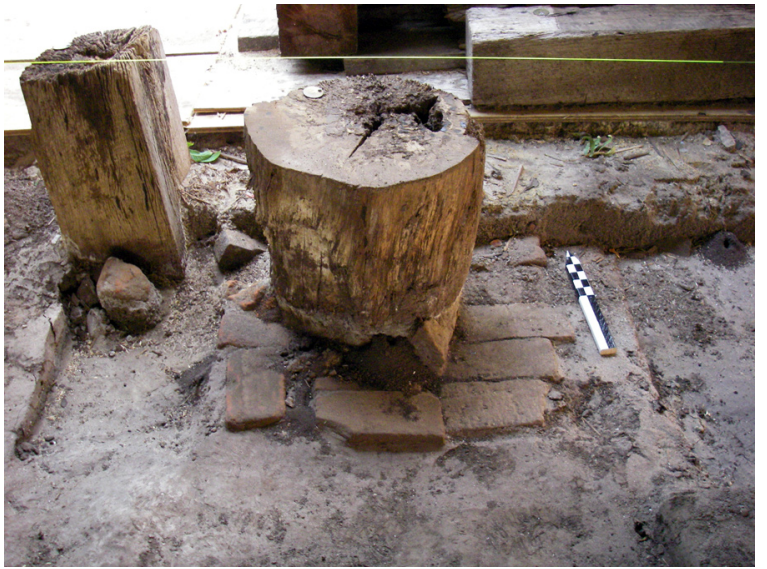

d

Figure 6.12. Views of the bottom-course brick pads that served as footings for original piers along the north wall of the antebellum house. The north arrows and scales are $1 \mathrm{ft}$ long. (a) View north of the Pier G1 footing; (b) view north of the Pier J1 footing; (c) view north of the Pier L1 footing (note that some bricks may have been removed; (d) view north of the M1 pier showing the oak timber post in situ on the brick footing (the later square block Pier N1 is to the left).

after the wooden timber was set in place and its size was determined.

Artifacts collected from the Pier G1 excavation include one undecorated whiteware sherd, $22.2 \mathrm{~g}$ of window glass, nine bottle glass frag- ments, a decorated rectangular shell button, one wire nail, one square nail, $387.8 \mathrm{~g}$ of bulk nails, 20 bone fragments, and two pieces of coal. These artifacts are not particularly diagnostic and do not provide evidence of the pier's age. 


\section{PIER J1}

The timber portion of Pier J1 was removed by Phoenix 1 prior to PAI's work, leaving little indication of its location (see Figure 6.2). However, a brick footing exposed during excavation of the northeast block could be linked to this pier location. The surface of the brick pad was found 6-7 inches below the ground surface. It was a single course footing composed of 15 bricks, and it measured 26 inches north-south by 23 inches east-west (see Figure 6.12b). Three complete bricks and several fragments on top of the pad on the northwest side may have served to level the timber, or possibly were added later as wedges to stabilize a rotting timber.

The builder's trench for Pier J1 was apparently very narrow and was only noted on the east side of the footing, where it was only 2 inches wide. A disturbance noted on the west side may have obscured the builder's trench. Matrix from the builder's trench and around the brick footing was screened, but no artifacts were recovered.

After the brick footing was removed, an oval stain was exposed directly beneath and centered under the pad. It was a patch of silty sand that was slightly lighter in color than the surrounding sediment, and it had pale brown laminated layers throughout. It measured 15 inches northsouth by 10 inches east-west and was only 1 inch deep. The matrix within the stain was looser in texture and was mottled with charcoal flecks and pale brown flecks. The excavation was terminated at the bottom of the stain, 10 inches below the surface. One undecorated whiteware sherd was recovered from the oval stain.

The laminated layers in the oval stain suggest that it was a water-laid deposit in a small depression or hole. This sediment and the single ceramic sherd could have been deposited sometime before the pier was put in, but it is more likely that they were deposited during pier construction. It is possible that there was a small void under the brick pad when it was laid, and that it got filled in naturally, during a lull in the construction process or when the builders added water into the pier hole to pack down the sediments in the builder's trench.

\section{PIER L1}

The post for Pier L1 was removed by Phoenix 1 prior to the Phase II investigations (see
Figure 6.2). The pier footing was first exposed during shovel skimming and hand trenching of deposits under the north beam of the plantation house. The excavation revealed a brick footing composed of six bricks and measuring 17 inches north-south by 14 inches east-west (see Figure 6.12c). The footing was only one course thick, and several of the bricks had been fractured in place. The bricks were arranged in a neat rectangle, with four laid header and two bricks laid stretcher. A fairly large builder's trench was observed around the brick footing. It extended ca. 7 inches to the north, 4 inches to the east, 3 inches to the west, and 1.5 inches to the south. No artifacts were recovered from the matrix below the brick footing or from the builder's trench fill.

Pier L1 is somewhat odd in that its pier pad was so small relative to the large builder's trench. It is quite possible that the original pier post and a portion of the original brick pad were removed in a repair episode. Alternatively, this pier footing may have been smaller because it supported a smaller secondary pier. Pier L1 is located very close to Pier M1, which is also an old pier with a brick footing. Both of these piers are centered in the middle of the north wall of the antebellum house, under the location of the doorway. It is possible that Pier L1 was added to provide some extra floor support at the north door.

\section{PIER M1}

Pier M1 was one of the few original antebellum house piers that had its original timber pier still in place when the Phase II investigations began (see Figure 6.12d). The timber was identified as live oak (see Appendix B). The log section was slightly ovate and measured $15 \times 17$ inches, and its top was 14 inches above the brick footing.

Loose matrix at the base of the timber was carefully excavated, and modern artifacts were found to be coming from a rodent burrow. Observed artifacts (not collected) included plastic toys, plastic wrappers, and modern roofing nails. The deposit below the timber was bisected along its east-west axis, and the south half was removed. A builder's trench was first observed 5 to 8 inches below the ground surface, and its fill was composed of lighter soil (5YR 4/3) with pale brown silty mottles and brick flecks. 
Once the timber was removed, excavation revealed that Pier M1 had a brick footing consisting of two courses of brick. The upper course measured 21 inches north-south by 27 inches east-west, and the lower course measured 25 inches north-south by 23 inches east-west. The east side of the upper course was composed of two rows of five bricks aligned north-south, while the westernmost row was composed of two complete bricks running north-south and one smaller fragment running east-west. The lower course of bricks consisted of five rows of bricks laid stretcher (east-west), with each row composed of two full bricks and a half brick that alternated between the central position and the southernmost position in each row. The westernmost row was laid similarly but composed of only two complete bricks. The upper course extended slightly beyond the lower brick to the east and west, while the lower course was wider than the upper course from north to south.

A narrow (ca. 1-inch wide) builder's trench was observed as a band of lighter-colored and mottled sediment around the west, east, and south sides of the footing. The fill from this trench and the matrix from between the two courses of footing bricks was screened, but no artifacts were recovered.

Bricks in the lower course had remnants of mortar on their bases, and two bricks had a small amount of mortar between them. This appeared to be loose mortar that fell into the pit rather than mortar intentionally applied to the bricks in the pier footing. After this discovery, the bricks from the upper course were reexamined, but no trace of mortar was found on them. It is likely that when the original house piers were being excavated, the chimneys were also under construction, and mortar would have been mixed somewhere near the house. Consequently, the presence of some mortar pieces in some of the original pier holes is not unexpected.

The typical dark brown homogenous clay was exposed below the bricks, with the exception of an oval stain below the northwest corner of the brick pad. The excavation revealed this to be a 2-inch-deep oval basin, measuring ca. $5 \times 6$ inches, with a ca. 3 -inch offshoot to the northwest. Screened matrix from the basin deposit revealed many brick fragments, one piece of window glass, and an unidentifiable nail. It is likely that this deposit resulted from digging the original pier hole too deep and having to add fill (with cultural materials) to the bottom to level it before the brick footing was constructed.

\section{PIER Q1}

Pier Q1 originally consisted of a timber post on top of a brick footing, but this timber apparently fell or was moved off the footing long ago. It was laying next to the brick footing for some time. When Phoenix 1 removed the timber, it left a 16-inch-diameter depression that was not directly above the small brick pad that was found in place (Figure 6.13a). Rather, this depression was offset to the north and was no longer in line with the north wall of the original house. It is not certain why the large timber was moved, but it might have served as a support for the south wall or floor beams of the twentieth-century ell. In any case, the timber had been set upright into the silty clay without any footing, but this new location was immediately north of its original brick footing.

The pier pad associated with Q1 was partially exposed during the excavation of the northwest block. Unfortunately, a large brick rubble layer (see Feature 32 in Chapter 8) surrounded Pier Q1, including its original footing and the relocated post. Because of the brick rubble, the ground surface in the vicinity of this pier was higher and sloped off to the north, and a large area of extensive rodent activity was observed just south of the pier pad. All of these factors complicated the excavation and interpretation of Pier Q1, and it appears that most of the original builder's trench for this pier was disturbed, with only a sliver near the southeast corner and along the west edge intact.

The excavations ultimately revealed that only a portion of the Pier Q1 footing remained intact; it consisted of one course of six bricks at 3 to 9 inches below the surface (see Figure 6.13a). The pad measured 14 inches (northsouth) by 18 inches (east-west). One row was four bricks laid header (with the bricks running north-south), and the next row to the south was two bricks laid stretcher. This configuration does not represent the original footing in its entirety, and it is likely that the original pad extended to the north but was disturbed when the timber was moved.

Artifacts recovered from the sediments around the Pier Q1 footing consist of two undecorated and one embossed whiteware sherds, 


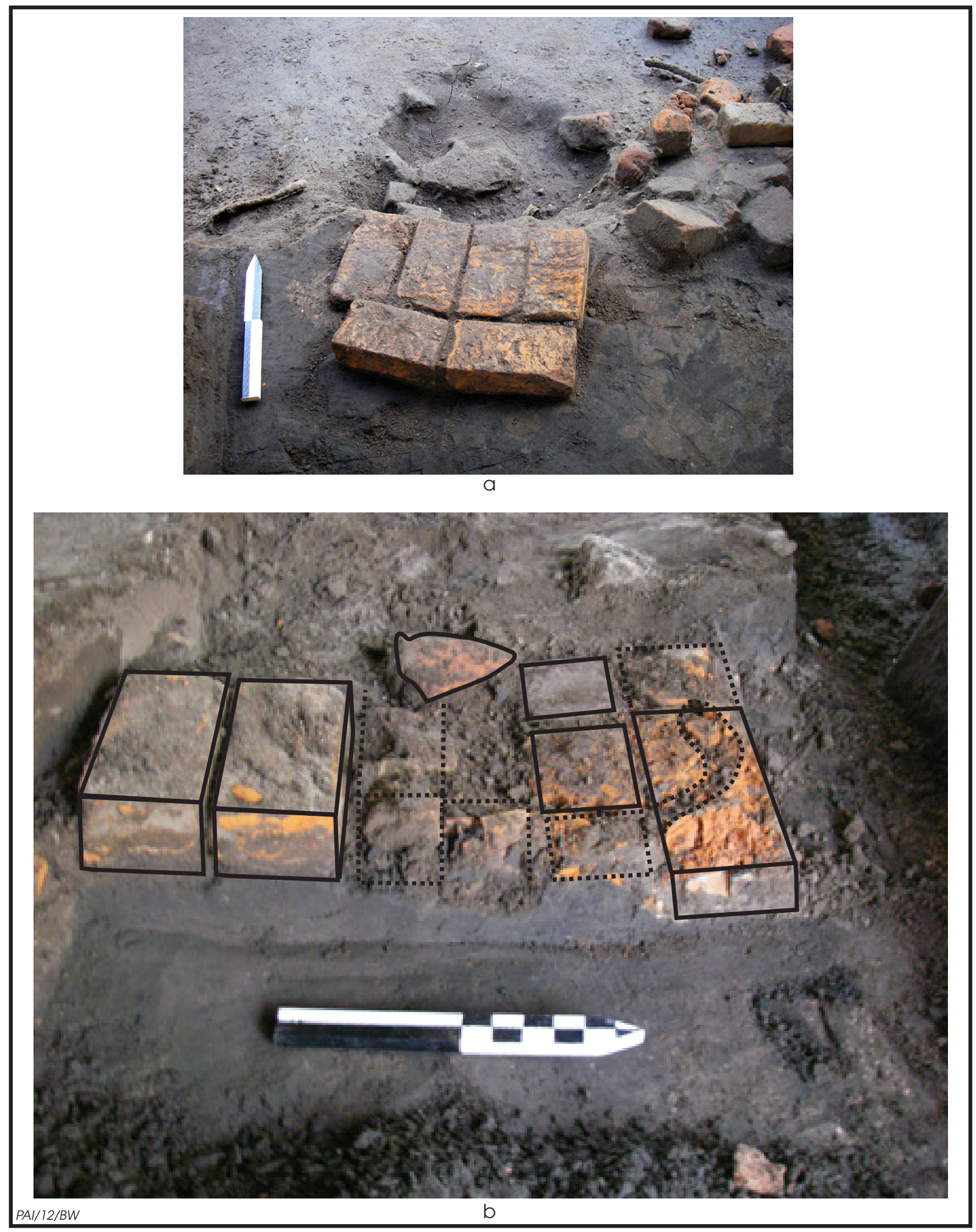

Figure 6.13. Photographs of footings for Piers Q1 and S1. The north arrows are $1 \mathrm{ft}$ long. (a) Looking north at the intact remnant of the Pier Q1 footing. Note the disturbed area with scattered bricks and the depression on the north side of the pad. (b) Looking west at the in situ portion of the Pier S1 footing. Note that only two bricks are complete; the others are partial bricks or crushed in place. Dashed lines indicate crushed brick while solid lines denote the intact bricks or brick sections. 
a thin glass fragment from a container or lamp chimney, and one piece of metal. But these artifacts may well be associated with the brick rubble feature (see Feature 32 in Chapter 8). The brick footing was removed, and no additional evidence of a builder's trench was observed. The sediment beneath the brick pad was intact homogenous dark brown clay, and no artifacts were found in the sediments immediately below the pad.

\section{PIER S1}

Pier S1 represents one of the few complete original piers under the north wall of the antebellum house. Its timber and footing were both intact when the Phase II investigations began. The Pier S1 post was a log section identified as live oak (see Appendix B). It measured 16 inches (north-south) by 14 inches (east-west) and was 20 inches tall above the brick footing.

Excavation revealed an intact remnant of the Pier S1 brick footing centered under the post. The footing was in poor shape, and some of the bricks had been crushed in place by the weight of the house (Figure 6.13b and see Figure 6.11). Unfortunately, the brick rubble layer (see Feature 32 in Chapter 8) abutted the timber on the north side, and during the excavation it was difficult to distinguish scattered brick rubble from the crushed in situ bricks on this side of the footing. The footing remnant consisted of one row of bricks laid header (bricks oriented east-west), but only the southern two bricks are complete. This brick row was along the south edge of the pier post, and all the bricks to the north were crushed into small fragments so that the original brick locations and orientations could not be determined.

When the in situ remnant pier footing was removed, it was clear that this had been a singlecourse brick pad, but the excavation did expose a single intact brick under the crushed rubble of the north side of the footing. This brick seems to have been placed there to fill a void in the bottom of the original builder's trench when it was leveled and the footing was constructed. Very few artifacts were recovered from Pier S1 sediments, but $22.5 \mathrm{~g}$ of bulk nails and one bone were recovered from within and under the remnant brick pad.

\section{Original South Wall Piers}

Three original foundation piers were excavated along the south wall of the house:
Piers 3, 38, and Feature 29. Piers 3 and 38 were evident under the south wall of the house before the Phase I work started, but Feature 29 was completely covered by the 1961 concrete foundation beam (see Figure 6.1). It was not discovered until this concrete beam was removed during Phase II. All three of these piers are considered to be associated with the original construction of the antebellum house.

\section{PIER 3}

Pier 3 was located $13-15 \mathrm{ft}$ west of the southeast corner of the house and was first exposed during Phase I in Unit D8. Like Pier 2 at the southeast house corner, the upper portion of the pier post was visible from the ground surface at that time. It was a 20 -inch wooden timber (presumed to be oak), but it was in bad shape and no longer functioned as a support. The timber was angled to the north, and it was probably pushed down and tilted by the weight of the house as the wood deteriorated.

The Phase I excavation exposed a profile on the south side of Pier 3, revealing that the large timber had decayed completely below ground (Figure 6.14). Eight inches of the southern portion of the rotten wood and sediment were removed to obtain a good profile view. The profile showed that there were patches of imported sand, laid down as the base for the 1961 concrete porch that was removed in 2002 . The profile also showed a large pocket of darker sediment, about 20 inches wide with straight vertical edges. This deposit clearly represented where the wooden post had rotted in place, and it revealed that the post sat on top of a single-course brick footing. The footing bricks form a basin shape due to the weight of the house on the pier. No evidence of a builder's trench was observed. The brick pier footing was left in place, and the feature was backfilled at the end of Phase I work.

The Phase II investigations began with a hand-dug trench running east-west under the south wall to relocate piers. This trench further defined the upper portion of Pier 3 , and the northern part of Unit D8 was reexcavated to expose the southern part of the pier (see Figure 3.4). The excavation was expanded and the wooden post was removed, which exposed a single-course brick footing at 12-16 inches below the surface (Figure 6.15). The brick footing was approximately 30 inches wide north-south 


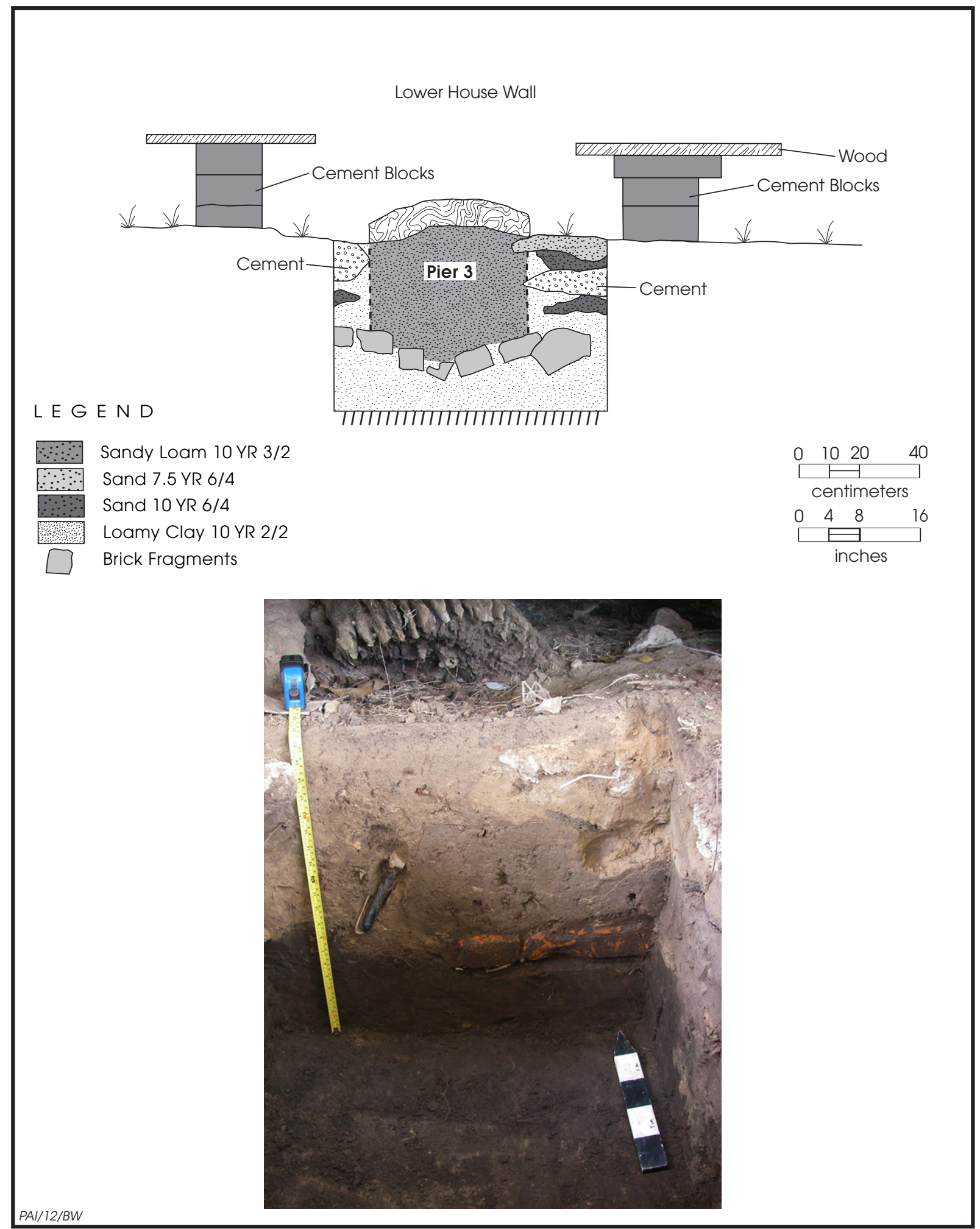

Figure 6.14. Photograph and profile of Pier 3 from the Phase I investigation. The photo is looking north at the southern edge profile. The rotted wood of the pier post is at top. The north arrow is $25 \mathrm{~cm}$ long (ca. 10 inches). 


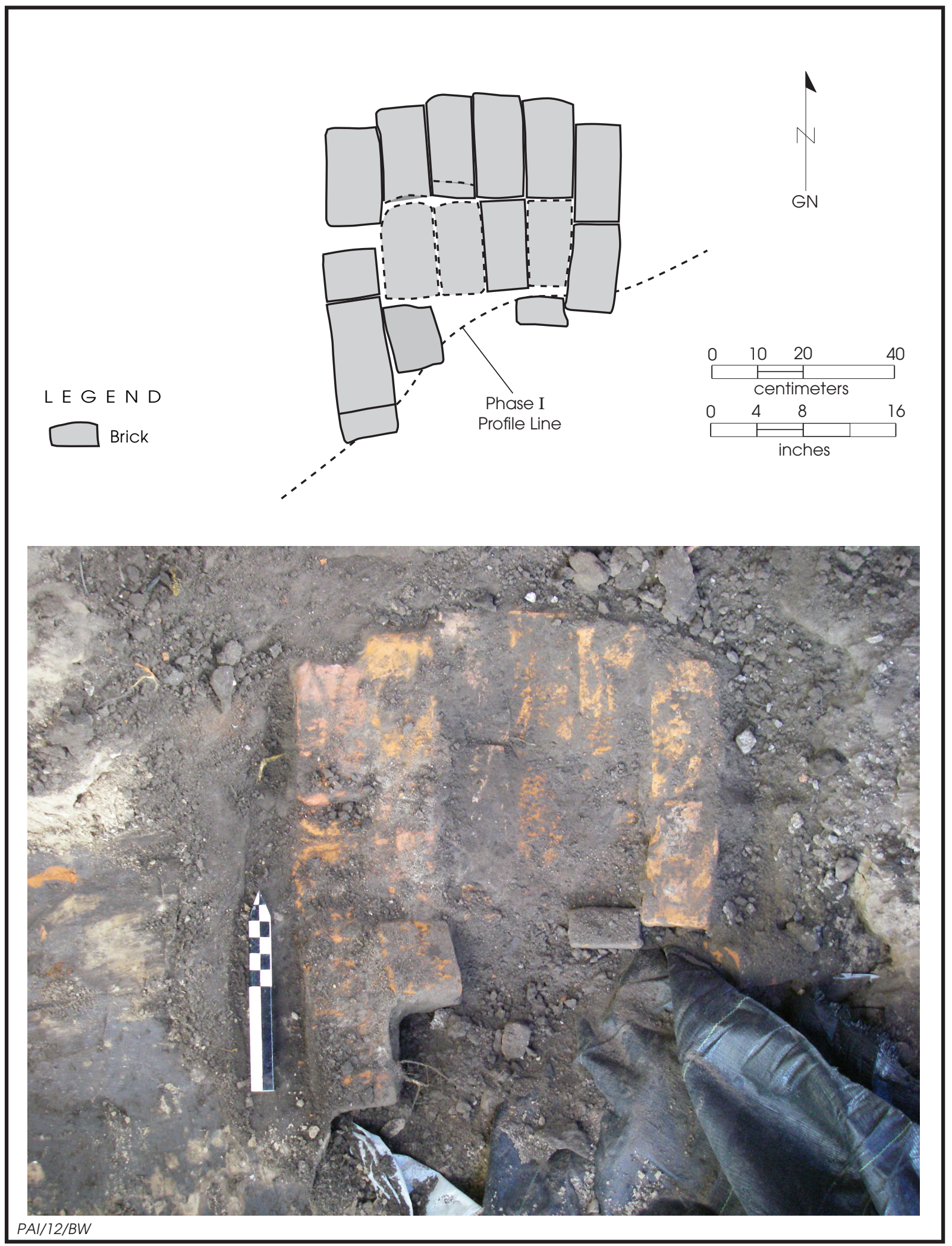

Figure 6.15. Plan map and photograph of the Pier 3 footing at 12 to 16 inches below the surface. View is to the north. Note that some bricks on the south edge may have been removed in the Phase I profile excavation. The north arrow is $1 \mathrm{ft}$ long. 
by 25 inches wide east-west. It consisted of 16 bricks or half-brick fragments, with two rows of six bricks laid stretcher (long axes oriented north-south), and the other bricks and halfbricks along the south edge. The brick pad formed a concave basin, due to the weight of the house, which pushed the center of the pad down several inches. No construction trench was visible around the footing.

Artifacts collected from Pier 3 area include one square nail, one unidentifiable nail, four iron conglomerates, $100.3 \mathrm{~g}$ of bulk metal, in addition to many modern materials such as asphalt roofing shingle fragments and modern drinking glass fragments. These items are further proof of the heavy disturbance caused by the 1961 front porch construction.

\section{PIER 38}

Pier 38, located ca. $6.5 \mathrm{ft}$ west of the southeast corner of the house, was first exposed in Unit D12 during Phase I. At that time, the upper portion of the pier post was visible at the surface and consisted of a 17.5-inch-diameter timber (presumed to be oak) located ca. 18 inches north of the south wall of the house. The pier post was partially embedded in the ground and appeared to have been pushed or moved during previous repairs. It was no longer functional as a foundation support; rather, stacks of cement blocks on either side served as the piers.

The pier was bisected along its east-west axis, slightly south of its center, to expose an east-west profile from surface to $21 \mathrm{~cm}$ below ground (Figure 6.16). The excavation revealed an upper layer of artificial sand that had been laid down as the base for the 1961 concrete porch. This sandy zone was discarded without screening. The sandy fill was as much as 16 inches deep in the west half of the profile. Also found was a large area of darker sediment that clearly represented the pier post wood that had deteriorated in situ. Under this darker sediment were three bricks from 13 to 16 inches below the surface. These represented a single-course brick footing on which the pier post sat. The profile excavation was terminated about 5 inches below the bottom of the brick footing.

No construction trench was visible in the Phase I profile. The presence of the thick artificial sand deposit indicates that much of the upper part of Pier 38 was probably obliterated during the 1961 porch construction. A chunk of concrete, a tool handle (heavily corroded but possibly from a pair of pruning shears), and a glass jar observed (not collected) during the excavation of Pier 38 reveal the extent of the disturbance to the south half of this feature.

The Phase II investigations concentrated on relocating and reexposing Pier 38 and the north edge of Unit D12, documenting and removing the brick footing, and screening matrix. Since only the southwestern edge of the brick footing was exposed in Phase I, the majority of the footing was exposed for the first time in the Phase II excavation. The complete brick footing consisted of 10 bricks in a single course (Figure 6.17). Although some bricks appear to have been removed from the southeast side, the original footing probably consisted of two rows of five bricks laid stretcher (long axes oriented eastwest), with two or three bricks laid in a header row on the west side.

The fact that several bricks seem to have been missing from the pad suggest some postdepositional disturbance, most likely associated with a repair episode or the 1961 concrete porch installation. No builder's trench was observed around the brick footing; all such evidence was probably destroyed. In addition, when the footing was removed, a rodent burrow was found running northeast-southwest about 1 inch below the bricks. Artifacts collected from the Pier 38 Phase II excavation consist of one bone fragment, $8.9 \mathrm{~g}$ of window glass, and $7.7 \mathrm{~g}$ of bulk nails.

\section{FEATURE 29}

The western half of the south wall foundation had been altered by the addition of the concrete south porch in 1961. Attached to the south porch concrete slab was a 31 -ft-long, 2 -ft-wide concrete beam that was poured in an east-west line underneath the west end of the south wall. This beam, along with some concrete blocks (each 12x12x4-inches) on top of it, served as the house foundation (see Pier 37 in Figures 3.3 and 6.1). After removal of the concrete porch, PAI archeologists were able to investigate the below it. The work began with a hand-dug, east-west trench running the full length of the south wall. Feature 29 was found at this time, and excavation showed it to be an original house pier footing. Features 30 and 31 also were found under the concrete beam, but these were investigated 


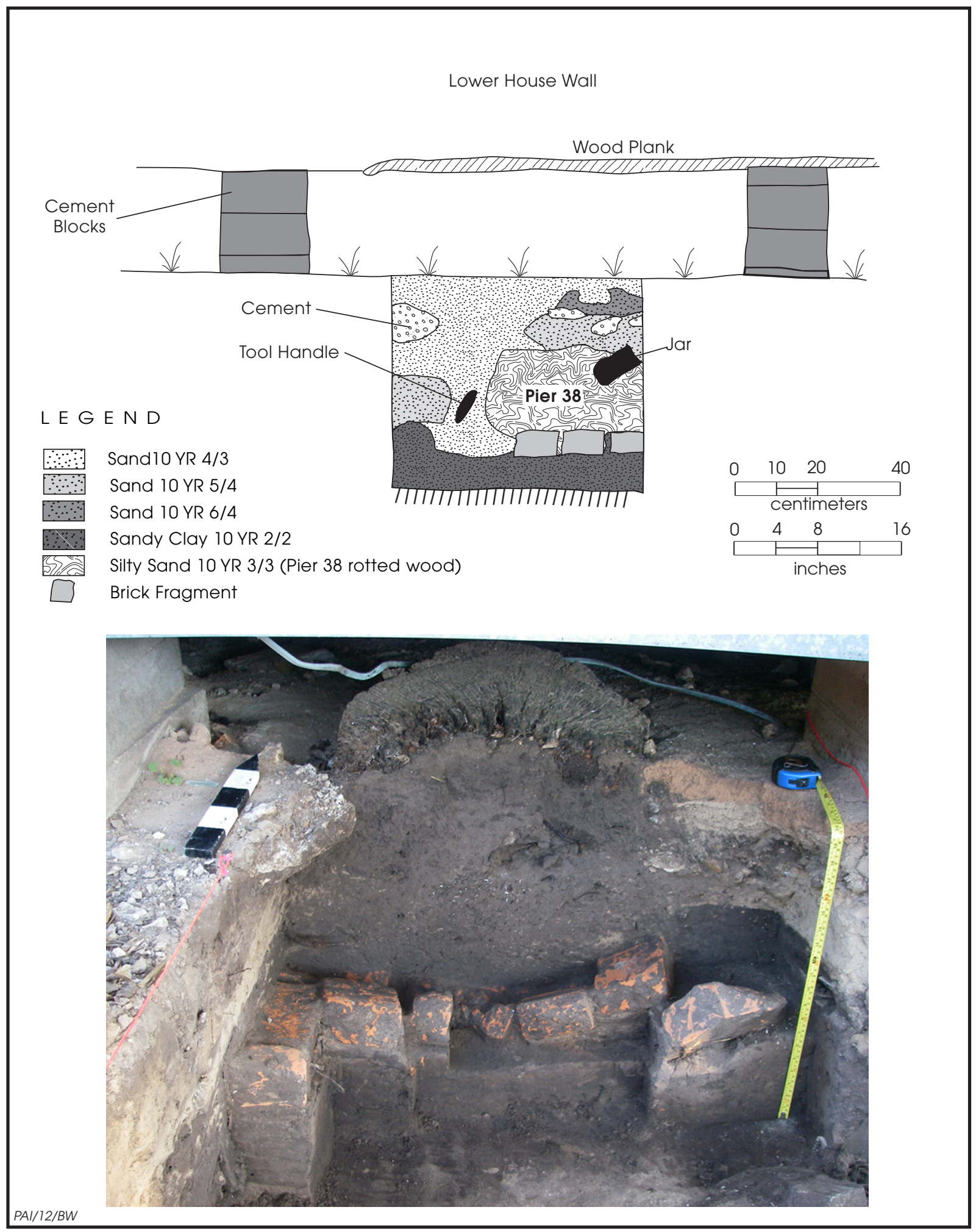

Figure 6.16. Profile and photograph of Pier 38 from the Phase I investigations. The view is north, and the north arrow is $25 \mathrm{~cm}$ long (ca. 10 inches). 


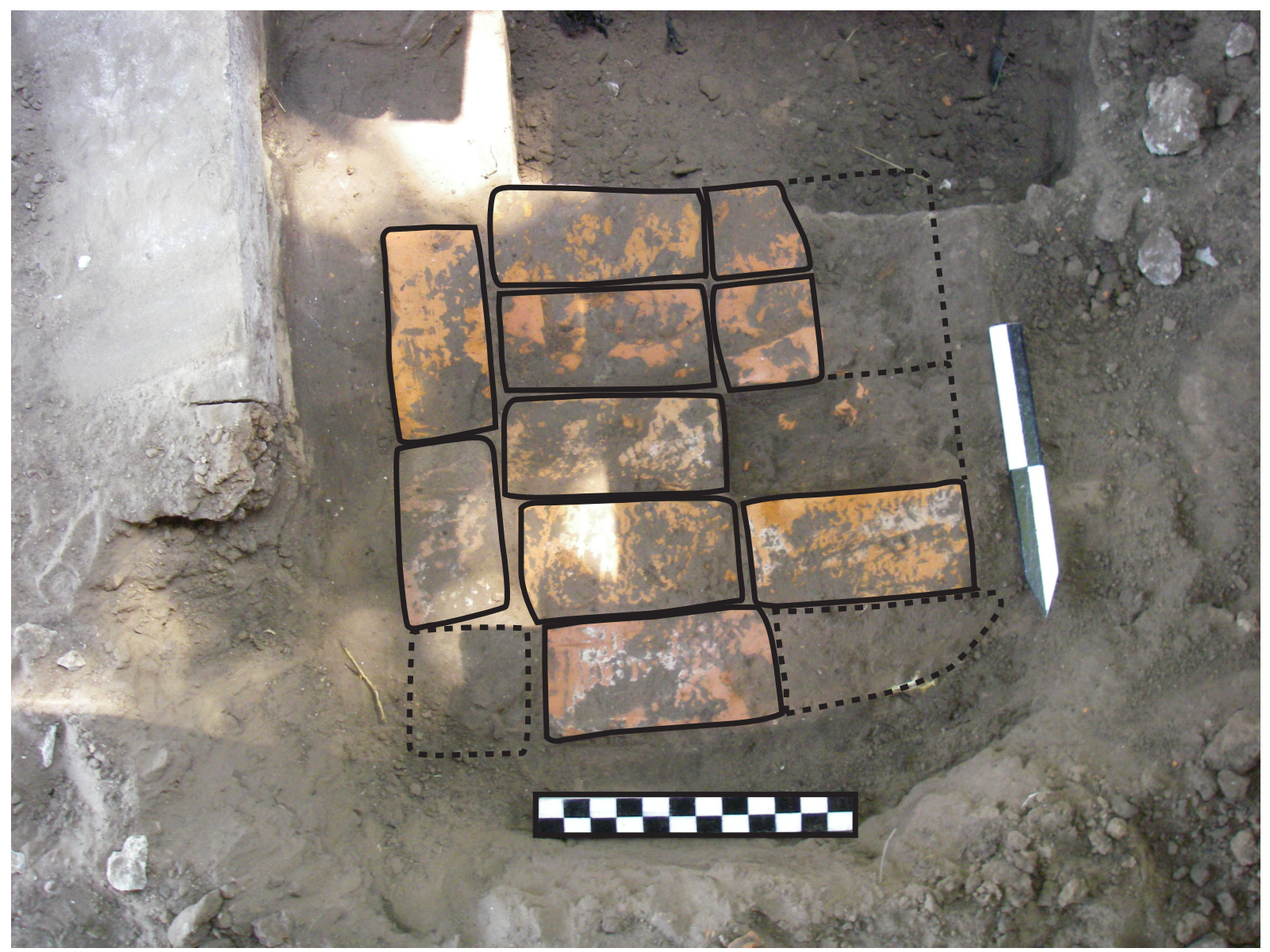

Figure 6.17. The Pier 38 brick footing at $13-16$ inches below the surface. View is to the south. Scale and north arrow are each $1 \mathrm{ft}$ long.

only by shallow scraping. They are considered to be possible pier features and are discussed later in this chapter.

The excavation revealed that Feature 29 was an original pier footing located ca. $13-15 \mathrm{ft}$ east of the southwest corner of the house. Five bricks aligned side by side were exposed in an east-west row immediately adjacent to the remnant 1961 concrete porch (Figure 6.18). This row of bricks, which was 18 inches wide, dipped southward under the concrete foundation beam. The angle of the bricks indicates that a pier pushed the southern portion of the brick pad deeper into the ground.

After the Phoenix 1 workers removed the concrete beam, additional bricks associated with Feature 29 were exposed, but this portion of the footing was in poor condition. The bricks were crushed in place by the weight of the house and the concrete beam. A second row of bricks was exposed to the south, and it was identical to the first row. Beyond this, other isolated bricks continued farther to the south, but they were crushed and probably in disturbed contexts. The clay matrix surrounding the south half of the footing was so compact that it had to be excavated with a pick. Because of this, the exact size and shape of the Feature 29 pier pad could not be determined. The original pad was at least 18 inches east-west, and the other dimension was probably of equal length or greater. It appeared that there might be a partial second course of bricks (highly fragmented) on the south side, but this could not be determined with certainty. It is likely that Feature 29 was a single course footing, and that the underlying bricks were used to level the bottom of the pad (as was done with Pier S1 described above). 


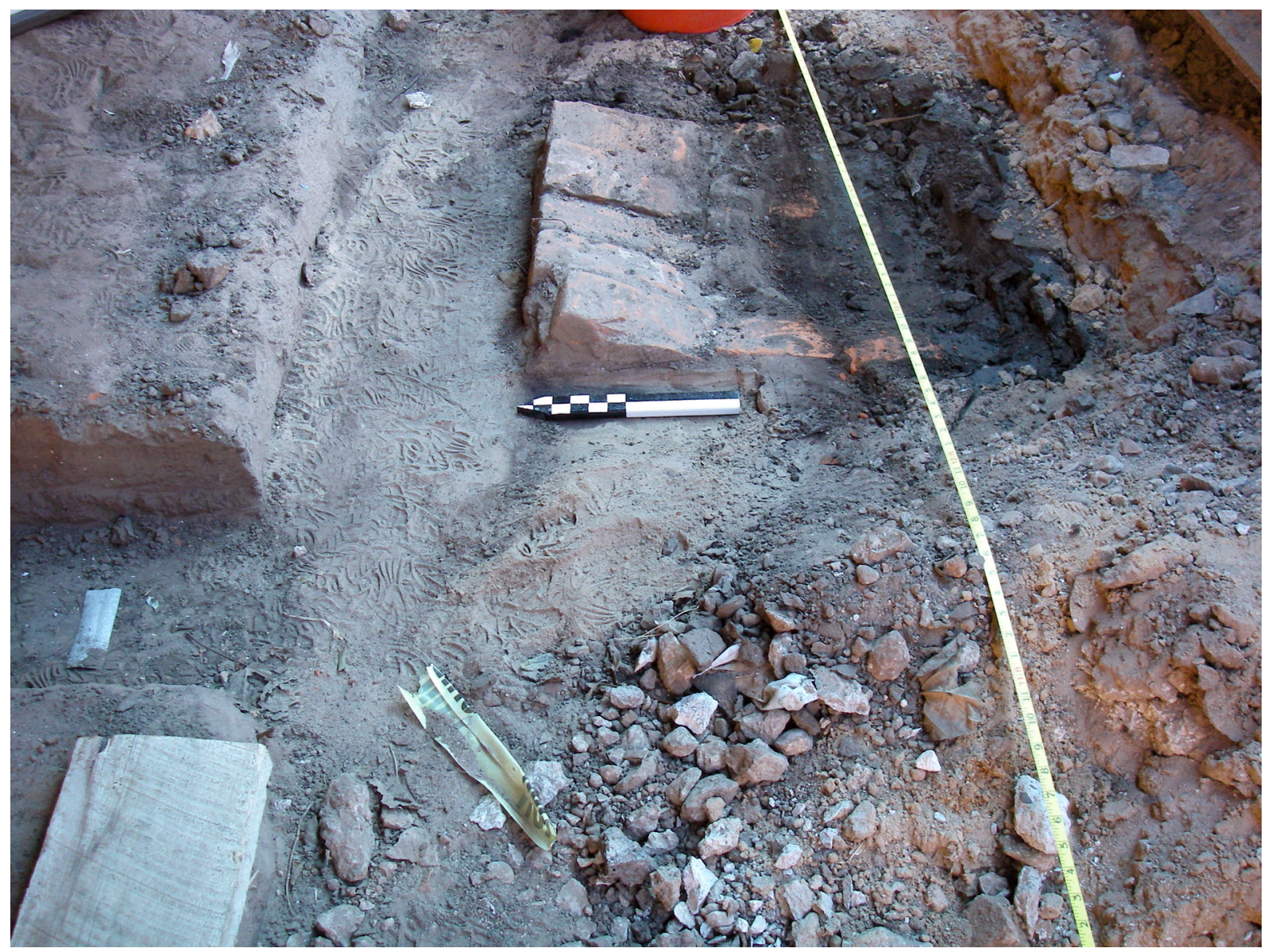

Figure 6.18. Feature 29, an intact brick footing for an original pier along the south wall of the antebellum house. View is to the east, and the tapeline marks the exterior side of the south wall. North arrow is $1 \mathrm{ft}$ long.

Artifacts recovered from within the Feature 29 pier footing area consist of $6.5 \mathrm{~g}$ of window glass, three clear bottle glass fragments, and three wire nails.

\section{Other Piers on the Shared North Wall}

Seven piers found along the north wall of the antebellum house are probably piers that were constructed when the ell addition was added in the early twentieth century to reinforce the shared wall. These include five oak timbers that lacked brick footings and three piers with other types of wooden posts. All of these piers appear to postdate the construction of the original house. There is no way to precisely date the construction of these piers, but it is notable that most of their posts sit on top of a brick rubble layer. The brick rubble is designated as Feature
32 and covers a broad area north of the main house, with a concentration of bricks in an eastwest line along the north edge of the original house. This brick layer could be derived from one or multiple sources, but it is possible that much of it is related to the damages caused by the 1900 hurricane to the original east wing (see Feature 32 in Chapter 8). Because the pier posts for these seven piers sit atop this brick rubble, they are tentatively interpreted as repair piers that postdate 1900. Furthermore, it is presumed that timber piers (which are consistent with the original cut log piers) that lack brick footings and lie on top of the Feature 32 brick rubble have been moved.

\section{PIER C1}

Pier C1 was composed of a wooden timber, identified as live oak (see Appendix B), that was 
apparently the post of an original north wall pier that got moved from its original location to a new location. The Pier C1 timber measured 20 inches (east-west) by 13 inches (north-south) and stood 14 inches above ground surface. The excavation revealed decomposing wood down to ca. 10 inches below the surface, but no brick footing was found below this. The degree of decay in the buried portion of this timber suggests that it had sat in this location for a long time. Several bricks and brick fragments were observed at the base of the timber primarily on the north side. Three of the bricks were complete; they are red bricks manufactured on a modern dry-press brick machine, with mortar still adhering on several faces. One brick was impressed with the name "HOUSTON RED B." Clearly these bricks were intentionally placed at the base of the pier post as shims. Artifacts recovered from the Pier
C1 excavation consist of $5.9 \mathrm{~g}$ of window glass, two clear bottle glass fragments, and one metal fragment.

\section{PIER H1}

Pier H1 consisted of a wooden timber that was 15 inches (east-west) by 12 inches (northsouth) and stood 13 inches tall (see Figure 6.11). The wood was identified as live oak (see Appendix B). Excavation around its base exposed only scattered brick rubble (Figure 6.19). Removal of the timber revealed that the brick rubble layer was present underneath the pier post, clearly dating the placement of the timber after the deposition of the brick rubble layer (see Feature 32 in Chapter 8). The Pier H1 timber was most likely moved to this location long after the construction of the house, perhaps after the 1900

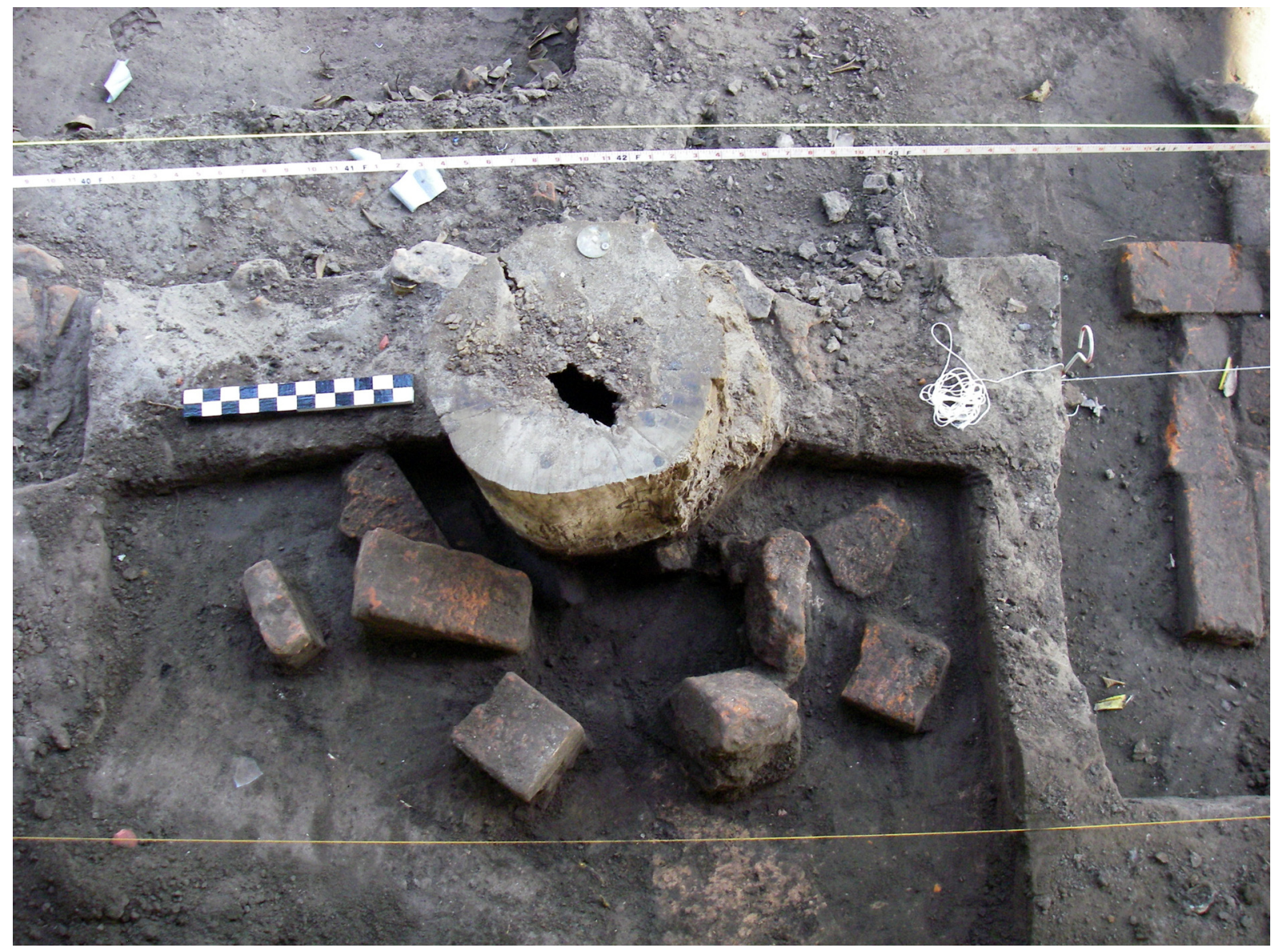

Figure 6.19. Overhead view of Pier H1 showing the large oak post sitting on the brick rubble zone. View is to the north, and the tape line marks the north edge of the house wall. Scale is $1 \mathrm{ft}$ long. 
hurricane. The pier post had been in place long enough to produce 10 inches of decayed wood at the bottom.

\section{PIER K1}

Pier K1 consisted of two stacked railroad ties lying horizontally to serve as a makeshift foundation pier (see Figure 6.11). Each tie was 8 to 9 inches square, and both segments were 31 inches long. One tie was stacked on the other, with their long axes running north-south under the north wall of the house. Excavation revealed that the bottom tie was less than 3 inches below ground, and there was no evidence of a footing or foundation beneath it. Several loose brick fragments were found below the pier; these are believed to be associated with the Feature 32 brick rubble layer (see Chapter 8). No artifacts were collected in association with Pier K1.

\section{PIER N1}

Pier N1 was a vertical section of cut lumber measuring $10 \times 10$ inches and standing 20 inches above the ground surface (see Figure 6.11). A sample of the wood was collected and determined to be live oak (see Appendix B). Excavation revealed no brick footing, but the Feature 32 brick rubble layer (see Chapter 8) was found around the base of and underneath this pier post.

\section{PIER P1}

Pier P1 was a wooden timber, identified as live oak (see Appendix B), that measured 17 inches (east-west) x 14 inches (north-south) and was 15 inches high. It was in place along the north wall of the house, but it leaned considerably to the southeast (see Figure 6.11). The excavation revealed the pier post was set about 6 inches into the ground and did not have a brick footing. The bottom of the pier was rotted, and the Feature 32 brick rubble zone (see Chapter 8 ) was around and underneath it.

\section{PIER V1}

Pier V1 was a wood timber, identified as live oak (see Appendix B), that was 13 inches (north-south) x 12 inches (east-west) and stood 12 inches above the ground surface. The Feature 32 brick rubble zone (see Chapter 8 ) surrounded and was underneath the base of the timber. This timber block may have been an original pier in another location that was moved to its current location after the deposition of the brick rubble.

\section{PIER W1}

In preparing for the house lifting, Phoenix 1 workers removed a large timber pier from a spot along the north wall about $10 \mathrm{ft}$ east of the northeast corner. The Phoenix 1 crew believed that Pier W1 was one of the original piers along the north wall. In Phase II, PAI archeologists observed only a slight depression about 11 inches in diameter where the pier timber had been. Brick rubble was visible inside the depression. The area was shovel skimmed to reveal more of the Feature 32 brick rubble layer (see Chapter 8), but no brick footing was found. Thus, it appears that a large oak timber was removed from one of the original pier locations and placed in a new spot that was recorded as Pier W1.

\section{Interior Piers Centered under the House}

When the plantation house was elevated and placed on the cribbing structure, it provided easy access to the area under the house so that piers could be investigated. When the Phase II began, some piers and pier locations under the house were obvious and others were more subtle or disturbed. PAI archeologists excavated north-south trenches under each of the four house foundation beams to search for hidden piers, and they targeted all the known pier locations. At that time, four piers stood out as being unusual and perhaps older than all the others. Three piers with cut wooden block piers still in place were lined up, east to west, down the center of the house (Figure 6.20a). The fourth block was displaced, but a depression marked the location where it had been until recently. These features, designated Piers D11, J11, Q12, and V1, were each centered under one of the four primary north-south foundation beams (see Chapter 5). All four were wooden blocks that had been cut with a 48-inch-diameter circular saw, the same kind and size of saw used to cut many of the floor joists in the original house. The wood blocks ranged slightly in size, but all were roughly $12 \times 12 \times 16$-inches, and had clipped 
corners. Samples of three of these piers (D11, $\mathrm{J} 11$, and V11) were collected and identified as live oak (see Appendix B), so it is presumed that the displaced block (Q12) is oak also. The bottoms of all the oak blocks were deteriorated, indicating that they had all been in the ground for some time.

\section{PIER D11}

Pier D11 was centered under Beam D (see Figure 6.3), and it consisted of a square-cut pier block measuring $103 / 8 \times 12$ inches. The wood was identified as live oak (see Appendix B). At the time of the investigation, only 7 inches of the wooden block was above the ground surface. An excavation on the west side of the block went 19 inches deep and exposed 12 inches of rotted wood and 7 inches of loose stained sediment. The stained sediment in the bottom of this hole probably represents completely deteriorated wood and extensively bioturbated soil (Figure 6.20b). No artifacts were found in association with Pier D11.

\section{PIER J11}

Pier J11, centered under Beam J, consisted of a block of wood that was still in situ but had fractured into three large sections (Figure 6.20c; see Figure 6.3). Only two pieces of the wooden block were present at the time of excavation, and the third had been removed. The block appears to have originally measured about $12 \times 12$ inches, and it stood 4 1/2 inches above the ground surface. The east side of the wooden block was excavated to profile the east face of the pier. This profile revealed one section of rotten wood to a depth of 6 inches below the surface, and another section of rotted wood extended down to 8 inches. So it appears that the original pier hole was only 6 to 8 inches deep. A thin piece of lumber was present under the northernmost portion of the fragmented wooden block; it clearly represents an attempt to repair the pier. Several small brick fragments found near the base of the block appear to have been jammed into the edge of the pit as a makeshift wedge to shore up the foundation block.

The evidence indicates that the original wooden block was about 12 to 13 inches tall. It was laid into the ground without any footing. The wooden block eventually developed vertical stress fractures due to the weight of the house as its foundation began to sag. When the block finally cracked, the section of the block that bore most of the weight was pushed deeper into the ground, and it tilted slightly to the north. One of the fragmented pieces was later removed, and a piece of lumber was added as a shim. Brick wedges were then added to stabilize the base of the rotting pier. At some point, continued deterioration of the pier block rendered it useless as a foundation support.

Artifacts collected from within the Pier J11 hole include $2.6 \mathrm{~g}$ of window glass, eight container glass fragments (six clear and two colored), one tiny Prosser button, four bone fragments, and a modern metal can fragment. Some artifacts could have been introduced when this pier was originally installed, but additional materials were probably introduced when the pier block failed and was repaired (perhaps multiple times), probably in the last half of the twentieth century.

\section{PIER Q12}

The location of Pier Q12 was not evident on the surface during Phase II work. The wooden block of this pier had been displaced, and it was found lying on its side at the north end of foundation Beam Q (see Figure 6.3). Shovel skimming was done under the entire length of Beam $Q$ to search for evidence of the pier holes and footings. But since the other three wooden block piers were lined up east-west down the center of the house, the original location of Pier Q11 was easily predicted.

The ground surface below Beam Q was highly disturbed. A large animal burrow and backdirt pile covered an area roughly $6-8 \mathrm{ft}$ in diameter near the southern end of the beam. At the northern end, many rodent burrows were observed in the Beam Q trench, and surface clusters of modern artifacts were present in this area. In addition to the displaced pier block, numerous pieces of lumber, splintered wooden block pieces, rotted cores of timbers, and a 12x12inch concrete block were scattered along the length of the trench prior to excavation. It was impossible to tell where these bits and pieces of wood originated.

While shovel skimming the Beam Q trench, a slight texture difference was noted 8 inches below the undulated ground surface in the 

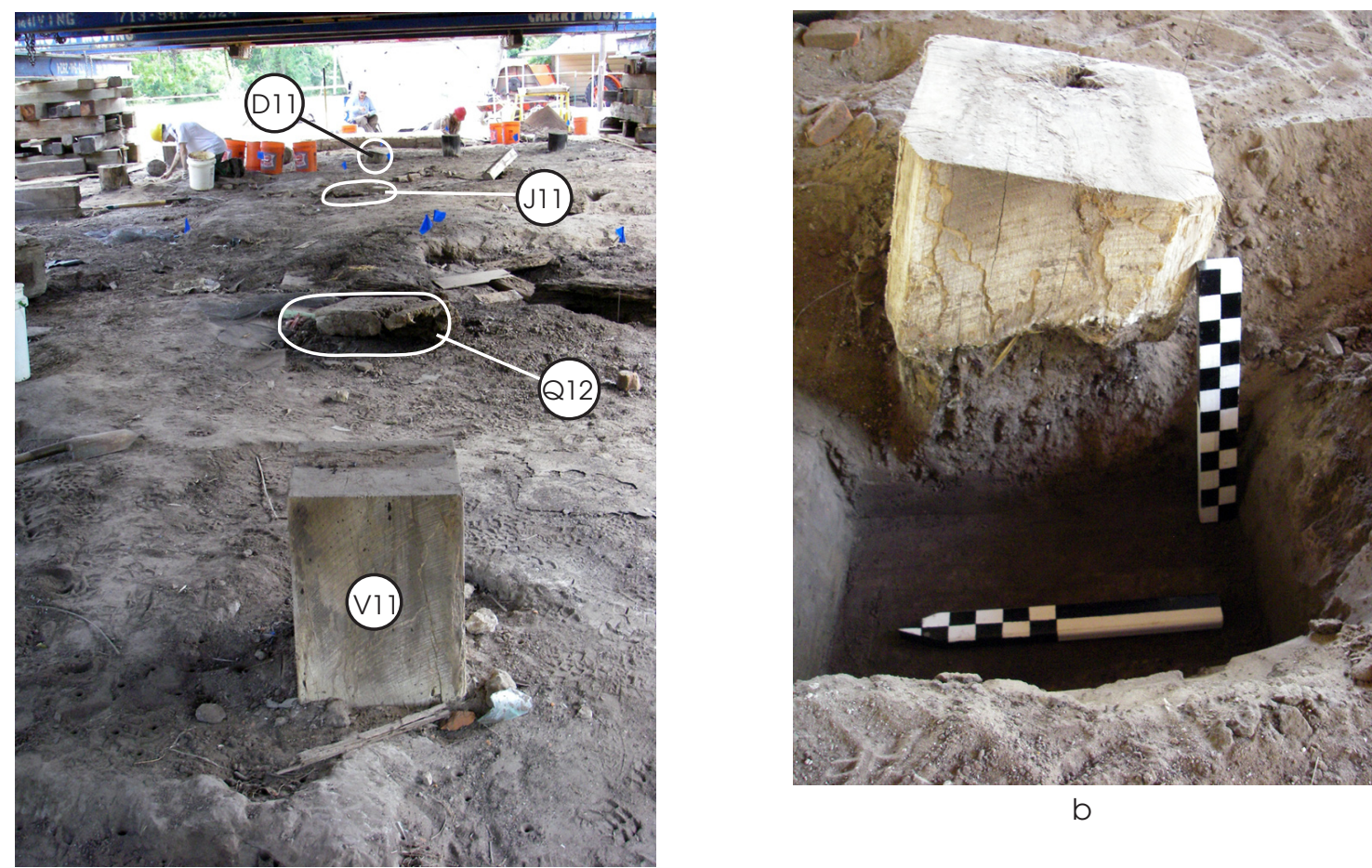

$\mathrm{b}$

a

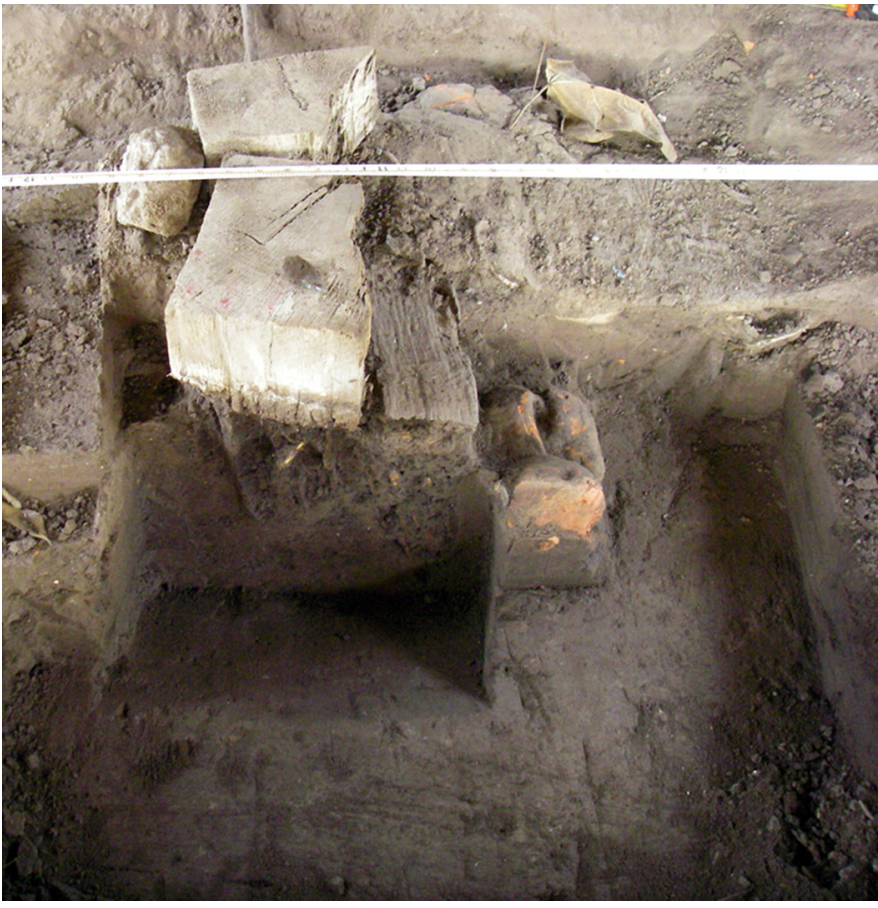

C

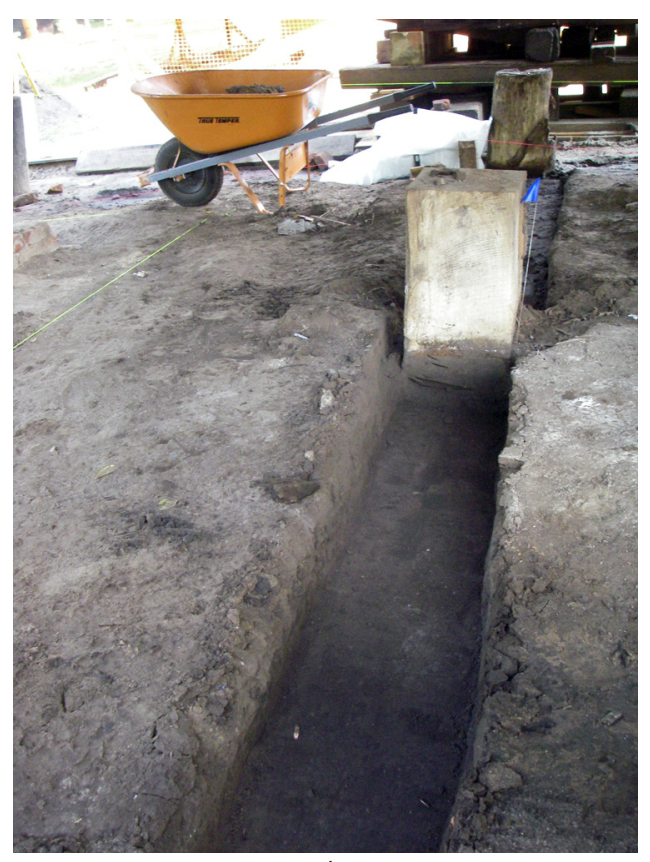

d

Figure 6.20. The square-cut oak block piers underneath the original house. (a) Looking east down the centerline at the row of piers. (b) View east of the Pier D11 with the square oak block leaning to the south. Scale and north arrow are each $1 \mathrm{ft}$ long. (c) View west of Pier J11, with the square oak block fractured in place. The tapeline marks the centerline of foundation Beam J. (d) View north of the Pier V11 oak block in place. 
center of the trench. Artifacts observed (not collected) in the area around the stain included a metal oil can key, several small brick fragments, two ash concentrations, and a ca 3 -inch tin pipe elbow fragment. Troweling of this area exposed a fairly extensive S-shaped soil stain. A distinct pit edge was not observed in plan view, so the disturbed area was profiled (from east to west) at its southern end. Additional east-west profiles were then excavated in 2- to 3 -inch increments, with each one moving farther northward through the feature. Several of the profiles exposed a distinct straight-sided pit that was generally 10 to 15 inches wide at 8 inches below the undulating ground surface, and the pit tapered quickly to 8 inches wide at 10 inches deep. The west side of the stain was well defined, and had straight sides, while the east edge formed a distinct angle. The bottom of the stain was only 5 inches wide.

A second profile of the soil stain was a few inches north of the first profile line. In this second profile, both the east and west sides of the stain were clear and straight. The upper part of the soil stain was now 15 inches wide, and it tapered to 7 inches wide near the bottom. The feature was 14 inches deep at this point (estimated from ground surface).

There is little doubt that the soil stain found under the center of Beam Q represents the posthole where the displaced 12x12-inch oak block pier had been originally. The dark stained deposit was from the rotting wood and subsequent bioturbation of the organic-rich posthole fill.

\section{PIER V11}

Pier V11 was the best-preserved wooden block pier, and it was identified as live oak (see Appendix B). The 12x12-inch block was found in situ under the center of Beam V (see Figure 6.3). The block rose ca. 14 inches above the ground surface (see Figure 6.20a). A trench was shovel skimmed along the entire length of Beam V, but no other pier features were found. The sediment around the base of the pier was troweled in search of a builder's trench, but none was found. Instead, it appears that the block was placed in a hole the same size as the block. The excavation was continued until the base of the oak block was exposed (see Figure 6.20d). The block was set only about 4 to 5 inches into the ground, but its bottom had deteriorated considerably and graded into dark organic sediment where the post had rotted away completely. When the block was removed, several inches of dark clay adhered to the base of the block. This sediment was troweled off the base and screened, but nothing was recovered.

\section{Other Interior Piers}

Nine other piers found under the house appear to be repair piers that were added in the twentieth century, quite possibly in the second half of the century based on their characteristics. Although some handmade bricks and other artifacts were scattered under the house (on the surface and shallowly buried), none of these nine repair piers had a formally prepared footing.

These nine additional piers occurred underneath three of the four main north-south foundation beams (see Figure 6.3). These additional piers were under Beam D (Piers D10, D12, and D13), Beam J (Piers J10, J12, and J13), and Beam Q (Piers Q10, Q11, and Q13). No additional piers were found in the excavations under the westernmost Beam V except for the center pier V11 described above. This suggests that the foundation Beam V may have been more stable than the others.

\section{PIERS D10, D12, AND D13}

Piers D10, D12, and D13 were in a northsouth line under foundation Beam D (see Figure 6.3). They were virtually identical, and each consisted of a 10.5-inch-diameter milled wooden post (Figure 6.21). The Pier D10 post had been displaced, but it was laying horizontally next to the depression where it sat. The carbonate staining on the bottom of the post was still fresh, indicating that it was displaced when the house was elevated and that it had been set about 6 inches in the ground. Pier D10 was not excavated, but it is presumed that it was similar to Piers D12 and D13.

A trench was excavated that covered the south half of Beam D, in order to examine the subsurface portions of Piers D12 and D13. Both piers were found to be set into the ground less than 6 inches. Some scattered bricks and artifacts were observed in the Beam D trench, but no evidence of builder's trenches for the piers or pier footings was observed. 


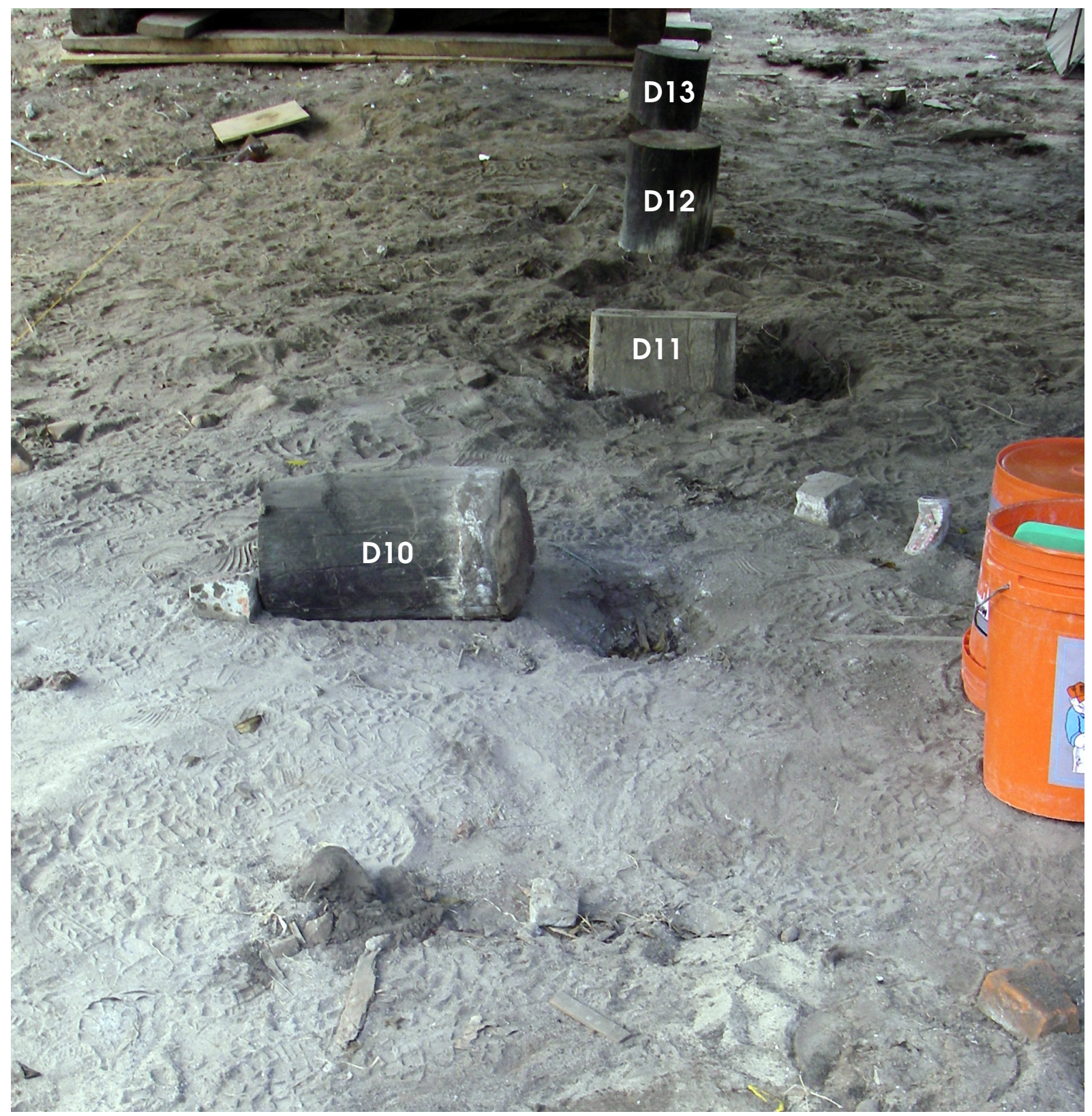

Figure 6.21. View of the interior pier posts under foundation Beam D of the original house. View is to the south. The base of a cribbing structure is in the background.

\section{PIER J10, J12, AND J13}

Piers J10, J12, and J13 were in a northsouth line under foundation Beam J (see Figure 6.3). Pier J10 was a 24-inch-long section of railroad tie ( $8 \times 8$ inch), lying horizontal and oriented east-west. Excavation revealed that this pier was not set into the ground and was probably a very recent repair.
Pier J12 was a concrete block (12x12x4 inch) located less than 6 inches south of the fractured square block Pier J11. Excavation below the concrete block revealed no associated pit, and the block appears to have sat on the modern ground surface in an area that was extensively disturbed. It is possible that Pier J12 was not a separate pier but was originally placed on top of Pier J11. This inference is supported by the fact 
that the J11 wood block sat only a few inches above the surface and was not tall enough to reach the foundation beam without something in between (see Figure 6.20a).

Pier J13, a 24-inch-long section of railroad tie (8x8 inch) lying horizontal and oriented eastwest, was nearly identical to Pier J10. A 12x14inch soil stain was found immediately south of the $\mathrm{J} 13$ railroad tie. Excavation revealed that it was only a few inches deep and consisted of loose, mottled sediment with fragments of reddish bricks. The association between this infilled pit and the railroad tie is not clear, but it is likely that the railroad tie was originally set into this pit but got displaced.

\section{PIER Q10, Q11, AND Q13}

Piers Q10, Q11, and Q13 were in a northsouth line under foundation Beam Q (see Figure 6.3). A modern $1 \times 6$-inch board was lying on the surface in the vicinity of Pier Q10, and the Beam $\mathrm{Q}$ trench excavation revealed a concentration of shallowly buried modern and historic artifacts (e.g., brick fragments, bone, ceramics, glass, plastic items, a partial leather shoe, foam plumbing insulation, and a corncob) in this area. Excavation revealed that Pier Q10 was a circular soil stain that measured 20 inches north-south by 14 inches east-west. It was only a few inches deep and filled with mottled sediment, and a rodent burrow ran through a portion of the stain. It appears that Pier Q10 is the posthole for a wooden pier post (perhaps a milled post like those in Piers D10, D12, and D13) that was removed some time ago. The excavation also revealed that there was no pier footing under the Pier Q10 soil stain.

Pier Q11 was first observed as a circular depression centered under the foundation Beam Q. Excavation revealed that this feature extended down about 8 inches below the surface and was filled with loose mottled sediment. It appears to be a posthole where a circular wooden post was set into the ground without any pier footing.

Pier Q13 was a ca. 30-inch-long section of railroad tie (ca. 8x8-inch) that was laid horizontal in an east-west line and centered under foundation Beam Q. There was a shallow, long oval depression parallel to and immediately north of the tie that was approximately the same size as the tie. Excavation revealed that the depression was filled with loose sediment, and at about 4 inches below the surface, it measured 33 inches long by 12 inches wide. The rectangular pit was oriented in the same east-west direction, and it appeared that the tie had once sat in this depression.

At the conclusion of the Beam Q investigations, it was clear that Piers Q10, Q11, and Q13 were modern attempts to shore up the house foundation.

\section{Piers Associated with the Twentieth-Century East Wing}

Six piers on the east wing of the twentiethcentury ell were examined during the Phase I investigations: Piers 5, 6, 10, 11, 13 and 16 (see Figure 6.1). No additional work was done on these features during Phase II. All appear to be additions or repair piers that were part of the ell addition.

\section{PIER 5}

Pier 5 sat on the southeast corner of the east wing and was exposed in Unit E10 (see Figure 6.1). The north wall of the original house abutted Pier 5, but did not sit on the pier. The original $20 \times 60$-ft house was offset from the east wing by ca. $3 \mathrm{ft}$, creating an L-shaped niche between the two structures. Pier 5 sat within this niche and appeared to be the southernmost pier for the east wall of the ell addition.

The northern half of Pier 5 was excavated to expose an east-west profile of the feature. The pier consisted of a 13-inch-diameter creosote post overlying brick fragments. The top of the post was altered slightly, with its east edge planed or flattened to sit flush with the structure's east wall. The post was 27 inches long, with 18 inches above ground and 9 inches below ground. The pier post was in relatively good condition, with only minor decay near the bottom. No construction trench was observed in the walls or the floor of the excavation.

An irregular cluster of brick fragments was found directly under the pier post from 9 to 13 inches below the surface. No bricks or brick fragments were observed on either side of the wooden post, so there was no prepared pier footing. It appears that this post was set into a circular hole that was the same size as the post, and a few brick fragments fell or were thrown in 
the bottom beneath the post. No artifacts were collected during the excavation of Pier 5 .

\section{PIER 6}

Pier 6 was located $5 \mathrm{ft}$ north of the intersection of the east wing and the original house (see Figure 6.1). The pier was exposed in Unit E8 and consisted of a modern 13-inch utility pole, heavily coated with creosote overlying brick rubble. The pole sat on top of two wooden boards, each $1 \times 6$-inches and 41 and 44 inches long. The two boards were lying flat under the post, parallel to each other and oriented north-south. The boards extended 12 inches beyond the pier post to the south and 4 inches beyond the post to the north. Both boards were shallowly buried, with only $11 / 2$ to 2 inches of soil over them. A few small fragments of bricks were present in the sediment below the boards, but these are probably not associated with the pier feature. There was no evidence of a posthole or construction trench below the horizontal boards.

The upper part of the pier post was in good condition, but the lower two inches were decayed as a result of contact with the soil. The horizontal boards were partially decayed. Some modern and historic artifacts were found in the excavations above the horizontal boards, including window glass, clear bottle glass, nails, and a pink plastic fingernail clipper.

\section{PIER 10}

Pier 10 sat at the northeast corner of the east wing (see Figure 6.1). Unit E9 was excavated on the east side of the pier to expose a west wall profile. The excavation revealed that the 10 1/2-inch milled pier post (a section of creosote-soaked utility pole) was placed into a hole that had a layer of brick rubble at the bottom. The post sat 8 inches above the ground surface and extended to 7.5 inches below ground. It was in relatively good shape.

The brick rubble layer was generally 3 inches thick, from 7 to 10 inches below the surface. It was flat underneath the post, but it lipped up higher around the south edge of the post (from 4 to 10 inches below the surface) and extended out 4 inches farther beyond the south edge of the post. Although the sediments were homogenous around the post and the edges of the posthole were not observed, the southern edge of the brick rubble shows that the posthole for this pier was about 15 inches wide. It appears that a flat-bottomed posthole was dug and filled with brick fragments, and some of the brick fragments were squished up around the edge of the post when it was jammed into the hole.

Artifacts were common in the upper 15 inches of Unit E9, with only a few items found in the bottom two inches. No artifacts were found immediately adjacent to or under the pier post, and the other artifacts found in the unit are not associated with this pier.

\section{PIER 11}

Pier 11 was located $5 \mathrm{ft}$ west of the northeast corner of the east wing (see Figure 6.1). Unit G2 was excavated on the north side of the pier to expose an east-west profile of the feature. The pier consisted of a 10-inch milled post (a section of creosote-soaked utility pole) that extended 10.5 inches above the ground. The excavation went down to 18 inches below the surface and exposed 11.5 inches of the post below ground. There was no evidence of the posthole or a pier footing of any kind. Many artifacts were recovered from Unit G2, but none are associated with the pier. Pier 11 was most likely associated with the original construction of the ell addition in the twentieth century.

\section{PIER 13}

Pier 13 was located at the intersection of the northwest corner of the east wing and the east-wing porch (see Figure 6.1). The pier consisted of an 11.5-inch-diameter milled pole (possibly a section of a utility pole, although it was not obviously creosote-soaked) that extended 10 inches above ground. Unit G4 was excavated on the north side of the feature to expose an east-west profile. Excavation of this unit was made difficult by six utility lines (two cast-iron pipes, one electrical line, a copper gas line, and two PVC pipes) running in and out of the east wing addition. None of the utility lines directly impacted the pier feature, and the excavation revealed that the post went 12 inches below ground. No evidence of a posthole or pier footing was observed. Many artifacts were recovered from the upper part of Unit G4, but these are not associated with the pier feature. 


\section{PIER 16}

Pier 16 was located at the northwest corner of the east wing porch that was attached to the west side of the east wing (see Figure 6.1). Unit G3 was excavated on the north side of the feature to expose an east-west profile, and the excavation only went 7 inches below the surface. This pier consisted of a 3.5-inch-square wooden post set on top of an octagonal poured-concrete pad with a flat surface on top. The pad was 6 inches thick from 1 to 7 inches below ground. This concrete pad continued into the southwest walls of the unit, so its full size could not be determined. The portion of the pad exposed in Unit G3 measured 9 inches (north-south) by 11 inches (east-west). Many historic and modern artifacts were recovered from Unit G3, but none of them are associated with the pier feature.

\section{Possible Pier Features}

Fifteen investigated features are classified as possible pier features. Some are definitely postholes where vertical posts were once located, while others are circular or rectangular soil stains that look like they may have once had posts or other large objects (such as concrete blocks) in them. Any of these posthole features could have functioned as foundation piers of some sort, and several of them almost certainly did. But the inference that a post served as a foundation pier depends on knowing the pattern of many similar posts to infer the size and configuration of the structure or feature they supported. In the absence of such evidence, these features remain classified as possible piers.

The locations of the 15 possible pier features are shown in Figure 6.22. For discussion purposes, they are grouped by area and possible structural association. These six groups of possible pier features are: north side of the original house; possibly associated with an original west wing; along the south wall of the original house; possibly associated with a south porch; possibly associated with an east porch; and possibly associated with a west porch.

\section{North of Original House}

Four possible piers are located on the north side of the original house-Features 22, 25, 26, and 27 . Feature 22 is isolated and near the north wall of the original house, while the others are clustered in a relatively small area north of Feature 22 (Figure 6.23). Features 25 and 26 were exposed along the west side of the north block extension of the northeast block. Feature 25 was $1 \mathrm{ft}$ north of Feature 26 and Feature 27 was $3 \mathrm{ft}$ to the northeast of Feature 25. Features 25 and 26 were bisected along the same northsouth line and profiled together, and they share many attributes. The western halves of the two features remain intact. This area north of the original house was capped with a ca. 1-ft-thick layer of construction sand to protect subsurface features. Although the contrast of the sand and the natural A horizon was distinct, the modern ground surface undulated considerably, due in part to construction activities. This made it difficult to get accurate depth-below-surface measurements.

\section{FEATURE 22}

Feature 22 is a clear rectangular soil stain 17 inches north-south by 11 inches east-west. It was found just north of the north wall of the main plantation house (see Figure 6.22). The feature did not extend underneath the north wall, but its southern edge began at the north edge of the wall. Excavation revealed that the stain was only about 2 inches thick, from about 3 to 5 inches below the surface. Compared with the surrounding dark soil, the feature fill was light-colored, mottled sandy loam with flecks of charcoal and small brick fragments. No artifacts were found in the fill.

The excavation produced no evidence that would definitely identify the function of this feature. However, its shape and location suggest that it may be a shallow posthole where a rectangular block of wood (or concrete block) was set into the ground as a foundation pier. Given its location, it could have been a pier for the original east wing, a backyard porch area attached to the house, or the twentieth-century ell addition.

\section{FEATURE 25}

Feature 25 is a probable pier posthole (see Figure 6.22). In plan view, Feature 25 was a roughly rectangular stain comprised of a pale brown silty sand with some darker mottles within the central portion of the feature. The 


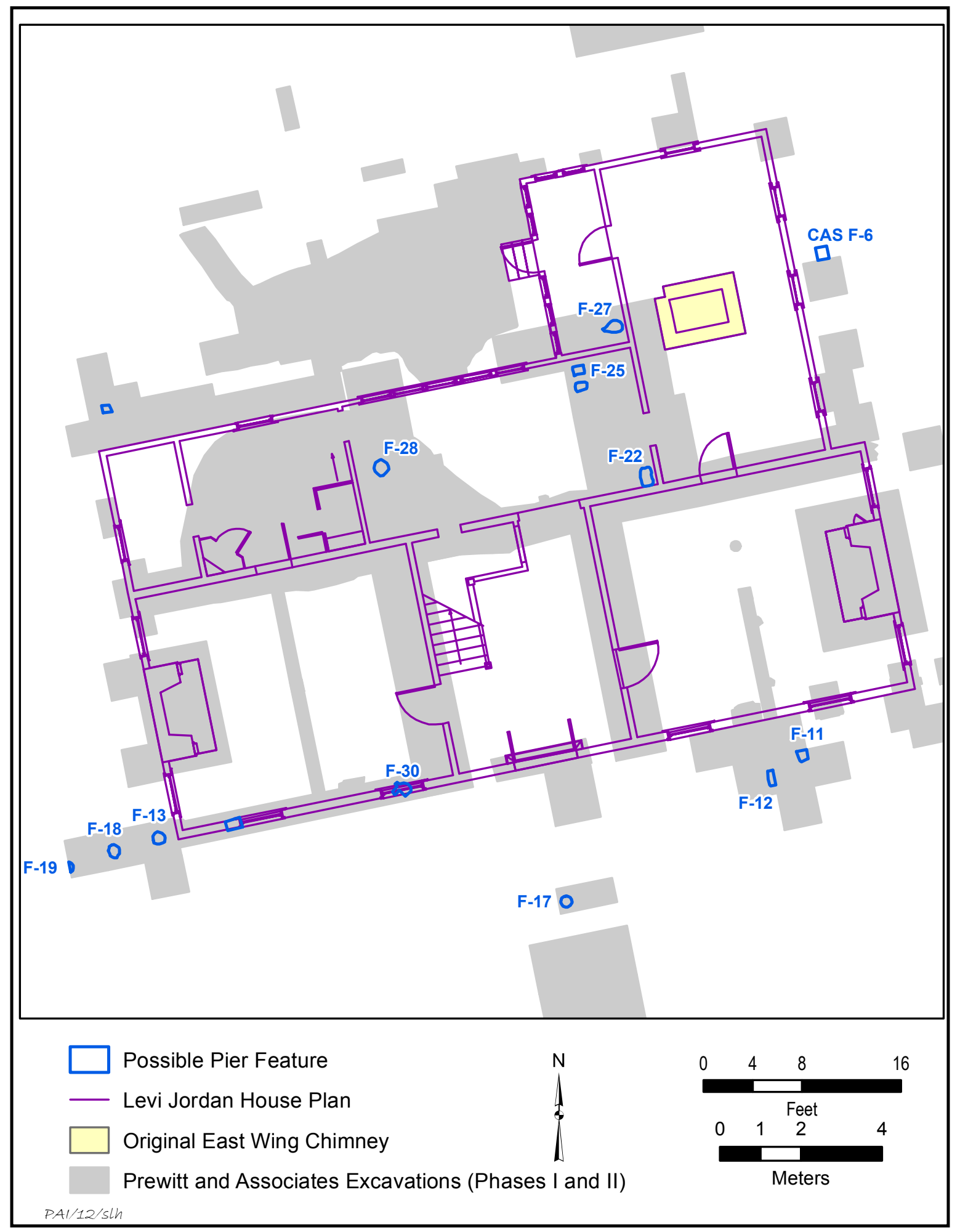

Figure 6.22. Map of possible pier features found around the original Levi Jordan plantation house. 


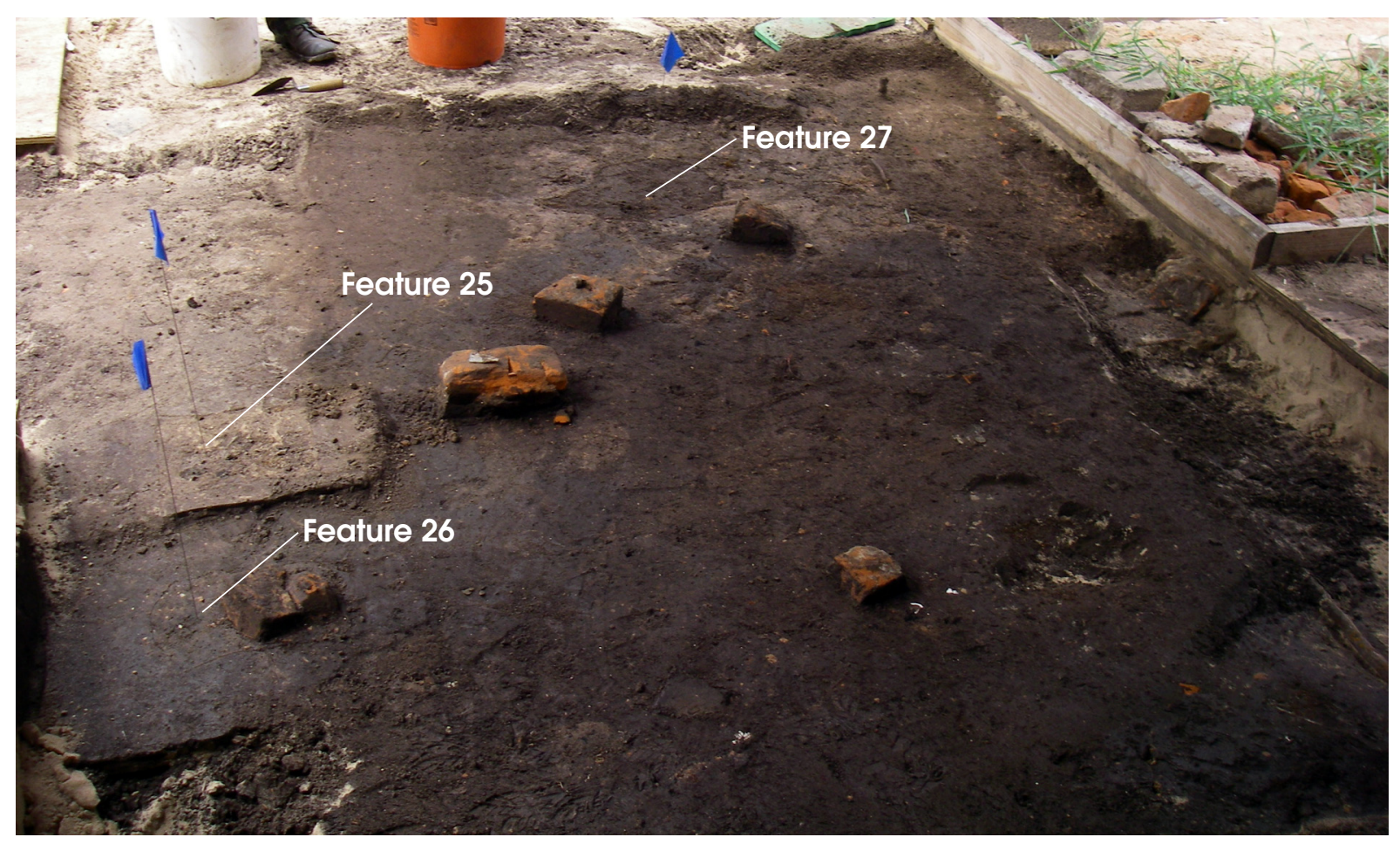

a

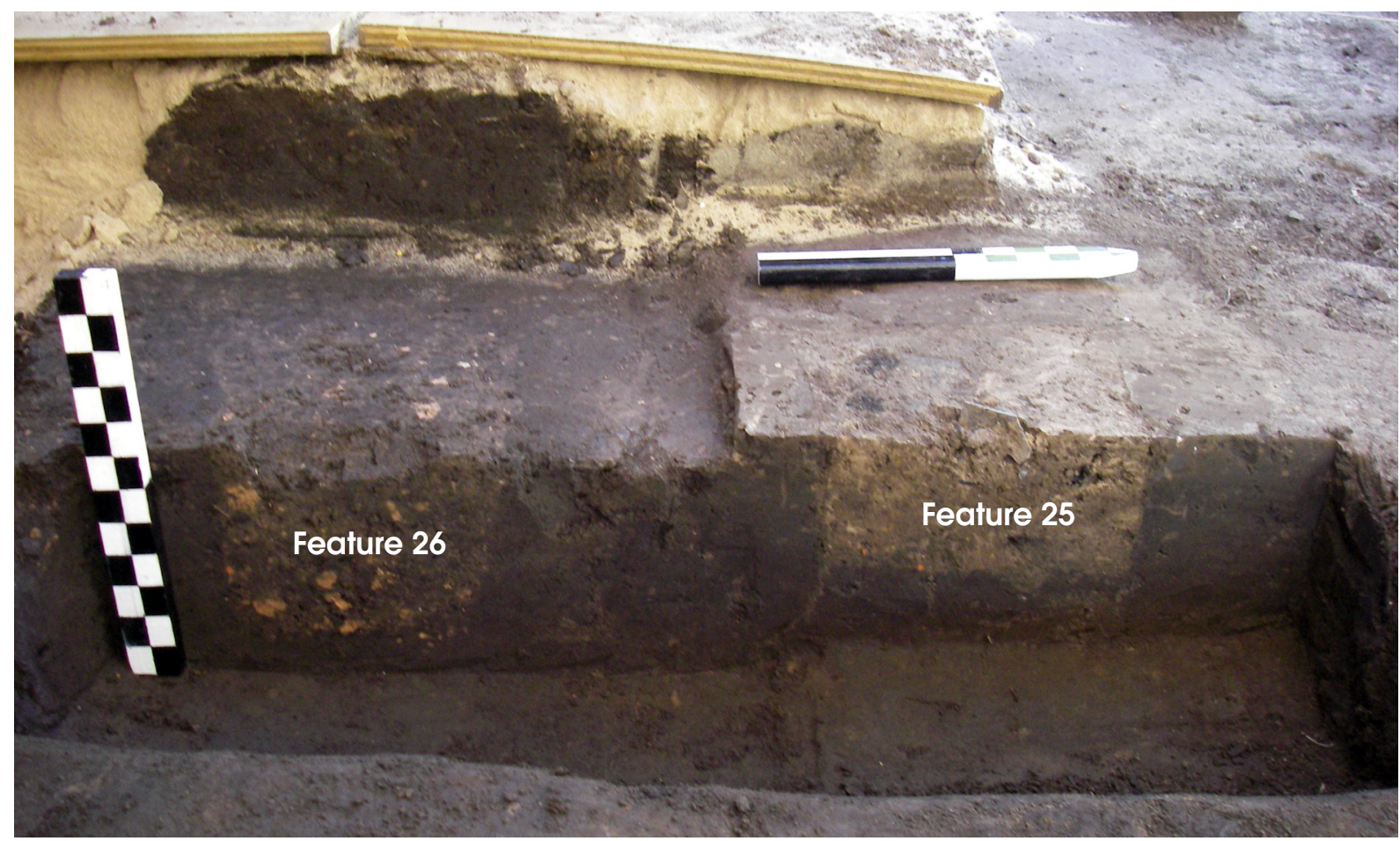

Figure 6.23. Views of possible pier Features 25, 26, and 27 north of the original house. (a) Looking north at a large portion of the northeast block extension, with the features exposed at 1 to 4 inches below the surface. (b) Looking west at the profile of Features 25 (4 to 8 inches below the surface) and 26 (4 to 10 inches below the surface). Vertical scale and north arrow are each $1 \mathrm{ft}$ long. 
stain was very distinct, surrounded by the typical homogenous dark brown clay loam.

Feature 25 measured 11 inches (east-west) by 10 inches (north-south). The stain was exposed at an estimated 4 inches below the surface. Its base was reached ca. $81 / 2$ inches below the surface, for a total feature depth of only 4 $1 / 2$ inches. In profile, the feature has square corners and a flat bottom (see Figure 6.23b). The mottled sediment appeared the same throughout the feature fill. The western half of the feature was left intact. No artifacts were recovered from the feature.

Feature 25 is interpreted as a possible pier posthole that might be associated with a pier that once supported either a porch or perhaps the west side of the original east wing.

\section{FEATURE 26}

Feature 26 is a probable pier posthole exposed along the west side of the northeast block extension (see Figure 6.22). Feature 26 lies ca. $1 \mathrm{ft}$ south of Feature 25, also a pier posthole, and the two features were profiled in a single linear excavation (see Figure 6.23b).

In plan view, Feature 26 was roughly rectangular. Two large brick fragments were exposed in the east half of the stain, and many smaller brick fragments were found throughout the exposure. The fill was a lighter brown than the surrounding dark brown clay loam, but it was not as light or sandy as the fill found in Feature 26 to the north.

The Feature 25 stain was bisected along its north-south axis, and the east half was removed and screened. The profile exposed a vertical shaft extending 6 inches below the excavation surface (see Figure 6.23b). The feature has a slightly rounded bottom. The western half of the feature was left intact. Only corroded iron nails were collected from the sandy fill in Feature 26.

\section{FEATURE 27}

An oval stain was exposed near the center of the northeast block extension, ca. $3 \mathrm{ft}$ northeast of Feature 25 (see Figures 6.22 and 6.23a). The feature was found at about 1 inch below the surface and appeared as a dark brown oval stain surrounded by a band of lighter soil. The $6 \times 8$-inch oval soil stain is interpreted as a postmold within a posthole, and it may have been a pier post. The lighter soil probably represents the excavated hole, while the darker soil may represent a post that deteriorated in place. Time did not permit additional investigation, and Feature 27 was not excavated. Its interpretation as a possible pier posthole is tentative.

\section{Possible Original West Wing Piers}

The idea that the original Levi Jordan plantation house had a west wing (attached to the north side on the west end) is a theory based on the fact that Greek Revival-style houses of the mid-nineteenth century were often built in a symmetrical pattern. We know that the house had an earlier east wing in the nineteenth century, and it is possible that it also had a west wing that was identical in shape and size. Features 20 and 28 are possible piers found north of the original house in locations that suggest they might be associated with a former west wing (see Figure 6.22). This interpretation is very tenuous, and the excavations in this area were much too limited to locate additional features that might be associated with an original west wing.

Another feature encountered in this area is mentioned because of its unusual nature and the remote possibility that it was a pier foundation. Feature 21 (see Chapter 8) consisted of a buried iron container full of rusted metal, nails, fragments of glass, ceramics, and other debris. This debris-filled container was placed into a circular hole and could have been a makeshift pad for a wooden pier. However, its location does not make sense as a foundation pier.

\section{FEATURE 20}

Feature 20 was exposed in a $1 \mathrm{x} 4$-ft exploratory trench excavated near the west end of Unit N5, a 3 -ft-wide by 21 -ft-long exploration along the north side of the west wing of the twentieth-century ell. In plan view, the postmold was 9x9 inches, fairly square in shape, and was first observed at 10.5 inches below the surface (Figure 6.24). The stain was bisected, and the western half was excavated to expose a northsouth profile. The upper 9 inches of the stain was relatively straight-edged and is interpreted as a square post. The stain narrows considerably from 19-23 inches below surface, and this 


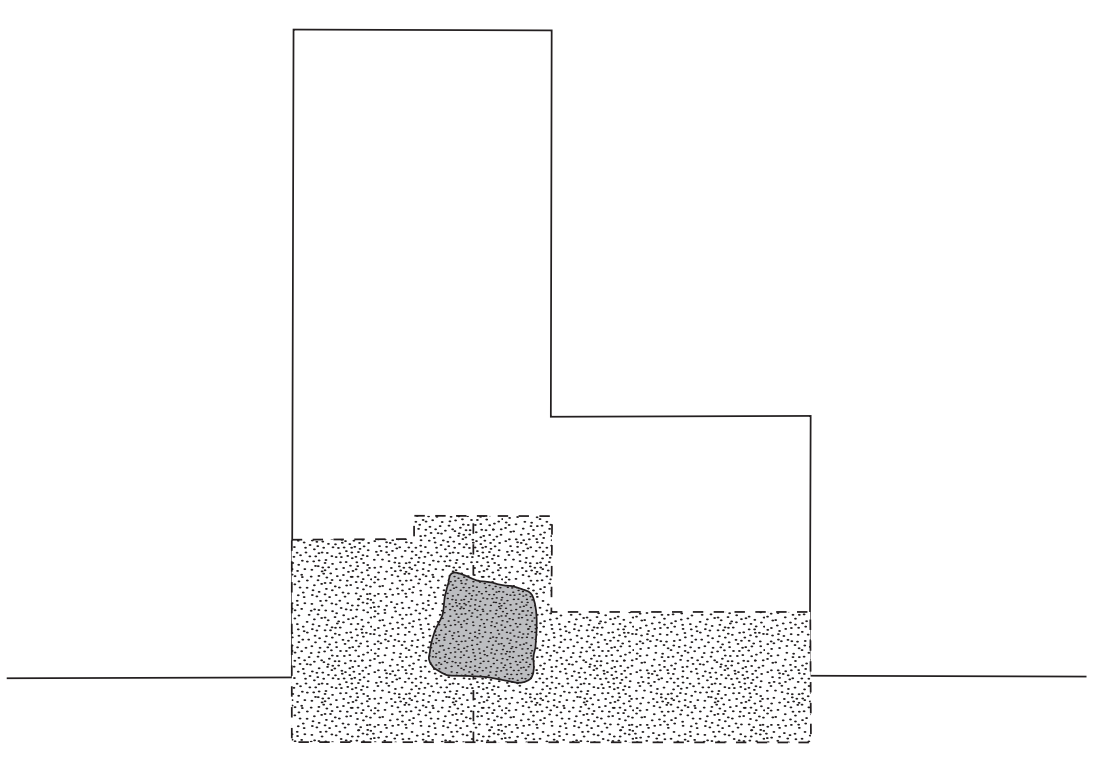

$L E G E N D$

Feature 20 Soil Stain

$\because \quad$ Mottled Grey Brown Soil

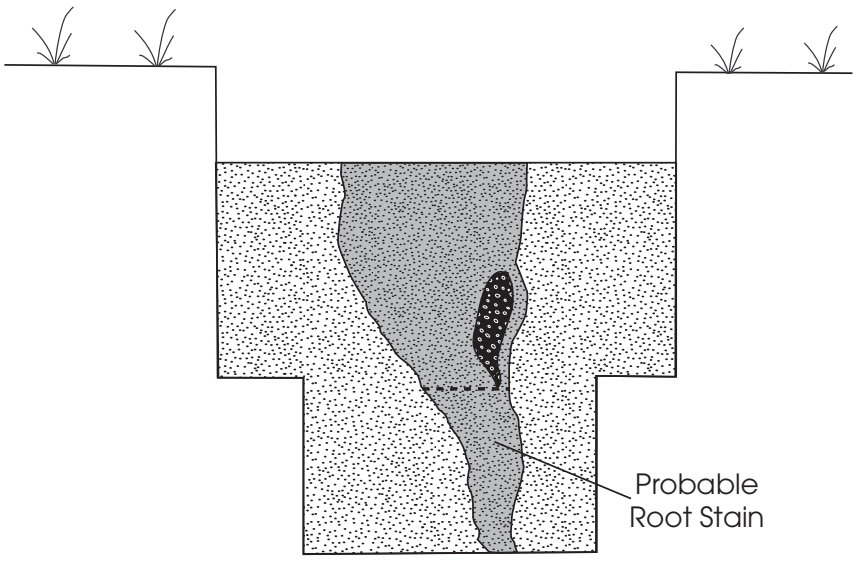

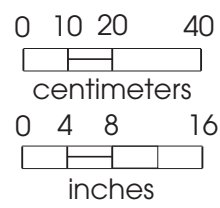

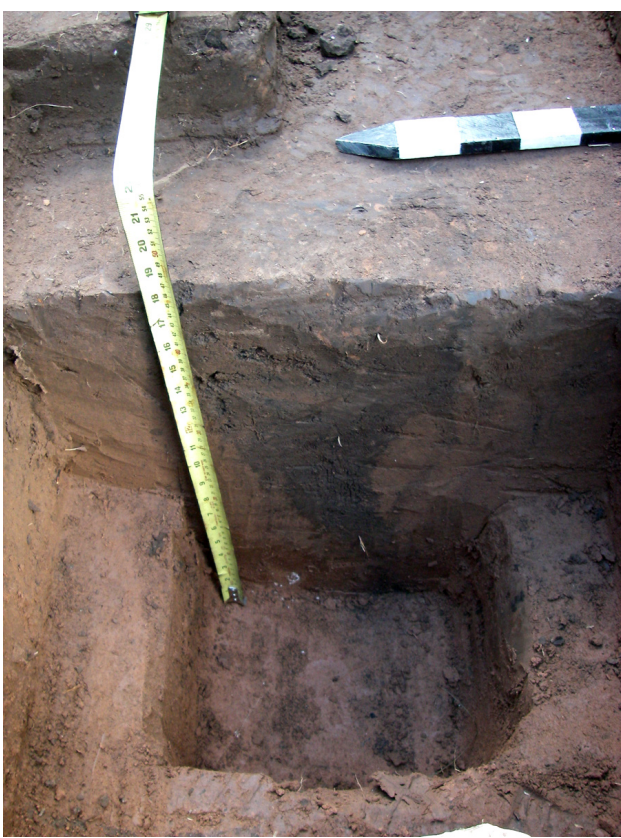

$P A I / 12 / B W$

Figure 6.24. Plan, profile, and photograph of Feature 20, a possible pier feature on the north side of the Levi Jordan house. Photo view is east, and the north arrow is $25 \mathrm{~cm}$ long (ca. 10 inches). 
lower portion is interpreted as a root that was intrusive into the existing post mold.

No artifacts were recovered from Feature 20. The eastern half of the feature was left intact.

\section{FEATURE 28}

Feature 28 is a circular stain containing some bricks, and it may be a pier posthole and footing (see Figure 6.22). The southern portion of the circular stain was exposed along the northern edge of the northwest block, and the excavation was extended northward to investigate the rest of the feature. When fully exposed, the Feature 28 plan view consisted of a roughly circular soil stain encompassing two handmade bricks and two brick fragments that were lying flat (Figure 6.25). The bricks are within an 8x8inch area, but they are surrounded by a band of lighter colored sediment that is roughly 16 to 17 inches in diameter, with a slightly darker arcshaped band on the north side. Thus, the entire soil stain is about $16 \times 20$ inches and represents an intrusive feature into the darker natural clay sediments. Feature 28 was not bisected or further investigated. The feature was covered with a thin layer of white sand to protect it when the area was backfilled.

It is likely that the oval stain represents a posthole and that the bricks were placed in the bottom of the hole as a post footing. The arch-shaped soil stain on the north appears to be part of the same posthole that was filled in with slightly different sediment. And the small circular stain probably represents the postmold where a wooden post deteriorated in place. In any case, Feature 28 appears to be a post feature, and its location suggests it may have been for a pier associated with an original west wing or porch attached to the Levi Jordan house.

\section{South Wall of Original House}

Features 30 and 31 were found underneath the concrete bench that was added in 1961 to serve as the foundation for the west end of the south wall of the original plantation house. They are located below the south wall in places that suggest they are probably pier features. These features were found at the end of the Phase II investigation and they were not excavated, so the interpretation that they are piers is tentative.

\section{FEATURE 30}

Feature 30 is a possible pier feature found when the concrete foundation beam (see Pier 37 in Figure 6.1) was removed from under the south wall of the Levi Jordan house. It was located about $3 \mathrm{ft}$ east of Pier Feature 29 and was first observed as a soil stain. Troweling of the area revealed that the feature consisted of a circular concentration of light brown sediment, ca. 12 inches in diameter, with three brick fragments (two being large half bricks) along the south edge. The bricks appear to be inside a larger oval posthole (ca. 16×19 inches), and the brown sand is probably where a wooden post rotted in place. The feature is definitely intrusive and appears to be a posthole with bricks wedged along one side of the post. Time constraints did not permit any additional investigation, but Feature 30 is most likely a twentieth-century replacement pier along the south wall. The location might be associated with an original antebellum pier (i.e., with a prepared brick footing deeper), but no additional excavations were conducted to investigate this possibility.

\section{FEATURE 31}

Feature 31 is a circular depression found when the concrete foundation beam (see Pier 37 in Figure 6.1) was removed from under the south wall of the Levi Jordan house. The irregular depression was about 15 inches in diameter, and some brick fragments were observed inside it. The depression was shovel-skimmed as part of a long hand-dug trench investigation under the south beam, but no footing was found. The tentative interpretation that it represents a pier posthole is based solely on its location under the south wall.

\section{Possible South Porch Piers}

Three sand-filled pits exposed in excavations on the south side of the house are designated as Features 11, 12, and 17. All of these features were underneath the concrete front porch that was built by a renter in December 1961 (see Chapter 4). When TPWD workers removed this concrete porch in 2002 , the concrete was sitting on a layer of sand that had been laid down as the base material. Consequently, it is likely that these three features are pier postholes 


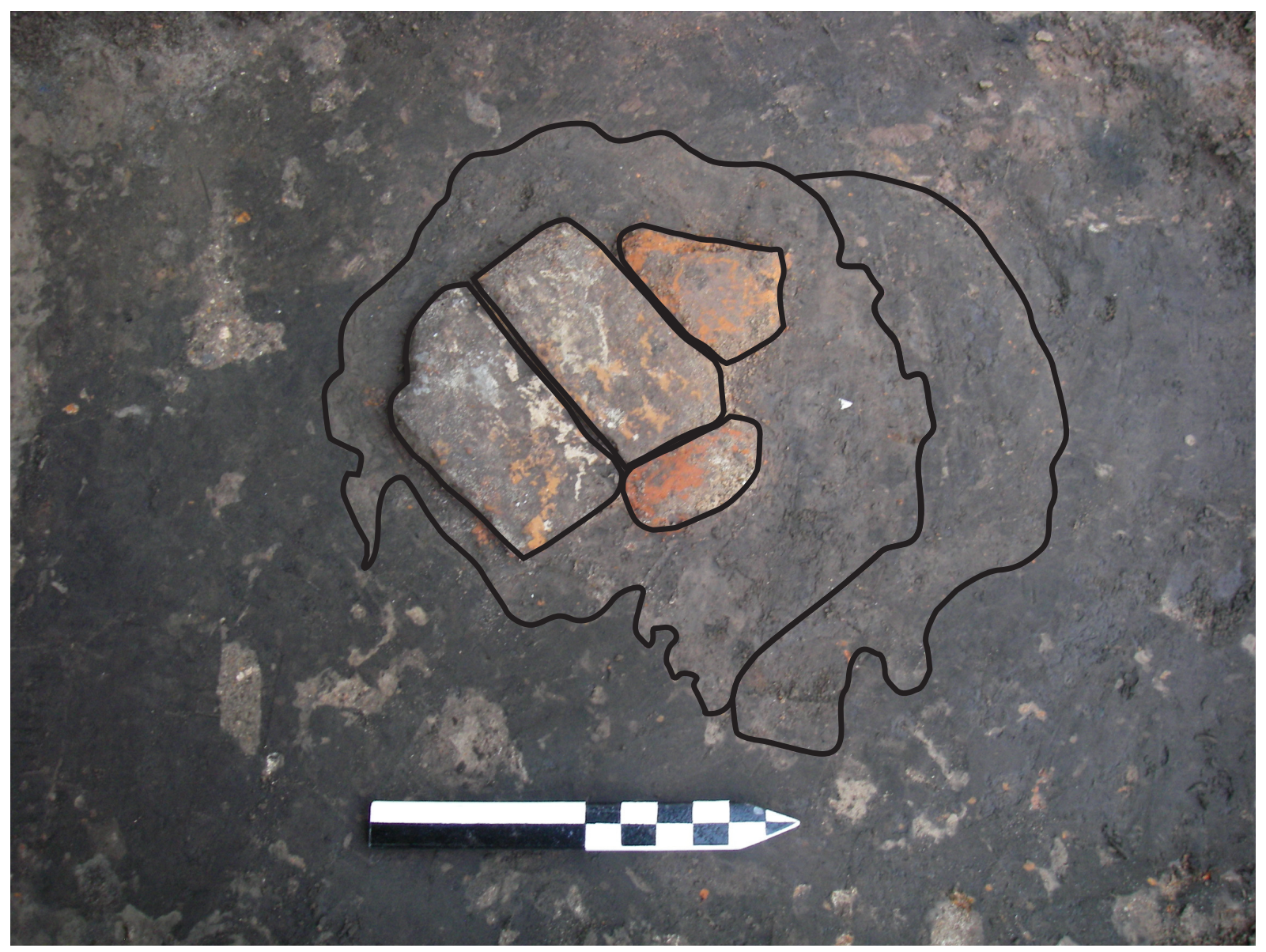

Figure 6.25. Feature 28, a possible pier posthole and brick footing. Photo view is to the west, and the north arrow is $1 \mathrm{ft}$ long.

associated with a previous front porch, and historic photographs reveal several different front porch variations in the twentieth century (see Figure 4.2). It is likely that an earlier wooden porch was removed during the 1961 construction episode and that the pier posts were pulled at that time. The construction sand was then laid down that filled in some of the pier holes before the concrete porch was poured.

\section{FEATURE 11}

Feature 11, an 11-inch-diameter circular post mold, was exposed in the northeast corner of Unit D4 and the southeast corner of Unit D3. The feature appeared as a circle of pale brown fine sand surrounded by the natural dark brown clay, and it was first observed at the base of a the extensive 10-inch-thick sand layer laid down under the concrete porch that was constructed in
1961. The conical post mold extended 21 inches below the contact between the sand layer and the dark brown clay. Feature 11 is interpreted as an old porch pier that was removed when the 1961 porch was added. When the pier post was pulled, a sizable hole remained and was immediately filled with the construction sand. No artifacts were present below the 1961 sand.

\section{FEATURE 12}

Feature 12 was exposed in Units D4 and D9. It was first observed in the west wall of Unit D4, where it measured 11.5 inches wide (north-south) at the bottom of the construction sand layer ( 8 inches below the modern ground surface). It extended 10 inches into the dark brown clay loam, ending with a flat bottom at about 18 inches below the surface (Figure 6.26a). Subsequent excavation of Unit D9 to 
the west revealed that it was probably a square or rectangular hole in plan view. Although disturbances to the sediments on the east side of this feature confused its interpretation, Feature 12 compares favorably with the other two sandfilled possible pier holes.

Artifacts collected from the feature fill include $3.8 \mathrm{~g}$ of window glass and a metal can fragment. It is likely that these materials were introduced during the 1961 porch construction episode.

\section{FEATURE 17}

Feature 17 is the most distinct of the three possible south porch piers, and its location is the most revealing. The feature was exposed in the southwest corner of Unit D13 while investigating the north side of the front porch steps (see Chapter 8).A 10.5-inch-diameter soil stain was found about 1 inch north of the porch steps (Figure 6.26b). It was first observed 11 inches below the ground surface, which was at the bottom of the artificial sand layer for the concrete porch. At this depth, the stain appeared as a circle of grayish brown sand surrounded by the natural dark gray clay loam. Initially, half of the feature was excavated for a profile, and a rounded bottom of the sandfilled pit was clearly defined at 21 inches below the surface, or 10 inches below the sand layer. The remainder of the feature was then excavated.

Artifacts collected from the Feature 17 fill were $2.3 \mathrm{~g}$ of window glass, one bone fragment, one wire nail, three unidentifiable nails, $5.8 \mathrm{~g}$ of bulk nails, and $198.8 \mathrm{~g}$ of bulk metal. It is probably that these items were introduced into the Feature 17 pit during the 1961 porch construction episode.

\section{Possible East Porch Piers}

\section{CAS FEATURE 6}

In their 2005 excavations, CAS archeologists uncovered one feature east of the east wing of the ell addition that may be a pier posthole, perhaps associated with an east porch (see Figure 3.5). They exposed a well-defined rectangular soil stain in the southeast corner of Unit E2 that was designated as Feature 6 (Leezer 2006:51). Feature 6 was identified at 16 inches below the surface and it was defined by both a color and texture change in the sediment. It was a lighter brown and softer soil, surrounded by darker and more compact sediment. The feature measured $10 \times 12$ inches in plan view. CAS archeologists did not excavate the feature, but it appeared to extend into the south and east walls of the unit. CAS recovered many artifacts from Unit E2, but none are mentioned as being directly associated with Feature 6.

During the Phase I investigations, PAI excavated Unit E6 immediately south of CAS's Unit E2. The edge of their old unit was found along the northern edge of Unit E6, as was the edge of an older University of Houston excavation unit in the southeast quadrant of E6. However, the Unit E6 excavation did not find any evidence of CAS's Feature 6 at $16 \mathrm{~cm}$ below the surface. This indicates that the Feature 6 soil stain may be confined to the small rectangular area in the southeast corner of Unit E2 (although excavations to the east would be needed to confirm this).

CAS's Feature 6 may well be an intrusive hole associated with a pier post that was subsequently removed, but its location is puzzling. It could be a corner pier associated with a previous east wing addition or, perhaps more likely, a pier associated with a former east porch. Since Feature 6 was found at $16 \mathrm{~cm}$ below the surface and was covered by the dense layer of brick rubble, the evidence suggests that Feature 6 predates the brick rubble layer that may be associated with the collapse of the original east wing chimney. The brick rubble zone in this area, designated Feature 9, is discussed in Chapter 8.

The idea that there was once a wooden porch on the east side of the east wing is based on circumstantial evidence. The hypothesis that Feature 6 is a pier feature associated with a former east wing porch is certainly testable. Excavation of Feature 6 might find evidence of a pier pad that would indicate it was a pier post of some kind, or it might show that there is no pier pad deeper in the hole and that a post was probably set directly into the ground. This alone would be inconclusive. The proof that this feature was a pier posthole associated with a larger architectural feature, such as an east wing porch, could only come from block excavations that reveal interpretable alignments of similar posthole features.

\section{Possible West Porch Piers}

Three features exposed along the west side of the original house are interpreted as postholes 


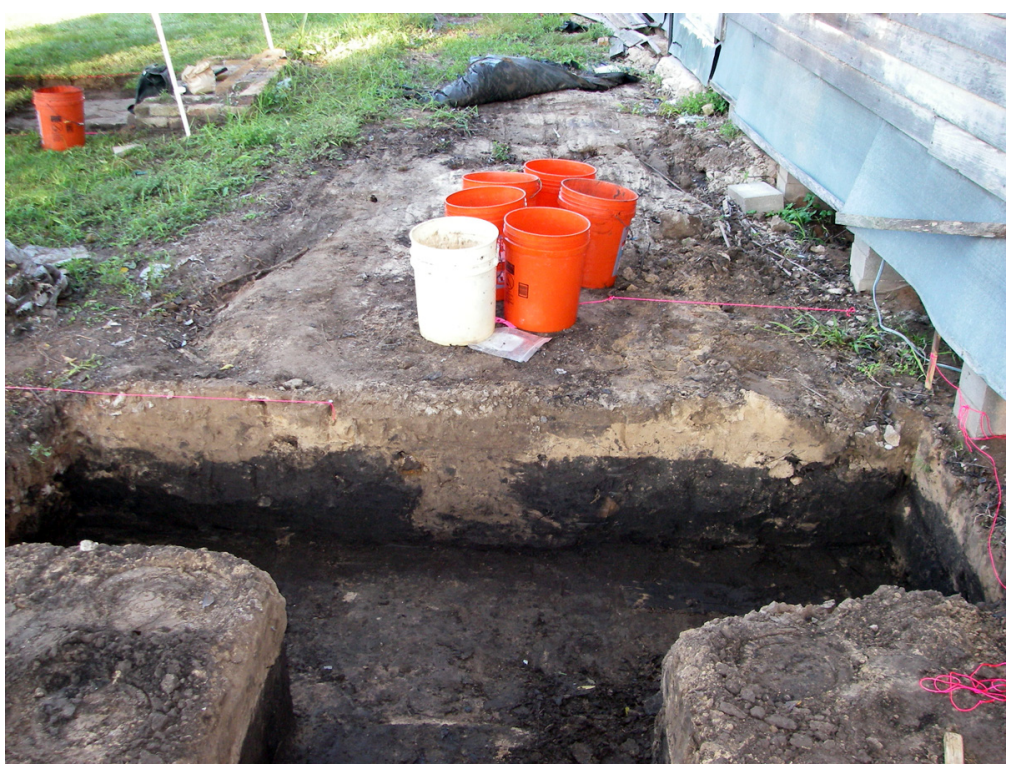

a

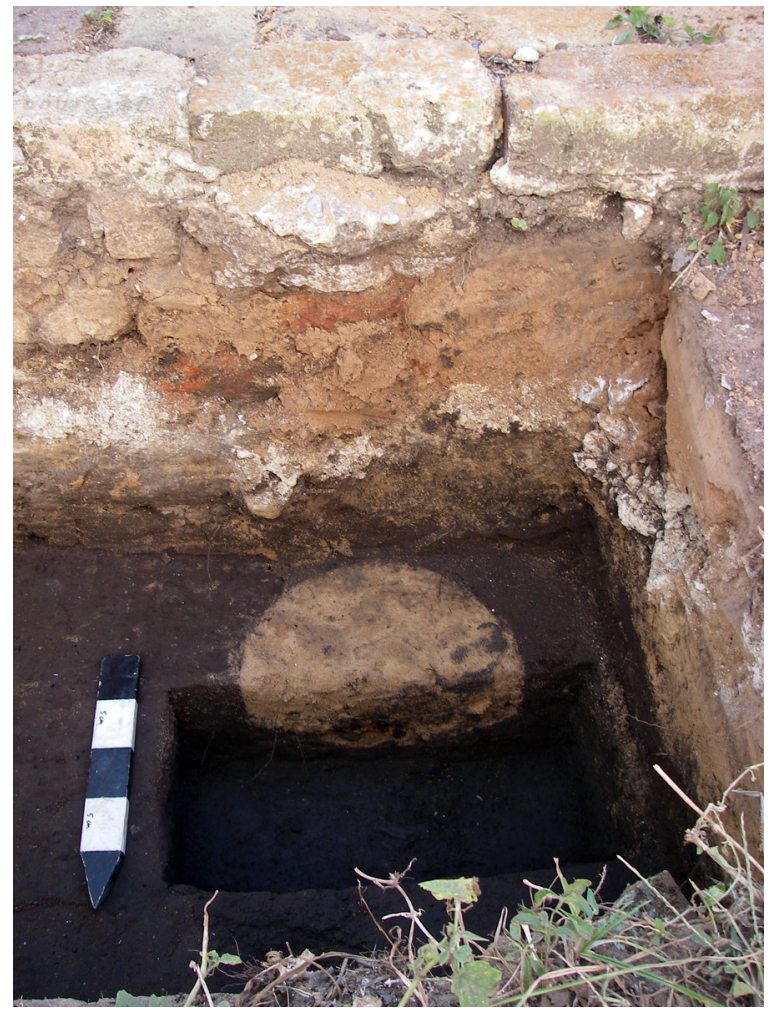

b

Figure 6.26. Possible pier Features 12 and 17. (a) View west of Feature 12 soil stain in the west wall of Unit D9. Note the construction sand layer at the top of the profile. (b) View south of the Feature 17 soil stain on the north side of the front porch steps. The north arrow is $25 \mathrm{~cm}$ long (ca. 10 inches). 
that are probably piers associated with a west porch (Figure 6.27). Features 13, 18, and 19 are roughly circular soil stains, each spaced ca. $3 \mathrm{ft}$ apart, that run in a line west-southwest from the southwest corner of the house. While the easternmost of these three features (Feature 13) was found by chance, the excavations in this area were then expanded to look for other possible postholes after seeing a porch-like structure in a historic photograph of the Levi Jordan house (Figure 6.28).
Half of Feature 13 was excavated, but Features 18 and 19 were only seen in plan view and not excavated. The similar nature of these three soil stains as first encountered, along with their alignment running west from the corner of the house, provides strong circumstantial evidence that they belong to the same structure. While not conclusive, the historic photograph suggests that the south porch wrapped around the southwest corner of the house and continued along the west side in the early twentieth century. The inter-

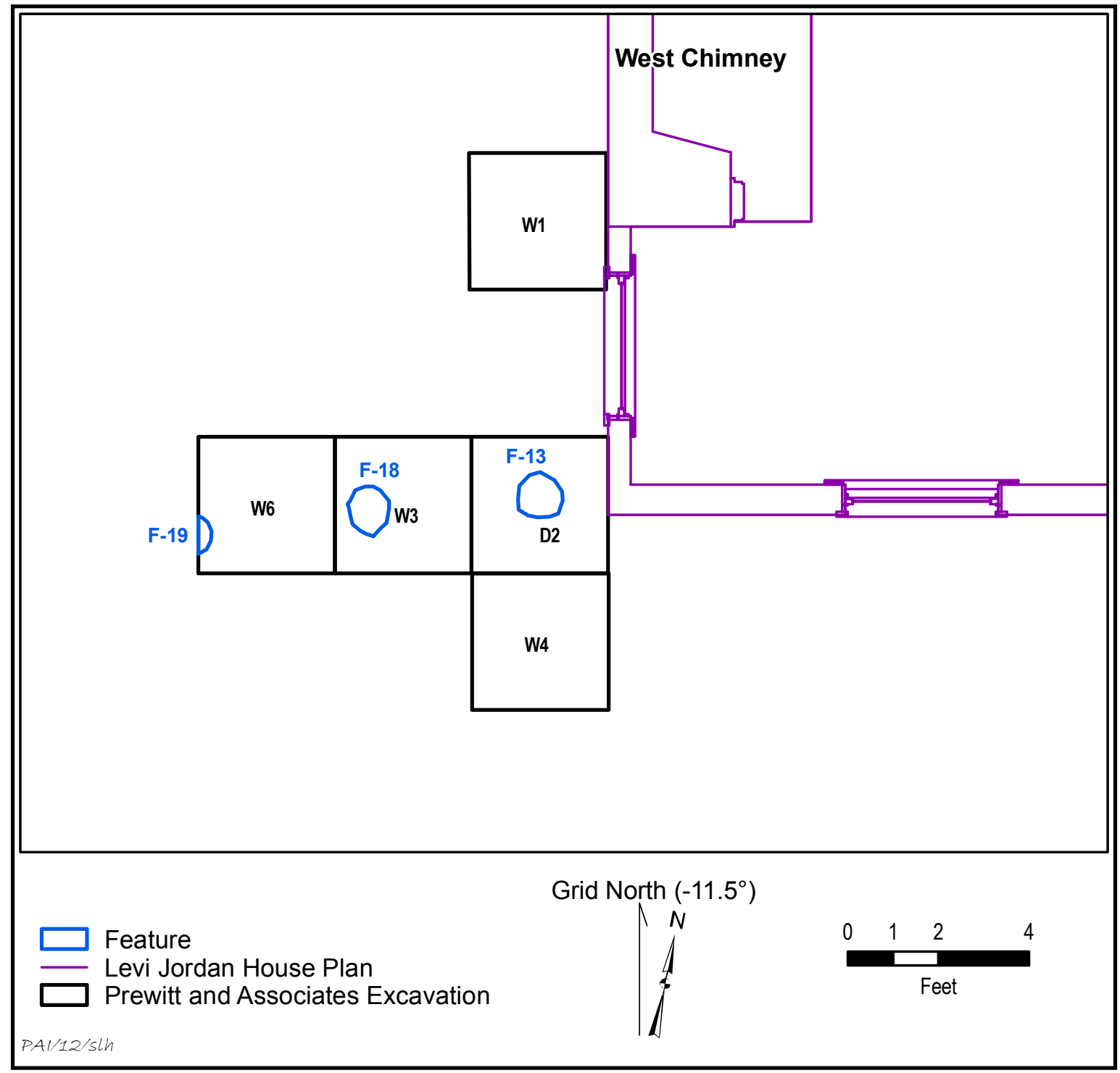

Figure 6.27. Map showing the locations of Features 13, 18, and 19 at the southwest corner of the original house. These features are tentatively interpreted as pier postholes associated with a porch on the west side of the house. 


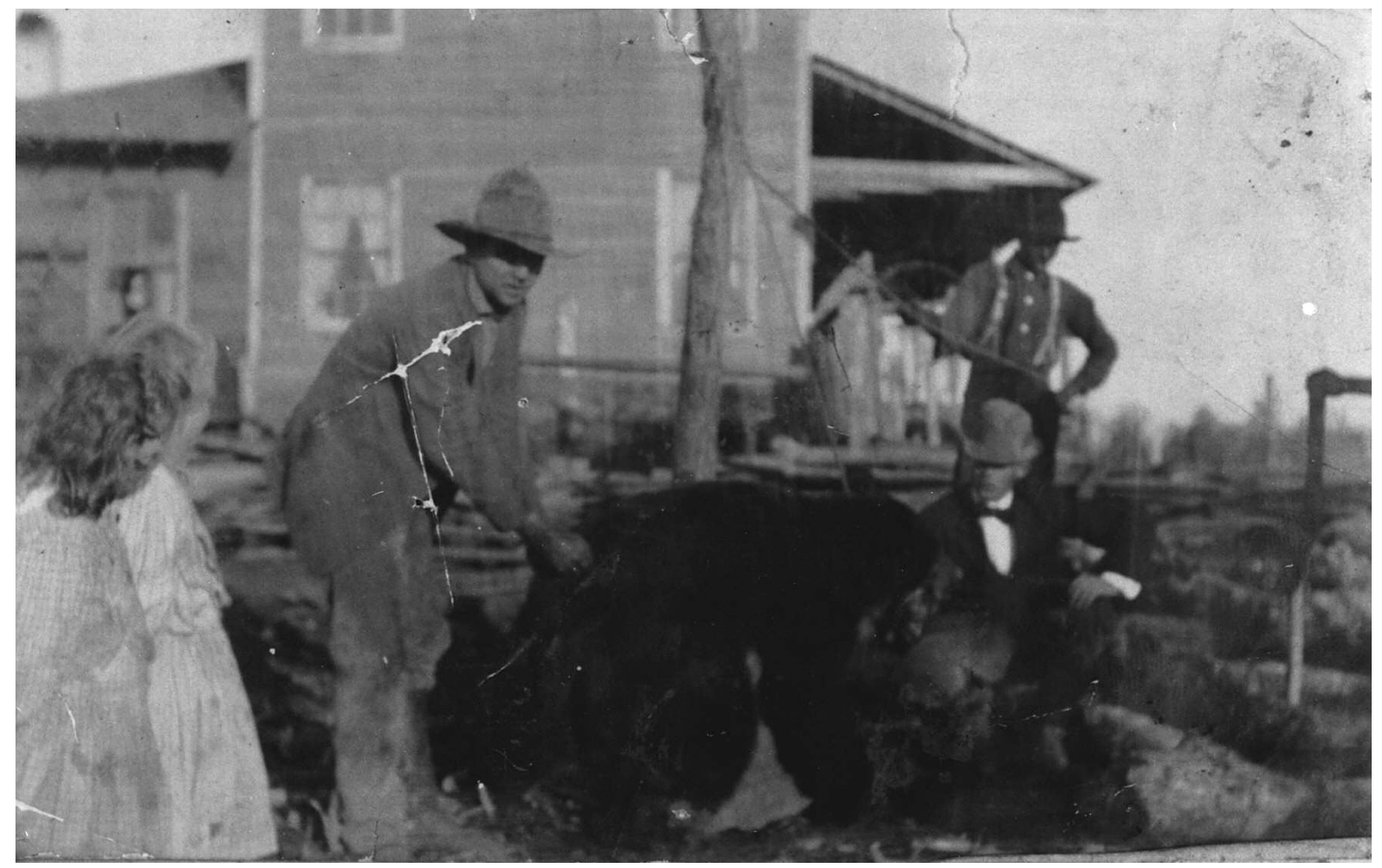

Figure 6.28. Historic photograph that shows a possible deck or porch structure on the west side of the Levi Jordan house. The date of the photograph is unknown, but it is believed to date around 1905. Photograph by Bruce Gotcher in the Texas Parks and Wildlife collection. Courtesy of the Texas Historical Commission.

pretation of a possible west porch is discussed more at the end of this section.

\section{FEATURE 13}

Feature 13 was found by PAI archeologists when they reexcavated CAS Unit D2 at the southwest corner of the house. This soil stain is visible in a CAS photograph of the unit (Leezer 2006:Figure 5-13) immediately north of the Feature 5 brick pad and west of the "brick footing" (now identified as part of Pier 1). PAI reopened the unit to explore the southwest corner house pier and to investigate Feature 5 (interpreted as a possible rain barrel pad; see Chapter 8).

In the Unit D2 reexcavation, the top of the Feature 13 soil stain was found at 16 inches below the surface, where it measured 12 1/2 inches east-west by 10 inches north-south. Feature 13 was then bisected along its north-south axis, with a 12x18-inch excavation down to 37 inches below the surface. The west half of the feature was removed for this profile, and the east half was left intact. A piece of clear plastic was draped over the excavation pit prior to backfilling.

In profile, Feature 13 was 10 to 11 inches wide near the top and it tapered to 7 inches wide at 37 inches below the surface (Figure 6.29). The pit was filled with brown silty clay (7.5YR 4/4) mottled with very dark grayish brown to dark brown (10YR 3/2 to $2 / 2$ ) silty clay. Within this posthole is a 5.5-inch-wide column of dark brown (10YR 2.1) silty clay. This darker fill was homogenous and had almost no mottling, and it represents the postmold where a wooden post rotted in place. The bottom of the postmold was at 33 inches below the surface, and its base was flat. The post was either round or rectangular. The base of the posthole was not reached since it began to taper at its base, but it is probably not much deeper than 37 inches.

A variety of artifacts were found in the Feature 13 posthole fill, including many small brick fragments, most of which are less than 


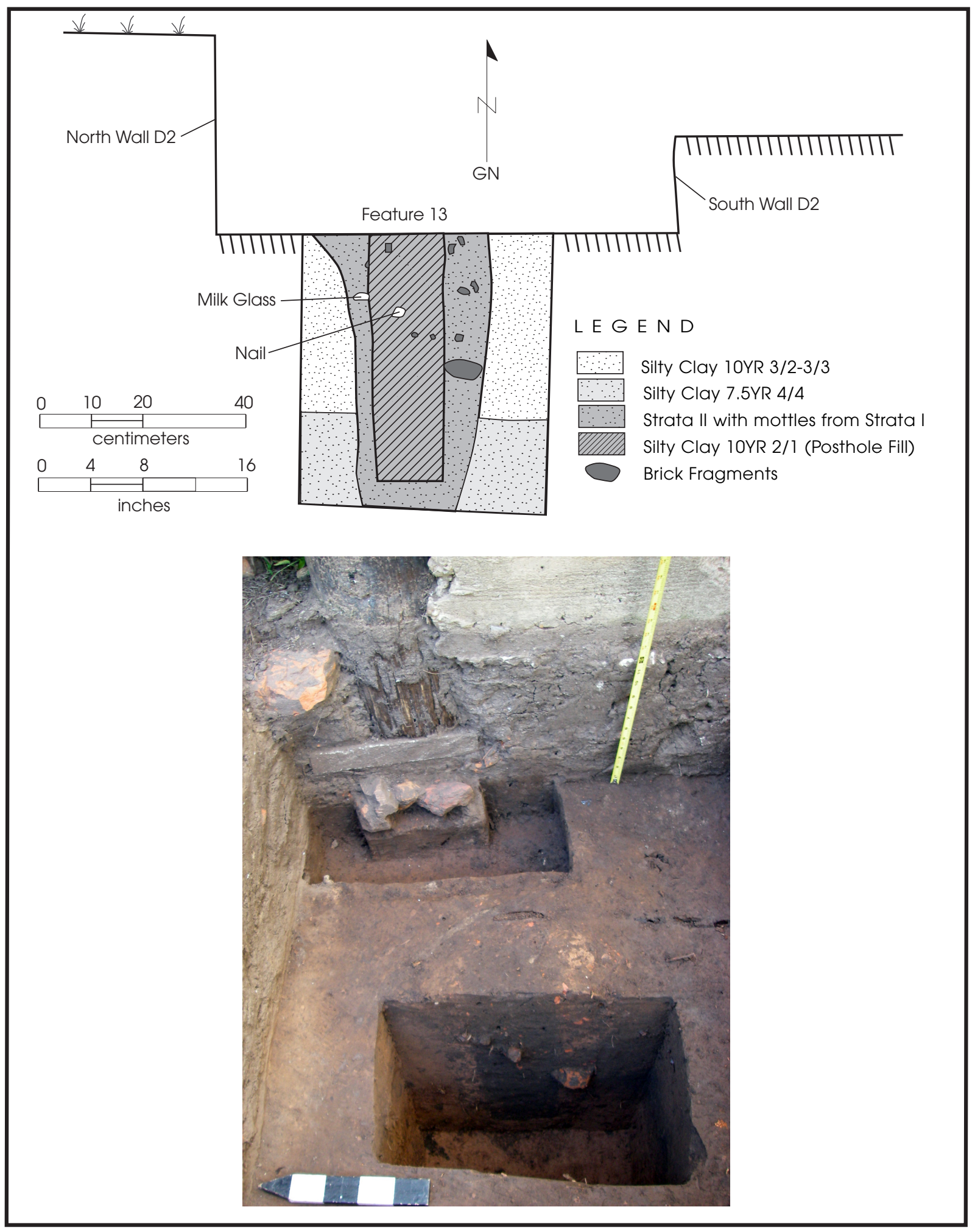

Figure 6.29. Photograph and profile of Feature 13, a possible west porch pier. The photograph is looking east with the southwest corner pier of the main house in the background. The north arrow is $25 \mathrm{~cm}$ long (ca. 10 inches). 
1/2 inch. A large nail was found in the post stain at 21 inches below the surface. Other artifacts collected from 16 to 37 inches include three undecorated whiteware sherds, $221.1 \mathrm{~g}$ of window glass, three pieces of clear container glass, a piece of laminated pink-and-white milk glass, a white glass canning jar lid (marked "Boyd's"), 10 square nails, 21 unidentifiable nails, one bone fragment, and $114.7 \mathrm{~g}$ of bulk nails. It is notable that all the identifiable nails are square nails, perhaps indicating that Feature 13 construction may date to the nineteenth century.

One other unusual artifact was recovered from the Feature 13 fill at 16-37 inches below the surface. A round disc of white metal with a central hole (Figure 6.30) was recovered in the 1/4-inch screen, so its exact location within the feature is unknown. The disc is generally round but slightly irregular. It weights $14 \mathrm{~g}$ and is $14 \mathrm{~mm}$ in diameter and 0.7 to $1.0 \mathrm{~mm}$ thick. The disc is almost flat but curves slightly near two edges. An irregular oval-shaped hole ca. 2.21 to $2.25 \mathrm{~mm}$ in diameter appears to have been punched through the disc just off center. Because it is slightly lopsided, the disc may have been cut out of sheet metal and then ground into its rounded form. The white metal has not been identified, but it is probably some type of alloy.

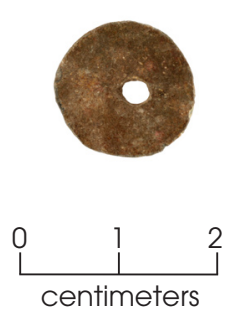

Figure 6.30. The perforated white metal disc recovered from the fill in possible pier Feature 13 (Lot 2010-2).

This perforated metal disc may be an important artifact for relative dating of Feature 13 and the possible west porch. This object is potentially significant because of who may have made it and how it may have gotten into this pier posthole. This artifact is discussed more at the end of this chapter.

\section{FEATURE 18}

Feature 18 was found about $3.75 \mathrm{ft}$ west of Feature 13 (measured center to center) in Unit W3. A rough circular stain was exposed at 19 inches below the surface. The unit was excavated to 21.5 inches below the surface, where the soil stain was mapped and photographed, but it was not bisected or excavated. The feature consisted of a circular stain of dark homogenous brown sediment 9 inches in diameter, surrounded by a band of slightly lighter sediment that measured about $11 \times 13$ inches.

This feature would not be disturbed by the house stabilization work, so it was left intact for future investigations, and the bottom of Unit W3 was lined with landscape fabric before being backfilled.

\section{FEATURE 19}

The eastern half of a circular stain (Feature 19) about 8.5 inches in diameter was found at 19 inches below the surface in Unit W6. At this depth, the stain appeared to be a posthole, and there was no evidence of a deteriorated postmold inside it as was seen in Features 13 and 18. A possible root disturbance was observed just beyond the northeast edge of the stain.

The excavation of Unit W6 was terminated at this point, and no attempt was made to expand the excavations to the west. Since Feature 19 would not be impacted by the house stabilization work, it was left in place for future investigation. The base of the unit was covered with landscape fabric before being backfilled.

\section{INTERPRETATION OF PIER GROUPS AND ARCHITECTURAL ASSOCIATIONS}

\section{Variability in Pier Construction and Modification}

The construction of the Levi Jordan foundation piers varies considerably, with some characteristics attributed to different construction periods and other characteristics attributed to repair episodes such as replacing pier posts or wedging objects into the ground or between the posts and foundation as shims. In some cases, an original pier was replaced with a new footing and post. The foundation 
piers are probably associated with many different construction and repair periods, from the original house construction in the 1850 s to recent repairs as late as the $1980 \mathrm{~s}$. Some piers do not appear to have been repaired at all, but many have obvious evidence of at least one modification, and some were modified several times. In some cases, entirely new foundation support structures were built over or next to failing piers. The most prominent example is the 30 -ft-long section of poured concrete along the west half of the front (south) edge of the original house, which replaced several old foundation piers. In other places, railroad ties were laid horizontally to serve as a makeshift or temporary pier (see Pier K1), and concrete blocks were stacked on either side of deteriorating wooden piers (see Piers 2 and 38).

Many of the repair episodes involved placing shims or wedges around or below the edges of pier posts. This was undoubtedly done because pier posts deteriorated underground and became unstable, and the simple temporary fix was to add a shim or wedge. A wide variety of materials were used as shims and wedges (see Table 6.1). Shimming above the post usually consisted of hammering lumber, such as $1 \mathrm{x} 4$-inch or $1 \mathrm{x} 6$-inch boards, between the post and the foundation. But shims were also made out of wooden tongueand-groove flooring, plywood, and other pieces of thin lumber. Wedges were objects shoved in along the sides of the posts or underneath posts, and the latter usually required some digging to expose the deteriorating post bottoms. Since the handmade bricks at Levi Jordan are poorly fired, most became soft and crumbly due to periodic wetting and drying, and the brick pier footings sometimes failed. Many of these were repaired by adding complete or partial new footings of poured concrete, stacked lumber, linoleum, corrugated fiberglass, and whole bricks or crushed brick fragments (both modern and reused handmade bricks).

It is important to remember that the pier attributes recorded for this project are rarely representative of their original construction. In many cases, the attributes documented archeologically reflect a long and sometimes complex evolution, with some modifications being obvious and others more difficult to discern. Even when repair was apparent, it was usually impossible to determine when those later changes occurred except in a very gross chronological sense. Per- haps the most important contribution of this work, however, is the ability to define the characteristics of the original antebellum piers and what distinguishes them from the later piers and modifications.

\section{Pier Groups and Architectural Associations}

The pier investigations revealed basic construction differences that relate to the architectural chronology of the Levi Jordan house. Four basic pier groups are defined for the original antebellum house (Figure 6.31; Table 6.3). Group 1 piers are the original piers around the perimeter of the 20x60-ft antebellum house, and these were probably constructed in 1853 (see Chapter 9). Each of these piers was originally composed of a live oak log section placed on top of a handmade brick pad consisting of one to three courses of bricks. Although most of these piers were subject to one or more repair episodes, they all retain remnants of their original brick footings. Modifications to the original antebellum perimeter piers usually involved replacing the oak logs with other pier posts and, frequently, the removal and replacement of part of the original brick footing. In some cases, the original brick footings were still in place, but portions of them had been crushed from the weight of the structure.

The 13 Group 1 piers are not evenly distributed around the house, but this pattern does not reflect the complete picture of the original piers. There was only a short time to search and investigate possible piers along the south wall in the disturbed area where the 1961 concrete foundation beam was removed. Since the entire south wall area was trenched, it is unlikely that any original piers were missed. It is more likely that the original piers were obliterated by the 1961 porch and foundation beam construction. Many more piers were investigated on the north wall of the house, so the pattern of original 1850s house piers there is more complete. The placement of the original piers is not as uniform as expected. Interestingly, no evidence of intrusive features was found in some key areas where original piers were suspected, and there are at least two 10-ft gaps between piers on the north wall that are not easily explained. In contrast, two of the original north wall piers seem to be spaced quite close together (M1 and L1 are 2 to 


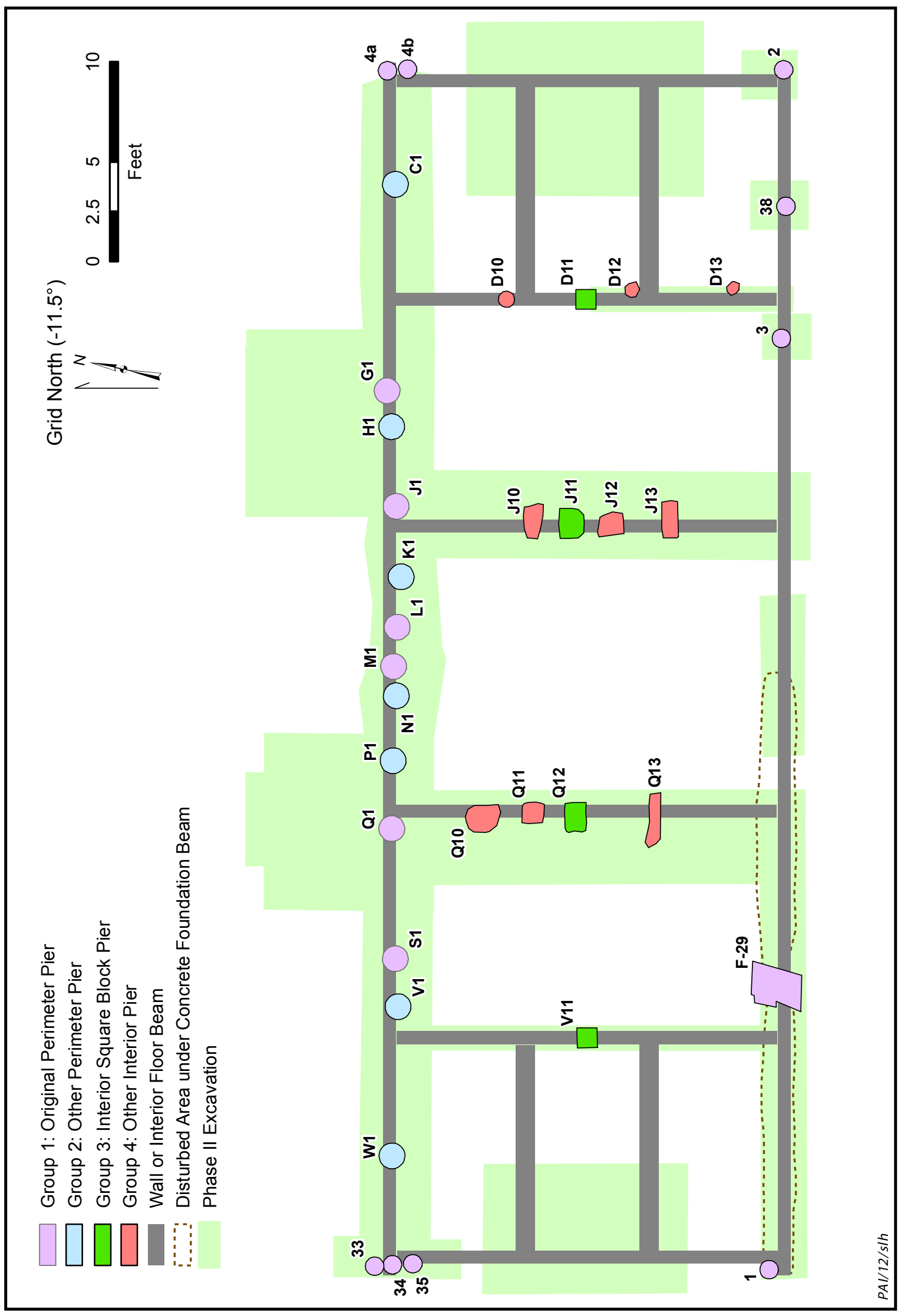

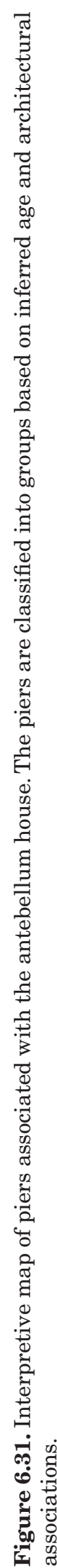


Table 6.3. Summary of foundation piers by group and inferred age

\begin{tabular}{|c|c|c|c|}
\hline $\begin{array}{c}\text { Pier } \\
\text { Location }\end{array}$ & Pier Number & Pier Group & Inferred Age \\
\hline \multicolumn{4}{|c|}{ PIERS ASSOCIATED WITH THE ANTEBELLUM HOUSE } \\
\hline \multicolumn{4}{|c|}{ Original Corner Piers } \\
\hline & Pier 1 , southwest corner & Group 1 & 1853 \\
\hline & Pier 2, southeast corner & Group 1 & $1853^{*}$ \\
\hline & Pier 4, northeast corner & Group 1 & 1853 \\
\hline & Piers 33, 34, and 35, northwest corner & Group 1 & 1853 \\
\hline \multicolumn{4}{|c|}{ Original North Wall Piers } \\
\hline & Pier G1 & Group 1 & 1853 \\
\hline & Pier J1 & Group 1 & 1853 \\
\hline & Pier L1 & Group 1 & 1853 \\
\hline & Pier M1 & Group 1 & 1853 \\
\hline & Pier Q1 & Group 1 & 1853 \\
\hline & Pier S1 & Group 1 & 1853 \\
\hline \multicolumn{4}{|c|}{ Original South Wall Piers } \\
\hline & Pier 3 & Group 1 & 1853 \\
\hline & Pier 38 & Group 1 & 1853 \\
\hline & Feature 29 & Group 1 & 1853 \\
\hline \multicolumn{4}{|c|}{ Other Piers on the Shared North Wall } \\
\hline & Pier C1 & Group 2 & Unknown, late 19 th or early 20 th century \\
\hline & Pier H1 & Group 2 & Unknown, late 19 th or early 20 th century \\
\hline & Pier K1 & Group 2 & Unknown, late 19 th or early 20 th century \\
\hline & Pier N1 & Group 2 & Unknown, late 19 th or early 20 th century \\
\hline & Pier P1 & Group 2 & Unknown, late 19 th or early 20 th century \\
\hline & Pier V1 & Group 2 & Unknown, late 19 th or early 20 th century \\
\hline & Pier W1 & Group 2 & Unknown, late 19 th or early 20 th century \\
\hline \multicolumn{4}{|c|}{ Interior Piers Centered Under the House } \\
\hline & Pier D11 & Group 3 & Unknown, possibly 19th century \\
\hline & Pier J11 & Group 3 & Unknown, possibly 19th century \\
\hline & Pier Q12 & Group 3 & Unknown, possibly 19th century \\
\hline & Pier V11 & Group 3 & Unknown, possibly 19th century \\
\hline \multicolumn{4}{|c|}{ Other Interior Piers } \\
\hline & Pier D10 & Group 4 & Probably latter half of the 20 th century \\
\hline & Pier D12 & Group 4 & Probably latter half of the 20th century \\
\hline & Pier D13 & Group 4 & Probably latter half of the 20 th century \\
\hline & Pier J10 & Group 4 & Probably latter half of the 20th century \\
\hline & Pier J12 & Group 4 & Probably latter half of the 20th century \\
\hline & Pier J13 & Group 4 & Probably latter half of the 20th century \\
\hline & Pier Q10 & Group 4 & Probably latter half of the 20 th century \\
\hline & Pier Q11 & Group 4 & Probably latter half of the 20 th century \\
\hline & Pier Q13 & Group 4 & Probably latter half of the 20th century \\
\hline \multicolumn{4}{|c|}{ PIERS ASSOCIATED WITH THE TWENTIETH-CENTURY ELL } \\
\hline \multicolumn{4}{|c|}{ East Wing Piers } \\
\hline & Pier 5 (B1) & Group 5 & Early 20th century \\
\hline & Pier $6(\mathrm{~B} 2)$ & Group 5 & Early 20th century \\
\hline & Pier $10(\mathrm{~B} 6)$ & Group 5 & Early 20th century \\
\hline & Pier 11 (D7) & Group 5 & Early 20th century \\
\hline & Pier 13 (G4) & Group 5 & Early 20th century \\
\hline
\end{tabular}


Table 6.3, continued

\begin{tabular}{|c|c|c|c|}
\hline \multirow[t]{2}{*}{$\begin{array}{c}\text { Pier } \\
\text { Location }\end{array}$} & Pier Number & Pier Group & Inferred Age \\
\hline & Pier 16 (J5?) & Group 5 & Early 20 th century \\
\hline \multicolumn{4}{|c|}{ POSSIBLE PIER FEATURES } \\
\hline \multicolumn{4}{|c|}{ North of Original House } \\
\hline & Feature 22 & Posthole & Unknown, possibly 19th century \\
\hline & Feature 25 & Posthole & Unknown, possibly 19th century \\
\hline & Feature 26 & Posthole & Unknown, possibly 19th century \\
\hline & Feature 27 & Posthole & Unknown, possibly 19th century \\
\hline \multicolumn{4}{|c|}{ Possible Original West Wing } \\
\hline & Feature 20 & Posthole & Unknown, possibly 19th century \\
\hline & Feature 28 & Posthole & Unknown, possibly 19th century \\
\hline \multicolumn{4}{|c|}{ South Wall of Original House } \\
\hline & Feature 30 & Posthole & Unknown, possibly 19th century \\
\hline & Feature 31 & Posthole & Unknown, possibly 19th century \\
\hline \multicolumn{4}{|c|}{ Possible South Porch } \\
\hline & Feature 11 & Posthole & Unknown, possibly 19th century \\
\hline & Feature 12 & Posthole & Unknown, possibly 19th century \\
\hline & Feature 17 & Posthole & Unknown, possibly 19th century \\
\hline \multicolumn{4}{|c|}{ Possible East Porch } \\
\hline & CAS Feature 6 & Posthole & Unknown, possibly 19th century \\
\hline \multicolumn{4}{|c|}{ Possible West Porch } \\
\hline & Feature 13 & Posthole & Before $1905^{* *}$ \\
\hline & Feature 18 & Posthole & Possibly before 1905 \\
\hline & Feature 19 & Posthole & Possibly before 1905 \\
\hline
\end{tabular}

* Pier 2 is the only foundation pier that can be directly dated by an artifact association. All other Group 1 piers are assigned the same date.

** Feature 13 is tentatively dated based on a historic photograph.

$2.5 \mathrm{ft}$ apart), and this, too, is puzzling. Excluding the four corner piers, the absence of piers under the east and west walls is easily explained by the fact that the chimney footings served as the foundation for the east and west walls as well as the main floor beams under the east and west rooms.

The live oak posts used in the Group 1 piers ranged from 17.5 to 21 inches in diameter. These large log posts were only found under the walls of the antebellum house, and none were found underneath the house, under the twentiethcentury ell addition, or in the investigated areas outside the structures. The original pier features on the north wall of the original house were better preserved because they had been protected from the weather since the ell was built in the early twentieth century. In contrast, the piers on the four corners of the original house were in relatively poor shape and had been modified extensively because they had deteriorated faster than the others. The original pier footings for the northwest corner (Pier 33/34/35) and southwest corner (Pier 1) were virtually obliterated in repair episodes, and only one of the four corners still had its original oak timber post in place (Pier 2).

Excavations of the footings below the oak posts revealed that they were generally square or rectangular brick pads, but they were not uniform in size or shape. Figure 6.32 illustrates the diversity of the pier footings associated with the antebellum house, and Table 6.4 summarizes the pier footing data. Some of the original pier footings were pads of neatly arranged bricks, while others appear to have been haphazard. 


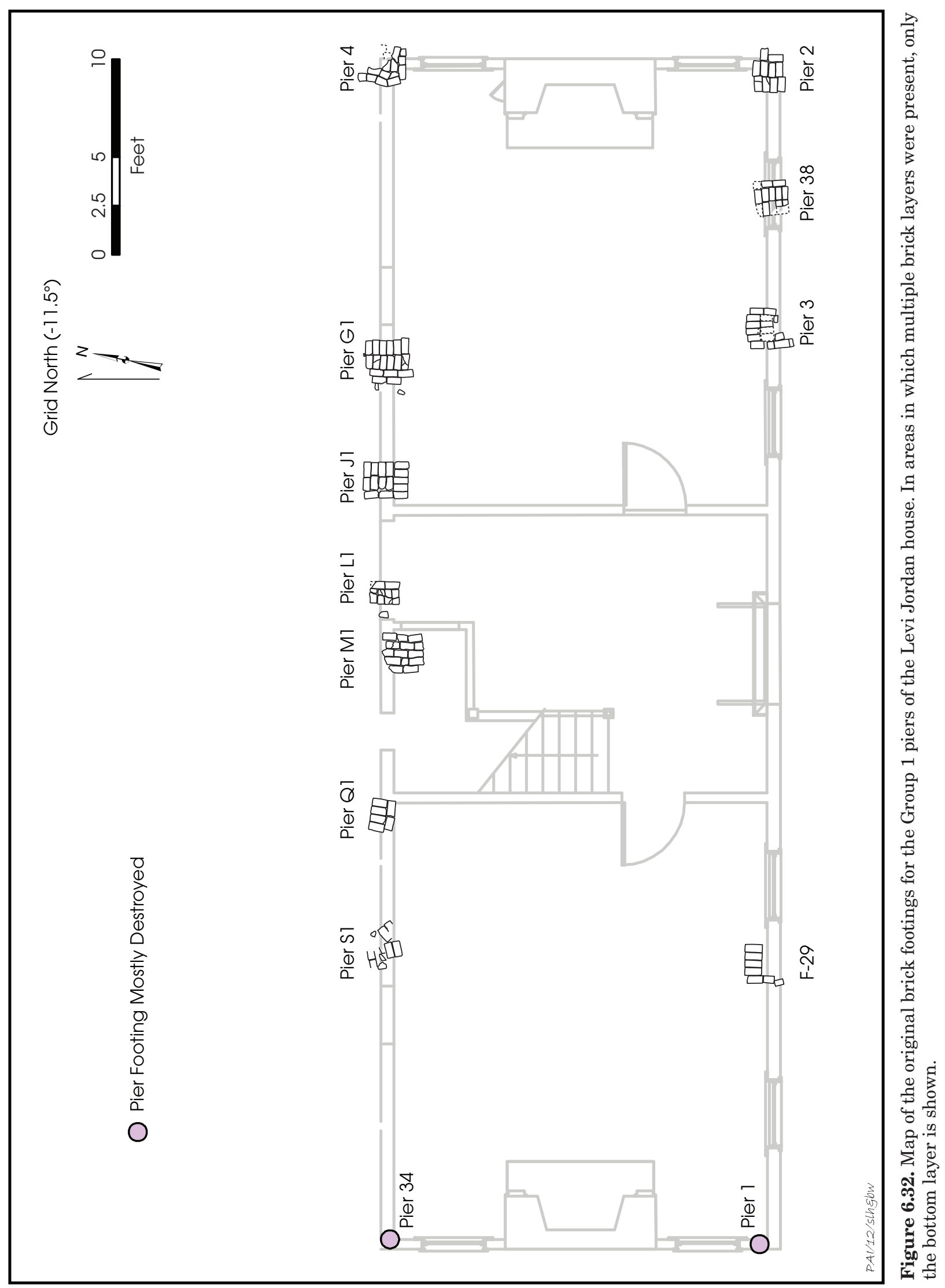


The arrangement of the bricks within a single course varied considerably also, and there was no apparent patterning in the use of one or two courses of brick in the pier pads. Three courses of bricks were relatively intact in the southeast corner pier pad (Pier 2) and partially intact in the northeast corner pier pad (Pier 4). While the original footings in the northwest and southwest corner piers were too extensively disturbed to determine the original number of courses, it is likely that all four of the corner piers had threecourse brick footings.

Group 2 consists of seven piers under the north wall of the antebellum house. Five of these are oak timbers that were probably 1853 pier logs that were moved from their original location when the ell was added (i.e., Piers C1, H1, P1, $\mathrm{V} 1$, and W1). Only one of these was placed on a new footing of machine-made bricks (Pier C1), while the others had no footings. The other two piers in Group 2 are a makeshift pier of railroad ties laid horizontally on the ground (Pier K1) and a small square cut block with no footing (Pier N1). It is likely that most of these piers were constructed when the twentieth-century ell was added (noting that the north wall of the antebellum house is the shared wall with the ell addition), but some were added later.

Group 3 consists of the four piers that run in an east-west line underneath the center of the antebellum house. They are quite different from the other piers, and each consists of a circular saw-cut block of timber that was placed into the ground without any footing. Each of these pier posts measured $1 \mathrm{x} 1 \mathrm{ft}$, and the more complete ones were originally more than 16 inches tall. All of these piers had evidence indicating the bottoms of the timber blocks were rotting in place. The degree of deterioration, relative to that observed for the twentieth-century piers, indicates that the square Group 3 piers probably date to the nineteenth century.

The Group 3 square posts are interesting. They were cut with the same-size circular saw (a 48-inch-diameter blade) used to cut the main foundation beams and floor joists under the house (see Chapter 5). One could argue that these piers are associated with the original house construction and that the lack of a footing was a functional difference. These piers were located underneath the house where it was drier and they were more protected, so the builders may have felt that they did not need brick footings or the massive girth of large oak tree piers underneath the house. Alternatively, it seems unlikely that the original builder would have used tree logs on brick pads for all of the perimeter piers and used cut blocks without footings as piers under the house. Cutting the oak trees into logs was relatively quick, but the extra effort to cut them into blocks would have been totally unnecessary. Consequently, it is suggested that the four Group 3 piers were added under the house in the last three decades of the nineteenth century. It seems likely that the original builders used only perimeter piers, but the house had begun to sag in the middle within a few decades. The simple solution was to add a single row of piers in the middle of each of the four major floor beams.

The addition of the Group 3 piers may have fixed the sagging foundation for a while, but the problem apparently returned in the twentieth century. Group 4 consists of nine more piers under the house, and these also were placed underneath the four main floor beams. Most of these piers consist of 10-inch milled lumber posts (creosote-soaked telephone pole sections) put into holes without any footing. Others are makeshift piers consisting of horizontally laid railroad ties (J10 and Q13), a concrete block (Pier J12), and an empty posthole where a pier post had been removed (Pier Q10). All of the Group 4 piers are probably less than 50 years old, and some may have occurred around 1961, when a renter named Brannon made other major foundation repairs (see discussion of repair episodes below).

Group 5 consists of all the piers associated with the twentieth-century one-story ell except for the perimeter piers on the shared south wall (see Figures 6.1 and 6.2). These piers are quite different from the pier groups described above. Group 5 includes original piers and piers that were added later, as well as piers that were repaired one or more times. Most of the Group 5 piers had 10-inch diameter milled lumber posts (i.e., sections of creosote-soaked telephone poles). Some had no footing, while others had footings consisting of a few bricks, brick rubble, or concrete. Oral history evidence suggests that the ell was constructed sometime after the 1900 hurricane and possibly in the 1920s (Brown 2005a:54; Freeman 2004:136; see Table 2.2), and this seems to be a plausible age for the piers associated with the ell. It is notable that many of 


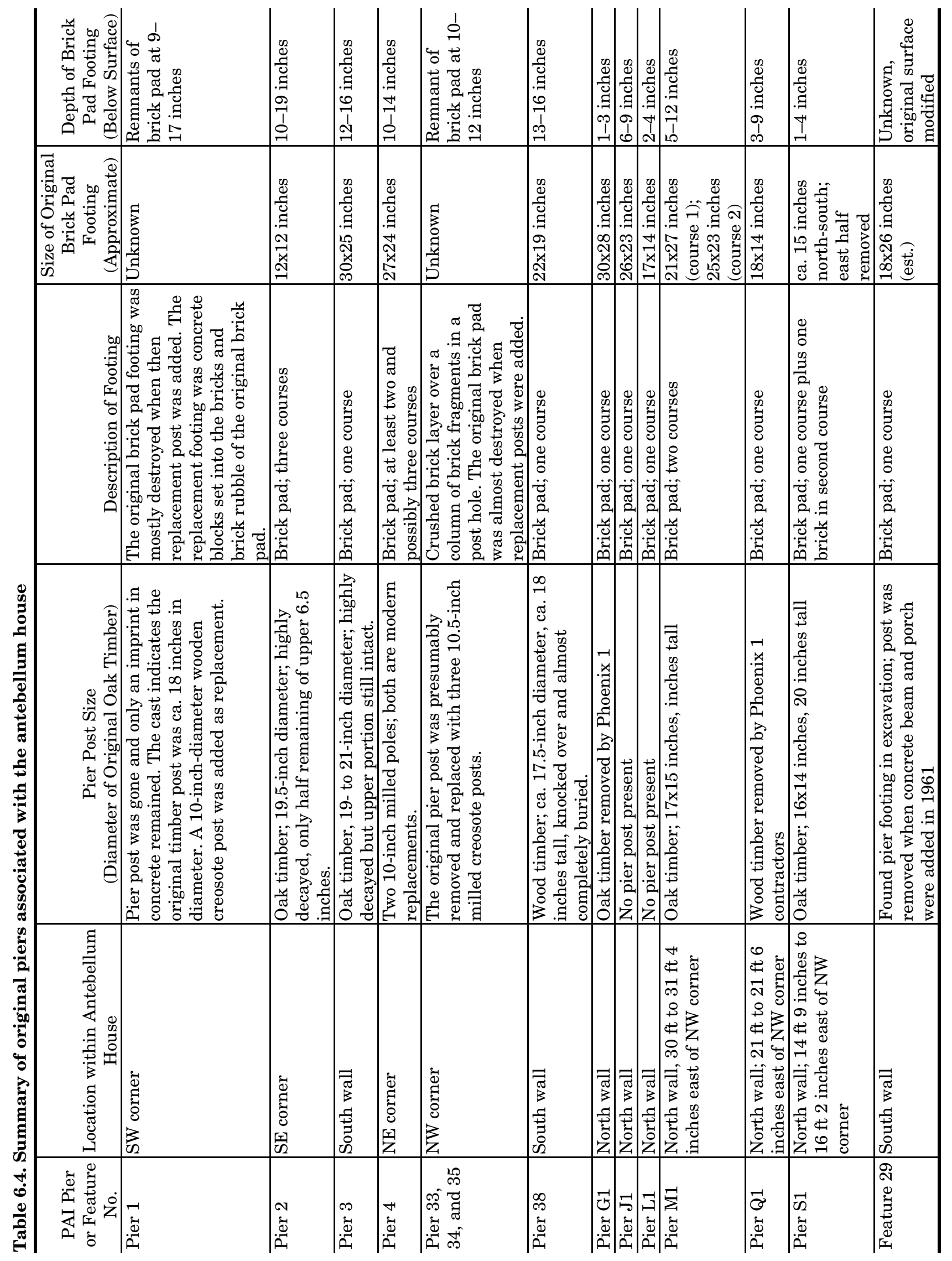


the ell piers seem to have been repaired one or more times. These twentieth-century piers were not nearly as substantial as the original 1850 s piers, and it appears that the house shifted and settled enough that pier repairs were needed regularly.

\section{HISTORICAL EVIDENCE OF HOUSE REPAIR EPISODES}

Unfortunately, detailed historical information related to home repairs and architectural additions is minimal and sheds only a little light on the subject. Five known episodes of house repairs are documented: (1) a major renovation episode occurred soon after Levi Jordan's death in 1873 (Freeman 2004:12729); (2) repairs following the devastating 1900 hurricane destruction; (3) major changes in the 1920s (Brown 2005a:54); (4) renovations by Harry Martin in the late 1930s to early 1940 s prior to his family's occupation; and (5) the renovations by a renter named Mr. L. E. Brannon in the late 1950 s to early 1960s (see Chapter 2 ). We know only a few details about each of these episodes, and there were undoubtedly many other renovation episodes that we have no record of.

Of the five known renovation and repair episodes, two stand out. It is likely that the most substantial home repairs and additions occurred after the damages from the September 1900 hurricane (see Tables 2.1 and 2.2). This is when the original east wing was reportedly destroyed, and the expansive ell addition on the north side of the original house may date soon after this. The 1961 renovations by the Brannons also are significant from a structural point of view. They put in a large concrete porch across the front of the house, which was attached to a long concrete foundation beam that effectively replaced half a dozen piers on the south wall. This episode speaks volumes about the state of the house foundation at that time, and it reveals that many piers had deteriorated past the point where simple repairs would suffice. Despite knowing about these five main house renovation episodes, there were probably many undocumented renovation and repair episodes during the home's nearly 140 years of occupation. Foundation piers could have been added or repaired during any of these renovations.

\section{Dendrochronology of Levi Jordan Pier Posts}

The potential for conducting dendrochronological studies on the live oak piers from the Levi Jordan house was considered. It was assumed that tree rings on these large pier posts could be examined, and the data might be useful for inferring a cutting date that approximates the beginning of the house construction and possibly provide climatic data for many decades prior to the house construction. Consequently, sections of three piers were cut, sanded, and shipped to the Tree Ring Laboratory at the Department of GeoSciences, University of Arkansas in 2011. Two samples are from antebellum piers from the perimeter of the Jordan house, and the third is a pier post that was added later underneath the Jordan house: (1) Pier P1 is an original timber moved to a new location along the north wall; (2) Pier S1 is an original timber found on its original brick footing along the north wall, and (3) Pier V11 is a square-cut post under the central west end of the house (see Table 6.1 and Figures 3.3, 6.2., 6.3, 6.11, and 6.20). No funds were available to conduct the dendrochronological study on the Levi Jordan house piers, but the samples will be kept at the Tree Ring Laboratory for possible analysis in the future.

Post oaks are quite well suited for dendrochronological studies and have been used for dating historic structures and climatic reconstruction in Texas (Mauldin 2003; Stahle and Cleaveland 1988, 1995; Therrell 2000). Unfortunately, less work has been undertaken with live oaks, and this species presents problems because old timbers tend to break in radial fractures, making the tree rings difficult to see (David Stahle, personal communication 2011). Stahle, one of the directors of the University of Arkansas Tree Ring Laboratory, believes the Levi Jordan samples each have about 50 rings and that they might be datable. He states that "the annual rings are reasonably well delineated on at least portions of all three specimens" and the "ring patterns also exhibit some variability in width, so there is at least a chance for crossdating" by comparison with existing post oak chronologies (David Stahle, personal communication 2013). In addition, a recent exploratory study of the dendrochronology potential for live oaks uses some new analytical methods, and the results are quite encouraging (Bartens et al.2012). So it 
is likely that dendrochronological analysis of the Levi Jordan pier samples could yield important historical evidence in the future.

\section{A Possible West Porch?}

The identification of posthole features in a line extending west directly from the south wall of the antebellum house is intriguing. This led to the obvious speculation that these features were postholes associated with a fence line or piers for a west porch. Since the corners of houses are commonplace for fence lines that separate the front and backyard spaces, this possibility must be considered. However, the ca. 1905 historic photograph (see Figure 6.28) depicts an architectural feature on the west side of the Levi Jordan house. Though it is somewhat difficult to discern, the photograph shows a stepped porch that is definitely west of the front porch and continues around the west side of the southwest corner of the house. The subject of the photograph is the man preparing to stringing up a bear that was killed on the property, and two men and two young girls are observing. Carol McDavid thought this photo may have been taken in 1917, based primarily on her interview with descendant Ewing Martin (Martin 1998). However, bears were shot on the property on more than one occasion. Jordan family descendant Bruce Gotcher, who owns the original photograph, believes that one of the two girls is his grandmother, Gertrude Nadine Martin Gotcher (1903-1975) and the other girl is her sister, Katherine Eulalie Martin Prell (1895-1987). The girls appear to be roughly 4 to 8 years old in this photo, suggesting that it was taken about 1900-1905. This photograph would indicate that a west porch was in place by at least 1905 .

The perforated disc recovered from Feature 13 warrants more consideration for what it might tell us about the possible west porch and who built it. PAI archeologists found at least five other similar specimens, but all of these specimens are from mixed deposits that do not provide any chronological or associational context. The specimen from Feature 13 is from a context that predates 1905 and could be much earlier.

After finding several modern roofing nails and lead-rings from roofing nails around the house, we considered the possibility that many of the perforated discs found around the Levi
Jordan house might be homemade washers for roofing nails or some other type of washer for small bolts or rivets. However, in comparison with all the other perforated discs, the Feature 13 specimen is the most unusual one. It is different from the others in that its hole is much smaller, and the 2-mm opening is not large enough for a roofing nail or any type of bolt or rivet to pass through.

The Feature 13 perforated disc definitely came from the original construction hole in which the wooden post was placed. Since there was no evidence of postdepositional disturbance, all the objects from below 16 inches in this feature are presumed to date to the time the hole was dug and the post was placed in the ground.

There are several plausible explanations for the occurrence of perforated disc in a pre-1905 posthole. One is that the object dates earlier than the post-construction episode but was accidentally knocked into the pier hole during construction. This is certainly a possibility given the amount of other debris that apparently fell into the hole or was mixed with the sediment that was put back into the hole. In this case, the perforated disc would have nothing to do with the pier construction. A second explanation is that the disc was used as a button on a worker's shirt, or perhaps worn on a necklace or an ankle bracelet, and it accidentally got lost during the construction episode. In this case, its deposition is associated with the pier construction event, but it is not functionally related. The third interpretation is that this disc was intentionally placed into the pier hole as some type of ritual offering by someone who dug the hole and built the porch pier. In this case, the disc would be temporally associated and functionally related to the construction episode.

Since the Feature 13 perforated disc is homemade, we must seriously consider the possibility that it was an African American ritual item that was made and worn by an African American worker and perhaps even placed in the pier hole intentionally. When Dr. Kenneth Brown saw this artifact, he responded that he had found "identical pieces" in the Quarters archeological deposits (in addition to several perforated coins) ${ }^{36}$ In the Quarters, the drilled discs are clearly associated with the African Americans living at the plantation, probably before and after emancipation. In this context, 
the drilled disc may have functioned similar to how a perforated coin functioned (several of which have also been found in the Quarters; see Brown 2005b:Figure 85; 2012:n.p.; Brown 2012:129-130, 170). However, there is abundant evidence that coins - especially silver coins - and round discs with holes drilled through them were associated with African American beliefs and rituals. Brown (2012:127) also reports that one perforated "concave metal disc" is from a ritual "curer's kit" found in one of the Levi Jordan slave cabins (Cabin II-B). Perforated coins were often worn on a string around a person's ankle as a good-luck charm or to ward off evil spirits. Davidson (2004) presents a thorough discussion on the use of perforated coins as charms by African Americans, noting that they have been found in occupation sites and mortuary contexts worn by deceased persons. He also presents a table of dozens of accounts from the WPA slave narratives documenting people who wore pierced coins as charms (Davidson 2004:Table 2). Davidson (2004:34) states that one of the three main reasons "why enslaved African Americans likely adopted coin charms is that their circular form, as simple flat discs, evoked the basic form of the Bakongo cosmogram." Enslaved peoples without easy access to coins may well have made their own perforated disc charms from scratch. The wearing of charms suspended on strings was a common West African tradition. Thompson (1993:57, as cited in Stine et al. 1996:54) gives the example that Kongo mothers would "fashion a small round disc from wood or a seed, perforate it, and attach it to a string to hang over his heart or tie around her neck, waist, or ankle. This wold become a guide and charm to the child's soul, guarding its round boundaries, charting the child's safe circuit to maturity and old age."

Based on the Feature 13 archeological data, it is impossible to determine how or why the perforated disc ended up in the posthole. Given that so many other artifacts were found in the posthole fill, it is likely that the perforated disc had been lost and was among other debris and sediment that was used to backfill the hole. Regarding its original function, there are plenty of practical reasons why someone might have made a perforated disc, but the possibility is intriguing that it might have been made and worn as a charm by one of the enslaved or free African Americans at the plantation. The possibility that the perforated disc and other items may have been intentionally buried near the master's big house as a charm is even more interesting. Leone and Fry (1999:372-373, 377) report that pierced discs and coins were among the items found in African American caches at plantation sites in Virginia, and they were also found at the Charles Carroll big house in Annapolis, Maryland. In the latter context, they were buried with other ritual objects in hidden caches by Carroll's enslaved workers. These caches were interpreted as a form of conjure similar to how West African minkisi bundles were used (Leone and Fry 1999:379).

\footnotetext{
${ }^{36}$ Brown saw this artifact during a workshop he hosted on the interpretation of religion and spirituality in African diaspora contexts at the 2011 Society for Historical Archaeology annual meeting held in Austin, Texas (January 5-9, 2011). In an unpublished 2012 draft report on the University of Houston investigations in the Quarters, Brown illustrates many of the perforated coins that were found but does not discuss the perforated discs.
} 



\section{CHIMNEY FOUNDATION INVESTIGATIONS}

The original Levi Jordan plantation house had two chimneys composed of handmade bricks: one on the east wall and one on the west wall. As part of the structural stabilization of the house, the Texas Historical Commission (THC) reconstructed the chimneys and their foundations. However, a complete investigation of these chimney foundations was not possible while the house structure remained in place. The hydraulic lifting of the house during the stabilization enabled Prewitt and Associates, Inc. (PAI) archeologists access to the chimney bases so they could complete large excavations to fully expose both chimney foundations. The house was lifted and the two chimneys were disassembled brick by brick, leaving only the last three and five courses of bricks above ground level. This was followed by the archeological investigation of the remaining lower courses to fully document the chimney foundations. After this, new concrete foundations were poured and the chimneys were reconstructed. They were faced with original handmade bricks to preserve the appearance of the original chimneys.

The two chimneys conform to the typical regional architecture in that they are on both ends of the long rectangular house. However, they differ from much of the regional architecture in that instead of sitting on the outside of the structure, they are flush with the outside end walls. Platter (1961:160) describes this configuration as "unique" (see Figures 1.2 and 4.2).

Two other chimney foundations associated with the Jordan household were also investigated and are discussed in this chapter. One, underneath the twentieth-century east wing, was investigated by Texas Parks and Wildlife Department (TPWD) archeologists in 2003 and by Center for Archaeological Studies (CAS) archeologists in 2005. PAI archeologists did not conduct additional investigations of this feature, but the PAI work on other chimney foundations enhances the interpretation of this feature, which was apparently associated with the original (pre-1900) east wing of the Jordan plantation house.

The other chimney foundation is about $10 \mathrm{ft}$ north of the twentieth-century east wing. Now a completely isolated brick feature, it was investigated by the University of Houston in 1996, by CAS in 2005, and a third time by PAI archeologists in 2010. This large chimney foundation is interpreted as being from the original "detached kitchen" behind the original plantation house.

\section{EAST CHIMNEY FOUNDATION}

\section{Previous Work}

Prior to the PAI work, previous investigation of the main chimneys of the plantation house was limited to test excavations next to the east chimney foundation by CAS in June 2005 (Zone C as described by Leezer 2006:82-83, Figure 7.6). This was due in part to the placement of the chimneys, which are enclosed inside the house walls, thus limiting access only to the outer edge of the footings. CAS archeologists excavated two $3 \times 3-\mathrm{ft}$ excavation units, designated Units $\mathrm{C} 1$ and $\mathrm{C} 2$, at the northeast and southeast corners of the east chimney to expose the easternmost portion of the foundation (Leezer 2006:48) (see Figure 3.13). Both units were excavated to a depth of 16 inches below datum. Between Levels 2 and 3, they encountered an original construction trench ( 4 to 8 inches below 
datum). This trench was designated Feature 3 in Unit C1 and Feature 4 in Unit C2 (Leezer 2006: Figures 5-9, 5-10, and 7.6).

Various types of construction material and artifacts were recovered by CAS from this area, including brick and brick fragments, concrete, mortar, various shells, ceramics, window glass, bottle and jar glass, nails, and metal hardware (Leezer 2006:48, 49). It is unclear if any of these materials were found in the construction trench itself. Both units revealed five courses of bricks in the chimney footing, with the brick layers forming "step-outs" (Leezer 2006:Figures 5-10 and 7-6). The chimney foundations were built in a stair-step pattern, being widest at the chimney base and inset a few inches with each consecutive layer of bricks. On the north side of the chimney base exposed in Unit C2, an exploratory column was excavated to expose the lowest course of brick and the base of the construction trench at 16.5 and 17.5 inches below datum (Leezer 2006:49). All bricks were left in situ.

\section{PAI Investigations}

PAI conducted additional investigations on the east chimney during the Phase II work. At this point, the house was raised 5 to $6 \mathrm{ft}$ above the ground, so the entire chimney base was easily accessed. At this point three courses of bricks were exposed, and excavation revealed that there were seven courses below ground (Figure 7.1).

PAI's investigations of the east chimney foundation began by laying out one large excavation unit around the entire exposed chimney base. Based on Leezer's previous work, the lowest course of stepped brick foundation, which

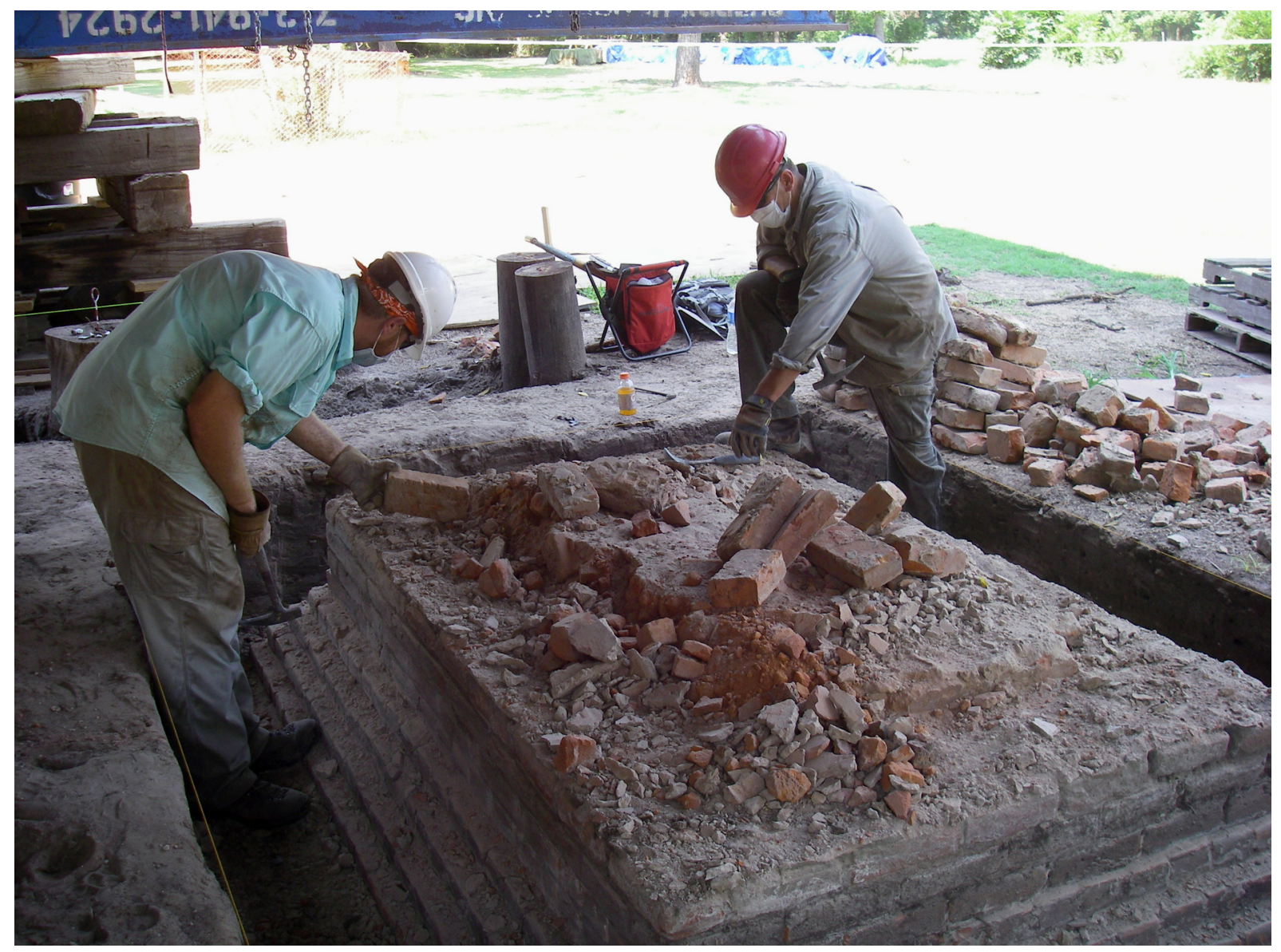

Figure 7.1. PAI crew working on the east chimney under the raised house. View is to the north as the archeologists remove one layer of foundation bricks. 
is the bottom of the spread footing, ${ }^{37}$ extended ca. $1 \mathrm{ft}$ from the exposed walls of the chimney base. So the excavation unit around the chimney base extended $2 \mathrm{ft}$ from each side, resulting in a unit measuring $11.5 \mathrm{ft}$ (north to south) by $8.75 \mathrm{ft}$ (east to west), which was large enough to encompass the entire spread footing that would be encountered below the surface. For ease of excavation and to provide horizontal control, the chimney excavation was divided into four quadrants labeled NE, NW, SE, and SW.

Because the previous CAS investigations revealed the subsurface layout of the chimney footing, PAI archeologists knew what to expect. In addition, since the focus of the excavation was to investigate the architectural feature, arbitrary excavation levels and datum points were not employed. All horizontal measurements were taken relative to the ground surface, and the excavation levels followed the courses of brick in the footing.

To prepare the unit for excavation, all loose fill, brick rubble, and modern debris was removed from the excavation area to provide a clean exposure of the intact chimney foundation. In areas of CAS's Units C1 and C2, the old units were reexcavated, but the backfill was not screened. These old units were completely cleared to expose all five of the brick "step-outs." This provided a window into the basal courses of the chimney foundation-and this knowledge of how the chimney's spread footing was constructed served as a guide during the subsequent excavation.

Working with the established quadrant system for the east chimney, each quadrant was excavated in horizontal levels consistent with each course of brick in the chimney foundation. First, the uppermost level was excavated down to the top of the first stepped layer of bricks, which marked the top of the spread footing. Then, the next five levels were excavated from the surface to the base of the feature, each corresponding to a layer of bricks in the spread footing. Any cultural materials recovered were recorded in their respective quadrants and levels. All excavated fill was placed in buckets, then screened through 1/4-inch-mesh hardware cloth.
The excavation levels corresponding to the stepped brick levels were referred to as courses, and the first course was the top layer of bricks in the spread footing, with subsequent courses numbered downward. For example, glass found at the level of the second course of stepped bricks in the northeast quad would be assigned the provenience "NE Quad, Second Course." Any cultural materials not obviously related to the historical occupation of the house was discarded. (Modern roofing nails and screws were scattered throughout the site due to recent construction related to the structural stabilization.) All other artifacts were bagged, inventoried, and returned to the PAI laboratory in Austin.

For the purpose of excavating the feature and assigning provenience to the collected artifacts, the excavation levels corresponding to brick courses were numbered from the top of the stepped footing downward. For all other discussions throughout this chapter, the brick courses are numbered from the bottom layer upward, after the full feature was excavated.

When the chimney foundation was completely exposed, the entire base was mapped in plan view and profile showing the location of each brick, and photographs were taken at various stages of the excavation (Figures 7.2 and 7.3). The north and east walls of the chimney base each consisted of five courses of stepped bricks, terminating at the top to form the main body of the chimney. The west and south walls each had four courses of stepped bricks. At the top of the sixth course, the center of the chimney foundation encompassed a T-shaped area that was filled with various sizes of brick rubble fragments and pulverized brick powder. While the T-shaped rubble-filled void was evident in the sixth course, it changed to a rectangular void in the fifth course. In courses 4 to 2 , the void was stepped in by a few inches on all sides so that the void became progressively smaller. The bottom course 1 was a solid brick pad. It is notable that the void is not centered in the east chimney footing but is offset toward the interior of the house. The void would have been immediately below the chimney firebox, which also was toward the

\footnotetext{
${ }^{37}$ A "spread footing" is the architectural term for a foundation that spreads out with depth and is wider than the structural element that it supports. For brick chimneys, the spread footing begins at or just above the ground level, and the first brick layer marks the transition between the bottom of the chimney base and the spread footing.
} 

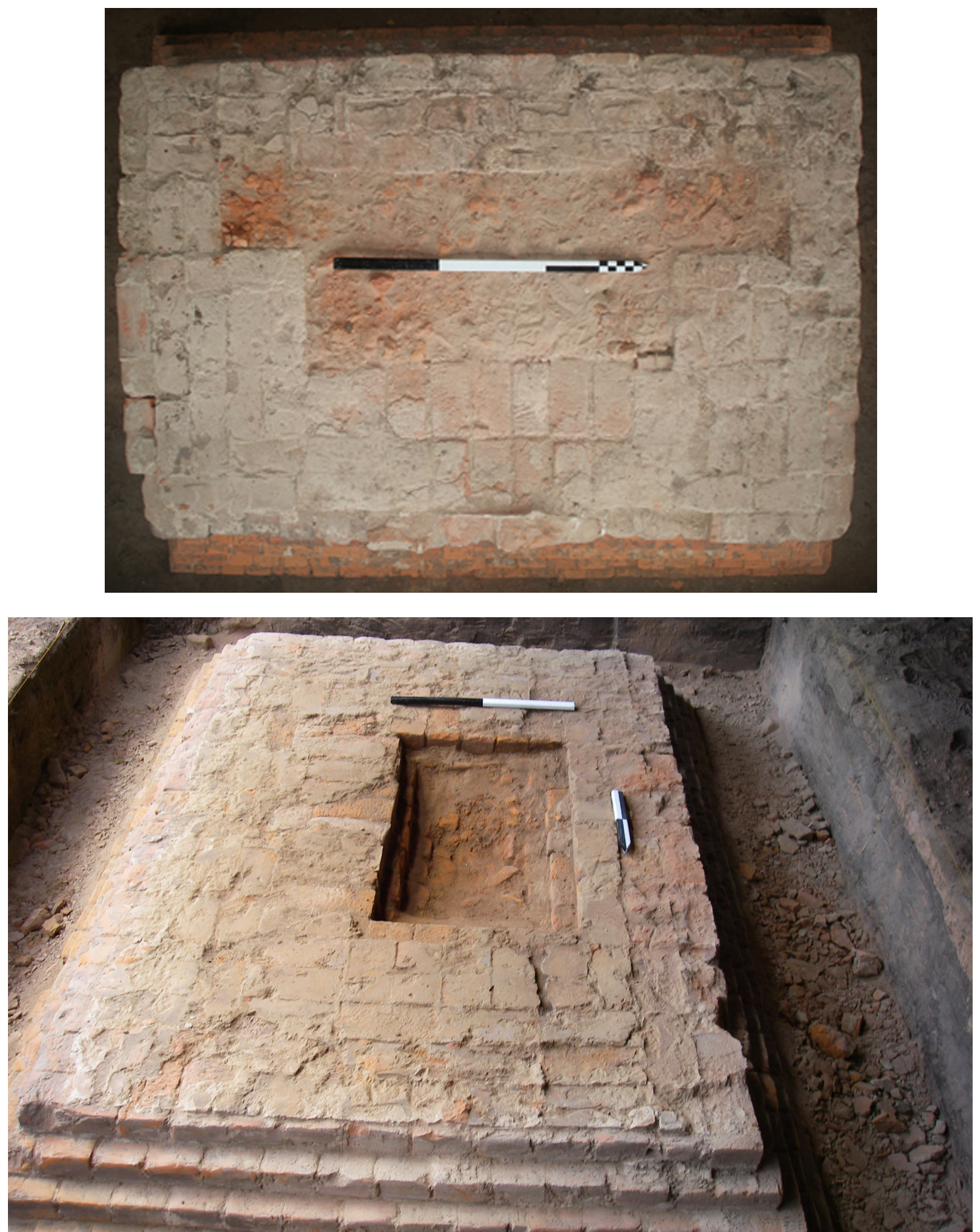

Figure 7.2. Photographs of the east chimney foundation. (Top) Overhead composite view of the spread footing at the sixth course (from the bottom). Note the T-shaped rubble-filled void. Scale is $3 \mathrm{ft}$ long with 1-ft increments. Image compiled from multiple overhead photos, looking west. (Bottom) Oblique view of the spread footing at the fifth course, looking south. Note the rectangular rubble-filled void. The scale is $2 \mathrm{ft}$ long, and the north arrow is $1 \mathrm{ft}$ long. 
Chapter 7: Chimney Foundation Investigations

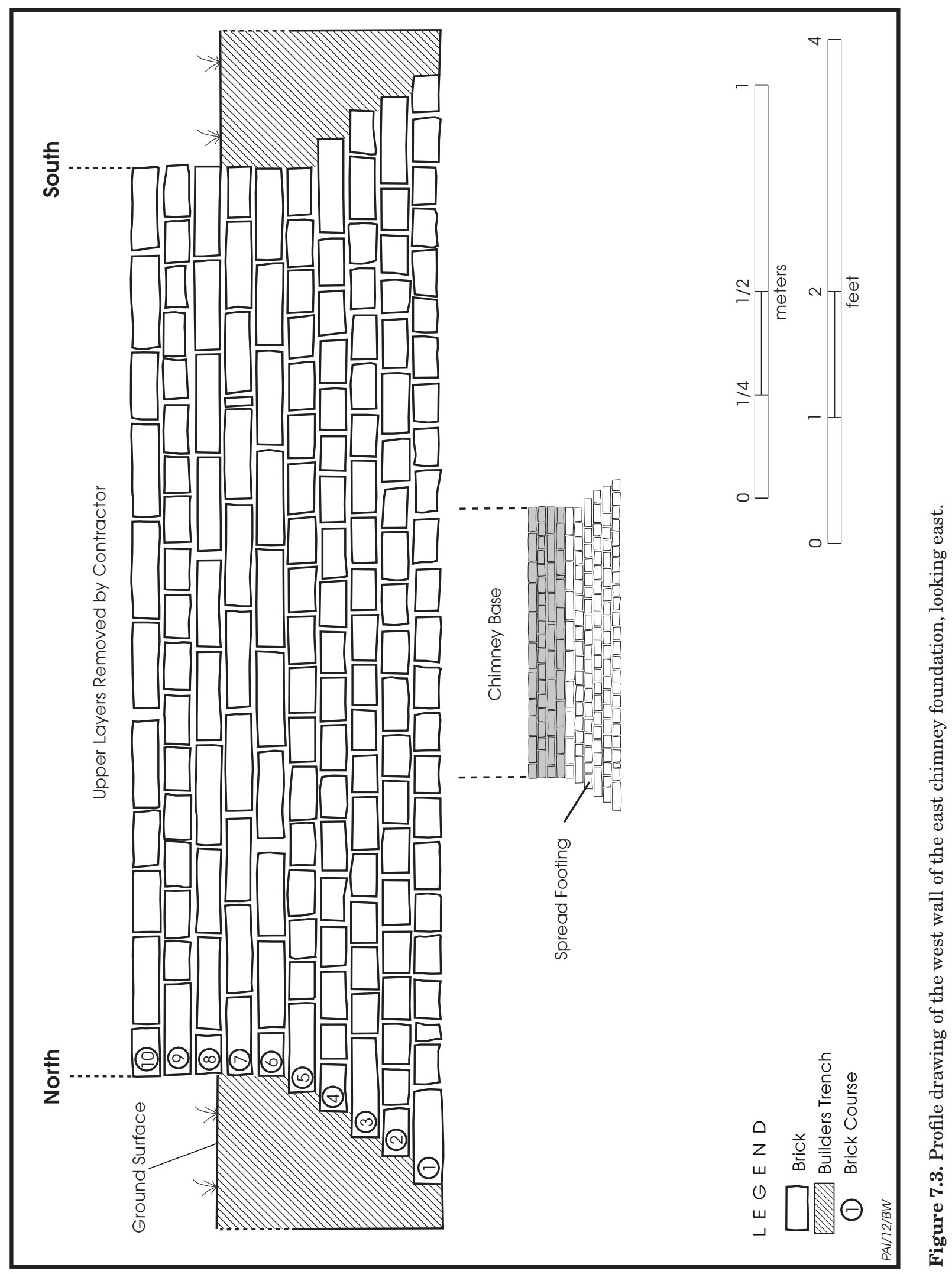


interior. The solid brick areas around the void were the footing's support for the chimney walls, which were more than $20 \mathrm{ft}$ tall.

Once the east chimney was dismantled, the aboveground section remaining was three courses high and measured 5.0x7.5 ft. This represents the size of the chimney base at ground level, before the foundation step-outs. At the very bottom of the foundation, the lowest course of bricks making up the solid chimney base measured 6.6x9.3 ft. Brick dimensions were relatively consistent throughout the feature, with each brick measuring ca. 8.5 inches long, 4.5 inches wide, and 2.5 inches high. Occasionally, a unique or unusually shaped brick would be placed within a gap where a standard brick could not fit. Spacing of bricks was also consistent, typically with a half inch of mortar between the bricks.

In the original CAS excavations of Units $\mathrm{C} 1$ and C2, Leezer (2006:Figures 5-9, 5-10, and 7-6) designated the "construction trench" Features 3 and 4. In 2005, Leezer (2006:48) observed that this trench had different-colored sediment than the surrounding undisturbed soil, and the trench fill was described as a "brown, silty loam with flecks of black clay." Although it is clear that this intrusive excavation actually represents the edges of a large rectangular pit inside which the chimney foundation was constructed, the feature appeared in plan view as a trench all the way around the chimney foundation (see Figure 7.3). During the PAI excavations, we simply referred to this as the builder's trench and assumed that any artifacts found in the trench fill probably dated to the initial construction period unless evidence of disturbance was observed.

PAI's excavations encountered the builder's trench on all sides of the chimney foundation, but the fill varied somewhat, and the fill distinction was quite subtle in some places. The trench fill was very close in color to the chimney bricks, and it is possible that the clayey sediment placed in this trench after the chimney base was built was from the same clay source that was used for making the bricks. Where the edges of the builder's trench could be determined accurately, the trench fill was excavated and screened separately. Once the excavations were below all evidence of disturbance, the sediment surrounding the builder's trench was considered culturally sterile and was discarded without screening.
The only artifacts recovered from the builder's trench around the east chimney were brick fragments. Two concentrations of brick rubble were found in the lower part of the builder's trench: one in the northwest quadrant and one in the southwest quadrant. This rubble appears to have been thrown into the bottom of the pit after the chimney footing was built and before the pit was filled in with sediment.

\section{Dismantling and Examining the East Chimney Footing}

Because the end result of the stabilization process required a new foundation for the house, both chimneys had to be removed completely. After the chimney base was completely exposed, mapped, and photographed, the remaining portion of the chimney base was deconstructed. Rock hammers were used to tap the bricks apart, then the remaining mortar was chipped away. Care was taken when removing the bricks so that whole bricks could be saved, but in some cases the bricks were deteriorated and many broke. Each brick was inspected for markings, and intact bricks were placed on pallets corresponding to the course from which they came. Phoenix 1 contractors thoroughly washed the bricks and further examined them for any with unusual markings. Bricks with markings or imprints were stored in a container in the THC storeroom. Unmarked bricks were stacked onsite until they were needed for the chimney reconstruction. Most of the brick fragments were discarded by Phoenix 1 because they offered little research or construction value.

Just below the basal layer of bricks was a thin layer of sand or sandy mortar, generally less than $1 / 2$ inch thick. It was placed there to level the ground and provide a secure flat platform on which to build the footing. Below that, the undisturbed clayey sediment was very hard and difficult to dig by hand, having been compressed by many tons of weight for more than one and a half centuries.

Two samples were collected from the east chimney investigation. A mortar sample was collected from the interior of the foundation in the lower courses of brick, and a clay sample was collected from the builder's trench in the northwest quadrant at the level of the third course of brick. 


\section{WEST CHIMNEY FOUNDATION}

No previous investigations of the west chimney foundation had occurred, and the PAI investigations were conducted during Phases I and II. During the Phase I investigations, two test units were dug along the exterior side of the west chimney: Unit W1 at the southwest corner of the chimney and Unit W2 at the northwest corner. Both units were $3 \times 3 \mathrm{ft}$ and were dug to the bottom of the spread footing. Two courses of stepped bricks were above the ground surface, and the excavations exposed three courses of footing bricks below ground.

Artifacts recovered from these units included glass, nails, screws, bone, ceramic sherds, shell, a 1908 penny, and miscellaneous modern debris. In addition, several pounds of brick rubble and mortar were recovered. In both units, artifacts became less frequent with depth, and no evidence of a builder's trench was observed.

Phase II work on the west chimney followed the east chimney excavations, and the methods used were essentially the same. When the excavation began, five courses of bricks were left in place, two above ground and three below. The previously dug Units $\mathrm{W} 1$ and W2 were reexcavated to expose the subsurface construction of the chimney footing. Then the excavation was expanded to a single block extending about $2 \mathrm{ft}$ out from all sides of the chimney foundation, measuring $9.3 \times 11.5 \mathrm{ft}$ (slightly larger than the east chimney block). Unlike the east chimney, the west chimney lacked a discernible original builder's trench, and many more artifacts were found throughout the deposits. Consequently, all of the fill from the excavations was screened.

After the chimney footing was fully exposed, five courses of stepped bricks were evident on all sides. It was documented with photographs and plan and profile drawings showing the orientation of all the bricks in the footing layers (Figures 7.4 and 7.5). The bottom of the chimney base, forming the main body just above the spread footing, measured $4.5 \times 7.4 \mathrm{ft} —$ only slightly smaller than the east chimney. The basal layer of brick measured $6.4 \times 9.0 \mathrm{ft}$, again slightly smaller than the east chimney. The west chimney footing was not as well preserved as the east chimney footing. As discussed later, the lack of a builder's trench, and the presence of mottled soil with abundant artifacts around the footing, indicated that the west chimney foundation had a very different postdepositional history. This was confirmed when the chimney was dismantled to reveal a water-formed depression and drainage channels beneath the footing (see below). Although these chimneys were located less than $60 \mathrm{ft}$ apart, there were significant differences in the nature of the deposits around their footings. The west end of the house sat on a sloping area of land that drained immediately into a slough ca. $100 \mathrm{ft}$ to the west. As a result, a large portion of the chimney footing that was originally buried eventually eroded and became exposed, and was later filled in through natural or cultural processes.

One factor that limits the interpretation of the west chimney is that PAI archeologists got to examine only five courses of bricks in place, as opposed to seeing ten courses of the east chimney. ${ }^{38}$ The west chimney foundation is different in at least one way from the east chimney-the rubble-filled void of the east chimney extended from course 6 down through course 2 , but the bottom course laying on the ground was a solid brick pad. In contrast, the rubble-filled void in the center of the west chimney extended from course 5 down through the bottom course. And photographs taken by the Phoenix 1 crew dismantling the chimney show that the west chimney's rubble-filled void actually extended up to the sixth and seventh courses. It is interesting that the west chimney's bottom course has a central void while the east chimney's bottom course was a solid brick pad. From a functional standpoint, however, this difference in the spread footings would not have mattered much for the stability of the chimney.

\footnotetext{
${ }^{38}$ One factor in the removal of the upper courses of bricks that differed between the east and west chimneys is the hardness of the mortar. Phoenix 1 contractors removed the upper courses of the east chimney first and found that was rather easy and fast. They expected the same when they dismantled the west chimney, but were surprised to find the mortar was significantly harder. They had to change tools and get more aggressive to dismantle the west chimney, but they got overzealous in their attempt to remove the brick layers in preparation for the archeological investigation.
} 


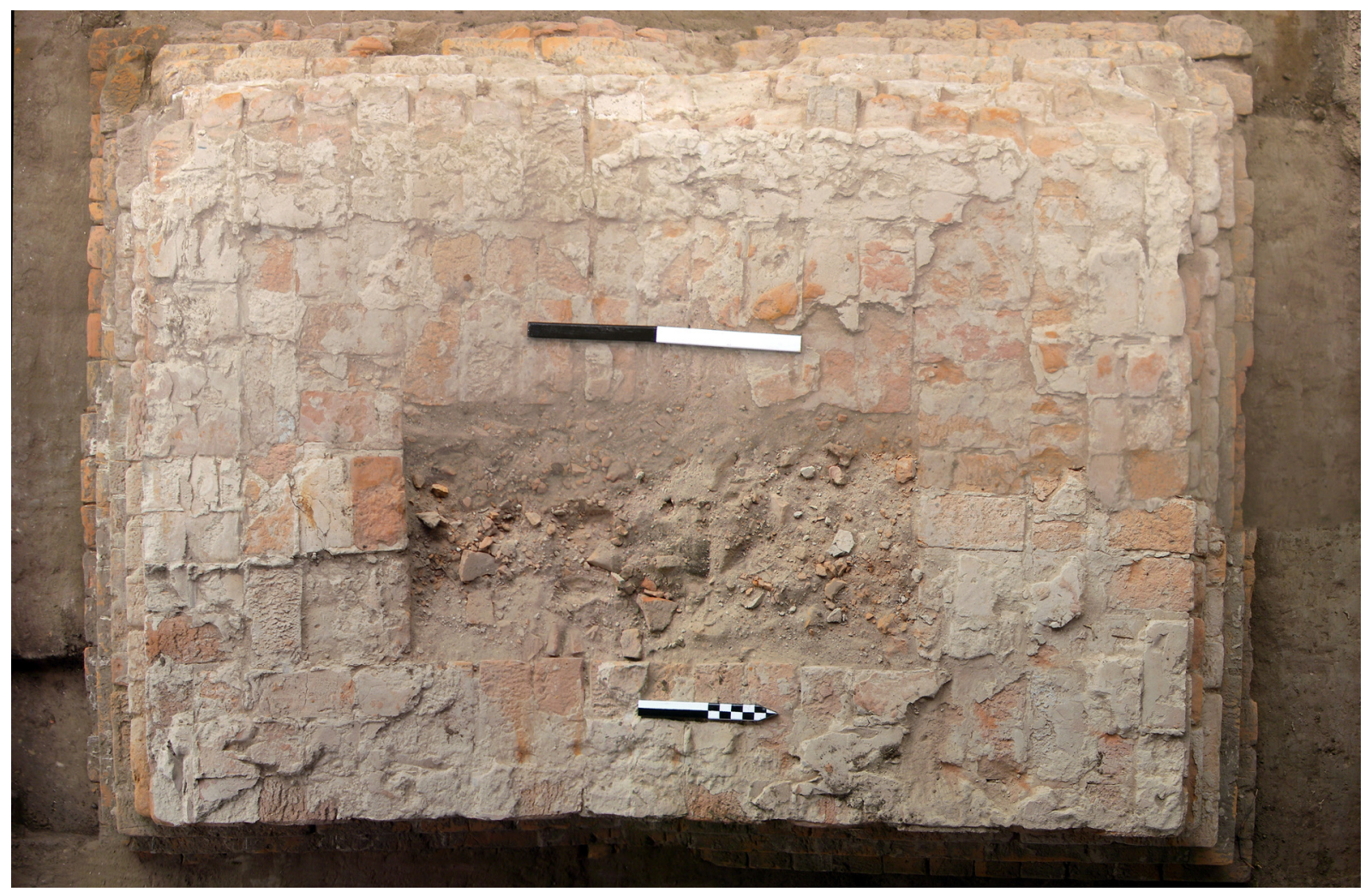

a

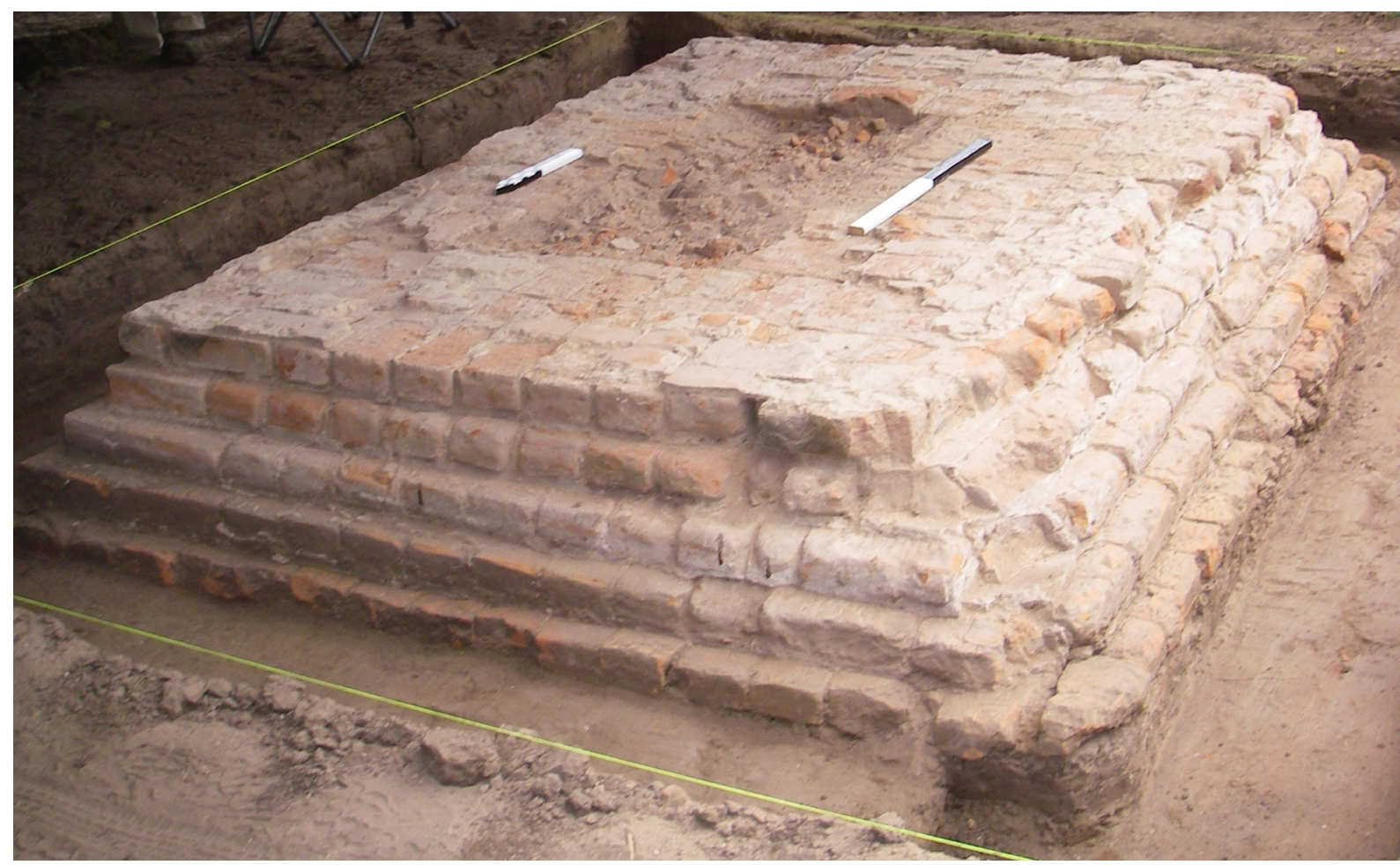

$\mathrm{b}$

Figure 7.4. Photographs of the west chimney spread footing at the fifth course from the bottom. (a) Overhead composite view compiled from multiple overhead photos, looking west. Note the rectangular rubble-filled void. Scale is $2 \mathrm{ft}$ long, and the north arrow is $25 \mathrm{~cm}$ long. (b) Oblique view of the spread footing, looking southeast. Note the rectangular rubble-filled void. The scale is $2 \mathrm{ft}$ long, and the north arrow is $25 \mathrm{~cm}$ long. 


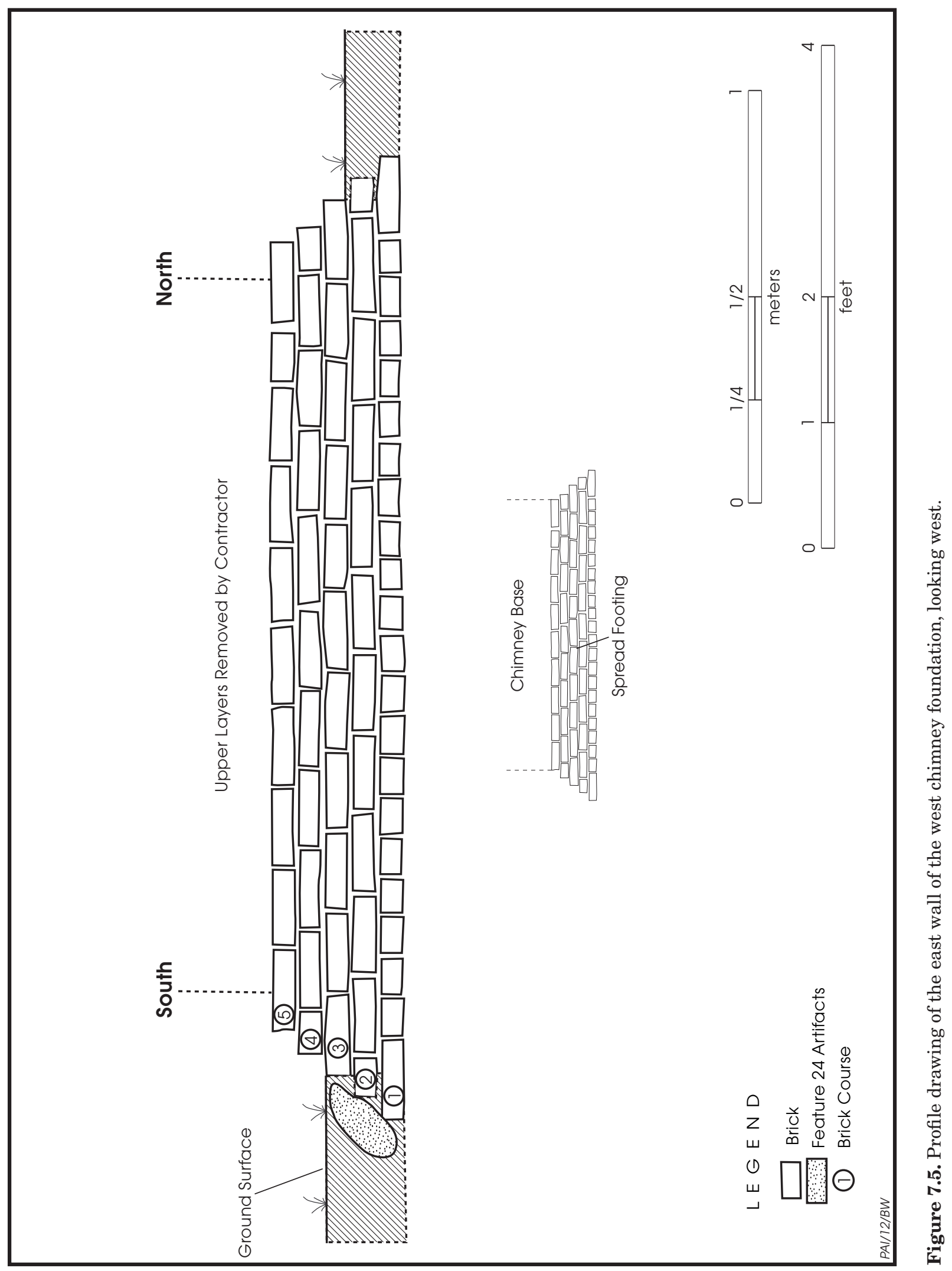


Archeological Investigations for the Levi Jordan Plantation House Stabilization

\section{Feature 24}

Feature 24 was a small collection of artifacts in the southeast quadrant of the west chimney excavation (see Figure 7.5). The feature was first noticed in the excavation at the level of the third course of bricks, when a clear glass fruit jar and a brick fragment were found next to the chimney foot. These were mapped, then removed, and the excavation continued. Just below the bottle, next to the second course of brick, a large iron can (similar to a coffee can) was found laid on its side (Figure 7.6). The upper half of the can was gone, essentially corroded away, but several oyster shells were found inside the remaining portion. Some artifacts were recovered in the area around the can, including a brass cartridge case and fragments of animal bone, glass, and nails.

The glass bottle and metal can are both twentieth-century artifacts. The bottle (Lot 2011-38) is $51 / 4$ inches tall and $31 / 8$ inches in diameter, with a widemouth screw top. It has mold seams all around the body and mouth and was made on an automatic bottle machine. An embossed maker's mark centered on the bottom indicates that it was manufactured by the Hazel Atlas Glass Company, and this particular mark (the large " $\mathrm{H}$ " over the small "A") was used from 1920 to 1964 (Toulouse 1971:239-240). The metal coffee-like can (Lot 2011-48) is heavily corroded but appears to have been about 5 inches in diameter and at least 6 inches long. Its base is crimped around the edges, indicating it is a modern sanitary can, which was invented in 1897 and became popular in the early twentieth century (Busch 1981:95-96).

The most plausible interpretation of Feature 24 is that these artifacts were washed or brought in with the sediment fill. Much of the sediment surrounding the west chimney footing was mottled and unusually organic-rich (compared with the east chimney area) and very moist, indicating that water pooled in this area. The sediment around the west chimney also contained substantial cultural debris, including some possible nineteenth-century artifacts but dominated by twentieth-century materials. Because the west end of the house is downslope toward the slough, erosion and sheetwashing during heavy rainfalls has probably been a constant problem there. The evidence suggests that a foot or more of the sediment around the west chimney foundation had eroded away at some point in the past, and that someone either brought in fill to raise the area or altered the landscape to stop the erosion and allow the area to slowly fill in over time. In this scenario, the twentieth-century artifacts associated with Feature 24 were washed in or dumped there with artificial fill.

A second possible interpretation is that the larger artifacts in Feature 24 were left there by one of the many children who grew up on the property in the twentieth century. Because of the erosion around the west chimney, it would have been a cool, covered play area where a child could hide under the west edge of the house.

\section{Dismantling and Examining the West Chimney Footing}

Much of the west chimney footing was disassembled by workers from Phoenix 1 , but the work was supervised by PAI. The brick layers were extremely compact and strong, so a jackhammer was needed to remove the brick courses. As with the east chimney, all of the intact or nearly complete bricks were set aside on pallets corresponding to the course of brick from which they were removed. These bricks were later cleaned and examined for any unusual markings. Generally, the west chimney bricks were in poorer condition than those from the east chimney, and many broke during the dismantling process. This is probably a result of the extra-hard mortar, which would force bricks to break in place without impacting the stronger mortar. Exposure and erosion wore down many of the bricks on the exterior (west) wall of the chimney base.

Just below the bottom course of footing bricks, the ground surface was covered with a layer of mortar and sand. Within this layer, two small channels ran toward a depression in the middle of the foundation area (Figure 7.7). The roughly oval depression was immediately below the rubble fill, and it measured ca. 30x35 inches and was 2 to 4 inches deep. It appears that this depression may have formed naturally, perhaps because water ran down the chimney and saturated the rubble-filled void and pool at the bottom. Eventually the standing water may have percolated underneath the foundation wall and perhaps created the small drainage channels under the footing walls. One of the drainages 

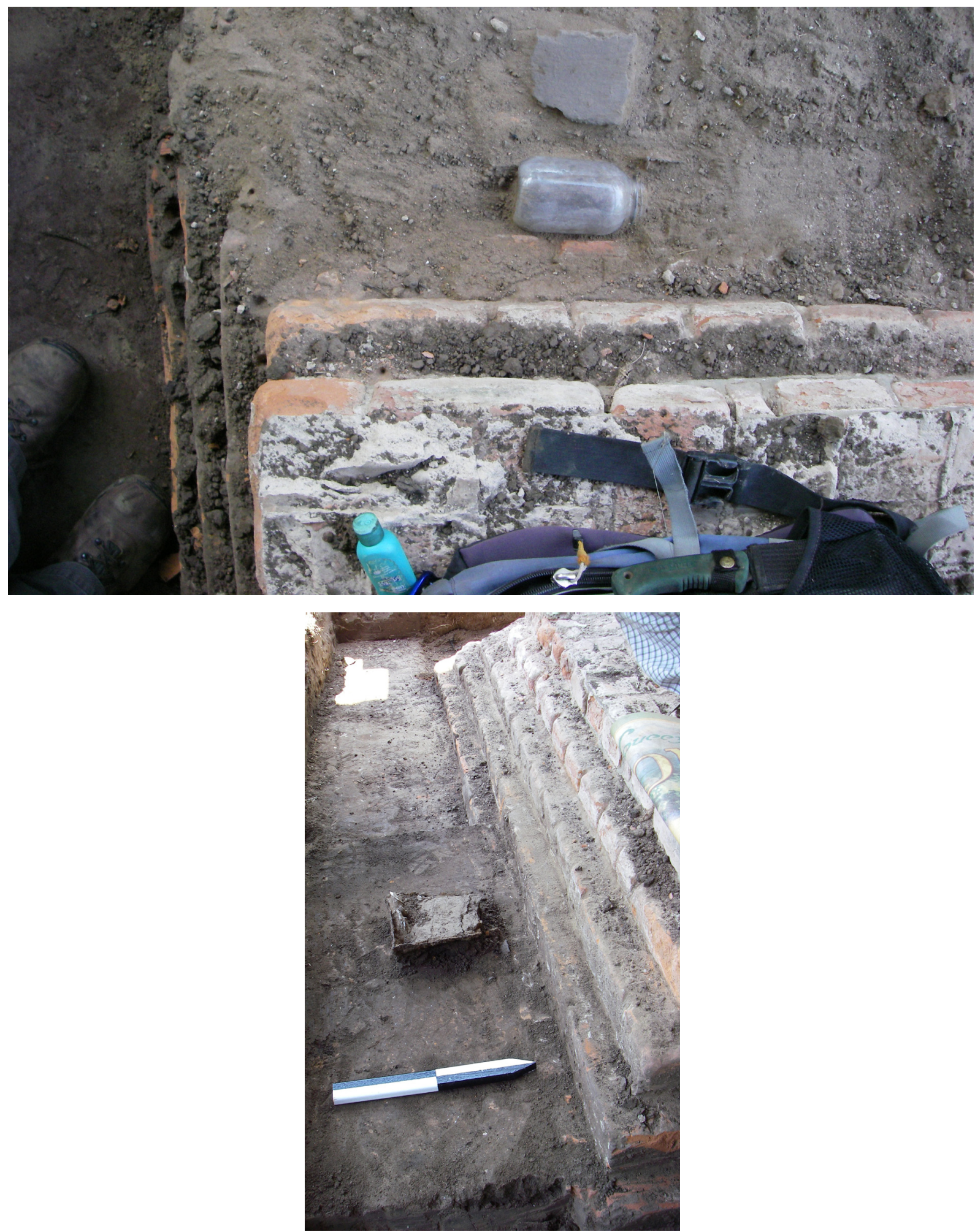

Figure 7.6. Photographs of the Feature 24 artifacts on the south side of the west chimney footing. (Top) Overhead view (looking west) of the brick fragment and clear glass fruit jar; (bottom) view (looking west) of the rusted iron can containing oyster shells found below the fruit jar and just above the bottom layer of bricks in the footing. North arrow is $1 \mathrm{ft}$ long. 


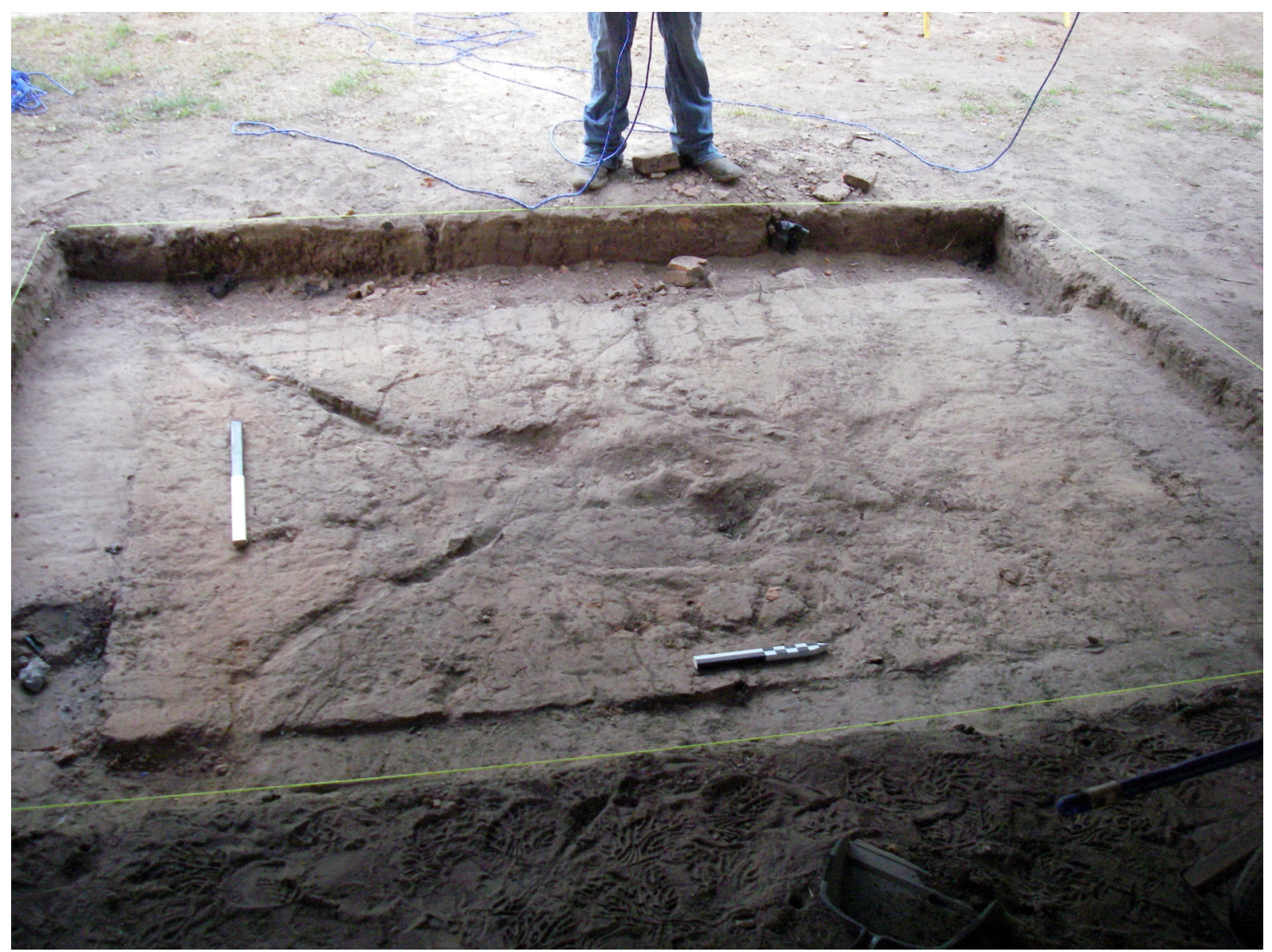

Figure 7.7. View of the compacted soil beneath the bottom course of footing bricks of the west chimney, looking west. Note the drainage channels converging on the irregular depression in the central area. The scale at left is $2 \mathrm{ft}$, and the north arrow in the foreground is $25 \mathrm{~cm}$ (ca. 10 inches).

measured ca. 3 to 4 inches wide and ran from the depression to the southeast corner of the chimney base. The second drainage measured ca. 3 inches wide and ran from the depression to the northeast corner of the chimney base.

\section{HOW WERE THE CHIMNEYS BUILT?}

The east and west chimney footings associated with the Levi Jordan house are very similar, with only minor variations. The substantial spread footings of these chimneys may be typical for Brazoria County plantations; a similar chimney foundation associated with the Bernardo plantation big house was excavated in 2009 (Woodrick 2011:162-163). Similarly, spread footings were found under brick walls at the Lake Jackson and Eagle Island plantations in Brazoria County (Few 2006:150; Gross et al. 1993:Figure 43). The following description details how the Levi Jordan chimneys were built, using the east chimney dimensions as a primary example.

The first step involved digging a rectangular pit about $7 \mathrm{ft} 3$ inches by $9 \mathrm{ft} 9$ inches. It was hand dug to a depth of ca. 16 inches, and the bottom was leveled off. A thin layer (about half an inch) of sand or sandy mortar was laid down, and the first course of bricks was laid out to form a solid rectangular brick pad measuring approximately $6 \mathrm{ft} 7$ inches x $9 \mathrm{ft} 4$ inches. A second, slightly smaller course of bricks was then laid down on the first, leaving a few inches of the first course showing around the edges. This layer had a small rectangular void (where 
no bricks were placed) near the center. The third, fourth, and fifth courses of bricks were added in the same manner, each slightly smaller and stepped-in and with a slightly larger rectangular void near the center (see Figure 7.2, bottom). The patterning of the bricks in each course was changed so that headers and stretchers alternated, providing strength to the structure. The sixth course was added next, and it was the last one that was stepped in to complete the spread footer. The next dozen or more courses of brick were the same size as the sixth course, forming vertical sides of the chimney base and firebox. The void on the sixth course was rectangular, measuring about $1.9 \times 3.5 \mathrm{ft}$ and oriented on the same long axis as the footing, but it had two small wings (a 9x9-inch expansion on the southwest side and a $9 \times 12$-inch expansion on the northwest side) (see Figure 7.2, top).

At some point after the spread footing was completed, the builder's trench around the footing was filled in with sediment. The main body of the chimney was built one course at a time. The trench could have been filled in at any time during the chimney construction or after it was completed. The sediment used to fill the trench appears to be the same local clay that was used to make the bricks. It is likely that this clayey sediment was packed tightly inside the trench to stabilize the chimney foundation and prevent water from collecting around the footing.

Several bricks and brick fragments were found in the builder's trench near the base of the footing. Most were fragmentary, but a few whole bricks were recovered. There was no patterning evident, and it appears that these bricks and brick fragments were extra or unusable construction material that was simply tossed into the trench before or while it was backfilled. Consequently, these bricks and fragments probably date to the original construction episode.

At some point before the chimney firebox was built, the void in the spread footing was filled with loose sediment and brick rubble. The function of this rubble-filled void is not fully understood, but an 1879 book on foundation construction suggests that it was a common practice when building chimneys (Powell and Baumann 1879:Figure 19). No explanation was given, but it was probably done to reduce the amount of bricks needed without sacrificing stability. Since the core of the chimney is hollow, the spread footing only needs to support the walls and not the hollow center.

The footings of the east and west chimneys, excavated more than 160 years after they were built, were in good condition. They were extremely well built, following a tried-and-true construction template that obviously served its purpose.

\section{MARKED BRICKS ASSOCIATED WITH THE BIG HOUSE CHIMNEYS}

Some of the bricks associated with the big house chimneys have unusual markings and warrant discussion because of the possibility that they represent some type of ritual marks that denote spiritual beliefs of African or European origin. PAI archeologists were not involved in the disassembling of the brick chimneys between the Phase I and Phase II archeological investigations, but the contract workers were asked to examine all the bricks and look for any that had unusual markings. During the dismantling process, the stabilization contractors found several bricks with markings etched into them. The most unusual marks are illustrated in Figure 7.8. While their precise provenience is not known, most of these marked bricks came from one of the two big house chimneys. ${ }^{39}$

Of the seven illustrated bricks, the markings on five (see Figures 7.8a to e) were made by incising into clay when it was still wet and pliable. All but one have the marks on the molded face. The other two specimens (see Figures 7.8f and $\mathrm{g}$ ) have an $\mathrm{X}$ engraved into the dry clay or the fired brick, both on the end of the brick.

\footnotetext{
${ }^{39}$ One caveat is offered here. Some marked bricks that were picked up previously from other parts of the Levi Jordan site may have been mixed in with those from the chimneys. It is not certain that this occurred, and most of the marked bricks were from the chimneys. All of the specimens illustrated in Figure 7.8 have mortar attached and probably came from the big house chimneys.
} 

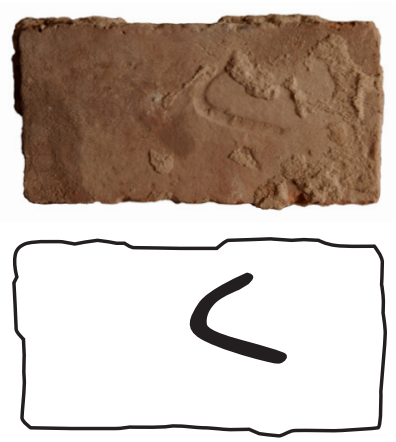

a
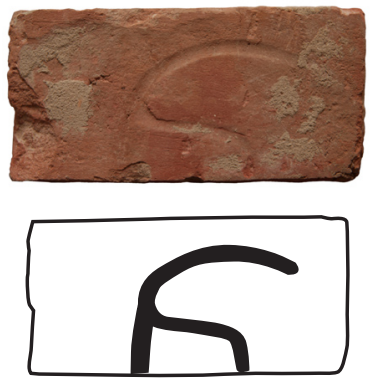

d
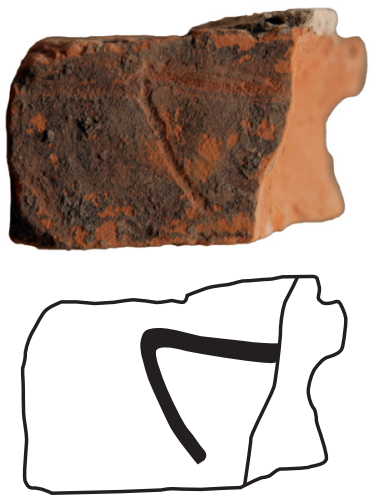

b
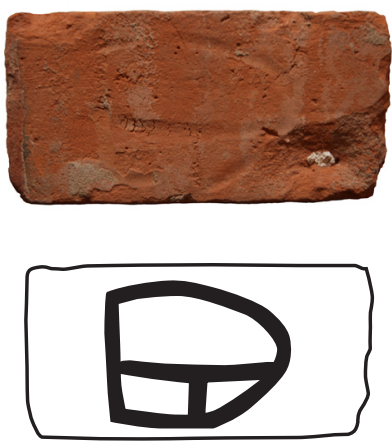

C
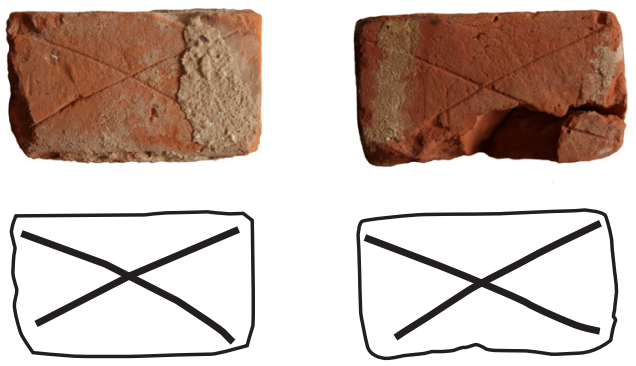

f

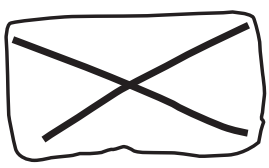

9

Figure 7.8. Bricks with unusual markings. Most of these bricks, found by the contractors dismantling the chimneys, are from the chimneys of the big house.

The simplest marks may have served a purely practical purpose. For example, the check mark on one brick face (see Figure 7.8a) may simply be a brick maker's finger test to check the plasticity of a freshly molded brick. The two engraved X marks could have been made to mark a stack of dried bricks for some purpose. It is possible that some or all of the markings had a deeper meaning, perhaps even spiritual significance to the enslaved people who made them.

Perhaps placing a marked brick in the big house chimneys was a type of "chimney charm" used by African Americans (Arnett et al. 2000:79). At many sites occupied by African Americans, $\mathrm{X}$ symbols were etched into a variety of objects such as spoons, glass, pottery, and marbles (Fennell 2007:44, 78; Joseph 2011:139_ 143 , Figure 2). The $\mathrm{X}$ symbol is interpreted as an African symbol-most commonly suggested to be a variation of a Bakongo cosmogram (Brown 2005b:107-128; Fennell 2007:78). Dr. Kenneth Brown (2005a:43-44; 2005b:107-110;
2012:8, 16, 62-66) describes similar West African symbolism in the form of cosmograms represented in the placement of objects and groups of objects in some of the cabins at the Levi Jordan slave/freedmen community. Two refit brick fragments from the Elder's Cabin have a raised oval and cross design, interpreted as a cosmogram (Brown 2005b:Figure 107; 2012:Figure 32), that is similar to the symbol etched into one of the chimney bricks (see Figure 7.8c). Brown (2012:4) notes the importance of "symbols placed on portable objects that are potentially reflective of broadly based West African cultural traditions."

Because some critical provenience data is lacking, we may never know if any of these marked bricks was placed in a prominent location within the big house chimneys or had some ritual significance. For now, they are simply construction bricks with unusual modifications that are not easily explained and warrant consideration. 


\section{ORIGINAL EAST WING CHIMNEY FOUNDATION}

On April 7-9, 2003, TPWD archeologists conducted a limited investigation of two brick features underneath the twentieth-century additions on the north side of the original Levi Jordan plantation house. These features were evident on the surface under the floor. The archeologists used pin flag probes to find the edges of the features, then "cleared debris from the surface and removed a thin overburden to expose the features beneath two additions on the rear of the main house" (Howard 2003b:2, 8). Units $6 \mathrm{~A}$ and 7A were excavated over the brick feature under the center of the "Kitchen/Dining Room," which was described and mapped as a "brick chimney foundation" (Howard 2003a:3-6; 2003b:10, Kitchen/Dining Room map). Howard (2003a:10) described the brick feature as measuring $5 \times 6.5 \mathrm{ft}$ with brick walls laid in a running stretcher bond pattern around "a central rubble core" (but field sketch maps show its width as $6 \mathrm{ft}$ 7 inches). They dug a shovel test along one edge and identified "at least three courses of bricks stepped out in 2.5 inch treads."

In 2005, CAS archeologists working in Zone B excavated two $3 \mathrm{x} 3 \mathrm{-ft}$ units on opposite corners of this brick chimney foundation (Leezer 2006:46-48, 79-82, Figures 5-5 to 5-7 and 7-2 to 7-4). Unit B1 was placed at the southwest corner and excavated to 16 inches below datum with an exploratory column to 18 inches. This unit revealed five step-out brick layers of the foundation, with a construction trench parallel to the edge of the bottom layer and evident from 4 to 16 inches deep; the trench was only 4.5 inches wide at 16 inches. Unit B2 was placed at the northeast corner and excavated to a depth of 16 inches, with an exploratory column to $18 \mathrm{~cm}$. A construction trench was also evident from 4 to 16 inches in this unit, and five step-out brick layers of the foundation were uncovered.

Figure 7.9, reproduced from CAS's report, shows the large brick fireplace foundation with an opening to the south. However, CAS conducted no excavations in this spot, and this depiction is incorrect. Although the report (Leezer 2006:79) states that "Initial investigations by TPWD indicated that the fireplace faced south," there is no explanation of the U-shaped foundation depicted in Figure 7.9. CAS archeologists did not excavate the south-central part of the feature, and Howard (2003a, 2003b) describes in this location a complete foundation pad that has a rubble-filled core like those in the two chimney foundations in the big house. The rectangular chimney foundation is correct, and Figure 7.9 depicts the locations of the two units accurately but the chimney base outline is incorrect.

The unit excavation illustrations (Leezer 2006:Figures 5-7 and 5-8) show the width of the step-outs on all four sides of the foundation. The south side step-outs are about 10 inches wide and the west side are about 12 inches wide, while the north and east sides are 12 and 13 inches wide, respectively. Thus, the south wall step-outs are the narrowest, again providing evidence that the firebox opened to the south. Leezer does not state the full dimensions of this original east wing chimney foundation, but if we use Howard's (2003a) notes and maps and add the widths of the step-outs from Leezer's drawings, this chimney foundation was $6 \mathrm{ft} 7$ inches east-west by $5 \mathrm{ft}$ north-south at the base of the firebox, and the spread footing expanded to $8 \mathrm{ft}$ 7 inches east-west by $6 \mathrm{ft} 10$ inches north-south.

\section{DETACHED KITCHEN CHIMNEY FOUNDATION}

A handmade brick feature located north of the east wing (see Figure 5.1) was exposed during two previous investigations, and PAI also investigated the feature during Phase I. This feature remains largely intact and interpreted as a detached kitchen hearth (Barrera 1999:42; Dr. Kenneth Brown, personal communication 2010; Leezer 2006:40, 86). The feature lies $10 \mathrm{ft}$ north of the twentieth-century east wing, but it lies $20 \mathrm{ft}$ north of the east wing chimney foundation that was inside the original east wing.

\section{Previous Investigations}

Two previous investigations of this brick chimney foundation have occurred. In December 1996, University of Houston archeologists excavated eighteen $1 \times 1-\mathrm{ft}$ shovel tests and five $5 \times 5$-ft units in the vicinity of the feature (see Figure 2.4) as well as north and northeast of the feature under the direction of Dr. Kenneth Brown. The results of these investigations have not been published, but a site visit with Brown combined with a limited review of the excavation 


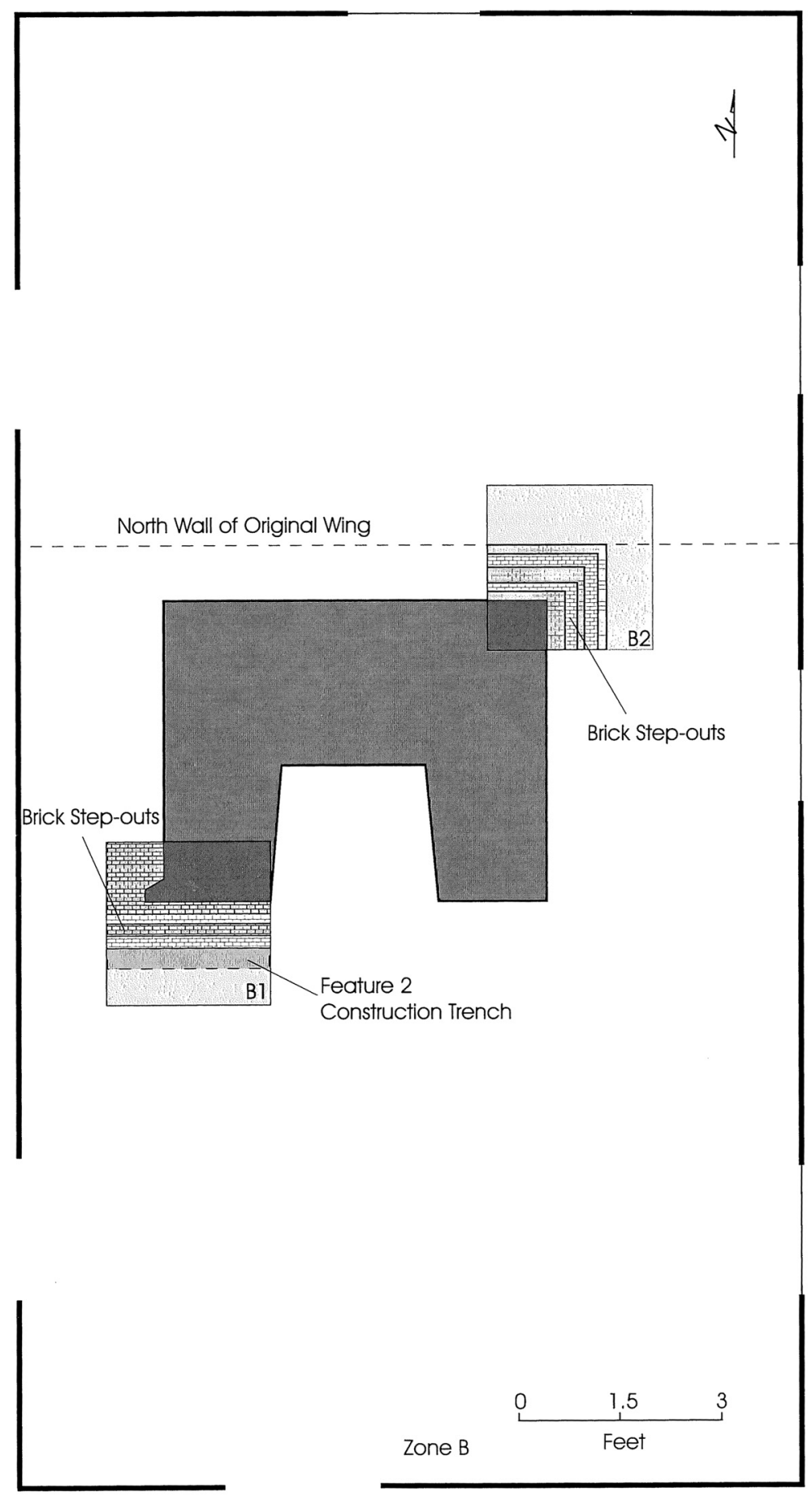

Figure 7.9. Map of the original east wing chimney foundation showing the two 3x3-ft excavation units dug by Center for Archaeological Studies archeologists in 2005 . The outer line represents the walls, doorways, and windows of the kitchen/dining room that comprise the twentieth-century east wing addition. The dashed line represents the hypothesized north wall of the original east wing. Figure is reproduced from Leezer (2006:Figure 7-3). 
level forms (University of Houston and TPWD Level Records) has added to the overall interpretation of this feature and its surrounding context. In addition, Rebecca Barrera mentions the detached kitchen chimney foundation in her master's thesis on the archeological investigations in the "backyard area." She states that "during the shovel testing operation a large brick hearth was discovered approximately $20 \mathrm{ft}$ from the original back of the main house. The hearth base measured $9 \mathrm{ft} \times 4 \mathrm{ft}$ and extended down 6 courses. Excavation of 11, $5 \mathrm{ft} \times 5 \mathrm{ft}$ units within the area demonstrated that it was the original kitchen. Evidence from shovel testing appears to indicate that the kitchen faced west...." (Barrera 1999:42). ${ }^{40}$

A second investigation of this feature was conducted by CAS in the summer of 2005. Leezer (2006:40) described this location as being associated with "a possible freestanding kitchen" located "in a mounded area approximately $10 \mathrm{ft}$ north of the current rear wing extension." She does not state where this functional interpretation came from other than generically attributing it to the University of Houston (Leezer 2006:40,53, 86). She designated the location as Area G, and one 3x3-ft unit, G1, was excavated to 24 inches below datum (ground level at the southwest corner of the house). This unit was located in the southeast corner of the feature. Within the unit, Leezer (2006:52-53) designated the exterior "wall or foundation" of the hearth as Feature 7 and the interior brick rubble fill as Feature 8. Both were identified at 4 to 8 inches below datum. Feature 7 is described as 13.5 inches wide and extending 20 inches below datum with brick step-outs. Feature 8 is described as brick rubble inside the wall, and it extended to a depth of 24 inches below datum. Brick and mortar samples were collected at that time. Features 7 and 8 are illustrated in three photographs by Leezer (2006:Figures 5-17, 5-18, and 5-19).

\section{PAI Investigations}

The PAI investigation began with locating and reexcavating the old Unit G1 to expose a portion of the feature. Once reexcavated, this unit showed the rubble-filled interior deposits as illustrated by Leezer (2006:Figure 5.18). PAI archeologists then dug a little deeper in one area to get completely below the rubble fill, exposing the top of a hard-packed layer of mortar that appears to go below the bottom of the brick footing and the rubble fill.

The excavations were then expanded to follow the east and south walls, with excavations extending deep enough to expose the exterior of the east wall and most of the south wall down to the base of the spread footing. The excavation was expanded again by stripping off a few inches of grass and soil to expose the top layer of bricks over the rest of the feature. Although the time for this investigation was limited, the excavation block covered an area of approximately $12 \mathrm{ft}$ east-west by $8.5 \mathrm{ft}$ north-south. The goal was to follow the top edges of the brick foundation, and this work defined the complete outline of the brick-walled structure, as shown in Figures 7.10 and 7.11). Although it could not be completely excavated, this feature is interpreted as the foundation of a large chimney base rather than the brick walls of a structure. The wall profiles and orientation of the bricks at the top of the wall (i.e., the pattern of headers and stretchers) were mapped for comparative purposes. The feature is relatively complete but impacted by a modern electrical line trench that cuts across the southwest corner.

When fully exposed, the outside dimensions of the chimney base are $8.5 \mathrm{ft}$ east-west by $6.5 \mathrm{ft}$ north-south at the top of the feature bricks, which is slightly larger than the chimney base dimensions for the east and west chimneys of the big house. The fully exposed portion of the south wall is 14 inches wide at the top, while the east wall varies from 16 inches wide at the southeast corner to 22 inches wide in the middle section. Both the east and west walls have two courses of spread footings below three remaining rows of the chimney. It is notable that the north wall is 20 to 21 inches wide (see Figures 7.10b and 7.11).

The PAI investigation of this feature was conducted in Phase I, before we excavated the

\footnotetext{
${ }^{40}$ Subsequent work shows that the chimney foundation was much larger than stated by Barrera (1999:42). It is not clear why the University of Houston archeologists measured the north-south dimension as $4 \mathrm{ft}$.
} 


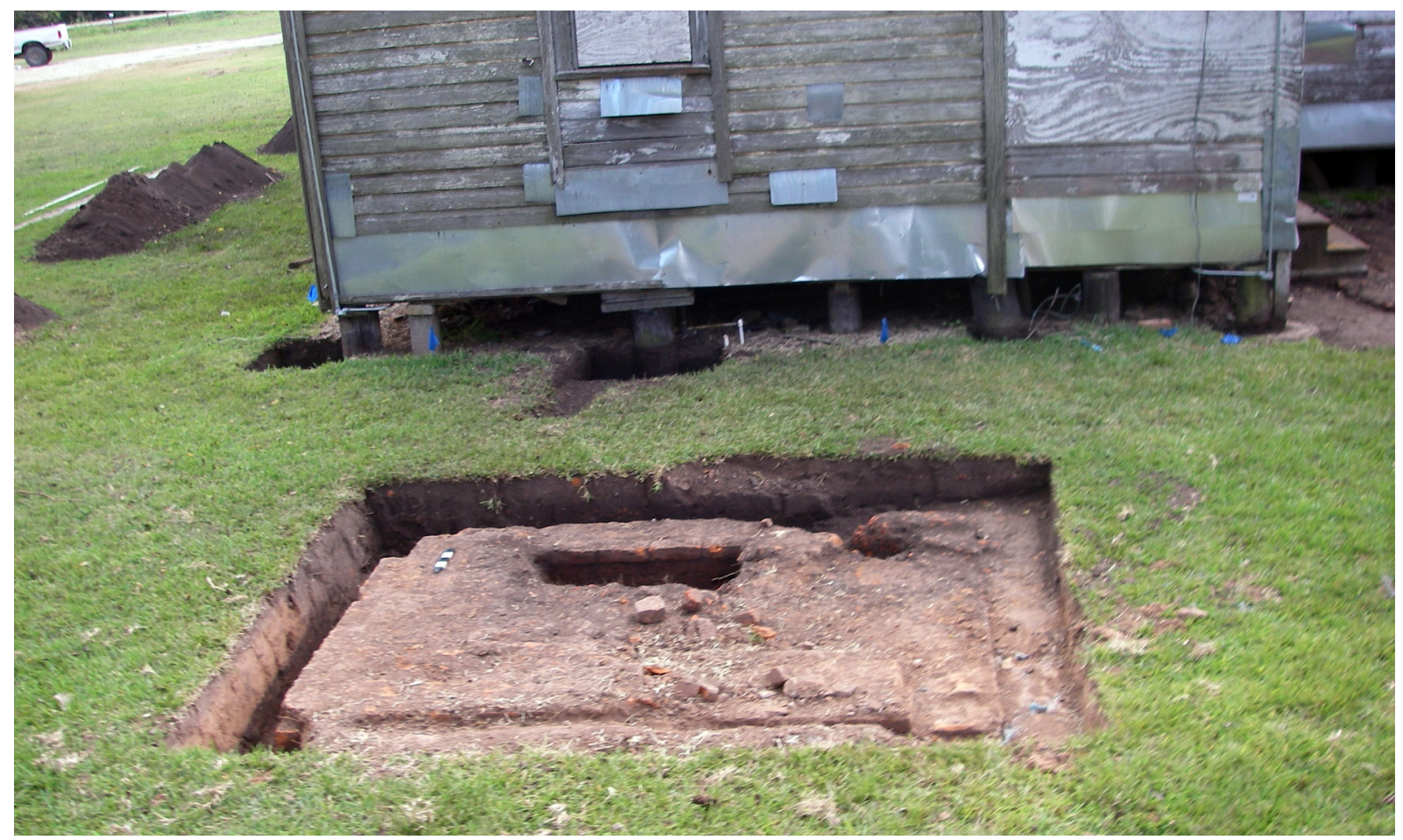

a

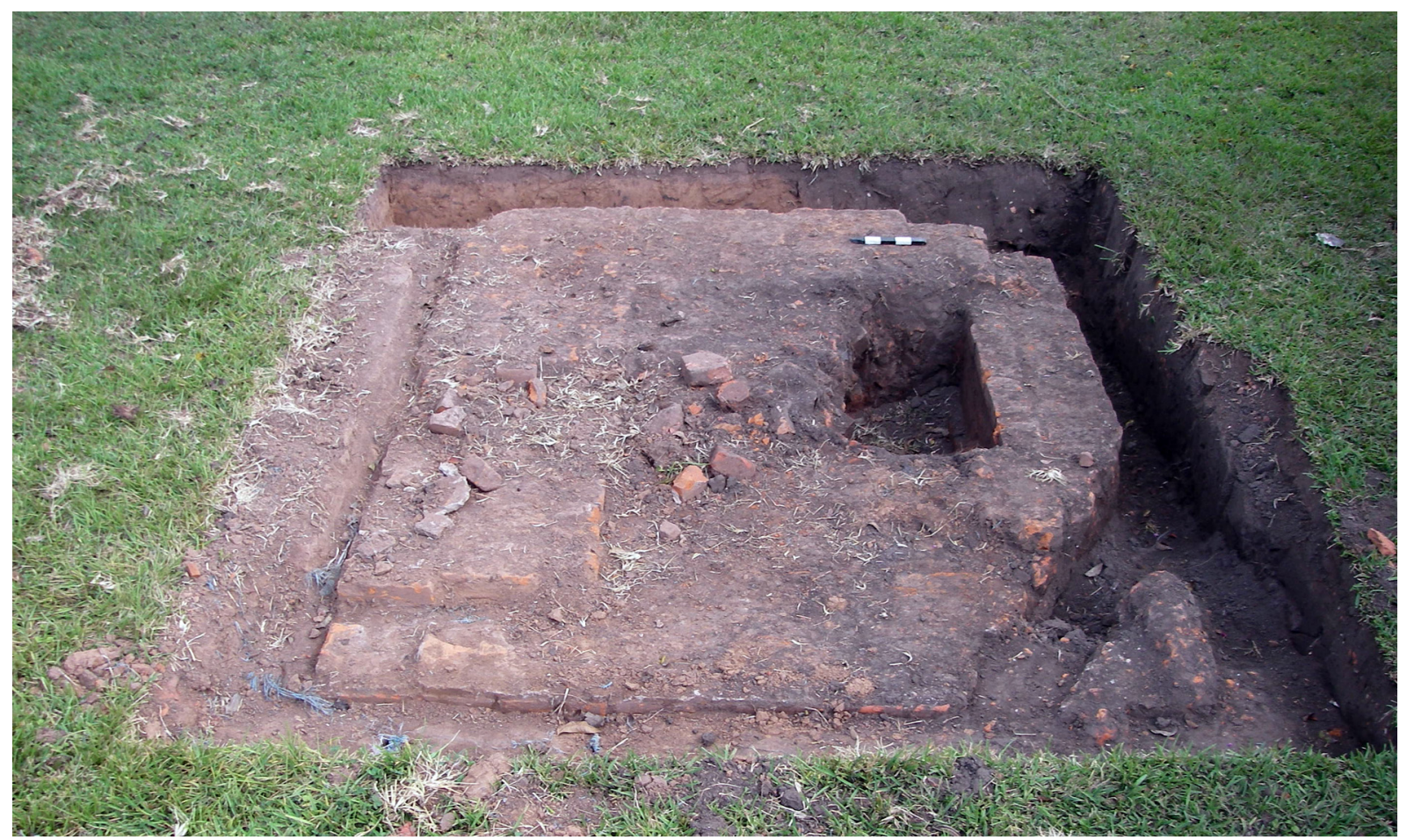

b

Figure 7.10. Photographs of the detached kitchen chimney foundation. (a) The entire feature is exposed, view looking south with the twentieth-century east wing of the plantation house in the background. (b) Oblique view of the exposed feature, looking east. North arrow is $1 \mathrm{ft}$. Note the exterior and interior edges of the north wall, on the left, which is much wider than the south wall, on the right. 


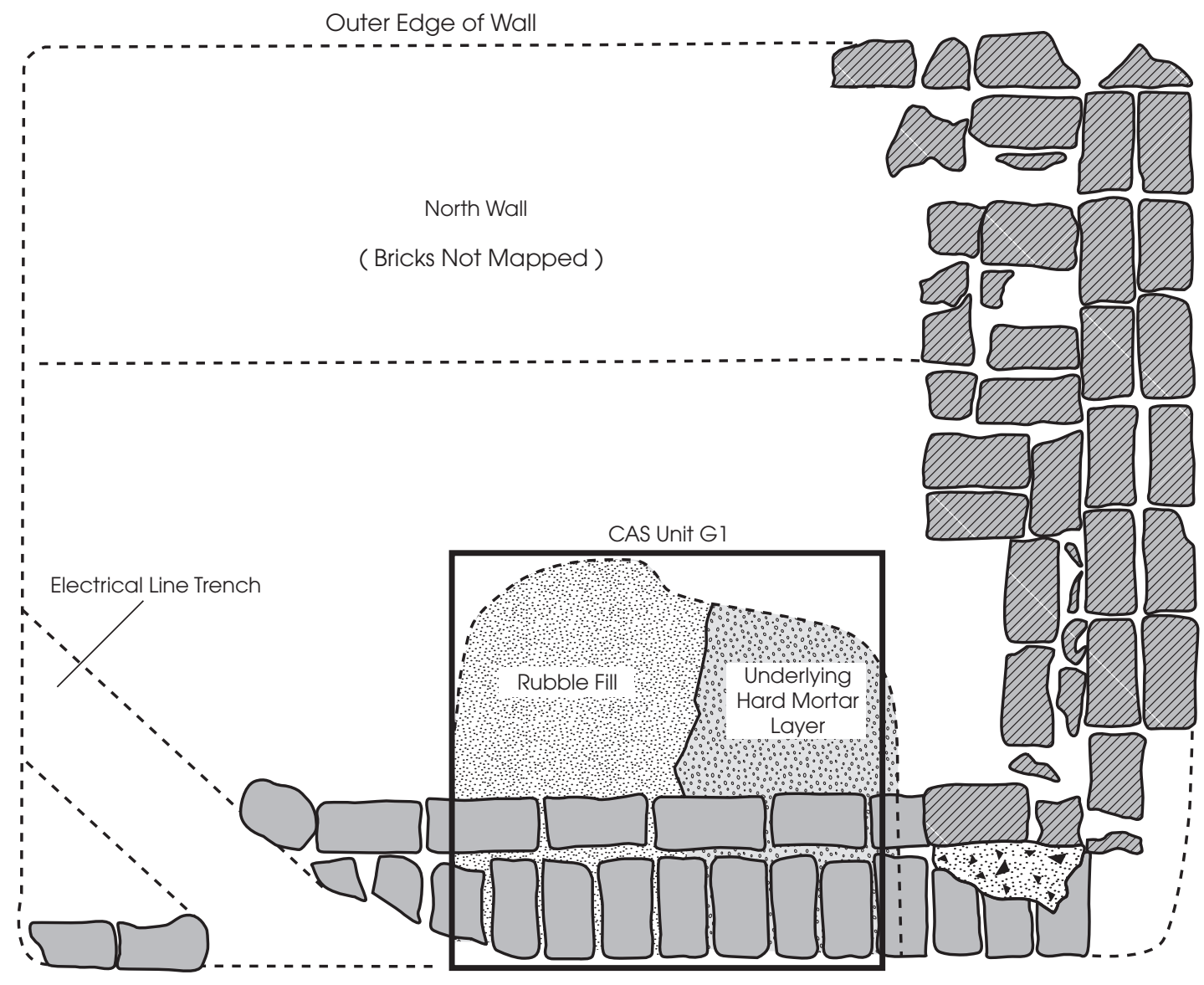

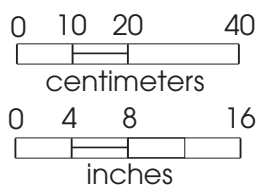

Al/12/BW

Figure 7.11. Map of the detached kitchen chimney foundation. Note the relative thickness of the north wall compared to the south wall.
$L E G E N D$

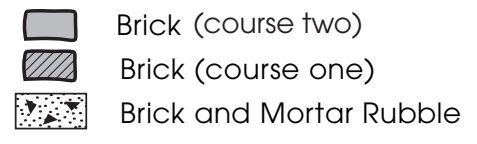


east and west chimney footings of the big house. Consequently, it was not always clear during the excavation how the overall feature should be interpreted. After comparing this feature with the fully excavated big house chimney foundations, it is relatively certain that this feature represents a large chimney base and footing because it shares many attributes with the big house chimney foundations. Given its location, the idea that this feature represents a chimney foundation for a detached kitchen is indeed likely.

Figure 7.12 is a hypothetical reconstructed profile of the detached kitchen chimney foundation. The most notable similarity between this chimney base and those of the big house is that they all have a large rubble-filled void that would have been just below the firebox. In all three cases, this void is offset relative to the rectangular foundation. Based on the fact that both of the big house chimneys had thick footing walls on the back side of the chimney firebox and thinner footing walls on the inside (facing into the structure), it is assumed that this detached kitchen chimney had a firebox that opened to the south, toward the big house. It is presumed that this chimney once had a small wooden structure attached to it, and this structure probably extended southward as well. Because the testing of this feature is so limited, these interpretations must be considered preliminary and should be framed as a testable hypothesis for further investigations.

As a cautionary note, there are conflicting ideas about where the detached kitchen was located and how it was constructed. A 1937 Houston Chronicle article described the kitchen as a "brick building apart from the mansion" (Humphries 1937:12), but this article presents many erroneous details as facts. Although a brick kitchen makes sense for fire prevention, there is no historical or archeological evidence that the detached kitchen at Levi Jordan was a brick structure. During a site visit, Dr. Kenneth Brown (personal communication 2010) stated that he had exposed architectural features-pier footings - that he interpreted as evidence of a wooden kitchen structure north of the brick fireplace foundation. Barrera (1999:40) also notes "a high concentration of square nails in level two" in the kitchen area, but this location is not identified precisely. Notably, the groundpenetrating radar survey results (see Chapter 5 and Appendix A) show some isolated anomalies forming a rectangle north of the chimney foundation. The survey also shows concentrated anomalies south of the chimney foundation, but this area is extensively disturbed, so at least some of the anomalies were caused by concentrations of buried pipes as well as previous archeological excavations. The only way to resolve these discrepancies and determine what the detached kitchen was like would be to design a targeted archeological investigation to look for buried piers or wall foundations.

Whatever the structure was like, it is assumed that the detached kitchen building and its chimney were probably destroyed in one of the many hurricanes or possibly torn down when they fell into disrepair. In either case, the building and chimney have been gone since the early twentieth century, ${ }^{41}$ and it is likely that all the bricks from the chimney, and maybe the kitchen walls, too, were removed for salvage or discard.

\section{COMPARISON OF THE LEVI JORDAN CHIMNEY FOUNDATIONS}

The four investigated chimneys at Levi Jordan are interesting for what they reveal about the history of the house and its improvements. Table 7.1 shows the size and construction attributes of the four chimney foundations that were investigated. All four are similar in construction in that they have deep spread footings with a rubble-filled core. The east and west chimneys of the big house are virtually identical in size and construction but display minor variations such as the two wings in the top level of the

\footnotetext{
${ }^{41}$ The only notable artifacts found adjacent to the detached kitchen chimney are two wrenches. One was found at the southwest corner of the chimney footing, and the other at the southeast corner. These tools may have been buried by Levi Jordan descendant Mike Martin (see Figure 2.1) when he was a young boy (see Chapter 4). If this is true, then at least some portion of this chimney base was visible above or at ground level when Martin lived there in the early 1940s.
} 


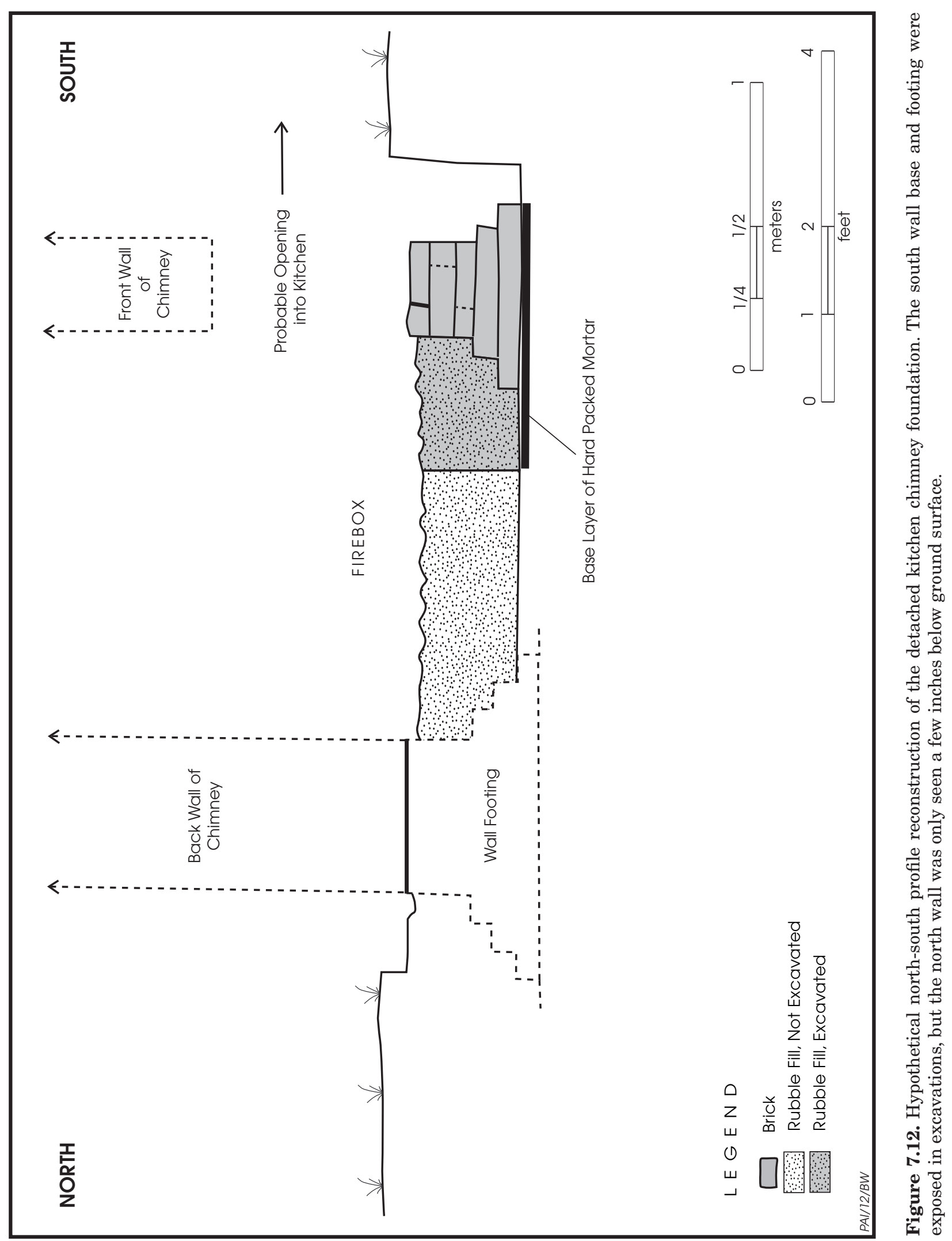


Table 7.1. Summary of attributes and size data for four chimney foundations at the Levi Jordan plantation

\begin{tabular}{|c|c|c|c|c|}
\hline Attribute & $\begin{array}{c}\text { East Chimney } \\
\text { of Big House }\end{array}$ & $\begin{array}{l}\text { West Chimney } \\
\text { of Big House }\end{array}$ & $\begin{array}{l}\text { Original East Wing } \\
\text { Chimney }\end{array}$ & $\begin{array}{c}\text { Detached Kitchen } \\
\text { Chimney }\end{array}$ \\
\hline Associated features & $\begin{array}{l}\text { Feature } 3 \text { and } \\
\text { Feature } 4\end{array}$ & none & Feature 2 & Features 7 and 8 \\
\hline Excavation units & $\begin{array}{l}\text { CAS Units C1, C2 } \\
\text { and PAI block } \\
\text { excavation }\end{array}$ & $\begin{array}{l}\text { PAI Units W1, W2 } \\
\text { and block } \\
\text { excavation }\end{array}$ & $\begin{array}{l}\text { TPWD Units 6A } \\
\text { and 7A and CAS } \\
\text { Units B1 and B2. } \\
\text { PAI made } \\
\text { observations but did } \\
\text { no excavations }\end{array}$ & $\begin{array}{l}\text { UH excavations and } \\
\text { CAS Unit G1; PAI } \\
\text { block excavation }\end{array}$ \\
\hline $\begin{array}{l}\text { Builder's trench } \\
\text { observed }\end{array}$ & $\begin{array}{l}\text { Yes. Identified by } \\
\text { CAS as Features } 3 \\
\text { and } 4\end{array}$ & $\begin{array}{l}\text { No. Original } \\
\text { builder's trench } \\
\text { likely disturbed by } \\
\text { erosion }\end{array}$ & $\begin{array}{l}\text { Yes. Identified by } \\
\text { CAS as Feature } 2\end{array}$ & $\begin{array}{l}\text { Unknown. Possibly } \\
\text { observed by UH } \\
\text { archeologists }\end{array}$ \\
\hline $\begin{array}{l}\text { Orientation of long } \\
\text { axis of foundation }\end{array}$ & North-south & North-south & East-west & East-west \\
\hline $\begin{array}{l}\text { Direction firebox } \\
\text { opening faced }\end{array}$ & West & East & South & South \\
\hline $\begin{array}{l}\text { Size of chimney base* } \\
\text { (width and depth of } \\
\text { firebox exterior, above } \\
\text { footing) }\end{array}$ & $\begin{array}{l}7 \mathrm{ft} 4 \text { inches } \times 4 \mathrm{ft} \\
11 \text { inches }\end{array}$ & $\begin{array}{l}7 \mathrm{ft} 4 \text { inches } \times 4 \mathrm{ft} 6 \\
\text { inches }\end{array}$ & $\begin{array}{l}6 \mathrm{ft} 7 \text { inches } \times 5 \mathrm{ft} 0 \\
\text { inches }\end{array}$ & $\begin{array}{l}8 \mathrm{ft} 6 \text { inches } \times 6 \mathrm{ft} 6 \\
\text { inches } * *\end{array}$ \\
\hline $\begin{array}{l}\text { Maximum size of } \\
\text { spread footing } \\
\text { (width and depth of } \\
\text { lowest course of } \\
\text { bricks) }\end{array}$ & $\begin{array}{l}8 \mathrm{ft} 11 \text { inches } x 6 \mathrm{ft} \\
8 \text { inches }\end{array}$ & $9 \mathrm{ft} \times 6 \mathrm{ft} 5$ inches & $\begin{array}{l}8 \mathrm{ft} 7 \text { inches } \times 6 \mathrm{ft} \\
10 \text { inches }\end{array}$ & $\begin{array}{l}\text { Unknown but } \\
\text { minimum estimate } \\
\text { is } 9 \mathrm{ft} 6 \text { inches x } 7 \mathrm{ft} \\
6 \text { inches* }\end{array}$ \\
\hline $\begin{array}{l}\text { Number of courses in } \\
\text { spread footing }\end{array}$ & 5 & 5 & 5 & $\begin{array}{l}\text { Barrera }(1999: 42) \\
\text { states "6 courses" of } \\
\text { bricks observed, but } \\
\text { it is not clear how } \\
\text { they defined the } \\
\text { footing }\end{array}$ \\
\hline $\begin{array}{l}\text { Depth below ground } \\
\text { surface to bottom of } \\
\text { footing }\end{array}$ & 17.5 inches & $\begin{array}{l}9 \text { inches } \\
\text { (but erosion has } \\
\text { removed some } \\
\text { deposits) } \\
\end{array}$ & 16 inches & 14 inches \\
\hline $\begin{array}{l}\text { Prepared bottom } \\
\text { mortar/sand layer }\end{array}$ & Yes & Yes & Unknown & Unknown \\
\hline $\begin{array}{l}\text { Vertical rubble-filled } \\
\text { void }\end{array}$ & $\begin{array}{l}\text { Present in Courses } \\
2 \text { through } 6,\end{array}$ & $\begin{array}{l}\text { Present in Courses } \\
1 \text { through } 5, \text { and } \\
\text { possibly } 6 \\
\end{array}$ & Appears in Course 5 & $\begin{array}{l}\text { Appears in Course } 5 \\
\text { or } 6\end{array}$ \\
\hline $\begin{array}{l}\text { Maximum horizontal } \\
\text { size of the rubble-filled } \\
\text { void (width and depth } \\
\text { at top of spread } \\
\text { footing) }\end{array}$ & $\begin{array}{l}3 \mathrm{ft} 6 \text { inches } \mathrm{x} 1 \mathrm{ft} \\
11 \text { inches in Course } \\
6 \text { (with } 9 \times 9 \text {-inch } \\
\text { wings attached on } \\
\text { both sides ) }\end{array}$ & $\begin{array}{l}3 \mathrm{ft} 7 \text { inches } \times 1 \mathrm{ft} 9 \\
\text { inches in Course } 5\end{array}$ & $\begin{array}{l}4 \mathrm{ft} \times 2 \mathrm{ft} \text { in Course } \\
5 \text { (estimated) }\end{array}$ & $\begin{array}{l}4 \mathrm{ft} 4 \text { inches } \times 4 \mathrm{ft} 8 \\
\text { inches in Course } 5 \\
\text { or } 6\end{array}$ \\
\hline $\begin{array}{l}\text { Dimensions of actual } \\
\text { firebox*** } \\
\text { (width and depth) }\end{array}$ & $\begin{array}{l}4 \mathrm{ft} 4.5 \text { inches } \times 1 \mathrm{ft} \\
5.1 \text { inches }\end{array}$ & $\begin{array}{l}4 \mathrm{ft} 4.5 \text { inches } \mathrm{x} 1 \mathrm{ft} \\
8.6 \text { inches }\end{array}$ & Unknown & Unknown \\
\hline $\begin{array}{l}\text { Size and area of the } \\
\text { rubble-filled void in } \\
\text { upper course of spread } \\
\text { footing }\end{array}$ & $\begin{array}{l}42 \mathrm{ft} \times 23 \mathrm{ft}=966 \\
\text { square inches }\end{array}$ & $\begin{array}{l}43 \mathrm{ft} \times 21 \mathrm{ft}=903 \\
\text { square inches }\end{array}$ & not applicable & $\begin{array}{l}52 \mathrm{ft} \times 56 \mathrm{ft}=2,912 \\
\text { square inches }\end{array}$ \\
\hline
\end{tabular}


Table 7.1, continued

\begin{tabular}{l|l|l|l|l}
\hline \multicolumn{1}{c|}{ Attribute } & \multicolumn{1}{|c|}{$\begin{array}{c}\text { East Chimney } \\
\text { of Big House }\end{array}$} & $\begin{array}{c}\text { West Chimney } \\
\text { of Big House }\end{array}$ & $\begin{array}{l}\text { Original East Wing } \\
\text { Chimney }\end{array}$ & $\begin{array}{l}\text { Detached Kitchen } \\
\text { Chimney }\end{array}$ \\
\hline $\begin{array}{l}\text { Area of rubble-filled } \\
\text { void in square feet }\end{array}$ & 6.7 & 6.3 & 8.0 & 20.2 \\
\hline $\begin{array}{l}\text { Builder's trench } \\
\text { observed }\end{array}$ & Yes & $\begin{array}{l}\text { No; evidence } \\
\text { probably destroyed } \\
\text { by erosion }\end{array}$ & Yes & $\begin{array}{l}\text { Not observed in } \\
\text { limited } \\
\text { investigations }\end{array}$ \\
\hline $\begin{array}{l}\text { Chronological evidence } \\
\text { and inferred date of } \\
\text { construction }\end{array}$ & $\begin{array}{l}\text { direct association } \\
\text { with original } \\
\text { plantation house }\end{array}$ & $\begin{array}{l}\text { direct association } \\
\text { with original } \\
\text { plantation house }\end{array}$ & $\begin{array}{l}\text { Unknown date of } \\
\text { construction, but } \\
\text { possibly pre-Civil } \\
\text { War **** }\end{array}$ & $\begin{array}{l}\text { Likely pre-1890 and } \\
\text { possibly pre-Civil } \\
\text { War }\end{array}$ \\
\hline $\begin{array}{l}\text { References } \\
\text { Leezer (2006:39,48- }\end{array}$ & $\begin{array}{l}\text { This report only } \\
\text { report }\end{array}$ & $\begin{array}{l}\text { Howard (2003a, } \\
2003 b) ; \text { Leezer } \\
(2006: 46-47,79- \\
80) ; \text { this report }\end{array}$ & $\begin{array}{l}\text { Ken Brown } \\
\text { (personal } \\
\text { communication, } \\
2010) ; \text { Leezer } \\
(2006: 52-53 ; 86) ; \\
\text { this report }\end{array}$ \\
\hline
\end{tabular}

* The width of the chimney bases as stated in the Texas Historical Commission's "Construction Documents" (January 4, 2011, Sheet A-410, Fireplace Details) are: East Chimney $7 \mathrm{ft} 3.5$ inches and West Chimney $7 \mathrm{ft}$ 5.25 inches.

** Barrera (1999:42) states "The hearth base measured $9 \mathrm{ft}$ x $4 \mathrm{ft}$ ” but this differs significantly from the PAI data.

*** The dimensions of the first-floor chimney fireboxes are from the Texas Historical Commission's

"Construction Documents" (January 4, 2011, Sheet A-410, Fireplace Details).

**** The window glass study by CAS revealed that most of the window glass from Units B1 and B2 was manufactured prior to 1900 (Leezer 2006:Figure A-3). This supports the interpetation that the chimney may have fallen during the 1900 hurricane.

rubble-filled core of the east chimney. The fact that the original east wing chimney is so similar to the big house chimneys suggest that the east wing may have been constructed at about the same time. The size similarities also suggest that the original east wing might have been two stories tall.

A comparison of the four foundation features shows that the isolated northernmost chimney foundation is somewhat larger than the others -6 to 7 inches wider and 8 to 13 inches deeper. What is most notable is that the rubblefilled core of this foundation is much larger, being 4 to 10 inches wider and 32 to 35 inches wider. This evidence supports the interpretation that this chimney was associated with a detached kitchen behind the big house. The thinner foundation walls indicate the chimney was probably only one story tall. Second, the large size of the core indicates there was a very large firebox above it-one that could be used to cook lots of food at one time. 



\section{EXTERIOR FEATURES}

Prewitt and Associates, Inc. (PAI) investigated 10 exterior features around the Levi Jordan plantation house: 2 cisterns, a front walkway and porch steps, a brick patio in the back of the house, a possible brick rain barrel pad, 2 large brick rubble features, 1 small brick cluster, a buried iron container filled with materials, and a concentration of seashells (Figures 8.1 and 8.2).

\section{CISTERNS}

The two brick-walled cisterns are on the north side of the house near one another (Figure 8.3). The two cisterns include the older Cistern 1 , which is completely buried (with no aboveground remains), and the younger Cistern 2 , with its shoulder and neck above ground. In 2009, Texas Historical Commission (THC) personnel constructed an open-sided wooden structure with a tin roof to protect Cistern 2, and this was how it appeared when PAI began the Phase I archeological investigations. The approximate location of Cistern 1 was indicated only by a slight depression.

\section{Cistern 1}

Cistern 1 is roughly centered in the back of the house ca. $10 \mathrm{ft}$ north of the north side of the twentieth-century house addition (the ell) and about $23 \mathrm{ft}$ north of the original house. This cistern was not visible on the surface at the time of the investigations, and its remains had been buried for many years. However, it was remembered by many of the former occupants of the plantation (see Chapter 4), and its location appears on the feature maps by University of Houston archeologists (see Figure 2.7) and the map drawn by Aunt Eula (see Figure 4.1). At the time PAI began its Phase I investigations, this feature was evident as a circular depression in the grass-covered yard just east of Cistern 2. It was presumed that this depression represented the location of a circular cistern body that had its top removed. PAI archeologists used a soil probe (a steel rod) and hand excavations to identify the edges of the cistern body. Once the cistern walls were located, handdug trenches were placed on all four sides to expose the walls and determine the size and shape of the buried cistern (see Figure 8.2). The four trenches were designated Units N1 to N4. Each one was $1 \mathrm{ft}$ wide, and they ranged from 3 to $10 \mathrm{ft}$ in length. These excavations revealed the size and shape of the buried cistern remains as well as some interesting remnants of brick pavement (Figures 8.4, 8.5, and 8.6). Since excavations focused on revealing the cistern architecture, none of the fill was screened, but notes were made on some of the cultural materials observed.

The excavations encountered all four walls of the cistern between 5 and 12 inches below the ground surface. The evidence indicates that the cistern was bottle shaped and that its dome and neck had been removed at some time in the past. The body is 14.5 to $15 \mathrm{ft}$ in exterior diameter (ca. $13 \mathrm{ft}$ interior diameter), and its brick walls are 9.5 to 10 inches thick. The walls were constructed of hand-molded bricks, with all the bricks laid perpendicular to the wall and flat (face upward). The handmade bricks were held together with a sandy mortar, and the mortar was used to create a thin (less than 1/4 inch) plaster layer on the interior and exterior of the walls. The mortar was still in good shape but it was relatively soft and easily scratched. 


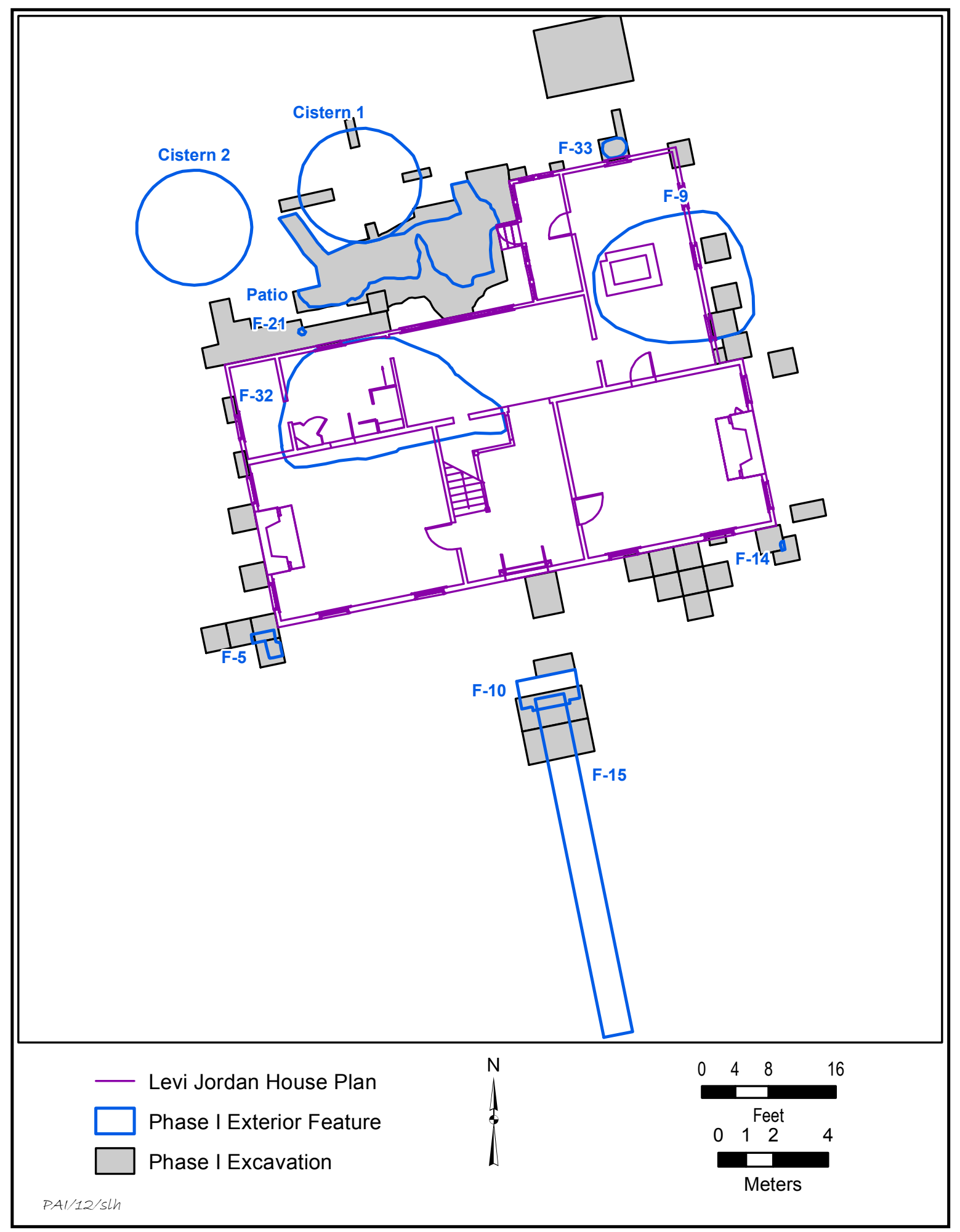

Figure 8.1. Map of investigated exterior features around the Levi Jordan house. 


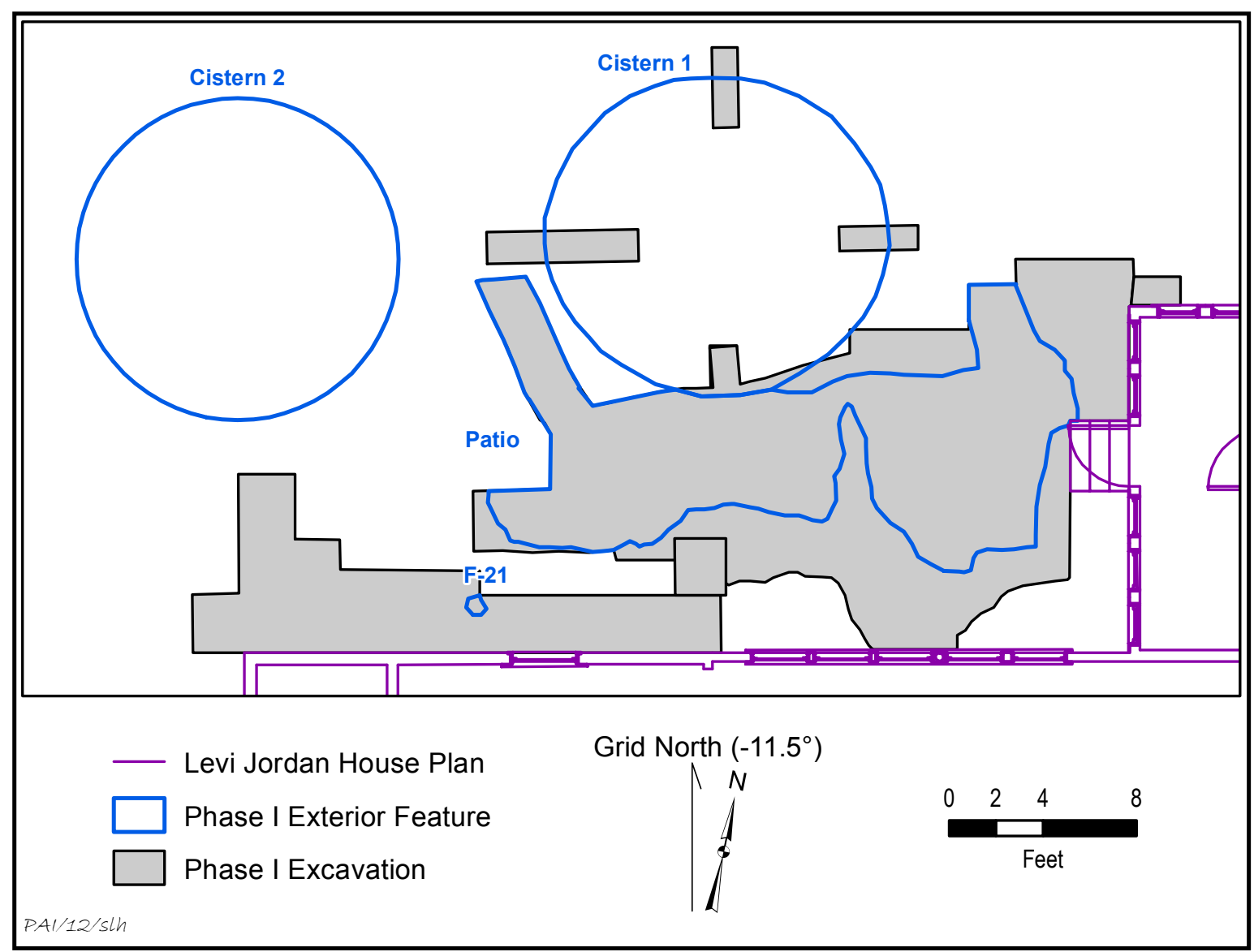

Figure 8.2. Closeup map of the backyard features, including the two cisterns and the brick patio.

\section{Cistern 1 Test Units}

Unit N1 (3 ft east-west by $1 \mathrm{ft}$ north-south) was excavated over the east wall of the cistern to a depth of 15 inches (see Figure 8.4). The top of the brick wall was ca. 4 to 5 inches below the surface. The wall measured 9.5 inches thick, and all visible bricks were laid flat and perpendicular to the wall direction. A soft grainy mortar or plaster was present on the interior and exterior of the wall, but it is very thin. The profile of Unit $\mathrm{N} 1$ (north wall) revealed a small remnant of the original builder's trench, and it was only a small wedge of mottled fill just above the curved shoulder edge. This indicates that the original builder's trench was almost exactly the same size as the cistern's circular brick wall, meaning that a circular hole was dug and the bricks were laid against the sediment from the inside.

The excavation over the west wall of the cistern was Unit N2 ( $6 \mathrm{ft}$ east-west by $1 \mathrm{ft}$ northsouth). Much like the east wall, the cistern's west wall was ca. 10 inches thick with bricks laid in the same manner as observed in N1. The cistern wall was first encountered ca. 10 inches below the surface and the unit was excavated to 22 inches (see Figure 8.5). Outside the cistern wall to the west, a solid horizontal brick pavement was encountered at about 3 to 4 inches below the surface, which was much higher than the top of the truncated cistern wall. There also was a horizontal gap of about 3 to 4 inches between this brick pavement and the west edge of the cistern wall.

Unit N3 (10 ft north-south by $1 \mathrm{ft}$ east-west) was excavated over the south wall of the cistern. This wall was 10 inches thick and it was encountered 10.5 inches below the surface. Just south of and abutting the cistern wall was a horizontal brick pavement that extended 51 inches to the 


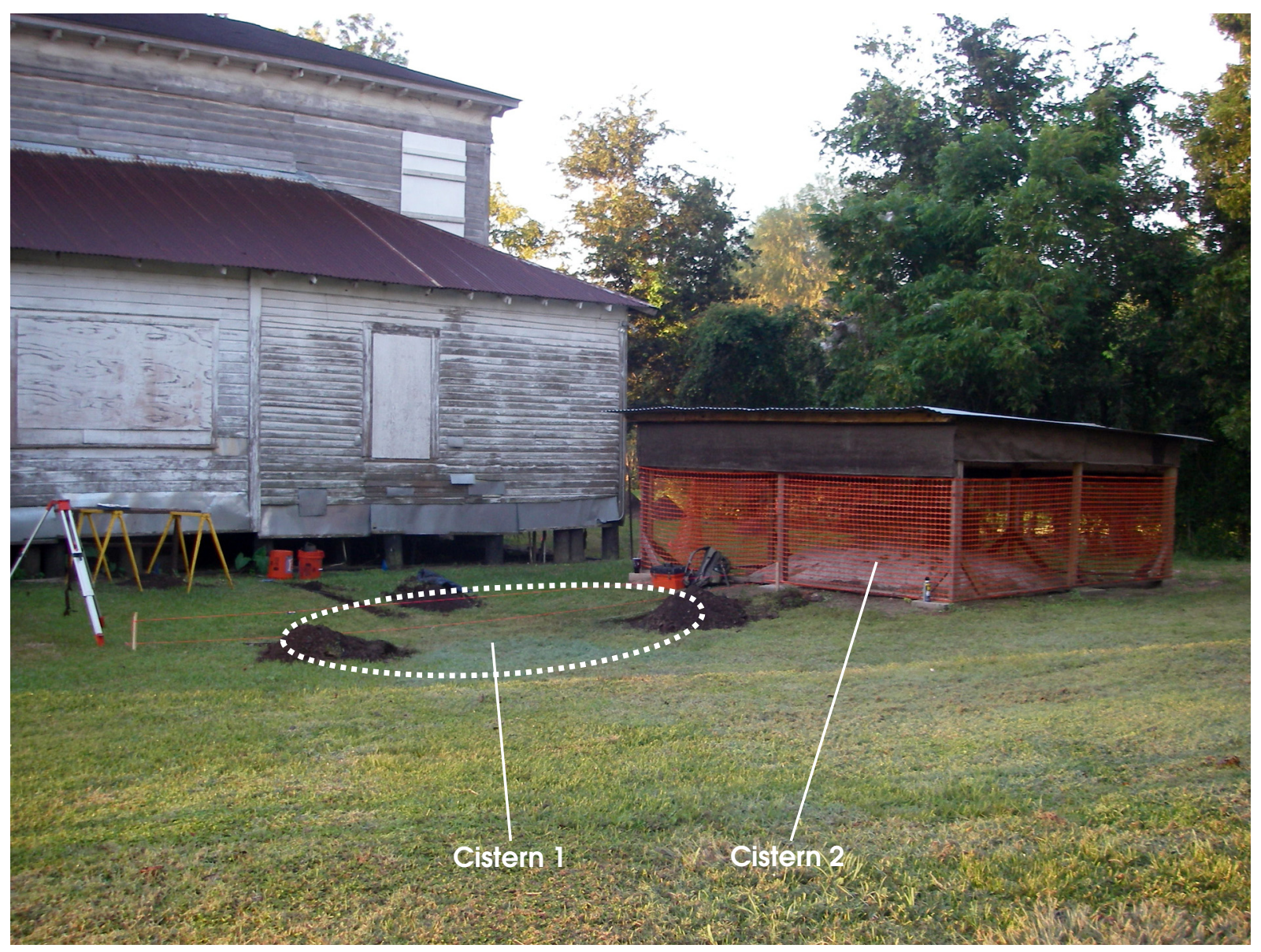

Figure 8.3. Overview photograph of the backyard cisterns, looking southwest, before the removal of the twentieth-century additions. Cistern 1 was evident as a shallow depression, and the mounds of dirt are from the hand-dug trenches that exposed the cistern walls below ground surface. Cistern 2 is inside the small structure on the right, with its domed shoulder and neck visible behind the orange mesh.

south and ended abruptly with a sharp edge (see Figure 8.6). This pavement has about 6 inches of brick rubble next to the edge of the cistern, and then it switches to a patterned surface with bricks laid in parallel rows. This pavement is part of the large backyard brick patio discussed later in this chapter.

Unit N4 was placed to cross section the cistern's north wall. The top of the wall was encountered at 12 inches below the surface and measured 10 inches thick. The same pattern of perpendicular brick construction was observed. Two pipes were found in this unit but are not related to the cistern. A 1-inch cast-iron pipe extends east to west and may go to Cistern 2, while a PVC pipe likely runs to the modern water pump 25 to $30 \mathrm{ft}$ to the northwest.

\section{Cistern 2}

Cistern 2 is bottle shaped with its dome and neck standing $3.5 \mathrm{ft}$ above the ground surface (Figure 8.7). Its domed shoulders and square neck were built from handmade bricks and are partially intact, but there may be significant breaks along the shoulder at ground level. The thin concrete layer that covers the dome is an obvious recent addition. The square neck is ca. $3 \mathrm{ft} 8$ inches on all sides and about 18 inches tall. The mouth is roughly circular and measures ca. 22 inches in diameter. The interior of the cistern is filled with sediment.

A measured plan drawing was made of the neck and mouth, along with a profile of the cistern dome and neck. Like Cistern 1, Cistern 2 is 


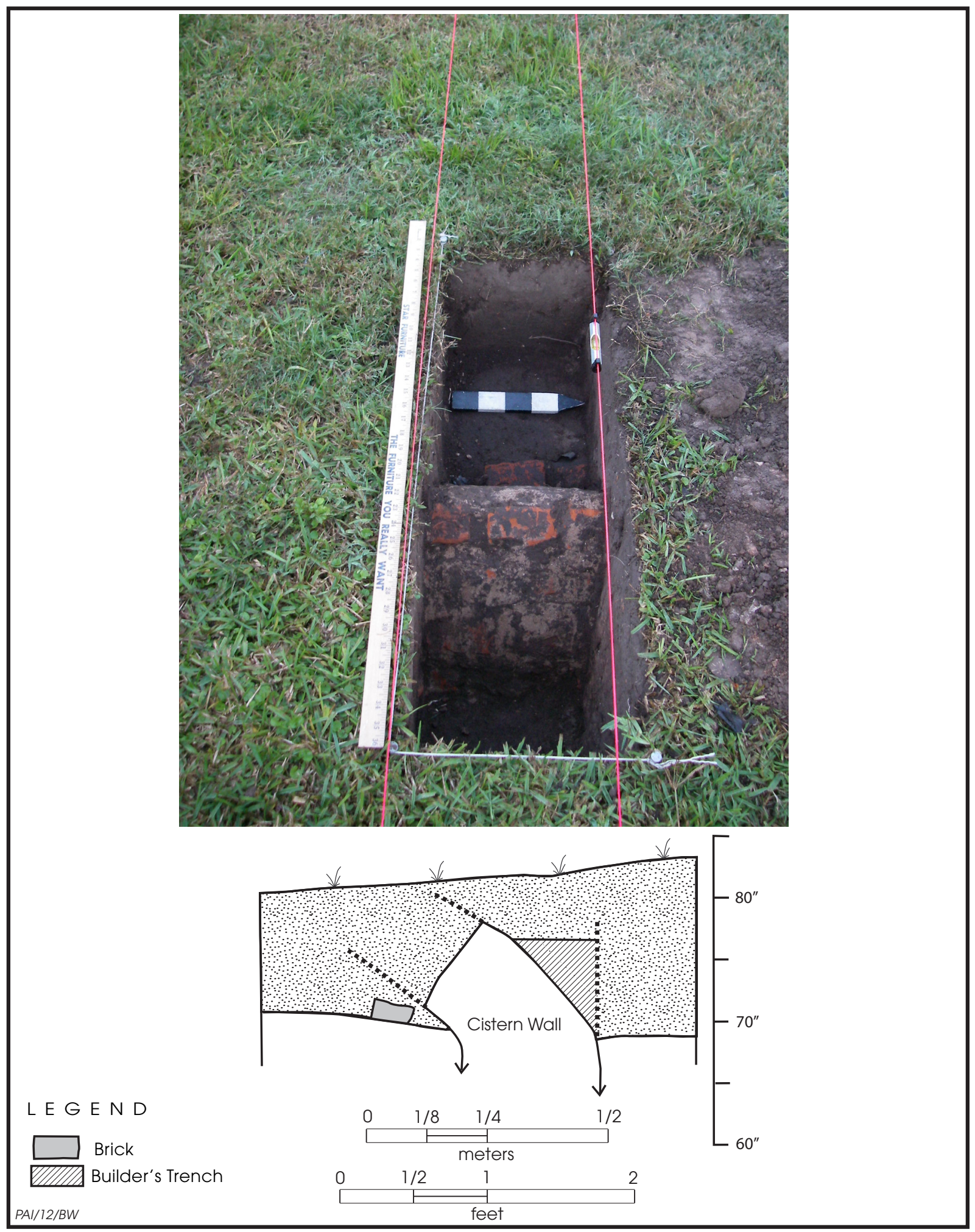

Figure 8.4. Photograph and profile of Unit N1 exposing the east wall of Cistern 1. Photo is looking east at the truncated cistern wall. Horizontal scale is $3 \mathrm{ft}$ long, and the north arrow is $25 \mathrm{~cm}$ (ca. 10 inches). 


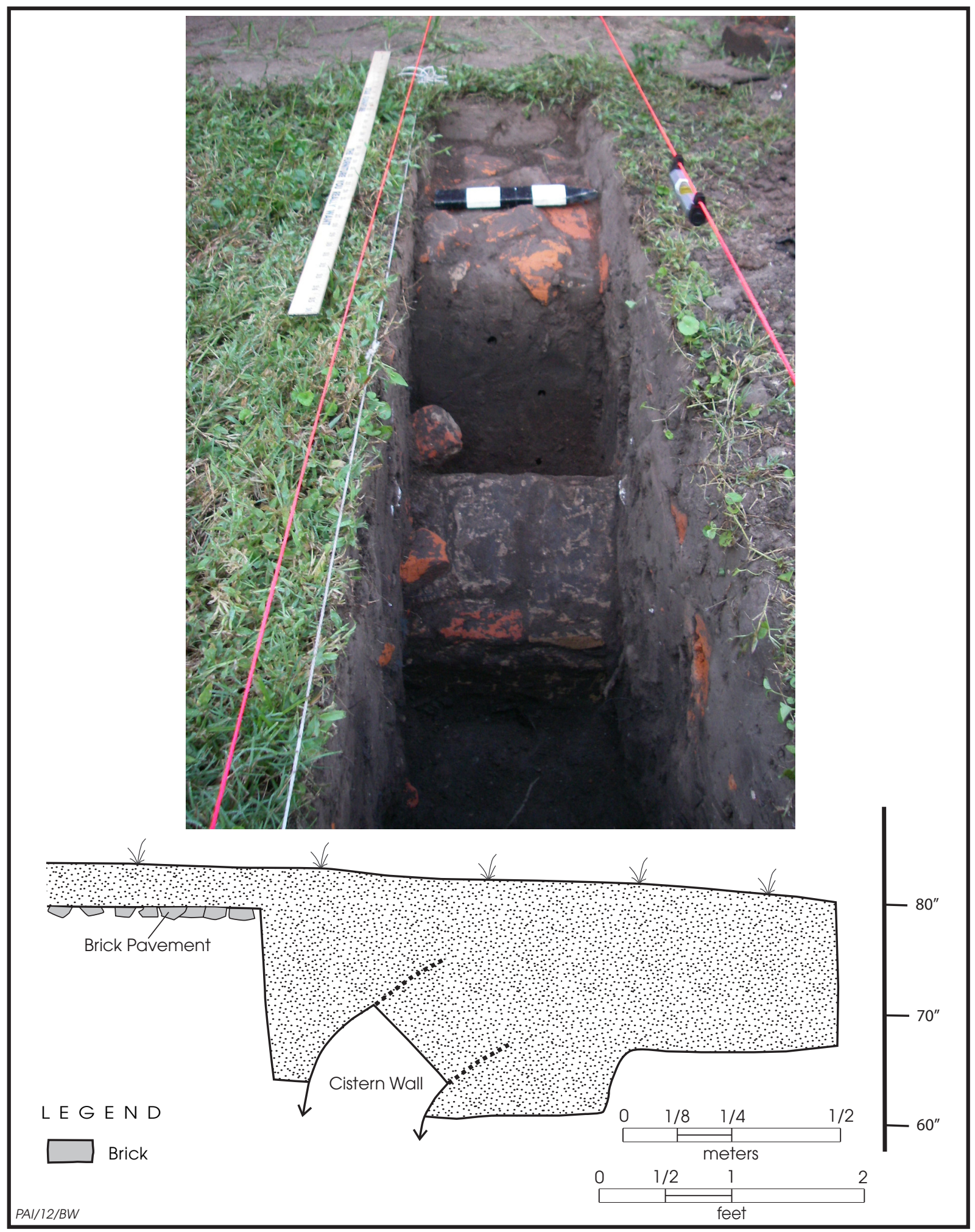

Figure 8.5. Photograph and profile of Unit N2 exposing the west wall of Cistern 1. Photo is looking west with the truncated cistern wall in the foreground and the brick pavement behind. Horizontal scale is $3 \mathrm{ft}$ long, and the north arrow is $25 \mathrm{~cm}$ (ca. 10 inches). 


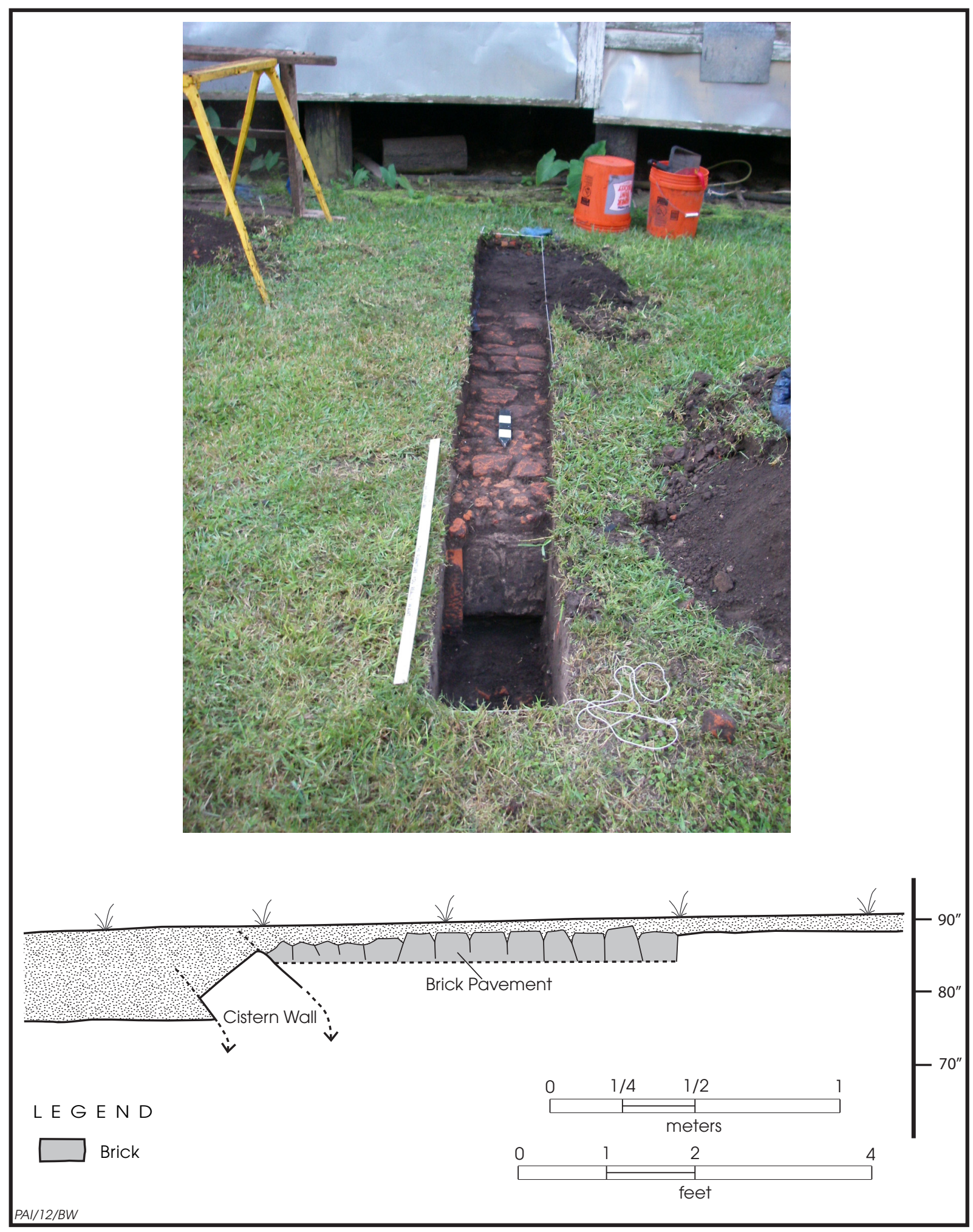

Figure 8.6. Photograph and profile of Unit N3 exposing the south wall of Cistern 1. Photo is looking south toward the twentieth-century house addition. The truncated cistern wall is in the foreground and the brick pavement is behind. Horizontal scale is $3 \mathrm{ft}$ long, and the north arrow is $25 \mathrm{~cm}$ (ca. 10 inches). 


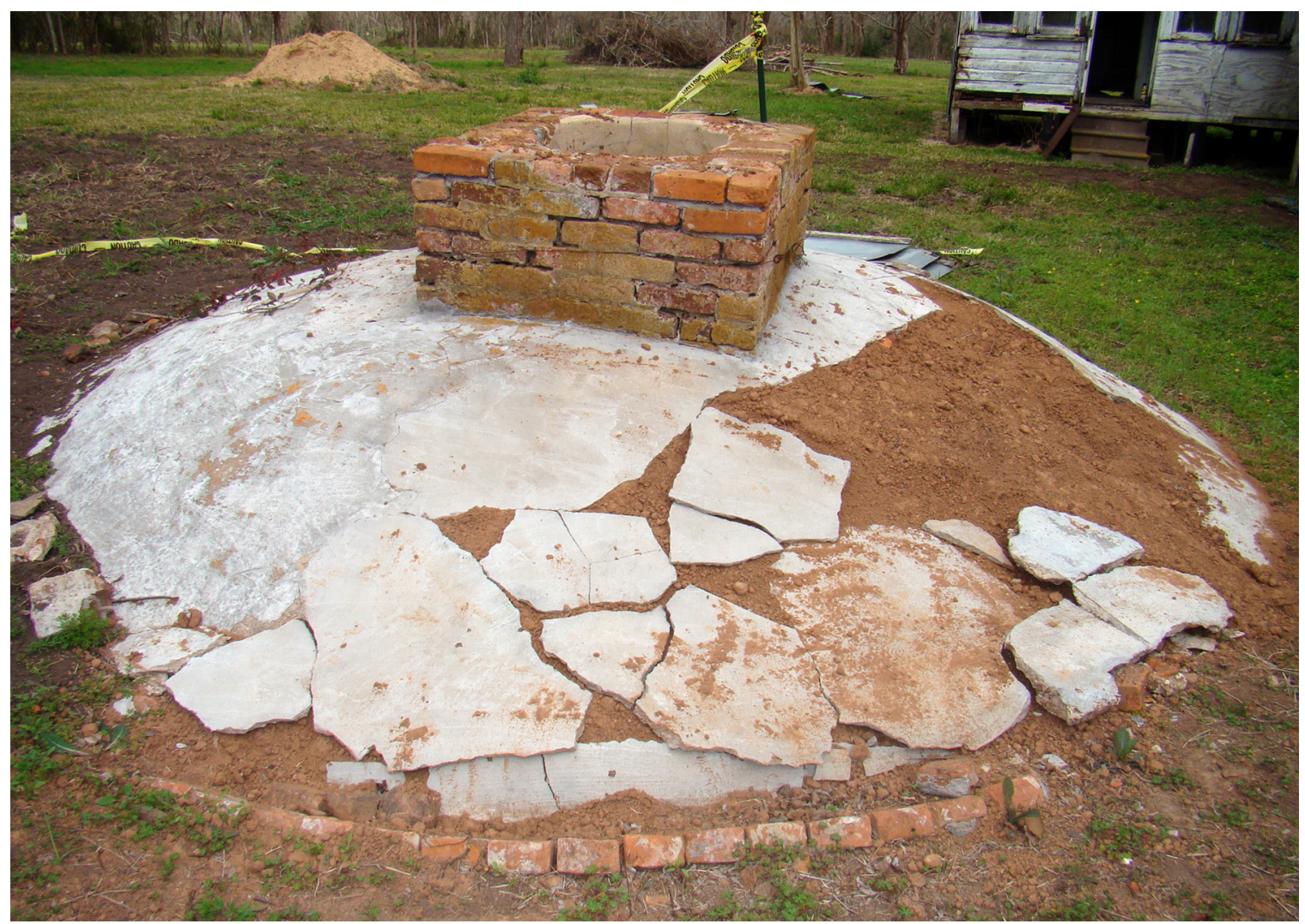

West

East

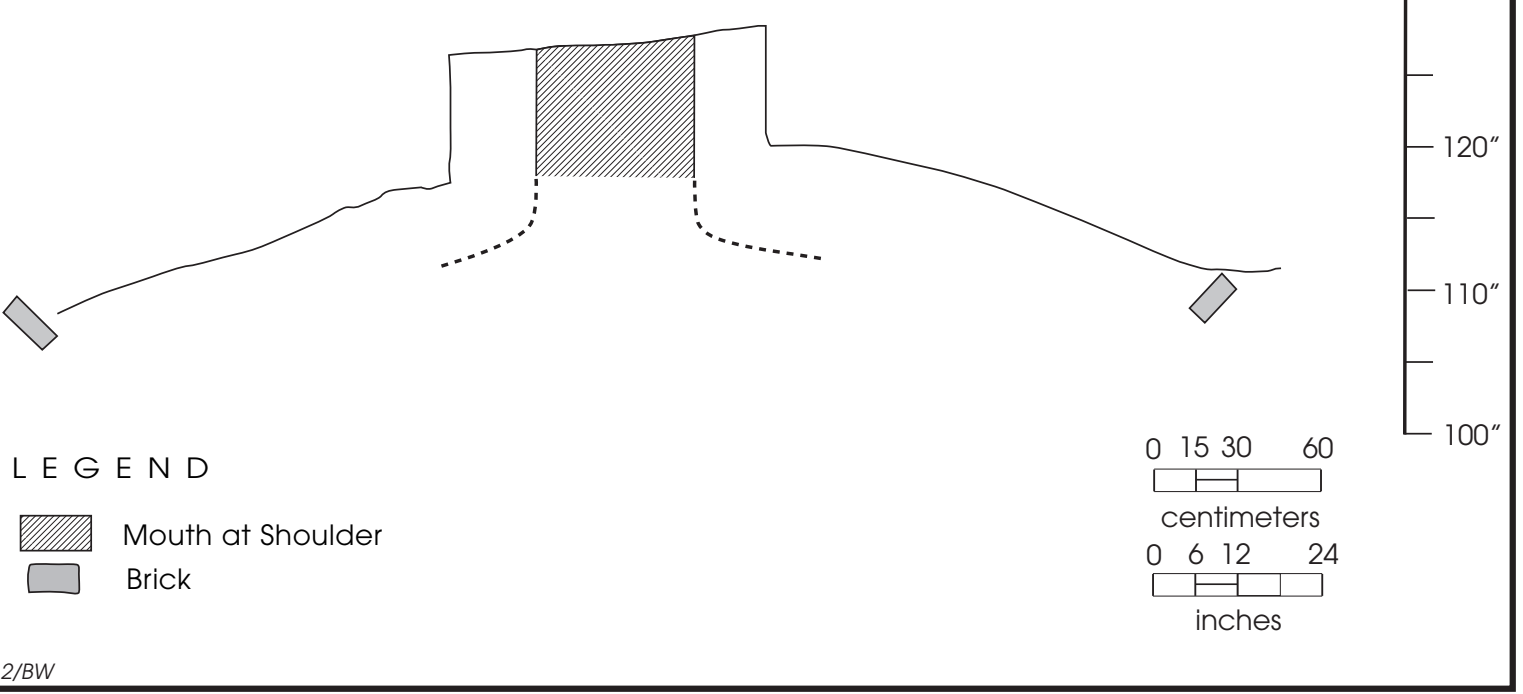

Figure 8.7. Photograph and profile of Cistern 2. The photograph (courtesy of the Texas Historical Commission) shows the cistern in 2009, before the protective structure was built over it. The view is looking east with the northern end of the east wing in the background. The cracked dome plaster and sediment in the foreground is the collapsed portion of the shoulder that was backfilled with sediment. 
about 13 to $14 \mathrm{ft}$ in diameter. ${ }^{42} \mathrm{~A} 1 / 2$ - to $3 / 4$-inchthick concrete coating was applied to the dome by descendant Bruce Gotcher in 1970, and he inscribed his name into it (Bruce Gotcher, personal communication 2010). The inscription"Bruce 70"-is still present on the north side of the cistern dome, just below the neck.

According to THC staff (Dusty Fritts, personal communication 2010), the cistern was repaired in 2009. Sometime prior to 2009, the southern portion of the Cistern 2 dome collapsed. THC personnel then filled in this area with sediment to stabilize it (see Figure 8.7). To prevent additional deterioration, a wooden frame structure with a corrugated tin roof was built over Cistern 2 in February 2009 (see Figure 8.3).

\section{Interpretive History of the Big House Cisterns}

Oral history evidence reveals that Cistern 1 fill was dug out by residents of the Levi Jordan house at least twice. The first excavation was recalled by Ewing Martin, who was born in 1915 and lived in the house until 1920. In an oral history interview, Martin (1998, n.p.) stated:

The old cisterns were brick. Both of them were up and while we lived there my Dad [Calvin Martin] got some colored fellows and they cleaned that cistern out-the first one-the one that is all filled up now... While we lived there, Uncle Will [Martin] had a well dug. Before that they were relying on the cistern, see? They had these gutters that channeled water into the old brick system and we left there-of course, we put a cover on it so nobody could get in it...

According to this recollection, Calvin Martin (1873-1928) apparently excavated Cistern 1 sometime between ca. 1915 and 1920. It is unknown why they did this, if they cleaned the cistern out completely, or what contents were removed. But Martin's statement does suggest that Cistern 1 was abandoned before 1915 and that it was considered to be the "old" cistern at that time. ${ }^{43}$ The statement also dates the house's first water well to the 1915-1920 period and includes an observation that prior to excavation of the well, the household relied on the cisterns for water. This would suggest that Cistern 2 was abandoned as a water source by 1920 .

For whatever reason, Cistern 1 became dysfunctional sometime in the early twentieth century, and its shoulder and neck were removed and the cavity was backfilled. Major damage to the Jordan house occurred during the 1900 storm, specifically to the east wing and the roof. Cistern 1 might have been damaged at this time as well, but there is no definitive evidence to support this supposition. If Cistern 2 was built as a replacement, it is likely that Cistern 1 was abandoned at about the same time, and these events occurred before 1915. Alternatively, it is possible that the two cisterns were used together for some time.

Cistern 1 was excavated again by June Birmingham, who rented the Jordan house sometime from the late 1960s to 1980s (Bryan McAuley, personal communication 2010). Again, it is not clear why this was done, if the cistern body was cleaned out entirely, or if the same fill was put back into it. Because the cistern fill seems to contain some historic artifacts and brick fragments, it seems likely that it was backfilled with the same fill that was dug out of it.

No early pictures of Cistern 1 exist, but two historic photographs of Cistern 2 are of interest. The first is believed to be from 1927-1937 and shows Eloise Masterson Martin (McWillie Martin's wife) and two of her daughters (Texas Parks and Wildlife Department (TPWD) collection, now at THC). Only the square brick neck of the cistern appears in this photograph, but it looks essentially the same as it does today. The appearance of the dilapidated wooden cover placed over the cistern's mouth seems to suggest that Cistern 2 was no longer in use. The

\footnotetext{
${ }^{42}$ Exact measurements of the Cistern 2 body would require some excavations, and none were undertaken.

${ }^{42}$ Humphries' 1937 Houston Chronicle article states that "underground cisterns [plural] lift their heads where no roofs remain to fill them" (Humphries 1937), suggesting that both cistern mouths were standing in 1937 (see Chapter 4).
} 
second photograph is from 1958 (with a date stamp imprint of "JUN 58") and shows the entire plastered dome with brick top. The cistern dome and neck in this photograph appear similar to how they look today.

The bricks in Cistern 1 would have been hand-molded by the Levi Jordan slaves at the time the cistern was built. But less is known about the handmade bricks in Cistern 2, since this feature may date to the late-nineteenth or early-twentieth century. It is possible that these bricks came from the house's original east wing chimney (see Chapter 7) or perhaps another chimney associated with an original west wing of the plantation house. In any case, it is likely that this cistern was built using salvaged bricks or bricks purchased elsewhere.

Because most of the lands in Brazoria County are prone to occasional flooding during hurricanes, the old plantation cisterns seem to have been built with prominent domes and necks extending several feet above the ground surface (Gross et al. 1993:127). This would have prevented them from filling with floodwater and sediment during extreme rainfall events. The square neck on Cistern 2 is somewhat odd, since many of the plantation cisterns that still exist in Brazoria County have round necks (Gross et al. 1993:127). It may represent an early-twentiethcentury style. The shape of the Cistern 1 neck is not known.

The depths of the two cisterns were not investigated, so their volumes cannot be calculated. Cisterns at some other Brazoria County plantations are about the same diameter as these and have known depths. For example, Gross et al. (1993:127, Figure 4) report that the cistern at the Eagle Island Plantation overseer's house (an 18x45-ft, possibly two-story brick structure) measured $14.5 \mathrm{ft}$ in interior diameter and was at least 8 to $10 \mathrm{ft}$ deep. A geotechnical study at the Levi Jordan plantation encountered groundwater at a depth of $6 \mathrm{ft}$ in the vicinity of the house (Hammock 2004:4). Although the water table would have fluctuated considerably in the past, these cisterns may have extended down below the average depth of the water table. When the water table was high, it is possible that water would have filtered through the walls to fill the lower portions of the cisterns.

\section{FRONT WALKWAY AND PORCH STEPS}

The ground-penetrating radar survey revealed a linear anomaly extending southward off the front porch steps (see Figure 5.1 and Appendix A). It seemed likely that this anomaly was a long walkway leading to the porch and running perpendicular to the front door of the house. While investigating the front steps (designated Feature 10), a section of the front walkway (designated Feature 15A/B) was exposed and investigated. Units $\mathrm{J} 1$ and $\mathrm{J} 2$, comprising an $8 \times 8$-ft area, were excavated to exposed the 38-inch-wide concrete walkway near the front steps (Figures 8.8 and 8.9). The concrete was extensively cracked in situ, and bricks could be seen beneath the concrete cap. Additional investigation revealed that the brick layer was a walkway composed of one course of dry-laid handmade bricks that obviously predates the concrete cap. This earlier walkway is just over $2 \mathrm{ft}$ wide, and profiles along its edges showed that bricks were placed directly on the ground surface with no sand, mortar, or other base preparation.

The unit excavations to expose the walkway only extended $8 \mathrm{ft}$ south of the porch, but a soil probe was then used to follow the buried feature to the south. The concrete walkway was only a few inches under the surface, and the probing revealed that it extends $41 \mathrm{ft}$ south of the front steps or just over $50 \mathrm{ft}$ from the front door-a length confirmed by GPR survey data. It terminated abruptly, probably where a gate in a perimeter fence once stood. ${ }^{44}$ Because the GPR grid also stopped at this distance, without additional excavations, the southern extent of the earlier brick walkway remains unknown.

At the northern end of the sidewalk, the concrete surface went underneath the front porch steps, and three concrete blocks comprise the first step at this juncture. When these were removed, it exposed an inscription in the concrete sidewalk below, with the name "Will

\footnotetext{
${ }^{44} \mathrm{~A}$ front gate and fence are pictured in many historic photographs, and the approximate distances generally appear to match this length (see Figures $4.2 \mathrm{a}$ and $4.2 \mathrm{c}$ ).
} 


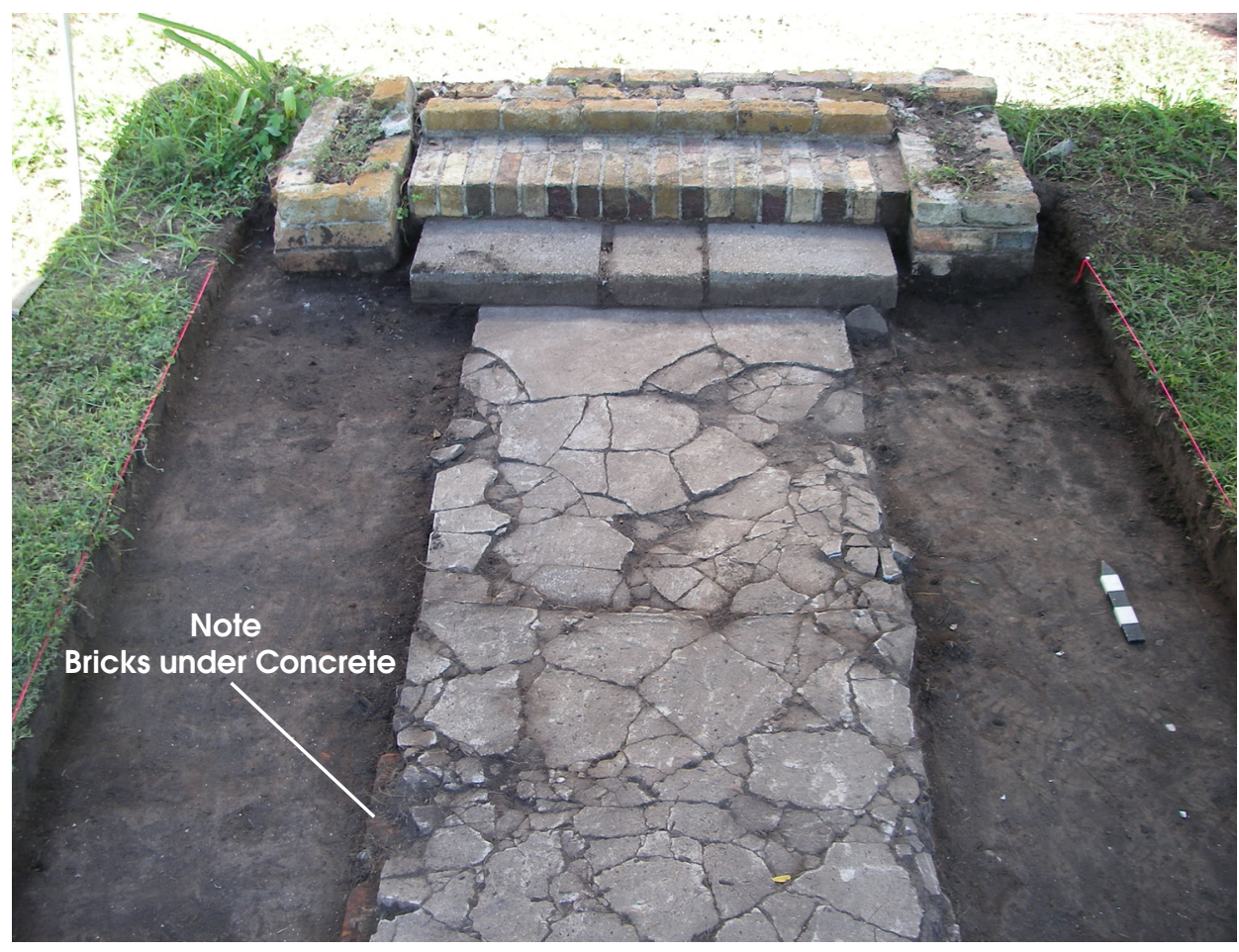

a

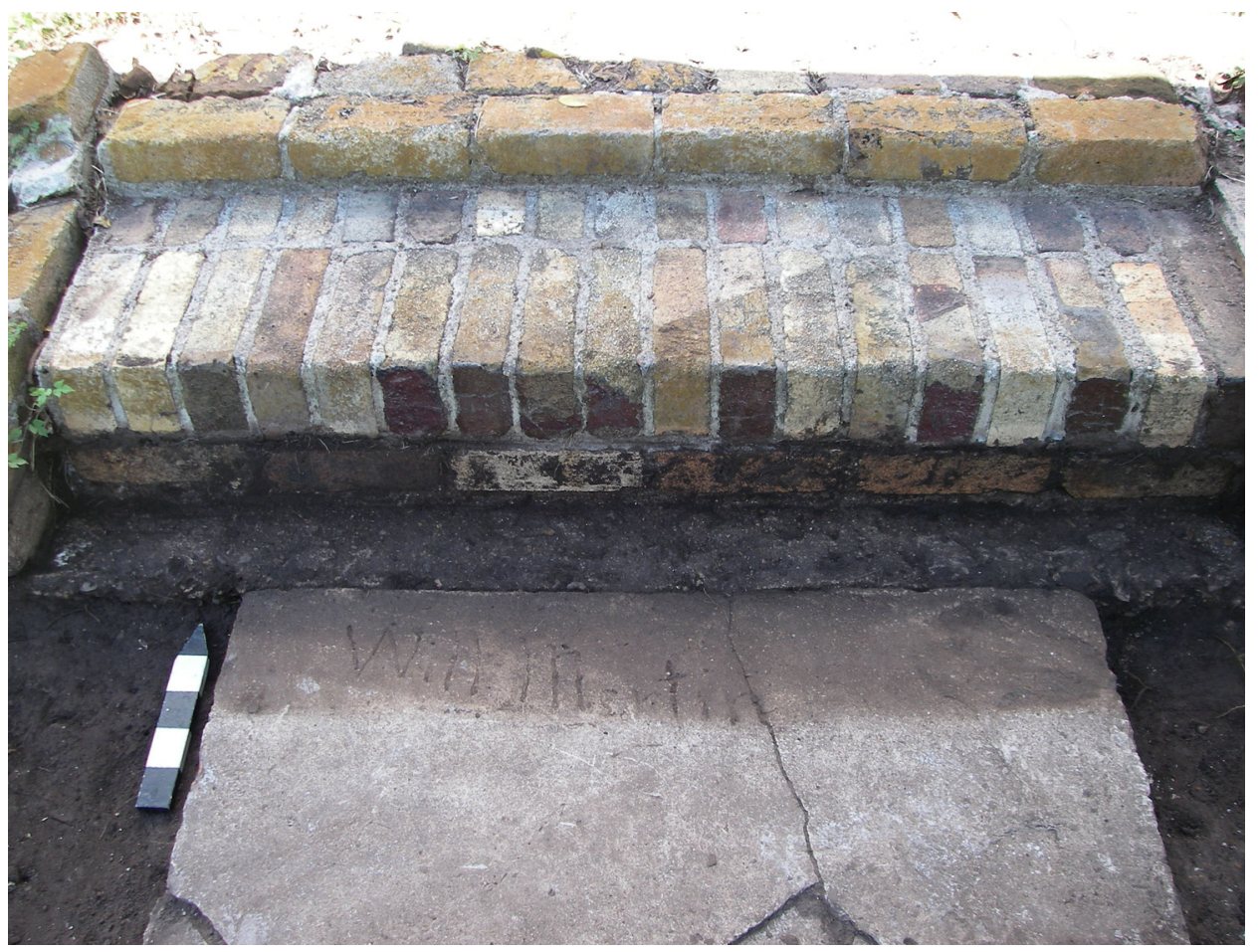

$\mathrm{b}$

Figure 8.8. Photographs of the front walkway and front porch steps, looking north. (a) Overview shows the broken concrete sidewalk with bricks from an earlier sidewalk underneath. (b) The front porch steps with the cinder blocks (first step) removed to expose the "Will Martin" inscription and handprint. 


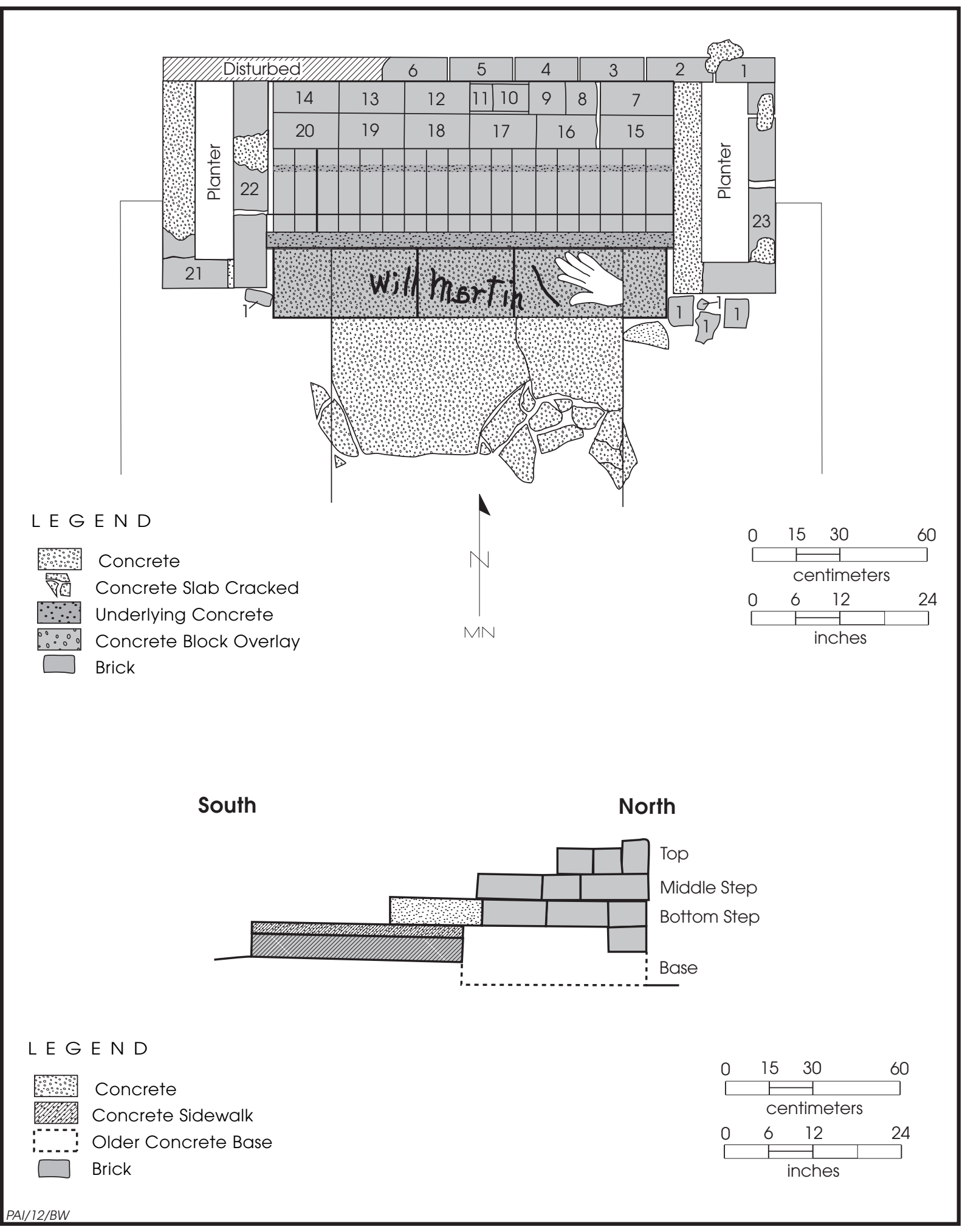

Figure 8.9. Plan and profile of the front porch steps. 
Martin" and a right handprint (see Figure 8.8b). McWillie "Will" Martin obtained the Jordan house and 200 acres in 1891 after a legal battle, and records indicate that he moved into the house sometime after 1894 (Freeman 2004:136). Since Will Martin died in December 1937, the concrete cap on the walkway would have been laid between about 1894 and 1937. All known photographs of the walkway show it to be concrete, not brick. But Ewing Martin (1998:n.p.) describes the front walkway he remembered as a child from around 1920 as being a "brick walk." This information narrows the probable construction date of the concrete walkway to the period from 1920 to 1937.

Unfortunately, no archival or oral history evidence provides any more specific chronological evidence for the earlier brick walkway. The majority of the artifacts recovered from the excavations there date from 1950 to the 1970 s, but these deposits do not necessarily indicate the construction date or age of the walkway. However, some early artifacts recovered warrant mention: two bone buttons, two Prosser buttons, and an 1873 penny. While they do not provide any definitive age for the walkway, these artifacts do note that there were nineteenth-century activities occurring near the walkways. If the backyard brick patio is an early, pre-Civil War feature, as is suspected (see discussion below), it is possible that the front brick walkway might also be of pre-Civil War construction. Alternatively, it is possible that the brick walkway was built at the end of the nineteenth century or in the early twentieth century using handmade bricks that were salvaged from the abandoned brick slave quarters, sugar mill, or other deserted building.

The front porch steps consist of three steps-two composed entirely of bricks and one composed of bricks and concrete blocks. Two rectangular planter boxes with interlocking brick walls flank each side. The entire feature is $7 \mathrm{ft}$ wide (east-west) by $2 \mathrm{ft} 7$ inches long (northsouth). As recently as 2006, these steps led to a concrete front porch that was built in 1961 (Howard 2003; see Chapters 2 and 3). Prior to that porch, the steps probably led to an earlier wooden porch as seen in photographs as early as the $1940 \mathrm{~s}$, and some incarnation of a front porch predates that (see Figure 4.2). Consequently, the front porch steps appear to have been altered several times over the years to accommodate entry onto various porch structures.
The steps are $10 \mathrm{ft}$ south of the southern facade of the house and are constructed primarily of bricks. The archeological excavations that exposed the sidewalk also exposed the base of these steps on the south and north sides. The porch structure was left intact, and the excavations were backfilled. A detailed plan and profile were drawn to document the feature and show the relationships between the various layers of the porch steps and the walkway (see Figure 8.9). In addition, all of the impressed markings on the machine-made bricks were documented, and some have been identified (Table 8.1). All of the markings are from brick companies that were in operation between 1904 and 1942.

The three steps and the planter boxes seem to represent at least two separate construction phases demonstrated by the differences in materials and building styles. The top step consists of a mixture of bricks that vary widely in color, size, manufacture method, and age. This step includes a couple of handmade bricks as well as many machine-made bricks. The same mixture of bricks appears to have been used to build the flanking planter boxes, which were probably made at the same time as the top steps. Modern concrete mortar was used in both the top step and the planter boxes. Each of the planter boxes is 28 inches long (north-south) by $133 / 8$ inches wide (exterior dimensions), and about 12 inches deep. Each is composed of three courses of bricks except at the north end, where a fourth brick from the top step overlaps the back edge of the planter box.

The westernmost of the two brick planter boxes is clearly visible in a photograph that shows Mike Martin as a baby with his father, Harry Martin (TPWD photograph collection). They are sitting in the lawn with the south porch and southwest corner of the house in the background; the photo shows that the planter box was six courses of bricks tall and had a ceramic flower pot sitting on top. Since Mike was born in October 1942, the photograph probably dates to the first half of 1943, and it shows that the planter boxes, and presumably the brick steps as well, were built by this time. But the photo also shows grass in the area in front of the steps, suggesting that the original brick walkway was not in use and was covered by grass, while the concrete walkway had not yet been built.

Many of the machine-made bricks in the top step and planter boxes have impressed 
Table 8.1. Descriptions of bricks in the front porch steps

\begin{tabular}{|c|c|c|c|c|c|}
\hline $\begin{array}{l}\text { Brick } \\
\text { No.* }\end{array}$ & \begin{tabular}{|c} 
Size \\
(in inches)
\end{tabular} & $\begin{array}{l}\text { Markings and } \\
\text { Description** }\end{array}$ & Color & $\begin{array}{c}\text { Date of } \\
\text { Manufacture }\end{array}$ & Company and Reference \\
\hline \multicolumn{6}{|c|}{ TOP STEP, TOP ROW (northermost) } \\
\hline 1 & $87 / 8 \times 43 / 8$ & $\begin{array}{l}\text { MEXICO MO } \\
\text { ORO... }\end{array}$ & $\begin{array}{l}\text { pink to yellowish } \\
\text { pink }\end{array}$ & $\begin{array}{l}\text { possibly } \\
1919-1931 \\
\end{array}$ & $\begin{array}{l}\text { A.P. Green Fire Brick Co. } \\
\text { (Gurcke 1987:264-265) }\end{array}$ \\
\hline 2 & $85 / 8 \times 41 / 4$ & None & $\begin{array}{l}\text { pink to yellowish } \\
\text { pink }\end{array}$ & - & - \\
\hline 3 & $93 / 8 \times 41 / 2$ & None & dark purple & - & - \\
\hline 4 & $85 / 8 \times 43 / 8$ & $\begin{array}{l}\text { LACLEDE } \\
\text { K-NG } \\
\text { St. Louis } \\
\end{array}$ & grayish tan & $1904-1942$ & $\begin{array}{l}\text { Laclede-Christy Clay } \\
\text { Products Co. (Gurcke } \\
\text { 1987:258-259) }\end{array}$ \\
\hline 5 & $91 / 8 \times 41 / 8$ & $\begin{array}{l}\text { MEXICO MO } \\
\text { EMPIRE }\end{array}$ & $\begin{array}{l}\text { pink to yellowish } \\
\text { pink }\end{array}$ & $\begin{array}{l}1919-1931 \text { or } \\
1942\end{array}$ & $\begin{array}{l}\text { A.P. Green Fire Brick Co. } \\
\text { (Gurcke 1987:232-233, } \\
\text { 264-265) }\end{array}$ \\
\hline 6 & $\begin{array}{l}9 ? \times 41 / 4 \\
\text { (broken) }\end{array}$ & $\begin{array}{l}\text { CORUNDITE } \\
\text { MASSI-ON } \\
\text {--SSION ONO-- } \\
\end{array}$ & $\begin{array}{l}\text { gray with very } \\
\text { large gravel or } \\
\text { oyster chips }\end{array}$ & $1921-1927$ & $\begin{array}{l}\text { Massillon Stone \& Fire } \\
\text { Brick Co., Ohio. (Gurcke } \\
\text { 1987:220-221) }\end{array}$ \\
\hline \multicolumn{6}{|c|}{ TOP STEP, MIDDLE ROW } \\
\hline 7 & $? \times 41 / 8$ & Handmade & orange & $\begin{array}{l}\text { probably } \\
\text { nineteenth } \\
\text { century }\end{array}$ & - \\
\hline 8 & $\begin{array}{l}1 / 2 \text { brick } x \\
41 / 2\end{array}$ & None & dark purple & - & - \\
\hline 9 & $\begin{array}{l}1 / 2 \text { brick } x \\
41 / 2 \\
\end{array}$ & None & tan to pink & - & - \\
\hline 10 & $\begin{array}{l}1 / 2 \text { brick } x \\
41 / 2\end{array}$ & None & tan to pink & - & - \\
\hline 11 & $1 / 2$ brick $\mathrm{x} ?$ & None & dark purple & - & - \\
\hline 12 & \begin{tabular}{|l|}
$1 / 2$ brick $x$ \\
$41 / 4$
\end{tabular} & MEXICO_EMPIR-- & $\tan$ & $\begin{array}{l}1919-1931 \text { or } \\
1942\end{array}$ & $\begin{array}{l}\text { A.P. Green Fire Brick Co. } \\
\text { (Gurcke 1987:232-233, } \\
\text { 264-265) }\end{array}$ \\
\hline 13 & $1 / 2$ brick x 4 & None & $\begin{array}{l}\text { grayish tan- } \\
\text { gravelly (caliche?) }\end{array}$ & - & - \\
\hline 14 & $\begin{array}{l}1 / 2 \text { brick } x \\
41 / 4\end{array}$ & Handmade & $\begin{array}{l}\text { deep red to } \\
\text { maroon }\end{array}$ & $\begin{array}{l}\text { probably } \\
\text { nineteenth } \\
\text { century }\end{array}$ & - \\
\hline \multicolumn{6}{|c|}{ TOP STEP, BOTTOM ROW (southernmost) } \\
\hline 15 & $? \mathrm{X} 4$ 1/8 & None & pinkish orange & & \\
\hline 16 & $83 / 4 \times 45 / 8$ & WALSHXX & pink & $\begin{array}{l}1930-1942 \text { or } \\
1921-1927\end{array}$ & $\begin{array}{l}\text { Harbison-Walker } \\
\text { Refractories Co. or Walsh } \\
\text { Fire Clay Products Co. } \\
\text { (Gurcke 1987:312-313) } \\
\end{array}$ \\
\hline$\overline{17}$ & $83 / 4 \times 41 / 4$ & $\begin{array}{l}\text { MEXICO MO } \\
\text { EMPIRE }\end{array}$ & $\begin{array}{l}\text { gray to pinkish } \\
\text { gray; large gravels }\end{array}$ & $\begin{array}{l}1919-1931 \text { or } \\
1942\end{array}$ & $\begin{array}{l}\text { A.P. Green Fire Brick Co. } \\
\text { (Gurcke 1987:232-233, } \\
\text { 264-265) }\end{array}$ \\
\hline 18 & $85 / 8 \times 41 / 4$ & None & $\begin{array}{l}\text { pink (probably } \\
\text { same as \#17 }\end{array}$ & - & - \\
\hline 19 & $85 / 8 \times 43 / 8$ & $\begin{array}{l}\text { LACLEDE } \\
\mathrm{K}-\mathrm{NG} \\
\text { St. Louis } \\
\end{array}$ & grayish tan & $1904-1942$ & $\begin{array}{l}\text { Laclede-Christy Clay } \\
\text { Products Co. (Gurcke } \\
\text { 1987:258-259) }\end{array}$ \\
\hline 20 & $85 / 8 \times 43 / 8$ & $\begin{array}{l}\text { LACLEDE } \\
\mathrm{K}-\mathrm{NG} \\
\text { St. Louis }\end{array}$ & grayish tan & $1904-1942$ & $\begin{array}{l}\text { Laclede-Christy Clay } \\
\text { Products Co. (Gurcke } \\
\text { 1987:258-259) }\end{array}$ \\
\hline
\end{tabular}


Table 8.1, continued

\begin{tabular}{|c|c|c|c|c|c|}
\hline $\begin{array}{l}\text { Brick } \\
\text { No.* }\end{array}$ & \begin{tabular}{|c} 
Size \\
(in inches)
\end{tabular} & $\begin{array}{l}\text { Markings and } \\
\text { Description*** }\end{array}$ & Color & $\begin{array}{c}\text { Date of } \\
\text { Manufacture }\end{array}$ & Company and Reference \\
\hline \multicolumn{6}{|c|}{ MIDDLE STEP } \\
\hline $\begin{array}{l}\text { Not } \\
\text { numbered }\end{array}$ & $85 / 8 \times 4$ & $\begin{array}{l}\text { Unknown. Bricks laid } \\
\text { on side and mortared } \\
\text { in place. No faces } \\
\text { visible. }\end{array}$ & $\begin{array}{l}\text { range in color } \\
\text { from deep reddish } \\
\text { brown to pale } \\
\text { yellowish tan }\end{array}$ & - & - \\
\hline \multicolumn{6}{|c|}{ BOTTOM STEP } \\
\hline $\begin{array}{l}\text { Not } \\
\text { numbered }\end{array}$ & $12 \times 20 \times 4$ & $\begin{array}{l}\text { Preform concrete } \\
\text { block. No markings. }\end{array}$ & gray & $\begin{array}{l}\text { twentieth } \\
\text { century }\end{array}$ & - \\
\hline \multicolumn{6}{|c|}{ PLANTER BOXES } \\
\hline 21 & $85 / 8 \times 43 / 8$ & $\begin{array}{l}\text { LACLEDE } \\
\mathrm{K}-\mathrm{NG} \\
\text { St. Louis } \\
\end{array}$ & grayish tan & 1904-1942 & (Gurcke 1987:258-259 \\
\hline 22 & $\begin{array}{l}9 ? \times 41 / 4 \\
\text { (broken) }\end{array}$ & $\begin{array}{l}\text { CORUNDITE } \\
\text { MASSI-ON } \\
\text {--SSION ONO-- }\end{array}$ & $\begin{array}{l}\text { gray with very } \\
\text { large gravel or } \\
\text { oyster chips }\end{array}$ & 1921-1927 & $\begin{array}{l}\text { Massillon Stone \& Fire } \\
\text { Brick Co., Ohio (Gurcke } \\
\text { 1987:220-221) }\end{array}$ \\
\hline 23 & $91 / 8 \times 41 / 8$ & $\begin{array}{l}\text { MEXICO MO } \\
\text { EMPIRE }\end{array}$ & $\begin{array}{l}\text { pink to yellowish } \\
\text { pink }\end{array}$ & $\begin{array}{l}1919-1931 \text { or } \\
1942\end{array}$ & $\begin{array}{l}\text { A.P. Green Fire Brick Co. } \\
\text { (Gurcke 1987:232-233, } \\
\text { 264-265) }\end{array}$ \\
\hline
\end{tabular}

*Brick numbers refer to Figure 8.9.

**Double dash indicates letters missing or illegible.

markings. On the top step, the northern row of bricks (closest to the house) was intentionally laid with the impressed names facing upward so they could be "read" by anyone walking south off of the porch. This line of bricks runs the entire width of the feature $(7 \mathrm{ft}$ ) and extends over each of the planter boxes. The second two rows of bricks in the top step have the impressed names oriented in the opposite direction, so people walking northward toward the house can read the names. These rows of bricks butt up against the inside edges of the planter boxes.

The middle step and bottom steps (second and third courses) may have originally served as a single step that was made of two courses of bricks; its bottom rests on concrete (at the south edge) and is level with the concrete walkway. But a row of preform concrete blocks was added to extend the second course to the south and create the third, or bottom, step. These steps are very different from the top step. They are constructed with only one type of brick, all machine-made and identical in size and exhibiting a similar range of colors. This suggests that these courses were built in one construction episode and that they formed a single bottom step that almost certainly went to a wooden porch. The three preform concrete blocks used to create the bottom step are surely a recent addition, probably dating after ca. 1960. All of the blocks are 4 inches thick; two measure 20x12 inches and one is $10 \times 12$ inches. These blocks were laid directly onto the concrete walkway, covering over the inscription made by Will Martin in the concrete walk.

Based on all of the archeological evidence, including the manufacturing dates of the bricks and historic photographs, the following interpretive summary is offered for the construction of the front porch steps and walkway. The original brick walkway is probably a nineteenth-century feature and may even be a pre-Civil War feature associated with the earliest occupation of the Levi Jordan house. It probably was in use until the 1920s. At some point between 1920 and 1937, a concrete base was laid at the southern end of the brick walkway, and the one step (two courses thick) was constructed of bricks (excluding the concrete blocks). Sometime before 1943, the top steps and planter boxes were built, and the northernmost line of bricks in the top step was added before 1961, when the concrete front porch was built. The concrete walkway was not present in 1943, and it is possible that this long 
concrete path was poured directly over the old brick walkway in 1961, when the concrete porch was added.

\section{BRICK PATIO}

A brick patio was exposed during excavations around Cistern 1 on the north side of the house in the interior portion of the north additions (see Figure 8.2). A surface of handmade bricks was first exposed during the investigation of Cistern 1 , in the west portion of Unit N2. An even larger segment of brick pavement was exposed in the southern portion of Unit N3. Shovel skimming was done to expand on these excavations, and it eventually exposed an irregular-shaped area encompassing roughly 265 square feet. A few inches of grass and topsoil were removed from this entire area to expose a pavement of intentionally laid bricks, with many areas being very intact and other areas being somewhat disturbed. The bricks were neat and patterned in many places, while some areas were more haphazard and looked like a pavement of brick rubble.

In one area just southeast of Unit N3, a large blue tarp was uncovered just under the grass. At first it appeared to cover an old archeological excavation, but further examination revealed that the tarp was laid on the ground surface and fill had been screened on top of it. This location was probably where the TPWD or CAS archeologists screened fill excavated from their units inside of the east wing in 2003. Once the tarp and some sediment were removed, the intact brick pavement was found underneath.

This large area of brick pavement is interpreted as a backyard brick patio (Figure 8.10). Although this extensive feature could not be fully investigated for this project, the excavations show that it was once expansive. There were enough variations in the brick pavement to suggest that it was not all from one single construction episode but was probably built in a series of construction episodes or modifications over many years. Some portions of the brick pavement such as walkways may have been laid earlier, and a later expansion tied it all together into a large patio. In some places, sections of the brick pavement were removed when utility lines were cut across the area, and smaller disturbances may represent twentiethcentury intrusive activities such as planting ornamental shrubs.
In an informal interview, Levi Jordan descendant Bruce Gotcher (2010) stated that the brick patio may have once extended throughout the "whole back yard." Gotcher kept "hitting bricks" when he tried to find an area to build a smokehouse in the backyard. His uncle, Archibald Martin, told him that the patio extended back to the large walnut tree, which is about $100 \mathrm{ft}$ north of the north end of the "den" or "enclosed porch" (part of the ell addition).

In an interview with Carol McDavid in 1998, Ewing Martin, who was born in 1915 and lived on the plantation from 1916 until 1920 , remembered the backyard he played in. He remembered lots of brick walkways and an extensive brick area:

[By] the time I came along to remember things, it was all covered up. Now, there were some brick walks around the place...when I was a little boy, it was open because I remember playing on those bricks. There was a lot of brick around there...there was a brick walk that came out the front of the house... It came around the side and I was thinking it went on out to this place where we played...It seems like there was a little fence around the house area proper...but it had a little gate and Aunt Hester used to wash clothes beyon[,] outside the fence, see, in the open back there... [Martin 1998]

Mike Martin (2010), another Levi Jordan descendant, was born in 1942 and lived in the plantation house as a child. But he does not remember a patio or large brick-paved area. In 2010, Martin was surprised at the extent of the buried brick pavement found on the north side of the house by PAI archeologists.

It is likely that there was a large brick-paved patio dating to the nineteenth century but that it had become covered with silt and vegetation by the 1940s. A family photograph of the cistern taken in the early to mid-1930s shows high brush or saplings just north of the cistern. This suggests that there was enough dirt to support vegetation and that plant roots were interwoven between the gaps in the brick pavement.

Dr. Kenneth Brown (2005b:14-15) and Brown and Cooper (1990:11) believe that 


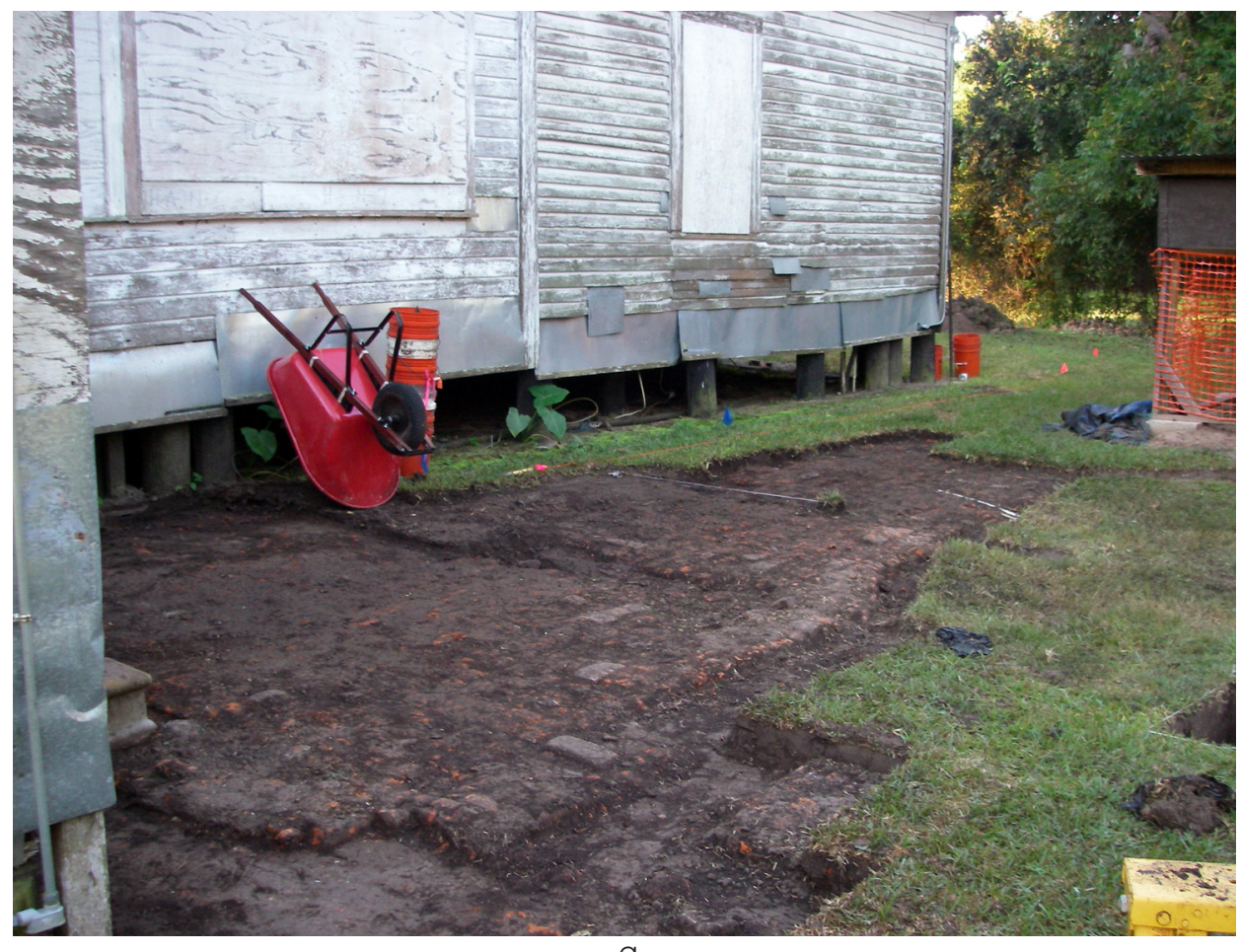

a

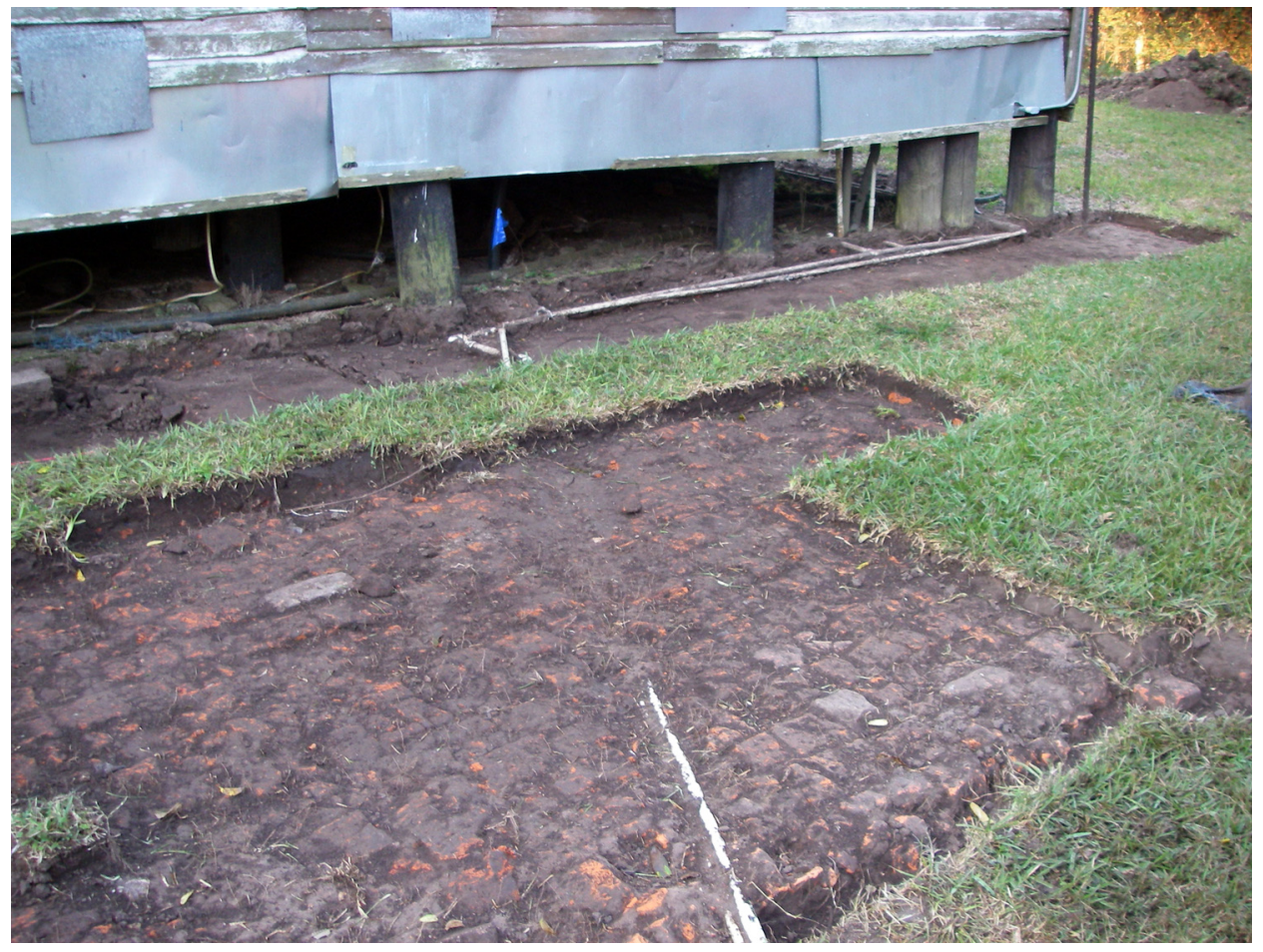

b

Figure 8.10. Photographs of the backyard brick patio exposed in archeological excavations. (a) Overview of the brick patio exposed behind the twentieth-century addition. The corner of the east wing is on the left, and the structure built over Cistern 2 is on the right. (b) Closeup of the brick patio. 
archeological deposits in the slave quarters were effectively sealed beneath a 3 - to 6 -inch layer of silt laid down during a flood that occurred in 1913 (see Table 2.1). This flood could have effectively covered the brick patio with sediment. It seems likely that once silt and grass covered the patio, its existence was all but forgotten.

\section{FEATURE 5, RAIN BARREL PAD}

A small brick feature found near the southwest corner of the original house was investigated by CAS archeologists in 2005 and PAI archeologists in 2010. Based on these investigations and on information from Dr. Kenneth Brown (personal communication 2010), this feature is interpreted as a possible rain barrel pad.

The feature was first exposed by CAS archeologists and designated Feature 5 (Leezer 2006:50, Figures 5-12 and 5-13). Partially exposed in Unit D2, it was originally interpreted as part of a brick walkway. It consisted of a single course of handmade bricks encountered at 4 to 8 inches below the surface. Leezer (2006:89) recommended additional investigations to determine the nature and function of this feature.

During the Phase I investigations, PAI archeologists reexcavated CAS Unit D2. Although the bricks had been removed from the unit by the CAS archeologists, the location of the feature was revealed by brick fragments that extended into the west and south walls of the unit. PAI archeologists then excavated Unit W3 west of Unit D2. One single layer of handmade brick fragments was identified in the southeast corner of the unit. It measured 16 inches (north-south) by 8 inches (east-west) and was clearly an extension of CAS's Feature 5. The fragmentary nature of the brick suggests that this portion of the feature had been disturbed.

PAI then excavated Unit W4 south of Unit D2 to further explore the feature. A ca. $2 \mathrm{ft}$ square of horizontally laid bricks was identified in the east-central portion of the unit (Figure 8.11). It was composed of large brick fragments, mostly half bricks ( $4 \times 4$ or $4 \times 5$ inches) that had been laid out in rows. Many were broken in place. This single course of bricks was laid flat at 9 inches below the surface, while the bricks found in Unit W3 were slightly higher at 6.5 to 7 inches below the ground surface.
Dr. Kenneth Brown (personal communication 2010) believes that he exposed a brick rain barrel pad in a $5 \times 5$-ft unit near the northeast corner of the house. A site map by Brown and McDavid (1998b) indicates the location of this rain barrel (see Figure 2.7). Brown (personal communication 2010) believes that a wraparound porch once extended all along the south, east, and north sides of the house and that a rain barrel was placed at the northeast corner to collect water off the kitchen/dining room porch. None of the original excavation notes were available for this feature, but Feature 5 appears to be similar. Because of the location and configuration of Feature 5, it is tentatively interpreted as a rain barrel pad.

\section{BRICK RUBBLE FEATURES}

Three exterior features identified by PAI archeologists are composed primarily of brick rubble and artifacts. Two are expansive brick rubble and artifact scatters, and one is a small isolated brick cluster with artifacts mixed in. These features are all located in close proximity to the Levi Jordan house: Feature 9 is along the east side of the east wing; Feature 32 is underneath and along the north edge of the twentieth-century ell addition; and Feature 14 is the small feature near the southeast corner of the original house, just east of the front patio (see Figure 8.1). Feature 23 is a subfeature within the larger Feature 32 brick rubble concentration, and it is considered to be part of this larger feature.

\section{Feature 9, Eastern Brick Rubble Concentration}

PAI designated the brick rubble concentration east of the east wing as Feature 9, but the archeological evidence of this feature was encountered in previous investigations. CAS archeologists were the first to report a dense zone of brick rubble and artifacts in this area (Leezer 2006:51-52). They also found black plastic in the northern edge of this unit that was placed there by University of Houston archeologists while backfilling one of their excavation units, indicating that they certainly encountered this deposit. 


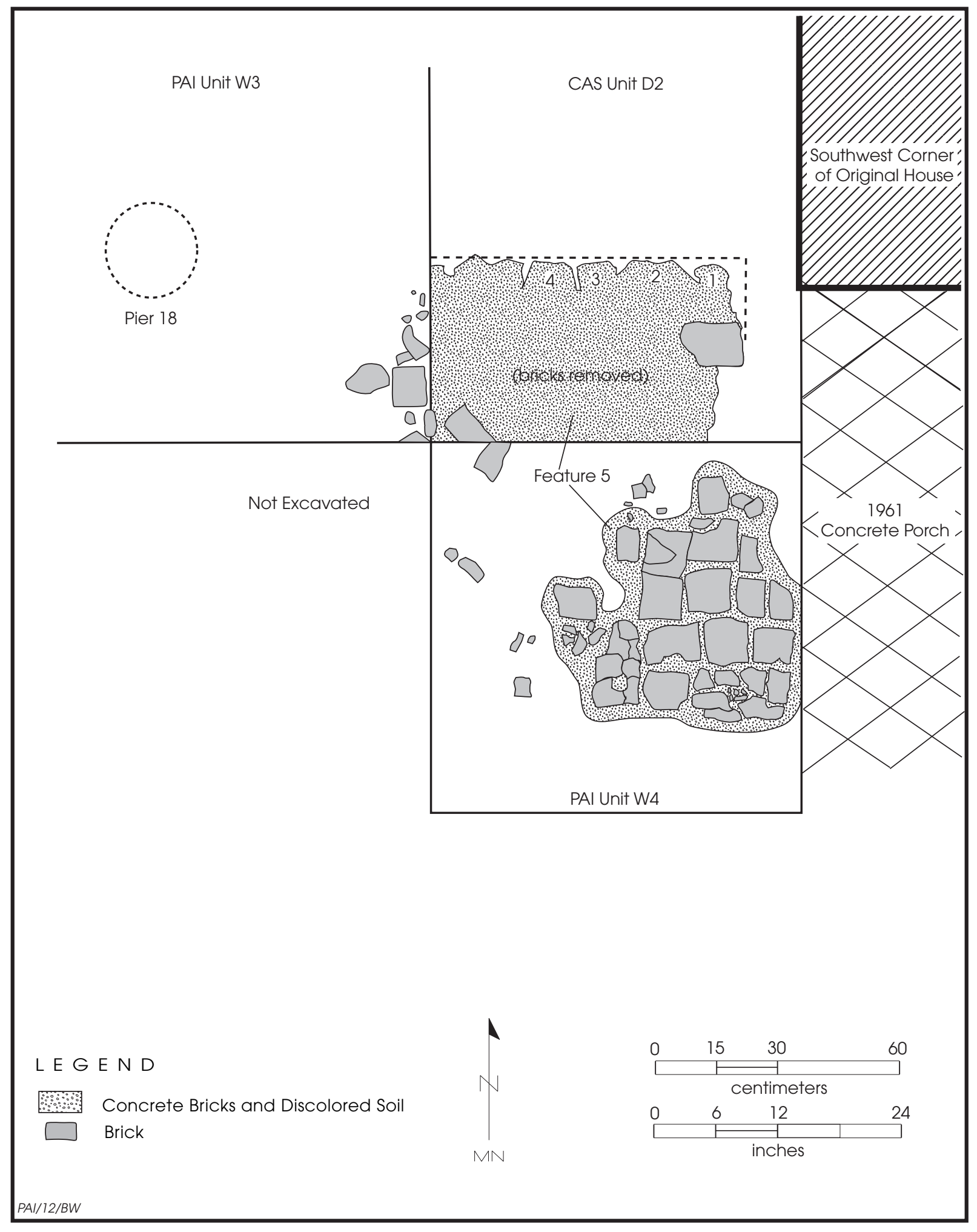

Figure 8.11. Map of the Feature 5 brick concentration interpreted as a possible rain barrel pad. 
Archeological Investigations for the Levi Jordan Plantation House Stabilization

\section{University of Houston Investigations}

University of Houston archeologists dug seven units along the east side of the house, but results of these investigations have not been published. PAI excavations in the areas where University of Houston units were mapped near the northwest corner of the house found that very little had been disturbed, and this may have been the case in other areas of the yard. Consequently, it appears that the University of Houston excavations were quite shallow, perhaps only removing the grass and soil down to the point where brick rubble and artifacts were first encountered. Fortunately, University of Houston archeologist Dr. Kenneth Brown visited the site during PAI's Phase I work and offered his thoughts on the architecture of the east side of the house. Specifically, he stated that the University of Houston excavations revealed that the east side of the house was lined with a dense deposit of artifacts, but the highest density of artifacts began several feet away from the side of the house. Brown believes this is evidence of a porch along the east side of the house. He estimates that the porch was ca. $5 \mathrm{ft}$ wide and that its presence prevented artifacts from being deposited immediately adjacent to the house (Dr. Kenneth Brown, personal communication 2010). The accumulation of artifacts just beyond the porch edge would have resulted from periodic sweeping of the porch and from activities in the adjacent yard.

\section{CAS Investigations}

CAS excavated two units along the east side of the east wing with two goals in mind. The first goal was to test the existence of the University of Houston's hypothesized east porch. The second stated goal was to learn more about the location of the east wall of the original rear wing (Leezer 2006:40).

Unit E1 was excavated $6 \mathrm{ft}$ east of the junction of the original house and the east wing. Artifact recovery from this unit was higher than in any other unit during the CAS investigations. Recovery included 734 pieces of window glass (with manufacture dates based on thickness spanning from the mid-nineteenth to mid-twentieth centuries), $2 \mathrm{lbs}$ of nails (evenly divided between round and square nails), ammunition dating from 1867-1902, $2.5 \mathrm{lbs}$ of bricks, faunal remains, ceramics (including tableware and jar lid liners), and glass fragments (including bottle, chimney lamp, and drinking glass) (Leezer 2006:51). The deposits in Unit E1 were interpreted as a trash dump (Leezer 2006:84).

Unit E2 was dug adjacent to the east wall of the east wing, in line with the hypothesized location of the "North Wall of Original Wing," which would have been at the back edge of the chimney foundation (see Figure 7.9). The unit contained an "overwhelming amount of brick fragments" (Leezer 2006:51). Also found in Unit E2 was Feature 6, described as a well-defined square soil stain identified 16 inches below the surface. Based on subsequent PAI work, it is likely that Feature 6 is a foundation pier (see Chapter 6). The total weight of bricks in Unit E2 was not reported, but CAS said it "contained a tremendous amount of brick fragments" and that "a small sample of less than ten percent (two pounds)" was collected (Leezer 2006:52). This suggests that at least $20 \mathrm{lbs}$ of bricks were in the $3 \times 3$-ft unit.

Diagnostic artifacts found in Unit E2 generally date from the late nineteenth century through 1916 (Leezer 2006:52, 84-85). Most of the recovered ceramics (whiteware, ironstone, blue decal, spongeware, and flow blue) were manufactured between 1850 and 1895. Three shotgun shell bases were manufactured between 1867 and 1902. The collection was attributed to a refuse midden "supportive of domestic, household activities of an upper middle class family between the mid-1800s and early 1900s" (Leezer 2006:86). An eroded pipe was exposed at 10 to 12 inches below the surface in the south wall of the unit; its function or relation to the brick rubble was unknown (Leezer 2006:Figure 5-15, 51, 84).

\section{PAI Investigations}

The previous investigations provided a baseline for PAI to develop two goals for its investigations east of the east wing. First, the excavations would look for additional evidence of the possible collapsed original east wing chimney, as proposed by Leezer (2006:84). Second, the excavations would target potential architectural features, especially foundation piers, that might exist if there had been a porch along the east side of the original wing, as proposed by Dr. Kenneth Brown (personal communication 2010). 
PAI excavated Units E3 to E10 along the east side of the east wing, in part to expose pier footings associated with the house, but also to investigate the brick rubble deposit and search for any evidence pertaining to the east-wing porch theory. The concentration of brick rubble in many of these units was recognized as something unusual in the field, but it was not assigned a feature number until the data analysis phase. Feature 9 , generically called the eastern brick rubble feature, is essentially a dense zone of brick rubble with some associated artifacts. Figure 8.12 shows that the main concentration of brick rubble is confined to an area about $14 \mathrm{x} 18 \mathrm{ft}$. But this is simply the known extent of the concentration, which could extend farther in all directions except to the southeast, where its edge is better defined.

In Unit E6, PAI archeologists found the corroded metal pipe that was encountered by CAS and left in situ in Unit E2 (Leezer 2006:Figure 5-16). Further investigation revealed that it was an isolated section of pipe that was not related to any larger system.

Table 8.2 summarizes all the artifacts found in the excavations of Units E5, E6, and E8 and associated with the Feature 9 brick rubble. No attempt was made to analyze these materials in detail, and such an effort is not warranted. The artifacts represent a wide range of typical household debris that date to the late-nineteenth and early-twentieth centuries. Some modern materials were mixed, including aluminum ring pull tabs (invented in 1959) and plastic items that were certainly deposited within the last 50 years. But this is not surprising given the site's history. Although the bulk of these materials suggest that the Feature 9 brick rubble deposit dates to the early twentieth century, there was certainly ample opportunity for later materials to be introduced in this area. From a functional perspective, the abundance of broken window glass is notable, as is the large number of kitchen-related artifacts (including dinnerware fragments, complete glass bottles and fragments, a canning jar lid, and animal bones). The many bulk nails throughout the Feature 9 deposit could indicate that much of this debris is from a wooden structure that was razed or destroyed.

The combined historical and archeological evidence suggests that Feature 9 is probably related to the collapse of the original east wing chimney. This idea was first proposed by Leezer
(2006:84), who suggested the dense zone of brick fragments found in Unit E2 "most likely resulted from the collapse of the east chimney from the original rear wing extension." During the Phase I investigations, the densest concentrations of brick rubble were observed in Units E5 and E6, located $6 \mathrm{ft}$ east of the east wing chimney base, and the evidence seems to support Leezer's theory. Historically, it is likely that this chimney collapsed in a catastrophic event related to the severe 1900 hurricane, which reportedly destroyed the "kitchen-dining room annex" that comprised the original east wing (recalled by Furniss Martin Davis in Freeman 2004:136). The large number of nails in the Feature 9 deposit may be evidence of the remains of this wooden structure.

The foundation of the original east wing chimney still exists (see Chapter 7), but the aboveground portion was gone before the ell addition was built. If it collapsed, all of the brick debris would have fallen down near its base, leaving a large pile of brick rubble. The occupants could have hauled off the brick rubble and dumped it elsewhere, but this would have required a substantial effort. It would have been easier to salvage unbroken bricks and simply disperse the rubble in the general area where it fell, especially if the occupants knew that the brick rubble would be covered over later by a porch, flower beds, or a new addition to the house.

\section{Feature 32, Northern Brick Rubble and Artifact Scatter}

A second large brick rubble feature was designated as Feature 32 by PAI, and it is present over a large area on the north side of the house. It is called a brick rubble and artifact scatter, and it is quite similar to the Feature 9 brick rubble concentration. TPWD and CAS archeologists first investigated this feature, but their excavations were limited and did not reveal its vertical or horizontal scope. PAI's excavations in the northwest block (western end of the twentieth-century addition along the north wall) and along the north edge of the original house provided additional data that illuminate the magnitude of this feature. The jumbled brick fragments and artifacts appear to have been pushed into a linear pile north of and along the north edge of the western end of the original 


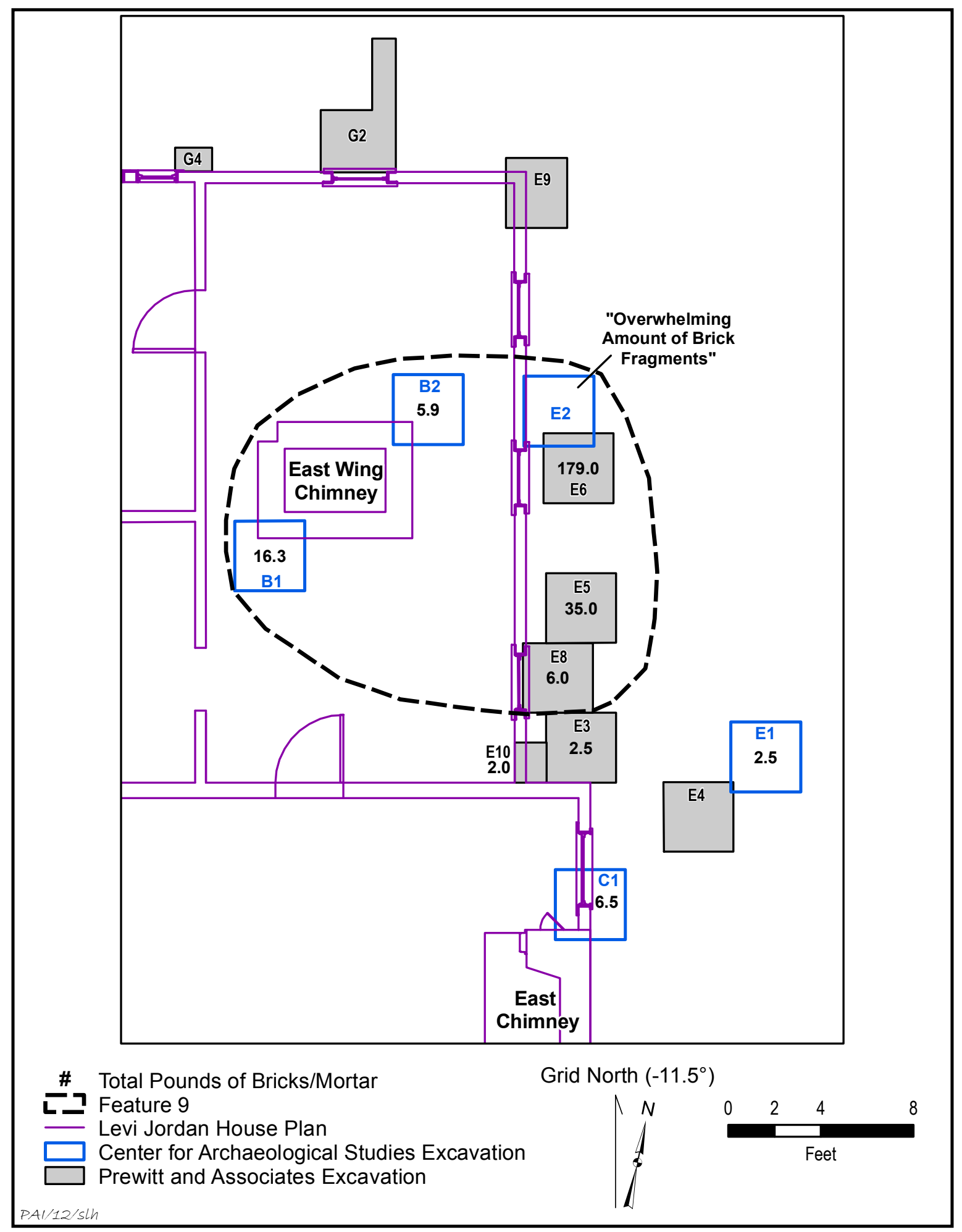

Figure 8.12. Map of the Feature 9 brick rubble concentration on the east side of the east wing. The density of brick rubble (in lbs.) in the excavation units is indicated. 
Table 8.2. Summary of artifacts from the Feature 9 brick rubble concentration*

\begin{tabular}{|c|c|}
\hline Artifact & Quantity \\
\hline Undecorated whiteware & 49 \\
\hline Decorated whiteware embossed & 1 \\
\hline $\begin{array}{l}\text { Ceramic with maker's mark } \\
\text { ("H \& Co" and "OS \& SON" }\end{array}$ & 2 \\
\hline Decorated whiteware & 7 \\
\hline Porcelain & 21 \\
\hline Bulk window glass (g) & $2,326.7$ \\
\hline Clear bottle glass fragments & 168 \\
\hline Colored bottle glass & 162 \\
\hline Decorative glass & 13 \\
\hline Thin glass (includes lamp chimney) & 48 \\
\hline Canning jar lid (“Boyd's" mark) & 1 \\
\hline Complete or identifiable bottle & 4 \\
\hline Drinking glass & 13 \\
\hline Ammunition & 5 \\
\hline Button & $3 * *$ \\
\hline Copper or brass strap & 2 \\
\hline Historic metal & 1 \\
\hline Bulk nails (g) & $9,623.5$ \\
\hline$\overline{\text { Bulk unidentified metal }(\mathrm{g})}$ & 1 \\
\hline Heavy iron counterweight & 1 \\
\hline Animal bones & 88 \\
\hline Oyster shells (g) & 270.7 \\
\hline Other seashells & 1 \\
\hline Possible native-made ceramic & 1 \\
\hline Modern materials & yes*** \\
\hline Brick samples & yes \\
\hline Mortar samples & yes \\
\hline
\end{tabular}

*Specimens are from Units E5, E6, and E8 (Lots 2010-028, 029, 030, 031, and 035).

** Includes Prosser, metal, and bone buttons.

*** Includes aluminum, plastic, black plastic sheeting, 1 brass key, lead roofing washer, rubber, terra-cotta pot fragments, tar pieces, pull tabs, plastic wire coating.

house. A portion of this feature extends under the original house.

\section{Texas Parks and Wildlife Department Investigations}

In 2003, TPWD archeologists excavated an area underneath the den of the ell addition (see Figure 2.2; Howard 2003b:2, 11-14). They found abundant late-nineteenth- and twentiethcentury artifacts in their shallow sweeping and scraping of the deposits. In the center of the room, they exposed a $3.5 \times 4.5$-ft concentration of "dry laid bricks of different sizes, positioned in a variety of orientations and lying on a bed of mortar" (Howard 2003b:11). They noted that a few bricks were whitewashed, suggesting they had once been part of an exterior surface of a structure or feature. The function of this brick rubble layer was not clear, but Howard (2003:12) thought it might be "the foundation for a small stoop or porch." The TPWD team also found a 3 -ftlong row of bricks, apparently in situ and laid lengthways that might be from a "garden bed" related to the postulated porch. These features were not excavated.

\section{CAS Investigations}

In 2005, the CAS archeologists excavated five $3 \times 3-\mathrm{ft}$ units underneath the gallery (den) of the ell addition and on three sides of the brick feature found by TPWD. The goal of these investigations was to examine the "brick walkway" or "possible porch" (Leezer 2006:43, 77) identified by TPWD. CAS Units A1, A2, and $A 3$ were dug to $8 \mathrm{~cm}$ below the surface. Leezer (2006:77) believed that Units A1 and $\mathrm{A} 2$ "point to the existence of a brick walkway that extended to the north of the house, further into the backyard," while Unit A3 was inferred to be "the location of a sheet midden." Units A4 and A5 were only excavated to $4 \mathrm{~cm}$ below the surface, and both units terminated on a "layer of hard, crushed brick mixed with caliche."

The CAS excavations did not extend deep enough to reveal much about the brick rubble zones encountered in Units A1 and A2, and their work was too limited to determine the 
horizontal extent of this possible "brick walkway." Based on the evidence in Units A4 and A5, Leezer (2006:46, 78) also identified a "brick caliche terrace" that was different from what was exposed in Units A1 and A2. She suggested that the "compact brick caliche mix" in these units "probably served as a foundation for the original terrace." But the terrace foundation that is described is quite different than the patterned brick layer comprising much of the backyard patio (described earlier in this chapter).

\section{PAI Investigations}

The PAI Phase II investigations on the north side of the house included excavation of the northwest block (see Figure 3.9). It consisted of an east-west excavation along the west half of the north wall of the original antebellum house, with a square block jutting northward from the east end and encompassing a narrow strip between two large cribbing structures. This northwest block was further expanded with the excavation of the northwest extension in an attempt to connect the finds underneath the ell addition with the backyard brick patio area farther to the north. The northwest block overlapped with the previous TPWD and CAS excavations, and PAI archeologists encountered the same kind of hardpacked brick rubble and artifact scatter that was described by TPWD and CAS. This large feature is designated as Feature 32 and is generically called a brick rubble and artifact scatter. Its horizontal extent is shown in Figure 8.13.

Feature 32 is characterized by a horizontally extensive zone of brick and mortar rubble with artifacts mixed in. This zone is extremely hard-packed, and it is estimated to cover an area of at least $26 \mathrm{ft}$ east-west by $14 \mathrm{ft}$ north-south. It seems to be confined to the area under the ell addition, and this deposit was probably in place before that addition was built in the early part of the twentieth century. As summarized in Table 8.3, hundreds of artifacts were mixed into this brick rubble zone, and they represent a wide range of cultural materials in terms of age and functional diversity. In many ways, the artifacts associated with Feature 32 are similar to those associated with Feature 9 described above. The Feature 32 artifacts include some obviously modern materials (less than 50 years old), but the majority of the assemblage dates to the nineteenth and early twentieth centuries. The materials exhibit a wide range of typical household debris, but the abundance of window glass and kitchen-related artifacts is notable.

Feature 23 is a small cluster of bricks and artifacts located along the north wall of the house about 6 inches southwest of Pier V1 (see Figure 8.13). Several whole bricks and large brick fragments are jumbled around a large conical iron object. The latter is 4 inches long and 4 inches in diameter, weighs about $5 \mathrm{lbs}$, and is heavily corroded. The specimen could not be identified, but its shape is reminiscent of the nose of an artillery shell. Many other small artifacts (i.e., unidentifiable iron, nails, fence staples, window glass, milk glass, whiteware sherds, animal bones, toy marbles, and a slate fragment) and brick fragments were mixed in and scattered around the cluster, but the dense concentration of bricks and the iron object were in a shallow basin-shaped pit that was about 20 inches in diameter and 9 inches deep.

After careful analysis, Feature 23 is not considered to be a separate feature. Rather, it is interpreted as part of the larger Feature 32 brick and artifact scatter. The fact that the bricks and artifacts appear to be in a shallow pit simply indicates that this pit was present under the house when the larger debris scatter accumulated. It is possible that this shallow pit represents the location of a wooden pier that was removed before the deposition of the large brick rubble layer. The artifacts associated with Feature 23 are included with the Feature 32 artifacts summarized in Table 8.3.

Feature 32 is complicated indeed, and the interpretation of this archeological deposit has a bearing on interpreting the outdoor features behind the original Levi Jordan house, the potential for an original west wing, and the evolution of subsequent structural additions to the north side of the house. The fact that this extensive brick and artifact zone was found under the ell addition indicates that Feature 32 was in place in the early twentieth century but has been altered since then. There is no way to know for sure what Feature 32 represents, but the best guess is that the brick rubble mixed with artifacts represents debris that was intentionally discarded and spread out over this area. But if this debris was deposited in the early twentieth century before the construction of the ell, what are its ultimate origins? 


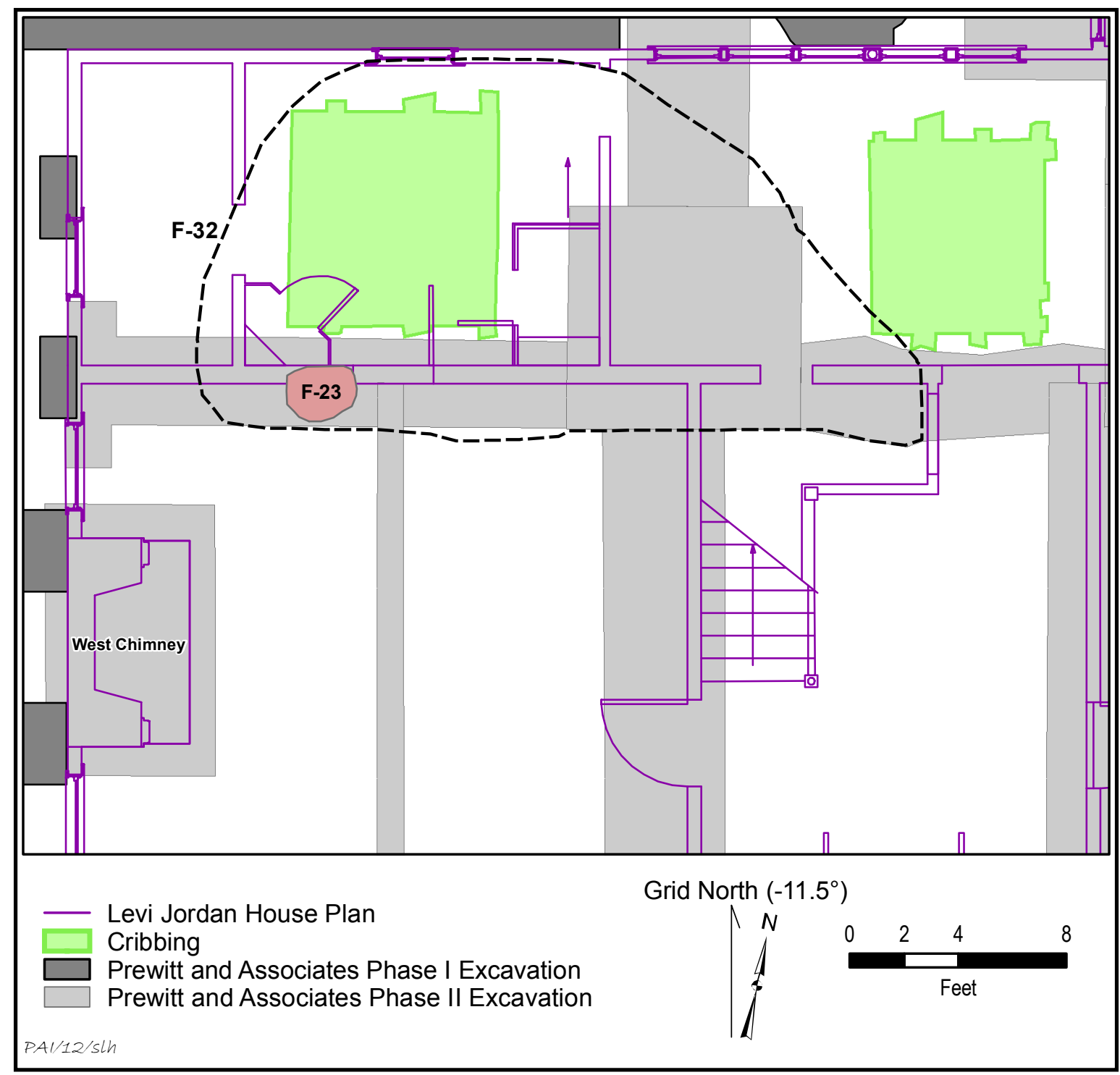

Figure 8.13. Map of the Feature 32 brick rubble and artifact scatter. Feature 23 is a dense cluster of bricks and artifacts, but it is considered part of Feature 32.

The handmade bricks in Feature 32 could have come from multiple sources, but some possibilities are more likely than others. It seems unlikely that the bricks were transported up to the main house from some unknown brick structure on the property or the brick cabins at the slave quarters. It is more likely that the bricks in Feature 32 were originally part of the dome and shoulder of Cistern 1 , the original east wing chimney, the brick footing that TPWD exposed under the den, or perhaps an original west wing chimney (the existence of which is only a hypothesis at this point). The bricks could even have been from any or all of these sources, and it is assumed that any of these features could have been destroyed and become a source of the brick rubble before the ell was constructed sometime in the early twentieth century. The abundant artifacts mixed in with the Feature 32 deposit could have come from a variety of sources, and some of these materials could be related to structures that were damaged or destroyed by hurricanes. One final hypothesis is that the Feature 32 and Feature 9 deposits are both associated with the same single event such as the damages from the 1900 hurricane. 
Table 8.3. Summary of artifacts from the Feature 32 brick rubble and artifact scatter*

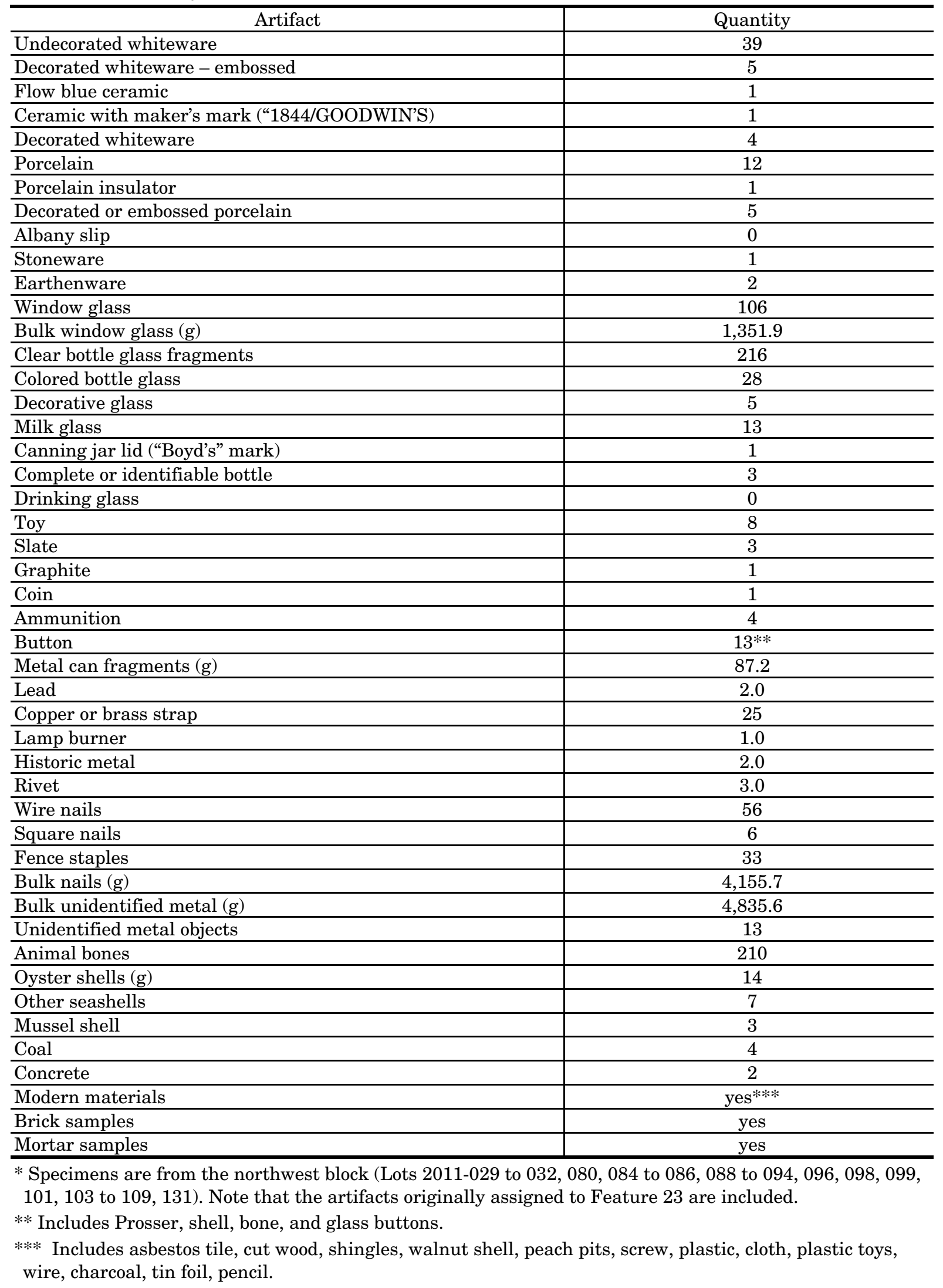




\section{Feature 14, Small Brick Cluster}

PAI archeologists excavated Feature 14 during the Phase I investigations. A small cluster of bricks was exposed along the east side of Unit D7, which was excavated at the southeast corner of the original plantation house, just $2 \mathrm{ft}$ southeast of the house's southeast corner pier. This location is just east of where the 1961 concrete porch had been until it was removed in 2002. To further investigate this feature, Unit D10 was excavated south and east of Unit D7. This unit exposed a main concentration of large brick fragments and artifacts within an 18x20inch area, with another large brick fragment and a few artifacts located 4 to 12 inches to the southeast (Figure 8.14). All of these materials were concentrated from 6 to 13 inches below the surface. The brick fragments removed from
Feature 14 weighed $9.5 \mathrm{lbs}$, and a group of oyster shells was found in the main concentration. Other artifacts in the main concentration-or very close by-include nails, whiteware, modern debris, bone, glass, a slate fragment, and a glass syringe fragment.

This brick and artifact cluster was designated as Feature 14, but the excavations did not reveal any distinctive shape or other attributes that would confirm its function. The large objects are deep enough that it would appear that the feature was intrusive, though there is no evidence of an intrusive pit. It was originally thought that this brick cluster might be a step off the east side of the old concrete porch, but the materials are too deeply buried and jumbled to have functioned in this manner. Their randomness suggests that this feature could represent a dump of some kind, perhaps in a small pit, but

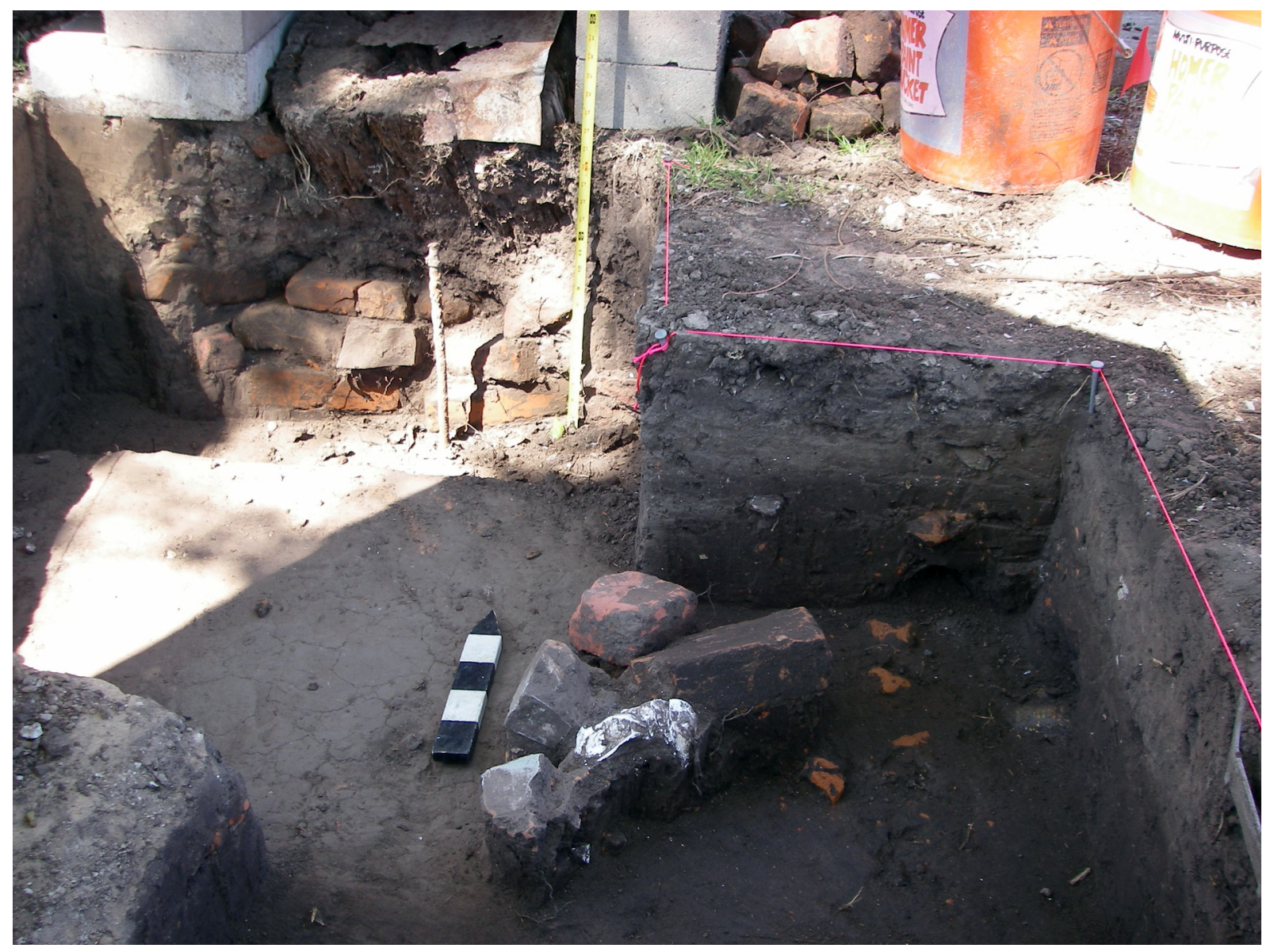

Figure 8.14. Photograph of the Feature 14 brick cluster, looking north, with the southeast corner pier of the original plantation house in the background. Photo scale is $25 \mathrm{~cm}$. 
this makes no sense unless children created it. Two alternative explanations are offered based largely on the feature's location at the southeast corner of the original plantation house and east of the old concrete porch. First, Feature 14 could be a haphazard pier pad associated with one of the wooden porches from the twentieth century (but prior to the 1961 porch). Second, Feature 14 could be a brick pad for a rain barrel. But neither theory if very satisfying given the jumbled nature of this feature. It appears that the original function of Feature 14 cannot be determined with any degree of confidence.

\section{OTHER EXTERIOR FEATURES}

\section{Feature 21, Buried Container}

Feature 21 was a cylindrical iron container, badly rusted, found 6 to 14 inches below the surface (Figure 8.15). It was found in Unit N5 north of the Feature 32 brick rubble layer described earlier in this chapter. The iron container appeared to be a bucket or a large thick-walled can 12 inches in diameter and 8 inches deep. It was buried upright with its open end facing upward and was filled with artifacts. The container had been placed into a hand-dug pit, and the vertical pit edge was observed ca. 3 inches west of the metal container. The top rim of the container appeared to be relatively flat, while the profile showed that it had a flat bottom. Immediately beneath the container was a small rectangular soil stain measuring about $4.5 \times 7$ inches. This thin stain appeared to be the bottom of the hole that was dug for the container to be inserted. Unfortunately, the metal container had deteriorated to such a degree that no identifying characteristics or diagnostic features remained intact.

This feature was located in the backyard, about $2 \mathrm{ft}$ north and $9 \mathrm{ft}$ west of the northwest corner of the twentieth-century ell addition. Since it was found under the brick rubble layer, it probably predates the construction of the ell. The feature was completely excavated and removed, and its contents were investigated in the laboratory. The following items were found inside the metal container (Lot 2010-60):

unidentified metal conglomerates, $72.3 \mathrm{~g}$ unidentifiable metal, $2000 \mathrm{~g}$

11 wire nails

4 square nails
1 copper washer

3 small whiteware sherds (one embossed) window glass fragments, $3.2 \mathrm{~g}$

11 bottle glass fragments ( 9 clear, 1 thick dark brown or black, and 1 thin amber)

1 Prosser button fragment

1 bone fragment

oyster shell fragments, $58.7 \mathrm{~g}$

3 small handmade brick fragments

None of these items is particularly diagnostic and all could be from the late nineteenth to the mid-twentieth centuries. The wire nails indicate that Feature 21 probably dates after 1886 , when wire nails started to replace squarecut nails (Adams 2002:72).

This collection of items was tightly packed into the container. It is likely that most of the unidentifiable corroded metal represents construction materials such as nails, screws, and bolts. Unfortunately, the function of Feature 21 remains a mystery, although there is one plausible explanation. Former resident Mike Martin (2010) lived in the house until he was five years old (ca. 1947), and he remembers that one of his favorite activities was burying his father's tools around the house. It is possible that the container filled with broken items and construction debris may be the result of the childhood antics of Mike Martin (see Chapter 4).

\section{Feature 33, Seashell Concentration}

Whole or fragmentary oyster shells were common in many of the CAS (Leezer 2006:159) and PAI excavations (see Appendix C), but other types of seashells were not. Whole or nearly complete seashells (excluding oyster) were recovered in low quantities from the east and north sides of the house as follows:

1 from Unit E6, Feature 9 (Lot 2010-29)

3 from Unit E9, Pier 10 (Lot 2010-38)

7 from the backyard brick patio (Lots 2010-55 and 2010-75)

3 from the northwest block (Lots 2011-30, 2011-32, and 2011-91)

1 from Pier G1 (Lot 2011-55)

In contrast to these occurrences, one significant concentration of seashells was found 


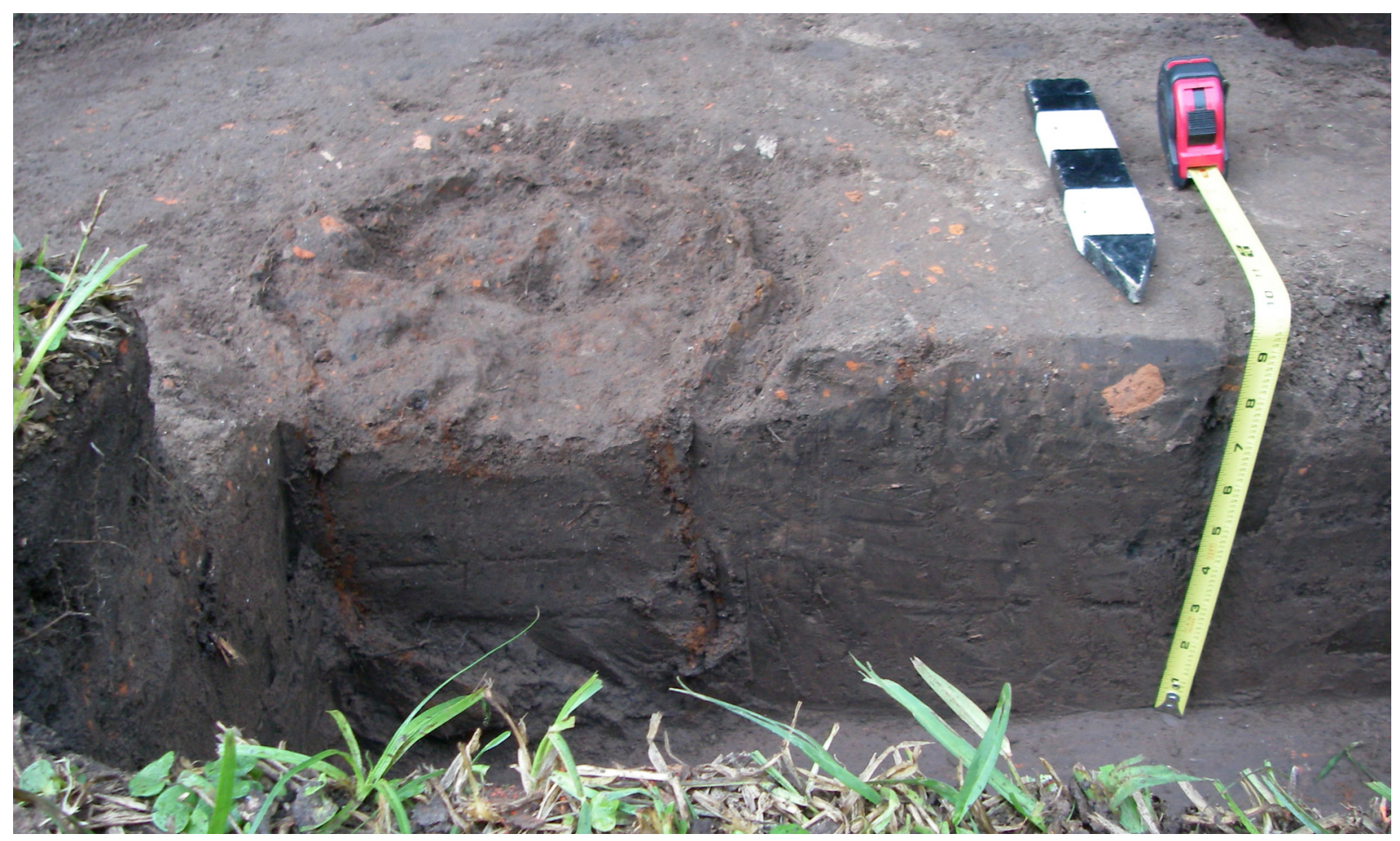

a

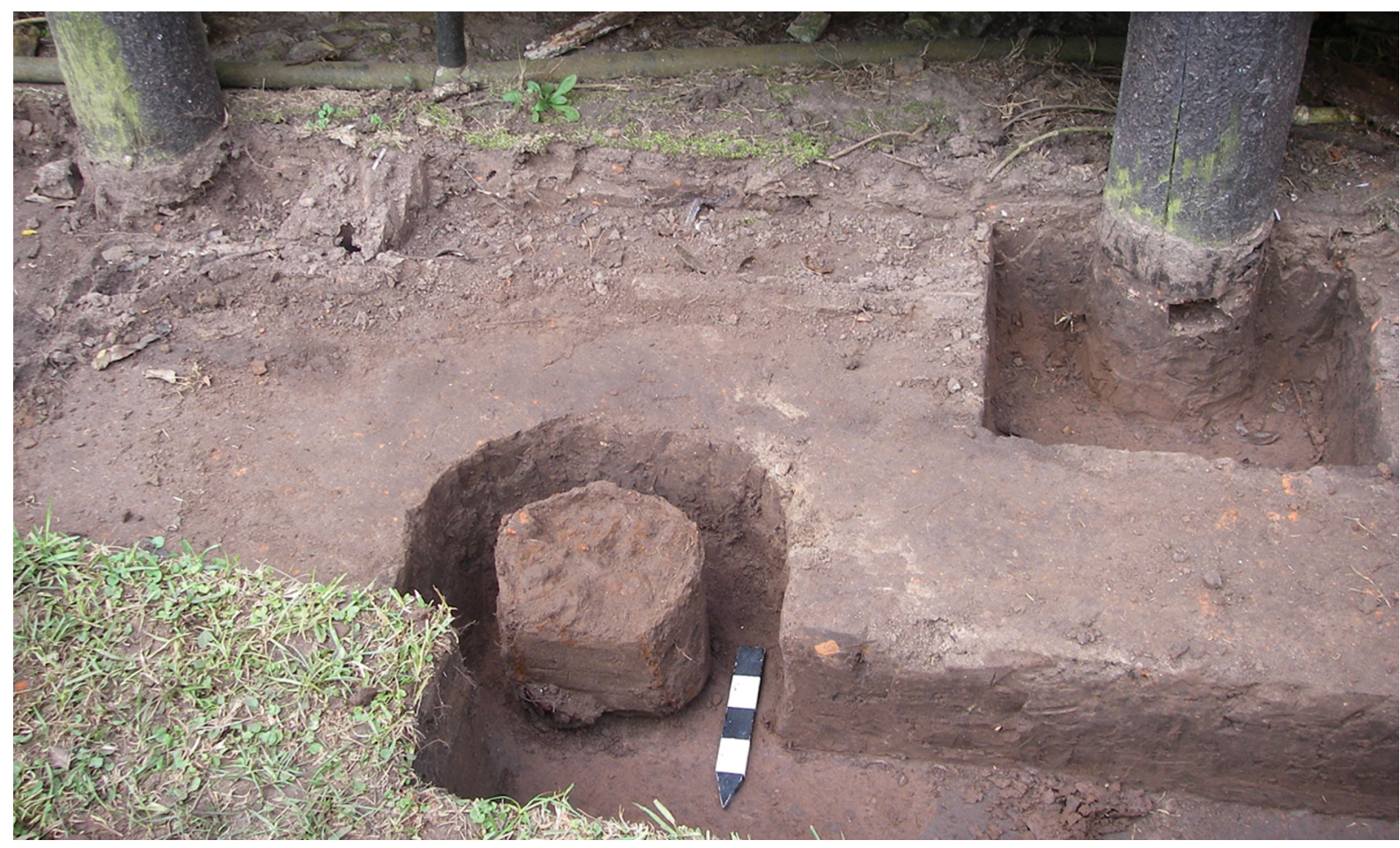

b

Figure 8.15. Photographs of the Feature 21 buried iron container in Unit N5. North arrow is $25 \mathrm{~cm}$ (ca. 10 inches). (a) Closeup of the buried container exposed on top and one side. (b) Overview showing the buried container exposed on all sides in relation to the house piers behind. The excavated feature at back right is Pier 29. 
in Unit G2, located just north of the twentiethcentury east wing (see Figure 8.1). The concentration was not recognized as being unusual in the field but was designated Feature 33 in the analysis phase. Thirty-three complete or nearly complete seashells were recovered in this unit (Figure 8.16). No attempt was made to identify genus and species for these specimens, but they were grouped by type and shape using the shell terminology in Andrews (1971). The specimens consist of 10 fan-shaped bivalves (scallop shells) and 23 gastropods ( 7 conic, 4 globular conic, and 12 pyriform, probably Olive).

Although this seashell concentration is rather unusual, we can offer no definitive theory to explain its occurrence. The shells might have been decorations in a flower garden, a child's play toys, or even a shell collection that was discarded or lost. Unfortunately, the archeological deposits provide no hint of how old this shell deposit might be. 

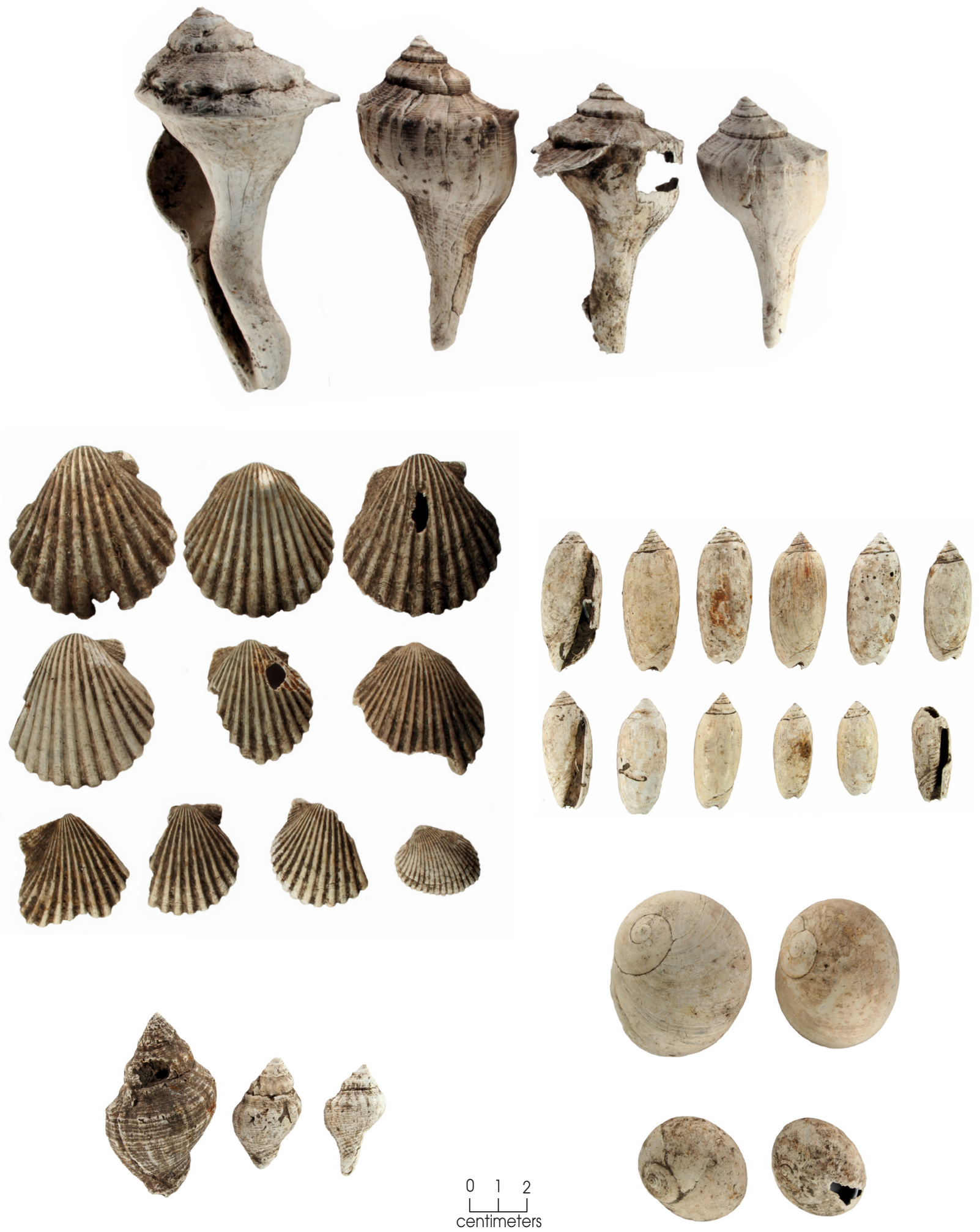

Figure 8.16. Photograph of selected seashells recovered from Unit G2. 



\section{CONCLUSIONS AND RECOMMENDATIONS}

\section{9}

"Research about the history of the Levi Jordan Plantation is not complete..."

-Martha Freeman, 2004

Historian Martha Freeman (2004:139) made this statement at the end of her study on the historic landscape of the San Bernard River and the Levi Jordan Plantation. Her report is the most comprehensive historical study of the Levi Jordan plantation to date based on primary sources, and it provides an excellent contextual overview of antebellum plantations in southwestern Brazoria County. But Freeman's study only scratches the surface of the fascinating history of the Levi Jordan plantation, from its inception in 1848 to its acquisition by the State of Texas in 2002. A great deal more can be learned by synthesizing research that has already been done and by conducting more in-depth archival research and oral history interviews. However, a large part of the plantation's story will never be revealed in historical documents or people's memories and can only be reconstructed through the archeological remains preserved at the site. Like the historical research, the archeological research on the Levi Jordan plantation is far from complete, and there is much more that can be learned.

The 2010 and 2011 investigations conducted by Prewitt and Associates, Inc. (PAI) archeologists add new information to the story of the Levi Jordan Plantation. This work builds on the previous archeological research that has been ongoing, intermittently, since 1986. The intensive investigations conducted by University of Houston archeologists and students, directed by Dr. Kenneth Brown, focused mainly on the "quarters community" where enslaved Africans and African Americans lived beginning in 1848. After the Civil War, these people transitioned to a community of freedmen and continued to live and work on the Jordan Plantation until the late 1880 s or early 1890 s. The community ultimately disbanded because the Jordan descendants (Martins and McNeills) were feuding and the plantation was in economic turmoil. Recently freed blacks were leaving Brazoria County and other rural parts of the South to flee the growing racial persecution of the Jim Crow era. Unfortunately, the stories of the black community on the Jordan plantation are poorly documented in archival records, especially when compared with the stories of the white plantation owners. However, some 16 seasons of archeological research by the University of Houston's Anthropology Department have yielded a vast amount of data that will help tell the stories of the African Americans who lived, worked, and died on the Levi Jordan Plantation.

Only a small amount of the University of Houston archeological investigations were conducted outside the Quarters community. Although University of Houston archeologists dug some excavation units near the Levi Jordan house, most of this work is unreported. The one notable exception is the master's thesis by Barrera (1999), which reported on the shovel testing (a gridded pattern of 385 1x1-ft units) across the "yard" area north of the house. After the plantation and house were purchased by the State of Texas in 2002, the Texas Parks and Wildlife Department (TPWD) conducted limited investigations at the Jordan house in 2003 (Howard 2003a, 2003b). This was followed by similar limited investigations around the Jordan house in 2005 by Texas State University's Center for Archaeological Studies (CAS) under contract 
with TPWD (Leezer 2006). The next archeological investigations at Levi Jordan were conducted by PAI in 2010 and 2011, and are documented in this report.

This chapter provides a brief summary of what PAI archeologists found in the investigations at the Levi Jordan plantation house and what we learned from this new evidence. These investigations were undertaken in conjunction with the Texas Historical Commission's (THC) structural stabilization project as part of the agency's long-term plan to develop the public interpretation of this important historical site. The successful stabilization project was completed in 2011 and was publicly announced in an open house on March 3, 2012 (McAuley 2012). Having been neglected for many years, the 160-year-old house has been fully stabilized and sits on a solid new foundation. THC is now developing an interpretive master plan for the Levi Jordan Plantation State Historic Site. It is hoped that this archeological research will provide insights useful for telling the stories of the intertwined black and white communities on the Levi Jordan Plantation.

\section{WHEN WAS THE LEVI JORDAN HOUSE BUILT?}

The question of when the Levi Jordan house was built is not a purely academic one. Knowing when the two-story, wood-frame plantation house was constructed is important for the region's antebellum archeology and history. Up to this point, it was generally agreed that the house was built between 1848 and 1857, but attempts at further refinement of the date led to different interpretations of the data. Several researchers have looked at the evidence and speculated on this topic. The following statements have been published regarding the construction date for the Levi Jordan Plantation house:

- "The new house is almost done, it looks magnificent." Mrs. Charlotte Nuckols wrote this in her August 1857 letter to Sarah "Sallie" McNeill (Raska and Hill 2009:11, 163). Charlotte had just visited the plantation and was writing to Sallie, Levi Jordan's granddaughter, who was away at school. The statement is the only firsthand account from the time, but what it means is not exactly clear. Does it mean that the house construction was finished in 1857 , or does it refer to the final decorative touches inside the house?

- "The frame residence, which was constructed in 1854, was made from oak timbers... The house was under construction when the hurricane hit." These statements were made by University of Houston student Allen Platter in his dissertation (1961:159, $163)$, but he does not cite his source. Since much of Platter's information about the Levi Jordan house and plantation came from an interview with an L. J. McNeill at the Mims Plantation in August 1960 (Platter 1961:159, footnote 1), this is probably his source. According to the comprehensive Jordan family genealogy on the Levi Jordan Plantation Historical Society website (McDavid 1998), the informant would be Levi Jordan McNeill, who was born in 1916 (Freeman 2004:18).

- "Home built 1848-1851 by slave labor..." This is the construction date stated on the 1967 Texas Historical Marker (No. 9570) at the Levi Jordan Plantation.

- "Construction of the main plantation buildings was begun in 1848 and finished in 1854 with the completion of the sugar mill and, possibly, the main house....Both the main house and the sugar mill appear to have been completed by 1854 , when the first cane crop was processed." These statements were made by Brown (2005a:48). He does not cite any sources to support this interpretation, but he does acknowledge using Freeman's (2004) historical study. It is presumed that this interpretation is based on the large increase in the real property value of the Jordan plantation from 1853 to 1854 as stated by Freeman (2004:112-113).

- "This last increase occurred as the family was constructing a new two-story frame home." Historian Martha Freeman (2004:113) made this statement in reference to a significant increase in real estate tax evaluation of the plantation, from $\$ 30,000$ in $1855-1866$ to $\$ 40,000$ in 1857 . She interprets this increase as being related to the construction of the house, noting that the August 1857 Nuckols letter to Sallie McNeill (cited above) that stated, "The new house is almost done..." 
In the statements above, the strongest primary source evidence is the tax data that shows when significant increases in the real estate value occurred. Freeman (2004:108, 110, 112-113) cites the following values from Brazoria County ad valorem tax records assigned to the Levi Jordan plantation for the 1848 to 1857 period:

$\begin{array}{lc}1848 & \$ 8,884 \\ 1849 & - \\ 1850 & \$ 11,105 \\ 1851 & \$ 11,105 \\ 1852 & \$ 11,105 \\ 1853 & \$ 11,105 \\ 1854 & \$ 21,105 \\ 1855 & \$ 30,000 \\ 1856 & \$ 30,000 \\ 1857 & \$ 40,000\end{array}$

These data show three significant increases in the real property value: a jump of $\$ 10,000$ from 1853 to 1854; a jump of $\$ 8,895$ from 1854 to 1855 ; and a jump of $\$ 10,000$ from 1856 to 1857 . These increases are almost certainly attributable to the capital improvements made on the property, such as the addition of the house, the sugar mill, and other structures. Freeman (2004:112-113) attributes the 1854 property value increase to the construction of the sugar mill and notes a sudden jump in sugar production by “Jordan \& McNeill." She does not specify a reason for the 1855 value increase but then attributes the 1857 property value increase to the construction of the house and cites the 1857 Nuckols letter as supporting evidence. Freeman's interpretation is certainly a logical one, but it is not the only plausible interpretation of the data. The fact remains that none of the historical data cited above provides a definitive answer to the question of when the house was constructed.

Into this debate we can now add an interesting bit of archeological evidence. As described in Chapter 6, an 1853 U.S. one-dollar gold coin was found between the two bottom brick courses of the pier footing at the southeast corner of the house (Pier 2). In the discussion that follows, historical and archeological evidence are presented to make the case that the gold coin was intentionally placed inside the corner pier footing as a "foundation coin" or "cornerstone coin" that had symbolic and spiritual meaning.
Such coins were commonly placed in a prominent corner foundation at the start of the building's construction, and the widely accepted custom was to use a special gold or silver coin minted in the same year. Furthermore, it is argued that the coin was placed in a sacred spot in the structural foundation as part of a foundation ceremony or cornerstone rite. Such rites were common in many cultures around the world and are best represented by the traditions of the Freemasons. Modern groundbreaking ceremonies for public buildings and the placement of an inscribed cornerstone, often encapsulating a sealed time capsule, are rituals that evolved from foundation rites practiced hundreds and even thousands of years ago (Burdick 1901; Jarvis 2003; Morris 2010; Robinson 2011; Thurston 1913; Vallely 1962; Vincent 1976).

Coins are frequently found at historical archeological sites, but they are often given little thought and are assumed to represent nothing more than lost money. This may be true in many cases, but archeologists should be cautious and look closely at the contexts of such finds. Coin caches are perhaps the easiest to recognize archeologically. They were usually left by people hiding the money in an era when many people distrusted banks. This behavior was suggested for a cache of 214 coins ( 87 silver dollars, 86 halfdollars, 40 quarters, and 1 gold coin) dating from 1842 to 1882 that had been "hidden beneath the floor board of a previous structure" in downtown San Antonio, Texas (Shafer 2007:22). All coin caches, however, are not the same, and they can reflect a wide range of underlying beliefs that vary according to age, cultural association, and context. Coins found in human burials, for example, certainly have deeper meaning than simply being currency (Davidson 2004). In other contexts, such as the placement of coins in building foundations, the evidence is not so obvious. If archeologists are not aware of these rituals, they will not search in the right places to find such evidence. The fact that rare coins are often associated with foundations of old houses is common knowledge among metal detector enthusiasts. "The corners of older houses are also some of the best places to find money and jewelry with a metal detector. These were also areas where jars or boxes of money, jewelry, and other valuables were typically buried, and a metal detector makes finding them easier than ever" (Ray 2008:n.p.). 
Two excellent references for understanding the diversity of social, political, and spiritual contexts in which coins have been used are Coins in Context I: New Perspectives for the Interpretation of Coin Finds (Von Kaenel and Kemmers 2009) and "Rethinking Numismatics: The Archeology of Coins" (Kemmers and Myrberg 2011). The content of Coins in Context is summarized in an online review: "Coin finds are an integral part of the archaeological record. By studying coins in the contexts in which they were found, a great deal of information can be gained on how coins functioned in past societies" (Elkins 2009:n.p.; Von Kaenel and Kemmers 2009:cover jacket). "Rethinking Numismatics" is an article that describes a wide range of sociocultural contexts in which coins have meaning beyond their currency value. The authors mention foundation coins as one of the key sociocultural contexts in which coins were used:

\begin{abstract}
Another type of deposit is foundational, like coins in ditches, postholes and pits in several of the temples mentioned above, a practice known from many times and places. It is well known in Scandinavia, where in historic times coins (mainly silver and copper) were often placed under a threshold, a posthole or a mast to provide riches and luck for a new-built house or ship. During medieval times, small hoards or deposits were sometimes placed in the foundation of a church....[Kemmers and Myrberg 2011:101].
\end{abstract}

There are many examples of foundation coins having been found in archeological contexts in the United States. An article in an 1874 issue of the American Journal of Numismatics and Bulletin of American Numismatic and Archaeological Societies reports two finds of coins under foundation stones (Anonymous 1874:n.p.). A copper penny dated 1723 was found at a farm in Somerset, Rhode Island, in 1874. "In removing a portion of an old stone wall, the coin was found embedded in the earth under the foundation stone, and was perfect with the exception of being thickly pitted." In the second example: "While workmen were digging recently for the foundation of the old Portsmouth Savings Bank, several copper coins were found. One of them bears the date of 1757 , and has the same symbol as the old pine tree shilling." In 1876 , the same journal published an article titled: "Coins under Foundation Stones-Black Money." The author (Anonymous 1876:n.p.) discusses "the ancient custom of placing coins under Foundation Stones" and references a written account of building foundation ceremony held on the island of Malta on March 28, 1566. After a procession made its way to the site of the first building in the new city of Valletta, the ceremony began and was conducted by the Grand Master La Valletta of the order of St. John of Jerusalem. An eyewitness described the events:

Under a rich canopy stood an altar, at which high mass was said; and after this an Augustinian monk preached an eloquent discourse. After the sermon, the vice-prior pronounced the benediction. Then several gold and silver Medals, bearing on one side the effigy of the Grand Master, and on the other appropriate inscriptions, were placed beneath the stone before it was lowered into its place... Then, having been formally tapped with a mallet and carefully examined with a square, and pronounced duly laid, a loud shout burst from the assembled crowd... On the foundation-stone was engraved an inscription which mentioned the fact that La Vallette had placed beneath it several gold and silver coins [Anonymous 1876:n.p.].

In the United States, there is an especially strong connection between building foundation ceremonies, coins placed in the foundation corner or cornerstone, and the Freemasons. In a 1901 book about "Foundation Rites" and "Kindred Ceremonies," Burdick (1901:70) states:

In the Masonic ceremony of laying the foundation, the Grand Treasurer places under the stone various sorts of coins and medals, amidst solemn music the stone is let down to its place, the Grand Master applies the plumb, square and level to the stone, in their proper positions, and pronounces it to be "well formed, true and trusty," then 
from the gold and silver vessels, the Grand Master, "according to ancient ceremony, pours the corn, the wine, and the oil on the stone," invoking a blessing upon the people, and assistance of the higher powers in the erection and completion of the structure, and protection for the workmen in their labor, and preservation from decay for the building. He then strikes the stone thrice with his mallet. The corn is emblematic of nourishment, the wine of refreshment, and the oil of joy. In commenting upon this ceremony, and with particular reference to the burying of the coins and medals and pictures, Mr. Speth observes: "I do not assert that one in a hundred is conscious of what he is doing; if you ask him he will give some different reason; but the fact remains that unconsciously, we are following the customs of our fathers, and symbolically providing a soul for the structure. The oil and wine and corn have taken the place of the blood of the primitive sacrifice..."

In another treatise on foundation stone rites, Vallely (1962), a Mason from New Zealand, notes that Masonic rituals for the laying of the foundation stone or cornerstone have roots dating back some 6,000 years. Vallely (1962:n.p.) describes the underlying meaning of the ritual:

Laying a Foundation Stone then, has been an important and colourful ceremony from many points of view, psychological, architectural, sociological and religious, for many thousands of years, and it has flourished throughout the Christian era...Records of the ceremony, which has never been denominational or sectarian, go back some 200 years in America and 900 years and more in England; the first stone of Gloucester Cathedral for instance was set by the Bishop of Hereford in 1089, 300 years before the writing of our oldest Masonic Charge, the Regius Poem...indeed the earliest record of an official Masonic ceremony is that of the laying, on request, of the Foundation
Stone of the new Royal Infermary of Edinburgh by the Grand Master of Scottish Masons, the Earl of Cromarty, in 1738.

In his study, Vallely (1962:n.p.) suggests that the ancient rituals involved human or animal sacrifices at the laying of the cornerstone, but that coins and other offerings eventually replaced "the barbaric features" of this custom. Vallely (1962:n.p.) describes the connection between foundation stone rites, cornerstone time capsules, and ancient sacrifices:

This was done by placing certain objects in or under the Foundation Stone itself, and later by placing them in a cavity fashioned between the Foundation Store [sic] and what is known as Foot-Stone, which was tried and proved and well and truly laid and which then received the Ceremonial Stone; or the cavity between them may be closed by a plaque. Sometimes the Foot-Stone is called the First Stone, but in this sense it is the first stone in the laying ceremony, and not the first stone of the building to be laid. These objects, known as foundation deposits, ....are often placed in a glass cylinder and sealed off against air and moisture, nowadays they commonly comprise newspapers, medals, coins and other articles, such as a roll or descriptive statement. This practice has caused the Foundation Stone to be called by many the Memorial Stone, particularly in Scotland. It has been said that by including coins each bearing the imae [sic] of a much loved sovereign, we are unconsciously continuing the early human Foundation Sacrifice, and symbolically providing a soul for the structure. This may be so, but it is perhaps more likely that we wish thereby to provide hisorical [sic] data for our successors (if any).

Vallely (1962:n.p.) then lists the 12 steps in the Masonic ceremony at the laying of the foundation stone of the Masonic Memorial Freemasons' Hall in London on July 14, 1927: 
1. The Grand Master is requested to lay the stone.

2. The stone is raised.

3. The phial containing the roll and coins is placed in the cavity.

4. The inscription upon the stone is read.

5. The Grand Master receives the trowel and spreads the cement upon the lower stone.

6. The upper stone is lowered by three movements.

7. The maul is handed to the Grand Master who strikes the stone at corner, "Temperance, Fortitude, Prudence and Justice."

8. The plumb rule is handed to the Grand Master who proves the stone plumb.

9. The level is handed to the Grand Master who proves the stone level.

10. The square is handed to the Grand Master who proves the stone square.

11. The maul is handed to the Grand Master who strikes the stone three times and declares the stone well and truly laid.

12. The ceremony concludes with patriarchal Benediction and the Consecration Ceremony, the stone being consecrated with corn, wine, oil and salt.

13. As noted in the sequence above, No. 3 is the placement of the coins and other items inside a cavity in the cornerstone. As an interesting aside, some sources say the term "fair and square" originated in connection with the Masonic foundation ceremony (Grand Lodge of Maine 2012).

In his classic 1893 study of builders' rites and Masonic folklore, Freemason and Masonic scholar G. W. Speth (2010:n.p.) notes that a single coin or multiple coins might be used in the ceremony:

Many of us have seen a foundationstone laid, and more have read an account of the proceedings usual on such an occasion. When conducted by Freemasons the ceremony includes much beautiful symbolism, such as trying and pronouncing the stone well laid, pouring out of wine and oil over it, and other similar rites; but in almost all cases, whether the ancient Craft be concerned in the operation or not, there are placed in a cavity beneath the stone several objects of a peculiar nature, such as a list of the contributors to the funds, a copy of the newspaper of the day, and above all, one or more coins of the realm.

The Masonic foundation or cornerstone ceremony evolved through time, and there were many different versions that varied slightly in their details (Morris 2010:n.p.). The location of the significant foundation stone corner varies. Some Masonic accounts note the significance of the northeast corner of a building, and the northeast corner inside a Masonic lodge has special meaning as well. But modern building cornerstones may be placed in any corner, and the only general rule is that they are on the front side of the building where they face the public. When the Masonic ritual was held for the first Southern University building in New Orleans on May 8, 1886, the cornerstone, which contained a time capsule with many objects, including "Pieces of coin of the United States government," was placed in the northwest corner of the future building (Vincent 1976:338). The cornerstone for the U.S. Capitol in Washington, D.C., was laid in the southwest corner of the building by Masons on September 18, 1793 (Hodapp 2012). Although placement of an aboveground public cornerstone might be different from placement of ritual offerings in a belowground foundation stone, the concept that the front corners of the building were important probably dates back many millennia. None of the older foundation rites that were examined make any specific claims regarding the corner for the ceremonial foundation stone.

Like the relative locations of cornerstones placed in buildings, what is inscribed on these stones varies greatly. An engraved cornerstone might include the name of the building or institution, the names of the builders or important political people, dedication statements, or symbols (e.g., balance scales or the Goddess of Justice on courthouses). The one thing that almost all cornerstones have inscribed into them is the construction date (Robinson 2011:30; Thurston 1913:n.p.).

Coins can have multiple and complex meanings when used in foundation ceremonies, (good 
luck, symbolic sacrifice, recognition of higher authority, etc.). Their original meanings probably changed through time and have become lost even to those who now perform the ceremonies. The dates of the foundation coins, however, were not a random affair. The coin served as a commemoration of the foundation-laying event, and the coin was intended to be a snapshot in time, just as modern cornerstones and time capsules are. Lyons (2001:n.p.) notes the following foundation coin customs from Ireland: "Items were buried in the foundations of the house, these were of two kinds, religious or superstitious. The main place for burial was under the foundation stone of a house. A new coin with the date of the year in which the house was built was the most favoured. A coin was supposed to bring prosperity, the owners of the house would never be without money."

The importance of coin dates in foundation stone contexts is perhaps best expressed by the historical example of the second San Francisco mint building, constructed in 1870 (Kelly and Oliver 2004). The building's superintendent of construction, William Stebbins, sent specific details about the cornerstone ceremony to the newspapers after the event, noting that that the ritual conformed to the "Masonic tradition." The newspapers then reported that the coinage was: "One of each denomination of the several coins of the United States of America, all struck off at the San Francisco Branch Mint in the year 1870" (Kelly and Oliver 2004:n.p.). Although some had argued about the dates of the coins placed in the cornerstone, the article's authors emphatically state: "any cornerstone or time capsule would traditionally contain artifacts of the year of placement if at all possible, and in the case of coins, the exact year of same" (Kelly and Oliver 2004:n.p.).

This research suggests that the 1853 U.S. one-dollar gold coin found in a Levi Jordan house pier footing was intentionally placed there in some type of foundation stone ritual. Based on this information, the following interpretations are offered:

- The coin was found in the southeast corner pier of the Levi Jordan house, which is on the right front side when facing the house. This is consistent with well-documented variations in foundation stone and cornerstone ceremonies.
- The coin was found above the bottom layer of bricks in the footing and under the second layer. This is consistent with well-documented foundation stone rituals in which a coin or coins were placed on the bottom foundation stone and covered with a footstone.

- Foundation stone ceremonies did not use random coins; a coin minted in the year of construction would have been used if possible. The Levi Jordan house coin was a commemorative offering that dates the beginning of the house construction to 1853 .

- The coin could have been placed in the southeast corner pier footing by Levi Jordan himself, or perhaps by a master builder that he hired to oversee the house construction. The ceremony might have been a relatively private affair, involving only one or two people. Or it might have been more public, perhaps involving several members of the Jordan family, neighbors, and friends.

- It is possible that the coin was placed in the corner pier of the Levi Jordan house by a Freemason during a Masonic cornerstone ceremony. Freemasons played a prominent role in the Republic of Texas and early statehood. The Grand Lodge of the Republic of Texas was established in Houston in 1838, and by 1845 there were 25 Masonic lodges in the Republic, including one in Brazoria (Grand Lodge of Texas 2012; Vaughn 2012). Levi Jordan would not have had to look far to find a Freemason to conduct his foundation ceremony, and he might have been a Freemason himself.

One final comment on the foundation coin is warranted. The 1853 construction indicated by the coin does not contradict any of the other historical facts mentioned earlier. The combined evidence indicates that the house construction began in 1853 but that the house sustained damage in the July 1854 hurricane. This would have delayed the construction, and the house was probably still under construction through the end of 1854 and perhaps into 1855. The Jordan family was probably living in the house by 1855 , and the $\$ 8,895$ increase in the real estate value of the plantation from 1854 to 1855 probably reflects this improvement. When the house was "finished" was probably a matter of subjective 
interpretation. For Levi Jordan, the house may have been essentially completed by 1855 , when the family probably moved in. But in the eyes of his granddaughter, Sallie McNeill, and her friend Charlotte Nuckols, the house might not have been considered complete until all the interior trim and decorations were finished or the back wing(s) was built. The Nuckols letter makes it clear that the family was living in the house in August 1857, despite the fact that the house was not yet done (Raska and Hill 2009:11, 163).

\section{ARCHITECTURAL ARCHEOLOGY AT LEVI JORDAN}

Established in 1848, the Levi Jordan Plantation was only one of at least 45 plantations in Brazoria County (Few 2006:6-7; Stroebel 2006:6-7) and hundreds of plantations on the Texas Gulf Coast. Many hundreds of antebellum plantation houses once existed in this region, but the Levi Jordan house is one of the very few that have survived. Of those that once stood, the majority now exist only as buried archeological remains. The stabilization project undertaken by THC in 2010-2011 therefore provided a rare opportunity for archeologists to investigate and document the foundation of a standing woodframe antebellum house. Gathering detailed archeological and architectural evidence for a plantation house that was occupied continuously and evolved over more than a century and a half has provided valuable data. The Levi Jordan data may be useful for interpreting other plantation sites that are currently being investigated, such as the Bernardo and Pleasant Hill Plantations in Waller County (MercadoAllinger and Bruseth 2010; Woodrick 2011), or perhaps reinterpreting evidence from previously investigated plantation sites such as at the Lake Jackson and Eagle Island plantations (Few 2006; Gross et al. 1993). Furthermore, the Levi Jordan archeological data may prove useful for interpreting plantation sites that will be investigated in the future. In short, the architectural evidence derived from a well-preserved plantation like Levi Jordan may be critical to our eventual understanding of Texas plantation sites that are not as well preserved.

Figure 9.1 is a map of the Levi Jordan house and yard features that existed or possibly existed in the antebellum period. Parts of the map are admittedly speculative. The main house was certainly there, and the east wing and cistern almost certainly were as well. The size and configuration of the east wing is conjectural, but the back wall is drawn at the back edge of the chimney foundation, which is the configuration of the chimneys on the east and west walls of the main house. The existence of the west wing is based on a single historical source (Platter 1961:160) and sketchy architectural evidence, ${ }^{45}$ so it has not been substantiated. Even if it did exist, there is no evidence that it was original to the antebellum house. Archeological evidence shows that the brick patio was present in the backyard, but the investigations are too limited to determine its horizontal extent. It is assumed that this brick patio and the brick walkway may be original antebellum features, but this has not been substantiated archeologically or historically.

In the northeastern corner of the yard, the size and configuration of the detached kitchen is purely guesswork. The large chimney definitely opened to the south, so it is hypothesized that the back wall of the building was at the north edge of the chimney, and that the wooden structure went to the south toward the main house. In this configuration, the gap between detached kitchen and the east wing was about $12 \mathrm{ft}$, giving the detached kitchen plenty of workspace in front of the fireplace. This interpretation is different from that of Barrera (1999:42), who suggested that "the kitchen faced west and the porch extended to a point in direct line with the hallway dividing the main house in half." A porch is shown on the front of the house in this map because one appears in the earliest known photograph from 1904 (see Figure 4.2a). Notably, no porches are shown on the east, north, or west sides of the house in this map. There is little evidence for the existence of these porches, and none that indicates that any of these possible porches actually dated to the antebellum period.

\footnotetext{
${ }^{45}$ Architect John Volz (personal communication 2013) thinks the door and window configurations on the north wall and double mortices on the second floor girt may indicate that there was a one-story addition on the west side.
} 


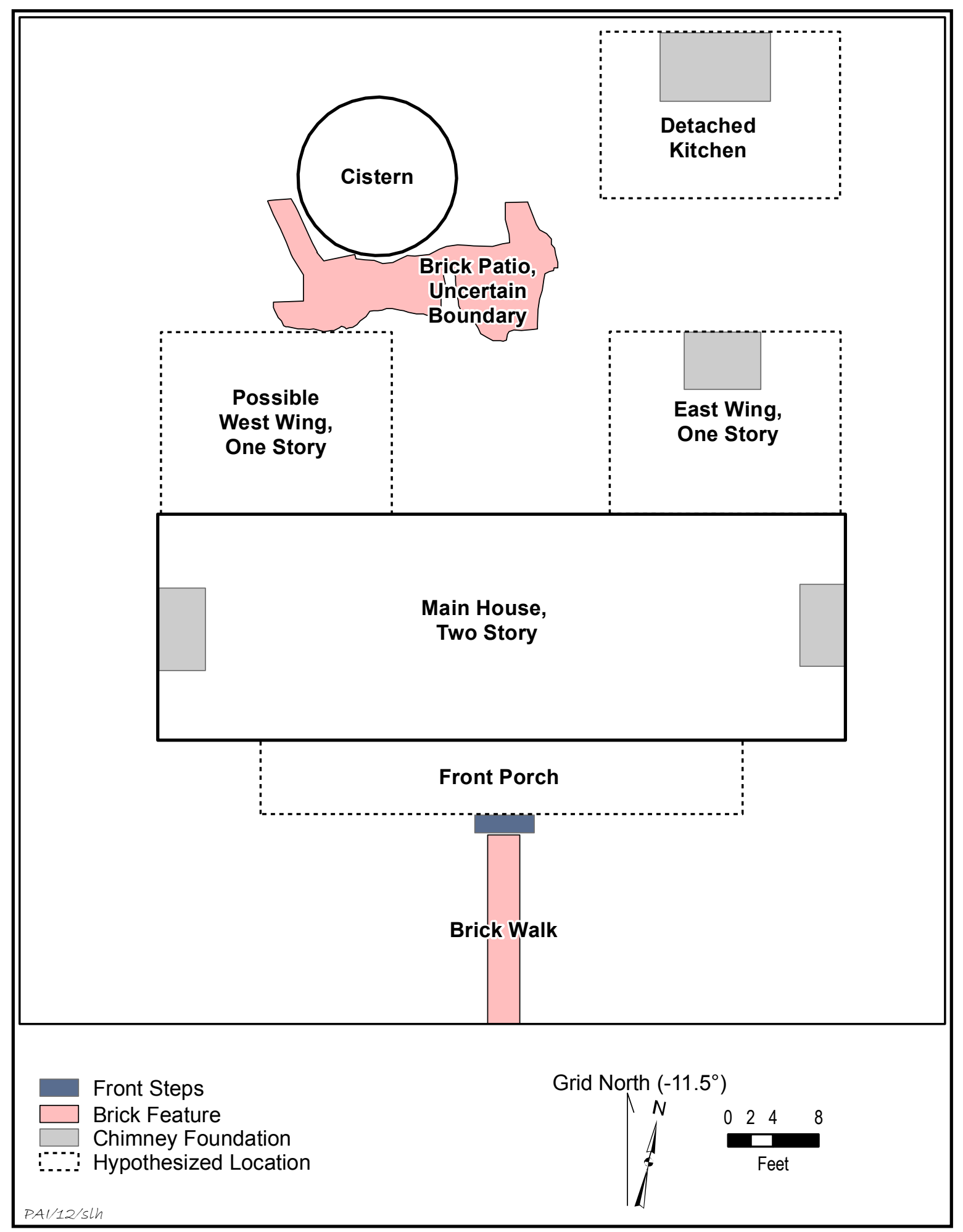

Figure 9.1. Map of the Levi Jordan house and yard as it might have looked in the antebellum period. 


\section{Material Culture at the Plantation House}

The PAI archeological work focused on examining archeological features around and underneath the Levi Jordan house. Thousands of artifacts were recovered, and these materials were inventoried by basic identification categories (see Appendix C). With a few exceptions, most of the recovered artifacts are from shallowly buried deposits that contain a mix of materials from a century and a half of occupations. Materials from these archeological contexts have limited research value because they cannot reasonably be sorted into meaningful assemblages associated with specific time periods. This is not to say that these cultural materials have no value. Such assemblages do indeed have value when they are analyzed with the contextual constraints in mind. The assemblage does contain many temporally or functionally diagnostic specimens that will be informative because they represent different time periods, occupants, and activities at the Levi Jordan plantation. For this project, however, the decision was made by PAI and THC to focus the archeological effort, both field and laboratory, on the features related to the architecture of the Levi Jordan house and the activities in the surrounding yard.

\section{The House Foundation and Its Piers}

The lifting of the Levi Jordan house during the stabilization project provided an unparalleled opportunity to examine the house foundation and its supporting piers. The architectural and archeological details revealed in these investigations provide an important snapshot of one mid-nineteenth-century plantation house, and it is even more meaningful when viewed in light of other antebellum plantations along the Texas coast. Freeman (2004:66) notes that "While most plantation homes in Brazoria County appear to have been constructed of wood, a handful were made of brick" (also see Stroebel 2006). Built in 1853-1854, the Levi Jordan wood-frame house appears to be typical in this regard. But we now know a great deal more about how the Jordan house was constructed, and this knowledge can be applied when investigating other antebellum sites.

A careful inspection revealed that the wall foundation beams around the perimeter of the house, the four major north-south foundation beams, and the four largest floor joists that tied into the chimney base were all cut with a 48-inch-diameter circular saw blade. The rest of the floor joists under the house had straight saw blade marks, having been cut with a sash saw. By the early 1850 s, there certainly were many sawmills in Brazoria County that used circular saws, although sash saws were probably more common. Levi Jordan could have purchased the largest timbers from one of the local mills or had them shipped in from Houston. It is possible that he rented or hired a portable sawmill crew to come to his property and cut the large timber onsite. But once the biggest beams and joists were cut, it appears that Jordan switched to using a sash saw to cut the smaller lumber. Presumably, this would have been the less expensive option. He might have purchased the sash-cut lumber directly from a local mill, or perhaps rented one and cut the lumber onsite. In any case, all of the big frame lumber used in the foundation beams and floor joists were cut by machine saws, probably steam-powered.

These interpretations, though somewhat speculative, do not necessarily contradict Platter's (1961:159) statement that the house "was made from oak timbers cut from the forest and from lumber brought across the Gulf and up the San Bernard River." It would seem logical that Jordan would have tried to cut local oak trees for use as the biggest foundation beams because of the significant costs of transporting such large members. The large oak logs used as piers (see below) were almost certainly cut onsite (unfortunately, their ends were too deteriorated to preserve original saw marks). It is likely that the medium-sized floor joists cut with a sash saw could have been cut locally, too. If Platter's informant was correct, the imported wood brought up the river would be the milled flooring, interior and exterior walls, and roofing elements.

The PAI investigations documented 69 foundation piers and 15 possible pier features at the Jordan plantation. Many of these were investigated through archeological excavations, with the piers being documented in profiles, plan drawings, and photographs. This documentation is especially important for the piers associated with the antebellum house because they were destroyed in the process of installing a new continuous concrete foundation around the house perimeter. Collectively, the piers and possible 
pier features provide a wealth of data relating to pier construction at different times in the history of the house. But even within one time period or construction episode, there is a great variability in how these features were built.

In differentiating piers by construction dates, one fact is clear and is an important temporal key for the Jordan plantation architectural archeology. All of the original piers associated with the $20 \mathrm{x} 60-\mathrm{ft}$ antebellum house were significantly different from the piers that were added or repaired later during many different episodes of remodeling, repair, and house expansion. The classic antebellum pier for the Levi Jordan house consisted of a large oak log section ${ }^{46}$ that was set into the ground on top of a pier footing constructed of one to three courses of handmade bricks (see Figures 6.4 to 6.11). These footings were composed of bricks that were lined up and arranged in patterns, but without any mortar. Many of these original piers had been modified in one or more repair episodes, but the most intact pads were as large or larger than the oak log piers they supported. It was found that some of the brick footings had been damaged by the shifting weight of the house. Each pier that had an intact brick footing-whether it was a complete footing or only a remnant-was found along the perimeter of the main house and is considered to be an original pier constructed in the 1850s house building episode (see Figure 6.32).

The original house pier footings were surprisingly varied. After seeing how uniform the brick chimney foundations were, it was assumed that the brick pier footings would be uniform as well. This was decidedly not the case, and no two pier footings were identical in their size and brick arrangement. In fact, some footings were rather neat and tidy, while others were haphazard and even sloppy. The inference here is that during the original house construction, experienced brickmasons built the chimneys but multiple crews or workers with different levels of experience built the brick footings. It is clear that they did not follow any standard template, and the pier footings reflect varying degrees of knowledge and skill. This observation had significance for interpreting foundation footings found in archeological excavations at other plantation sites.

It is not possible to determine when the next piers for the original house were added or repaired, but the frequency of pier repairs increased through time. A series of four large oak blocks, all cut with a 48-inch-diameter circular saw, were placed in an east-west line under the center of the house, with each pier under a major north-south foundation beam (see Figures 6.3 and 6.21). Because these piers were cut into square blocks and set into the ground without any footing, they likely represent a later repair episode that occurred in the late nineteenth or early twentieth century. It is possible that this work was done in response to sagging beams that were noticeable as an uneven floor inside the house. The last foundation repair episode for the interior of the original house was the addition of nine other piers, three each along three of the north-south beams. Most of these were milled lumber posts set into the ground without any footing, and others were railroad ties and concrete blocks. The placement of these piers cannot be precisely dated, but they were probably all added in the early to mid-twentieth century. These piers suggest that the interior foundation continued to sag under the weight of the house and that the original line of square-cut blocks had not solved the problem.

Some of the piers along the north wall of the original house and all the piers around the perimeter of the ell addition are interpreted as original piers and repair piers (see Figures 6.2 and 6.3). As discussed in Chapters 2, 4, and 6, it is likely that the ell was built in the early twentieth century, after the original east wing was damaged or destroyed in the 1900 hurricane. Although the ell is called an addition, there is some architectural evidence that it was actually a series of additions built in the early twentieth century. Unfortunately, some of the evidence was stripped away before it was carefully examined by historical architects (John Volz, personal communication 2012).

Most of these piers in the ell addition are milled posts (with creosote-soaked utility poles being common) set onto various types of

\footnotetext{
${ }^{46}$ Wood samples from eight original perimeter pier posts were analyzed and identified as live oak (see Appendix C). Thus, it is presumed that all of the original posts were oak.
} 
footings (e.g., brick rubble, concrete blocks, or cut lumber) or without footings. If the piers from the various parts of the ell addition contained any chronological distinctions, it was not readily apparent, with the exception that some of the pier posts had fresh creosote while others were weathered. In some cases, these milled posts had been put onto original brick pier pads to replace the original oak logs, and some piers had multiple (two or three) milled posts placed in a single pier location. Other twentieth-century repairs were made with large cut lumber blocks, railroad ties, and concrete blocks.

Fifteen features interpreted as possible piers were found around the original Levi Jordan house. Although they had no evidence of aboveground posts, they represent postholes or posthole stains in locations that suggest they functioned as piers. Most of these features were not investigated fully, and no positive identification could be made. While two of the possible piers were found under the south wall of the antebellum house (but were not investigated), most of these possible piers are in locations suggesting they might have been associated with the original east wing or with porches attached to the east, south, or west sides of the house. Unfortunately, the association with these porches is speculative, and there are so few posthole-like features that the patterns of porch piers cannot be determined. More archeological investigations would be needed to test various porch hypotheses. However, in the case of three possible piers near the southwest corner of the original house (see Features 13, 18, and 19 in Chapter 6), a historic photograph suggests that a porch-like structure did extend west of the house in 1905 (see Figure 6.28). The photo seems to show a westward extension of the south porch, or perhaps a wraparound west porch.

\section{The Four Chimneys}

Four chimney footings were documented at the Levi Jordan plantation (see Chapter 7). Two of the chimneys were on either end of the antebellum house, and one was attached to an original east wing that may have been destroyed in the 1900 hurricane. The fourth is in an isolated area north of the house, and it is inferred to have been inside the detached kitchen (see Figure 9.1). The east and west chimneys of the antebellum house were probably constructed in
1853 , and the original east wing chimney might have been built at the same time or within a few years (probably completed by 1857). There is no firm evidence regarding when the detached kitchen chimney was built, and it is interesting that Sarah "Sallie" McNeill never mentioned a kitchen in her 1858-1867 diary. She also never mentioned where the slaves prepared the meals, but this is not the kind of detail she would have considered important. It is likely that the detached kitchen would have been among the earliest structures on the plantation, and it was probably functional by the time the whole family moved into the main house.

Archeologically, the construction details of the chimney footings are of interest, and all four share many common attributes, with one significant difference (see Table 7.1). The four chimney foundations consist of spread footings with five (or six?) courses of bricks in the footings. All had three wide load-bearing walls, with the back wall being the widest, and a thinner wall on the front side, where the firebox opening was located. All four chimneys had a rubble-filled core in the footing that approximates the size of the firebox that was directly above. The significant difference is that the east and west chimneys in the main house and the original east wing chimney are all similar in size, while the detached kitchen chimney is much larger. When the size data for the rubble-filled voids (see Table 7.1) are converted to square footage, the approximate areas of the chimney fireboxes are as follows:

$$
\begin{array}{ll}
\text { East Chimney of Big House } & 6.7 \mathrm{ft}^{2} \\
\text { West Chimney of Big House } & 6.8 \mathrm{ft}^{2} \\
\text { Original East Wing Chimney } & 8.0 \mathrm{ft}^{2} \\
\text { Detached Kitchen Chimney } & 20.2 \mathrm{ft}^{2}
\end{array}
$$

These measurements reveal that the house had small fireboxes that were intended primarily for heating rather than cooking. The original east wing chimney was slightly larger, perhaps designed for heating and some limited cooking for a small number of people. In contrast, the firebox of the kitchen chimney is at least 2.5 times larger than the others, lending support to the interpretation that it was a giant firebox intended for cooking meals for large numbers of people. Some of the interesting artifacts recovered from the Levi Jordan Quarters are a pothanger (from 
Cabin I-A-1; Brown 1995b:Figure 79) and fragments of a "cast iron kettle" and "many large fragments of cast iron vessels" (Brown 2012:7, 65-67, 75 . These items indicate that cooking methods at Levi Jordan included the use of cast-iron cooking pots (probably with swing handles) suspended over fires using tripods and pothangers. This would have been a common method of cooking in a large open hearth, and the giant firebox of the detached kitchen would have accommodated many large cooking pots.

In the southern United States, cooking in chimney fireplaces was most common through the Civil War, and cookstoves did not become widespread until around 1870, when American manufactures introduced smaller and more compact ranges that were easy to use and transport (Hanson 1986:171). Only wealthy families could afford cookstoves at first, but most families had them by 1900 . Thus, it is likely that the large fireplace in the detached kitchen was used up through the Civil War, but it was probably abandoned once the Jordan family acquired a cookstove.

When the east and west chimneys were disassembled by the stabilization contractors, they collected and cleaned the mortar off all the handmade bricks so they could be used again in rebuilding the chimneys. The workers were asked to set aside any bricks with unusual markings. They pulled many bricks with unusual markings, seven of which are illustrated in Figure 7.8. The markings include engravings in dry brick and marks made while the bricks were in a stiff-mud state. The marks vary from a simple $\mathrm{X}$ or check mark to more complex geometric symbols. It is impossible to know with certainty what the markings represent, but the possibility that some of these brick marks were made by African Americans in a ritual or spiritual context is discussed in Chapter 7. Chimney charms were important, as were symbols engraved into a variety of objects (Arnett et al. 2000:79; Fennell 2007:44, 78; Joseph 2011:139-143). University of Houston archeologists interpreted the mark on a brick found in one of the Quarters cabins as being a West African cosmogram symbol (Brown 2005b:Figure 107; 2012:Figure 32).

\section{Exterior Features and Activity Areas}

Ten exterior features are reported in Chapter 8. Three of these are north of the Jordan plantation house and are of particular interest for understanding the evolution of improvements in the backyard: two large brick-lined cisterns and a brick patio. Cistern 1 is the older of the two, and it was probably constructed in the $1850 \mathrm{~s}$, when the original house was built. It is centrally located in the yard behind the house, with its south wall about $23 \mathrm{ft}$ north of the house. But it is not perfectly centered behind the antebellum house. The center of the cistern is offset $10 \mathrm{ft}$ to the west of a north-south centerline through the original 60-ft-long house (see Figure 9.1). At the time this cistern was built, the original east wing and detached kitchen were probably present. So the original cistern was located in an excellent spot to capture rainfall runoff from the Jordan house and provide water for the main house, the detached kitchen, the east wing, and even a west wing. The house had a simple system of gutters and might have had one or more underground pipes (or brick-lined channels) going from the house to the cistern. Former resident and Levi Jordan descendant Ewing Martin remembered that the house had gutters (see Chapter 4), but no archeological evidence of underground pipes or channels going from the house to Cistern 1 has been found. It may be that belowground features were never present (acknowledging the possibility that the inflow pipes were suspended above ground and flowed into the top of the neck), that they were at or near the current ground level and have been destroyed, or that they could be present below ground but were simply missed in the limited excavations.

Cistern 2, set off in the west side of the backyard, was built after the first one was abandoned. It is not clear when this happened, although the original cistern could have been seriously damaged in one of the severe hurricanes, possibly the 1900 storm that may have destroyed the original east wing. The two large brick rubble features in the backyard and in the east wing area (see Figures 8.12 and 8.13) may be direct evidence of the destruction caused by the 1900 hurricane; the brick rubble probably came from the original east wing chimney and Cistern 1.

Archeological evidence reveals the existence of a backyard brick patio, but the excavations were too limited to define its full boundaries. The oral history evidence suggests that there were extensive walkways and brick surfaces in the backyard (see Chapter 4), but there is no definitive evidence of when such features were built. 
It is possible that the archeologically recorded brick patio is part of the "veranda" where the family watched the sunset, according to Sallie McNeill's diary (Raska and Hill 2009:107). If so, the original brick patio would have been built before 1860 or 1861, the years Sallie first mentions the veranda.

A single-course, rectangular cluster of horizontally laid bricks was found at the southwest corner of the house. This feature is inferred to be a possible rain barrel pad, but there is no historic evidence (archival or oral) to support this. The age of this feature is also unknown.

The last three exterior features are a small brick cluster, a buried iron container filled with materials, and a concentration of complete or nearly complete seashells. While interesting, the functions of these features are not known. The ages of the brick cluster and seashell concentration are not known, but the buried iron container has wire nails in it and probably dates to the twentieth century.

\section{MANAGEMENT RECOMMENDATIONS}

THC has just completed a much-needed stabilization of the original Levi Jordan house. The project involved removal of the twentiethcentury addition, adding concrete foundations to stabilize the superstructure, adding new concrete chimney footings, rebuilding the chimneys, and restoring the exterior of the original house to its nineteenth-century appearance. The public celebration to announce the completion of the stabilization work was held onsite on March 3, 2012 , the day after the 176th anniversary of Texas independence. The press release issued by THC on the day of the event stated:

The THC assumed management of the property in 2008 and immediately began preservation planning for the house, which was in a severely dilapidated state. Exterior preservation began in May 2011 and was completed in January 2012. Significant aspects of the project included leveling and squaring the house, stabilizing the structure atop a concrete foundation and piers, restoring windows and doors, installing a new cedar shake roof, reconstructing chimneys faced with historic brick, and repainting the house's exterior (McAuley 2012).

With the stabilization of the Levi Jordan big house now complete, THC has moved into the development phase for the plantation. The agency is now planning the public interpretation for the historical site, and in the development process, it must still try to preserve and protect the archeological remains while balancing the need for interpretive and logistical infrastructure. In the future, there will likely be a need to conduct additional archeological investigations in areas that will be impacted by site development, and the potential to conduct periodic research-driven archeological investigations and integrate them into the public site interpretation is significant indeed. A great deal can still be learned from the buried archeological remains at Levi Jordan, and the specific recommendations below are presented in the form of archeological research questions that might be addressed in future investigations.

- Where was the detached kitchen relative to the chimney footing inside it? This would require additional archeological excavations over a broad area to look for pier features associated with the structure. The groundpenetrating radar survey conducted might be useful for targeting such excavations. The hypothesis that the structure's back wall was along the back (north) side of the chimney footing is also a logical starting point in searching for pier features.

- What was the full extent of the backyard brick patio, and can it be dated to either the late-nineteenth century or the antebellum period? This would require very targeted hand excavations over a broad area. It is likely that if there had been an extensive backyard brick patio, many parts of it would have been destroyed or extensively disturbed over the years, but remnants should survive. Although PAI archeologists left the brick patio intact during the current investigations, eventually it would be necessary to conduct some sample excavation below intact portions of the brick pad to look for temporally diagnostic artifacts. Few or only mid-nineteenthcentury artifacts would mean the patio is 
an antebellum feature. But finding definite late-nineteenth- or early-twentieth-century artifacts could mean the brick patio was a later construction, assuming that one could rule out the possibility that postdepositional disturbances introduced later materials. As a cautionary note, some intact portions of the brick patio could be pre-Civil War construction, while other sections could have been repaired at various times. (PAI archeologists noted quite a bit of variation in the brick patterning in the patio feature. ${ }^{47}$

- Are there any buried pipes or brick-lined channels that would have carried water to either of the cisterns? The water-intake conduits would probably not be more than 18 inches below ground, and handexcavated trenches around the interior or exterior walls of the cisterns would be the quickest way to reveal if they existed and where the conduits entered the cisterns. If an intake opening is identified, it could be traced back toward its origin with targeted excavations. A straight line drawn from the intake opening at the cistern and the corners of the house and wings is one logical way to predict the locations of subsurface water conduits, and finding such evidence might provide circumstantial evidence for an original west wing.

- Were there porches on the east and west sides of the house, and can they be dated to the nineteenth century? Can additional pier features associated with the original wooden front porch on the south side of the house be located? The existence of the front porch is known through historical photographs, but the possible presence of porches on other sides of the house has been hypothesized by University of Houston researchers based on oral recollections (see Figure 2.7) and by PAI based on archeological evidence (possible west porch described in Chapter 6). Hand excavations would be needed to search for pier features that might be associated with these porches. The possible pier features located during the current investigations provide a starting point for predicting where other possible east, west, and south porch piers might be located. Careful examination of the historic photographs could help predict possible pier locations for the south and west porches.

- Can the brick-lined walkway in front of the house be dated to either the late-nineteenth century or the antebellum period? It is likely that most of the brick-lined front walk, and perhaps all of it, is intact and sealed below the concrete walkway. Archeological investigation of this original brick feature would require selection of several sample areas, removal of the concrete layer to look for artifacts between the concrete and the brick layer, and then removal of the brick layer to look for artifacts below it. As with the brick patio, any artifacts found in undisturbed areas below the brick walk would indicate a maximum age but not a minimum age. If the sample size were sufficient, the absence of later artifacts might provide circumstantial evidence for a minimum age.

- Can any of the hypothesized buildings and features around the main house be located? Various sources indicate that many buildings and structures were present near the house, including the kitchen, a hospital, the "Boy's House," house slaves' or servants' cabins, corncribs, a smokehouse, a dairy, a loom house, a "smith shop" (presumably blacksmith), and sheds. The existence of these structures is documented in historic records and oral recollections, but most of the information is from the twentieth century and sources differ as to the identification and names of the structures. Unfortunately, the hypothesized locations are sketchy at best (see Figures 2.5-2.9). Testing of the groundpenetrating radar anomaly suggesting a buried feature in front of the house (just east of the front walkway) might be productive (see Figure 5.1). The next logical step in identifying possible areas for archeological investigations is to expand the ground-

\footnotetext{
${ }^{47}$ The brick feature identified by TPWD archeologists under the twentieth-century ell (den) may be a remnant of the backyard patio closer to the antebellum house (Howard 2003a:Figure 3).
} 
penetrating radar survey to cover a large area north and west of the house. Most of these building locations are taken from archeological maps prepared by University of Houston researchers, and there may be unpublished archeological evidence pertinent to some of them. For example, the corncribs (see Figure 2.9) are reported to be $75 \mathrm{ft}$ northwest of the house based on "a series of postmolds" that define "a long, very narrow type of structure" (Barrera 1999:41). Since no published maps or feature descriptions support this inference, it would require going back to the original field records to reexamine this evidence.

- Can the "well" reportedly located east of the house be found? University of Houston researchers identified a possible well location east of the main house (see Figure 2.6), presumably based on oral testimony of former residents (Brown 2012). Another cultural resources map shows a location of a second well west of the house near the edge of the slough (Texas Parks and Wildlife Department 2004:Figure 13). Conducting ground-penetrating radar surveys in these areas could be productive, and any deep intrusive anomalies should be archeologically tested.

- Can any of the privy locations be identified and investigated? Privies can be a valuable source of data for interpreting the lives of historic people, especially diet and discard behaviors (Wheeler 2000a, 2000b). There were probably many privy locations used during the first century of occupation of the Jordan plantation, and one twentiethcentury privy location was remembered by Aunt Eula (see Figure 4.1). It is acknowledged that antebellum privy pits may be rare, and human waste from the big house might have been dumped into the slough, but privy pits from the late-nineteenth and earlytwentieth centuries should be present. A comprehensive ground-penetrating radar survey could locate intrusive anomalies along the back side of the yard area that might be privy pits.

- Can additional research on the artifacts found during the PAI investigations yield insights into the lives of the Jordan plantation occupants, especially the more unusual artifacts that may date to the late nineteenth century?

- Is there archeological evidence for an original west wing on the north side of the main house? To address this question, excavations should target the area between west side of the house and Cisterns 1 and 2 to determine if any structural piers or a chimney footing are present. This would require digging through the brick rubble layer (Feature 32) and brick patio to search for these possible antebellum features (see Figure 8.1).

- Dendrochronological analysis of three live oak timber samples from Levi Jordan house piers is recommended. The three samples, which were from two original antebellum pier timbers (Piers P1 and S1) and one later square-cut pier (Pier V11), were sent to the University of Arkansas Tree Ring Laboratory, where they were evaluated by one of the lab directors, David Stahle (see Chapter 6). Each sample has about 50 annual growth rings of varying widths, so the potential for cross-dating with existing post oak tree ring chronologies is good. This means that the samples could yield tree-cutting dates that would approximate the age of the house construction as well as provide climatic evidence for the half century before the house construction.

- Although extensive archeological investigations were completed in the slave quarters area by University of Houston archeologists, no reports provide detailed descriptions of all the features or the artifact assemblages. Much can still be learned from continued analyses of the excavated data. In addition, targeted excavations in the slave quarters could be done to obtain geomorphic and stratigraphic evidence that might have a bearing on some controversial interpretations. One example is the hypothesis of an archeological abandonment zone representing an abrupt and forced abandonment episode (Brown 2012:3, 10-16; Cooper 1989; 1992).

Thousands of artifacts recovered from PAI's archeological investigations are from contexts that are less than ideal, but additional analyses could still yield some important data, especially if the studies focused on identifying nineteenthcentury items. Some of the probable nineteenth- 
century or early-twentieth-century artifacts in the assemblage (see Appendix C) are the flow blue, transfer-printed, and embossed whiteware ceramics; decorated porcelain pieces; ceramics with maker's marks; some of the stonewares; some of the bottle glass fragments; several coins (i.e., an 1873 penny, a 1889 nickel, and a 1908 penny); an oil lamp burner; and ceramic pipe bowl fragments. Many of the recovered specimens are quite unusual. As mentioned in Chapter 6, a perforated disk found in a pre-1905 context could have symbolic meaning (see Feature 13), and several other similar perforated disks were found as well. Examples of other unusual specimens that might warrant some attention are a hand-carved bone pipe stem and mouth (Lot 2010-58 from Unit N5) and a small animal toe bone (possibly domestic pig) with intentional modifications in the form of grinding/polishing, etched lines, and drilled holes (Lot 2010-66 from Unit W3).

The final management recommendation is historical rather than archeological, and it relates to the finding of the 1853 coin. More research is needed on the possible connection between this unique object and the Freemasons in Texas during the Republic of Texas and early statehood periods. Was the placement of the coin likely to have been in connection with a foundation rite conducted by Freemasons? Was Levi Jordan a Freemason himself? Or were some of Levi Jordan's relatives, close associates, or neighbors Freemasons? Although this line of inquiry is a small part of the story, it helps paint a picture of life on a Texas plantation in the antebellum period. 



\section{REFERENCES CITED}

Adams, William Hampton

2002 Machine Cut Nails and Wire Nails: American Production and Use for Dating 19thCentury and Early-20th-Century Sites. Historical Archaeology 36(4):66-88.

Alvarado, Luis

2002 Daily journal entries for July 8-12, 2002. Archeological Investigations at Levi Jordan Plantation for Texas Parks and Wildlife Department. Unpublished manuscripts on file at the Historic Sites Division, Texas Historical Commission, Austin.

Andrews, Jean

1971 Shells and Shores of Texas. University of Texas Press, Austin.

Anonymous

1842 Pages Portable Sawmill. The Cultivator, A Consolidation of Buel's Cultivator and the Genesee Farmer, Designed to Improve the Soil and the Mind and to Elevate the Character and Standing of the Cultivators of the American Soil. Vol. 9. Luther Tucker, Albany, New York. Google Books Online. Electronic document, http://books.google.com/book s?id=hjgxAQAAMAAJ \&pg $=$ PA $46 \& d q=$ page+portable+sawmill\&hl $=$ en $\&$ sa $=X \&$ ei=GbTpT_ylHMLS2gWt8IHxCA\&ved= 0CEEQ6AEwAA\#v=onepage\& $\mathrm{q}=$ page $\% 2$ 0 portable $\% 20$ sawmill\&f=false, accessed July 26, 2012.

1850 Page's Portable Saw Mill, as worked by Steam Power. The Ohio Cultivator: A Semi-Monthly Journal, Devoted to the Improvement of Agriculture and Horticulture. Vol. 6. M. B. Bateham, Columbus, Ohio. Electronic document, http://books.google. com/books?id=Zc8IAQAAIAAJ\&pg=
PA118\&dq $=\% 22$ Page $\% 27 \mathrm{~s}+$ Portable $+\mathrm{S}$ $\mathrm{aw}+\mathrm{mill} \% 22 \& \mathrm{hl}=\mathrm{en} \& \mathrm{sa}=\mathrm{X} \& \mathrm{ei}=\mathrm{CrvpT}$ 8_YD4SA2wXUyazrCA\&ved $=0 \mathrm{CEEQ}$ $6 \mathrm{AEwAA \# v}=$ onepage $\& \mathrm{q}=\% 22$ Page $\% 27$ $\mathrm{s} \% 20$ Portable $\% 20$ Saw $\% 20$ mill $\% 22 \& \mathrm{f}=$ false, accessed July 26, 2012.

1874 Newspaper Cuttings: An Old Coin. American Journal of Numismatics and Bulletin of American Numismatic and Archaeological Societies 8(3):57-58. Google Books. Electronic document, http://books.google. com/books?id=_nY9AAAAYAAJ\&pg=RA1PA $57 \& \mathrm{lpg}=\mathrm{R}$ A 1 - PA $57 \& \mathrm{~d} q=$ foundation+stones+and+date+coins\&sou $\mathrm{rce}=\mathrm{bl} \& \mathrm{ots}=\mathrm{P} 8 \mathrm{jzy} 6 \mathrm{U} 7 \mathrm{rW} \& \mathrm{sig}=\mathrm{km} 0 \mathrm{~V} 5 \mathrm{R}$ QN105KlhMR5gfKBykjxUY\&hl=en\&ei=b dezTsM5sv-xAs2IpfsD\&sa=X\&oi=book result \& c t $=$ result \& resnum =

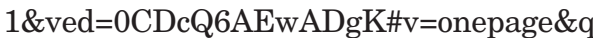
$\& \mathrm{f}=$ false, accessed November 4,2011 .

1876 Coins Under Foundation Stones-Black Money. American Journal of Numismatics and Bulletin of American Numismatic and Archaeological Societies 11(1):6-7. Google Books online. Electronic document, http://books.google.com/books?id=YHTR AAAAMAAJ\&pg $=$ PA $4 \& d q=$ numismatic + foundation+stones\&hl=en\&ei=XNuzTsy MH6TosQKyoKHtAw\&sa=X\&oi=book_re sult\&ct=result\&resnum $=3 \&$ ved $=0 \mathrm{CEs} Q$ $6 \mathrm{AEwAg} \# \mathrm{v}=$ onepage $\& \mathrm{q}=$ numismatic $\% 2$ 0 foundation\%20stones\&f=false, accessed November 4, 2011.

Arnett, Paul, William Arnett, Robert Hobbs, Theophus Smith, and Maude Southwell Wahlman

2000 Souls Grown Deep: African American Vernacular Art of the South, Volume One: The Tree Gave the Dove a Leaf, edited by Paul Arnett and William Arnett, pp. 66-105. Tinwood Books. Atlanta, Georgia. 
Barnes, Mary K.

1999 Church and Community: An Archaeological Investigation at the Levi Jordan Plantation, Brazoria County, Texas. M.A. thesis, Department of Anthropology, University of Houston.

Barrera, Rebecca A.

1999 The Jordan Plantation: Black and White Interpretation of the "Backyard": An Archeological Study of the Backyard Area of the Levi Jordan Plantation, Brazoria County, Texas. Senior honor's thesis, Department of Anthropology, University of Houston.

Bartens, Julia, Henri D. Grissino-Mayer, Susan D. Day, and P. Eric Wiseman

2012 Evaluating the Potential for Dendrochronological Analysis of Live Oak (Quercus Virginiana Mill.) from the Urban and Rural Environment-An Explorative Study. Dendrochronologia 30:15-21. Electronic document, http://web.utk.edu/ grissino/ downloads/Bartens\%20et\%20al\%202012. pdf, accessed February 28, 2013.

Brazosport Facts, The

Brown, Kenneth L.

1994 Material Culture and Community Structure: The Slave and Tenant Community at Levi Jordan's Plantation, 1848-1892. In Working Toward Freedom: Slave Society and Domestic Economy in the American South, edited by Larry E. Hudson, Jr., pp. 95-118. University of Rochester Press, Rochester, New York.

2003 Interwoven Traditions: Archaeology of the Conjurer's Cabins and the African American Cemetery at the Jordan and Frogmore Manor Plantations. In Places of Cultural Memory: African Reflections on the American Landscape, compiled by the National Park Service, pp. 99-114. Conference Proceedings, May 2001, Atlanta, Georgia. Electronic document, http://www. cr.nps.gov/crdi/conferences/conflinks.htm, accessed June 19, 2012.

2004 Ethnographic Analogy, Archaeology, and the African Diaspora: Perspectives from a Tenant Community. Historical Archaeology 38(1):79-89. 2005a The Levi Jordan Plantation Historical Archaeological Research Design. Levi Jordan Plantation State Historic Site, Technical Report Series No. 1. Texas Parks and Wildlife Department, Austin.

2005b The Archaeology of Cabin I-A1: The Levi Jordan Quarters Community's Praise House/Church. Levi Jordan Plantation State Historic Site, Technical Report Series No. 2. Texas Parks and Wildlife Department, Austin.

2005c The Archaeology of Cabin I-B-3: The Carver's Cabin in the Levi Jordan Quarters and Community. Levi Jordan Plantation State Historic Site, Technical Report Series No. 3. Texas Parks and Wildlife Department, Austin.

2010 Oral history interview with Jennifer K. McWilliams and Bryan McAuley, onsite at Levi Jordan Plantation, October 20, 2010.

2012 Untitled comprehensive draft report on the University of Houston archeological investigations at the Levi Jordan Plantation. Draft manuscript in preparation for the Historic Sites Division, Texas Historical Commission, Austin.

Brown, Kristine N., and Kenneth L. Brown

1998 Archaeology and Spirituality:The Conjurer/ Midwife and the Praise House/Church at the Levi Jordan Plantation. On the Levi Jordan Plantation website. Electronic document, http://www.webarchaeology.com/ html/krissha.htm, accessed June 19, 2012. Paper originally presented at the Annual Meeting for the Society for Historical Archaeology, Atlanta, Georgia, January 1998.

Brown, Kenneth L., and Doreen C. Cooper

1990 Structural Continuity in an AfricanAmerican Slave and Tenant Community. Historical Archaeology 24(4):7-19.

Brown, Kenneth L., and Carol McDavid

1998a Map of the Entire Site. The Levi Jordan Plantation. Electronic document, http:// webarchaeology.com/html/sitemap.htm, accessed June 8, 2009.

1998b Map of the House and Surrounding Buildings. The Levi Jordan Plantation. Electronic document, http://webarchaeology.com/html/ maphouse.htm, accessed June 8, 2009. 
Bruner, David E.

1996 Hidden Power: Burial Practices from an African-American Slave and Tenant Community. M.A. thesis, Department of Anthropology, University of Houston.

Burdick, Dayton Lewis

1901 Foundation Rites with some Kindred Ceremonies: A Contribution to the Study of Beliefs, Customs, and Legends Connected with Buildings, Locations, Landmarks, Etc, Etc. The Abbey Press, New York.

Busch, Jane

1981 An Introduction to the Tin Can. Historical Archaeology 15(1):95-104.

Campbell, Randolph B.

1989 An Empire for Slavery: The Peculiar Institution in Texas, 1821-1865. Louisiana State University Press, Baton Rouge.

Cooper, Doreen C.

1989 The Archaeology of Abandonment at the Levi Jordan Plantation. M.A. thesis, Department of Anthropology, University of Houston.

Cotton, Dorothy Davis

1998 My Family's History. The Levi Jordan Plantation. Electronic document, http:// www.webarchaeology.com/html/drthyhis. htm, accessed June 8, 2009.

Creighton, James A.

1975 A Narrative History of Brazoria County. Texian Press, Waco, Texas.

Cushwa, B.

1841 Circular Saw Mill. Patent No. 46, June 19, 1841. Google Patents Online. Electronic document, accessed September 9, 2011.

Daigle, Robert Patrick

1996 Soil as Artifact: Soil Chemistry from the Levi Jordan Plantation in Brazoria County, Texas. M.A. thesis, Department of Anthropology, University of Houston.

Davidson, James M.

2004 Rituals Captured in Context and Time: Charm Use in North Dallas Freedman's Town (1869-1907), Dallas, Texas. Historical Archaeology 38(2):22-54.
Edwards-Ingram, Ywone

2001 African American Medicine and the Social Relations of Slavery. In Race and the Archaeology of Identity, edited by Charles E. Orser, Jr., pp. 34-53. University of Utah Press, Salt Lake City.

Elkins, Nathan

2009 Online book review of Coins in Context I: New Perspectives for the Interpretation of Coin Finds edited by Hans-Markus Von Kaenel and Fluer Kemmers. Blog post on Numismatics and Archaeology: News and Discussion on Greek and Roman Art, Archaeology, and Numismatics, June 18, 2009. Electronic document, http://coinarchaeology.blogspot.com/2009/06/coinsin-context-i-new-perspectives-for.html, Accessed October 13, 2011.

Fennell, Christopher C.

2007 Crossroads and Cosmologies: Diasporas and Ethnogenesis in the New World. University Press of Florida, Gainesville.

Few, Joan

2006 Sugar, Planters, Slaves, and Convicts: The History and Archaeology of the Lake Jackson Plantation, Brazoria County, Texas. Few Publications, Gold Hill, Colorado.

Few, Joan, and Susan Dial

2002 History of the Lake Jackson Plantation. Texas Beyond History. Electronic document, http://www.texasbeyondhistory.net/ jackson/history.html, accessed June 28, 2012.

Freeman, Martha Doty

2004 An Overview of the Development of an Historic Landscape on the San Bernard River, Brazoria County, Texas, and a History of the Levi Jordan Plantation. Unpublished manuscript prepared for TBG Partners, Inc., Austin, Texas. On file at the Historic Sites Division, Texas Historical Commission, Austin.

Garcia-Herreros, Jorge

1998 A Munition Maker's Cabin: An Archeological Investigation at the Levi Jordan Plantation, Brazoria County, Texas. M.A. thesis, Department of Anthropology, University of Houston.

Gotcher, Bruce, and Denise Gotcher

2010 Oral history interviews with Jennifer K. McWilliams, onsite at the Levi Jordan Plantation, October 13 and 14, 2010. 
Grand Lodge of Maine

2012 Instructor's Manual. The Grande Lodge of Maine: Ancient Free and Accepted Masons. Electronic document, http://www.mainemason.org/resources/instructormanual/ manualfc.asp, accessed October 15, 2012.

Grand Lodge of Texas

2012 The Grand Lodge of Texas. Ancient Free and Accepted Masons. Electronic document, http://www.grandlodgeoftexas.org/ node/1238, accessed October 15, 2012.

Gross, W. Sue, Chris Knuepper, W. L. McClure, Johnney T. Pollan, Jr., and James L. Smith

1993 Archeological Excavations at the Overseer's House, The Eagle Island Plantation, Brazoria County, Texas. Bulletin of the Texas Archeological Society 61:59-138 (for 1990).

Gurcke, Karl

1987 Bricks and Brickmaking: A Handbook for Historical Archaeology. University of Idaho Press, Moscow.

Hammock, Arnie K.

2004 Subsurface Exploration and Geotechnical Evaluation, Proposed Levi Jordan Site Renovations, Brazoria, Texas. PSI File No. 303-45021. Unpublished report submitted to Texas Parks and Wildlife Department by Professional Service Industries, Inc., Austin, Texas.

Handbook of Texas Online

2012 Handbook of Texas Online, s.v. "Richardson, Stephen." Electronic document, http:// www.tshaonline.org/handbook/online/articles/fri09, accessed June 25, 2012.

Hanson, Susan Atherton

1986 Home Sweet Home: Industrialization's Impact on Rural Households, 1865-1925. Ph.D. dissertation, Department of American Studies, University of Maryland, College Park.

Harris, Robert N.

1999 Craft Specialization in a 19th Century African-American Community: The Shell Carver's Cabin on the Levi Jordan Plantation, Brazoria County, Texas. M.A. thesis, Department of Anthropology, University of Houston.
Hill, Mary Lynne Gasaway

1997 The Discipline of Social Corsets: Negotiation of the Gender Typification of the Southern Lady by Female Descendants of Levi and Sarah Stone Jordan. M.A. thesis, Department of Anthropology, University of Houston.

Hodapp, Christopher

2012 Freemasons and the U.S. Capitol Cornerstone. Freemasons for Dummies. Electronic document, http://freemasonsfordummies.blogspot.com/2011/01/freemasons-and-us-capitol-cornerstone.html, accessed October 12, 2012.

Houston Chronicle, The

Howard, Margaret

2002 Daily journal entries for July 24, 2002. Archeological Investigations at Levi Jordan Plantation for Texas Parks and Wildlife Department. Unpublished manuscripts on file at the Historic Sites Division, Texas Historical Commission, Austin.

2003a Daily Journal for April 7-9, 2003. Archeological Investigations at Levi Jordan Plantation for Texas Parks and Wildlife Department. Unpublished manuscript on file at the Historic Sites Division, Texas Historical Commission, Austin.

2003b Levi Jordan State Historic Site, Brazoria County. Unpublished report by Texas Parks and Wildlife Department, Cultural Resources Program, Archeological Survey Team. On file at the Historic Sites Division, Texas Historical Commission, Austin.

Humphries, Flora

1937 “Jordan Plantation Mirror on Texas' Past." The Houston Chronicle, April 4, 1937.

1986 "Jordan Plantation Mirror on Texas' Past." Reprinted and edited versions of the article that appeared in The Houston Chronicle April 4, 1937. Brazoria Banner, Sesquicentennial Edition, April 9, 1986. On file at the Brazoria County Historical Museum, Angleton, Texas.

Hyatt, Harry Middleton 1900-1978 Hoodoo-Conjuration-Witchcraft-Rootwork: Beliefs Accepted by Many Negroes and White Persons These Being Orally Recorded Among Blacks and Whites. 5 vols. Western Publishing Co., Cambridge, Maryland. 
Jarvis, William E.

2003 Time Capsules: A Cultural History. McFarland and Company, Jefferson, North Carolina.

Joseph, J. W.

2011 “...All of Cross"-African Potters, Marks, and Meanings in the Folk Pottery of the Edgefield District, South Carolina. Historical Archaeology 45(2):134-155.

Joyner, Brian D.

2003 African Reflections on the American Landscape: Identifying and Interpreting Africanisms. Office of Diversity and Special Projects, National Center for Cultural Resources, National Park Service, U.S. Department of the Interior, Washington, D.C.

Kelley, Sean M.

2010 Los Brazos de Dios:A Plantation Society in the Texas Borderlands, 1821-1865. Louisiana State University Press, Baton Rouge.

Kelly, Richard G., and Nancy Y. Oliver

20041870 San Francisco Mint Cornerstone Coins. The E-Sylum 7(16):Article 14. Electronic document, http://www.coinbooks. org/esylum_v07n16a14.html, accessed September 13, 2012.

Kemmers, Fluer, and Nanouschka Myrberg

2011 Rethinking Numismatics: The Archeology of Coins. Archaeological Dialogues 18(1):87-108. Electronic document, http://uni-frankfurt.academia. edu/FleurKemmers/Papers/567753/ Rethinking_numismatics_the_archaeology_of_coins, accessed October 13, 2011.

Kleiner, Diana J.

2011a Handbook of Texas Online, s.v. "Brazoria County." Electronic document, http://www. tshaonline.org/handbook/online/articles/ hcb12, accessed October 7, 2011.

2011b Handbook of Texas Online, s.v. "China Grove (Brazoria County).” Electronic document, http://www.tshaonline.org/ handbook/online/articles/hvc49, accessed October 7, 2011.

Leezer, Carole

2006 Archaeological Investigations at the Levi Jordan Plantation State Historic Site, Brazoria County, Texas. Archaeological Studies Report No. 7. Center for Archaeological Studies, Texas State University, San Marcos.
Leone, Mark P., and Gladys-Marie Fry

1999 Conjuring in the Big House Kitchen: An Interpretation of African American Belief Systems Based on the Uses of Archaeology and Folklore Sources. Journal of American Folklore 112(445):372-403.

2001 Spirit Management Among Americans of African Descent. In Race and the Archaeology of Identity, edited by Charles E. Orser, Jr., pp. 143-157. University of Utah Press, Salt Lake City.

Library of Congress

2001 Born in Slavery: Slave Narratives from the Federal Writer's Project, 1936-1938. Electronic document, http://lcweb2.loc. gov/ammem/snhtml, accessed December 9 , 2010.

Lindsey, Jack

2000 Tradition and Continuum in African American Folk Art. In Souls Grown Deep: African American Vernacular Art of the South. Volume One-The Tree Gave the Dove a Leaf, edited by Paul Arnett and William Arnett, pp. 52-65. Tinwood Books, Atlanta, Georgia.

Lyons, Jane

2001 Rules and Pisheogs. Electronic document, http://www.from-ireland.net/custom. php?id=19, accessed November 3, 2011.

Maas, Lauren F.

2010 A Comparative Analysis of Decorative Ceramics and Choice at the Gregory Lincoln/HSPVA Site and the Levi Jordan Plantation Site. M.A. thesis, Department of Anthropology, University of Houston.

Martin, Ewing

1998 Ewing Martin Remembers: The Levi Jordan Plantation. Oral history interview with Sarah Martin and Carol McDavid. Electronic document, http://www.webarchaeology.com/html/ ewing.htm\#on\%20the\%20archaeology, accessed June 8, 2009.

Martin, Mike

2010 Oral history interview with Jennifer K. McWilliams, by phone on October 3, 2010

2011 Oral history interview with Jennifer K. McWilliams, during site visit on August 24, 2011. 
Archeological Investigations for the Levi Jordan Plantation House Stabilization

2012 Oral history interview with Jennifer K. McWilliams, by phone on November 1, 2012.

Mauldin, Raymond P.

2003 Exploring Drought in the San Antonio Area Between 1700 and 1979. Special Report No. 29. Center for Archaeological Research, University of Texas at San Antonio.

Maxwell, Robert S., and Robert D. Baker

1983 Sawdust Empire: The Texas Lumber Industry, 1830-1940. Texas A\&M University Press, College Station.

McAlester, Virginia, and Lee McAlester

1984 A Field Guide to American Houses. Alfred A. Knopf, New York.

McAuley, Brian

2012 "Levi Jordan Plantation Celebration Unveils Notable Improvements, March 3, 2012." Texas Historical Commission, Austin, Texas. Electronic document, http://www.visitlevijordanplantation. com/Modules/Show Document. aspx?documentid=613, accessed June 22, 2012.

McDavid, Carol

1995a Many Pasts and Many Presents: Collaboration in Planning the Public Interpretation of the Archaeology of the Levi Jordan Plantation. Paper presented at the Southeast Preservation Conference, Birmingham, Alabama.

1995b The Importance of Archaeology in the Preservation of African American Heritage: The Levi Jordan Plantation Project. Paper presented at African Americans \& Heritage Preservation: Practical Strategies for Livable Communities. Conference in Houston, Texas, sponsored by the Texas Historical Commission.

1996 The Levi Jordan Plantation: From Archaeological Interpretation to Public Interpretation. M.A. thesis, Department of Anthropology, University of Houston.

1997 Descendants, Decisions, and Power: The Public Interpretation of the Archaeology of the Levi Jordan Plantation. Historical Archaeology 31(3):114-131.
1998 The Levi Jordan Plantation. Electronic document, http://www.webarchaeology.com/ html/Default.htm, accessed June 8, 2009.

2003 Context, Collaboration, and Power: The Public Archaeology of the Levi Jordan Plantation. In SAA Community Partnership Handbook, edited by L. Derry and M. Malloy, pp. 45-66. Society for American Archaeology, Washington, D.C.

2004 From "Traditional" Archaeology to Public Archaeology to Community Action: The Levi Jordan Plantation Project. In Places in Mind: Archaeology as Applied Anthropology, edited by Paul A. Shackel and Erve J. Chambers, pp. 35-56. Routledge Press, New York.

McVay, Amanda

2012 Levi Jordan Plantation Preservation Celebration. See the Sites: Telling the Stories at the Historical Commission's Real Places. Electronic Document, http://seethesites.blogspot.com/ 2012_04_01_archive.html, accessed June 22, 2012.

Mercado-Allinger, Pat, and Jim Bruseth

2010 Collaboration for Discovery: Bernardo and Pleasant Hill Plantations, Waller County. Current Archeology in Texas 12(1):1-3.

Morris, S. Brent

2010 The Evolution of the Cornerstone Ceremony. Electronic document, http://www.masonicworld.com/ education/files/jun03/evolution of the cornerstone cer.htm, accessed October 15, 2012.

National Oceanic and Atmospheric Administration 2012 Historical Hurricane Tracks. Electronic document, csc.noaa.gov/hurricanes/\#, accessed December 29, 2011.

Page, George

1841 Portable Circular Saw Mill. Patent No. 2174, July 16, 1841. Google Patents Online. Electronic document, http:// www.google.com/patents?id=8qBAAA AAEBAJ\&pg=PA2\&dq=george + page + portable +sawmill\&hl=en $\& \mathrm{sa}=$ $\mathrm{X} \& \mathrm{e} \mathrm{i}=\mathrm{p}-\mathrm{zoT} 5 \mathrm{a} \mathrm{n} \mathrm{C}-\mathrm{be} 2 \mathrm{AW}$ g 9 I W 1 D Q \& v ed $=0$ C D M Q 6 A E w A A \# v = onepage\&q\&f=false, accessed September $9,2011$. 
Phaup, Nancy Ann

2001 Cultural Modification of Buttons at the Levi Jordan Plantation, Brazoria County, Texas. M.A. thesis, Department of Anthropology, University of Houston.

Phillips, D.

1849 Circular Saw Mill. Patent No. 6580, July 3, 1849. Google Patents Online. Electronic document, http://www.google.com/patents $? \mathrm{id}=\mathrm{nVdFAAAAEBAJ} \& \mathrm{pg}=\mathrm{PP} 1 \& \mathrm{dq}=6580$ $\&$ source $=$ gbs_selected_pages $\&$ cad $=2 \# \mathrm{v}=0$ nepage\&q\&f=false, accessed September 9 , 2011.

Platter, Allen Andrew

1961 Educational, Social, and Economic Characteristics of the Plantation Culture of Brazoria County, Texas. Ed.D. dissertation, College of Education, University of Houston.

Powell, George T., and Frederick Baumann

1879 Foundations and Foundation Walls, for all Classes of Buildings, Pile Driving, Building Stones \& Bricks. Bicknell and Comstock, Publishers, New York.

Powers, Betsy J.

1994 From Cotton Fields to Oil Fields: Economic Development in a New South Community. Ph.D. dissertation, Department of History, University of Houston.

Puckett, Newbell Niles

1926 Folk Beliefs of the Southern Negro. The University of North Carolina Press, Chapel Hill.

Raska, Ginny

2012 Speech by Levi Jordan Descendant Ginny Raska. Levi Jordan Plantation State Historic Site Preservation Celebration, March 3, 2012. Electronic document, http://www.visitactontx.com/Modules/ ShowDocument.aspx?documentid $=657$, accessed June 22, 2012.

Raska, Ginny McNeill, and Mary Lynne Gasaway Hill

2009 The Uncompromising Diary of Sallie McNeill, 1858-1867. Texas A\&M University Press, College Station.

Ray, Crystal

2008 The Best Places to Find Old Money and Jewelry with a Metal Detector: Search Old Homesteads. Yahoo! Voices. Electronic document, http://voices.yahoo.com/the- best-places-find-old-money-jewelry-with1712141.html, accessed October 5, 2012.

Robinson, Williard B.

2011 Symbols of Strength: Cornerstones of Texas Buildings. Heritage: A Publication of the Texas Historical Foundation 2:30-31.

Roth, David

2010 Texas Hurricane History. National Weather Service, Camp Springs, Maryland. Electronic document, http://www.hpc.ncep. noaa.gov/research/txhur.pdf, accessed June 21, 2012.

Russell, Aaron E.

1997 Material Culture and African American Spirituality at the Hermitage. Historical Archaeology 31(2):63-80.

Shafer, Harry, J.

2007 Archaeological Monitoring and Minor Testing at the Site of Marti's, 310 West Commerce Street, San Antonio, Texas. Report No. 74. Abasolo Archaeological Consultants, San Antonio, Texas.

Singleton, Theresa A.

1995 The Archaeology of Slavery in North America. Annual Review of Anthropology 24:119-140.

Singleton, Theresa A. (editor)

1999 "I, Too, Am America”: Archaeological Studies of African-American Life. University Press of Virginia, Charlottesville.

Speth, G. W.

2010 Builders' Rites and Ceremonies: The Folk Lore of Masonry. Originally published 1893. Kessinger Publishing, Whitefish, Montana.

Sprague, J. R.

1920 "The World's Largest Film Developing Business" in Business Digest and Investment Weekly. Electric document, http:// books.google.com/books?id=CW3nAAAA MAAJ\&pg=PA155\&lpg=PA155\&dq=the + Fox+company+san+antonio+business \& source $=$ bl\&ots $=-y$ NwmUv4WC\&sig $=X Y Z$ MHfvh3hnkPld13dE-fZjzSMQ\&hl=en\&e$\mathrm{i}=13 \mathrm{sETJPAFqDYMOPIiDw \& sa}=\mathrm{X} \& \mathrm{oi}=$ book_result\&ct $=$ result\&resnum $=1 \&$ ved $=0$ CBIQ6AEwAA\#v=onepage\& $\mathrm{q}=$ border $\& \mathrm{f}=$ false, accessed December 30, 2011. 
Stahle, David W., and Malcolm K. Cleaveland 1988 Texas Drought History Reconstructed and Analyzed from 1698 to 1980. Journal of Climate 1:59-74.

1995 Texas Paleoclimatic Data from Daily to Millennial Timescales. In The Changing Climate of Texas: Predictability and Implications for the Future, edited by J. R. Norwine, G. R. North, J. B. Valez, and J. R. Giardino, pp. 49-69. Geobooks, Texas A\&M University, College Station.

Stine, Linda France, Melanie A. Cabak, and Mark D. Groover

1996 Blue Beads as African American Cultural Symbols. Historical Archaeology 30(3):4975 .

Stroebel, Abner J.

2006 The Old Plantations and Their Owners of Brazoria County, Texas. Originally published 1930. Lake Jackson Historical Society, Lake Jackson, Texas.

TBG Partners

2003 Levi Jordan Plantation State Historic Site, Brazoria, Texas: Discovery Phase. Manuscript prepared for the Texas Parks and Wildlife Department by TBG Partners, Austin, Texas.

Texas Parks and Wildlife Department

2004 Levi Jordan Plantation State Historic Site Master Plan: Facility Plan and Program. Texas Parks and Wildlife Department, Austin.

Therrell, Matthew D.

2000 The Historic and Paleoclimatic Significance of Log Buildings in Southcentral Texas. Historical Archaeology 34(2)25-37.

Thompson, Robert Farris

1993 Face of the Gods: Art and Alters of Africa and the African Americas. Museum for African Art, New York.

Thurston, Herbert

1913 Corner Stone. Catholic Encyclopedia. Electronic document, http://en.wikisource. org/wiki/Catholic_Encyclopedia_(1913)/ Corner_St, accessed April 28, 2012.

Toulouse, Julian

1971 Bottle Makers and Their Mark. Thomas Nelson, Inc., New York.
Vallely, N. M.

1962 The Foundation Stone. Kamloop Freemasons. Reprint of article published in Selected Papers Vol. 3, United Masters Lodge, No. 167. Auckland, New Zealand. Electronic document, http://www. kamloopsfreemasons.com/wp-content/ uploads/Foundation-Stone.pdf, accessed October 15, 2012.

Vaughn, William Preston

2012 Handbook of Texas Online, s.v. "Freemasonry." Electronic document, http://www.tshaonline.org/ handbook/online/articles/vnf01, accessed October 19, 2012.

Vincent, Charles

1976 Laying the Cornerstone at Southern University. Louisiana History: The Journal of the Louisiana Historical Association 17(3):335-342.

Vlach, John Michael

1993 Back of the Big House: The Architecture of Plantation Slavery. University of North Carolina Press, Chapel Hill.

Volz and Associates, Inc.

2011 Levi Jordan Plantation. Volz and Associates, Inc. Electronic document, http:// www.volzassociates.com/VolzAssociates_/ Levi_Jordan_Plantation.html, accessed December 20, 2011.

2012 Levi Jordan Plantation, Volz and Associates, Inc. Electronic document, http:// www.volzassociates.com/VolzAssociates_/ Levi_Jordan_Plantation.html, accessed June 19, 2012.

Von Kaenel, Hans-Markus, and Fluer Kemmers (editors)

2009 Coins in Context I: New Perspectives for the Interpretation of Coin Finds. Studien zu Fundmünzen der Antike 23 (Mainz: von Zabern). Electronic document, http://coinarchaeology.blogspot.com/ 2009/06/coins-in-context-i-new-perspectives-for.html, Accessed October 13, 2011.

Wheeler, Kathleen

2000a View from the Outhouse: What Can We Learn from the Excavation of Privies. Historical Archaeology 34(1):1-2. 
2000b Theoretical and Methodological Considerations for Excavating Privies. Historical Archaeology 34(1):3-19.

Wilkie, Laurie A.

1997 Secret and Sacred: Contextualizing the Artifacts of African American Magic and Religion. Historical Archaeology 31(4):81106.

Woodrick, James V.

2011 Bernardo: Crossroads, Social Center and Agricultural Showcase of Early Texas. Published by the author.

Wright, Cheryl L.

1994 I Heard It Through the Grapevine: Oral Tradition in a Rural African American Community in Brazoria, Texas. M.A. thesis, Department of Anthropology, University of Houston.

1998 “Oral History Information: Birth, Death, and Everything in Between." Excerpt from "I Heard It Through the Grapevine: Oral Tradition in a Rural African American Community in Brazoria, Texas,” by Cheryl Wright, 1994. Electronic document, http://www.webarchaeology.com/ html/cheroral.htm, accessed July 7, 2011.

Yakubik, Jill-Karen, and Rosalinda Mendez

1995 Beyond the Great House: Archaeology at Ashland-Belle Helene Plantation (16AN26) Ascencion Parish, Louisiana. Discovering Louisiana Archaeology, One. Division of Archaeology, Louisiana Department of Culture, Recreation, and Tourism, Baton Rouge.

Yeoman, R. S.

1961 1962, A Guide Book of United States Coins. Whitman Publishing Company, Racine, Wisconsin. 



\section{APPENDIX A: Proton Magnetometer and Ground-Penetrating Radar Surveys}

Jennifer K. McWilliams and

Douglas K. Boyd 

Texas Historical Commission (THC) personnel Tiffany Osburn and Bill Pierson conducted remote sensing surveys at the Levi Jordan Plantation on August 10, 2010. The ground-penetrating radar (GPR) and proton magnetometer surveys were conducted before Prewitt and Associates, Inc. (PAI) archeologists began their Phase I fieldwork. Figure A.1 shows the locations of the GPR and magnetometer survey grids. The surveys were conducted within a 54x37-m area around the Levi Jordan house. The grid numbering reflects the grid blocks used during the surveys (four blocks for the GPR and three blocks for the magnetometer). Once the surveys were completed, the surveyors stitched the grid block data together and provided PAI with final GPR and magnetometer maps annotated with anomaly interpretations.

\section{GPR AND MAGNETOMETER SURVEY RESULTS}

It was assumed that the magnetometer survey would mainly detect metal artifacts and that its utility would be limited to finding many types of buried features. In contrast, the GPR survey was specifically aimed at finding the buried cistern in the backyard. Both surveys detected many anomalies (Figure A.2), and the GPR survey was successful in finding the buried cistern and the many other subsurface features that were later investigated by PAI archeologists. Figure A.3 shows the GPR survey data depicted in five horizontal slices, with each representing a subsurface slice about $10 \mathrm{~cm}$ deeper than the previous slice. Figure A.4 is a closeup view of GPR Slices 2 and 3. Figure A.5 is a closeup view of GPR Slices 4 and 5.

\section{Identifiable Anomalies}

There is a high degree of correlation between the GPR anomalies and the archeological features that were encountered. Many of the GPR anomalies depicted in Figures A.4 and A.5 were confirmed through subsequent archeological investigations. The buried cistern (Cistern 1) is clearly shown in Slices 2 through 5 . This area was characterized by a very slight depression in the ground surface, and archeological excavations and probing confirmed the precise location of the cistern. The excavations also revealed the presence of a paved brick patio around part of the cistern and other disturbances. This helps explain some of the confusing anomalies in Slices 2 and 3 between the buried cistern and the house.

A linear anomaly in Slice 2 running south from the front porch steps is obviously a walkway. Subsequent excavations uncovered a concrete walkway that had been poured over an older brick-paved walkway. PAI personnel confirmed the extent of the front walkway, which reaches $50 \mathrm{ft}$ beyond the front of the house, or ca. $41 \mathrm{ft}$ beyond the front steps.

To the east of the east wing, another anomaly appears in Slices 2 to 5 , and it is labeled as a possible structural feature (see Slice 2). Leezer (2006) had also investigated this area and encountered dense brick rubble, interpreting it as debris from the east wing chimney. PAI conducted additional investigations in this area while exposing the base of piers along the east wall of the east wing. This work also exposed dense brick rubble. Thus it appears that this GPR anomaly represents chimney fall that may have collapsed in the 1900 hurricane, which reportedly destroyed the earlier kitchen. A brick fireplace foundation found beneath the current east wing is probably where the chimney stood (Howard 2003a, 2003b).

The magnetometer survey appears to have identified some of the same anomalies as the GPR survey (see Figure A.2). But the magnetometer data are not as refined, and many of the anomalies may be caused by large metal objects rather than buried features.

\section{Modern Grate}

One anomaly detected by the GPR and magnetometer surveys was found at the southeast corner of the house, just east of the east end of the front porch. It is labeled in Figure A4 (Slice 3 ) as one of the possible "structural features." This location was just east of a PAI test unit, and a quick expansion of the unit revealed a large metal grate just inches below the ground surface. The area was exposed, and the metal grate was found laying flat. It was determined that this metal grate probably served as a shoe scraper to clean the mud off one's work boots and shoes before stepping onto the porch. The east end of the front porch is a logical location for such an implement. The metal grate is probably associated with some of the later occupations and is probably a late-twentieth-century feature. 
Archeological Investigations for the Levi Jordan Plantation House Stabilization

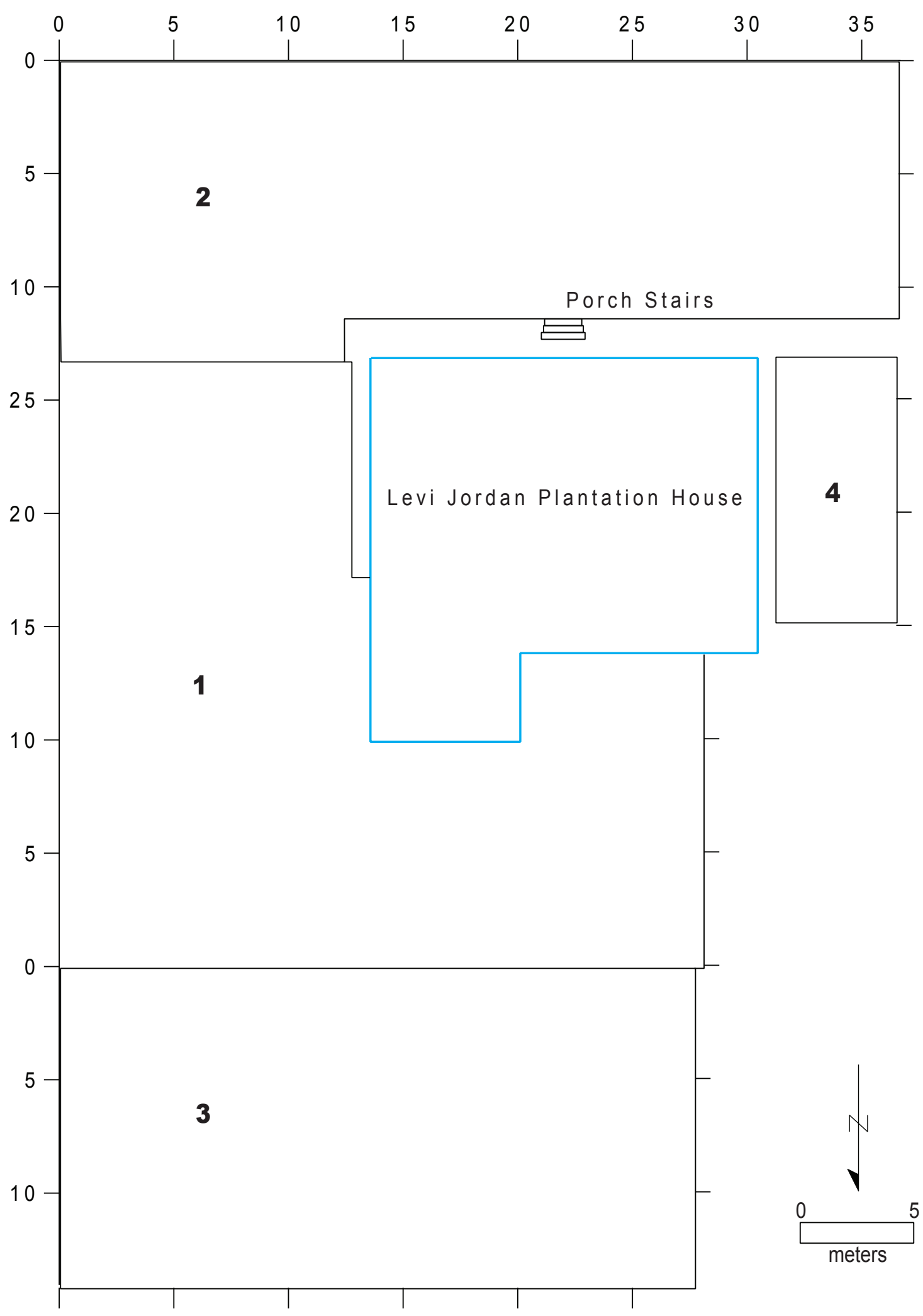

Figure A.1. Map of remote sensing survey grids around the Levi Jordan house. The GPR and magnetometer grids were the same except that the GPR survey includes one small (ca. 12x5 m) additional area on the east side of the house. 


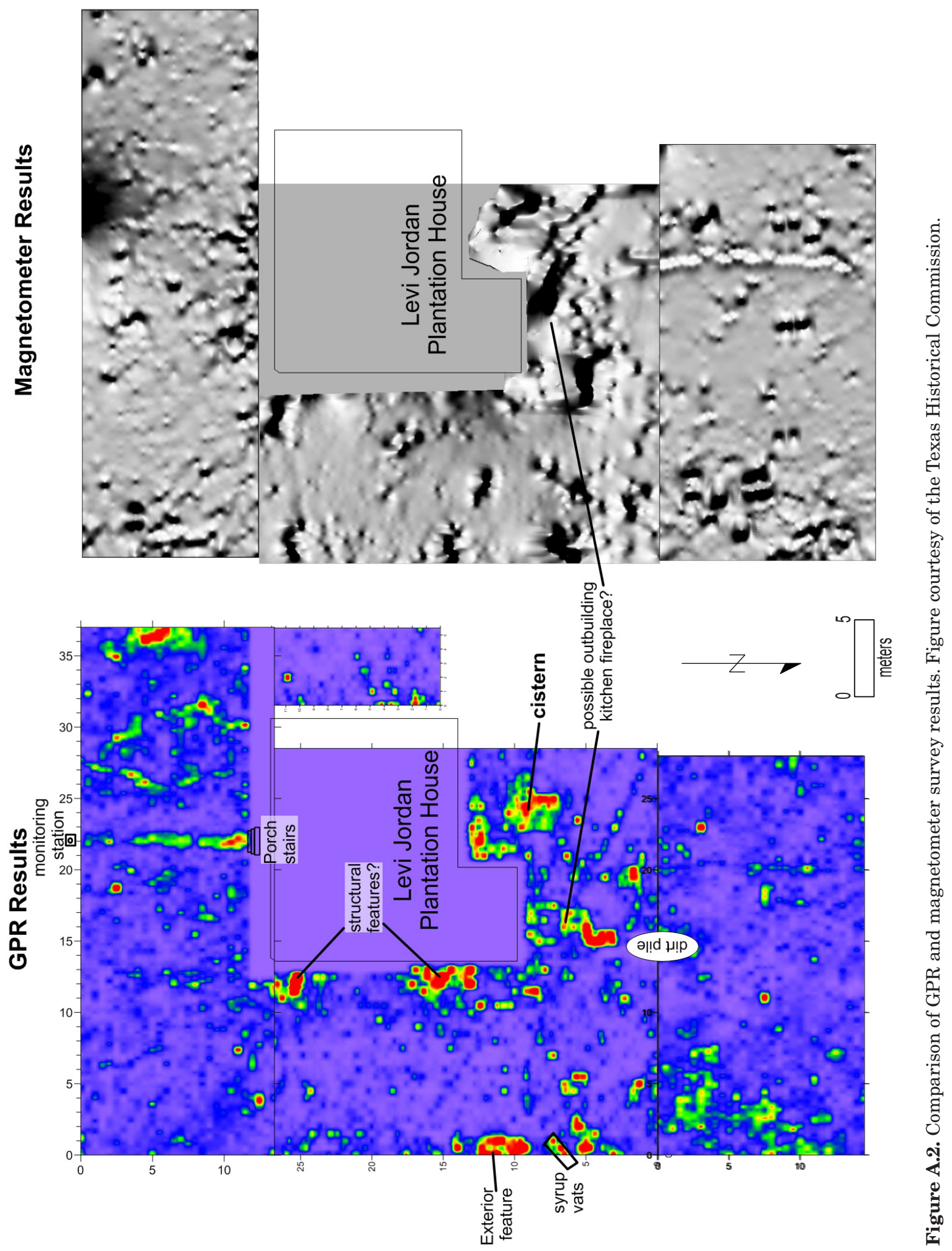




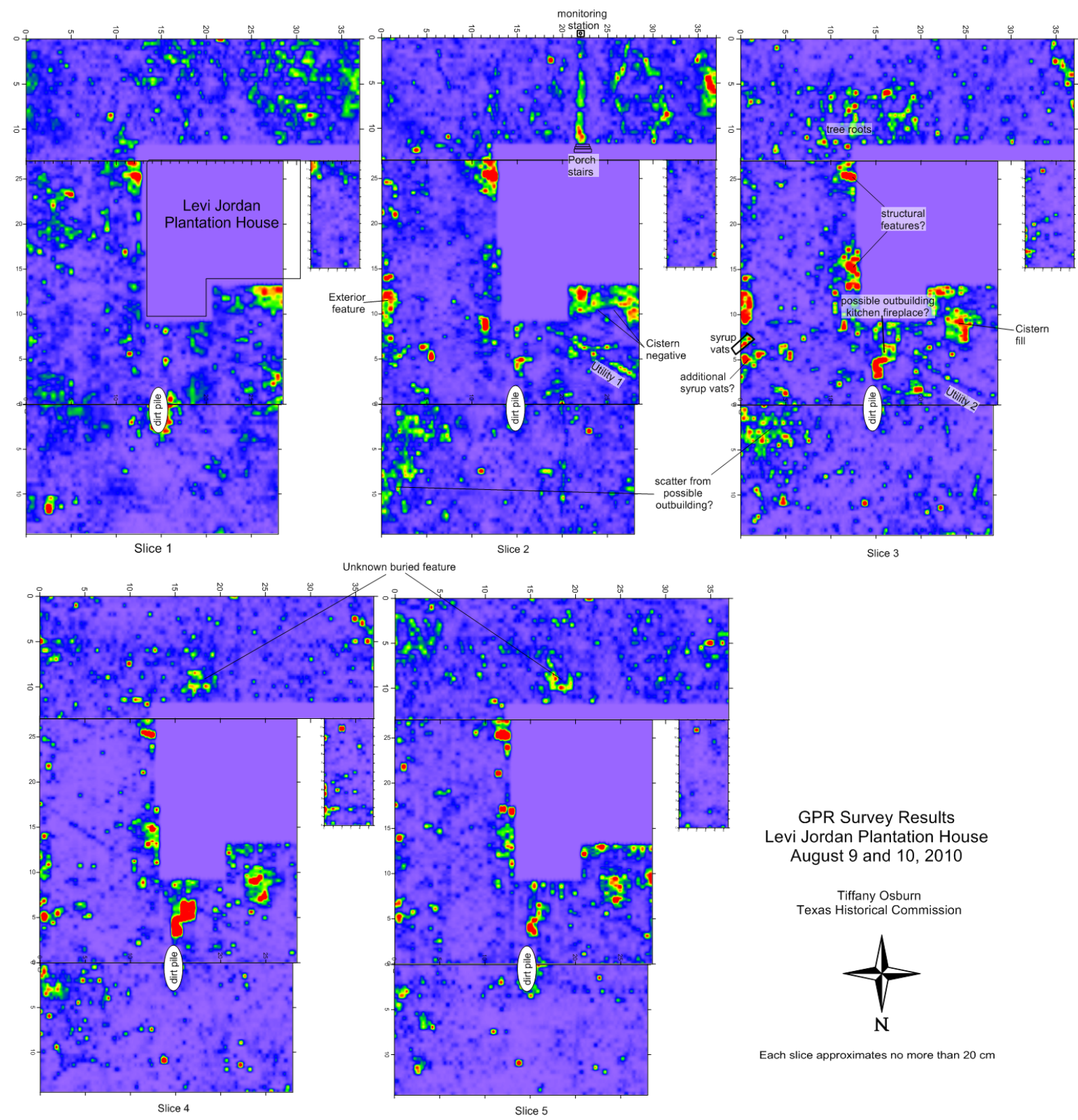

Figure A.3. Comparative view of GPR data depicting five horizontal slices (each representing approximately $10 \mathrm{~cm}$ of additional depth). Minimal anomaly interpretations have been added. Figure courtesy of the Texas Historical Commission. 


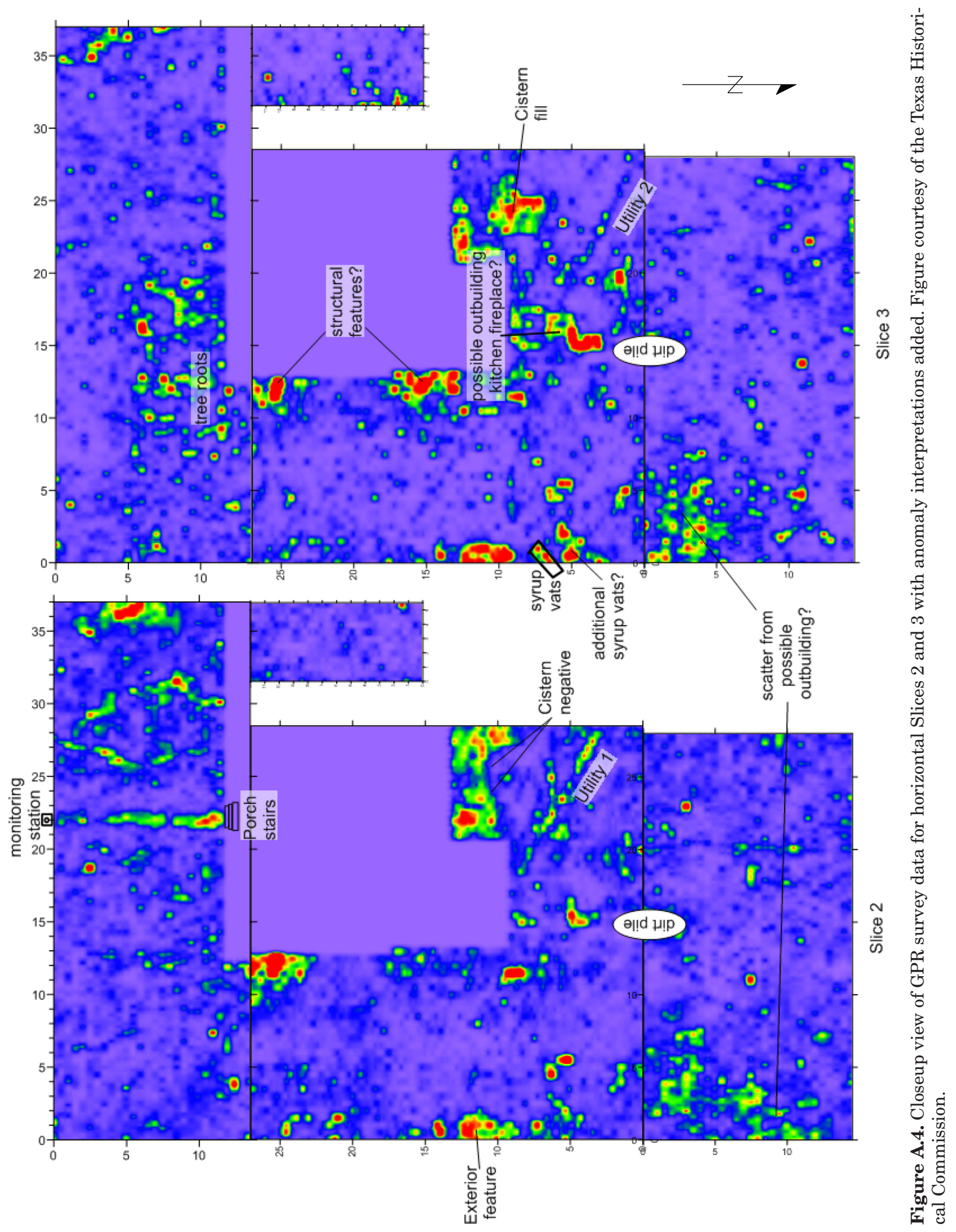


Archeological Investigations for the Levi Jordan Plantation House Stabilization

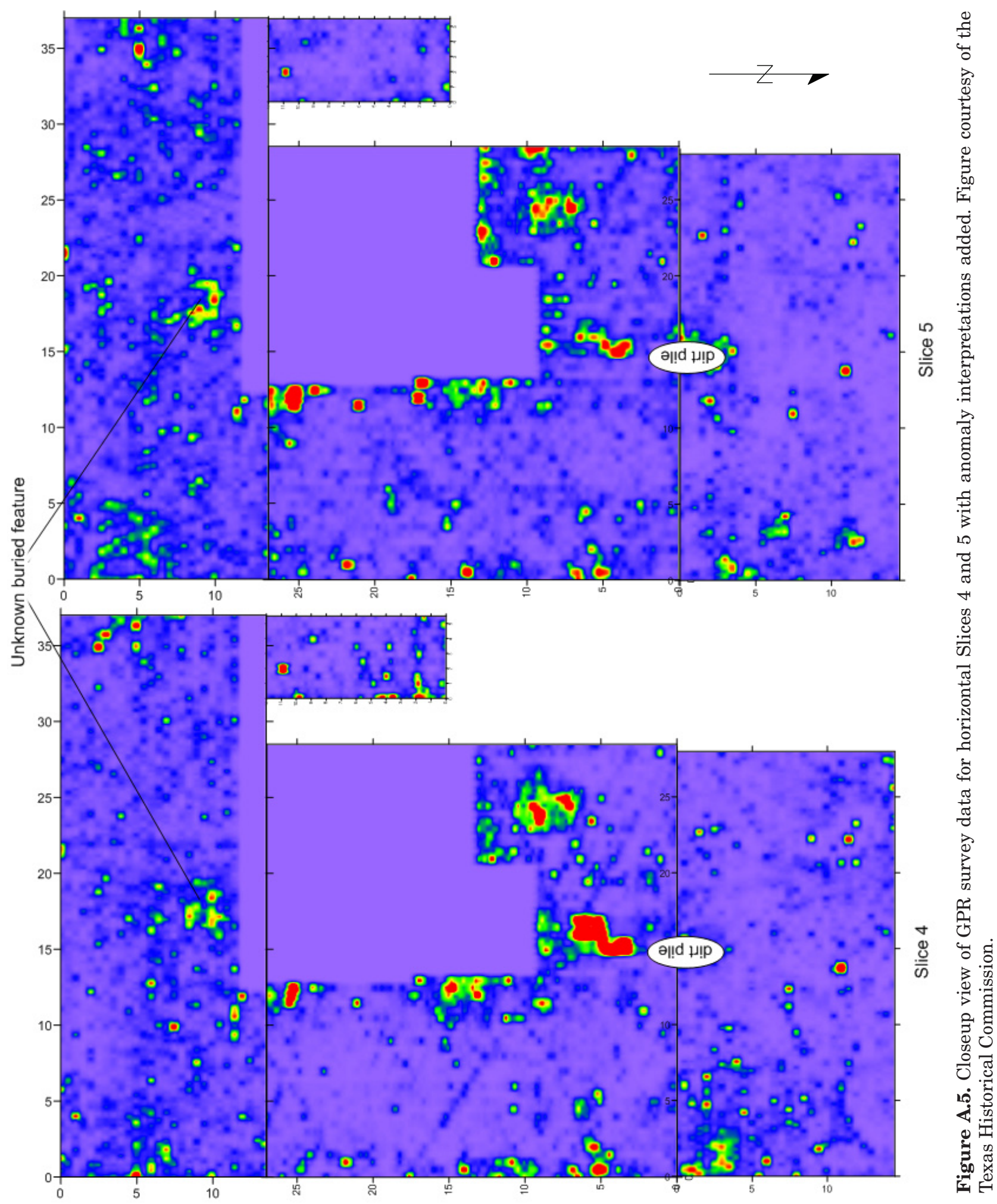


The GPR anomaly is interesting from a methodological standpoint. Although it was found laying flat in the upper 6 to 12 inches, the mesh configuration apparently caused the GPR signal to bounce off, making it appear deeper than it actually was.

\section{Unidentified GPR Anomalies}

Several anomalies remain uninvestigated and unidentified. A large anomaly appears in the front (north) of the house, just east of the front steps. It sits between the front steps and a large walnut tree that has a corresponding "tree root" anomaly. As seen in photographs dating back to the 1930s, this walnut tree was a sizeable tree then. The tree would have provided shade for this area, and this may have some bearing on what this anomaly represents. The unknown anomaly does not appear in the upper two slices (1 and 2), but it appears in Slice 3 as an L- or partial hexagon shape, and become squarish in shape in Slices 4 and 5. This feature was not investigated during PAI's work, but is thought to possibly be a landscape or water feature in the yard, perhaps something like a water fountain. It is possible that this anomaly represents a relatively modern feature, perhaps even something associated with children playing in the yard (noting that many recent toys were left by the young boys of a renter who occupied the house from the 1970 s to the $1980 \mathrm{~s}$ ).

Other unidentified anomalies include an unknown "exterior feature" about $13 \mathrm{~m}$ east of the northeast corner of the house. This area was not investigated.

\section{REFERENCES CITED}

Howard, Margaret

2003a Daily Journal for April 7 to 9, 2003. Unpublished manuscript on file at the Historic Sites Division, Texas Historical Commission, Austin, Texas.

2003b Levi Jordan State Historic Site, Brazoria County. Unpublished report by Texas Parks and Wildlife Department, Cultural Resources Program, Archeological Survey Team. On file at the Historic Sites Division, Texas Historical Commission, Austin, Texas.

Leezer, Carole

2006 Archaeological Investigations at the Levi Jordan Plantation State Historic Site, Brazoria County, Texas. Archaeological Studies Report No. 7. Center for Archaeological Studies, Texas State University, San Marcos. 

APPENDIX B: Wood Identification of Structural Piers

Leslie L. Bush, Ph.D., R.P.A.

Macrobotanical Analysis 

Eleven wood samples from piers at the Levi Jordan Plantation were submitted by Prewitt and Associates, Inc., for botanical identification. All of the samples were taken by Jennifer McWilliams during PAI's Phase II investigations in September 2011, and the identifications were completed in November 2011. All of the samples are from wooden piers associated with the original antebellum plantation house.

\section{LABORATORY METHODS}

Clean transverse sections of wood were prepared by creating a fresh surface with a razor blade or by snapping off a section of wood. Transverse sections were examined under a stereoscopic microscope at 7-45x magnification. In cases in which the wood was sufficiently decayed to impact the transverse section, identification was confirmed by examination of tangential sec- tions. Wood samples were identified to the lowest possible taxonomic level by comparing them to materials in the Macrobotanical Analysis comparative collection and through the use of standard reference works (e.g., Core et al. 1979; Hoadley 1990; Panshin and de Zeeuw 1980). Plant nomenclature follows that of the PLANTS Database (USDA, NRCS 2011). After identification, wood samples were weighed on an Ohaus Scout II 200x0.01 g electronic balance.

\section{RESULTS}

Identifications are presented in Table B.1. All wood samples were identified as oak of the live oak group. Wood was assigned to the species Quercus virginiana based on the infrequent presence of tyloses (an adaptation to xeric environments common in Plateau live oak, Quercus fusiformis) and the geographic location of the site.

Table B.1. Levi Jordan Phase II excavations wood samples from piers

\begin{tabular}{|c|c|c|c|c|c|c|c|}
\hline Lot No. & $\begin{array}{c}\text { Pier } \\
\text { Designation }\end{array}$ & Pier Type & Location Description & $\begin{array}{c}\text { Sample } \\
\text { Type }\end{array}$ & $\begin{array}{c}\text { Identified } \\
\text { Taxa }\end{array}$ & $\begin{array}{c}\text { Common } \\
\text { Name }\end{array}$ & $\begin{array}{l}\text { Weight } \\
\text { (g) }\end{array}$ \\
\hline $2011-120$ & Pier 2 & Log, perimeter & $\begin{array}{l}\text { Under southeast corner } \\
\text { of house }\end{array}$ & Wood & $\begin{array}{l}\text { Quercus } \\
\text { virginiana }\end{array}$ & live oak & 268.15 \\
\hline $2011-121$ & Pier C1 & Log, perimeter & Under north wall beam & Wood & $\begin{array}{l}\text { Quercus } \\
\text { virginiana }\end{array}$ & live oak & 34.02 \\
\hline $2011-122$ & Pier D11 & $\begin{array}{l}\text { Square cut, } \\
\text { interior }\end{array}$ & $\begin{array}{l}\text { Underneath house } \\
\text { below center of Beam D } \\
\text { (center of East Room) }\end{array}$ & Wood & $\begin{array}{l}\text { Quercus } \\
\text { virginiana }\end{array}$ & live oak & 49.13 \\
\hline $2011-123$ & Pier H1 & Log, perimeter & Under north wall beam & Wood & \begin{tabular}{|l} 
Quercus \\
virginiana
\end{tabular} & live oak & 159.65 \\
\hline $2011-124$ & Pier J11 & $\begin{array}{l}\text { Square cut, } \\
\text { interior }\end{array}$ & $\begin{array}{l}\text { Underneath house } \\
\text { below center of Beam J }\end{array}$ & Wood & $\begin{array}{l}\text { Quercus } \\
\text { virginiana }\end{array}$ & live oak & 392.9 \\
\hline $2011-125$ & Pier M1 & Log, perimeter & Under north wall beam & Wood & \begin{tabular}{|l|} 
Quercus \\
virginiana
\end{tabular} & live oak & 152.43 \\
\hline $2011-126$ & Pier N1 & $\begin{array}{l}\text { Square cut, } \\
\text { perimeter }\end{array}$ & Under north wall beam & Wood & $\begin{array}{l}\text { Quercus } \\
\text { virginiana }\end{array}$ & live oak & 132.59 \\
\hline 2011-127 & Pier P1* & Log, perimeter & Under north wall beam & Wood & $\begin{array}{l}\text { Quercus } \\
\text { virginiana }\end{array}$ & live oak & 142.75 \\
\hline $2011-128$ & Pier S1* & Log, perimeter & Under north wall beam & Wood & $\begin{array}{l}\text { Quercus } \\
\text { virginiana }\end{array}$ & live oak & 58.18 \\
\hline 2011-129 & Pier V1 & Log, perimeter & Under north wall beam & Wood & $\begin{array}{l}\text { Quercus } \\
\text { virginiana }\end{array}$ & live oak & 65.37 \\
\hline $2011-130$ & Pier V11* & $\begin{array}{l}\text { Square cut, } \\
\text { interior }\end{array}$ & $\begin{array}{l}\text { Underneath house } \\
\text { below center of Beam V } \\
\text { (center of West Room) }\end{array}$ & Wood & $\begin{array}{l}\text { Quercus } \\
\text { virginiana }\end{array}$ & live oak & 17.56 \\
\hline
\end{tabular}

* A section of this pier post was cut, sanded, and shipped to the University of Arkansas Tree Ring

Laboratory for possible dendrochronological analysis in the future. 


\section{REFERENCES CITED}

Core, H. A., W. A. Cote and A. C. Day

1979 Wood Structure and Identification. 2nd ed. Syracuse University Press, Syracuse, New York.

Hoadley, R. Bruce

1990 Identifying Wood: Accurate Results with Simple Tools. The Taunton Press, Newtown, Connecticut.
Panshin, A. J. and Carol de Zeeuw

1980 Textbook of Wood Technology: Structure, Identification, Properties, and Uses of the Commercial Woods of the United States and Canada. 4th ed. McGraw-Hill Book Company, New York.

USDA, NRCS (United States Department of Agriculture, Natural Resources Conservation Service)

2011 The PLANTS Database. National Plant Data Center, Baton Rouge, Louisiana. Electronic document, http://plants.usda. gov, accessed November 9, 2011. 
APPENDIX C: Preliminary Inventory of Cultural Materials Recovered 

This appendix presents provenience data and identifications of the material culture (artifacts and samples) recovered during Prewitt and Associates' 2010 and 2011 archeological investigations at the Levi Jordan plantation house.

Table C.1 summarizes the recovered cultural materials, consisting of 6,651 individual artifacts and $68 \mathrm{~kg}$ of bulk materials (window glass, some bottle glass, nails, iron can fragments, unidentified iron, oyster shells, and coal fragments) that were weighed but not counted. The classification categories generally follow the material and functional groups used in the previous investigations at the Levi Jordan Plantation by Leezer (2006:55-75, Appendix B).

Table C.2, which is presented here only in electronic format, is the master table of all provenience data and artifact identifications for the cultural materials recovered in the Phase I (2010) and Phase II (2011) investigations. The provenience data reported for the material culture includes the lot number, the excavation unit number or name, feature association, depth below surface or excavation level, the excavator, and date. The references cited section below includes the published works that were cited for artifact identifications in Table C.2.

Future researchers should be aware that Table C.2 is only a preliminary inventory of the collection (see Chapter 3 ). The artifact identifications are very general and, in some cases, somewhat tentative. More research and analysis would be needed to fully identify all the materials and sort out the specimens that were manufactured during different time periods. Table C. 2 does list diagnostic markings, dates of manufacture, and references for some selected artifacts (i.e., the ceramics, some glass, a few brass items, and coins), but many types of artifacts have not been identified beyond their initial functional group. The ammunition category is a good example. It contains many brass cartridge cases that can certainly be identified more precisely with additional research (e.g., cartridge type and caliber), and some have head stamp markings that are identifiable. Similarly, many of the glass bottles and bottle fragments have diagnostic attributes (e.g., neck finishes and mold seams) and embossed markings.

\section{REFERENCES CITED}

Godden, Geoffrey A.

1991 Encyclopaedia of British Pottery and Porcelain Marks. Barrie \& Jenkins, London.

Leezer, Carole

2006 Archaeological Investigations at the Levi Jordan Plantation State Historic Site, Brazoria County, Texas. Archaeological Studies Report No. 7. Center for Archaeological Studies, Texas State University, San Marcos.

Lehner, Lois

1988 Lehner's Encyclopedia of U.S. Marks on Pottery, Porcelain, and Clay. Collector Books, Paducah, Kentucky.

Roller, Dick

1983 The Standard Fruit Jar Reference. Acorn Press, Paris, Illinois. 
Table. C.1. Summary of recovered cultural materials by phase for the Levi Jordan Plantation House Stabilization Project, 2010 and 2011

\begin{tabular}{|c|c|c|c|c|c|c|}
\hline \multirow[b]{2}{*}{ Artifact Identification } & \multicolumn{2}{|c|}{ Phase I Recovery } & \multicolumn{2}{|c|}{ Phase II Recovery } & \multicolumn{2}{|c|}{ Total Artifacts } \\
\hline & Count & Weight $(\mathrm{g})$ & Count & Weight $(\mathrm{g})$ & Count & Weight $(g)$ \\
\hline \multicolumn{7}{|l|}{ Ceramic sherds } \\
\hline Undecorated whiteware & 685 & - & 152 & - & 837 & - \\
\hline Decorated whiteware - embossed & 46 & - & 14 & - & 60 & - \\
\hline Flow blue whiteware & 0 & - & 1 & - & 1 & - \\
\hline Transferware & 12 & - & 2 & - & 14 & - \\
\hline Decorated whiteware - other & 32 & - & 9 & - & 41 & - \\
\hline Porcelain, plain & 119 & - & 29 & - & 148 & - \\
\hline Decorated or embossed porcelain & 26 & - & 21 & - & 47 & - \\
\hline Albany slip & 7 & - & 3 & - & 10 & - \\
\hline Yellow ware & 7 & - & 0 & - & 7 & - \\
\hline Stoneware & 23 & - & 5 & - & 28 & - \\
\hline Earthenware & 0 & - & 7 & - & 7 & - \\
\hline \multicolumn{7}{|l|}{ Non-culinary ceramics } \\
\hline $\begin{array}{l}\text { Earthenware, decorative non-culinary } \\
\text { (e.g., flower pot or statue) }\end{array}$ & 42 & - & 3 & - & 45 & - \\
\hline $\begin{array}{l}\text { Porcelain, non-culinary } \\
\text { (e.g., insulator) }\end{array}$ & 9 & - & 2 & - & 11 & - \\
\hline \multicolumn{7}{|l|}{ Glass } \\
\hline Window glass & 214 & - & 289 & - & 503 & - \\
\hline Bulk window glass $(\mathrm{g})$ & - & $10,986.3$ & & $3,076.8$ & - & $14,063.1$ \\
\hline Clear bottle glass fragments & 924 & - & 595 & - & 1,519 & - \\
\hline Bulk clear blass bottle fragments $(\mathrm{g})$ & - & 0.0 & & 234.5 & - & 234.5 \\
\hline Colored bottle glass & 539 & - & 118 & - & 657 & - \\
\hline Decorative glass & 49 & - & 16 & - & 65 & - \\
\hline $\begin{array}{l}\text { Thin glass } \\
\text { (includes lamp chimney glass) }\end{array}$ & 203 & - & 2 & - & 205 & - \\
\hline Light bulb glass & 0 & - & 12 & - & 12 & - \\
\hline Milk glass & 40 & - & 18 & - & 58 & - \\
\hline Canning jar glass lid & 15 & - & 2 & - & 17 & - \\
\hline Complete bottle & 51 & - & 6 & - & 57 & - \\
\hline Drinking glass & 32 & - & 2 & - & 34 & - \\
\hline \multicolumn{7}{|l|}{ Clothing } \\
\hline Buttons (various materials and types) & 24 & - & 25 & - & 49 & - \\
\hline \multicolumn{7}{|l|}{ Nails and Staples } \\
\hline Wire nails & 80 & - & 156 & - & 236 & - \\
\hline Square nails & 40 & - & 26 & - & 66 & - \\
\hline Unidentified nails & 36 & - & 21 & - & 57 & - \\
\hline Fence staple & 4 & - & 36 & - & 40 & - \\
\hline Bulk nails (g) & - & $28,274.4$ & - & $9,128.3$ & - & $37,402.7$ \\
\hline \multicolumn{7}{|l|}{ Miscellaneous metal artifacts } \\
\hline Coin & 22 & - & 4 & - & 26 & - \\
\hline Ammunition (cartridges and bullets) & 92 & - & 18 & - & 110 & \\
\hline $\begin{array}{l}\text { Metal can fragments } \\
\text { (presence only; not counted or weighed) }\end{array}$ & 0 & - & 87 & - & 87 & - \\
\hline $\begin{array}{l}\text { Metal can fragments } \\
\text { (weight of single can) }\end{array}$ & - & 0.0 & - & 155.2 & - & 155.2 \\
\hline
\end{tabular}


Table C.1, continued

\begin{tabular}{|c|c|c|c|c|c|c|}
\hline \multirow[b]{2}{*}{ Artifact Identification } & \multicolumn{2}{|c|}{ Phase I Recovery } & \multicolumn{2}{|c|}{ Phase II Recovery } & \multicolumn{2}{|c|}{ Total Artifacts } \\
\hline & Count & Weight $(\mathrm{g})$ & Count & Weight $(\mathrm{g})$ & Count & Weight (g) \\
\hline Lead & 6 & - & 4 & \begin{tabular}{|l|}
- \\
\end{tabular} & 10 & - \\
\hline Metal rivet & 1 & - & 3 & - & 4 & - \\
\hline Copper or brass strap & 13 & - & 28 & - & 41 & - \\
\hline Lamp burner & 0 & - & 1 & - & 1 & - \\
\hline Other metal artifacts & 25 & - & 17 & - & 42 & - \\
\hline \multicolumn{7}{|l|}{ Unidentified metal objects } \\
\hline Metal blobs (unidentified) & 49 & - & 0 & - & 49 & - \\
\hline $\begin{array}{l}\text { Bulk unidentified metal } \\
\text { (rusted iron, g) }\end{array}$ & - & $5,380.0$ & - & $7,374.0$ & - & $12,754.0$ \\
\hline Unidentified metal objects & 70 & - & 24 & - & 94 & - \\
\hline \multicolumn{7}{|l|}{ Bone and shell } \\
\hline Animal bones & 570 & - & 438 & - & 1,008 & - \\
\hline Modified bones & 2 & - & 0 & - & 2 & - \\
\hline Oyster shells (g) & - & $2,993.4$ & - & 0.0 & - & $2,993.4$ \\
\hline Oyster shells (count) & 0 & - & 51 & - & 51 & - \\
\hline Other seashells & 52 & - & 9 & - & 61 & - \\
\hline Mussel shells & 1 & - & 7 & - & 8 & - \\
\hline \multicolumn{7}{|l|}{ Miscellaneous artifacts } \\
\hline Coal (g) & - & 22.8 & 0 & 0.0 & & 22.8 \\
\hline Coal (fragment count) & 0 & - & 19 & - & 19 & - \\
\hline Bricks & 45 & - & 14 & - & 59 & - \\
\hline Concrete fragments & 0 & - & 15 & - & 15 & - \\
\hline Children's toys & 49 & - & 13 & - & 62 & - \\
\hline Slate fragment & 12 & - & 4 & - & 16 & - \\
\hline Graphite & 0 & - & 2 & - & 2 & - \\
\hline Other artifacts & 21 & - & 32 & - & 53 & - \\
\hline Totals & 4,289 & $47,656.9$ & 2,362 & $19,968.8$ & 6,651 & $67,625.7$ \\
\hline
\end{tabular}


